UNIVERSIDADE DE SÃO PAULO

FACULDADE DE FILOSOFIA, LETRAS E CIÊNCIAS HUMANAS

DEPARTAMENTO DE ANTROPOLOGIA

PROGRAMA DE PÓS-GRADUAÇÃO EM ANTROPOLOGIA SOCIAL

TATIANA H. P. LOTIERZO

Contornos do (in)visível: $A$ redenção de Cam, racismo e estética na pintura brasileira do último Oitocentos

(versão corrigida)

SÃO PAULO

2013 


\section{Contornos do (in)visível: $A$ redenção de Cam, racismo e estética na pintura brasileira do último Oitocentos}

Dissertação de Mestrado apresentada ao Programa de

Pós-Graduação em Antropologia Social do

Departamento de Antropologia da Faculdade de

Filosofia, Letras e Ciências Humanas da Universidade de São Paulo para obtenção do título de Mestre em Antropologia.

Área de concentração: Antropologia Social

De acordo:

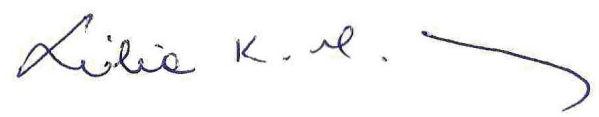

Profa. Dra. Lilia Katri Moritz Schwarcz

Orientadora.

SÃO PAULO

2013 
Autorizo a reprodução e divulgação total ou parcial deste trabalho, por qualquer meio convencional ou eletrônico, para fins de estudo e pesquisa, desde que citada a fonte.

Catalogação na Publicação

Serviço de Biblioteca e Documentação

Faculdade de Filosofia, Letras e Ciências Humanas da Universidade de São Paulo

Lotierzo, Tatiana Helena Pinto

L883c Contornos do (in)visível: A Redenção de Cam, racismo e estética na pintura brasileira do último Oitocentos / Tatiana Helena Pinto Lotierzo ; orientadora Lilia Katri Moritz Schwarcz. - São Paulo, 2013.

$306 \mathrm{f}$.

Dissertação (Mestrado)- Faculdade de Filosofia, Letras e Ciências Humanas da Universidade de são Paulo. Departamento de Antropologia. Área de concentração: Antropologia Social.

1. Racismo. 2. Estética. 3. Pintura. 4. Embranquecimento. 5. A Redenção de Cam. I. Schwarcz, Lilia Katri Moritz, orient. II. Título. 
Universidade de São Paulo

\section{RELATÓRIO DE DEFESA}

Aluno: 8134 - 2350526 - 1 / Página 1 de 1

Relatório de defesa pública de Dissertação do(a) Senhor(a) Tatiana Helena Pinto Lotierzo no Programa: Ciência Social (Antropologia Social), do(a) Faculdade de Filosofia, Letras e Ciências Humanas da Universidade de São Paulo.

Aos 03 dias do mês de outubro de 2013, no(a) Sala da Diretoria realizou-se a Defesa da Dissertação do(a) Senhor(a) Tatiana Helena Pinto Lotierzo, apresentada para a obtenção do título de Mestra intitulada:

"Contornos do (in)visível: a redenção de Cam, racismo e estética na pintura brasileira do último Oitocentos"

Após declarada aberta a sessão, o(a) Sr(a) Presidente passa a palavra ao candidato para exposição e a seguir aos examinadores para as devidas arguições que se desenvolvem nos termos regimentais. Em seguida, a Comissão Julgadora proclama o resultado:

$\begin{array}{llll}\text { Nome dos Participantes da Banca } & \text { Função } & \text { Sigla da CPG } & \text { Resultado } \\ \text { Lilia Katri Moritz Schwarcz } & \text { Presidente } & \text { FFLCH - USP } & \text { Aprovado } \\ \text { Ana Paula Cavalcanti Simioni } & \text { Titular } & \text { IEB - USP } & \text { Aprovado } \\ \text { Maria Helena Pereira Toledo Machado } & \text { Titular } & \text { FFLCH - USP } & \text { Aprovado }\end{array}$

Resultado Final: Aprovado

Parecer da Comissão Julgadora *

A banca considerou excepcional a dissertação de mestrado, em função da qualidade da pesquisa, da redação cuidadosa, bem como, das análises de imagem inovadoras. Trata-se de uma contribuição muito original ao debate sobre raça e gênero no Brasil do oitocentos. Por todas essas qualidades a banca aprovou a dissertação recomendando distinção e louvor, assim como sugerindo a sua publicação.

Eu, Daiane Neres da Silva haiane Nalva lavrei o presente relatório, que assino juntamente com os(as) Senhores(as) examinadores. São Paulo, aos 03 dias do mês de outubro de 2013.

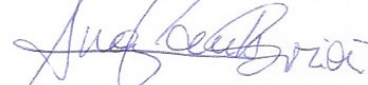

Ana Paula Cavalcanti Simioni
Mhis

Maria Helena Pereira Toledo Machado

$$
\begin{gathered}
\text { Lilia Katri Moritz Schwarcz } \\
\text { Presidente da Comissão Julgadora }
\end{gathered}
$$

* Obs: Se o candidato for reprovado por algum dos membros, o preenchimento do parecer é obrigatório.

A defesa foi homologada pela Comissão de Pós-Graduação em $07,10,2013$ e, portanto, o(a) aluno(a) faz jus ao título de Mestra em Ciências obtido no Programa Ciência Social (Antropologia Social) - Area de concentração: Antropologia Social.

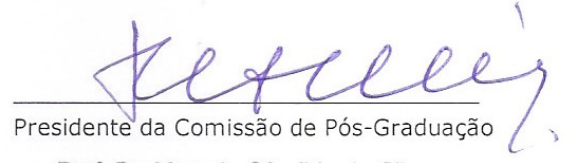

Prof. Dir. Marcelo Candidio da Silva

Presidente da CPG-FFLCH 


\section{RESUMO}

A tela $A$ Redenção de Cam (1895), de autoria de Modesto Brocos é um retrato de família marcado pelas distintas gradações de cor da pele entre seus membros, num movimento clareador que vai do negro (a avó) ao branco (o neto). Vencedora da medalha de ouro na Exposição Geral de Belas Artes de 1895, a pintura foi incorporada ao artigo apresentado por João Batista de Lacerda, diretor do Museu Nacional, no I Congresso Mundial das Raças em 1911, servindo de ilustração à tese do cientista, para quem o Brasil seria branco em três gerações. No mais, o quadro é fruto de um momento pós-emancipação, marcado pela forte adesão ao racialismo na esfera pública e da emergência de uma série de planos quanto ao destino da população de ascendência negra na ordem livre e republicana.

A despeito de sua apropriação por Lacerda, a presente dissertação analisa $A$ Redenção de Cam com base da hipótese de que a pintura procura demonstrar sua própria tese sobre o embranquecimento. Argumentamos que a tela concorre para fixar a imagem de um corpo negro branqueador, sobretudo na medida em que procura atribuir forma explícita a uma ideia ainda incerta, tanto aos olhos da ciência, quanto nos debates que ganhavam espaço junto à opinião pública de seu tempo. Logo, procuraremos discutir em que medida a pintura possibilita vislumbrar certas variáveis constitutivas de uma estética que, por sua vez, revela-se uma importante via de acesso a modos de ver profundamente imbricados em processos fundamentais daquilo que hoje entendemos como preconceito racial.

Procuramos levar adiante a proposição de alguns críticos atuais, segundo os quais a tela é preconceituosa, observando em maior detalhe as soluções pictóricas empregadas pelo artista na caracterização da cena e de suas personagens. Será essencial, nesse trajeto, o diálogo com outras imagens, por meio do qual se tornarão mais evidentes certas tendências marcantes no tratamento pictórico de personagens de ascendência negra no período e também as especificidades de $A$ redenção de Cam com relação a esses modelos.

Palavras-chave: racismo - estética - pintura - embranquecimento - $A$ redenção de Cam - Oitocentos 


\begin{abstract}
Modesto Brocos's painting Redemption of Cham (1895) is a family portrait marked by the different colour shades of each characters' skin, in a lightening movement from "black" (the grandmother) to "white" (her grandson). Awarded the golden medal in the 1895 Brazil's General Fine Arts Exhibition, in 1911 the painting was incorporated as an illustration to the paper presented in the First Universal Races Congress by João Batista de Lacerda, the director of the National Museum, in order to exemplify the scientist's thesis, arguing that in three generations, Brazil would be a white country. The painting is a post-emancipation work, marked by the strong adherence to racialism in the public sphere and by various projects regarding the black people's destiny in the Brazilian free, Republican order.

Despite of the painting's appropriation by Lacerda, the present master thesis analyzes Redemption of Cham through the hipothesis that it intends to demonstrante its own thesis on whitening. It will be argued that the painting contributes to fix the image of a black whitening body, especially when it seeks to attribute explicit form to an idea that still was not a consensus at that time, neither through the eyes of science, nor in the wider public debates on that issue. It will be asked to what extent the painting allows for envisaging certain aspects of an aesthetics that, in itself, could reveal to be an important chanel for accessing ways of seeing deeply embedded in fundamental processes of what is currently understood as racial discrimination.

The thesis is aimed at developing the proposition made by recent critics, according to whom Redemption of Cham is biased by racial prejudice, taking a closer look at the ways adopted by the artist to depict the scene and its characters. In such an analysis, the dialogue between this painting and other images will be crucial in order to render visible certain patterns used to depict non-whites at that time, as well as the particularities of Redemption of Cham.
\end{abstract}

Keywords: racism - aesthetics - painting - whitening - Redemption of Cham nineteenth-century 
Para Felipe, com amor.

À memória de meu pai. 


\section{AGRADECIMENTOS}

A Lilia Schwarcz, agradeço pela sugestão do tema da pesquisa. Reforço também minha gratidão pela aprendizagem, pelo diálogo sempre sincero e pelo voto de confiança, bem como minha admiração por uma intelectual que procura transmitir a seus orientandos seu enorme respeito pela tradição do pensamento social no Brasil, incentivando-nos continuamente a conhecer, debater e levar adiante este legado.

À professora Maria Helena Machado, agradeço pelos grandes ensinamentos no curso de História, pelas inestimáveis contribuições e pelo incentivo, bem como por participar nas bancas de qualificação e defesa. À professora Ana Paula Simioni, deixo meus agradecimentos pelas contribuições e pelo grande encorajamento, além da participação na banca de defesa. Ao professor Paulo Menezes, agradeço pela participação em minha banca de qualificação e pelas indicações valiosas para a presente dissertação.

Aos professores que colaboraram em contextos e encontros distintos com sugestões e estímulo para o presente trabalho: a Antonio Sérgio Guimarães e Vagner Gonçalves da Silva, deixo meus agradecimentos pelo incentivo e pelos aportes fundamentais recebidos no Seminário do NUMAS. Também agradeço aos professores Júlio Simões e Laura Moutinho e aos colegas presentes na ocasião pelo acolhimento, perguntas e sugestões preciosas. A Flávio Gomes, Keila Grinberg e Luiz Felipe de Alencastro, agradeço pela interlocução no Seminário Emancipações. Aos professores Sérgio Miceli e Cristina Wissembach, sou grata pelas aprendizagens em debates relacionados à pesquisa. Agradeço igualmente ao professor Leopoldo Waizbort, por seu interesse pelo trabalho e pelo empréstimo da dissertação de Amélia Siegl Correia sobre o pintor Alfredo Andersen. A Ana Paula Simioni, Débora Dorotinsky e Maíra Istar de Luca, agradeço pelas sugestões referentes ao artigo de Arteologie. A Maraliz Christo, pelos comentários sobre o projeto de pesquisa.

Ao querido professor Nicolau Sevcenko, deixo meu obrigada pelo apoio fundamental para as pesquisas realizadas na Universidade de Harvard, além da companhia sempre agradável e das profundas aprendizagens, tanto durante a graduação, quanto nestes últimos anos. Também agradeço a Clémence Jouët-Pastré pelos ótimos momentos passados em Cambridge. 
Agradeço ao professor Anton Corbacho Quintela por facilitar-me o contato com familiares de Modesto Brocos e por compartilhar seu trabalho sobre os imigrantes galegos no Brasil.

Esta dissertação não seria a mesma sem os ensinamentos de Paula Montero, Marta Amoroso, Renato Sztutman e Stelio Marras, meus professores no mestrado. A Paula Montero e Marta Amoroso, agradeço também pelos comentários e sugestões decisivas para o projeto de pesquisa.

A Ivanete Ramos, Soraya Gebara, Rose de Oliveira, Edinaldo Faria Lima e Celso Cunha Gonçalves, sou grata pelo apoio com as formalidades acadêmicas.

A pesquisa realizada na Biblioteca Nacional; no Museu Nacional; no Museu Nacional de Belas Artes; na Biblioteca da Escola de Belas Artes da Universidade Federal do Rio de Janeiro; nas bibliotecas Lamont, Widener, Tozzer, e Fine Arts, na Universidade de Harvard, não teria sido possível sem o auxílio prestimoso dos bibliotecários e funcionários presentes. Deixo, a eles, meus agradecimentos. Devo um obrigada especial a Marina Martins Gonzalez, que me facilitou o acesso a uma cópia de Viaje a Marte, direto da Real Biblioteca de Madrid.

Agradeço à CAPES e à Fapesp, pela concessão das bolsas que viabilizaram esta dissertação.

A Bernardo Machado, Bruna Della Torre, Claude Guy Papavero, Eduardo Dimitrov, Eduardo Dullo, Gabriel Pugliese, Leonardo Bertolossi, Maria José Campos, Mauricio Acuña, Ricardo Teperman e Samantha Gaspar, colegas do grupo EtnoHistória, agradeço pelo incentivo e pelas discussões sempre animadas.

Deixo um agradecimento especial a Daniela Carolina Perutti, que logo no início da pesquisa compartilhou um seu artigo fundamental sobre Almeida Júnior, peça-chave para o quebra-cabeça da pintura oitocentista.

Aos colegas do PPGAS-USP, com quem tanto aprendi nesses anos. Muito obrigada, Nathália Lago e Patrícia Ferreira e Silva, pelos diálogos e colaborações.

A Graça Lima, pelos sábios conselhos.

Devo minha gratidão a Camilla Croso, exemplo de perseverança e trabalho incansável que tanto inspira meu compromisso com os direitos humanos. Agradeço a Gerson Tanaka; Maria Candelária de Freitas; Fabíola Munhoz; Vagner de Alencar, Ilich Ortiz; Bruno Morais; e Fernanda Sucupira pela paciência, compreensão e 
incentivo durante o período de mestrado e pelo de companheirismo, das horas mais sérias às mais divertidas do dia.

Tenho uma dívida imensa para com os amigos que gentilmente dedicaram parte de seu tempo à leitura de capítulos desta dissertação. Não tenho palavras para agradecer a Eduardo Dullo, pela apreciação cuidadosa e os comentários do relatório de qualificação; a Rodrigo Gomes Lobo e Maurício Acuña pela leitura generosa e atenta dos capítulos 2 e 3 e o incentivo de sempre, com sugestões e questões instigantes que trouxeram um novo alento à escrita. Também aproveito para agradecer às queridas Fernanda Rosa, Samantha Gaspar e Amanda Brandão, pelos encontros e ocasiões em que pudemos ventilar as preocupações de pesquisa em conversas sobre a vida.

A Lisanne e Ilan Norman, deixo os maiores agradecimentos pela amizade, com muitas saudades de nossos passeios em Cambridge. Espero que possam encontrar, nesta dissertação, as marcas profundas de minha aprendizagem com nossas conversas. Clara Bonomi Barufi, Andrea Limberto Leite, Marcio Kameoka, Joana Matushita, Letícia Moraes, Marina Gonzalez outra vez, Luiza Clark, Fabiana Vezzali, Thais Brianezi, Marina Motomura e Marcy Figueiredo: obrigada pela companhia sempre alegre e divertida, que ajudou a espairecer durante eses anos de trabalho intensivo.

Deixo aqui meus agradecimentos e a maior admiração por Laura Giannecchini e Giovanna Modé: obrigada pela amizade, apoio e carinho ao longo do tempo e pela companhia que anima e alenta tantos dias e noites de trabalho, seja no Brasil, na Colômbia, na Argentina, na França, no Haiti e pela possibilidade de deixar a pesquisa por um tempo, rumo a um inesquecível casamento na Itália... (!) Agradeço pela parceria continuada e por vivermos juntas tantas coisas especiais. A Paulo Assis e Daniel Campos de Carvalho, um muito obrigada pela amizade.

À minha nova família: a Sedi e Toshimi, agradeço pelo acolhimento, carinho e apoio em todas as ocasiões. A Sedi, pelo apoio e o exemplo intelectual. Agradeço também a Ana Cristina e Serginho, Ana Helena, Ana Carolina e Fernando, Luis Afonso e Ana Paula e Aaron. A Ana Paula e Aaron, um obrigada especial pela recepção em Cambridge, estendido aos Litvin pelo acolhimento nos Estados Unidos: Maria, Gary, Margie, Ken, Henry e Esther. 
Agradeço a meus irmãos, Priscilla e Rodrigo, com quem tanto aprendo e com quem sigo compartilhando tantas identificações e cumplicidades, com afeto e admiração; ao Cristiano; e ao Lucas, que tem nos ensinado a importância de viver com entusiasmo as pequenas descobertas de cada dia.

À minha mãe, Lucia, e meu pai, Enio (in memoriam), meus maiores exemplos de retidão e caráter. De vocês, recebi sem dúvida todos os ensinamentos mais importantes. Agradeço, com amor.

Escrevo estas páginas segura de que, não fosse por Felipe, talvez esta dissertação jamais tivesse acontecido. Suas minuciosas leituras, discussões, comentários, críticas e sugestões, apoio incondicional, incentivo e interesse fogem ao alcance das palavras. Não há como exprimir tudo o que vivemos: os sonhos compartilhados, o riso e a tristeza, a beleza das pequenas coisas e também das grandiosas. Agradeço a você, Felipe, por existir - e por tudo o que representa em minha vida. 


\section{Sumário}

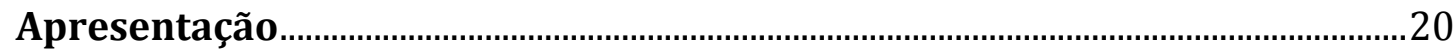

Discussão bibliográfica: o embranquecimento, como o tema da pintura......................26

Sobre Modesto Brocos e sua obra: notas teórico-metodológicas ....................................33

Uma estética do preconceito? Alargando fronteiras .........................................................51

Capítulo 1: A tela, por seu nome ………………………………………………….....59

O povo de Cam é uma imagem.....................................................................................6

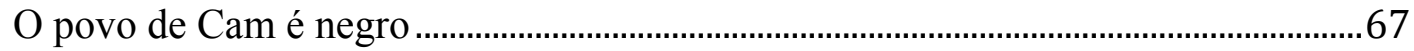

O povo de Cam é objeto de ciência ..................................................................................80

Pode o povo de Cam ser branco? ........................................................................................89

Há redenção para o povo de Cam? ...............................................................................107

Capítulo 2. A tela, por seu estilo …………………………….....................................129

Do estilo como um problema e do problema por trás do estilo...................................135

Da arte e seus atributos: referenciais.................................................................................158

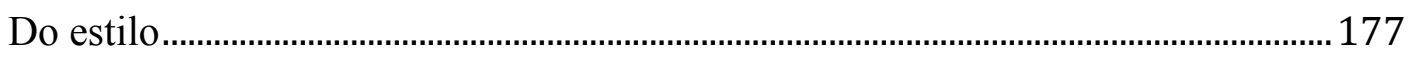

Capítulo 3. A tela, por seus esquemas...........................................................................181

Da mulher negra na pintura da Europa oitocentista: alguns exemplos......................185

Da mulher negra nas telas de Brocos: algumas observações ......................................210

Da mulher negra, segundo a opinião pública nacional: diálogos possíveis ............226

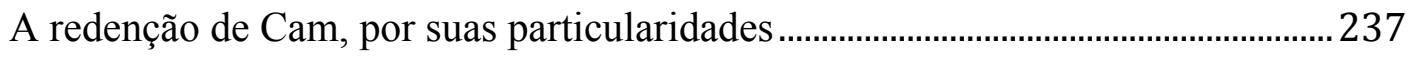

Contornos do (in)visível: considerações finais .........................................................256

Negra como exceção, na obra de Almeida Júnior ......................................................260

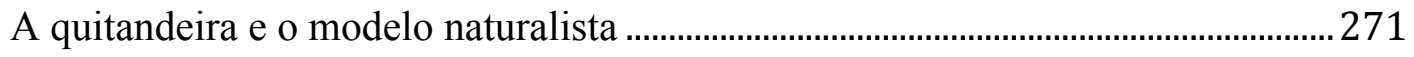

Aproximações e distanciamentos .................................................................................2276

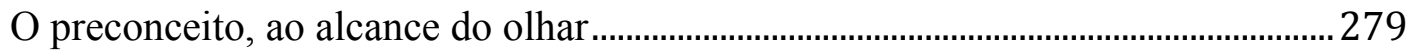

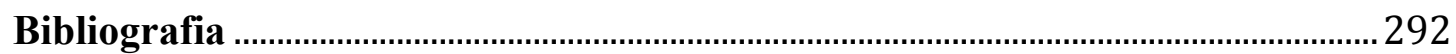




\section{ÍNDICE DE IMAGENS}

\section{Apresentação:}

Fig. 1: Modesto Brocos. A redenção de Cam (1895), p. 19

Fig. 2: Modesto Brocos. Autorretrato (1882), p. 32

Fig. 3: Modesto Brocos. Ilustração para O Mequetrefe, p. 32

Fig. 4: Victor Meirelles. A batalha dos Guararapes (1875-9), p. 36

Fig. 5: Modesto Brocos. Retrato de Arthur de Azevedo (s.d.), p. 39

Fig. 6: Henrique Bernardelli. "Sobre todo, las proporciones". Caricatura de Modesto Brocos, p. 39

Fig. 7: Modesto Brocos. Engenho de mandioca (1892), p. 44

Fig. 8: Modesto Brocos. A descascar goiabas (1901), p. 45

Fig. 9: Modesto Brocos Feiticeira (c.1895), p. 45

Fig. 10: Modesto Brocos Mulher, s.d., p. 45

Fig. 11: Modesto Brocos. Crioula de Diamantina (1894), p. 46

Fig. 12: Brocos, Modesto Mulher Coletando Água (1892), p. 46

Fig. 13: Modesto Brocos. Las tres edades, s.d. , p. 46

Fig. 14: Modesto Brocos Rebecca dando de beber a Eliezer (1883), p. 46

Fig. 15: Modesto Brocos. Lavanderas (1880), p. 47

Fig. 16: Modesto Brocos. Camponesa (s.d), p. 47

\section{Capítulo 1:}

Fig. 17: Cosmografia Universal (1575) de André de Thévet, p. 71

Fig. 18: Cosmografia Universal (1575) de André de Thévet, , p. 71

Fig. 19: Franz Post. A Ilha de Itamaracá (1637), p. 75

Fig. 20: Albert Eckhout. Mulher africana (1641), p. 75

Fig. 21: Albert Eckhout. Mulher mameluca (c. 1641-1644), p. 75

Fig. 22: Albert Eckhout. Homem mulato (s.d.), p. 76

Fig. 23: Albert Eckhout. Homem tapuia (1641), p. 76

Fig. 24: Zacharias Wagener. Aldeia (s.d.), p. 76

Fig. 25: Albert Eckhout ou Jaspar Benx (atribuições). Retrato de Dom Miguel de Castro (s.d.), p. 77 
Fig. 26: Albert Eckhout ou Jaspar Benx (atribuições). Servo de Dom Miguel de Castro com caixa decorada (s.d.), p. 77

Fig. 27: Albert Eckhout ou Jaspar Benx (atribuições). Servo de Dom Miguel de Castro com presa de elefante (s.d.), p. 77

Fig. 28: Annibali Carraci (atribuição). Portrait of an African slave woman (c.1680), p. 78

Fig. 29: Peter Paul Rubens. Head of a negro man (c. 1620), p. 78

Fig.30: Oficina de Gerard David. Adoration of the Magi (c.1514), p. 78

Fig. 31: African American Vitiligo, de L'Histoire Naturelle (servant de suite a l'histoire naturelle de l'homme), publicado pelo M. le Comte de Buffon em 1777 , p. 85

Fig. 32: Crânios estudados por Blumenbach, p. 87

Fig. 33: Miguel Cabrera: De Español y Mulata: Morisca (1763), p. 94

Fig. 34: Miguel Cabrera. De Español y Albina: Torna atras, (1763), p. 98

Fig. 35: Carlos Julião. Roupas de mulheres escravas (c. 1770), p. 100

Fig. 36: Carlos Julião. Negras vendedoras (c.1776), p. 101

Fig. 37: Carlos Julião. Escravas vendedoras (c.1776), p. 101

Fig. 38: Carlos Julião. Carregando uma liteira (c.1776), p. 102

Fig. 39: Leandro Joaquim. Vista da Lagoa do Boqueirão e do Arqueduto de Santa Teresa [detalhe] (c.1790), p. 102

Fig. 40: Leandro Joaquim. Vista da Lagoa do Boqueirão e do Arqueduto de Santa Teresa (c.1790), p. 103

Fig. 41: Johann Moritz Rugendas Benguela/Angola/Congo/Monjolo, p. 109

Fig. 42: Johann Moritz Rugendas Mozambique, p. 109

Fig. 43: Johann Moritz Rugendas Benguela/Congo, p. 109

Fig. 44: Johann Moritz Rugendas Cabinda/Quiloa/Rebolla/Mina, p. 109

Fig. 45: Jean-Baptiste Debret. Esclaves nègres de differentes nations, p. 110

Fig. 46: Jean-Baptiste Debret. Esclaves nègres de differentes nations, p. 110

Fig. 47: O ângulo facial de Petrus Camper, p. 116

Fig. 48: Profile of Negro, European and Oran Outan. Crania Americana (1831), de Samuel G. Morton, p. 116

Fig. 49: Antropogenia, de Ernst Haeckel (1874), p. 117

Fig. 50: Types of Mankind (1854), de Josiah Clark Nott (1804-1973), p. 117 
Fig. 51: Ilustração anônima para O Mequetrefe, 10 de setembro de 1885, p. 123

\section{Capítulo 2:}

Fig. 52: Modesto Brocos. Engenho de mandioca (1892), p. 139

Fig. 53: John Singleton Copley. Watson and the Shark (1778), p. 141

Fig. 54: William Sidney Mount. Eel Spearing at Setauket (1845), p. 142

Fig. 55: Eastman Johnson. Negro Life at the South (1859), p. 143

Fig. 56: Thomas Eakins. The Dancing Lesson [Negro Boy Dancing] (1878), p. 143

Fig. 57: Henry Ossawa Tanner.The Banjo Lesson (1893), p. 143

Fig. 58: Nicolas-Antoine Taunay. Entrée de la baie et la ville de Rio, de la terrasse du Convent de Saint-Antoine en 1816 (c.1818), p. 144

Fig. 59: Jean-Baptiste Debret. Negres scieurs de long. Voyage pittoresque et historique au Brésil (1834), p. 145

Fig. 60: Johann Moritz Rugendas. "Negres a fond de calle" (c.1830), p. 146

Fig. 61: Modesto Brocos. A descascar goiabas (1901), p. 151

Fig. 62: Modesto Brocos. A descascar goiabas (1901) [detalhe], p. 154

Fig. 63: Modesto Brocos. Engenho de mandioca (1892) [detalhe], p. 154

Fig. 64: Modesto Brocos. A redenção de Cam (1895), p. 155

Fig.65: Jacques-Louis David. Le serment des horaces (1784/5), p. 161

Fig. 66: Isidoro Brocos. La parva (c. 1887), p. 166

Fig. 67: Isidoro Brocos. Os últimos momentos de Herodes (1878), p. 166

Fig. 68: Modesto Brocos. Retrato de Rosalía de Castro (1880), p. 167

Fig. 69: Modesto Brocos. Galega (c.1880), p. 167

Fig. 70: Federico de Madrazo. Amalia de Llano y Dotres, condesa de Vilches (1854), p. 169

Fig. 71: Jean-Auguste Dominique Ingres.Comtesse D'Haussonville (1845), p. 169

Fig. 72: Henri Lehmann. Portrait de Paysan italien (s.d.), p. 170

Fig. 73: Henri Lehmann. Portrait de Paysanne italienne (1863), p. 170

Fig. 74: Henri Lehmann. Le repos (1864), p. 171

Fig. 75: Jules Breton. Le rapel des glaneuses (1859), p. 174

Fig. 76: Ernest Hébert. Les Fienaroles de Sant'Angelo vendant du foin à l'entrée de la ville de San Germano (1854), p. 175 
Fig. 77: Ernest Hébert. La Mal'aria (1848-49), p. 176

Fig. 78: Ernert Hébert. Tresseuses des cordages (s.d.), p. 176

Fig. 79: Ernert Hébert. Les Filles d'Alvito (1855), p. 176

\section{Capítulo 3:}

Fig. 80: Édouard Manet. Olympia (1863), p. 185

Fig. 81: Diagrama de classificação de cor de Chevreul (1855), p. 190

Fig. 82: Eugène Delacroix. Moulay Abd er-Rahman, sultão do Marrocos (1845), p. 192

Fig. 83: Eugène Delacroix. Os convulsionários de Tanger (1837-8), p. 193

Fig. 84: Théodore Chassériau. La toilette d'Esther (1841), p. 193

Fig. 85: Ernest Hébert. La Mal'aria (1848-49), p. 193

Fig. 86: Eugène Delacroix. Les femmes d'Algers dans leurs appartements (1834), p. 194

Fig. 87: Imagens de Sara Baartman, p. 198

Fig. 88: Human Ear, modelled and drawn by Mr. Woolner, p. 199

Fig. 89: Christopher Crupper Rumford. Love and beauty - Sartjee the Hottentot Venus (1811), p. 199

Fig. 90: Edwin Long. The Babylonian Marriage Market (1875), p. 200

Fig. 91: Acima: Léon Benouville. Odalisque (1843), p. 201

Fig. 92: À esq.: Jean-Marc Nattier. Mademoiselle de Clermont en sultane (1733), p. 201

Fig. 93: Félix Jacques Antonin Moulin. Odalisque (1853), p. 202

Fig. 94: Édouard Manet. Nana (1877), p. 203

Fig. 95: Théodore Chassériau. Intérieur oriental (c. 1850-52), p. 204

Fig. 96: Jean-Léon Gérôme. Le bain maure (c. 1874-77), p. 204

Fig. 97: Jules Jean Antoine Lecomte du Noüy. L'esclave blanche (1888), p. 204

Fig. 98: Jean-Léon Gérôme. Bain turc ou bain maure (1870), p. 204

Fig. 99: Édouard Debat-Ponsan. Le massage au Hamman (1883), p. 205

Fig. 100: Frédéric Bazille. La toilette (1869-70), p. 205

Fig. 101: Théodore Chassériau. Bain au serail (1849), p. 205

Fig. 102: Modesto Brocos. Engenho de mandioca (1892), p. 210 
Fig. 103: Victor Frond. Descascadoras de mandioca (1858-1861), p. 212

Fig. 104: Victor Frond. Rendeiras (1858-1861), p. 212

Fig. 105: Victor Frond. Produção de farinha e mandioca (1858-1861), p. 212

Fig. 106: Ernest Hébert. Homme piochant, et femme allaitant son enfant (s.d.), p. 213

Fig. 107: Ernest Hébert. Paysanne italienne assise à terre, de profil (s.d.), p. 213

Fig. 108: Ernest Hébert. Femme assise allaitant un enfant, et étude d'homme piochant (s.d.) [detalhe], p. 213

Fig. 109: Modesto Brocos. Engenho de mandioca (1892) [detalhe], p. 213

Fig. 110: Modesto Brocos. A descascar goiabas (1892), p. 213

Fig: 111: à dir.: Modesto Brocos. Engenho de mandioca (1892) [detalhe], p. 213

Fig. 112: à esq: Ernest Hébert. Quatre études de femme, assise, avec leurs enfants (s.d.), p. 213

Fig. 113: Marie-Guillemin Benoist. Portrait d'une Negrèsse (1800), p. 214

Fig. 114: Diego Velázquez. La escena de Emaús. La mulata (c.1618-1622), p. 214

Figs. 115, 116 e 118: Modesto Brocos. Crioula de Diamantina (1894), pp. 215, 217, 218

Fig. 117: Claude Monet. Femme au jardin (1866), p. 217

Fig. 119: Ernert Hébert. Les Filles d'Alvito (1855), p. 218

Fig. 120: Modesto Brocos. Mulher (s.d.), p. 219

Fig. 121: Modesto Brocos. Feiticeira (c.1895), p. 220

Fig. 122: Eugène Delacroix. Michelangelo in his studio (1850), p. 220

Fig. 123: Modesto Brocos. A descascar goiabas (1901), p. 223

Fig. 124: Modesto Brocos. Crioula de Diamantina (1894), p. 225

Fig. 125: Charge Um quadro de Brocos (1894), p. 225

Fig. 126: Modesto Brocos. A redenção de Cam (1895), p. 239

Fig. 127: A redenção de Cam (detalhe), p. 240

Fig. 128: Ernest Hébert. Vierge orant (s.d.), p. 240

Fig. 129: Ernest Hébert. Sainte debout et deux figures à ses pieds (s.d.), p. 240

Conclusão:

Fig. 130: José Ferraz de Almeida Júnior. Negra (1891), p. 261 
Fig. 131: José Ferraz de Almeida Júnior. Caipira picando fumo (1893), p. 262

Fig. 132: Modesto Brocos, charge na Gazeta de Notícias “Na exposição de Belas Artes - Picando Fumo Quadro de Almeida Júnior...” (1894), p. 264

Fig. 133: José Ferraz de Almeida Júnior. Cozinha caipira (1895), p. 268

Fig. 134: José Ferraz de Almeida Júnior. Apertando o lombilho (1895), p. 268

Fig. 135: José Ferraz de Almeida Júnior. Partida da monção (1897), p. 269

Fig. 136: José Ferraz de Almeida Júnior. Mendiga (1899), p. 270

Fig. 137: José Ferraz de Almeida Júnior. Negra (1891), p. 270

Fig. 138: Antonio Ferrigno. A quitandeira (s.d.), p. 272

Fig. 139: Antonio Ferrigno. Monjolo (c. 1895), p. 274

Fig. 140: Antonio Ferrigno. Nativa (s.d.), p. 275

Fig. 141: Antônio Rafael Pinto Bandeira. Moça sentada (1866), p. 279

Fig. 142: Antônio Rafael Pinto Bandeira. Feiticeira (1890), p. 281

Fig. 143: Antônio Rafael Pinto Bandeira. Jovem adormecida (1891), p. 283

Fig. 144: Antônio Rafael Pinto Bandeira. Cabeça de homem (1891), p. 284

Fig. 145: Peter Paul Rubens. Studies of a Male Head (c. 1617), p. 286

Fig. 146: Arthur Timótheo da Costa. Estudo de cabeças, d'après Peter Paul Rubens, (s.d.), p. 286

Fig. 147: Arthur Timótheo da Costa. Retrato de menino (1916), p. 287

Fig. 148: Arthur Timótheo da Costa. Ziza no ateliê (1919), p. 288

Fig. 149: Arthur Timótheo da Costa. Alguns Colegas (1921), p. 290 
Tu és dos de Cam, maldito, réprobo, anatematizado!

Cruz e Souza, Emparedado, 1898. 


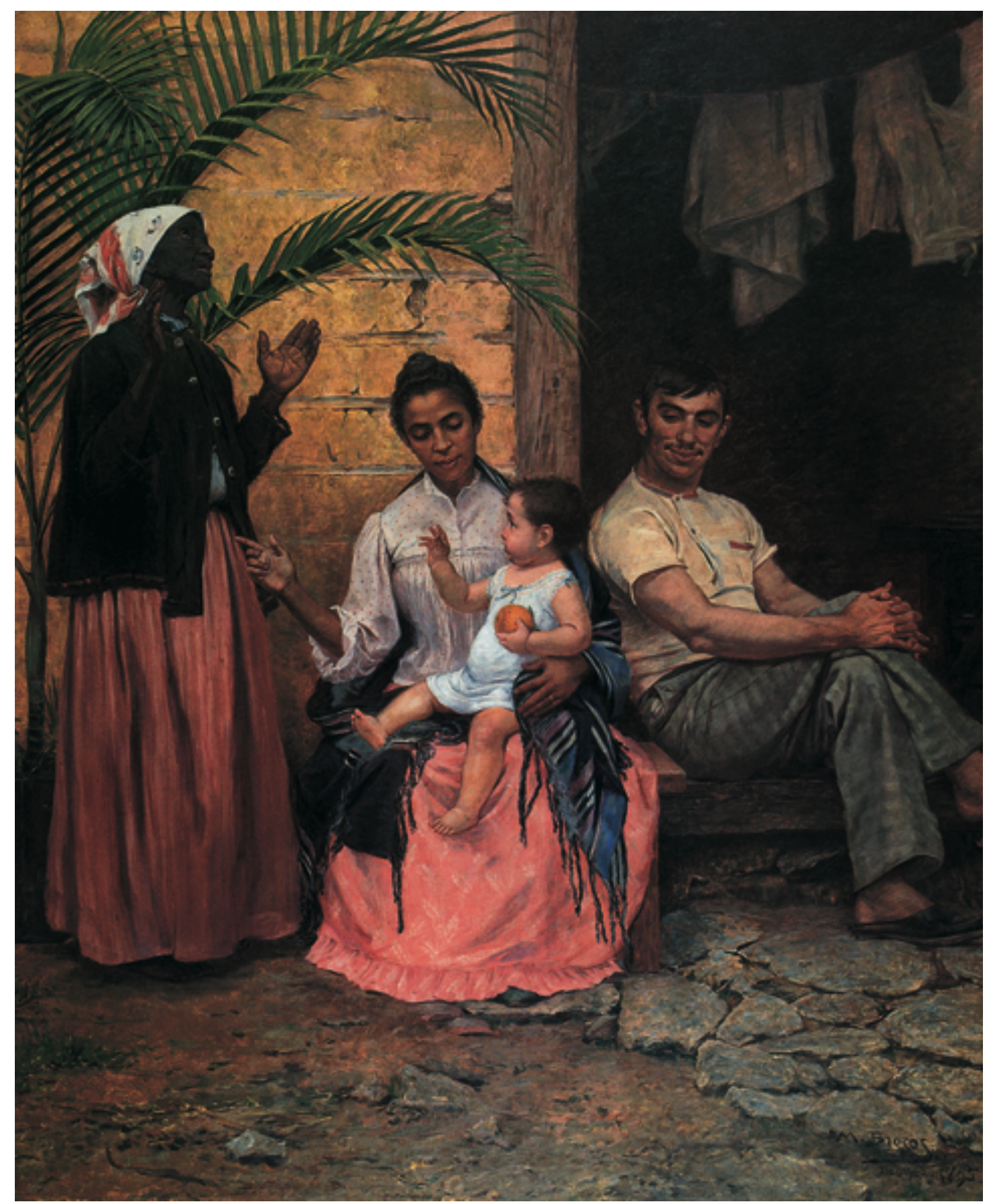

Fig. 1: Modesto Brocos. A redenção de Cam (1895). Óleo sobre tela, $199 \mathrm{~cm}$ x $166 \mathrm{~cm}$. Rio de Janeiro: Museu Nacional de Belas Artes. 


\title{
Apresentação
}

\author{
Não existe imagem simples. Qualquer imagem cotidiana faz parte \\ de um sistema, vago e complicado, pelo qual habito o mundo e graças ao \\ qual o mundo me habita \\ - Jean-Luc Godard, Aqui e alhures (1974).
}

Em pé, diante de uma palmeira, a senhora negra tem as mãos erguidas ao céu, como se agradecesse por um milagre. No centro da tela, uma jovem de pele mais clara está sentada. A personagem olha zelosa para o bebê em seu colo e aponta para a outra mulher, com ares de ensinamento - ainda que o ângulo percorrido pelo indicador pareça estranhamente não encontrá-la. A criança está completamente voltada para a velha e olha para ela com a mão direita erguida, enquanto a outra segura uma laranja. Fecha-se um círculo, que pode ser visto como um núcleo narrativo em marcante relação com o passado, entre o lado esquerdo e o centro da tela ${ }^{1}$ : avó e neto intercambiam impressões, sob mediação da mãe. À direita, um homem que cumpre o papel de pai nessa composição sorri, timidamente. Ele tem as costas viradas para a mulher, mas olha de esgueira para o menino. Não se tocam. De todas as figuras, este é o único que tende para fora do evento anunciado pela imagem, pois apenas seus olhos se voltam ao centro e àquele núcleo de figuras que interagem entre si. É diferente, portanto, da senhora, que tem o corpo virado para o centro, a despeito da tendência geral à verticalidade. Atrás dele, um varal com roupas brancas penduradas se faz ver na área interna da casa, colorida pelo amarelo fresco do pau-a-pique.

A senhora repousa em sua prece. Tem as mangas do casaco puídas e os pés descalços sobre a terra, sob o sol que faz resplandecer o lenço branco em sua cabeça, mas também lhe reforça uma indefinição no rosto. Os pés da filha, sentada na dupla transição da parede ao batente da porta, mas também do chão de terra ao pavimento de pedra, já estão calçados, como os de seu marido, que pisa plenamente em solo pétreo. A jovem mulher não usa roupas gastas como as de sua mãe e porta uma aliança no dedo, cuja visibilidade é redobrada pelo tamanho desproporcional da mão

\footnotetext{
${ }^{1}$ Como primeiro mostrou o téorico da arte Heinrich Wölfflin, o sentido da leitura ocidental, da esquerda para a direita, faz com que se tenha a sensação de que o porvir está à direita, e o passado à esquerda. Na tela de Brocos, esse efeito é reforçado pelo fato de a avó estar à esquerda. Cf. WÖLFFLIN, H. Conceitos fundamentais da história da arte. SP, Martins Fontes, 2001.
} 
esquerda, extrapolando a convenção imposta pelas leis da anatomia. Apesar de nãobrancas, nenhuma das mulheres usa trajes marcados por sinais "étnicos" evidentes: ambas se ajustam ao que por convenção é tomado como a moda ocidental e têm os corpos completamente recobertos. A primeira usa blusa azul clara, paletó verde musgo e saia azul escura, com um lenço branco e vermelho na cabeça, recobrindo os cabelos. A segunda, uma blusa estampada e saia em tons de rosa e xale de listras azuis e lilás, com cabelo preso em coque. $\mathrm{O}$ bebê veste uma bata de brancura resplandecente, cujo decote vem entrelaçado por uma fita azul celeste. Seus cabelos apresentam ondulações suaves e um tom castanho escuro. Se o centro da tela emana brancura na pele e no traje do menino - que constitui assim o ponto mais claro de toda a cena - o pai se torna opaco ao seu lado, apesar da similitude reforçada pelos marcadores de gênero (estas são as personagens de sexo masculino); raça/cor da pele (os dois são brancos, segundo a economia da obra); e vestimenta (eles usam os mesmos matizes: calça do pai é azul e a blusa, também branca, ligeiramente gris). As mangas curtas do adulto exibem braços fortes de trabalhador que, nesse momento de descanso em família, calça chinelas e esboça um sorriso.

A diferença de tom na pele das personagens merece atenção. Varia do marrom escuro (a avó) ao branco dourado pela luz solar que banha a cena (o bebê), passando pelo amarelo cálido da mãe e o tom de branco mais acinzentado da pele do pai. Diante da naturalidade com que as demais figuras harmonizam com o ambiente, a idosa captura a atenção: o matiz que colore sua pele é menos natural, como se a espessa camada de tinta em seu rosto conferisse a ela um aspecto argiloso, de feições menos nítidas que as de sua descendência. Também lhe falta o contraste e a profundidade que as sombras no rosto sabem incutir às demais figuras. Dessa forma, a velha senhora lembra uma espécie de estátua de barro na cor, textura da pele, rigidez da posição e gestual e na configuração menos nítida de suas expressões, realçada pela uniformidade da mancha de tinta que lhe recobre a face.

Por seu aspecto iconográfico ${ }^{2}$, o quadro $A$ redenção de Cam alude às natividades e demais imagens da Sagrada Família, incorporando também referências

\footnotetext{
${ }^{2} \mathrm{O}$ termo aqui corresponde à definição de Panofsky, para quem iconografia diz respeito ao segundo nível de interpretação de uma obra de arte, ou seja, o nível da decodificação da imagem por suas convenções. Além deste nível, os autor propõe articular a impressão inicial a partir da forma mais imediata (nível 1) e o ambiente histórico, geográfico, social, filosófico ou conceitual de produção da obra (nível 3) em sua interpretação. Em resumo, o modelo proposto por Panofsky depende de uma delimitação da dimensão natural da imagem (identificação de formas puras e qualidades
} 
emprestadas de outros motivos canônicos da iconografia cristã e/ou brasileira. Aqui a laranja parece fazer as vezes da velha maçã que inaugura o pecado original, impondo caráter tropical a esta alegoria e convertendo o fruto proibido em coisa distinta, autorizada, ao mesmo tempo em que aclimatada ao meio natural. As roupas brancas no varal falam à purificação de quem livra o tecido dos fluidos do corpo, habilitandoo a recobrir outra vez a intimidade das naturezas. A palmeira, por sua vez, possui um histórico particular nos trópicos, remetendo, do ponto de vista iconológico ${ }^{3}$, à palmeira imperial de D. João ${ }^{4}$, mas também ao dendezeiro, espécie tipicamente africana trazida pelos escravos a bordo dos navios negreiros. Neste caso, instaura-se uma correlação imediata, confirmando-nos o que os pés descalços e as mangas puídas, para além da cor da pele, já insinuavam: a senhora em cena teria sido escrava e, quiçá, proveniente da África.

Palmeira, laranja, roupas no varal e nos corpos, tons de pele, posturas e gestuais introduzidos na configuração estética da cena convergem para seu caráter alegórico, que o nome do quadro, A redenção de Cam, procura tornar explícito. No Genesis 9, Cam, filho de Noé, é castigado por revelar a nudez paterna aos irmãos, Sem e Iafet, desfazendo da situação e dos efeitos do vinho sobre o patriarca. Em reação contrária à de Cam, estes cobrem o corpo do pai, com os rostos voltados para trás para não vê-lo. Já desperto, Noé vem a saber do infortúnio e lança uma maldição irreversível sobre o ramo camita da família: condena o filho de Cam, Canaã, a ser escravo dos tios Sem e Iafet, estendendo o mesmo castigo ao conjunto de sua descendência. Ao sobrepor escravidão e interracialidade a um episódio bíblico, recontado à luz da passagem intergeracional de negro a branco, a pintura faz as vezes

expressionais); a interpretação iconográfica (articulação entre motivos artísticos e conceitos); e a penetração de seu significado intrínseco ou conteúdo como expressão de valores situados (nível 3). PANOFSKY, E. "Iconografia e Iconologia: Uma introdução ao estudo da arte da Renascença". In: Significado nas Artes Visuais. São Paulo: Perspectiva, 1986, pp. 47-65

${ }^{3}$ Idem, ibidem.

${ }^{4}$ Conta-se que em 1829 , na primeira florada da árvore matricial, o diretor do jardim botânico do Rio, Bernardo de Serpa Brandão, ordenou a queima de todas as sementes da planta. Em seus desígnios, imaginava a palmeira, símbolo da nobreza e do Império, como exclusividade vegetal daquele jardim. Entretanto, tendo a própria realeza por hábito oferecê-la aos súditos mais fiéis como símbolo de lealdade, e ante à identificação da espécie a uma imagem almejada de nobreza e distinção, um grupo de escravos decidiu coletar as sementes, antevendo um bom negócio em sua venda - quiçá, com chances de comprar-lhes a alforria. De qualquer forma, hoje sabemos que o plano não vingou e a palmeira imperial espraiou-se pelo país, convertendo-se em símbolo nacional. Cf. NEPOMUCENO, R.; SANT'ANNA, A. O Jardim de D. João: a aventura da aclimatação das plantas asiáticas à beira da lagoa e o desenvolvimento do Jardim Botânico do Rio de Janeiro, que vence dois séculos de umidade, enchentes, transformações da cidade, novos padrões científicos e mantém-se exuberante, com seus cientistas e suas árvores. Casa da Palavra, 2007, pp. 47-48. 
de exegese, alinhando-se a diversas interpretações das escrituras que atribuíam ao castigo impetrado pelo patriarca um enegrecimento da pele de Cam e/ou Canaã e seus descendentes e, desse modo, construíam um vínculo imediato entre escravidão e pele negra. Mas agora, todo o sentido da ideia de redenção, anunciada no título da obra, está ligado ao processo embranquecedor, visto como uma reversão da pena bíblica.

"Muito embora muitíssimo bem pintada, trata-se, sem dúvida, de uma das

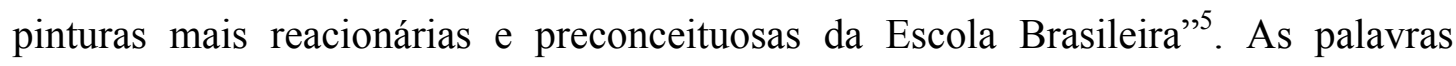
constam do Dicionário Crítico da Pintura no Brasil (1988), de José Roberto Teixeira Leite, em verbete sobre o quadro A Redenção de $\mathrm{Cam}^{6}$, do espanhol Modesto Brocos y Gómez (1852-1936). O parecer, emitido quase 90 anos após a primeira aparição pública do quadro, é provocador, e convida a um olhar mais atento para a tela. Em consonância, Rodrigo Naves observa que a mesma imagem é "atravessada por uma riqueza de detalhes patética, que tende apenas a dar um aspecto arejado a um significado absolutamente preconceituoso",7. Por seu turno, Maria Cecília França Lourenço afirma: "Relembre-se um dos expoentes do pensamento discriminatório deplorável, desejando o branqueamento da raça, a célebre Rendição [sic] de Cam"8.

O rechaço no presente da tela se contrapõe à sua exaltação no passado. Em seus $200,7 \mathrm{~cm} \times 166,4 \mathrm{~cm}$, esse retrato de família recebeu, no ano em que veio a lume (1895), a medalha de ouro da Exposição Geral de Belas Artes, o principal certame artístico do país. Pintada no início do período republicano brasileiro e pouco depois da emancipação, a imagem parecia então canalizar preocupações correntes quanto à incorporação dos ex-escravos e seus descendentes à ordem livre de uma nova sociedade nacional, especialmente ao abordar de forma direta a transformação da população de ascendência negra em branca, por meio das uniões interraciais. Assim, a variabilidade racial do núcleo familiar em cena é fundamental para a composição, podendo-se dizer que $A$ redenção de Cam encontra uma razão de ser na tentativa de

\footnotetext{
${ }^{5}$ LEITE, T. J. R. Dicionário Crítico da Pintura no Brasil. RJ: Artlivre, 1988, p. 177.

${ }^{6}$ A imagem 1, pertencente ao acervo do Museu Nacional de Belas Artes, no Rio de Janeiro.

${ }^{7}$ NAVES, R. Almeida Júnior: O sol no meio do caminho. Novos Estudos-CEBRAP, 73, nov. 2005, p. 138.

${ }^{8}$ LOURENÇO, M. C. F. Debates e posturas - Tempo humano. In: Almeida Júnior: um criador de imaginários. Catálogo da exposição na Pinacoteca do Estado. São Paulo, 25 jan.-15 abr. de 2007, p. 95.
} 
explorar as diferenças de gradação entre os tons de pele da avó negra; da mãe, de pele amarelo-dourada; do pai e do neto, brancos e, assim movimenta um jogo de expectativas quanto à definição racial $^{9}$ dessas figuras.

Tendo em vista que as personagens se tornam mais claras no correr das gerações da família retratada, a pintura pode ser entendida como uma mensagem em defesa da mescla racial ${ }^{10}$ orientada ao embranquecimento. É, por isso, sem dúvida preconceituosa sob o olhar de hoje - e os críticos estão corretos ao apontá-lo. Se de fato ela se insere, já por seu título, na tradição do pensamento euro-americano sobre raça - e mais especificamente, na vertente que remete às primeiras exegeses do Genesis 9, acoplando a pele negra e/ou a escravidão à ideia de danação, penalidade ou castigo -, tampouco se pode ignorar um episódio particularmente marcante na história do quadro: em 1911, ele serviu para ilustrar a tese que João Batista de Lacerda, médico, antropólogo e diretor do Museu Nacional, levou ao I Congresso Internacional das Raças, em Londres. Segundo o cientista, a tela mostrava que, em três gerações, uma "seleção sexual" ${ }^{11}$ permitiria alcançar o branqueamento da raça negra em solo nacional. Desse modo, a pintura ajudava a refutar a imagem do Brasil como "um exemplo do cruzamento extremado de raças"12, afirmando que "a mestiçagem brasileira seria (apenas) transitória e benéfica, uma vez que não deixaria rastros ou pistas"13, como observa Schwarcz. Na economia das intenções de Lacerda, portanto, o quadro também encarnava aquilo que poderia ser visto como a perspectiva popular sobre o tema - sua existência acenaria para entendimentos consolidados.

\footnotetext{
${ }^{9} \mathrm{O}$ emprego do conceito de raça nesta dissertação vai ao encontro da proposta de Guimarães: longe de reivindicar uma realidade biológica das raças, defendemos que tal conceito permite "desmascarar o persistente e sub-reptício uso da noção errônea de raça biológica, que fundamenta as práticas de discriminação, e tem na cor (...) a marca e o tropo principais” GUIMARÃES, A. S. A. Racismo e AntiRacismo no Brasil. São Paulo: Editora 34, 1999, p. 68.

${ }^{10}$ Os termos "mescla", "mistura", "amálgama", "miscigenação" e "mestiçagem", entre outros, referemse ao mesmo processo e adquirem pesos semânticos diferenciados de acordo com seu uso por autores, fontes ou contextos históricos distintos. Nesta dissertação, optamos por utilizar prioritariamente as palavras "mescla" e "mistura", a não ser quando citamos ou parafraseamos fontes que empregam outros termos. Agradecemos à professora Maria Helena P. T. Machado, por chamar a atenção aos impasses por trás dessa terminologia: ao referir-se à possibilidade de sucessão genealógica gerada pelas uniões interraciais, as palavras invariavelmente acarretam uma compreensão essencialista do termo raça. É válido reforçar, a esse respeito, a profunda inscrição desses termos num processo de etnogênese euro-americano.

${ }^{11}$ LACERDA. J. B. Sobre os mestiços no Brasil. Tradução de "Sur le métis au Brésil" (Premier Congrès Universel des Races: 26-29 juillet 1911, Paris, Devouge, 1911) In: SCHWARCZ, L. K. M. Previsões são sempre traiçoeiras. João Baptista de Lacerda e seu Brasil branco. In: História, Ciências, Saúde Manguinhos. RJ, v.18, n.1, jan.-mar. 2011, p. 228.

${ }^{12}$ SCHWARCZ, L. K. M. Previsões são sempre traiçoeiras. João Baptista de Lacerda e seu Brasil branco. In: História, Ciências, Saúde - Manguinhos. RJ, v.18, n.1, jan.-mar. 2011, p. 226.

${ }^{13}$ Idem, ibidem, p. 227.
} 
Não obstante sua indexação a esse episódio, a tela o antecipa em 16 anos e, com isso, convida a refletir sobre sua especificidade e independência com relação ao argumento do cientista. Se a imagem possui certas qualidades que permitiram sua apropriação por Lacerda, também nos parece fundamental perguntar em que medida ela se revela capaz de produzir sua própria tese sobre o embranquecimento e, mais além, de que modo possibilita vislumbrar esta tese a partir das propriedades materiais que lhe são específicas e por meio das quais inaugura uma narrativa particular acerca do tema ${ }^{14}$.

$\mathrm{Na}$ presente dissertação, procuraremos abordar distintos níveis de reflexão engendrados pelo quadro $A$ redenção de Cam. Porquanto a imagem se tem mostrado capaz de articular tão propriamente o problema do preconceito, também suscita reflexões sobre a consolidação de um marco de pensamento que embasa (e exprime) a constituição da branquitude - ou das distintas formas de percepção e auto-percepção que se assentam na prerrogativa de que ser branco constitui um privilégio que habilita outros privilégios $^{15}$ - no Brasil.

Nutrimos a hipótese de que $A$ redenção de Cam de fato propõe um modelo de reflexão pictográfica sobre o embranquecimento, procurando demonstrar uma tese acerca do tema. Por esse motivo, ela converte-se num objeto privilegiado para auferir o peso da dimensão estética na conformação do preconceito racial e do racismo, ao combinar atributos próprios à forma pictórica a um determinado entendimento das relações chamadas raciais no Brasil.

Aprofundaremos esta proposição mais adiante. Antes, é preciso compreender de que maneira a bibliografia já produzida sobre $A$ redenção de Cam também reforça o peso das discussões sobre o branqueamento na abordagem da tela; e apresentar algumas informações preliminares, que possibilitem situar Modesto Brocos enquanto artista e introduzir sua obra, além de esclarecer as escolhas teórico-metodológicas que norteiam a presente dissertação.

\footnotetext{
${ }^{14}$ A esse respeito, também é preciso indicar que não foi encontrado qualquer indício que aponte para uma encomenda da pintura por Lacerda.

${ }^{15}$ DYER, R. White. London and New York: Routledge, 1997. MISKOLCI, R. O desejo da nação: masculinidade e branquitude no Brasil de fins do XIX. São Paulo: Annablume, 2012. HIRANO, L.F.K. $\mathrm{O}$ imaginário da branquitude à luz da trajetória de Grande Otelo: raça, persona e estereótipo em sua performance artística. In: Afro-ásia, n. 48, no prelo.
} 


\section{Discussão bibliográfica: o embranquecimento, como o tema da pintura}

Até o presente momento, A Redenção de Cam não foi objeto de pesquisas acadêmicas mais aprofundadas, assim como não o foram as demais produções de Modesto Brocos ${ }^{16}$. Entretanto, esta é a tela mais conhecida do artista e também a mais citada, no conjunto de sua obra - ainda que a maioria dessas menções a utilizem a título de contraponto com outros quadros, ou como ilustração dos debates sobre o pensamento científico racial no Brasil da Primeira República. Destarte, a referência ao paper de João Batista de Lacerda é recorrente.

Identificamos dois focos de interesse prioritários nas análises que passam por A redenção de Cam: o primeiro engloba trabalhos de pesquisadores de diversas áreas, interessados nos debates sobre o racismo, a interracialidade e as teorias raciais no Brasil e também nos Estados Unidos. O segundo envolve pesquisas que discutem o tema da representação do negro na pintura, feitas sobretudo por historiadores e críticos de arte.

Um primeiro subconjunto de estudos cita o uso do quadro no episódio protagonizado por João Batista de Lacerda. Destacamos Seyferth ${ }^{17}$; Schwarcz ${ }^{18}$; Santos e Maio $^{19}$; e Hofbauer ${ }^{20}$, cujo objetivo é investigar a penetração e o teor das teorias raciais de caráter cientificista no Brasil da Primeira República e discutir o sistema de classificação com base no critério raça no país. Apesar da pintura não ser o tema imediato de seus trabalhos, todos os autores acentuam sua importância documental para os debates que desenvolvem.

Em artigo recente, Seyferth explora a pintura em maior detalhe e provê elementos elucidativos acerca de suas conexões com o mito bíblico que a nomeia, preservando o

\footnotetext{
${ }^{16}$ A exceção parece ficar por conta de NUNES, J. L. S. Modesto Brocos e a "Retórica dos Pintores". Tese de Doutorado (em andamento), Programa de Pós-Graduação em Artes Visuais da Escola de Belas Artes, Universidade Federal do Rio de Janeiro. Três estudos de menor profundidade merecem atenção: NUNES, J. L. da S.. Modesto Brocos: A Retórica dos Pintores. 19\&20, Rio de Janeiro, vol. V, n. 1, jan. 2010. Disponível em: http://www.dezenovevinte.net/criticas/mb_retorica.htm; JAUREGUÍZAR, A. El viaje a Marte de Modesto Brocos. In: ARBOR Ciencia, Pensamiento y Cultura, 740, nov-dez 2009, pp. 1313-1332; CAPEL, H. S. F., JUNIOR, G. W. Performances híbridas no pensamento utópico de Modesto Brocos y Gomez (1852-1936). In: Estudos Ibero-Americanos, PUCRS, v. 38, n. 2, jul./dez. 2012; e MASSÉ, M. C. Modesto Brocos. Artistas Galegos, Ed. Nova Galícia, 2000/1.

${ }^{17}$ SEYFERTH, G. João Baptista Lacerda. In: Revista do Museu Paulista, n.s., 30, 1985.

${ }^{18}$ SCHWARCZ, L. K. M. O espetáculo das raças. SP, Companhia das Letras, 2004.

${ }^{19}$ SANTOS, R. V.; MAIO, R. V. (orgs.) Raça, Ciência e Sociedade. RJ, Editora Fiocruz/CCBB, 1996.

${ }^{20}$ HOFBAUER, A. Uma história do branqueamento ou o negro em questão. São Paulo: Editora UNESP, 2006.
} 
enfoque sobre a participação de Lacerda no Congresso das Raças. A antropóloga assume a posição de que a tela "demonstra um fato científico"21 (grifos nossos), qual seja, a tese do médico carioca sobre o branqueamento.

Schwarcz é outra autora a revisitar em tempos recentes a imagem emblemática de $A$ Redenção de Cam. Atenta ao risco representado pelas leituras unívocas sobre a arte, situa os vínculos entre a tela e as projeções sobre o futuro racial do país feitas por Lacerda, mas também propõe uma interpretação alternativa de sua mensagem, ancorada pelo uso da iconografia religiosa por Brocos:

\footnotetext{
A tela permite também outra leitura, quem sabe menos científica. Num contexto marcado pelo catolicismo popular, a representação ganha um tom 'milagreiro'. A velha negra olha para os céus e, com um gesto milenarmente repetido e expresso pelas mãos, parece agradecer pela graça divina recebida. Mãe e pai olham orgulhosos para o filho, o qual, colocado bem no centro da cena, parece com Cristo na manjedoura. Dessa maneira, o que a ciência não resolvia, a crendice dava conta ${ }^{22}$.
}

Assim, a autora interroga esse objeto, buscando em certa medida problematizar o lugar que lhe foi atribuído em meio aos debates sobre o racismo na Primeira República - e com isso aventa novas possibilidades para sua interpretação.

Stepan, por sua vez, não se concentra no debate sobre as teorias raciais no Brasil, mas inclui a tela em seu estudo sobre representações dos trópicos entre os séculos XVIII e XX. Esta autora considera o quadro uma "representação dramática da fantasia brasileira da regeneração racial nos trópicos por meio do branqueamento" 23 , que em sua opinião "afirma o que Lacerda estava argumentando verbalmente" ${ }^{24}$.

Já os trabalhos de Sollors e Brody chamam atenção para o tema da miscigenação e da interracialidade, sem mencionar a apropriação da tela por Lacerda. Sollors detalha o percurso de transformações sofridas pela lenda bíblica sobre a maldição de Cam a partir de uma admirável quantidade de fontes textuais e visuais. A pintura de Brocos é um dos pontos de uma sequência mais ampla, qual seja, sua análise sobre a literatura a respeito da interracialidade, e serve para iluminar uma diferença marcante entre Brasil e Estados Unidos. Segundo o crítico literário, o que o escritor escravista norte-americano John Fletcher via como fonte de uma maldição (a mistura de raças), Brocos retratava como saída

\footnotetext{
${ }^{21}$ SEYFERTH, G. O futuro era branco. In: Revista de História, 2011.

${ }^{22}$ SCHWARCZ, L. K. M. Previsões são sempre traiçoeiras. João Baptista de Lacerda e seu Brasil branco. In: História, Ciências, Saúde - Manguinhos. RJ, v.18, n.1, jan.-mar. 2011, p. 229.

${ }^{23}$ STEPAN, N. L. Picturing tropical nature. London, Reaktion Books, 2006, p. 142.

${ }^{24}$ Idem, ibidem.
} 
que permitiria livrar-se do castigo. No entanto, como mostra Sollors, "this is hardly a view free of preconceptions, as it presumes the identification of whites as a racially chosen people. Even the (rare) redemptions of the curse may thus show what Patrick Girard has called "pigmentocracy",25.

Na visão de Brody, A Redenção de Cam é um exemplo incomum de exibição pública da "cladestine, illicit nature" ${ }^{, 26}$ das relações interraciais; ao inserir esta imagem entre fontes que elucidam a construção da feminidade na cultura vitoriana, a autora conclui que "the mulattaroon performs as an iconic sign of miscegenation, whose signification summarizes otherwise unrepresentable, unspeakable acts" ${ }^{27}$. Esta última perspectiva, que parece viabilizada por um olhar pautado pelo modelo de classificação racial binária adotado nos Estados Unidos, ilustra, ao lado de Sollors, um caminho de reflexão possível, que acentua o debate sobre a construção do desejo em clave interracial nos contextos coloniais, falando em miscigenação e não necessariamente em branqueamento.

O que é particularmente sugestivo nessas leituras é seu potencial de evidenciar diversas dimensões do debate racial, instigando a repensar a arraigada tradição do pensamento brasileiro sobre raça/cor (calcada na ideia de embranquecimento), em paralelo com outros modelos, notadamente, o norte-americano. Assim, Sollors tece considerações profícuas sobre determinados modelos classificatórios que hesitam em classificar como brancos os descendentes de uniões interraciais, contribuindo para alargar as dimensões do problema relativo aos sistemas de categorização e reconhecimento que partem do critério racial e colocando novas questões diante da tela. Por outro lado, ao discorrer sobre a pintura, ambos os autores tendem a vê-la como ilustração do contexto social que habilita seu enquadramento crítico - deixando de indagar este objeto como veículo produtor de interpretações acerca do universo relacional ao qual se vincula (o que, de todo modo, foge aos propósitos de suas investigações).

Por seu turno, os estudos de história e crítica de arte, que em sua maioria abordam a tela de Brocos em perspectiva comparada, possuem em comum a preocupação com a representação do negro e suas determinantes na pintura brasileira e primam por avaliar as

\footnotetext{
${ }^{25}$ SOLLORS, W. Neither black, nor white, yet both. Thematic explorations of interracial literature. Harvard University Press, 1999, p. 102. Por "pigmentocracia", Girard entende uma democracia em que a cor da pele define hierarquias de poder - e em que, particularmente, os brancos ocupam as posições priviegiadas.

${ }^{26}$ BRODY, J. D-V. Impossible purities: Blackness, femininity and Victorian culture. Duke University Press, 1998, p. 21.

${ }^{27}$ Idem, ibidem.
} 
imagens com base num contexto histórico que destaca o papel das elites na definição de projetos de nação e o impacto das teorias racialistas sobre o Brasil do período.

Em artigo, Maraliz Christo elabora um breve panorama das pinturas com o tema da mulher negra que foram premiadas e/ou adquiridas pelo governo do Brasil na Primeira República, revelando sua escassez no período. Acerca de A Redenção de Cam, a historiadora pondera que o quadro seria considerado, a seu tempo, “demonstrativo de uma tese, mais do que interrogação sobre as condições de incorporação da mulher negra na sociedade brasileira" 28 . A observação é importante e convida a um aprofundamento, com base na interpretação mais detida da tela - o que foge ao recorte proposto pelo artigo, que privilegia a elaboração de um profícuo mapeamento sobre a presença da mulher negra na pintura nacional dessa época.

Em trabalho que pode ser visto em complementaridade com o artigo de Christo, a historiadora Renata Bittencourt também discute a imagem da mulher negra, mas amplia o escopo para a produção visual do século XIX como um todo. A Redenção de Cam é descrita nesta dissertação de modo bastante atento e a autora também passeia pelo episódio protagonizado por Lacerda, concluindo que "a obra traduz bem a perspectiva das elites sobre o negro e a consequente perspectiva da academia sobre sua imagem" 29 . Por fim, ela atribui à pintura de Brocos "o objetivo claro de ilustrar as teses de branqueamento correntes na época" $" 30$ e considera, à luz do modelo proposto pelo historiador norte-americano Albert Boime, que a pintura exprime preocupação quanto à "capacidade [do negro] de integrar-se na sociedade dominante" 31 .

Ambos os trabalhos apontam de maneira sugestiva para uma discussão em aberto, também indicada no trabalho mais recente de Seyferth, pois abrem espaço

\footnotetext{
${ }^{28}$ CHRISTO, M. C. V. Algo além do moderno: a mulher negra na pintura brasileira no início do século XX. 19\&20, Rio de Janeiro, v. IV, n.2, abr. 2009. Disponível em: $<$ http://www.dezenovevinte.net/obras/obras_maraliz.htm>. Última consulta: 13/05/2012, grifos nossos. ${ }^{29}$ BITTENCOURT, R. Modos de negra e modos de branca: o retrato "Baiana" e a imagem da mulher negra no século XIX. Dissertação de Mestrado em História da Arte e da Cultura apresentada ao Departamento de História do Instituto de Filosofia e Ciências Humanas da Universidade Estadual de Campinas, 2005, p. 89.

${ }^{30}$ Idem, ibidem, p. 89, grifos nossos. É importante reforçar que até o presente momento não foram encontradas fontes textuais em que Brocos afirme tal intenção.

${ }^{31}$ Idem, ibidem, p. 91. O referido modelo de Boime identifica "tendências para as obras dos artistas americanos do século XIX que trabalharam com a representação do negro. As três questões centrais que se apresentavam eram a desumanidade do sistema, a sua capacidade de integrar-se na sociedade dominante e seu potencial para subir além de seu estado 'selvagem' e alcançar o nível de esclarecimento "espiritual'". BOIME, A. The art of exclusion. Representing blacks in the Nineteenth Century. Washington\&London: Smithsonian Institution Press, 1990.
} 
para perguntar se a tela demonstra ou ilustra uma tese (ou teses) sobre o embranquecimento. Conforme comentamos, nossa hipótese é que a tela procura demonstrar uma tese sobre o assunto - e isto dependeria da capacidade do quadro de convencer seus contemporâneos quanto à viabilidade e/ou limitações do processo branqueador, inscrita primeiro nos corpos das personagens, mas também na composição geral da cena. Num período em que a ciência racialista extraía suas conclusões de estigmas ou sinais corporais mais evidentes, veremos que $A$ redenção de Cam procurou definir os atributos físicos denotativos do que pudesse ser visto como um potencial para o embranquecimento - o que ainda não contava com uma imagística consolidada naquele momento. Assim, a tela busca propor um modelo pictórico para o processo branqueador, a partir de construções específicas da corporalidade e caracterização das personagens - daí, sua peculiaridade. Nesse sentido, também é importante destacar que o próprio branqueamento constituía naquele momento uma hipótese em aberto, tanto do ponto de vista da ciência, quanto dos debates que ganhavam espaço na esfera pública.

$\mathrm{O}$ argumento nos conduz a um rumo distinto daquele assumido por outras três análises. A primeira, dos historiadores espanhóis Fernando Bueno e José Jiménez, considera que "o quadro de Brocos responde ao pensamento das elites intelectuais da República nascida no pós-abolição da escravatura e da queda do Império"32, baseando-se para isto numa contextualização histórica que busca tecer conexões entre o episódio bíblico de Cam e os debates raciais no período republicano.

Já a antropóloga Heloísa Lima observa "a problemática da oficialidade no âmbito das expressões artísticas" ${ }^{\text {"33 }}$ produzidas na Academia Imperial de Belas Artes e na Escola Nacional de Belas Artes, a partir do que define como presença negra na pintura. Por meio desse recorte, ela identifica em Brocos "uma forma de representar, reificadora de idéias que defendem a inferioridade da população negra"34 que iria ao encontro de um discurso oficial.

\footnotetext{
${ }^{32}$ BUENO, F.; JIMÉNEZ, J. A Redención de Cam de Modesto Brocos. Estudios Migratórios, n. 9, 2000, p. 120 , grifos nossos.

${ }^{33}$ LIMA, H. P. A presença negra nas telas: visita às exposições do circuito da Academia Imperial de Belas Artes na década de 1880. 19\&20, Rio de Janeiro, v. III, n. 1, jan. 2008. Disponível em: http://www.dezenovevinte.net/obras/obras negros.htm.

${ }^{34}$ Idem, ibidem.
} 
Por seu turno, Rafael Cardoso ${ }^{35}$ empreende uma análise formal da tela, em que procura tornar evidente o esforço de Brocos para construir conexões internas à obra, de modo a convencer o espectador de sua mensagem, favorável ao embranquecimento. Ele conclui que o êxito da imagem teria sido seu realismo aos olhos do público.

Os três estudos introduzem reflexões importantes. Entretanto, procuraremos mostrar que os debates sobre o embranquecimento não convergiam para um consenso - o que também nos obriga a recolocar a discussão sobre o realismo da tela no período de sua produção. Introduziremos em nossas reflexões novos elementos, como o fato da própria crítica de arte produzida no período ter estado dividida diante da obra, o que fica patente, por exemplo, num artigo que questiona a adequação das figuras às leis da seleção natural ${ }^{36}$. Assim, empreenderemos um esforço para adensar a discussão sobre os sentidos de realismo do quadro à luz do debate sobre estilo e do recurso à crítica do período.

Em abordagem distinta, Nelson Inocencio ${ }^{37}$ procura pensar o quadro com base na semiótica greimasiana, numa comparação com a cédula de 500 cruzeiros, comemorativa do sesquicentenário da independência, que circulou durante a Ditadura Militar. A análise é original, na medida em que se atém à economia interna do quadro, e possibilita compreender a prevalência de uma visão que promove a ideologia do embranquecimento nesses dois objetos visuais. Nesse sentido, o autor argumenta que ambas as imagens fazem crer, por sua constituição formal, que ser branco resulta em benesses no seio da sociedade brasileira - contribuindo, assim, para um debate sobre as correlações entre o preconceito racial e o uso de determinadas formas visuais.

Em linhas gerais, é preciso sublinhar que esses autores fornecem elementos para delimitar o contexto de produção de $A$ redenção de Cam e inauguram um espaço de reflexão embasado por abordagens comparativas entre pinturas em que figuram personagens negras no período. Ao fazê-lo, abrem espaço para análises que discutam mais a fundo as particularidades dessas telas, sem descuidar do diálogo salutar entre elas.

Por fim, a mirada comparativa envolvendo $A$ Redenção de Cam também aparece num terceiro grupo de textos, que podem ser reunidos na medida em que estão

\footnotetext{
${ }^{35}$ DENIS, R. C. A arte brasileira em 25 quadros. SP, Record, 2008.

${ }^{36}$ NOTAS SOBRE ARTE. Jornal do Commercio, Rio de Janeiro, 7 set. 1895, p. 2

${ }^{37}$ INOCENCIO, N. A redenção do olhar: uma abordagem semiótica. In: Nguzu. Revista do Núcleo de Estudos Afro-Asiáticos da UEL, ano 1, nº 1, mar-jul 2011, pp. 116-123.
} 
fundamentalmente voltados ao exame de algumas pinturas de José Ferraz de Almeida Júnior (1850-1899) ${ }^{38}$. Desse modo, as três utilizam o quadro de Brocos sobretudo a título de contraste com pinturas do pintor ituano. Referimo-nos aos textos Debates $e$ posturas - tempo humano, de Maria Cecília França Lourenço ${ }^{39}$; O sol no meio de caminho, de Rodrigo Naves ${ }^{40}$; e Considerações sobre a representação do negro na obra de Almeida Júnior, de Daniela Perutti ${ }^{41}$.

O estudo de Lourenço, que integra o catálogo de uma exposição sobre Almeida Júnior, comenta a postura do artista ituano diante dos debates sociais de seu tempo - o lugar do negro, a pobreza, o trabalho. Naves analisa a tela Caipira picando fumo (1893), de autoria de Almeida Júnior; e Perutti se concentra em dois dos raros quadros deste pintor em que aparecem personagens negras ${ }^{42}$ : Negra (1891); e Partida da monção (1897). Esta autora e Naves enriquecem o exercício comparativo pela introdução da tela A Quitandeira, do italiano Antonio Ferrigno.

Em linhas gerais, nos dois primeiros casos, o paralelo busca evidenciar a originalidade de Almeida Júnior, visto como uma exceção em meio a uma época marcada por tendências racistas, mais imediatamente ilustradas pelo quadro de Brocos. Naves, particularmente, formula uma questão que inaugura um debate fundamental para as discussões sobre a pintura do período, qual seja, em que medida a obra de Almeida Júnior terá sido capaz de ultrapassar os determinismos ${ }^{43}$ de seu tempo. Acreditamos que é preciso

\footnotetext{
${ }^{38}$ Pintor de origem ituana, formado na Academia Imperial de Belas Artes, que se tornou célebre por suas telas que retratam caipiras em cenas de trabalho ou lazer. Diversos especialistas escreveram sobre o artista, com destaque para SOUZA, G. M. Pintura brasileira contemporânea: os precursores. In: Discurso. São Paulo, Faculdade de Filosofia, Letras e Ciências Humanas da Universidade de São Paulo, ano V, n. 5, 1974; LOURENÇO, M. C. F. Revendo Almeida Júnior, (Dissertação de Mestrado). São Paulo: ECA/USP, 1980; CHIARELLI, T. Um Jeca nos vernissages. São Paulo: EDUSP, 1995; COLI, J. A violência e o caipira. In: Estudos Históricos, vol. 2, No 30 (2002): Arte e História; PERUTTI, D. C. Almeida Júnior, gestos feitos de tinta. São Paulo, Alameda, 2011.

${ }^{39}$ LOURENÇO, M. C. F. Debates e posturas - Tempo humano. In: Almeida Júnior: um criador de imaginários. Catálogo da exposição na Pinacoteca do Estado. São Paulo, 25 jan.-15 abr. de 2007. A autora é especialista na obra do pintor ituano. Ver LOURENÇO, M. C. F. Revendo Almeida Júnior, (Dissertação de Mestrado). São Paulo: ECA/USP, 1980.

${ }^{40}$ NAVES, R. Almeida Júnior. O sol no meio do caminho. Novos Estudos-CEBRAP, 73, nov. 2005.

${ }^{41}$ PERUTTI, D. C. Considerações sobre a representação do negro na obra de Almeida Júnior. In: Perspectivas - Revista de Ciências Sociais, vol. 37 (2010). A antropóloga, especialista na obra de Almeida Júnior, também escreveu PERUTTI, D. C. Almeida Júnior, gestos feitos de tinta. São Paulo, Alameda, 2011.

${ }^{42}$ Esta autora, assim como Lourenço (op. cit.), não indica as demais telas de negros de Almeida Júnior. Além das mencionadas, encontramos uma personagem não-branca no retrato O Marroquino (1880), de viés orientalista.

${ }^{43} \mathrm{O}$ determinismo, como se sabe, foi uma corrente filosófica das mais importantes na constituição do realismo e do naturalismo na literatura e nas artes. São inúmeros os romances do período em que, nos momentos de tensão dramática, as personagens se descobrem determinadas por leis naturais que não controlam - sua constituição biológica, a natureza, o ambiente, as forças psíquicas e mesmo a posição
} 
levá-la adiante, a fim de alargar a compreensão do trabalho de outros artistas da mesma geração do pintor ituano. Por esse motivo, procuraremos inscrevê-la no marco de reflexões propostas nesta dissertação, na expectativa de ampliar tais debates.

O recorte proposto por Daniela Perutti traz novos elementos para a análise. Visto que propõe tratar especificamente a aparição de personagens negras na pintura de Almeida Júnior, a antropóloga abre espaço para um debate sobre o problema do preconceito na arte do período. Em primeiro lugar, ela evidencia uma quase ausência dessas figuras na produção almeidiana, em detrimento da valorização de "um certo tipo de caipira, mais produto do cruzamento do branco com o indígena do que o caipira negro ou mulato"44. Em segundo lugar, Perutti destaca que Almeida Júnior "não esteve vinculado explicitamente a discursos sobre o branqueamento por meio de suas pinturas, tal como Brocos em seu Redenção de Cam (...). Mas também optou por não representar o negro, mantendo apenas alguns discretos traços indígenas em seus caipiras" ${ }^{\$ 4}$. Assim, a antropóloga revela que a obra do pintor ituano, célebre pela imagem do caipira, apresenta uma faceta paradoxal quanto à presença de negros.

Abordaremos esse debate ao final da dissertação, como uma forma de convidar à continuidade das reflexões propostas. Além de Almeida Júnior, também incluiremos em nossa avaliação final telas de Antonio Ferrigno (1863-1940) ${ }^{46}$; Antonio Rafael Pinto Bandeira (1863-1896) ${ }^{47}$; e Arthur Timóteo da Costa $(1882-1923)^{48}$.

\section{Sobre Modesto Brocos e sua obra: notas teórico-metodológicas}

Espanhol compostelano de Santiago, Modesto Brocos nasce em 1852 em uma família de artistas e, com sólida formação na Europa, naturaliza-se brasileiro na década de 1890. É irmão mais novo do escultor Isidoro Brocos y Gómez (1841-1914), conhecido

social eram responsáveis por seus comportamentos e pelo destino que lhes aguardava. Um exemplo é a série de 20 romances intitulada Les Rougon-Macquart, publicada por Émile Zola (1840-1902) entre 1871 e 1893, cujo subtítulo era História Natural e Social de uma Família no Segundo Impéio. Cf. NORDMANN, J. T. Taine et la critique scientifique. Paris: Presses Universitaires de France, 1992.

${ }^{44}$ PERUTTI, D. C. Considerações sobre a representação do negro na obra de Almeida Júnior. Paper para o GT Pensamento Social Brasileiro, no XIV Congresso Brasileiro de Sociologia. RJ, 2009.

${ }^{45}$ Idem, ibidem, pp. 9-10.

${ }^{46}$ Pintor italiano que esteve em São Paulo de 1893 a 1905, onde produziu paisagens do interior de São Paulo e do litoral, valorizando tipos locais.

${ }^{47}$ Pintor formado na Academia Imperial de Belas Artes e professor do Liceu de Artes e Ofícios em Salvador, Bahia.

${ }^{48}$ Artista cuja formação inicial se deu no curso de desenho da Casa da Moeda e, depois, na Escola Nacional de Belas Artes (ENBA). Com uma trajetória prolífica como pintor e cenógrafo, em 1919 ele fundou a Sociedade Brasileira de Belas Artes. 
representante do renascimento regionalista galego da segunda metade do Oitocentos ${ }^{49}$, que o inicia na arte do gravado logo na infância. Massé ${ }^{50}$ pondera que o avô dos artistas, José Brocos teria sido gravador, dada a existência em coleções galegas de alguns exemplares de uma estampa da igreja da Nossa Senhora da Escravidão, datadas de 1865, que trazem sua assinatura. O pai de Modesto e Isidoro, Eugenio, também foi pintor e gravador, mas morreu cedo, quando o primeiro tinha quatro anos e o segundo, 14. Massé comenta que Modesto Brocos, cuja infância é marcada pela pobreza, chega a converter-se num dos principais xilógrafos do país, quiçá pela experiência precoce de aprendizagem do gravado, inclusive como forma de sustento. Além dos ensinamentos recebidos em casa, ele pôde receber uma formação artística inicial na Real Sociedade de Amigos do País, o único centro de Santiago que oferecia tal possibilidade naquele momento.

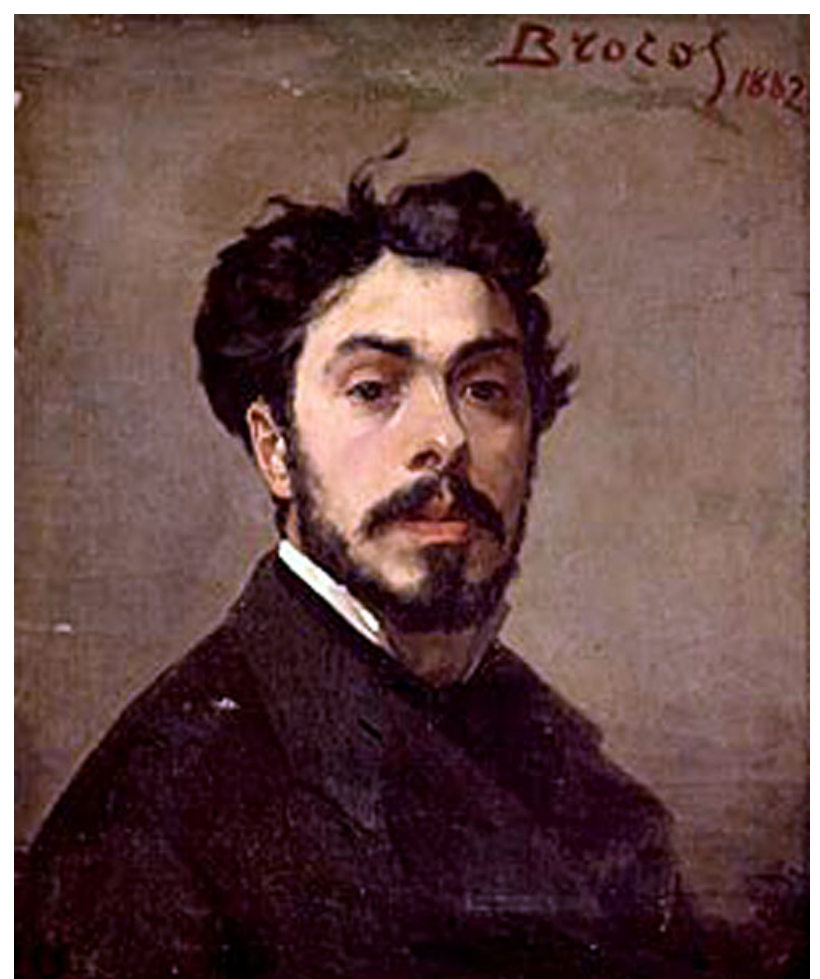

Fig. 2: Modesto Brocos. Autorretrato (1882). Óleo sobre tela, dimensões e paradeiro não localizados.

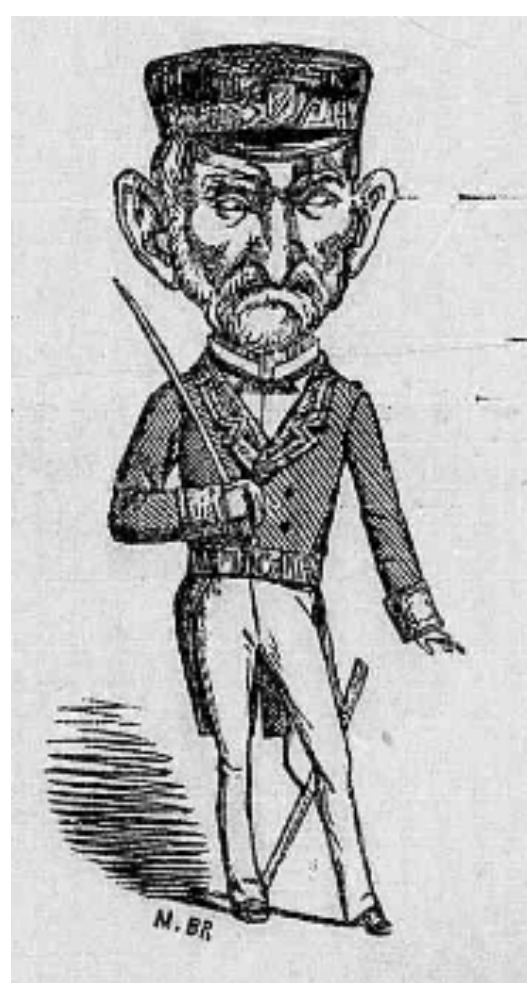

Fig. 3: Modesto Brocos. Ilustração para O Mequetrefe, ed. 2, janeiro de 1875, p. 3. A charge mostra personagem da crônica anônima $O$ reino de Nana.

\footnotetext{
${ }^{49}$ FERNÁNDEZ, X. J. B El Contexto Cultural Gallego (1880-1914) (La cultura urbana). In: Isidoro Brocos (1841-1914). Catálogo de exposição. Museu de Bellas Artes de A Coruña, 24/11/1989. VEGA, R. B. de la. Artistas y críticos españoles - siluetas de pintores, esculptores y críticos. Barcelona, 1891. MURGUÍA, M. Nuestro pensamiento. La Illustración Gallega y Asturiana, no 1, Madrid, 20 de marzo de 1879. LAMAS, M. C. "Isidoro Brocos". In: Isidoro Brocos (1841-1914). Catálogo de Exposição, Museu de Bellas Artes de A Coruña, de 24 de nov. a 22 de dez., 1989

${ }^{50}$ MASSÉ, M. C. Modesto Brocos. Artistas Galegos, Ed. Nova Galícia, 2000/1.
} 
A situação desfavorável à inserção artística na Galícia, segundo a mesma autora, terá impelido Modesto Brocos a deixar o país rumo à América do Sul em 1871. É assim que, aos 20 anos, ele desembarca no Rio de Janeiro, proveniente de Buenos Aires, onde trabalha como ilustrador de Los Anales de Agricultura. Já gravurista experiente e com formação em pintura e escultura, colabora na capital do Império com periódicos nacionais, como $O$ Mequetrefe, jornal republicano de sátira política $^{51}$, e atua como correspondente de revistas como La Illustración Española y Americana; La Illustración Gallega y Asturiana; e Artística. O pintor, aliás, é considerado o autor da primeira xilogravura publicada no Brasil, para $O$ Mequetrefe ${ }^{52}$.

A partir de 1875 participa, como aluno livre, dos cursos de Victor Meirelles (18321903); e Zeferino da Costa (1840-1915) na Academia Imperial de Belas Artes (AIBA). O primeiro, por sinal, é quem lhe propõe pela primeira vez pintar o tema de "Noé bebado"53, numa de suas aulas - o que sugere que talvez ele já estivesse pensando na composição que resultou em $A$ redenção de Cam desde a década de 1870. Através de Meirelles e da geração de artistas ligados à Academia nesse período, Brocos parece ter encontrado no país um ambiente capaz de aguçar o interesse pela temática que combinava as narrativas épicas ou bíblicas com a presença de tipos locais - o que impunha o desafio de explorar distintas tonalidades de tons terrosos na caracterização da pele de personagens consideradas tipicamente brasileiras $^{54}$-, num momento de ampla difusão

\footnotetext{
${ }^{51}$ Este periódico publica ilustrações de Brocos entre os anos de 1875 e 1876.

52 "Assim foi que $O$ Mequetrefe, redigido e litograficamente ilustrado pelo que de melhor existia à época na Corte, anunciou em seu número inaugural, de $1^{\circ}$ de janeiro de 1875 , que ia introduzir em suas páginas 'uma novidade: desenhos sobre madeira intercalados no texto'. E acrescentava: 'Sabe-se quanto é custosa entre nós a xilografia; a despesa portanto e as dificuldades com que vai tratar a empresa devem atrair-lhe a boa vontade do público, que tem' - findava tentando mascarar o seu pequeno golpe publicitário - 'só com isto, prova eloqüente de que O Mequetrefe não nasceu para negócio'. Importante é que o primeiro exemplo dessa novidade consistiu precisamente na primeira xilogravura publicada no Brasil pelo espanhol Modesto Brocos y Gómez (1852-1936), que aqui chegou em 1872, com 20 anos apenas. A colaboração, que consistia em vinhetas decorativas assinadas M Br. Brocos ou M. Brocos, ou mesmo sem assinatura, continuou, apesar de irregular, até 1876" FERREIRA, Orlando da Costa. Imagem e Letra: introdução a bibliologia brasileira a imagem gravada. SP: Edusp, 1994 , p. 200. Note-se também que segundo o mesmo autor, nos anos 1890 Brocos "salvo algum descobrimento inesperado, foi o primeiro gravador em metal que fez gravura de criação no Brasil" (idem, ibidem). Em outro trecho, diz que o artista foi o introdutor da técnica de gravura em água-forte no país.

${ }^{53}$ BROCOS, M. A questão do ensino de Bellas Artes, seguido de critica sobre a direção de Bernardelli e justificação do autor. Rio de Janeiro, 1915, p. 9.

${ }^{54}$ Brocos (idem, ibidem) comenta que "O velho mestre [Victor Meirelles], com a intenção de facilitar a tarefa do colorido, que tão grandes dificuldades offerece aos principiantes, nos fazia excutar, na palheta, series de combinações de diversas côres, o que nos tornava conhecedores de certos effeitos e que muito nos auxiliava no trabalho". Segundo Coli, na pintura de Meirelles "a cor é um dos fatores dentro da construção pictural, onde possui papel constitutivo". Ver COLI, J. A pintura e o olhar sobre
} 
do romantismo nativista também na literatura. Meirelles, como se sabe, foi o autor de pinturas em que a caracterização de tipos era central para a composição da cena, como se pode notar em telas como A batalha dos Guararapes, de 1879 (em que a presença dos negros é marcante $)^{55}$, que consolida alguns anos de reflexões do artista capixaba; e A primeira missa, de 1860 (celebrada na tela com largo contingente de indígenas). Tais composições pairam à sombra da ideia das três raças fundadoras da nação brasileira, ao gosto da historiografia de Von Martius, com uma preocupação em investigar tonalidades e traços característicos de cada grupo racial ${ }^{56}$.

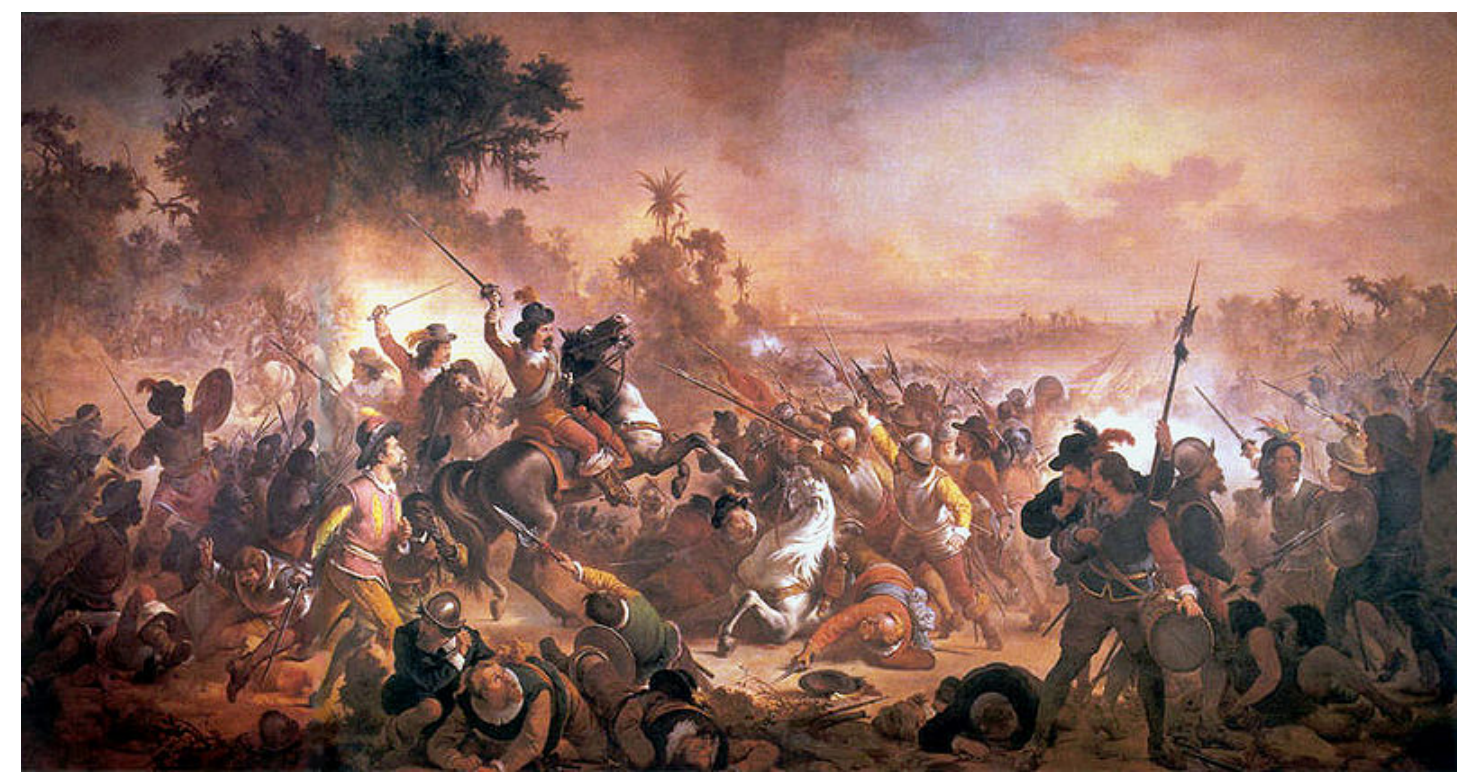

Fig. 4: Victor Meirelles. A batalha dos Guararapes (1875-9). Óleo sobre tela, $500 \mathrm{~cm}$ x $925 \mathrm{~cm}$. Rio de Janeiro: Museu Nacional de Belas Artes. A pintura, monumental, trata de um episódio da história nacional que é recontado como uma batalha que envolveu brancos, negros e indígenas na luta pela expulsão dos holandeses do Nordeste brasileiro. A despeito dos esforços, houve quem criticasse a cor dos negros em cena ${ }^{57}$.

De volta à Europa entre 1877 e 1890, Brocos estuda nos principais centros de referência artística, a saber, a Escola Nacional Superior de Belas Artes, em Paris; a Real Academia de Belas Artes de San Fernando, Espanha; o ateliê de Federico de Madrazo

si: Victor Meirelles e a invenção de uma história visual no século XIX brasileiro. In: FREITAS, M. C. (org.). Historiografia brasileira em perspectiva. SP: Editora contexto, 1998, p. 385.

${ }^{55}$ A respeito da data, é importante situar aqui o período em que o pintor trabalhou no quadro: de 1875 a 1879. Idem, ibidem.

${ }^{56}$ Pedro Américo, da mesma geração, em telas como Batalha de Campo Grande (1871); Batalha do Avahy (1877); e sobretudo Independência ou morte (1888), mostra preocupação semelhante, ao definir o colorido da população ou mesmo introduzir diferentes tipos locais. Para uma análise sobre o assunto, ver MATTOS, C. V. Independência ou morte!: O quadro, a Academia e o projeto nacionalista do Império. In: O brado do Ipiranga. SP: Edusp, 1999.

${ }^{57}$ Cf. GUARILHA, Hugo. A questão artística de 1879: um episódio da crítica de arte do II Reinado. 19\&20, Rio de Janeiro, v. I, n. 3, nov. 2006. Disponivel em: $<$ http://www.dezenovevinte.net/criticas/questao_1879.htm>. Consulta: 27/07/2013. 
(1815-1894), em Madri; a Academia de Belas Artes mantida pelo governo espanhol em Roma (a "Escola Espanhola de Roma"58) e a Academia Chigi, na mesma cidade, onde além disso frequenta o Circolo Internazionale. Nesse período, é importante destacar que o artista estudou nas principais academias e ateliês de renome na França, na Espanha e na Itália, convivendo em proximidade com artistas que ganharam notoriedade, como Georges Seurat (1859-1891); Edmond Aman-Jean (1858-1936); Joaquín Sorolla y Bastida (18631923); e Francisco Pradilla y Ortiz (1848-1921), bem como seus professores, Madrazo; Henri Lehmann (1814-1882) e Ernest Hébert (1817-1908), além se seu irmão Isidoro.

$\mathrm{Na}$ Escola de Belas Artes de Paris, também tem a oportunidade de assistir às aulas de Hippolyte Taine (1828-1893), então professor do estabelecimento. Taine, filósofo e historiador positivista de grande influência no último Oitocentos, defendia que a história era regida por leis naturais. A elucidação dos fatos históricos, segundo o teórico, dependeria da compreensão de vários determinismos, como o meio (clima, geografia), a "raça" (grupo humano determinado fisiologicamente) e o estágio de evolução de um dado grupo social. A arte, por sua vez, manteria com esses fatores uma relação direta no pensamento de Taine, servindo como expressão das determinações particulares, incidindo sobre uma dada sociedade $^{59}$. Nesse sentido, é válido destacar também a teoria sobre a evolução das artes apresentada por Brocos. Para ele, por exemplo, é "um fato indiscutível que as primeiras manifestações artísticas da humanidade começaram pelos ornatos, e foi por elles que se desenvolveram as artes, seguindo depois uma progressão ascendente até se chegar á figura humana" ${ }^{, 60}$ - o que colocaria a arte europeia no topo de uma cadeia evolutiva das formas.

\footnotetext{
${ }^{58}$ Segundo Vázquez, "por ese nombre se entiende comúnmente a los distintos artistas españoles que estuvieron pensionados en dicha ciudad italiana a fin de ampliar estúdios y conocimientos e, indirectamente, adquirir prestigio" (p. 231). A palavra escola provê sentido de tradição que unifica os estudantes de uma instituição com existência oficial, a Academia de Bellas Artes fundada pelo governo espanhol em Roma em 1873 - e não parece envolver a configuração de padrões estilísticos ou formais homogêneos entre os artistas. Vázquez destaca que "una vez en Roma, además de asistir a las clases de la Academia, los pintores frecuentaban talleres y centros de estudios, como la Academia Chigi, la Academía de San Lucca, la Academía de Bellas Artes francesa y el Centro Internacional de Arte [Circolo Internazionale], así como la Academia Cauva" (p. 232). A primeira, que Brocos frequentou além da última, era a mais concorrida. VÁSQUEZ, F. Los pintores orensanos de la "Escuela de Roma": aproposito de dos nuevos cuadros de Silvio Fernández. Porta da Aira: Revista de Historia del Arte Orensano, $n^{\circ} .4$, 1991, pp. 231-237. A despeito do reconhecimento destes centros de formação, Brocos comenta que foi um período de enormes dificuldades financeiras para a maioria dos artistas residentes em Roma. Ver Brocos, 1915, op. cit.

${ }^{59}$ NORDMANN, J. T. Taine et la critique scientifique. Paris: Presses Universitaires de France, 1992; MURRAY, C. Key Writers on Art: From Antiquity to the Nineteenth Century. Routledge, London \& New York, 2003.

${ }^{60}$ BROCOS, M. A questão do ensino de Bellas Artes, seguido de critica sobre a direção de Bernardelli e justificação do autor. Rio de Janeiro, 1915, p. 35.
} 
Após a conclusão dos estudos, ele se candidata ao cargo de professor de artes na Espanha. Diante da demora na divulgação da convocatória para assumir o posto e de algumas dificuldades financeiras, em 1891 o pintor espanhol decide retornar ao Brasil, onde adquire nacionalidade para poder exercer o cargo de professor de escolas de $2^{\circ}$ grau, a convite de Benjamin Constant. Logo, o escultor Rodolpho Bernardelli (1852-1931), amigo dos tempos de AIBA que ele reencontra na Itália, lhe propõe a vaga de professor interino de modelo vivo na Escola Nacional de Belas Artes (ENBA), que assume em 1892. Após alguns anos, Brocos decide regressar à Europa, onde permanece de 1897 a 1900. A viagem marca um período de renovação profissional, segundo o artista, que é obrigado a deixar o cargo de professor da ENBA para fazê-la. "A interinidade não admittia licença: renunciei, e parti para Pariz. Lá tomei um banho de arte, vizitando os dois salões; fui a Bruxellas ver a Exposição Universal e, bem saturado de arte, segui para a Italia. Ahi visitei Turim e Milão, que não conhecia, e cheguei a Roma dez annos depois de a ter deixado"61, escreve Brocos. De Paris, parte de volta ao Brasil. Durante a escala de seu navio na Corunha, Isidoro sobe a bordo para encontrá-lo. É a última vez que se encontram. Já no Rio, dedica-se à escultura, ao ensino na ENBA, à gravura e à pintura, isolando-se em sua casa em Teresópolis, onde vem a falecer em 1936.

Ao longo da vida, Brocos desenvolveu amizade com personalidades brasileiras de seu tempo. Os irmãos Rodolfo e Henrique Bernardelli ${ }^{62}$, colegas na AIBA e depois também na ENBA, mantêm relação estreita com o artista espanhol na juventude mas, já na maturidade, a amizade se dissolve. Brocos atribui esse fato à inveja de Rodolfo Bernardelli, que teria visto no colega que havia então decidido dedicar-se à escultura um concorrente indesejado ${ }^{63}$. Em 1912, após a ruptura, o artista compostelano publica uma série de artigos na imprensa, criticando o ensino de arte na ENBA e os rumos tomados pela Escola sob a

\footnotetext{
${ }^{61}$ BROCOS, M. A questão do ensino de Bellas Artes, seguido de critica sobre a direção de Bernardelli e justificação do autor. Rio de Janeiro, 1915, p. 100.

${ }^{62}$ Os irmãos Bernardelli integravam uma família de artistas. Rodolpho, nascido no México e naturalizado brasileiro, foi professor de escultura estatuária na Academia Imperial de Belas Artes e o primeiro diretor da Escola Nacional de Belas Artes, que chefiou por 25 anos. Henrique, nascido no Chile, formou-se pintor pela AIBA. Seu irmão mais novo, Félix, também foi pintor.

${ }^{63}$ Diz Brocos: "Com Bernardelli nossa amizade corria calma e intima. Eu trabalhava n'um gabinete ao lado do atelier e assim decorreram alguns annos. Succedeu, porém, sentir reviver em mim a velha affeição pela esculptura, pois meus princípios até os 18 annos foram de esculptor e gravador, aprehendendo uma com meu tio e a outra com meu irmão. O que elle percebendo, calla; sua amizade esfria; não é mais o mesmo. Já não me apresenta a seus amigos, fica reservado e considera-me um estranho. Em vista d'esta situação, separei-me d'elle, indo trabalhar em minha casa". O pintor diz ter aprendido a esculpir na infância com o irmão e que a escultura seria uma boa forma de sustento, pois assim poderia assumir projetos de obras públicas. Um exemplo das produções do período é o frontão da Biblioteca Nacional, no Rio de Janeiro (idem, ibidem, p. 102).
} 
direção de Rodolfo Bernardelli, bem como a atuação deste escultor. Os textos, reunidos no livro A questão do ensino de Bellas Artes, seguido de crítica à direcção de Bernardelli (1915), constituem fontes importantes para a pesquisa sobre a história da ENBA e também para conhecer melhor as ideias e trajetória de Brocos. Além dos irmãos Bernardelli, ele parece ter mantido uma amizade sólida com o escritor Arthur de Azevedo (1855-1908) ${ }^{64}$, que assinou durante mais de uma década a coluna de crítica de arte Palestra, em O Paiz, como A.A. Os comentários de Azevedo sobre obras de Brocos costumam ser elogiosos, mesmo quando todos os outros críticos tecem apreciações negativas sobre seu trabalho.

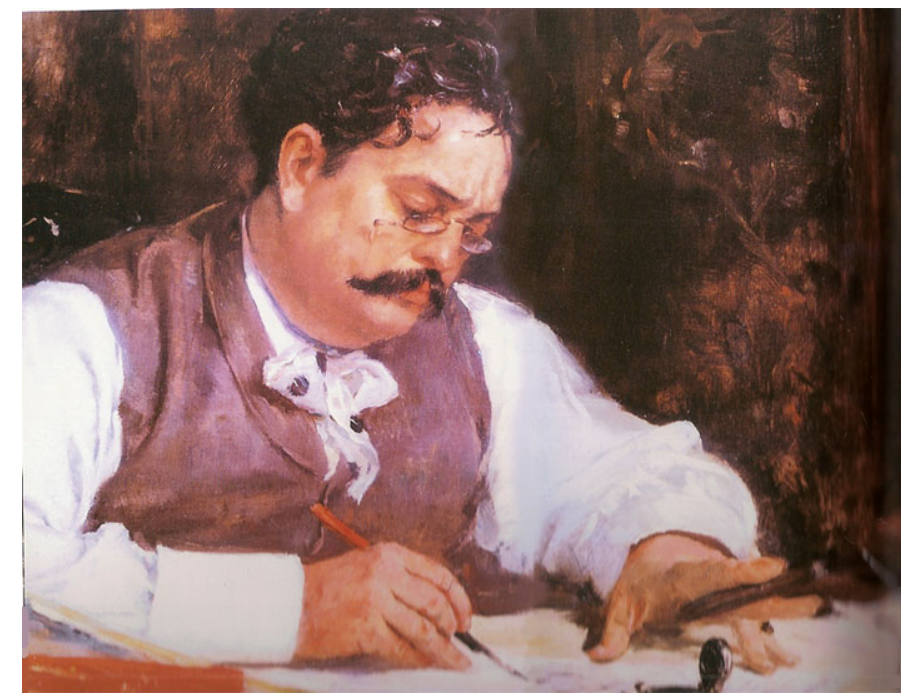

Fig. 5: Modesto Brocos. Retrato de Arthur de Azevedo (s.d.). Óleo sobre tela, dimensões e paradeiro não localizados

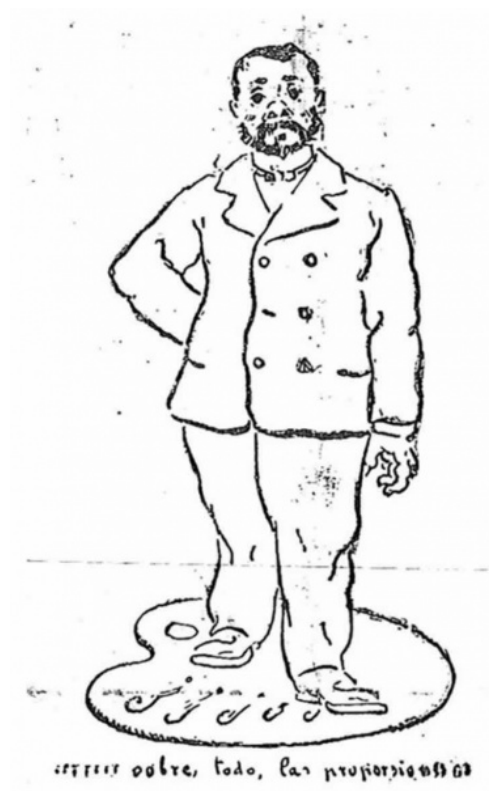

Fig. 6: Henrique Bernardelli.

"Sobre todo, las proporciones".

Caricatura de Modesto Brocos. Gazeta de Notícias, 10/05/1894, p. 1

No meio editorial, o pintor também foi autor de Retórica dos Pintores (1933), fonte importante que em que procura transmitir seus ensinamentos sobre pintura às gerações vindouras, rica em observações que permitem constatar a solidez de seu conhecimento técnico e teórico-conceitual; e da ficção científica Viaje a Marte (1930), da qual é personagem-narrador. $\mathrm{O}$ volume narra suas descobertas durante uma visita ao planeta vermelho, que o impressiona por aquilo que ele considera o auge da modernidade moral, política e científica de seu tempo ${ }^{65}$.

\footnotetext{
${ }^{64}$ Arthur de Azevedo, escritor e dramaturgo prestigiado no último Oitocentos, nasce no Maranhão. O irmão mais velho do escritor Aluísio de Azevedo, além de crítico, era colecionador de arte.

${ }^{65}$ Voltaremos a citar essas obras nos próximos capítulos.
} 
Por fim, a atuação de Brocos como professor é destacada por alunos, como Reis Júnior e Quirino Campofiorito. O primeiro descreve o artista como "um homemzinho atarracado, cabeçudo, com um grande rosto franco, cujo oval terminava em vastos bigodes pendentes sôbre um pequeno cavanhaque, movimentando-se em uma mistura de português com castelhano" pobre mesmo. Lembro-me ainda do jardinzinho da entrada onde havia uma reprodução da Vênus Calipígia, e da pequena sala atulhada de livros, de pincéis, de tintas, de telas, de cavaletes"68. Reis Júnior também considera que certos preceitos de inspiração cubista foram a base do ensino de desenho "inteligente e avançado" de Brocos, visto que o pintor não hesitava em adotar novas idéias estéticas, nem se exasperada diante das tendências de vanguarda. A mesma impressão está presente nos comentários de Campofiorito, que observa no professor uma abertura para que os alunos explorassem técnicas e tendências atuais - postura ímpar frente ao saber ultrapassado que o ex-aluno afirma ter sido então predominante na ENBA. Sobre isso, o mesmo autor nota que, já na década de 1920, ainda era ousada para tal insituição uma aula ao ar livre, ou o ensino de preceitos de uso da cor impressionista. Segundo os dois autores, ao incluir essas e outras modalidades na formação de seus estudantes, Brocos uma exceção entre os professores daquele estabelecimento ${ }^{69}$.

Por fim, é digno de nota que a preocupação com o ensino de artes e a formação para os ofícios de Brocos se reflete também no papel fundamental que desempenhou junto ao Liceu de Artes e Ofícios ${ }^{70}$. O pintor terá sido responsável por adquirir equipamentos para a oficina dessa instituição, que chegou a dirigir. Segundo Carlos Oswald,

esse material foi de primeira ordem: a prensa elétrica vinda da Alemanha até hoje funciona e é a maior que se importou no Brasil; podem-se nela imprimir chapas até quase $80 \mathrm{~cm}$ por $1 \mathrm{~m}$. O resto - chapas de cobre, buris, lentes, vernizes, raspadores, brunidores, todos os apetrechos indispensáveis à gravura vieram de Paris $^{71}$.

\footnotetext{
${ }^{66}$ EXPOSIÇÃo MODESTO BROCOS (RETROSPECTIVA). Ministério da Educação e Saúde, Museu Nacional de Belas Artes. Rio de Janeiro, Fev. 1952., (s/p).

${ }^{67}$ Idem, ibidem.

${ }^{68}$ Idem, ibidem.

69 "Demorada permanência em Roma e Paris, lhe despertam incontida necessidade de comunicação com um espirito aberto para novas formas do ensino artístico, quando via no Brasil persistir o superado sistema acadêmico trazido elos mestres neo-clássicos da Missão Francesa”, diz CAMPOFIORITO, Q. MODESTO Brocos. Rio de Janeiro: Bolsa de Arte, 1977.

${ }^{70}$ FERREIRA, Orlando da Costa. Imagem e Letra: introdução à bibliologia brasileira à imagem gravada. SP: Edusp, 1994

${ }^{71}$ OSWALD apud FERREIRA, op. cit.
} 
As fontes textuais apresentadas possibilitam situar Modesto Brocos como uma personagem que angariou reconhecimento em seu tempo e dialogou com as principais correntes artísticas do período. A moldura é importante, na medida em que permite a seleção de dados biográficos que contribuam para compreender melhor a formação do estilo e certas opções do artista, mas também quando provê informações que abram espaço para acessar debates que, no período, dialoguem diretamente com as questões propostas. Não obstante, numa discussão sobre arte, tal articulação só adquire sentido quando instaurada sob mediação da obra. Com isto em mente, a dissertação assume o desafio de empreender uma análise da tela que, em diálogo com dados biográficos e outros quadros, seja capaz de situar sua especificidade com relação ao branqueamento.

Conforme mencionamos antes, tal postura implica numa inversão estratégica de perspectiva na abordagem deste tema: ao invés de tomar a pintura como ilustração da tese de João Batista de Lacerda ou de outras teorias sobre embranquecimento, há que se perguntar também o contrário: em que medida a tela - que antecipa cronologicamente o artigo do cientista em 16 anos - não propõe sua própria tese ${ }^{72}$ Certamente, havia possibilidades abertas de diálogo entre artista e antropólogo, uma vez que a investigação realizada demonstrou que Brocos trabalhou como ilustrador para os Annaes do Museu Nacional ${ }^{73}$. Conquanto essa informação é ainda insatisfatória para qualificar melhor os vínculos entre os dois, consideramos a pintura A redenção de Cam como o documento da maior importância na presente dissertação, capaz de alargar o debate sobre embranquecimento a partir de um ponto de vista estético e pictórico. Isto não impede o reconhecimento do episódio envolvendo a viagem do médico fluminense ao I Congresso Internacional das Raças como emblemático quanto aos sentidos assumidos pela pintura, também aos olhos do cientista. Todavia, a tela também convida a outras miradas - e inclusive a vislumbrar

\footnotetext{
${ }^{72}$ Isto não supõe, evidentemente, o estabelecimento de hierarquias entre as duas fontes, visto que ambas têm importância na compreensão do pensamento racialista da época e se iluminam mutuamente. ${ }^{73} \mathrm{O}$ acervo iconográfico da Biblioteca Nacional, no Rio de Janeiro, guarda algumas dessas ilustrações. Segundo consta das gravuras (xilografias e linóleo), elas correspondem a urnas funerárias indígenas feitas nas décadas de 1870 e 1880, por encomenda do então diretor, o Conselheiro Ladislao Netto. Este dirigiu a instituição até 1895, quando Lacerda assumiu a função. Cf. LACERDA, J. B. Fastos do Museu Nacional. Rio de Janeiro, Imprensa Nacional, 1905. Disponível em: $<\mathrm{http} / / /$ www.obrasraras.museunacional.ufrj.br/o/0054/0054.pdf> Consulta: 14/07/2013.
} 
o alcance assumido pelas teorias do embranquecimento, que extrapola as fronteiras do campo científico $^{74}$.

Encarar a pintura per se como um documento de primeira grandeza exige, a princípio, reconhecer o tratamento direto e, aparentemente, didático que confere a seu tema. Ao mesmo tempo, discutir em que medida o quadro exprime uma tese sobre o embranquecimento demanda embrenhar-se num exame das próprias convenções artísticas. Para fazê-lo, é preciso articular aquelas fontes capazes de ampliar nossa capacidade de visualização das relações engendradas por esse objeto, em torno da questão.

Desse modo, procuramos sobretudo questionar a obra sobre suas intenções, de acordo com o modelo proposto por Baxandall, ou seja, indagá-la não sobre os desígnios do autor no momento de sua produção, mas sim sobre a qualidade intencional que emerge do próprio objeto e que, muitas vezes, independe da vontade do artista. É modelar o estudo desse historiador sobre o quadro Uma dama tomando chá (1735), de Jean-Baptiste-Siméon Chardin, ao mostrar que a impossibilidade de estabelecer uma correlação direta entre uma obra e um conjunto de teorias definidas como paradigmáticas em seu tempo (por exemplo, através da comprovação documental das relações do artista com essas teorias ou seus maiores expoentes) não inviabiliza o debate sobre suas intenções. Afinal, a tela de Chardin não se apresenta como um objeto imbuído de determinado apelo sensorial "lockeano"75 porque o artista teria sido um leitor ou convivido diretamente com Locke, mas porque Chardin “já vivia numa cultura lockeana" ${ }^{76}$, segundo a análise do historiador. Esta constatação abre espaço para recolocar a tela no centro dos debates e, a partir dela, encontrar novas dimensões da própria teoria elaborada pelo pensador setecentista e daquilo que Baxandall considera a cultura lockeana. Tendo este exemplo em mente, propomos observar $A$ redenção de Cam - quadro em que a referência ao embranquecimento é

\footnotetext{
${ }^{74}$ Como também observa Schwarcz, sobre a literatura do período. SCHWARCZ, L. K. M. O espetáculo das raças. Cientistas, instituições e a questão racial no Brasil - 1870-1930. São Paulo, Companhia das Letras, 2004.

75 Baxandall explica em maior detalhe a importância do universo perceptivo-sensorial para o pensamento de Locke. Grosso modo, trata-se de um tipo de pensamento que extrai conclusões das sensações provocadas por determinada substância (o objeto natural) e não da substância em si, que somente poderia ser acessada através dos sentidos. Em consonância, "os quadros de Chardin representam, sob a capa da sensação, a percepção da substância ou ideias complexas sobre ela, e não a substância em si”, diz o Baxandall. BAXANDALL, M. Padrões de intenção: a explicação histórica dos quadros. São Paulo: Companhia das Letras, 2006, p. 154.

${ }^{76}$ Idem, ibidem, p. 155.
} 
evidente -, como um objeto que habilita novas formas de compreender os debates sobre este assunto, permitindo deslindar certos modos de percepção historicamente situados das chamadas diferenças raciais. Ao mesmo tempo, consideramos que tal condução das reflexões sobre o quadro também possibilita auferir sua originalidade em meio a tais debates.

Destarte, é preciso apresentar algumas fontes fundamentais para a reflexão proposta, que viabilizam um diálogo seletivo com dados biográficos e contextuais, bem como introduzir algumas considerações sobre como o gênero e o estilo podem contribuir para as discussões propostas.

Dentre as fontes visuais de interesse da pesquisa, tem preponderância um grupo de pinturas de Brocos, marcado pela presença recorrente de mulheres de ascendência negra (ou consideradas como tal no período). Listamos: Engenho de Mandioca (1892); Mulher (s.d.); Feiticeira (c.1895); Crioula de Diamantina (1894); e $A$ descascar goiabas (1901).

A preocupação com o tema do parentesco, presente em A Redenção de Cam-e imediatamente associada à ideia da continuidade genealógica, mas também ao papel do indivíduo na construção de um futuro racial para sua linhagem -, também aparece em Rebeca dando de beber a Eliezer (1883) ${ }^{77}$; e As três idades (s.d), igualmente conhecida como As Estações - que servem de termômetro quanto à presença do assunto na obra de Brocos.

Um terceiro tema que unifica pinturas do artista é o trabalho, com destaque às figuras femininas - e, notadamente, camponesas. O labor feminino está presente em quadros como Lavanderas (1880); Mulher coletando água (s.d.); e a gravura Camponesa (s.d.), além de Engenho de Mandioca (1892); Feiticeira (c. 1895); Crioula de Diamantina (1894); e A descascar goiabas (1901). As críticas de jornais da época indicam a existência de outras pinturas com essa temática, como Scena doméstica (1904) e A peneirar café (1901).

\footnotetext{
${ }^{77}$ Ao comentar a tela Rebecca et Eliezer, de Poussin, Lévi-Strauss explica essa narrativa bíblica: “O problema do casamento de Rebecca resulta de uma contradição entre o que os juristas do Antigo Regime chamaram de raça e terra. (...) Abraão recusa qualquer ideia de casamento com os primeiros ocupantes [da Terra Prometida], e quer que seu filho Isaac despose uma moça de seu sangue. E como é proibido para ambos ausentar-se da Terra Prometida, Abraão envia Eliezer, seu homem de confiança, para junto de seus parentes afastados, a fim de trazer Rebecca". LÉVI-STRAUSS, C. Olhar, escutar, ler. SP: Companhia das Letras, 2010.
} 
Enquanto tais quadros acenam para uma preocupação temática com as relações entre trabalho, sucessão familiar e raça/embranquecimento, há ainda telas do autor que mostram o interior de navios de imigrantes, indicando como o mesmo pintor acompanhou por meio de sua obra os debates mais atuais de sua época. Além das cenas de trabalho e costumes e da pintura bíblica e histórica, a obra de Brocos, composta de gravuras, ilustrações, pinturas, projetos arquitetônicos, painéis e esculturas, é ainda frutífera em paisagens; e retratos - que foge a nosso alcance analisar $^{78}$.

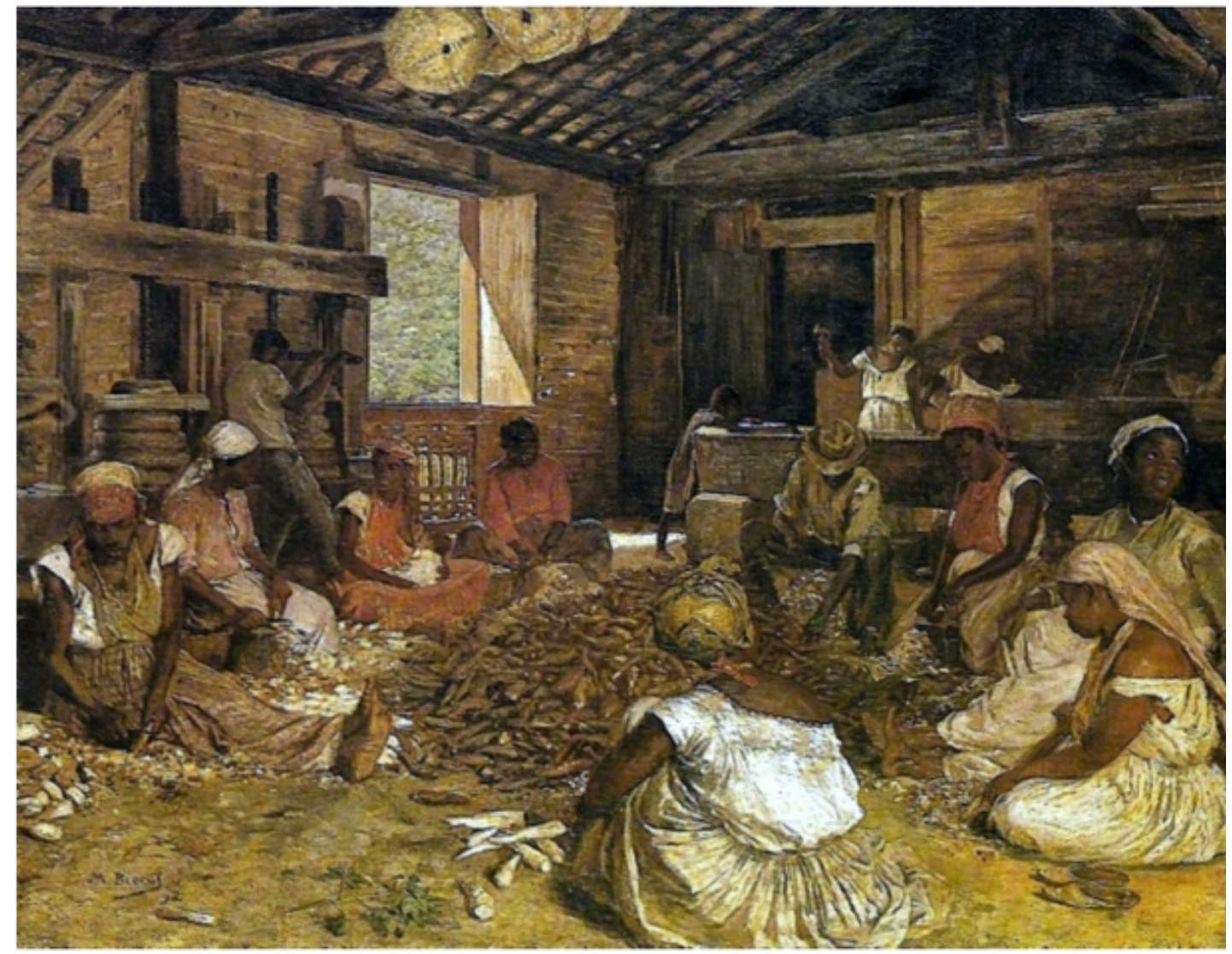

Fig. 7: Modesto Brocos. Engenho de mandioca (1892). Óleo sobre tela, 58,6cm x 75,8cm. Rio de Janeiro: Museu Nacional de Belas Artes.

\footnotetext{
${ }^{78}$ Uma ressalva é necessária: devido à alta vendagem dos quadros de Brocos no período e ao fato de que poucas instituições públicas os adquiriram, hoje é difícil o contato com telas desse artista. A análise dos títulos citados em catálogos de exposições e críticas de jornal indica que a maior parte dessas pinturas passou rapidamente para coleções particulares durante a vida do pintor e, hoje, não tem paradeiro certo - ainda que algumas aparecem à venda em leilões de obras de arte.
} 


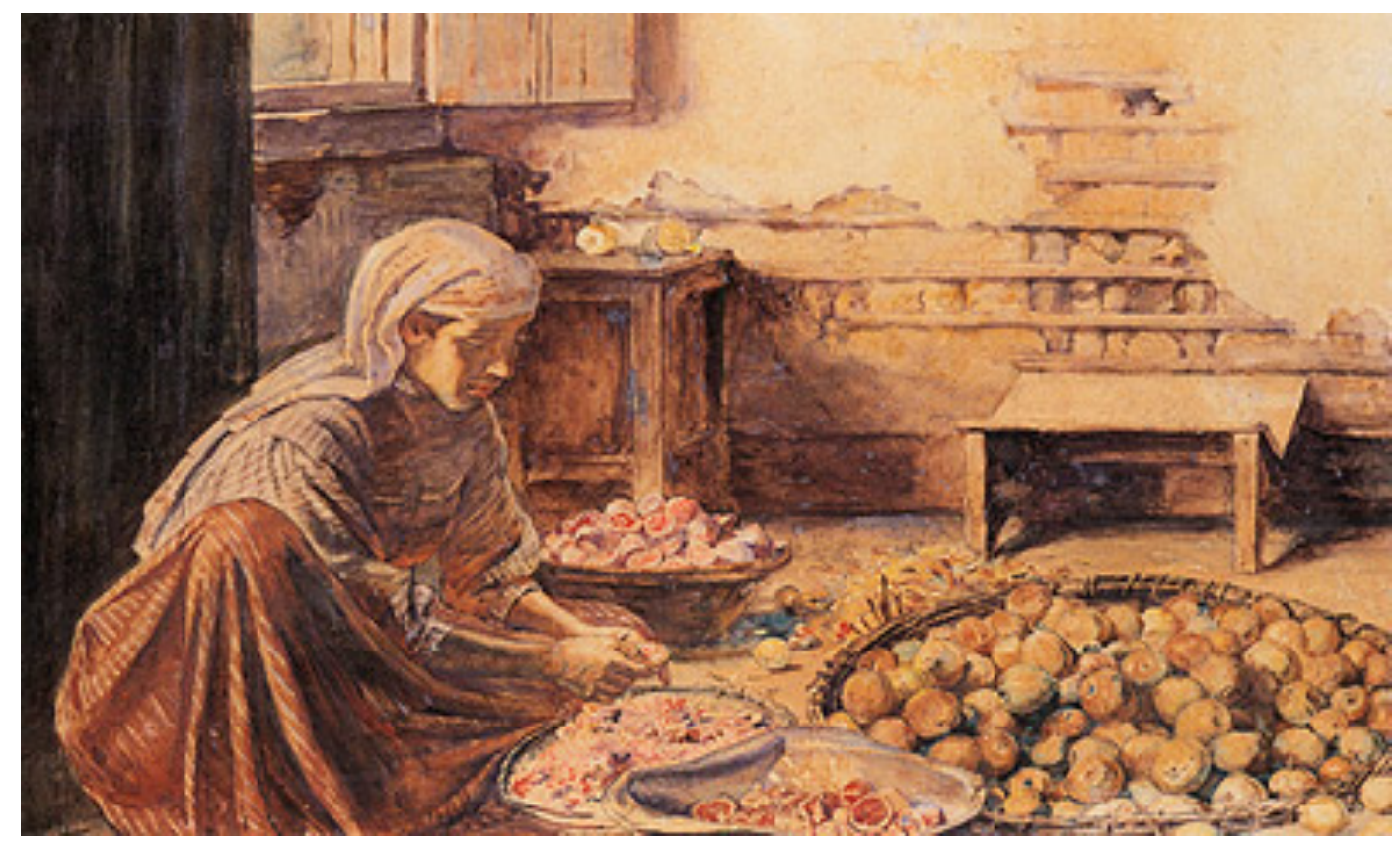

Fig. 8: Modesto Brocos. A descascar goiabas (1901). Aquarela sobre papel, $36 \mathrm{~cm}$ x 58,5cm. Coleção particular.

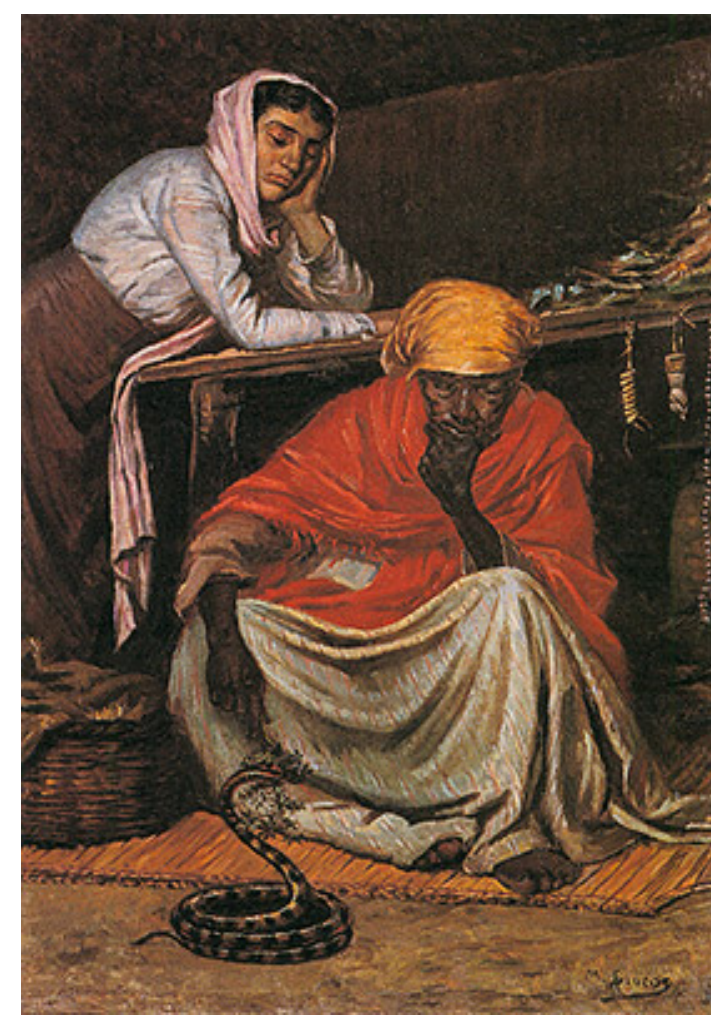

Fig. 9: Modesto Brocos

Feiticeira (c.1895)

Óleo sobre tela, $45 \mathrm{~cm} \times 34 \mathrm{~cm}$

Coleção Particular

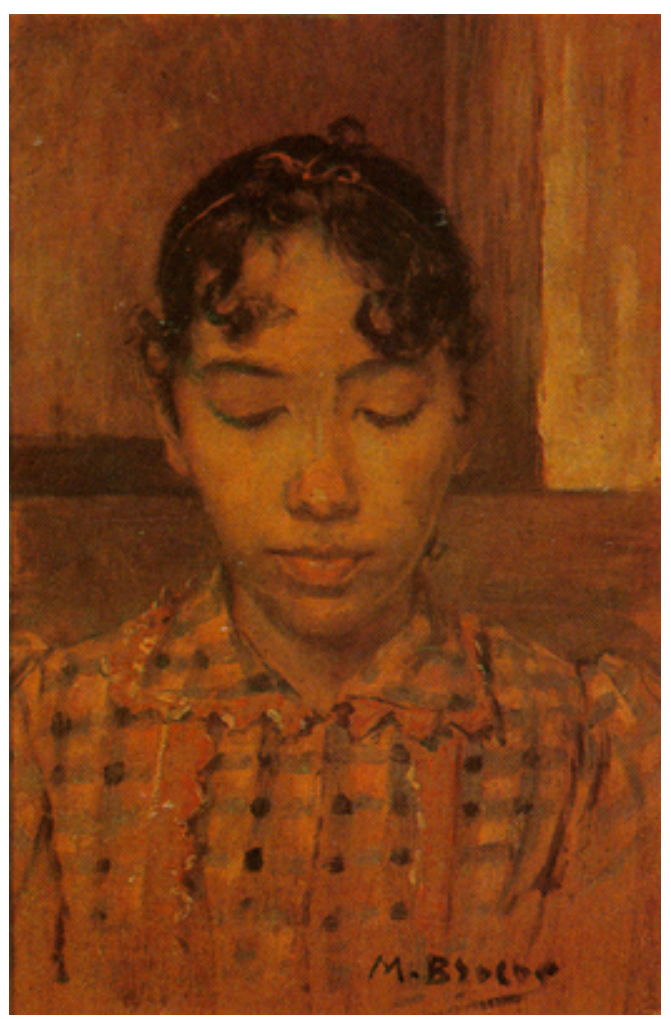

Fig. 10: Modesto Brocos

Mulher, s.d.

Óleo sobre tela, $25 \mathrm{~cm} \times 16 \mathrm{~cm}$

Coleção particular 


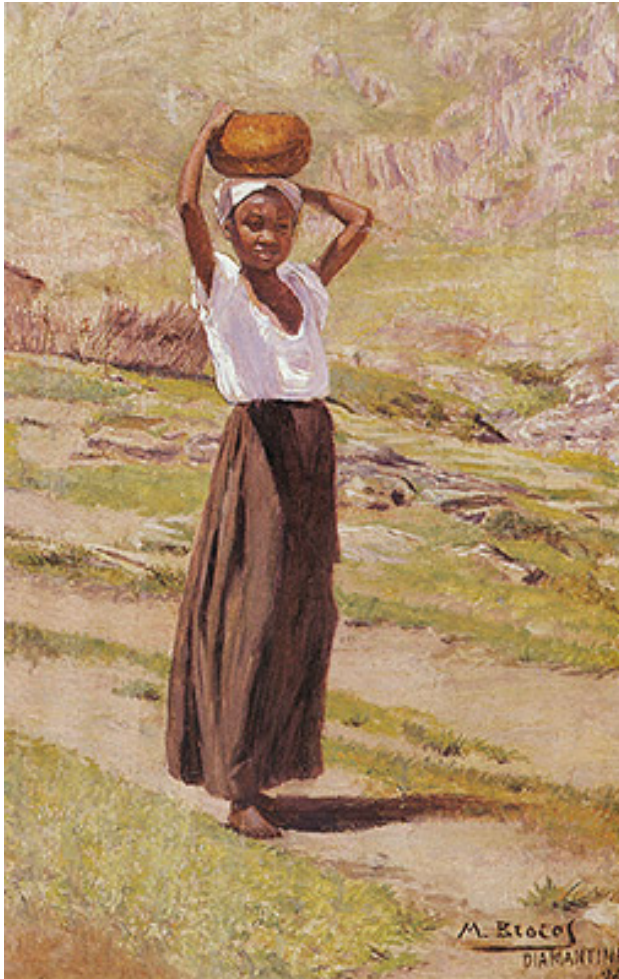

Fig. 11: Modesto Brocos

Crioula de Diamantina (1894)

óleo sobre madeira, $37 \mathrm{~cm} \mathrm{x} \mathrm{27,5} \mathrm{cm}$

Coleção Particular

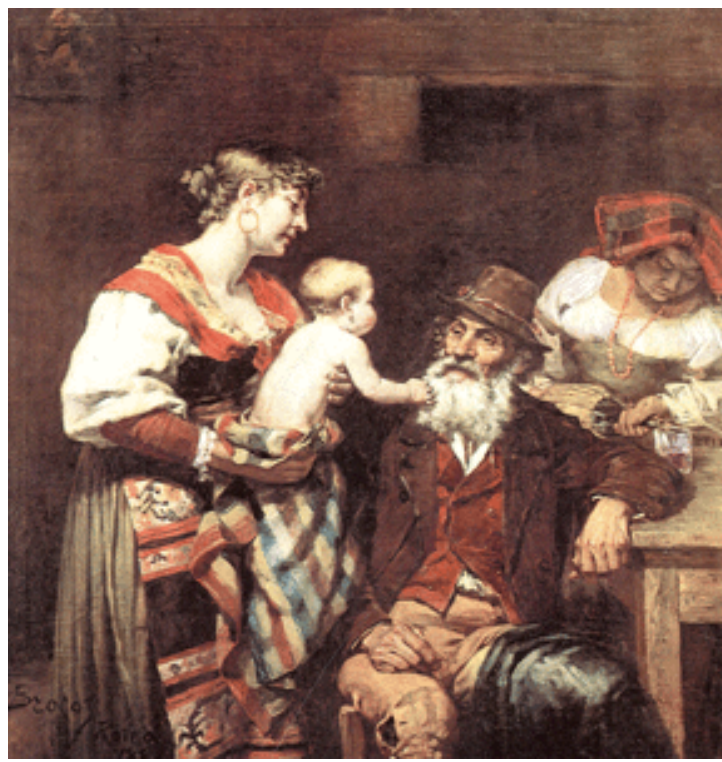

Fig. 13: Modesto Brocos

Las tres edades, s.d.

Óleo sobre tela, dimensões não identificadas A Corunha: Diputación de A Corunha.

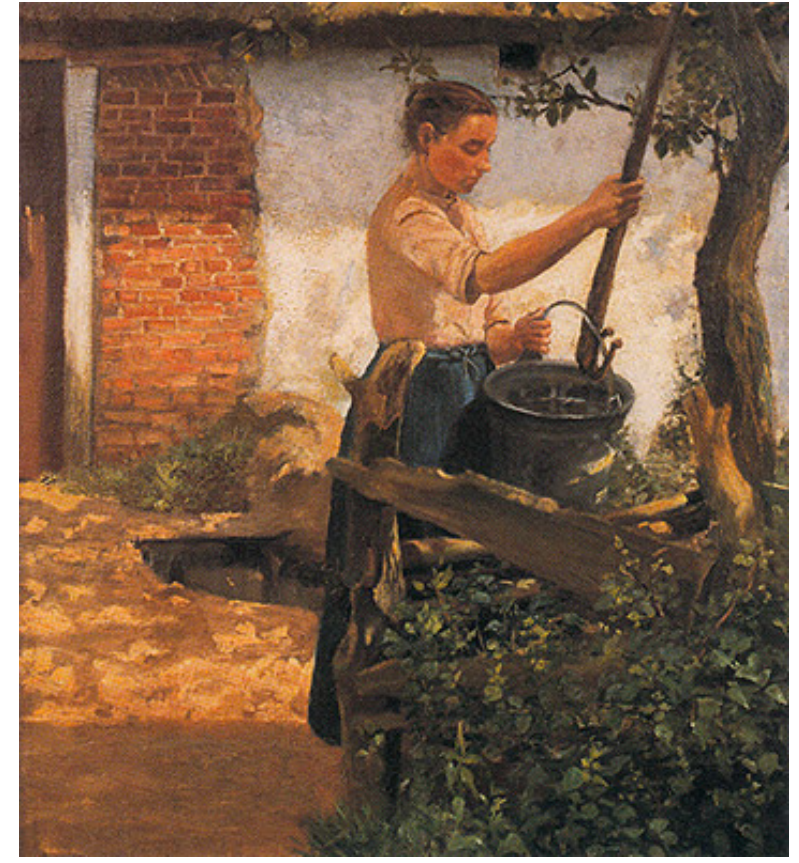

Fig. 12: Brocos, Modesto

Mulher Coletando Água (1892)

Óleo sobre tela, $64 \mathrm{~cm} \times 56,5 \mathrm{~cm}$

Coleção particular

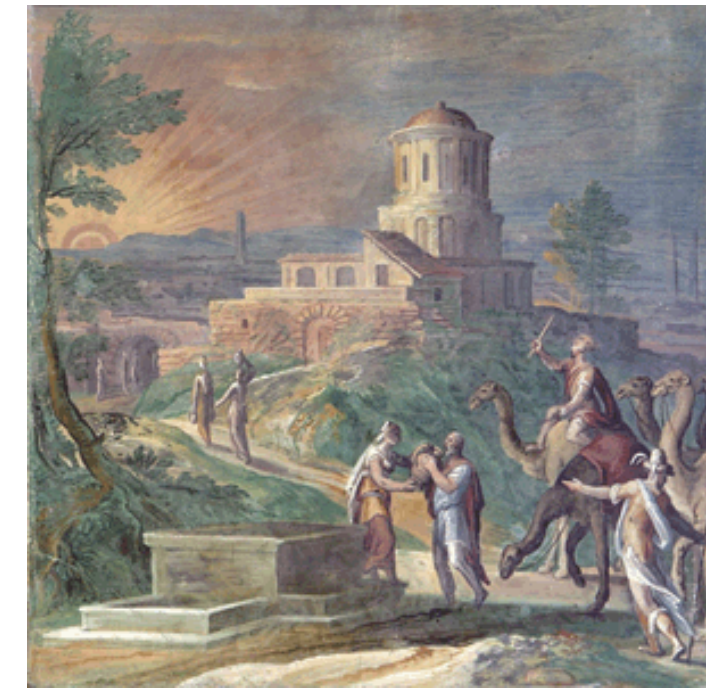

Fig. 14: Modesto Brocos

Rebecca dando de beber a Eliezer (1883)

Óleo sobre tela, dimensões não identificadas

A Corunha: Diputación de A Corunha. 


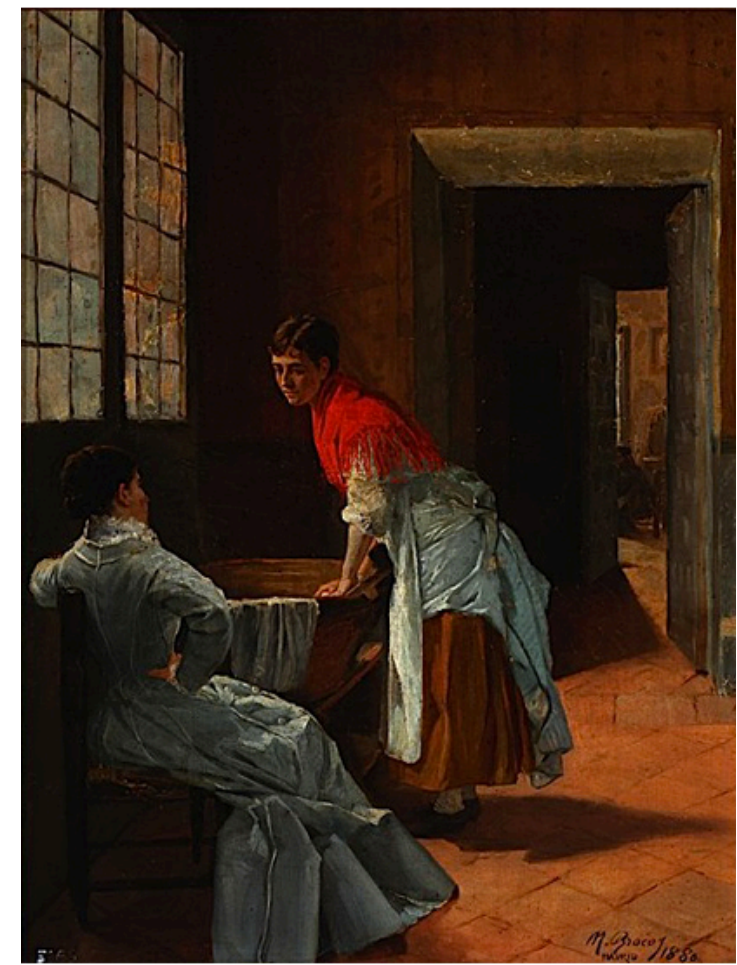

Fig. 15: Modesto Brocos.

Lavanderas (1880).

Óleo sobre tela, $42,8 \mathrm{~cm} \times 32,6 \mathrm{~cm}$

A Corunha: Museu de Belas Artes.

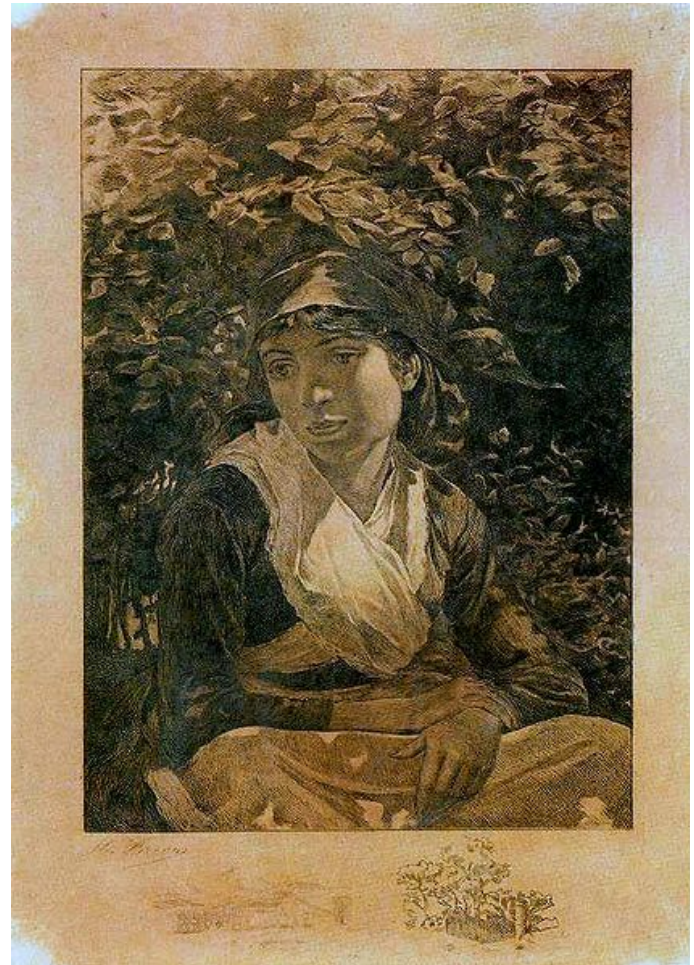

Fig. 16: Modesto Brocos.

Camponesa (s.d).

Água-forte, $31 \mathrm{~cm} \mathrm{x} 22,3 \mathrm{~cm}$

São Paulo: Pinacoteca do Estado.

É importante notar que Brocos foi reconhecido pelos críticos do período como um artista que se dedicou ao estudo e pintura de personagens negras, de modo que a produção de telas com essa temática parece ter feito parte de um projeto pictórico maior, que abraçou no Brasil. Além das seis telas citadas como componentes da série temática que embasa parte de nossas reflexões, outras pinturas aparecem como possíveis composições que podem ser incluídas nesse projeto - como O Progresso, representado pelas Amadríades surpreendidas com a passagem da locomotiva (paisagem brasileira) (1907); A Orphã (1892); e Cabeça de estudo - Negro (1895) - e que, infelizmente, só podemos computar pelos títulos que aparecem nos catálogos de exposições e críticas de época.

$\mathrm{Na}$ dissertação, procuraremos tecer conexões que possibilitem vislumbrar vínculos possíveis entre o tema do embranquecimento - indissociável de $A$ redenção de Cam -, e outras dessas telas. Daremos atenção particular às imagens de mulheres de ascendência negra pintadas por Brocos, que nos motivam a indagar sobre possíveis convergências entre elas - tanto com relação à constituição corporal dessas figuras, quanto por suas disposições de gênero, cor, gestual, postura, indumentária, relações entre si e com 
o meio. Ao longo da dissertação, iremos discutir em que medida certas tópicas e esquemas $^{79}$ comuns à composição dessas personagens entram para um marco geral de disposições estéticas presentes nessas telas, por exemplo, através de uma determinada maneira de sentar-se de cócoras no chão; pés descalços; uso de roupas e adereços convencionalmente associados à origem africana ou não; trajes brancos; e uma tendência a explorar tons quentes, alusivos à terra não apenas na pele, mas também no ambiente que envolve tais figuras, bem como contrastes complementares. Em igual medida, a comparação entre tópicas e esquemas desses quadros e outras caracterizações - textuais ou visuais - de mulheres de ascendência negra será salutar para alargar as possibilidades interpretativas das pinturas de Brocos, compreender mais profundamente certas tendências marcantes no momento de produção dessas telas e avaliar melhor a originalidade da solução proposta por $A$ redenção de Cam.

Comparação similar se torna possível entre personagens presentes nessas telas e em outras pinturas do mesmo gênero. Referimo-nos às chamadas cenas de costumes roceiros, que primam por capturar o aspecto prosaico da vida das camadas trabalhadoras - o que, por sua vez, constituiu uma tendência importante na pintura ocidental a partir da emergência do realismo e naturalismo ${ }^{80}$. Assim, despontam nas telas os chamados tipos - figuras identificadas por certas características étnicas ou raciais comuns, ou porque expressam costumes regionais, traduzidos em posturas, gestuais, vestimentas. Citamos os exemplos dos caipiras produzidas por Almeida Júnior (1850-1899); os gaúchos de Weingartner (1853-1929); quadros de Antonio Ferrigno (1863-1940); e de Henrique Bernardelli, entre outros. São, em certa medida, pinturas que dão um novo fôlego à tradição herdada dos viajantes naturalistas e também a um nativismo da Academia Imperial de Belas Artes, ao mesmo tempo em

\footnotetext{
${ }^{79}$ A ideia de tópica é proveniente da retórica e remete ao tratado De pictura (1435), de Leon Battista Alberti. O termo diz respeito aos motivos recorrentes da retórica e da pintura. Segundo Alberti, a pintura elevada seria responsável pela contínua redescoberta da beleza das tópicas consagradas. Já a noção de esquema (ou schema) é desenvolvida por Gombrich em referência a um conjunto de formas convencionais que permitem "copiar" a realidade. Tais formas se encontram largamente presentes na arte porque constituem modos de socialização da prática artística, mas também os mecanismos que possibilitam à percepção decodificar determinadas formas vis-à-vis o mundo exterior. Evidentemente, um esquema tende a não guardar nenhuma correlação com o real, funcionando antes como um constructo perceptivo. AlBERTI, L. B. Da Pintura. Campinas: Editora da Unicamp, 1999; GOMBRICH. E. Arte e Ilusão. Um estudo da psicologia da representação pictórica. SP: Martins Fontes, 2007.

${ }^{80}$ Cf. COLI, J. Pintura naturalista. In: O corpo da liberdade. São Paulo: CosacNaify, 2010.
} 
que assumem contornos particulares no que diz respeito à elaboração de um perfil pictórico para a população nacional $^{81}$.

Um aspecto que merece atenção nessas pinturas é sua preocupação comum de apresentar a variedade dos tipos existentes no país ${ }^{82}$, que concorre para construir uma ideia de raça. Fruto de um momento marcado pela propagação das teorias deterministas, do darwinismo social e do evolucionismo nos meios intelectuais e junto à opinião pública ${ }^{83}$, esses quadros parecem ajustar-se a uma tendência geral a estabelecer hierarquias raciais com base em determinados atributos corporais, a exemplo (e em certos casos sob inspiração) do que faziam os estudos antropométricos e de fisionomia. Desse modo, tais imagens convidam a refletir sobre o lugar que oferecem às figuras ali apresentadas: um lugar construído em conjunto com aquele que reservam para seus observadores ${ }^{84}$. Também merece atenção, nesse sentido, o fato de que as mesmas tendências classificatórias se fazem presentes em outras fontes do período - notadamente, na literatura de ficção -, que por esse motivo também provêm os debates propostos de uma série de parâmetros elucidativos. Pensamos, por

\footnotetext{
${ }^{81}$ Segundo Dazzi, "estes quadros de temática camponesa serviam como modelo para o tipo de pintura que, se esperava, passasse a ser realizada no Brasil. Se as paisagens representavam a nossa terra e a nossa cor local, o homem do campo representaria a nossa gente, nossas raízes nacionais". DAZZI, C. Relações Brasil-Itália na arte do segundo Oitocentos: estudo sobre Henrique Bernardelli (18801890). Dissertação de Mestrado apresentada ao Departamento de História do Instituto de Ciências Humanas da Universidade Estadual de Campinas. Campinas, 2006, p. 117.

${ }^{82}$ Mas é preciso não perder de vista que raça era um termo igualmente aplicável à população branca, vista nesse contexto como uma "raça superior". Desse modo, mesmo as personagens brancas são lócus de insinuações morais, desdobradas de atributos físicos.

${ }^{83}$ SEYFERTH, G. A antropologia e a tese do branqueamento da raça no Brasil: a tese de João Baptista Lacerda. In: Revista do Museu Paulista, 30, 1985; SKIDMORE, T. E. Preto no branco. RJ: Paz e Terra, 1989; SCHWARCZ, L. K. M. Retrato em negro e branco. Jornais, escravos e cidadãos em São Paulo no final do século XIX. SP: Companhia das Letras, 1987; SCHWARCZ, L. K. M. O espetáculo das raças. Cientistas, instituições e a questão racial no Brasil - 1870-1930. São Paulo, Companhia das Letras, 2004. SCHWARCZ, L. K. M. Questões de fronteira. In: Novos Estudos. São Paulo, Cebrap, $n^{\circ}$ 72, jul. 2005; SCHWARCZ, L. K. M. Previsões são sempre traiçoeiras. João Baptista de Lacerda e seu Brasil branco. In: História, Ciências, Saúde - Manguinhos. RJ, v.18, n.1, jan.-mar. 2011; CORRÊA, M. As ilusões da liberdade. A Escola Nina Rodrigues e a antropologia no Brasil. Bragança Paulista: Edusf, 1998; HOFBAUER, A. Uma história do branqueamento ou o negro em questão. SP: Editora UNESP, 2006.

${ }^{84}$ McCLINTOCK, Anne. Couro Imperial: raça, gênero e sexualidade no embate colonial. Campinas: Editora Unicamp, 2010. MISKOLCI, Richard. O desejo da nação: masculinidade e branquitude no Brasil de fins do XIX. São Paulo: Annablume, 2012. BEDERMAN, Gail. Manliness \& Civilization: a cultural history of gender and race in the United States, 1880-1970. Chicago: University of Chicago Press, 1995. MULVEY, L. "Visual pleasure and narrative cinema". In: Visual and other pleasures. Indiana University Press, Indianápolis, 1989. NOCHLIN, L. The politics of vision: essays on Nineteenth century art and society. Harper \& How Publisher, New York, 1983. LAURETIS, T. Technologies of Gender: Essays on Theory, Film, and Fiction. Indiana University Press, Bloomington, 1987. HOOKS, B. "The oppositional gaze: Black female spectators". In Black looks: Race and representation. South End Press, Boston, 1992, pp. 122-123. Disponível em: $<$ http://www.umass.edu/afroam/downloads/reading14.pdf $>$.
} 
exemplo, em romances como A escrava Isaura (1872), de Bernardo Guimarães; $O$ cortiço (1890); e O mulato (1881), de Aluísio de Azevedo.

Por sua temática, tais quadros parecem alinhar-se estilisticamente ao chamado realismo e/ou naturalismo ${ }^{85}$. Essa primeira indicação de estilo abre espaço para indagações mais profundas que, como procuraremos mostrar, contribuem de maneira decisiva para compreender as intenções de $A$ redenção de Cam. A título introdutório, no entanto, uma observação se faz necessária: é comum encontrar, para expoentes da geração de Modesto Brocos - e, na prática, para boa parte dos artistas a partir da segunda metade do século XIX -, a atribuição de um estilo academicista, academista, eclético, ou pompier ${ }^{86}$. Esses termos costumam ser usados como sinônimos, mormente de forma pejorativa: dizer que uma obra é academicista é quase afirmar que ela não possui estilo; assim, as palavras vêm imbuídas da ideia de uma arte marcada pela reapropriação indiscriminada de influências de períodos e tradições diferentes ou a reprodução mecânica de fórmulas feitas. Em contraposição, a rejeição ao academicismo encerra uma propensão a exaltar a modernidade como lócus da originalidade, seja pelo prazer encontrado na superação da forma antiga, ou pelo horror à ideia de obsolescência. Há também, por trás da classificação, uma tendência a vincular academicismo com a expansão do capitalismo industrial - e logo, com uma produção dirigida ao mercado -, em oposição a um ideal artístico de liberdade de criação e independência autoral $^{87}$.

\footnotetext{
${ }^{85}$ Como veremos, no capítulo 2, aqui realismo e naturalismo são antes vistos como definições a respeito de um sistema de notação, do que como critério de fidelidade ao "real" ou "natural". Além disso, enquanto denominativos de estilo, tais termos constituem noções que abrem um debate, mais do que o resolvem.

86 "Por Academismo poderíamos compreender o movimento que, durante o século XIX e parte do século XX, se caracterizou por uma releitura do Neoclássico por meio de adaptações modernizantes, configurou-se pela incorporação dos diversos movimentos artísticos que se sucederam ao longo do século XIX, desde o Romantismo ao Pontilismo", diz Zílio. ZÍLIO, C. A modernidade efêmera: anos 80 na Academia. In: 180 anos de Escola de Belas Artes. Anais do seminário EBA 180, 20-11 de nov., 1996, Rio de Janeiro.O uso do adjetivo pompier não tem origem clara. Thuillier chama a atenção para alguns sentidos - sempre pejorativos - da palavra: em primeiro lugar, pompier significa bombeiro em francês e poderia referir-se à semelhança formal entre o capacete grego conforme retratado nas pinturas e o dos bombeiros; também pode ser uma corruptela do termo pompéiste - referência ao resgate arqueológico das ruínas de Pompéia, que teve forte influência sobre a elaboração do estilo neoclássico (em consonância, por volta de 1848 termo estaria servindo aos críticos do neo-gréc para ridicularizar seu principal expoente, Charles Gleyre e discípulos); além disso, talvez fizesse alusão aos guardas nacionais de plantão nos Salões de Paris, que eram chamados pelos estudantes de arte de "bombeiros". THUILLIER, Jacques. Peut-on parler d'une peinture « pompier » ?. Paris: Presses Universitaires de France, février 1984.Ver também cf. ACADEMISMO. Rio de Janeiro: FUNARTE, 1986; ALVES, C. F. Benedito Calixto e a construção do imaginário republicano. Bauru: EDUSC, 2003.

87 "It has become a cliché to identify "academicism" in art as a negative force, associated with the mechanisation of culture and the repressive authority of social institutions (...) Academic art is bad art.
} 
As implicações de tal perspectiva têm sido bem apontadas pela crítica mais atual $^{88}$. Se, na prática, a decisão de marcar certas obras e artistas como expoentes de um artificialismo acadêmico permitiu a legitimação de outros tantos, por outro lado resultou, do ponto de vista da pesquisa, em estudos que fecharam os olhos para as inúmeras continuidades entre a tradição acadêmica e as chamadas vanguardas inviabilizando um conhecimento mais aprofundado de relações definidoras no que se refere à produção artística de ambas as vertentes. A presente dissertação alinha-se com esse entendimento. Optamos, assim, por alargar as discussões sobre estilo à luz de interrogações envolvendo a tela. Assim, será possível compreender o que o estilo pode revelar a respeito da intencionalidade de $A$ redenção de Cam, em contraposição com outros quadros - sejam de Brocos, ou de outros autores.

\section{Uma estética do preconceito? Alargando fronteiras}

Como mencionamos no início da apresentação, na medida em que procura demonstrar uma tese sobre o embranquecimento, A redenção de Cam constitui um objeto privilegiado para os debates sobre o peso de uma dimensão estética na conformação do preconceito - sobretudo, o chamado preconceito racial. Situar melhor essa proposição exige duas definições preliminares: é preciso delimitar tanto a ideia de preconceito, quanto a de estética, para então elucidar as conexões entre elas.

\footnotetext{
"Academic" is not simply a label which describes a particular type of painting. It is an act of evaluation. As [Clement] Greenberg himself says in his most influential essay, 'Avant-garde and kitsch' (1939), 'evidently, all kitsch is academic; and conversely, all that's academic, is kitsch'. (...) what Greenberg attempts to do is to claim both an equation of 'academicism' with industrial capitalism, and of good taste with the ethics of political radicalism" BARLOW, P. Fear and loathing of te academic, or Just what is it that makes the avant-garde so different, so appealing? In: CARDOSO, Rafael \& TRODD, Colin. Art and the academy in the nineteenth century. Manchester, Manchester University Press, 2000, pp. 15-18.

${ }^{88}$ Cf. THUILLIER, Jacques. Peut-on parler d'une peinture « pompier » ?. Paris: Presses Universitaires de France, février 1984. BARLOW, op.cit. Coli é um dos autores que, no Brasil, vem questionando a validade da classificação. Ao discutir a aproximação de Victor Meirelles e Pedro Américo sob o denominativo de acadêmicos, o historiador pergunta: "Basta, portanto, refletirmos: que valor possui um conceito classificatório ou analítico, que põe, sob o mesmo rótulo, duas obras tão absoluta e completamente distintas? Os modernos simplesmente não as viam. Eles não pousavam os olhos sobre a superfície pintada. Eles criavam uma fronteira, uma muralha. Daqui para cá, moderno. Daqui para lá, "acadêmico". E basta, para uma atitude que fazia uma ótima economia do olhar, da análise autêntica e da reflexão fecunda" COLI, J. Pedro Américo, Victor Meirelles, entre o passado e o presente. Anais do I Encontro de História da Arte - IFCH/UNICAMP. Disponível em:

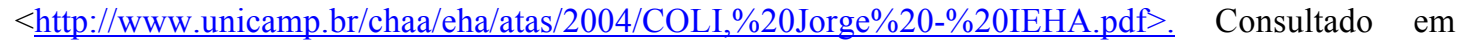
15/07/2013. Entre os autores que se alinham a tal perspectiva, destacamos ainda Arthur Valle, Camilla Dazzi, Maraliz Christo, Ana Paula Simioni, Luciano Migliaccio, Elaine Dias e Lilia Schwarcz.
} 
Antonio Sérgio Guimarães ${ }^{89}$ ensina que o termo preconceito, do ponto de vista sociológico, diz respeito a um conjunto de atitudes, propósitos e disposições interiores que contribuem para ver determinados grupos de forma negativa. No marco dos debates contemplados por esta dissertação, a definição abre espaço para uma avaliação das formas de caracterização das diferenças ditas raciais entre as personagens de $A$ redenção de Cam, além de autorizar uma análise transversal, articulando as variáveis raça e gênero no quadro.

No que se refere especificamente ao preconceito dito racial, a dissertação também se beneficia de outra definição apresentada por Guimarães, qual seja, a de racismo, entendido como "uma forma bastante específica de 'naturalizar' a vida social, isto é, de explicar diferenças sociais e culturais a partir de diferenças tomadas como naturais" $" 90$. O conceito possibilita indagar sobre as maneiras por meio das quais a tela concorre para processos de naturalização desse tipo - ou seja, como (re)produz modos específicos de ver os atributos considerados específicos a cada grupo "racial".

Em ambas as definições, a ideia da percepção aparece como um fator importante na configuração do preconceito e do racismo e, desse modo, tais conceitos abrem espaço para a discussão sobre estética ${ }^{91}$. Em linhas gerais, a análise social beneficia-se do conceito de estética na medida em que ele diz respeito às formas sociais ou materiais assumidas pela intuição sensível ou ainda ao efeito dos estímulos sensoriais sobre a percepção humana do mundo sensível ${ }^{92}$. Assim, o conceito tem sido empregado com o intuito de compreender de que maneira a experiência sensual ou sensorial está implicada nos processos de produção e transmissão de conhecimento no interior de diferentes grupos humanos ${ }^{93}$, perguntando-se sobre a forma como as

\footnotetext{
${ }^{89}$ GUIMARÃES, A. S. A. Preconceito e discriminação. Queixas de ofensas e tratamento desigual dos negros no Brasil. Salvador: Novos Toques, 1998.

${ }^{90}$ GUIMARÃES, A. S. A. Racismo e Anti-Racismo no Brasil. São Paulo: Editora 34, 1999, p. 9.

${ }^{91}$ Como se sabe, esta noção se desenvolve a partir de uma longa tradição reflexiva que remonta às formulações de Emmanuel Kant. Para um debate sobre o uso da noção de estética em antropologia, ver WEINER, J. Aesthetics is a cross-cultural category. In: INGOLD, T. Key Debates in Anthropology. London, Routledge, 1996. Cf. também . Aesthetics. In: BARNARD, A.; SPENCER, J. (ed.). Encyclopedia of social and cultural anthropology. London \& New York: Routledge, 2002, p. 9.

${ }^{92}$ Vale lembrar que a tradição de debates sobre estética no pensamento ocidental também remonta a outra definição formulada por Kant: na Crítica do Julgamento, ela aparece como uma modalidade de discernimento que habilita a apreciação da beleza. Idem, 2002, p. 9.

93 Destacamos aqui os trabalhos de Claude Lévi-Strauss e Marilyn Strathern - guardadas as especificidades de cada um -, como obras que buscam interrogar a noção de estética a partir de questões antropológicas. O primeiro é considerado o autor de uma teoria estética em antropologia, que inclui diversos escritos e depoimentos sobre arte. Cf. SIMONIS, Y. 1980. Claude Lévi-Strauss: Ou, La Passion de L'inceste. Introduction Au Structuralisme. Paris Flammarion, 1980; WISEMAN, B. 2007. Ideas in Context. Lévi-Strauss, Anthropology, and Aesthetics. Cambridge University Press;
} 
sensações e percepções mobilizam esquemas cognitivos que viabilizam (ou não) interações sociais e com o mundo sensível. Isto porque, como resume Weiner, "there is no effect of such stimuli by themselves, that is, apart from some prior cognitive schematism that makes such stimuli recognizable in their particular form"94.

No que tange aos limites desta dissertação, as discussões abertas por esse conceito abrem perspectivas para compreender em que medida o preconceito (ou racismo) se exprime por meio de um sistema estrutural de códigos e corporeidades, aparências capazes de antecipar a percepção de um universo sensível, impondo resistências à experiência relacional. Desse modo, propomos pensar a estética como uma experiência de si e do outro, em que a caracterização do corpo - passando pelas imagens procuram inscrevê-lo - é vista por sua capacidade de intervir em processos de diferenciação e identificação, incidindo sobre a constituição de subjetividades e sobre as próprias interações sociais. As reflexões de Schaeffer ${ }^{95}$ sobre o estatuto da imagem como um lugar de pensamento sobre o corpo na tradição ocidental, nesse sentido, são fundamentais para as discussões que procuramos empreender, assim como as considerações de Didi-Huberman sobre a capacidade dos corpos e volumes de ativarem presenças ou qualidades in absentia por meio de um imbricado jogo entre crença e tautologia que fundamenta processos de apreensão do mundo objetivo no ocidente ${ }^{96}$.

À luz desses parâmetros conceituais, é importante destacar a singularidade da fonte visual como um suporte que viabiliza a discussão sobre estética: a imagem, afinal, constrói e possibilita estabelecer relações a partir de convenções formais e qualidades materiais específicas. Constituindo-se como sistema de notação com uma capacidade única de simbolização e metaforização, ela tende a resistir às tentativas de adscrição textual mais evidentes. Assim, mesmo uma imagem que aparentemente não suscita dúvidas sobre o tema que aborda, como $A$ redenção de Cam, vai além da

(org.). 2010. The Cambridge Companion to Lévi-Strauss. Cambridge University Press, 296-314. Strathern propõe, sobretudo no clássico $O$ gênero da dádiva, que o processo social na Melanésia reside na aparência assumida pela vida social, que assim só adquire sentido na medida em que se revela como uma imagem - entendida como a forma adequada das relações. Assim, não se pode falar em sociedade como um conceito a priori para os grupos melanésios. STRATHERN, M. O gênero da dádiva. Campinas, Editora Unicamp, 2006. Cf. WEINER, J. op. cit.

${ }^{94}$ Idem, ibidem. Cf. também WEINER, J. Aesthetics is a cross-cultural category. In: INGOLD, T. Key Debates in Anthropology. London, Routledge, 1996.

95 SCHAEFFER, J.-M. Le corps est image. In: Image [\&] Narrative, 15, Battles around Images: Iconoclasm and Beyond, nov. 2006, s.p. Disponível em: $<\mathrm{http}$ ://www.imageandnarrative.be/inarchive/iconoclasm/schaeffer.htm>. Consulta a 10/05/2013.

${ }^{96}$ DIDI-HUBERMAN, G. O que vemos, o que nos olha. São Paulo: Editora 34, 2010. 
simples reafirmação de uma ideia preexistente, revelando uma trama argumentativa mais complexa: o que ela oferece é uma determinada maneira de ver um assunto. Percebê-lo nos permite novas articulações, que ajudam a explorar as possibilidades de análise da pintura.

Em primeiro lugar, é válido pensar que $A$ redenção de Cam constitui uma "imagem padrão de referência" 97 . Segundo Paulo Menezes, esse tipo de imagem opera por meio de formas "naturalizadas", capazes de expressar "os atributos do olhar de quem olha como se fossem expressão cultural do outro que é olhado" ${ }^{99}$. O termo autoriza correspondências com a definição de racismo proposta por Guimarães $^{100}$ - que, como vimos, diz respeito às formas de naturalização de determinados atributos, que passam a ser considerados raciais.

Ao mesmo tempo, ele propicia pensar em que medida as figuras da avó e da mãe, na cena pintada por Brocos, são tornadas voluntárias no processo branqueador e convertidas em exemplos de (e para) seu grupo racial e de gênero. Veremos que tal caracterização indica um certo grau de conformidade com um determinado paradigma de branquitude e masculinidade que ganha força no Oitocentos tardio ${ }^{101}$, de modo que a pintura insinua uma cumplicidade que espera encontrar no olhar de seu público. Há que se perguntar, portanto, sobre as posições que a tela induz seus espectadores a assumir $^{102}$, tendo em mente que a partir do momento em que ela impõe visões e

97 MENEZES, P. R. A. O nascimento do cinema documental e o processo não civilizador. In: MARTINS, J. S.; ECKERT, C.; NOVAES, S. C. (orgs.). O imaginário e o poético nas ciências sociais. Bauru, EDUSC, 2005, p. 73. Poderíamos acrescentar, aqui, a referência ao trabalho pioneiro de Teresa de Lauretis sobre as perspectivas de gênero no cinema, em que ela define a importância de reformular a relação entre espectador e imagem: é preciso substituir a ideia de que as imagens retratam mulheres pelo reconhecimento de que elas de fato lidam com a construção de um protótipo de feminidade, desde um ponto de vista masculino. LAURETIS, T. D. Figures of Resistance: Essays in Feminist Theory. Urbana and Chicago: University of Illinois Press, 2007; e LAURETIS T. D. Technologies of Gender: Essays on Theory, Film, and Fiction. Bloomington: Indiana University Press, 1987. Agradeço a Ana Paula Cavalcanti Simioni; Maira Ishtar de Luca; e Débora Dorotinsky, organizadoras do dossiê temático Art et genre: femmes creatrices en Amérique Latine da revista Arteologie, pela indicação de leitura de Teresa de Lauretis.

${ }^{98}$ Idem, ibidem.

${ }^{99}$ Idem, ibidem, p. 74.

${ }^{100}$ GUIMARÃES, A. S. A. Racismo e Anti-Racismo no Brasil. São Paulo: Editora 34, 1999.

101 Ver BEDERMAN, Gail. Manliness \& Civilization: a cultural history of gender and race in the United States, 1880-1970. Chicago: University of Chicago Press, 1995. McCLINTOCK, Anne. Couro Imperial: raça, gênero e sexualidade no embate colonial. Campinas: Editora Unicamp, 2010. MISKOLCI, R. O desejo da nação: masculinidade e branquitude no Brasil de fins do XIX. São Paulo: Annablume, 2012.

102 Como fizeram DYER, R. White. London and New York: Routledge, 1997. POLLOCK, G. Differencing the Canon. Feminist Desire and the Writing of Art's Histories. London and New York: Routledge, 1999; MULVEY, Laura. "Visual pleasure and narrative cinema". In: Visual and other pleasures. Indianápolis: Indiana University Press, 1989. HOOKS, b. "The oppositional gaze: Black 
modos de ver, inaugura um jogo potencial de deslocamento e/ou fixação de perspectivas.

Em segundo lugar, compreender como essa dimensão estética encontra fundamentação na pintura é discutir um equilíbrio tênue entre o uso de esquemas consagrados pela convenção e o tratamento de ordem técnica e estilística específico que o artista lhes confere. Esta relação é bem observada pelo historiador da arte Ernst Gombrich, quando observa que a pintura de caráter verista não extrai sua ilusão de um modelo real, mas a obtém pela maneira com que articula um conjunto de esquemas visuais básicos (schemata), transmitidos ao longo de gerações e continuamente readaptados pelos $\operatorname{artistas}^{103}$ - com atenção ao fato de que podem não guardar nenhuma correspondência imediata com as formas naturais que supostamente as inspiraram.

De acordo com Gombrich, perceber o uso de tais esquemas ajuda a entender que, diante de um universo relacional em que o conhecimento do outro e da natureza é mediado por imagens, "somos as vítimas passivas, embora voluntárias, de uma ilusão incontornável"104. A constatação faz emergir o problema do paradigma realista para a arte ocidental e, nesse sentido, convida a desconfiar das aparências codificadas por certas imagens, bem como os "contextos mentais" - convenções ou memórias de esquemas aprendidos - que poderiam induzir o espectador a partilhar de uma ilusão. Logo, se a pintura propõe um modo de ver, vale-se para isto da suposição de compartir determinados contextos mentais e esquemas com seu público-alvo. Isto é fundamental para que se possa levar adiante a proposição de que a pintura permite evidenciar uma dimensão estética do preconceito.

Por fim, um último ponto merece atenção. A ideia de que a pintura é preconceituosa (ou racista), como vimos anteriormente, encontra vazão em análises de alguns críticos contemporâneos - com os quais concordamos - e reflete um olhar atual que não corresponde, evidentemente, às perspectivas dominantes na época de produção do quadro. É preciso reforçar que o termo preconceito, aqui adotado, deve

female spectators". In:__ Black looks: race and representation. Boston, South End Press, 1992, pp. 122-123. Disponível em: < http://www.umass.edu/afroam/downloads/reading14.pdf $>$. Última consulta: 27/03/2013. LAURETIS T. D. Technologies of Gender: Essays on Theory, Film, and Fiction. Bloomington: Indiana University Press, 1987. Theory. Urbana and Chicago: University of Illinois Press, 2007.

${ }^{103}$ GOMBRICH, E. Arte e Ilusão. Um estudo da psicologia da representação pictórica. SP: Martins Fontes, 2007.

${ }^{104}$ Idem, ibidem, p. xvii. 
ser visto como um conceito analítico e anacrônico: viabiliza o acesso ao passado, mas também o reconhecimento de operar sobre ele uma reconfiguração ${ }^{105}$ que, por seu turno, resulta numa segunda reconfiguração, a do presente - ou pelo menos das formas com que lidamos com o passado e suas sobrevivências mais atuais. Se o entendimento de preconceito adotado aqui não fazia sentido no final do século XIX, ao mesmo tempo, ele nos é fundamental para a abordagem crítica dessa época - abre caminhos para uma análise mais detida das disposições presentes em $A$ redenção de Cam, mas também pode vir a contribuir para uma revisão sobre a presença de personagens não-brancas em outras telas.

A memória, como se sabe, é profundamente visual, ou profundamente ativada pelas sensações imagéticas. Devemos a Wiseman ${ }^{106}$ a recuperação do conceito de imagines agentes. $\mathrm{O}$ tratado Retórica em Herenius, como lembra o autor, defende a necessidade de construção dos palácios da memória, ou lugares imaginários que guardam os arquivos de tudo aquilo que se deseja recordar. Na metáfora, cada sala do palácio armazena uma sequência de argumentos complexos, que emergem da própria aparência do cômodo, no momento de sua recuperação mnemônica. O poder da imagem depende de um duplo apelo, sensorial - vez que propicia a sensação de estarse num espaço familiar - e cognitivo - porque o ato de rememorar garante o pensar. $\mathrm{O}$ interior do palácio é, assim, formado por aposentos decorados por imagines agentes, ou imagens com poder de ação ou agência sobre a existência. $\mathrm{O}$ deslocamento imaginário para um espaço que guarda as mais diversas aprendizagens habilita, nesse sentido, a vivência de estar-se imerso numa nova topografia, ativando sensações arquivadas pelos órgãos dos sentidos, o corpo, o pensamento.

Diante da metáfora, fica uma pergunta e um desafio, que nos propomos a enfrentar: e se $A$ redenção de Cam fosse vista como imagine agente? É possível trazer à vista sua história, como se passeássemos pelos corredores de um palácio da memória? Por um lado, é certo supor que uma pintura preconceituosa ative experiências sensoriais e cognitivas em torno do preconceito. Por outro, elas não se restringem jamais a uma única imagem, mas permitem conectá-la a outras imagines agentes - a um só tempo visuais e discursivas - e inseri-las numa história comum.

\footnotetext{
${ }^{105}$ DIDI-HUBERMAN, G, Georges. Devant le temps. Histoire de l'art et anachronisme des images. Paris: Minuit, 2000.

${ }^{106}$ WISEMAN, B. (org.). The Cambridge Companion to Lévi-Strauss. Cambridge University Press, 2010, p. 296-314.
} 
A partir desta metáfora, o trabalho se estrutura em três círculos em torno da tela, cuja abrangência diz respeito a diferentes níveis de abertura que ela desencadeia.

O primeiro círculo (capítulo 1), A tela, por seu nome apresenta dois tipos de imagines agentes que se desdobram numa visualização do quadro à luz do título que ele recebeu. Há, em primeiro lugar, interpretações do Genesis 9 produzidas desde o período medieval, ou seja, formas discursivas e visuais que operam uma série de mutações fundamentais no texto das escrituras - sendo a principal delas a introdução, no episódio bíblico, da ideia de que o castigo tornaria negra a pele dos descendentes de Cam. Veremos que essas elaborações de fundo escritural permitiram a emergência e difusão, sobretudo no ocidente, de uma série de justificativas cristãs para a escravidão dos africanos e teorias explicativas para as diferenças de cor da pele entre os humanos, até culminarem na consolidação da noção científica de raça - cujo alcance e incidência são particularmente notáveis no século XIX. Paralelamente, procuraremos mostrar a aparição da crença num poder redentor do branqueamento, com especial nas tradições portuguesa e brasileira, que serve de tema para $A$ redenção de Cam.

O segundo círculo (capítulo 2), A tela, por seu estilo, é inspirado por Carlo Ginzburg ${ }^{107}$, quando ensina a ver que o estilo pode funcionar como uma arma - um dispositivo cortante que tem cumprido um papel fundamental na justificação das diferenças na tradição ocidental. Assim, buscamos compreender o que o estilo pode nos dizer sobre as possíveis intenções de $A$ redenção de Cam, num contexto marcado por preocupações com a incorporação dos ex-escravos e seus descendentes à ordem livre e republicana. Procuraremos observar em que medida esta pintura é parte integrante de um projeto artístico que compartilhou uma indagação sobre tal assunto, ao mesmo tempo em que buscou uma solução original para endereçá-lo, do ponto de vista do estilo. A reflexão estrutura-se por meio do diálogo com outras pinturas, a fim de situar melhor alguns impasses por trás da definição de um tipo de arte que, talvez, possamos chamar de racial.

O terceiro círculo (capítulo 3), A tela e seus esquemas, visa levar adiante a discussão sobre as intenções ${ }^{108}$ do quadro, na medida em que busca circunscrever

\footnotetext{
${ }^{107}$ GINZBURG, C. Style as Inclusion, Style as Exclusion In: JONES, C. A., GALISON, P. (ed.). Picturing Science, Producing Art. Routledge, 1998.

${ }_{108}$ BAXANDALL, M. Padrões de intenção: a explicação histórica dos quadros. São Paulo: Companhia das Letras, 2006.
} 
diálogos entre esquemas e tópicas presentes em $A$ redenção de Cam e outras imagines agentes que marcaram modos de ver naquele momento. Dois elementos receberão atenção particular: a construção das posições de gênero e o uso da cor. O capítulo também procura descortinar a existência e os parâmetros que orientam a percepção do corpo negro e feminino, segundo um olhar branco, masculino e heterossexual. Assim, será possível auferir a originalidade de $A$ redenção de Cam e qualificar melhor as particularidades de seu preconceito. Logo, o capítulo complementa as discussões propostas nos anteriores, provendo elementos para compreender o peso da escolha de determinadas tópicas e esquemas na resolução de um problema pictórico e também na demonstração de uma tese pela obra de arte.

Por fim, teceremos algumas considerações em torno de pinturas produzidas por artistas contemporâneos a Brocos, num contraponto que visa sobretudo suscitar novas questões à luz do trajeto empreendido.

Sem mais, abrimos aqui os debates propostos. 


\section{Capítulo 1: A tela, por seu nome}

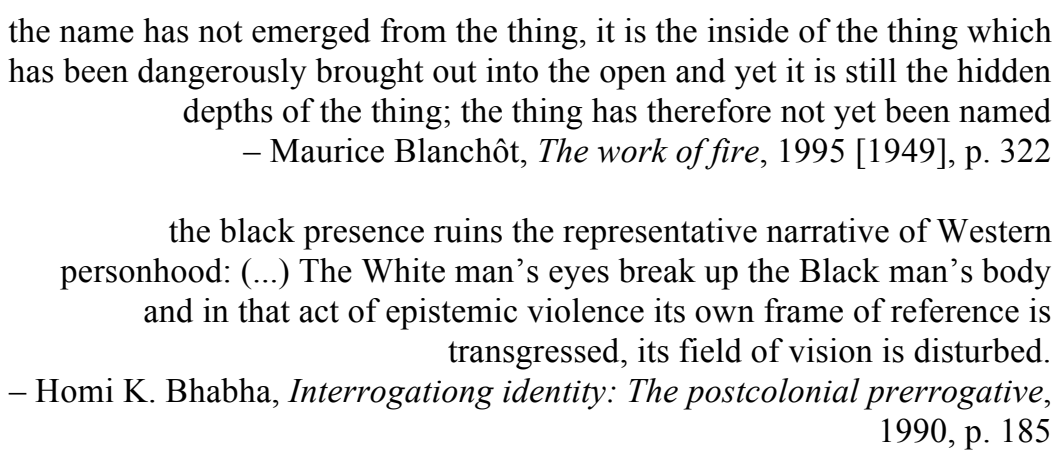

Se o nome mascara profundezas ocultas, também as delineia. $\mathrm{O}$ jogo consiste no esboçar, através do nome, uma tese sobre a coisa. Assim, tem-se de um lado a pintura e de outro, a existência da figura de nome Cam, que ali se redime. Os dois aspectos são indissociáveis. Mas se a ideia de redenção - que na imagem estaria ligada ao nascimento de uma criança branca - só se torna inteligível a partir da referência a Cam, compreendê-la é encontrar muitas outras possibilidades de contar a mesma história.

Segundo as escrituras, Cam teria exposto a nudez de seu pai, Noé, aos irmãos Sem e Iafet, motivo pelo qual foi castigado pelo patriarca. A maldição recaiu sobre o filho de Cam, Canaã, condenado a tornar-se servo dos tios. Da passagem à pintura, inúmeros caminhos interpretativos foram percorridos, por meio de imagens e narrativas que antecedem e acompanham preocupações de um ocidente escravista e pós-abolições. Em meio às especulações sobre diferenças que hoje chamamos raciais e à construção de justificativas para a escravidão dos africanos pelos europeus, emerge dessas proposições a imagem de Cam transformado em negro e, com ela, inúmeras teorias que procuram auferir as possibilidades de uma transformação oposta, de negro a branco.

Neste capítulo, procuramos mostrar em que medida as histórias sobre Cam tornam-se histórias de um processo de construção de uma imagem para a população negra, em que diversos narradores procuram reforçar traços distintivos, envolvendo fisionomias, medidas do corpo, marcas corporais, roupas e adereços, mas também o caráter. Veremos como, sobretudo no ocidente, o mito de Cam esteve ligado a debates 
responsáveis pela consolidação de modos específicos de ver e pensar as diferenças de cor/raciais.

Numa série de encontros em que a variabilidade de tons de pele humana se interpunha à classificação binária (negro e branco), um olhar europeu trabalhava construir sistemas de aproximações e diferenciações internas a grupos que ora poderiam ser vistos como homogêneos. Por um lado, operava cisões, fragmentos; por outro, agrupava e aproximava supostos iguais, sempre definidos a partir de impressões externas. A despeito da diversidade de teorias que se pudesse levantar, tinha-se como constante uma imagem em que o negro era tornado o avesso do branco e este, sempre alçado à posição mais nobre numa escala de valor que ele mesmo trabalhava para construir.

Percorreremos as interpretações do mito bíblico de Cam, acompanhando seus usos na explicação das diferenças, mas também a minimização do argumento bíblico em detrimento das justificativas que se convencionou chamar de científicas, em âmbito internacional e, mais especificamente, no mundo português e no Brasil. Em meio a tal movimento, refletiremos sobre o processo de demarcação das diferenças em meio a fronteiras hereditárias, fixadas ao corpo e à moral de forma indelével.

\section{O povo de Cam é uma imagem}

Alguém que quisesse encontrar a África deveria ir ao grande mercado próximo à Baía, onde se podia encontrar o povo de 'Cam' sentado, acocorado, onduloso e tagarela, com seu turbante de casemira, ou vestido de trapos, arrastando as rendas ou os andrajos - Charles de Ribeyrolles ${ }^{109}$.

Sensações visuais e sinestésicas viabilizam a descrição do povo de 'Cam' sob a pena do viajante Charles de Ribeyrolles (1812-1860). Trata-se de um povo “onduloso e tagarela", vestido à oriental com seus turbantes e casemiras. Metonímias de tecidos e modos alheios, extemporâneos, aqui as rendas se equiparam aos andrajos: valor comum para quem passa no mercado a céu aberto, podem ser cambiados sem prejuízo semântico algum, à medida que recobrem corpos tão indiferenciados, quanto iguais entre si. Entre relações de compra e venda, ruídos e ondulações, os tecidos transportam um pedaço de África para o Brasil - ou vice-versa.

A descrição de Ribeyrolles junta indefinição e particularismo. Fundamenta-

\footnotetext{
${ }^{109}$ RIBEYROLLES, C. de. Brasil Pitoresco. Belo Horizonte E São Paulo, Ed. Itatiaia/EDUSP, 1975, 1861, vol. 1, p. 203.
} 
se numa lógica de sensibilidades em que a impressão, o deslocamento de experiências prevalece sobre a familiaridade. Mais que isso, tal estratégia pautada no sensível é o anteparo que permite ao narrador adentrar numa África imaginária: procedimento em que a observação e registro distanciado permitem soprar ares de evidência por sobre elementos corriqueiros que, aos poucos, dão lugar a formas estáveis, passíveis de comunicar o que se vê a quem não presencia a cena.

Tudo de passa como se Cam fosse a senha que permite compreender o povo de que se fala, essa espécie de incógnita em turbante de casemira. A indefinição pessoal dessas figuras, eclipsada por objetos correntes (rendas, andrajos e turbantes), é um ingrediente sugestivo quanto à clareza visual com que o nome Cam reverbera no glossário do viajante europeu e seus leitores: sem nenhuma menção à raça ou cor da pele, tem-se no entanto uma série de atributos estéticos que definem uma África plenamente traduzida nos descendentes portuários de Cam.

Entretanto, voltar à narrativa escritural em que a figura de Cam dá o tom não resulta em maior embasamento para tal correlação entre África e a maldição bíblica. Diz o Genesis 9:

E começou Noé a ser lavrador da terra, e plantou uma vinha. E bebeu do vinho, e embebedou-se; e descobriu-se no meio de sua tenda. E viu Cão, o pai de Canaã, a nudez do seu pai, e fê-lo saber a ambos seus irmãos no lado de fora.

Então tomaram Sem e Jafé uma capa, e puseram-na sobre ambos os seus ombros, e indo virados para trás, cobriram a nudez do seu pai, e os seus rostos estavam virados, de maneira que não viram a nudez do seu pai. E despertou Noé do seu vinho, e soube o que seu filho menor lhe fizera. E disse: Maldito seja Canaã; servo dos servos seja aos seus irmãos.

E disse: Bendito seja o SENHOR Deus de Sem; e seja-lhe Canaã por servo.

Alargue Deus a Jafé, e habite nas tendas de Sem; e seja-lhe Canaã por servo $^{110}$.

Aqui se fala em castigo e servidão, faltando-se no entanto clareza quanto à extensão da pena a toda a descendência de Canaã. Além disso, escapa ao trecho qualquer referência à África. Como compreender que, no ano de publicação de Brasil Pitoresco (1861), a passagem bíblica já apareça perfeitamente ajustada a uma existência colonial, pese o fato de que os castigados usam turbantes, casemiras, rendas e andrajos, sentam-se no chão do mercado portuário e conversam em demasia, no dizer de Ribeyrolles? Como se a escritura encontrasse a história, o povo de Cam

${ }^{110}$ GENESIS, 9:20-27. 
ganha existência visível; pode-se apontá-lo, localizá-lo geograficamente, dizer de seus costumes e descrevê-los na roupagem e gestual. $\mathrm{O}$ único ponto que falta à passagem do viajante diz respeito à cor da pele, que fica cifrada nos demais elementos.

A menção a Cam também se faz acompanhar da referência africana no poema Vozes d'África, de Castro Alves (1947-1971) ${ }^{111}$. Mas, como observa Costa e Silva, sua África é construída pela imagem do deserto, consiste numa "ampliação, para todo o continente, da África do Norte. Do Egito. Da Líbia. Da Argélia, ocupada pelos franceses desde 1830. Da África de Delacroix e Victor Hugo. Da África do orientalismo, da literatura romântica e do imperialismo francês"112. Castro Alves afastava-se de Ribeyrolles, ao trasladar sua epopeia anti-escravista ao terreno das narrativas fantásticas de sultões e odaliscas, tão populares em seu tempo. Além disso, valia-se da imagem de uma África admirada por seu público para reforçar sua crítica à escravidão. Para tornar explícita esta intenção, aliás, "bastava-lhe aludir a Cam",113, figura cuja história se convertera em justificativa para a existência daquele sistema que, no Brasil, só seria legalmente abolido em 1888.

Mas se as citações orientalistas de Alves poderiam sugerir a ideia da pele clara que marcava tantas imagens produzidas pela arte orientalista europeia, de acordo com Seyferth, a associação que marcou definitivamente as exegeses do mito bíblico foi entre Cam, a pele negra e a escravidão:

\begin{abstract}
Antes que surgissem as primeiras classificações raciais da humanidade no século XVIII, duas crenças se afirmaram depois da descoberta da América, quando o conhecimento sobre outros povos se ampliou: os povos considerados decadentes estariam associados ao paganismo, e os negros estariam vinculados à prole de Cam. Mesmo com a utilização de vários critérios para justificar essas "descobertas", especialmente práticas religiosas, canibalismo e outros "costumes" considerados inconciliáveis com a civilização cristã, era normal associar a cor escura da pele à degeneração mais extrema - condição mais do que conveniente para justificar a prática da escravidão ${ }^{114}$ (grifos nossos).
\end{abstract}

\footnotetext{
111 Nascido em Corralinho, na Bahia, Castro Alves ficou conhecido como "poeta dos escravos". Abraçou cedo a luta pela emancipação, fundando com Rui Barbosa uma sociedade abolicionista. Teve grande êxito em seu tempo e conviveu com personalidades como Machado de Assis, José de Alencar e Joaquim Nabuco, no Rio, em São Paulo, Recife e na Bahia.

${ }^{112}$ COSTA e SILVA, A. Imagens da África. In: Revista de História, ed. no 24, set. 2007. Disponível em: < http://www.revistadehistoria.com.br/secao/leituras/imagens-da-africa $>$. Consulta realizada em 23/07/2013. Ver também Castro Alves: um poeta sempre jovem. São Paulo: Companhia das Letras, 2006.

${ }^{113}$ Idem, ibidem.

${ }^{114}$ SEYFERTH, G. O futuro era branco. In: Revista de História, ed. no 69, jun. 2011, s.p.
} 
Tal uso da passagem bíblica transformava a escravidão numa espécie de penalidade para um crime ancestral, cuja comprovação dependia de tomar-se a pele escura como evidência cabal. Merece atenção o peso assumido pela visão já no Genesis 9. No trecho escritural, cobrir ou dar a ver, exibir, expor, olhar ou virar o rosto são ações que conduzem ao veredicto de Cam e à recompensa de seus irmãos. Além disso, as escrituras jogam com a centralidade do olhar para a experiência dita social, mas também indicam um percurso de interdições que recaem sobre o ato de ver. Interessa notar que, do mito às exegeses, instaura-se uma forma de expor a condenação na própria imagem dos infratores, tornar as marcas da maldição de Cam explícitas ou cravá-las na pele de seus descendentes, instaurando-se, na prática de uma suposta justiça, a lógica da evidência ocular. Segundo tal modelo, o corpo passa a servir como lócus de uma verdade factual latente.

Por esse motivo, é marcante que o mito de Cam mobilize o reconhecimento da cor da pele como indício de um crime de origem, qual seja, a difamação da imagem paterna; a revelação da nudez e da natureza corpórea da autoridade. $\mathrm{Na}$ tradição bíblica, a pele é, como lembra Benthien, a vestimenta primeva do corpo nu; e a roupa, o lugar de diferenciação moral entre humanos e animais, o que é “emphasized by the fact that God will fashion 'tunics of skins' (Genesis, 3:21) for Adam and Eve at the gate of paradise to clothe them with: what is given to animals as birth, Adam and Eve must appropriate as a second skin in order to become human in this primal cultural act of the emerging sense of the body shame"115.

É preciso olhar com mais atenção o trajeto por meio do qual atrelou-se a cor da pele - e também a ideia de raça -, ao castigo de Cam. É digno de nota que a fixação da pele negra à ideia de maldição dependeu de uma indexação de imagens à algo que, na escritura, aludia à posição social de escravo, mas não a marcas corporais. Tal intuito parece prevalecer em meio a uma tradição que buscou prover consistência ao episódio bíblico ao inscrever a cor da pele e aspectos da aparência e comportamento numa lógica de exibição visual de assimetrias sociais.

Organizava-se assim um conjunto de imagens capaz de restituir posições e lugares possíveis. Sobretudo, capaz de falar em nome de origens remotas, por vezes olvidadas, de modo eficaz. Os códigos eram expressos pela cor da pele, mas também

\footnotetext{
${ }^{115}$ BENTHIEN, C. Skin: On the cultural border between self and the world. New York: Columbia University Press, 2002, p. 98
} 
por atributos limítrofes que figurassem como ameaças às fronteiras de um mundo naturalizado. Na opinião de Sollors, à medida que se buscava interpretar o Genesis 9 , "the oddities and difficulties of this passage were frequently placed into contexts that would seem to provide plausibility for nonscriptural and historical reasons"116.

Os questionamentos que buscaram justificar as diferenças que hoje chamaríamos de raciais remontam à antiguidade ${ }^{117}$. Já no período medieval, coube a autores como Venerable Bede (ca. 672-735) e Rabanus Maurus (776-865), por exemplo, a vinculação entre o povo judaico, os habitantes de Sodoma e a prole de Cam, além de uma possível origem textual do termo "infiel", referindo-se aos nãocristãos. Gregório de Tours (ca. 540-594) identificou os camitas entre aqueles que praticavam a magia diabólica. Já Isidoro de Sevilha (560-632) é o reputado autor de um mapa que busca fixar geograficamente o paradeiro dos descendentes de Cam. A imagem divide o mundo então conhecido entre os filhos de Noé, explicando que a Ásia era o reino de Sem; a Europa, de Iafet; e a África, de Cam. A seu turno, os vitrais da Catedral de Chartres, construída no século XII, na França, instauram uma correlação não menos interessante, em que os três filhos de Noé são distribuídos como os representantes originais dos estratos sociais: Iafet, Primeiro Estado; Sem, Segundo Estado; e Cam, Terceiro Estado ${ }^{118}$. Tais associações constituem resquícios de uma tradição cristã que, entre os séculos VI e XII, parecia nutrir o propósito de explicar e legitimar determinada ordem secular, tornando visíveis classificações e lugares próprios com o intuito de estabilizar posições sociais.

Quanto ao tema das diferenças "raciais", o Genesis 9 foi primeiro usado para explicar a existência da pele negra entre as tradições judaica, cristã e islâmica ${ }^{119}$, para depois se tornar justificativa para a escravidão no mundo moderno, além das políticas de segregação racial e da proibição aos casamentos interraciais nos Estados Unidos. A partir de então, a passagem bíblica passa a evocar "a particularly problematic interracial story" ${ }^{\prime 120}$, em que a emergência de variações de cor da pele no interior de grupos e, mais especificamente, de famílias, se torna uma questão que desafia os

\footnotetext{
116 SOLLORS, W. Neither black, nor white, yet both. Thematic explorations of interracial literature. Cambridge: Harvard University Press, 1999. pp. 81-82.

${ }^{117}$ Cf. Idem, ibidem; e PIMENTEL, M. R. O enigma da cor: dissertação sobre a variedade das cores da espécie humana. In: Ellipsis, 8, 2010, pp. 49-74.

${ }^{118}$ Para uma exposição detalhada destas e de outras referências ao Genesis 9, cf. SOLLORS, op. cit..

${ }^{119}$ Idem, ibidem, p. 86.

${ }^{120}$ Idem, ibidem.
} 
intentos classificatórios originais, como pontua Sollors ${ }^{121}$. Muito além de brancos e negros, há uma gama de cores e características que devem ser identificadas no espectro gradativo que se considerava remontar à origem mítica.

As primeiras fontes de que se tem notícia quanto a uma associação entre o Genesis 9 e a cor negra da pele são produto do período entre os séculos II e VI. Em alguns textos midráshicos e talmúdicos, assume-se que a maldição de Cam afetou sua tez, ainda que o sentido dessas afirmações permaneça enigmático ${ }^{122}$. No Talmude babilônico, uma passagem destaca que "Ham [Cam] was smitten in his skin" e, mais adiante, que "from him descended Cush (the negro), who is Black-skinned""123. Outro exemplo sugestivo acerca desta abordagem do texto bíblico encontra-se no místico Zohar, quando afirma que Canaã "darkened the faces of mankind", designando-o como "the notorious world-darkener"124.

Entre os cristãos, São Efraim de Nesebis (m. 373) teria parodiado a frase de Noé ao dizer: "accursed be Canaan, and may God make his face black" "125, ao mesmo tempo em que outros autores e fontes dão indicativos diversos de que ora Canaã, ora Cush - outro dos filhos de Cam - podia ser reconhecidos pela pele escura. Novamente, assim como no caso das fontes talmúdicas mencionadas, apresentam-se alusões aos mesmos personagens e correlações insatisfatórias entre a pele negra e a maldição impetrada por Noé ${ }^{126}$.

Por outro lado, a tradição islâmica apresenta particularidades interessantes quanto à leitura do Genesis 9. No Corão, não há relação entre o castigo impingido por Noé e a pele negra, até porque, no livro sagrado, o filho do patriarca morre em meio ao dilúvio. Outras fontes da mesma tradição explicam a cor da pele pelo clima -

\footnotetext{
${ }^{121}$ Idem, ibidem.

${ }^{122}$ Idem, ibidem.

123 EPSTEIN, I et al. (trad.). The Babylonian Talmud. London, 1935-1960 apud SOLLORS, W.
} Neither black, nor white, yet both. Thematic explorations of interracial literature. Cambridge: Harvard University Press, 1999, p.87.

${ }^{124}$ SPERLING, H. e SIMON, M. (trad.). The Zohar. London, 1931 apud SOLLORS, op.cit. Todos os trechos entre aspas do parágrafo encontram-se em Sollors, de quem esta genealogia do mito é debitária. Reforçamos a indicação a uma leitura da discussão empreendida pelo autor, que se baseia numa variedade impressionante de fontes históricas. Igualmente, vale pontuar as ressalvas do próprio Sollors quanto às dificuldades de interpretar tais referências de modo unívoco. Cf. também GOLDENBERG, D. M. The Curse of Ham: Race and Slavery in Early Judaism, Christianity, and Islam. NY: Princeton University Press, 2003; PIMENTEL, M. R., op. cit.; e HOFBAUER, A. Uma história do branqueamento ou o negro em questão. SP: Editora UNESP, 2006.

${ }^{125}$ DEVISSE, J. The image of the Black in Western Art: from the Early Christian Era to the "Age of Discovery" Cambridge, Harvard University press, 1979 apud SOLLORS, op. cit., p. 87.

${ }^{126}$ SOLLORS, op. cit., p. 87. 
quando mais quente, mais escura -, constituindo referências originais para um debate que seria retomado a posteriori pela geografia ocidental. É o caso de Ibn Khaldun que, em seu Mukkadima (História Universal, de 1377) afirma: "to connect the black color of the Sudan with (the curse laid upon) Ham is to fail to understand the nature of the heat and cold, and of their influence on climate and on the condition of animal life" 127 .

Em meio a diversos escritos que partem do Genesis 9 - e em que a cor da pele é vista antes como produto de milagres divinos do que de uma maldição -, é intrigante pensar que o historiador persa al-Tabari (ca. 838-923) inverteu os sinais dominantes, associando o mal a Iafet, o irmão de pele mais clara. Vale à pena transcrever a passagem: "Shem [Sem] begat the Arabs, Persians and Byzantines, in all of whom there is good. Japheth [Iafet] begat the Turks, Slavs, Gog e Magog, in none of whom there is good. Ham [Cam] Begat the Copts, Sudanese e Berbers" "128. Sollors indica que nesta genealogia já se nota um intento de identificar diferentes povos de acordo com atribuições físicas, uma vez que cada linhagem possui um tipo físico específico: o de Cam é descrito como negro, dotado de cabelos encaracolados que não crescem para além de suas orelhas. A história contada por al-Tabari também destaca a escravidão, vez que todo descendente de Cam deve tornar-se servo dos membros do tronco semita que cruzarem seu caminho.

Evidentemente, é impossível fazer jus à diversidade e riqueza de todas essas fontes, assim como percorrer toda a gama de referências dispersas em um sem número de outros textos e imagens remanescentes do mesmo período. De qualquer forma, mencioná-las ajuda a compreender que determinadas associações relativas à aparência e à cor da pele são fenômenos de longa duração, e recorrentes, que ativam metáforas bastante antigas, sedimentadas por diferentes tradições. É o caso, por exemplo, das associações negativas em torno da pele negra, mediante uma positivação da branca. Diante delas - e a despeito de haver relatos que partem de entendimentos contrários, como o já mencionado al-Tabari -, a permanência do preconceito racial

\footnotetext{
${ }^{127}$ DEVISSE, J. The image of the Black in Western Art: from the Early Christian Era to the "Age of Discovery" Cambridge, Harvard University press, 1979 apud SOLLORS, W. Neither black, nor white, yet both. Thematic explorations of interracial literature. Cambridge: Harvard University Press, 1999, p. 90. Sollors destaca o significado da palavra Sudão, "pele queimada". Vale a ressalva quanto ao fato dessa fonte ser muito posterior às demais, já do século XIV.

${ }^{128}$ AL-TABARI. The History of al-Tabari. Albany, State University of New York Press, 1987 apud SOLLORS, op. cit., p. 89. Ainda que os descendentes de Cam sejam vistos invariavelmente como escravos dos de Sem.
} 
em dias correntes nos faz pensar na antiguidade e na prevalência de um discurso que, como mostrava Seyferth, vinculava a negritude a algo indesejável ${ }^{129}$.

Pois é no âmbito de uma Europa moderna e escravista que tal concomitância adquire fixação, através de um processo em que a busca de explicação quanto às diferenças corpóreas e na cor da pele se torna uma necessidade constante, ao passo que as relações interraciais passam a ser mediadas pelo corte da escravidão. Por ora, cabe guardar a ideia de que o povo de Cam vinha adquirindo a forma de uma imagem, enlaçando na pele, a ideia de servidão e vice-versa - o que se atribuía a uma verdade sagrada e imemorial ${ }^{130}$. Os camitas transformavam-se na imagem da diferença, seja no tocante à posição social, seja em âmbito geográfico, seja no que concerne ao tom da pele. Aproximamo-nos aqui de sentidos que embasam a pintura de Brocos e do problema instaurado pela permanente indefinição que emerge da $\operatorname{cor}^{131}$.

\section{O povo de Cam é negro}

Entre os primeiros autores do período moderno que evidenciam a justificação corrente da escravidão com base na história da maldição noelina, está o cronista português Gomes Eanes de Zurara (1410-1474). Diz o viajante em sua Crónica do Descobrimento e Conquista de Guiné:

And here you must note that these blacks, though they were Moors like the others, were nonetheless slaves [servos] of these by ancient custom, which I believe to be by the curse which after the flood Noé threw on his son Cam, by which he cursed him, that his descendants should be subject to all the other peoples of the world, from whom [Cam] these [Blacks] descend, following what was written by the archbishop D. Rodrigo of Toledo and

\footnotetext{
${ }^{129}$ SEYFERTH, G. O futuro era branco. In: Revista de História, ed. nº 69, jun. 2011, s.p.; ver também GOLDENBERG, D. M. The Curse of Ham: Race and Slavery in Early Judaism, Christianity, and Islam. NY: Princeton University Press, 2003; PIMENTEL, M. R. O enigma da cor: dissertação sobre a variedade das cores da espécie humana. In: Ellipsis, 8, 2010, pp. 49-74; HOFBAUER, A. Uma história do branqueamento ou o negro em questão. SP: Editora UNESP, 2006; GUIMARÃES, A. S. A. Preconceito Racial: modos, temas e tempos. São Paulo: Cortez Editora, 2012.

${ }^{130}$ Pimentel considera que a cor negra, "com a introdução de certos argumentos religiosos, passa a representar as trevas, a acção demoníaca, a depravação, o desregramento e a impureza. A negrura da pele surge relacionada com a perversidade, a corrupção e o crime, dando origem a um preconceito terrível: a cor era símbolo de acção pecaminosa e correspondia ao castigo divino que se prolongava de geração em geração"- castigo este expresso no mito de Cam e em outra maldição correlata, a de Caim, condenado por Deus por assassinar o irmão, Abel. Cf. PIMENTEL, M. R. O enigma da cor: dissertação sobre a variedade das cores da espécie humana. In: Ellipsis, 8, 2010, p.53.

${ }^{131}$ Usamos a palavra cor, pois esta talvez seja a única capaz de dar conta desse amplo recuo no tempo. A cor da pele, desde a Antiguidade, foi considerada lócus de diferenças que hoje chamaríamos raciais e/ou fenotípicas. Considerando-se que, em particular no século XIX, a palavra raça adere a sentidos biológicos, o uso da palavra cor evita interpretações errôneas sobre os fenômenos anteriores a esta transformação.
} 
also Josephus, in the book of the Antiquities of the Jews and even Walter, with other authors who spoke of the generations of Noé after the exit from the $\operatorname{ark}^{132}$.

Na descrição de Zurara, escrita a pedido d'El Rei D. Afonso V e sob instruções científicas do infante D. Henrique no século $\mathrm{XV}^{133}$, é curioso notar que, diante da semelhança física e religiosa entre os negros escravizados e os demais, a única frente de diferenciação possível se torna a escravidão. No tocante às referências acionadas pelo cronista, Schorsch sugere que o mencionado Arcebispo seria Rodrigo Jiménez de Rada, por sua vez seguidor de Isidoro de Sevilha na atribuição da origem camita aos povos africanos - ainda que não vinculasse ancestralidade e maldição, o que teria ficado a cargo de Zurara. A referência a Rada também é evocativa quanto ao reforço deste autor à prescrição do Leviticus: "to avoid sexual turpitude, lest 'we incur the curse of Cham [Cam]",134.

Já em terras brasileiras e cerca de um século mais tarde, outro personagem a conectar a escravidão ao episódio bíblico é o jesuíta Manuel da Nóbrega (1517$1570)^{135}$ que, por volta de 1557 escreve o fictício Diálogo sobre a conversão de um gentio, travado entre Mateus e Gonçalo. No documento, o primeiro comenta com o segundo que a escravidão (no caso, indígena) "lhes veio por maldição de seus avós, porque estes cremos serem descendentes de Cam, filho de Noé, que descobriu as vergonhas de seu pai bêbado, e em maldição e por isso, ficaram nus e tem outras mais misérias. Os outros gentios, por serem descendentes de Sem e Jafete, era razão, por serem filhos de benção, terem mais vantagem"136. Aqui, destaca-se o uso do termo gentio como não-cristão em geral; o fato da maldição ter resultado na nudez dos camitas; e o silenciamento sobre qualquer alusão à cor da pele como sinal do castigo elementos que possibilitariam estender argumentos em favor da escravização aos

\footnotetext{
${ }^{132}$ ZURARA, G. E. Crónica do Descobrimento e Conquista de Guiné. Porto: Livraria Civilização, 1973 apud SCHORSCH, J. Jews and Blacks in the Early Modern World. Cambridge University Press, 2004, p. 147. As demais referências citadas permanecem ininteligíveis, segundo Schorsch. Dispomos de outra edição, publicada em 1841 em Paris, em que o nome do cronista é grafado como Gomes Eannes de Azurara.

${ }^{133}$ Zurara foi cronista e o segundo Guarda-mor da Torre do Tombo, função que assumiu em 1454, depois de Fernão Lopes.

${ }^{134}$ Idem, ibidem.

${ }^{135}$ Manuel da Nóbrega chefiou a primeira missão jesuítica ao Brasil, desembarcando na Bahia em 1549.

${ }^{136}$ HOFBAUER, A. Uma história do branqueamento ou o negro em questão. SP: Editora UNESP, 2006, p. 159.
} 
indígenas (os mesmos já eram aceito com relação aos negros) ${ }^{137}$. Em meio às informações que esta fonte confere sobre a descendência camita, a nudez é reveladora de uma lógica em que a exposição do corpo é associada ao primitivo, uma vez que não se recobre com vestimenta, que como mencionamos, corresponderia ao decoro moral que diferencia humanos de animais.

Vinte anos mais tarde, o frei dominicano Francisco de la Cruz $(?-1578)^{138}$ reportava à Inquisição que "the blacks are justly captives by just sentence of God for the sins of their fathers, and that in sign thereof God gave them that color" ${ }^{\text {"139. Aqui a }}$ referência é direta aos negros, sem que haja clareza sobre o fato de serem ou não mouros. O trecho não vincula o castigo ao Genesis 9 - e nesse sentido é válido lembrar que certas exegeses unem duas maldições lançadas contra personagens bíblicos de nomes parecidos: a de Cam e a de Caim, condenado por Deus por assassinar seu irmão, Abel $^{140}$. Dessa forma, em distintas interpretações, Noé e Deus, Cam e Caim são termos intercambiáveis em mitos com a mesma função, sem prejuízo para a mensagem que comunicam. Ao operar tal substituição, o excerto é indicativo quanto à leitura do pecado como uma espécie de herança genealógica: se os pais pecaram, os filhos são automaticamente vistos como reprodutores do mesmo feito; fica latente a ideia de que o caráter, portanto, seria transmitido através das gerações.

Paralelamente às explicações que privilegiavam o argumento bíblico, corriam outras vertentes interpretativas para as diferenças de cor e status instauradas entre cristãos brancos e outras populações de seu convívio - estas mais diretamente aplicadas a defender que a cor da pele é um fenômeno natural. No século XVI, encontram-se autores que, expondo-se a eventuais acusações de heresia, tentavam justificar a existência de diferentes tonalidades para a epiderme com base em fatores climáticos ou internos ao corpo. Alguns, como Paracelso (1493-1541) e Giordano

\footnotetext{
137 É interessante situar melhor os personagens do diálogo, à medida que Mateus insiste na desigualdade natural entre os indígenas e europeus, enquanto Gonçalo acredita na possibilidade de conversão ao cristianismo e ao modo de vida europeu. Vale ressaltar que Nóbrega, por sua vez, se mostrou contrário à escravização dos indígenas ao longo da vida.

${ }^{138}$ Catedrático e reitor da Universidade do Peru, Francisco de la Cruz foi autor de uma gramática e dicionário em língua quéchua. Ele morreu queimado, após ser julgado culpado de heresia pelo Tribunal da Inquisição.

${ }^{139}$ CASTELÓ, Vidal Abril; STOFFELS, Miguel J Abril (orgs). Francisco de la Cruz, inquisición, actas II-1: del mito bíblico a la utopía indiana y andina. Editorial CSIC - CSIC, Press, 1996, p. 1327 apud GOLDENBERG, D. M. The Curse of Ham: Race and Slavery in Early Judaism, Christianity, and Islam. NY: Princeton University Press, 2003, p. 177.

${ }^{140}$ Cf. PIMENTEL, M. R. O enigma da cor: dissertação sobre a variedade das cores da espécie humana. In: Ellipsis, 8, 2010, pp. 49-74.
} 
Bruno (1548-1600) ${ }^{141}$, chegavam a propor que os humanos não vinham da mesma origem - o par inaugural Adão e Eva -, o que explicaria porque os indígenas do Novo Mundo eram tão estranhos aos europeus ${ }^{142}$.

Em meio a tais fontes, encontramos por exemplo a Cosmografia Universal (1575) escrita pelo francês André de Thévet ${ }^{143}$, para quem o calor tropical dissipara os "elementos mais subtis" dos corpos dos africanos, deixando só "a parte terrestre que tomava a cor e a consistência da terra"144. Já o português Duarte Lopes (s.d.) ${ }^{145}$, viajando por terras de África na segunda metade do século XVI, argumenta que a cor resultava não do clima, mas "da natureza da semente" "146. Isso porque percebia nascerem homens "quase" brancos em reinos tão cálidos quanto Melinde, em Mombaça, além de São Tomé, filhos das famílias portuguesas aí residentes.

A seu turno, um autor como o viajante britânico George Best (?-1584) ${ }^{147}$ repunha o discurso religioso como palavra de ordem, incorporando os demais argumentos à mitologia já consagrada em torno do Gênesis 9: sem refutar totalmente a ideia de que a pele negra advinha do corpo (a "natureza da semente"), considera que sua origem estaria numa infecção natural provocada pela maldição lançada por Noé

${ }^{141}$ Paracelso foi um médico, alquimista botânico e astrólogo suíço, considerado pioneiro na área de toxicologia e nos estudos empíricos do corpo humano. $\mathrm{O}$ italiano Giordano Bruno foi frei dominicano, matemático, astrólogo e astrônomo. Considerado herege, ele foi condenado à fogueira pela Inquisição. Em vida, ampliou o modelo de sistema solar proposto por Copérnico, argumentando sobre a existência de outras estrelas e sistemas no universo.

142 "Curiosamente, a nudez dos índios do novo mundo, ademais da facilidade para embriagá-los e escravizá-los, constituíram argumentos para muitos escritores do século XVI, sobretudo na França e na Espanha, para considerá-los também camitas, descendentes do filho maldito de Noé", dizem Bueno e Jiménez (2000, p. 114). O franciscano Juan de Torquemada atribui a escravidão indígena à sina de Cam, em Monarquia Indiana (1612). Já o eclesiástico e historiador espanhol Francisco López de Gómara (1511-1566), por volta de 1555, vale-se do mito de Cam para argumentar em pró da escravização dos indígenas nas Américas, alegando que o pecado de tais nativos contra a ordem divina teria sido ainda mais grave que o de Cam contra seu pai. Todos esses pontos parecem interessantes dimensões de um mito bíblico sobre a origem das raças, ainda mais se as combinarmos com a perplexidade dos Europeus ao descobrir que, no Novo Mundo, a despeito da latitude tropical, os nativos não tinham a pele negra. Cf. Goldenberg, op. cit.; HOFBAUER, A. Uma história do branqueamento ou o negro em questão. SP: Editora UNESP, 2006 e SCHORSCH, J. Jews and Blacks in the Early Modern World. Cambridge University Press, 2004

${ }^{143}$ Francês, Thévet foi um frade franciscano e cosmógrafo de Henrique II, rei da França. E reputado como responsável pela disseminação do nome "França Antártica" em referência à colônia francesa no Rio de Janeiro - cujo fracasso atribui aos huguenotes.

${ }^{144}$ THÉVET, André. Cosmografia Universal. Batel, 2009 [1575] apud PIMENTEL, M. R. O enigma

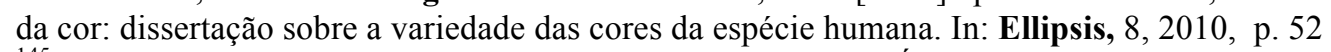

${ }^{145}$ Mercador tido como um dos primeiros exploradores da África, Duarte Lopes teria nascido em Benaventes, Portugal, numa família de cristãos-novos. Em sua viagem, acompanhou o tio, comerciante e conseguiu acessar distintas regiões do interior do Reino do Congo e áreas circunvizinhas.

${ }^{146}$ Idem, ibidem, p. 54.

${ }^{147}$ Pouco se sabe sobre este inglês, que integrou duas expedições importantes de Sir Martin Frobisher (c. 1535 ou 1539-1594) ao Novo Mundo. Frobisher atuou como corsário, a serviço da Rainha Elizabeth I (1533-1603). 
ao filho Cam, em obra de $1578^{148}$. Aqui fica marcada a vinculação entre doença e epiderme, acentuando-se a irreversibilidade da cor com base no castigo bíblico.

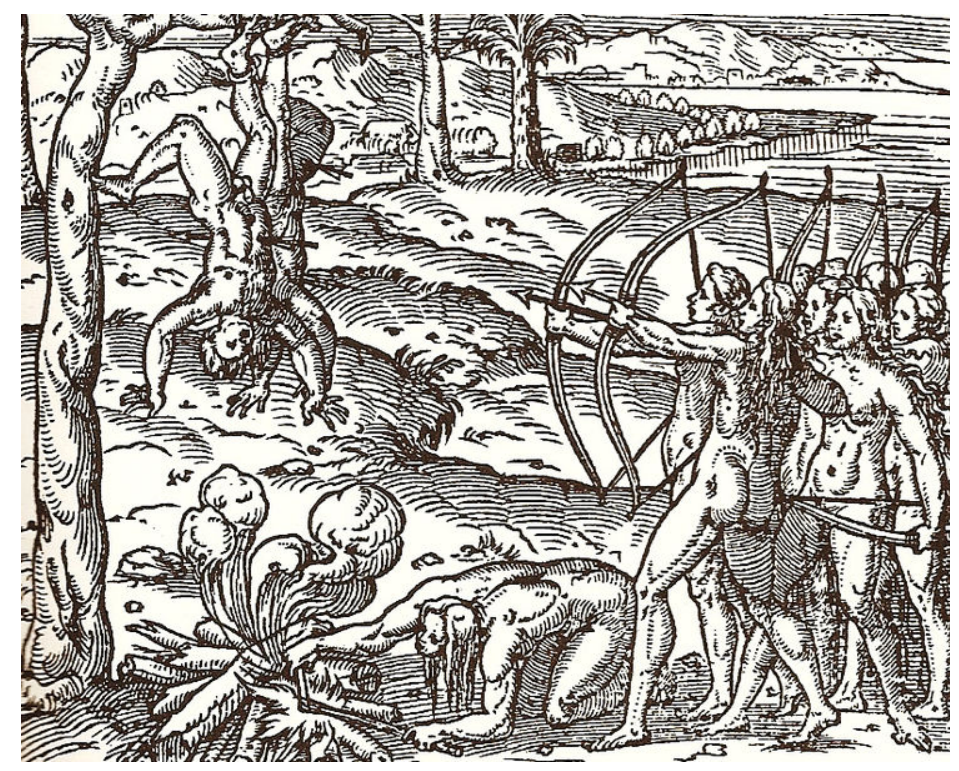

Fig. 17 e Fig. 18: $\mathrm{Na}$

Cosmografia Universal (1575) de André de Thévet, seres fantásticos se confundem com populações nativas.

À esquerda, a imagem mostra as Amazonas que, segundo o livro, habitariam o Brasil.

Abaixo, cena da Etiópia em que dois negros atacam um animal imaginário chamado Hulpalim.

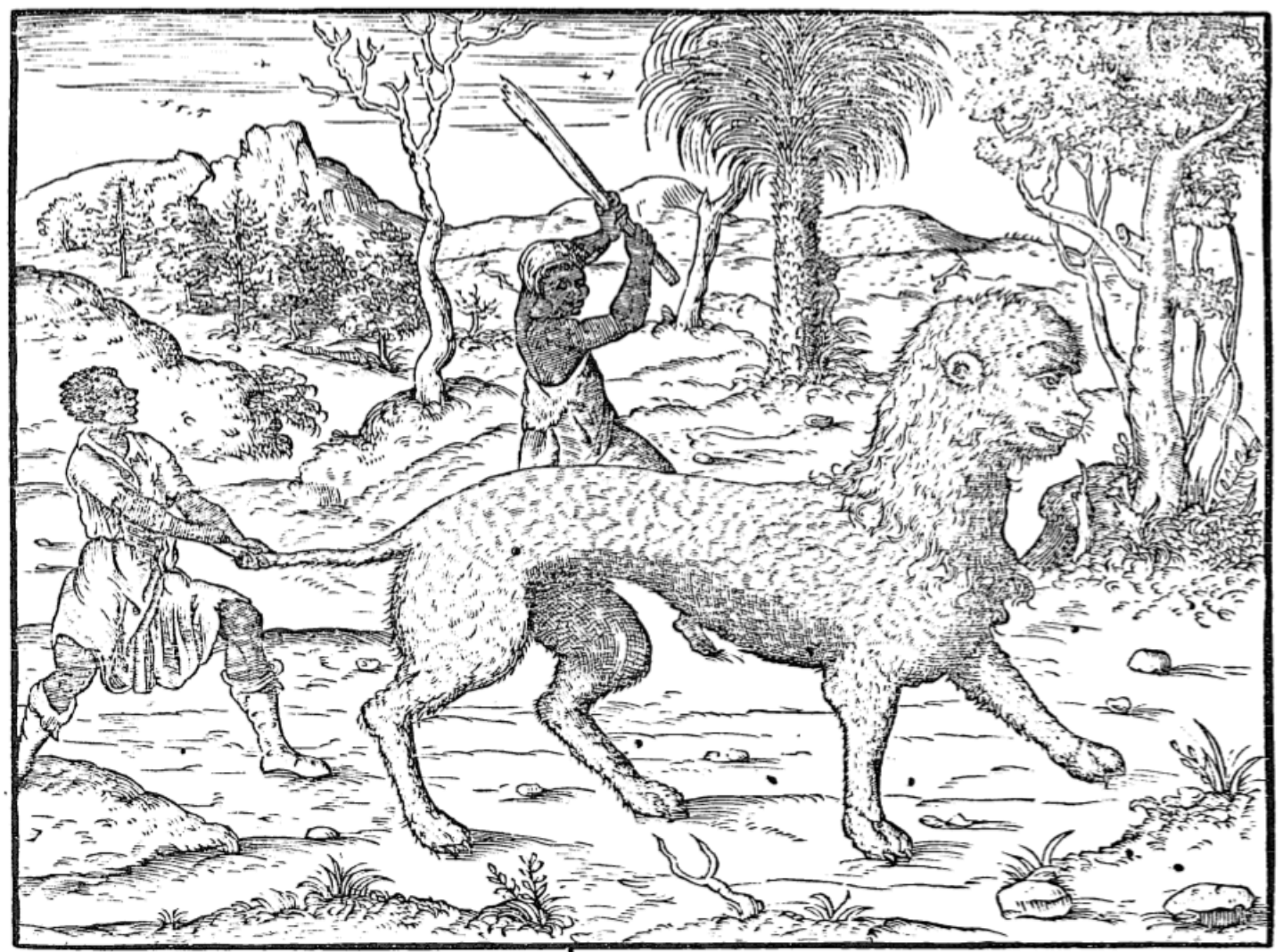

${ }^{148}$ Cf. HOFBAUER, A. Uma história do branqueamento ou o negro em questão. São Paulo: Editora UNESP, 2006 p. 102. 
Outro texto que procura conciliar as explicações de ordem climática e/ou intracorpórea com o recurso às escrituras é Diálogos das grandezas do Brasil, atribuído a Ambósio Fernandes Brandão ${ }^{149}$ (1555-?) - mas neste, veremos que não há tal irreversibilidade. Produto das primeiras décadas do século XVII (1618), esse documento consiste numa conversa entre os personagens de Brandônio - o sábio -, e Alviano. O primeiro explica ao segundo que o Brasil não sofre os efeitos maléficos do calor da zona tórrida, a despeito de sua localização tropical, porque nessa terra os ventos são frescos. Questionado por Alviano sobre a diversidade de tons de pele entre os humanos, o sábio argumenta que de fato, Adão e Eva eram brancos e não podiam gerar filhos negros; por outro lado, não discorda de Alviano, para quem um excesso de imaginação feminina durante o ato venéreo resultaria na geração de crianças negras, mas diz que esse era um fenômeno passageiro, visto que as gerações seguintes voltavam a ser brancas.

Mais que isso, a "causa verdadeira da cor negra e cabelo retorcido" seria a incidência do sol na zona equatorial. Da mesma maneira, os portugueses que habitam paragens africanas teriam mudado a tonalidade da pele ao longo de gerações, adquirindo uma cor baça. O vínculo entre o fator climático e a maldição bíblica residiria, segundo tal raciocínio, na incidência solar sobre os "descendentes do perverso Cam e de seu filho Canaã” após sua mudança para a África: "muito é que os raios do sol, dos quais são visitados duas vezes ao ano retamente, andando-lhe sempre vizinho, lhes tornasse a cor branca, que primeiro tinham herdado de seus pais e avós, nesta negra, que agora lhes vemos" ${ }^{" 150}$. A explicação é sugestiva, ao acenar para uma reversibilidade da cor da pele, que seria nada mais que o efeito de um processo físiconatural, no dizer de Brandônio. O clima arejado do Brasil, por seus ventos, inibiria a ação incisiva dos raios solares.

No diálogo, portanto, os descendentes de Cam são antes vistos como perversos, e depois como negros. Não se menciona a escravidão, embora se mantenha a postura de ver os africanos como herdeiros de ancestrais bíblicos que se considera perniciosos. Além disso, prevalece uma tendência a valorizar o matiz branco em detrimento do negro, à medida que as inquietações de Alviano (um nome por si só bastante sugestivo) são apaziguadas pelo fato de que a cor negra é reversível.

\footnotetext{
${ }^{149}$ Cristão-novo português, Brandão foi senhor de engenho na Paraíba, tendo antes vivido em Olinda.

${ }^{150}$ HOFBAUER, A. Uma história do branqueamento ou o negro em questão. São Paulo: Editora UNESP, 2006, p. 161.
} 
O mesmo princípio climático como justificação para as dessemelhanças na coloração da derme entre os homens, combinado à sina de Cam, é adotado pelo padre Antônio Vieira (1608-1697) ${ }^{151}$, em seus sermões. O clérigo argumentou que "por espaço de dois mil anos foram da mesma cor todos os homens, até que, habitando as duas Etiópias, os descendentes do segundo filho de Noé começaram muitos deles a ser pretos" $" 152$. Vale uma menção mais profunda à lógica argumentativa do jesuíta, na medida que seus escritos retiram, por um lado, da chancela bíblica quaisquer associações negativas no tocante à pele escura per se - visto que é o clima africano o responsável pela tez negra, não a maldição; por outro, consideram a escravidão como um caminho rumo à libertação da "condição negra", termo que sugere um caráter passageiro para a negritude, além de indicar que ela deve ser superada. Tal procedimento é obtido por meio de uma valorização da fé cristã, aos olhos da qual, nas palavras de Vieira, "não há diferença de nobreza, nem diferença de cor”, pois a água do batismo transformaria negros em brancos.

Fica indicada no texto do jesuíta, de qualquer forma, uma polarização entre negro e branco em que o primeiro termo é visto como negativo, à medida que se almeja transformá-lo no segundo. Reitera-se uma coincidência entre pele branca e cristianismo e, assim, o valor atribuído à pele negra é o oposto ao valor cristão. $\mathrm{O}$ fato da conversão exprimir-se por meio de uma "mudança" de pele indica, ademais, o lugar atribuído ao corpo como índice de valores espirituais e morais no pensamento religioso.

A mesma correlação entre o batismo e o branqueamento emerge em uma crônica da Companhia de Jesus, de Portugal, que menciona uma procissão em que “acudiram a esta Igreja mais de mil pretos: junto todo esse luzido exército de negros, branqueados com a água do santo batismo" ${ }^{\text {153 }}$. De modo análogo, a ideia de tornar-se branco como uma espécie de bem almejado também aparece em atas de processos e julgamentos da Inquisição do século XVI. Em 1556, um clérigo reporta que a condição de aceite imposta por uma mulher negra para seu batismo tinha sido a de

\footnotetext{
${ }^{151}$ Missionário jesuíta, escritor e orador português é figura extremamente influente no Brasil do século XVII. Conhecido pelos sermões em defesa do fim das diferenciações entre cristãos novos e velhos e do fim da escravidão de indígenas.

${ }^{152}$ VIEIRA, Padre Antônio. Sermão XX - Maria Rosa Mística, do Padre Antônio Vieira. In: Sermões, Padre Antônio Vieira, Erechim: Edelbra, 1998, (s.p.).

${ }^{153}$ HOFBAUER, A. Uma história do branqueamento ou o negro em questão. São Paulo: Editora UNESP, 2006, p. 161.
} 
clarear sua pele e comenta que isso de fato ocorreu, exceto por "umas pintas pretas que ainda tem no rosto de que a gente se espantou muito" ${ }^{\text {"154 }}$. Em outro desses documentos, a ré, uma afrodescendente, conta ter aceitado a oferta de uma cristã nova, que propusera torná-la branca.

Temos, portanto, um conjunto de elementos que se acoplam ao mito bíblico e dizendo de sua função: se de fato o mito fornece "um modelo lógico para resolver uma contradição (tarefa irrealizável quando a contradição é real)"155, na definição de Lévi-Strauss, aqui se revela um empenho incessante para prover respostas - cristãs ou laicas - para a preocupação corrente quanto à possibilidade de um negro tornar-se branco ou vice-versa, posta que estava a assimetria entre o projeto católico de conversão das almas, a existência da escravidão, a ideia de um castigo divino ancestral, a proximidade crescente dos europeus com africanos, indígenas e seus descendentes e a remissão de toda a humanidade a uma origem comum - qual seja, Noé e, consequentemente, Adão e Eva, seus ancestrais. Se no discurso da fé era possível tratar a transformação como uma espécie de milagre da cristandade, outras fontes apontam para as dificuldades impostas para a aceitação dos negros entre os brancos, revelando um ceticismo quanto aos sonhos de branqueamento, ou de igualdade humana.

Quem nos dá pistas a tal respeito é o dramaturgo português Gil Vicente (c.1465 - c.1536) $)^{156}$. Na peça Frágoa de Amor, de 1524, o escritor coloca em cena um negro que pede a Vênus para transformá-lo em branco "como ovo de galinha", sonhando em poder levar uma vida mais fácil. A comédia se desenrola à medida que $o$ êxito na transformação do negro em branco não se faz acompanhar de uma mudança em seu jeito de falar - a "fala da Guiné”, espécie de língua creole dos descendentes de africanos em solo português. Assim o personagem se vê em conflito com sua imagem, à medida que "Já mão minha branco estai, / e aqui perna branco é, / mas a mi fala guiné: / se a mi negro falai, / a mi branco para que?". Não sendo branco nem negro, uma vez que sua maneira de falar não condiz com a aparência, é ridicularizado tanto por uns, quanto por outros até decidir que quer voltar à condição inicial. Assim, a peça parece sugerir não apenas que ter a pele negra e outras qualidades da Guiné era

\footnotetext{
${ }^{154}$ Idem, ibidem, p. 93.

${ }^{155}$ LÉVI-STRAUSS, C. A estrutura dos mitos. In: Antropologia Estrutural. RJ: Tempo Brasileiro, 1973, p. 264.

${ }^{156}$ Pouco se sabe sobre Gil Vicente, considerado o primeiro dramaturgo português, responsável pela organização dos eventos na corte de Dom Manuel I (1469-1521).
} 
sinal negativo a seu tempo, mas que as diferenças que hoje chamaríamos raciais não poderiam jamais ser completamente transpostas.

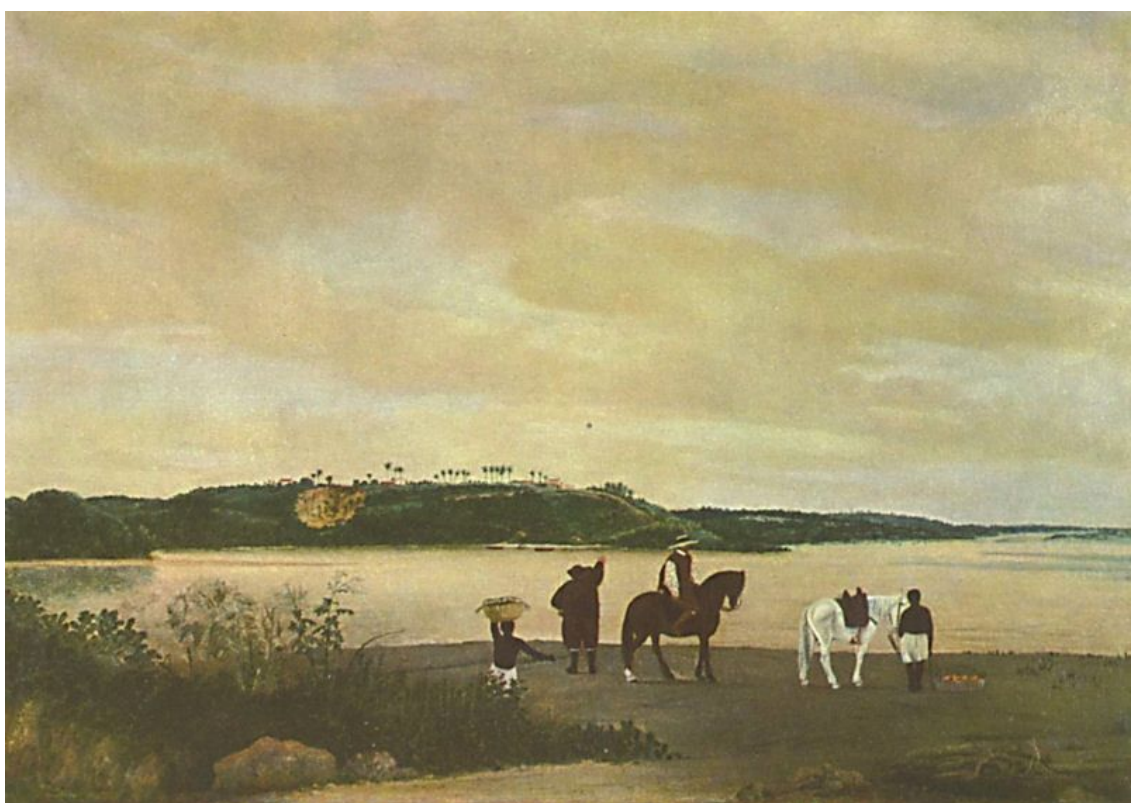

Fig. 19: Franz Post. A Ilha de Itamaracá (1637). Óleo sobre tela, $63.5 \mathrm{~cm} \mathrm{x}$ $88.5 \mathrm{~cm}$. Haia: Mauritshuis

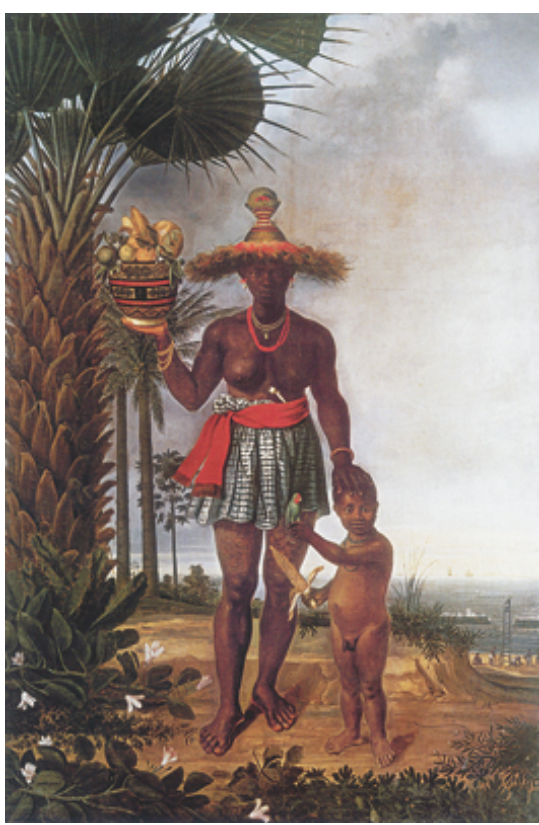

Artistas holandeses produziram as primeiras imagens conhecidas de negros no Brasil.

A Ilha de Itamaracá, de Franz Post ${ }^{157}$ mostra um grupo de escravos num momento de trabalho. As figuras estão reduzidas em meio à paisagem exuberante.

Já os retratos de Albert Eckhout $^{158}$ mostram figuras não-brancas marcadas por suas particularidades fisionômicas, corporais, cor da pele, cabelos, roupas, acessórios e produtos da terra.

Da esq. para a dir.:

Fig. 20: Albert Eckhout. Mulher africana (1641). Óleo sobre tela, $267 \mathrm{~cm} \times$ $178 \mathrm{~cm}$.

Copenhagen: Museu Nacional da Dinamarca

Fig. 21: Albert Eckhout. Mulher mameluca (c. 1641-1644).

Óleo sobre tela, $265 \mathrm{~cm} \times$ $157 \mathrm{~cm}$.

Copenhagen: Museu Nacional da Dinamarca

${ }^{157}$ O pintor holandês Franz Post (1612-1680) embarcou aos 24 com o conde João Maurício de NassauSiegl (1604-1679) ao Brasil, onde permaneceu durante cerca de oito anos. Nassau viveu no Nordeste de 1637-1643, como administrador de territórios ali ocupados pela Companhia das Índias Ocidentais. 158 Albert Eckhout (c. 1610-1665) também veio ao Brasil com Maurício de Nassau, permanecendo nestas terras durante sete anos. 

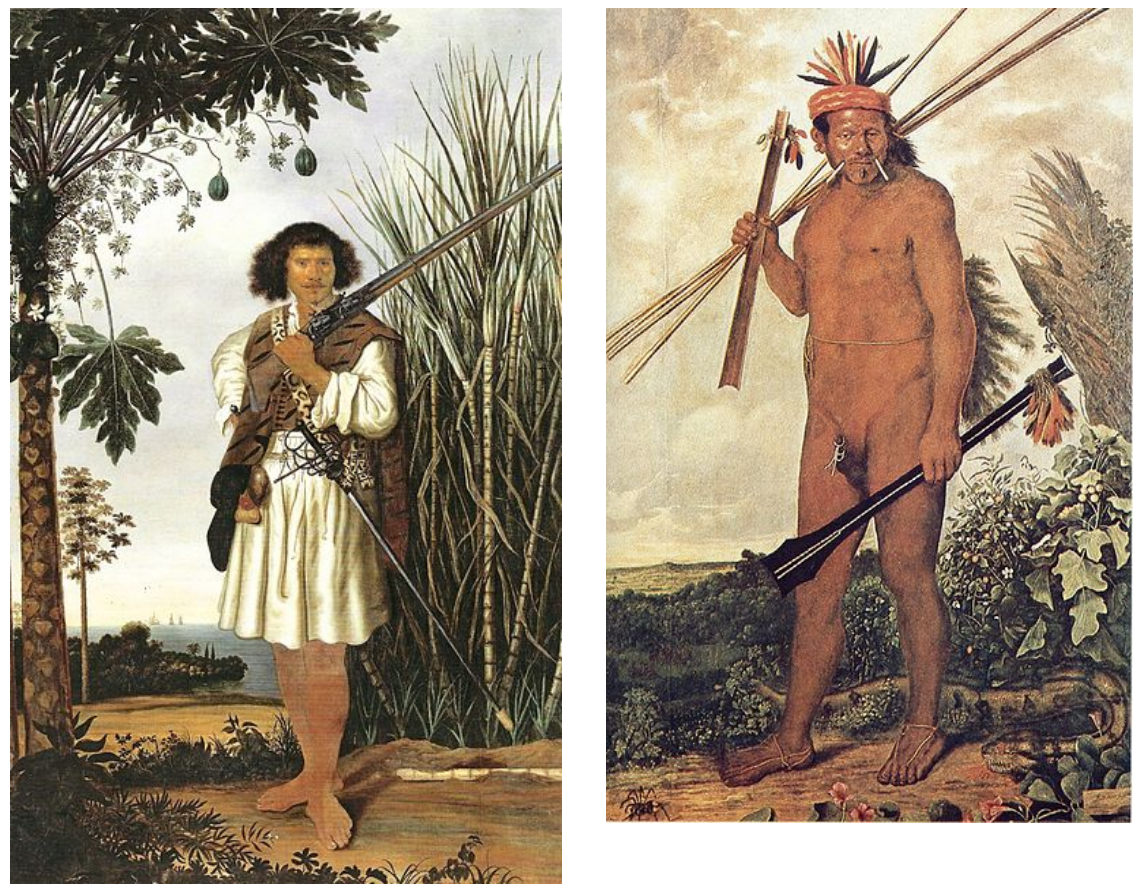

Da esq. para a dir.:

Fig. 22: Albert Eckhout.

Homem mulato

(s.d.).

Óleo sobre tela, $274 \mathrm{~cm} \times$

$170 \mathrm{~cm}$.

Copenhagen: Museu

Nacional da Dinamarca

Fig. 23: Albert Eckhout.

Homem tapuia

(1641).

Óleo sobre tela, $272 \mathrm{~cm} \times$

$161 \mathrm{~cm}$.

Copenhagen: Museu

Nacional da Dinamarca

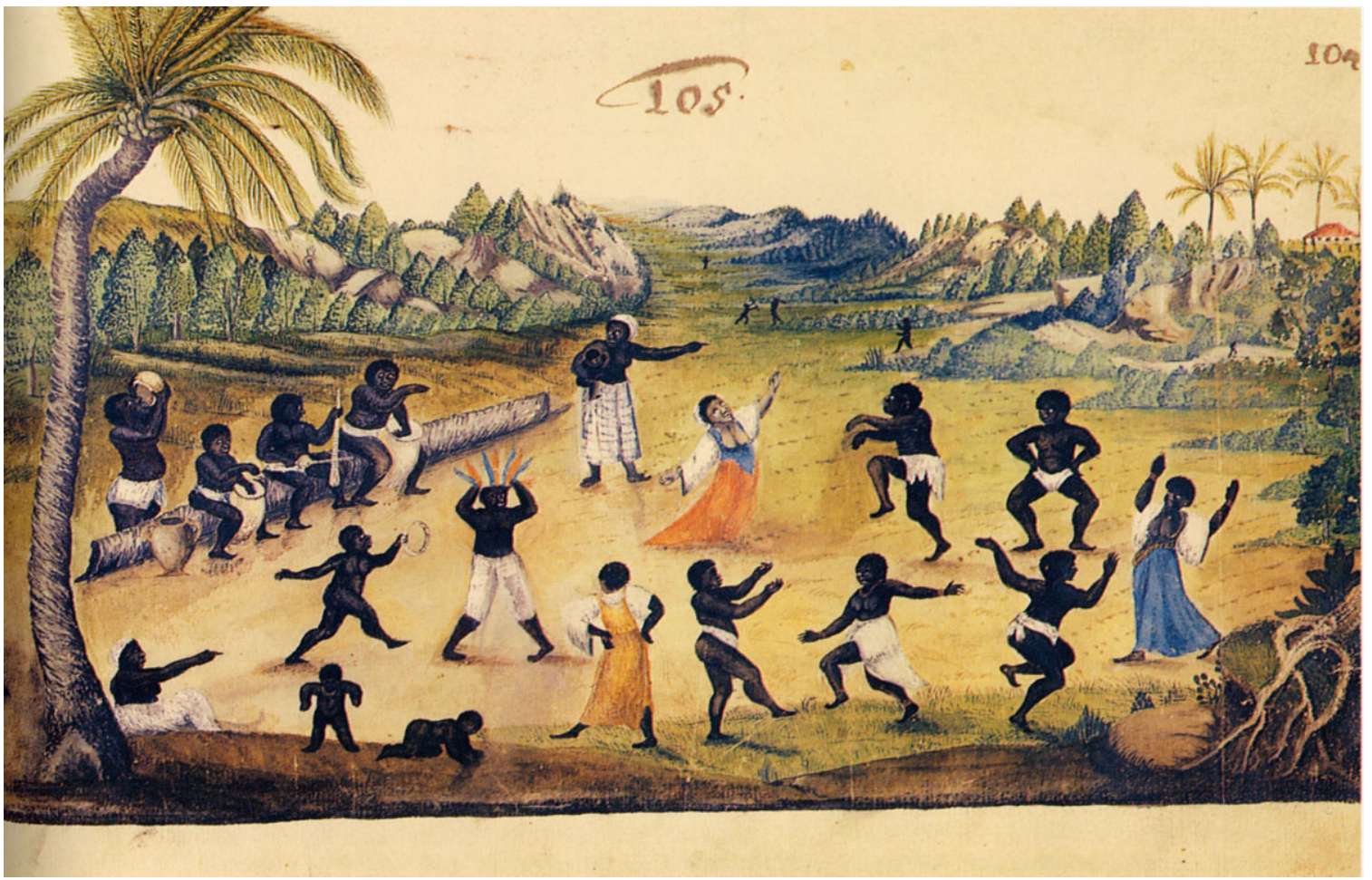

Fig. 24: Zacharias Wagener. Aldeia (s.d.). Aquarela ${ }^{159}$. A aquarela de Zacharias Wagener (1614-1668) ${ }^{160}$ reúne personagens negras com uma mulher ao centro, cuja tonalidade da pele é intermediárias, entre negro e branco. Segundo Wagener, a imagem mostra o domingo festivo dos escravos.

\footnotetext{
${ }^{159}$ Extraída de MOURA, C. E. M. A travessia da Calunga Grande. Três séculos de imagens sobre o negro no Brasil. São Paulo: Edusp, 2012.

${ }^{160}$ Wagener, clérigo e mercador alemão, ingressou na Companhia das Índias ocidentais em 1634, como soldado, e então foi enviado ao Brasil, onde foi contratado como escrivão do Conde João Maurício de Nassau. Em sua trajetória, também esteve no Japão, Ilha de Java, Marrocos e Cabo da Boa Esperança.
} 


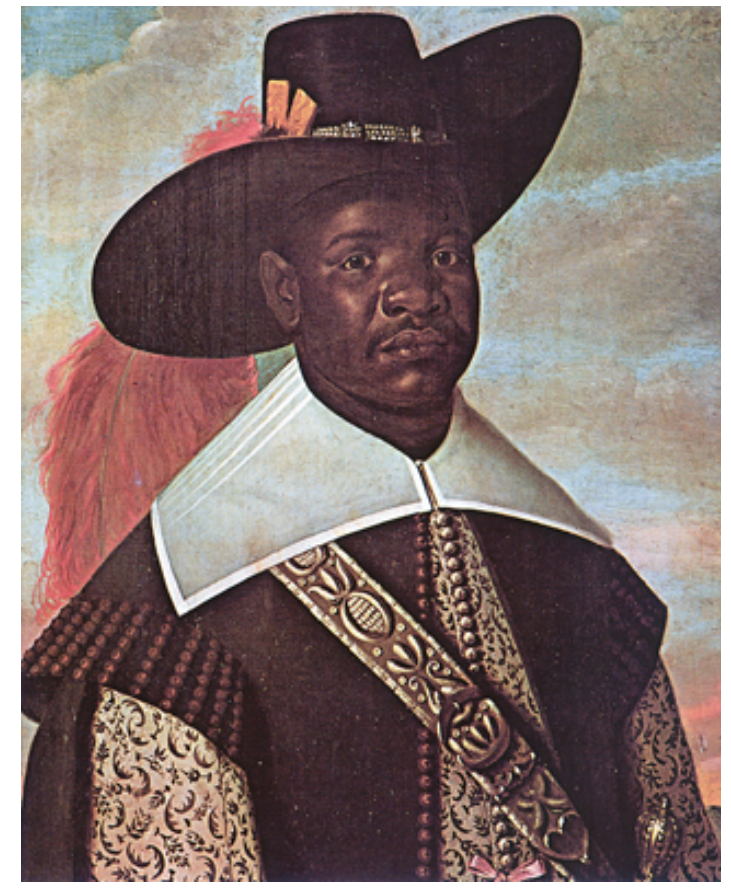

Fig. 25: Albert Eckhout ou Jaspar Benx (atribuições). Retrato de Dom Miguel de Castro (s.d.). Óleo sobre cartão, $72 \mathrm{~cm} \times 62 \mathrm{~cm}$. Copenhagen: Statens Museum for Kunst

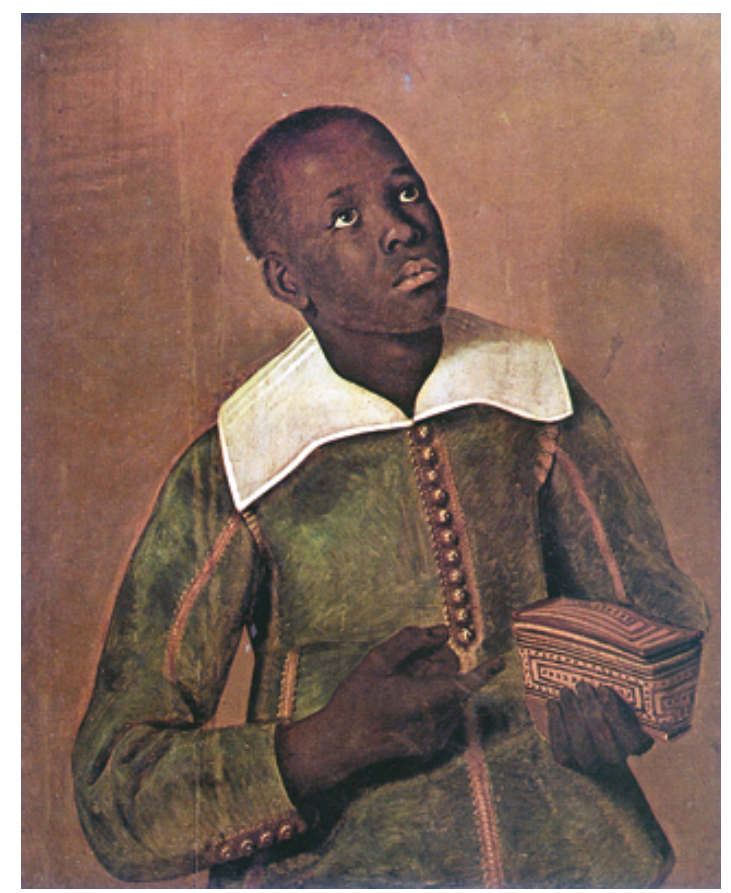

Fig. 26: Albert Eckhout ou Jaspar Benx (atribuições).

Servo de Dom Miguel de Castro com caixa decorada (s.d.).

Óleo sobre cartão, $72 \mathrm{~cm} \times 62 \mathrm{~cm}$.

Copenhagen: Statens Museum for Kunst
Albert Eckhout também é tido como possível autor de retratos marcantes, como os de Dom Miguel de Castro, embaixador do Congo, e seus criados, identificados como Pedro Sunda e Diego Bemba. Cogita-se que eles tenham sido feitos no Brasil, por onde o embaixador teria passado a caminho do Congo.

No entanto, a autoria das telas é incerta, pois há suspeitas de que possam ter sido pintadas por Jaspar Benx, também holandês, sobre o qual não se dispõe de maiores informações.

Os retratos mostram a sofisticação dos trajes de Castro; e produtos típicos do Congo, nas mãos de seus criados, cada qual com rostos expressivos e feições particulares.

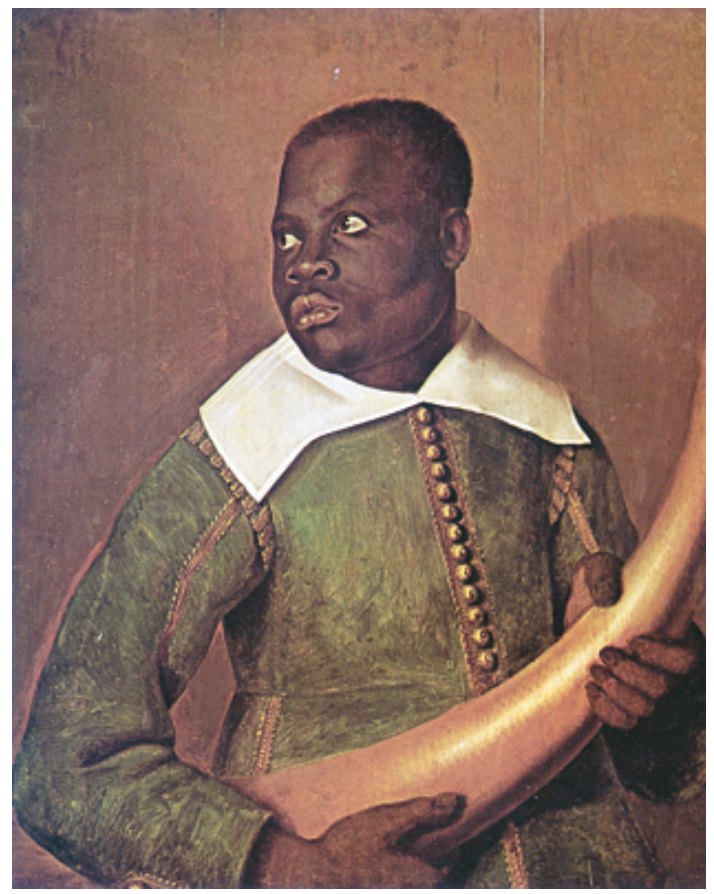

Fig. 27: Albert Eckhout ou Jaspar Benx (atribuições)

Servo de Dom Miguel de Castro com presa de elefante (s.d.).

Óleo sobre cartão, $72 \mathrm{~cm} \times 62 \mathrm{~cm}$.

Copenhagen: Statens Museum for Kunst 
A tradição holandesa do período é marcada por imagens de negros de grande expressividade, como os estudos de Peter Paul Rubens (1577-1640). É válido destacar que a pintura do Renascimento, na Holanda e na Itália, desenvolveu estudos e imagens elaboradas de negros, incluindo-se imagens como o da muher abaixo, atribuída a Annibali Carraci (1560-1609).

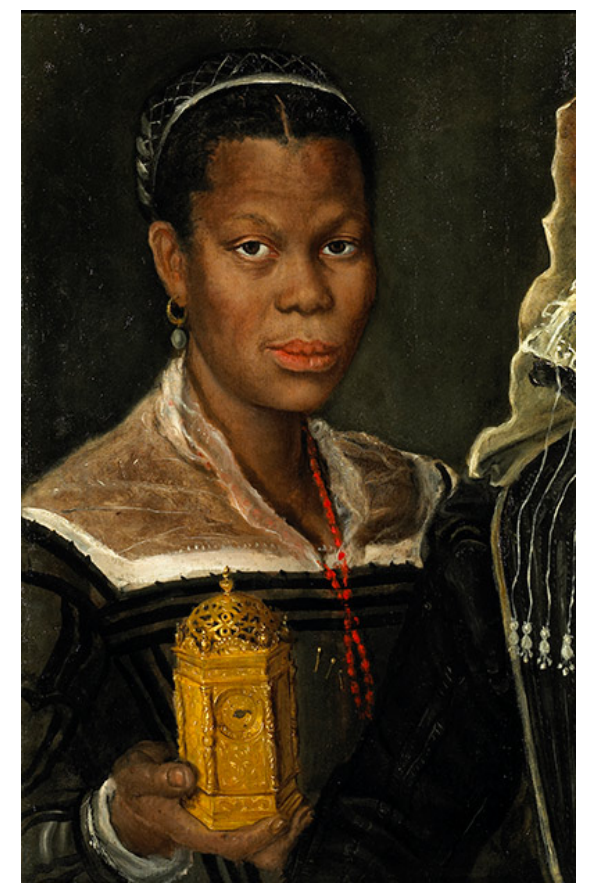

Fig. 28: Annibali Carraci (atribuição).

Portrait of an African slave woman (c.1680).

Óleo sobre tela, $60 \mathrm{~cm} \times 39 \mathrm{~cm}$.

Coleção particular. A tela é um fragmento de uma pintura maior, que incluía também a proprietária da escrava em cena.

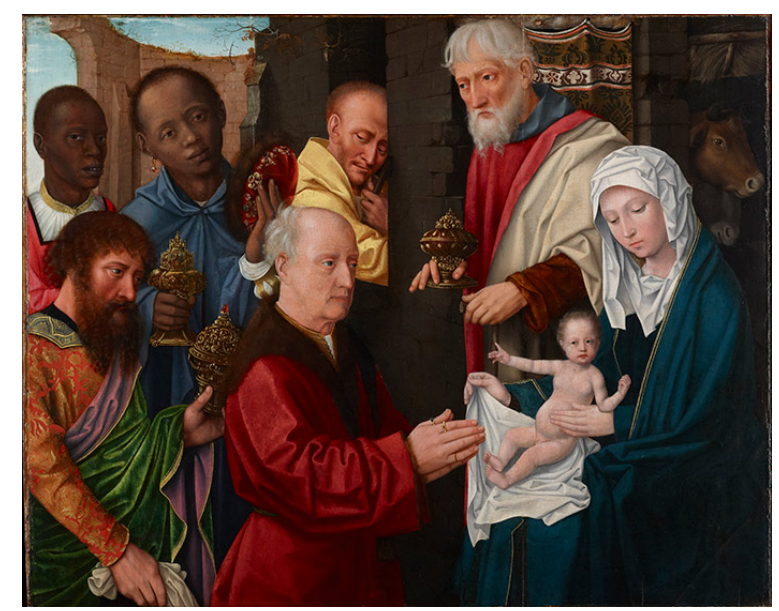

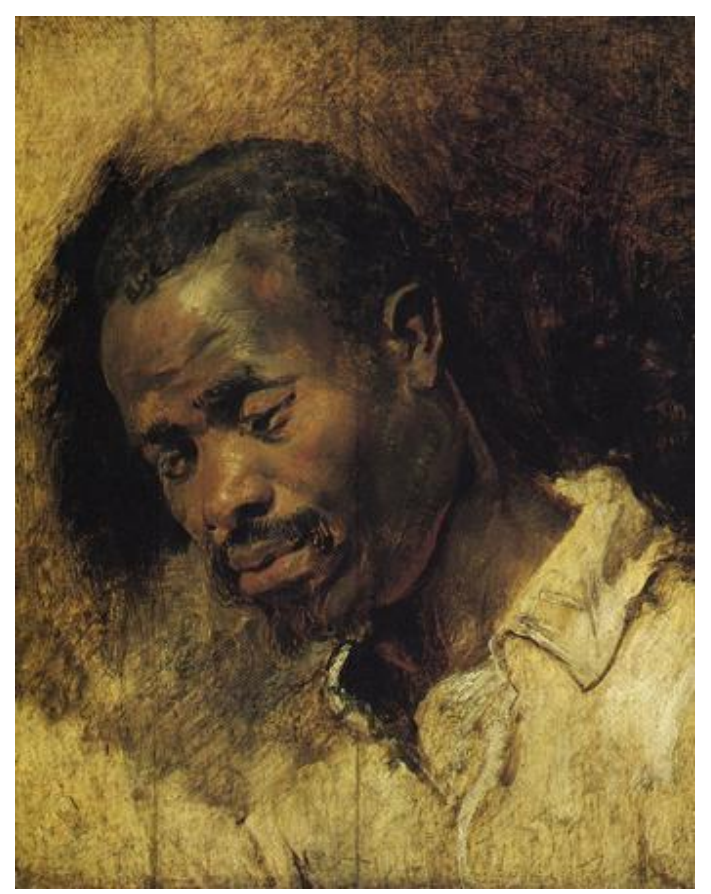

Fig. 29: Peter Paul Rubens.

Head of a negro man (c. 1620).

Óleo sobre cartão, $45,7 \mathrm{~cm} \mathrm{x} \mathrm{36,8cm.}$

Nova York: Hyde Collection.

É comum a presença de negros em imagens de Natividade, no papel do rei Mago Baltazar.

Segundo Boime, tais imagens exprimem uma fantasia do ocidente: "Instead of missionaries and slavers invading the black man's lands and plundering its wealth and subjugating its people by force, a noble and 'wise' black ruler comes of his own volition to the white man's land and lays down his wealth and his Power at the feet of the Christ child""161.

Fig. 30: Oficina de Gerard David. Adoration of the Magi (c.1514). Óleo sobre madeira, $64.2 \mathrm{~cm}$ x $82 \mathrm{~cm}$. Princeton: Princeton University Art Museum

\footnotetext{
${ }^{161}$ BOIME, A. The art of exclusion. Representing blacks in the Nineteenth Century. Washington \& London, Smithsonian Institution Press, 1990, p. 9.
} 
No último suspiro do século XVII, encontramos em 1700 o jesuíta italiano Jorge Benci (1650-?) ${ }^{162}$, que escreve:

(...) a servidão e o cativeiro teve sua primeira origem do ludíbrio, que fez Cam, da desnudez de Noé, seu pai. Sabendo é que dormindo este patriarca com menos decência descoberto, vendo Cam, e escarnecendo desta desnudez, a foi publicar logo a seus irmãos; e em castigo deste abominável atrevimento foi amaldiçoado do Pai toda a sua descendência, no sentir de muitos é a mesma geração dos pretos que nos servem; e aprovando Deus esta maldição, foi condenada à escravidão e cativeiro ${ }^{163}$ (grifos nossos).

No trecho, percebe-se já uma incerteza na atribuição de ancestralidade dos negros escravos com relação a Noé (transmitida pela expressão "no sentir de muitos") e, no entanto, a conexão entre imoralidade e escravidão é explícita. Noutras passagens, Benci considera que "os Pretos são sem comparação mais hábeis para todo o gênero de maldades que os Brancos", pois "não há nação mais inclinada e entregue aos vícios que a dos Pretos". Por fim, afirma que os negros são "entregues à impudícia", atribuindo este fato ao "clima quente em que nascem, mas muito mais do pouco temor a Deus, e pejo dos homens que neles há" ${ }^{164}$. Desse modo, o jesuíta dá indícios de que não havia acordo quanto ao fato dos negros descenderem de Cam, fazendo uso da teoria climática não para explicar a cor da pele, mas o comportamento, a impudícia dos negros. À medida que se mantém conforme às atribuições de imoralidade às populações de pele escura, não menciona a possibilidade de branqueamento. Por outro lado, tampouco dá a entender que tal impudícia ou a própria cor da pele sejam qualidades irreversíveis.

A despeito das particularidades relativas às fontes citadas, elas exprimem esforços para compreender e a origem das diferenças entre tons de pele, acentuando uma série de características negativas indexadas à tez escura e aludindo à ideia de branqueamento. Vistas em conjunto, insinuam em maior ou menor grau que os atributos de ordem moral vêm incrustados no corpo; além disso, convergem para uma

\footnotetext{
162 Jorge Benci é um jesuíta italiano que viveu no Brasil de 1683 a 1700. É autor de Economia Cristã dos Senhores no Governo dos Escravos, em que elabora um conjunto de preceitos a fim de propor um modelo de convivência entre senhores e escravos, segundo princípios cristãos. Ao defender condutas exemplares para os senhores, ele também justificava o cativeiro, com base no episódio bíblico de Cam e em julgamentos de ordem moral sobre os negros.

${ }^{163}$ BENCI, J. Economia Cristã dos Senhores no Governo dos Escravos. São Paulo: Grijalbo, 1977 [1700], pp. 64-65.

${ }^{164}$ Idem, ibidem, pp. 178-180.
} 
associação entre meio (natureza climática), corpo e moral - com a imagem do negro cercada de elementos que indicam altas temperaturas, integrada a um ecossistema específico. Não aparece o uso do termo raça nessas passagens - ainda que Benci empregue a palavra geração.

\section{O povo de Cam é objeto de ciência}

A ideia de raça parece ter nascido como um desdobramento das noções de origem e geração. Constitui um indicativo de tal procedência a própria definição atribuída, em castelhano corrente ao século $\mathrm{XV}$, à palavra: primeiramente, geração, tanto como sucessão, quando em referência ao conjunto de membros de um mesmo grupo etário; qualidade de sangue, relacionada portanto aos estatutos de nobreza e pureza de sangue ora vigentes; retalho ou tecido defeituoso; por extensão, contaminação $^{165}$. Stolcke mostra que nesse momento o termo buscava tornar explícitas as interdições impostas pelos estatutos de pureza de sangue no mundo ibérico, a saber, não misturar-se com mouros, judeus, hereges e penitenciados ${ }^{166}$.

Depreende-se daí que o termo raça abrevia uma preocupação genealógica, tão bem colocada pela evocação permanente à ancestralidade bíblica camita. A palavra encerra uma capacidade de impor sentidos à história familiar e pessoal: através dela, definem-se posições presentes e futuras, orientam-se caminhos e projetos constitutivos de um parentesco desejável. Além disso, introduz uma vinculação direta de determinados traços, qualidades ou características pessoais ao fator hereditário.

Alguns escritos anteriores ao século XV, ao remeter ao Genesis 9, deixam patente uma preocupação de ordem genealógica. Nessas exegeses, mais do que atrelar a pele escura de Canaã à maldição de Noé, buscava-se conferir coerência lógica a tal

\footnotetext{
${ }^{165}$ STOLCKE, V. "Los mestizos no nacen sino que se hacen”. In: STOLCKE, V.; COELLO, A. (Ed.) Identidades Ambivalentes en América Latina (Siglos XVI-XXI). Barcelona: Bellaterra, 2007.

${ }^{166}$ É central, neste ponto, reforçar que o problema imposto pelos chamados "estatutos da pureza de sangue" (ou "limpeza de sangue") não se exprime através da dimensão biológica que raça assumirá mais adiante. Diversos estudos apontam a ancestralidade da fé cristã como um fator de peso na atribuição do sangue "puro", destacando também a importância desse recurso em matéria de controle dos mecanismos de ascensão social. A própria Stolcke aponta que era a fé cristã que se convertia em um atributo natural, e portanto, hereditário, nessa fórmula, trazendo à tona uma nova dimensão do problema. Cf. KUHN, F. As redes da distinção familiares da Inquisição na América Portuguesa do século XVIII. Varia História, vol. 26, $\mathrm{n}^{\circ} 43$ Belo Horizonte, Jun. 2010; OLIVAL, F. Rigor e interesses: os estatutos da limpeza de sangue em Portugal. Cadernos de Estudos Sefarditas, no 4, 2004, pp. 151-182.; e VIANA, L. O idioma da mestiçagem. Campinas: Editora Unicamp, 2007. Isso não invalida reflexões acerca das implicações da aparência - incluída a cor da pele - para o estabelecimento da justiça e das relações interraciais no período.
} 
castigo, convencer quanto a uma imoralidade que se considerava inata à sucessão camita, cuja suposta comprovação seria sua curiosidade por desvelar a nudez paterna. Sollors comenta que, em algumas versões, a condenação se fazia justificar por meio de alegações de caráter sexual. Segundo tais versões, Cam teria desrespeitado a ordem divina de guardar celibato na travessia da arca, em certos registros, teria cometido incesto com a mãe ou seria culpado por olhar de forma lasciva o corpo nu do patriarca $^{167}$. Pode-se pensar que tais interpretações estariam, portanto, reforçando interdições raciais ${ }^{168}$ (leia-se geracionais, logo, sexuais), tornando a linhagem camita indesejável sob a lógica matrimonial cristã, pois se lhe atribuía a herança do pecado, da transgressão.

Posteriormente, somaram-se a este tipo de especulação escritos que procuravam encontrar na África uma qualidade primitiva, próxima à animalidade. No século XVI, o filósofo francês Jean Bodin $(1530-1596)^{169}$ difundiria histórias de relações sexuais entre humanos e animais no continente africano - motivo pelo qual, em sua opinião, essa terra seria habitada por monstros - e o viajante inglês Jean Battel fala da existência de seres meio homens, meio macacos no Congo ${ }^{170}$. Seguindo a mesma linha, por volta de 1570, o historiador humanista francês François Belleforest $(1530-1583)^{171}$ atribuía uma degeneração moral à descendência camita ${ }^{172}$.

${ }^{167}$ Cf. SOLLORS, W. Neither black, nor white, yet both. Thematic explorations of interracial literature. Cambridge: Harvard University Press, 1999, pp. 97-100. O autor destaca o Talmude Babilônico, o Sachenspiegel (ca. 1200) e o Soncino Chumash. Já no século XVIII, o verbete Cam no Universallexikon (1733) também registra a versão do incesto.

168 A palavra é utilizada nesta passagem com toda a ambiguidade que suscita a um olhar contemporâneo, ao mesmo tempo em que se refere a geração e origem, aludindo às prescrições relativas à sexualidade a aos planos para o futuro familiar e social. $\mathrm{O}$ itálico que passamos a usar no termo raça daqui por diante, chama a atenção a refletir sobre as implicações que ele assume nas fontes mencionadas: se origem, geração, ou recurso que inclui pensar em características físicas e morais relativas a um grupo. Para todos os efeitos, Stolcke situa que "o racismo moderno tem sua origem em finais do século XVII" - quando o termo raça aparece em referência a grupos marcados por características físicas e culturais. Cf. STOLCKE, V. "Los mestizos no nacen sino que se hacen". In: Solcke, V.; Coello, A. (Ed.) Identidades Ambivalentes en América Latina (Siglos XVI-XXI). Barcelona: Bellaterra, 2007, pp. 16-17.

${ }^{169}$ Filósofo e jurista francês, Jean Bodin é lembrado como um pensador que católico que, diante do processo de Reforma Protestante, empreendeu críticas à ingerência da igreja católica nos assuntos nacionais.

${ }^{170}$ Cf. HOFBAUER, A. Uma história do branqueamento ou o negro em questão. São Paulo: Editora UNESP, 2006, p. 102. Não identificamos Battel, mas esse e outros comentários sobre o Congo são citados por Jean-Jacques Rousseau (1712-1778) no Discurso sobre a Origem e as Fundações da Desigualdade Humana (1754).

${ }^{171}$ Escritor francês e tradutor de autores do Renascimento, como Bocaccio e Ludovico Giucciardini, na França.

${ }^{172}$ Cf. PIMENTEL, M. R. O enigma da cor: dissertação sobre a variedade das cores da espécie humana. In: Ellipsis, 8, 2010, pp. 49-74. 
À luz desse tipo de consideração, a imagem de Cam, além de remeter à escravidão e/ou à pele escura, passava também a indexar alusões a uma sexualidade incontida, ou mesmo tabu, à animalidade e à degeneração aos olhos do ocidente. Nas transformações do mito que partem de uma dimensão sexualizada, tudo se passa como se determinadas características de ordem moral fossem inatas, entrando para os traços hereditários da população camita. Desse modo, o corpo se torna aos poucos o indício de atributos comportamentais e psíquicos que se considera recorrentes em uma determinada linhagem.

Tal constatação não se revela de modo simples no pensamento da era moderna, pois pressupõe um modelo de conhecimento cristão sobre as diferenças em que, por um lado, a hereditariedade remonta a Noé e, em última instância, ao par original, Adão e Eva - o que equivale a atribuir uma origem comum à humanidade; por outro, se busca constantemente reiterar a existência de atributos físicos/psíquicos distintos - em particular no marco de um sistema assentado em desigualdades naturalizadas como a escravidão -, suscitando a procura constante por novos argumentos capazes convencer sobre uma incompatibilidade moral (logo, física) entre as linhagens dessa família única. No interior de um grupo que deveria ser homogêneo por prerrogativa bíblica, incutiam-se fronteiras à primeira vista intransponíveis, que por sua remissão à hereditariedade podem ser vistas como naturais.

Assim, o povo de Cam torna-se um objeto de investigação, cujo corpo e comportamento são encarados como problemas. Ao observá-lo, busca-se compreender a origem da humanidade, por que a mistura racial é possível e quais suas consequências, além de, por vezes, o que revelam sobre o ocidente. Se é verdade que as fontes mencionadas acima retomavam argumentos antigos que permitiam atribuir a pele negra a fatores climáticos e/ou a uma capacidade interna ao próprio corpo, lançando a ideia de uma origem distinta entre diferentes grupos, veremos uma ampla disseminação de teorias similares no século XVIII. Desse modo, não apenas a explicação escritural vai sendo deslocada, mas também a ideia de raça enquanto geração ou origem - que permanece em meio a referências crescentes às noções de povo e cultura. Ao lado destes novos termos, a palavra raça parece oscilar entre o sentido antigo e um termo que se referirá a grupos marcados por qualidades biológicas comuns, com destaque para a cor da pele. 
Em meio a uma gama de posições que emergiam no debate sobre a origem (e o futuro) das diferenças, o grande divisor de águas se torna a cisão entre monogenistas e poligenistas, respectivamente, os defensores de um nascedouro comum à humanidade - o Genesis (todas as raças seriam descendentes do par original, Adão e Eva) ou uma origem remota de outro tipo; e os que percebiam em cada raça uma origem distinta, enterrando de vez as alusões às escrituras como explicação. Mas à medida que o Genesis 9 perde espaço enquanto modo de explicação privilegiado pelos teóricos para as justificativas mais terrenas, baseadas em causas empíricas, preserva-se uma tendência a naturalizar as diferenças, bem como os esforços para demarcá-las em meio a fronteiras genealógicas e, portanto, fixadas ao corpo e à moral de forma indelével.

Já evocada em distintos momentos e recuperada com maior vigor entre os séculos XVI e XVIII, a explicação climática é posta a dialogar com a justificativa da escravidão por autores como Charles de Montesquieu (1689-1755) ${ }^{173}$. Para o pensador, o clima tinha "ação determinante sobre o caráter humano, a vida social e a civilização" ${ }^{174}$ : o calor das zonas tropicais incidia sobre seus habitantes, tornando-os propensos aos prazeres físicos e à preguiça, por um lado, e debilitando-os para empreendimentos mais nobres. Os homens nestas paragens seriam assim inferiores; os negros e indígenas, selvagens. Assim, no entender de Montesquieu, a melhor forma de poder para tais regiões seria o despotismo, justificando-se a prerrogativa escravocrata.

Paralelamente, certos autores dão vazão aos esforços para localizar no próprio corpo a origem da pele negra, que passaria, sobretudo a partir do século XVIII a ser compreendida como uma moléstia hereditária. Em caráter pioneiro, o médico François Bernier (1625-1688) ${ }^{175}$, no artigo Nova divisão da terra (1684), indica que a causa da cor negra devia ser buscada no organismo, no sêmen ou no sangue. O que o anatomista francês propunha, somando-se a especulações de autores precedentes como Duarte Lopes e George Best, implicava uma transformação completa na

\footnotetext{
${ }^{173}$ Pensador iluminista e aristocrata, Montesquieu foi anti-clericalista e anti-monarquista ferrenho. É autor de Cartas persas (1721) e O espírito das leis (1748).

174 Pimentel também comenta que Montesquieu seguia os passos de l'Abbé d'Espiard, seu contemporâneo, e de Jean Bodin. A citação é de $O$ espírito das leis. Cf. PIMENTEL, M. R. O enigma da cor: dissertação sobre a variedade das cores da espécie humana. In: Ellipsis, 8, 2010, pp. 49-74.

${ }^{175}$ Médico, viajante e antropólogo francês. Após longa viagem pela Índia, foi o primeiro europeu a chegar à região de Caxemira, para por fim tornar-se médico pessoal do Imperador mongol Aruzangzeb.
} 
maneira de perceber as diferenças, à medida que se deixava de lado explicações com base em causas externalistas, abraçando-se a ideia de que a pele negra era uma espécie de mal congênito, que advinha do interior do próprio corpo. Entre outros impactos, tal crença impunha novos obstáculos à defesa da reversibilidade da cor, ao inscrevê-la na chave da doença/cura, que exigia um esforço de medicalização.

Schwarcz ${ }^{176}$ situa as novas indagações sobre a ideia de raça que emergem no século XVIII a partir do recurso à oposição entre a vertente humanista, ilustrada por Jean-Jacques Rousseau (1712-1778) ${ }^{177}$, e o naturalismo expresso nas teorias de Georges-Louis Leclerc, o Conde de Buffon (1707-1788); e do jurista Cornelius DePauw (1739-1799) ${ }^{178}$. Rousseau é tido como o introdutor de um modelo de pensamento que preconizava a igualdade entre os homens, com a valorização da figura do selvagem e a decorrente crítica que propiciava ao estado de civilização europeu - binômio este de grande recorrência na literatura sobre as diferenças. Buffon e, mais especificamente, DePauw, levarão a extremos a compreensão do selvagem como degenerado e da natureza equatorial e tropical como degenerante. O conde, como pontua Schwarcz, vai acentuar a imagem da América como uma terra débil, em que o crescimento é estanque e onde tudo falta, uma espécie de lugar pertencente à infância da humanidade. Introduz, pelo argumento à imaturidade do homem e da natureza nos trópicos, uma visão essencialmente hierárquica, ainda que não descarte a remissão a uma origem comum. DePauw aporta ao argumento a ênfase na degeneração enquanto um conceito próprio, que agora remetia a um "desvio patológico" e não mais a uma espécie de decadência em certa medida reversível, como explica Schwarcz ${ }^{179}$.

Buffon, além disso, figura em meio ao pensamento iluminista como um dos mais célebres expoentes desse recuo ao corpo como fonte explicativa para as diferenças de cor. Autor de Dissertation Physique à l'ocasião du Négre Blanc (1744),

\footnotetext{
${ }^{176}$ SCHWARCZ, L. O espetáculo das raças. Cientistas, instituições e a questão racial no Brasil 1870-1930. São Paulo, Companhia das Letras, 2004.

${ }^{177}$ Pensador iluminista, escritor e compositor genebrino, é autor de ideias e teorias fundamentais para a Revolução Francesa e o pensamento ocidental, em ensaios sobre as desigualdades, educação e a origem e o sentido da noção de sociedade, entre outras.

${ }^{178}$ Buffon foi matemático e naturalista francês, autor da História Natural; e DePauw foi geógrafo, filósofo e diplomata na corte de Frederico, o Grande, da Prússia.

179 “Até então, chamavam-se de degeneradas as espécies consideradas inferiores porque menos complexas em sua conformação orgânica. A partir desse momento, porém, o termo deixa de se referir a mudanças de forma, passando a descrever "um desvio patológico do tipo original"'. Idem, ibidem, p. 46.
} 
o naturalista é explícito ao afirmar o branco como a cor da pele normal, saudável; "as the basic anthropological color" ${ }^{\prime 180}$ - o que dava a medida quanto à degeneração que teria ocorrido na pele negra, segundo o autor. Outro teórico que seguia a mesma linha de reflexões era Claude-Nicolas LeCat ${ }^{181}$, em seu Traité de la couleur de la peau humaine (1765) - obra esta que partia de uma classificação binária (negro e branco) para a cor da pele, dedicando-se a refletir sobre as transformações de negro em branco e vice-versa, sempre como um produto de anomalias, como o albinismo e o vitiligo entre os negros. De acordo com Benthien, LeCat e Buffon sustentavam que "a pele que se situa entre as 'raças' é maculada no sentido literal (Lat. mancha, nódoa) associação escolhida por vários autores" ${ }^{\prime 182}$.

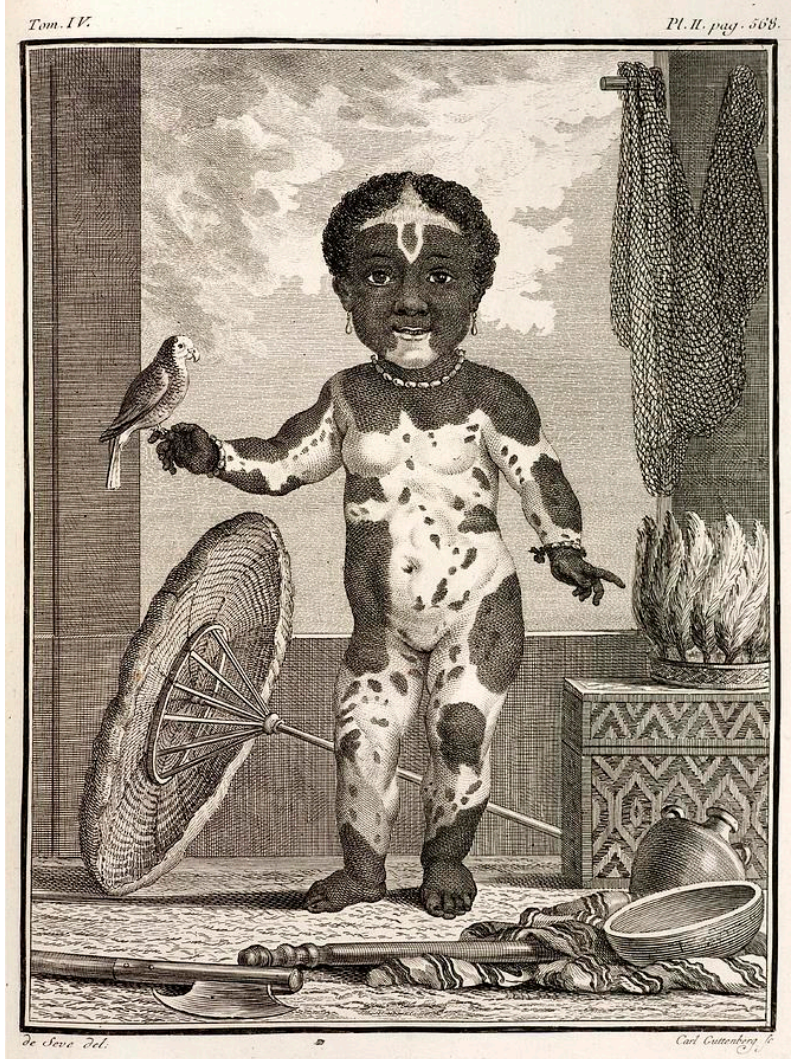

Coincidindo com a tese de Buffon, para quem a natureza equatorial e tropical era degenerante, a menina negra com vitiligo que aparece em sua História Natural está cercada de elementos alusivos à natureza dos locais de altas temperaturas.

Segundo o autor, a ilustração foi baseada numa pintura, cuja inscrição dizia tratar-se de Maria Sabina, criança nascida numa plantation jesuíta em Cartagena, filha dos escravos Martiniano e Patrona.

Buffon argumentava que um dos pais seria albino e o outro, negro - logo, a imagem também carrega a ideia de que a união entre pessoas de cores diferentes seria degenerante.

\section{Fig. 31: African American Vitiligo.} Prancha II, page 568. Suplemento do volume IV de L'Histoire Naturelle (servant de suite a l'histoire naturelle de l'homme). Publicado pelo M. le Comte de Buffon em 1777, na Imprimerie Royale, em Paris.

Entre os experimentos anatômicos que ora se realizavam para descobrir em que parte do corpo estaria armazenada a cor negra, há as dissecções de pedaços de

\footnotetext{
${ }^{180}$ BENTHIEN, C. Skin: On the cultural border between self and the world. New York: Columbia University Press, 2002, p. 145

${ }^{181}$ Médico e cirurgião francês, foi cirurgião-mor do Hospital Dieu e fundou a Academia Real de Ciências, Letras e Artes de Rouen.

182 BENTHIEN, C. Skin: On the cultural border between self and the world. New York: Columbia University Press, 2002, p. 146
} 
pele extraída de africanos. Consta do Universal-Lexiconn (1735), de Johann Heirich Zedler (1706-1751) ${ }^{183}$, a descrição de um experimento desse tipo: tomou-se um fragmento da pele de um mouro (termo usado pela enciclopédia), deixando-o submerso em uma solução de álcool etílico para tentar descolori-lo. Diante do sucesso do experimento, o autor concluía que a pele é naturalmente branca, mas no caso dos negros, ela recobre uma membrana de cor escura, chamada Malphigi ${ }^{184}$. Uma vez removida tal película, a epiderme tornava-se igual à de um europeu ${ }^{185}$.

Outro autor germânico que defende a existência de um tecido intracutâneo é Johann Gottfried von Herder (1744-1803) ${ }^{186}$, em suas Ideias sobre a filosofia da história da humanidade (1785). Segundo Herder, esta membrana presente em todos os seres humanos mudaria de cor de acordo com predisposições naturais e fatores externos - notadamente, culturais $^{187}$. Também o filósofo Immanuel Kant (1724-1804) se envolve em tais debates. Para ele, o que definiria a raça negra seria o fato de excretar uma substância chamada phlogistron através da derme ${ }^{188}$. Kant apresentou uma divisão da humanidade em quatro raças primordiais: as básicas, branca e negra; e duas intermediárias, hindustani e kalmuckian ${ }^{189}$. A seu turno, J. F. Blumenbach $(1752-1840)^{190}$, considerado o pai da Antropologia Física, ficou conhecido pelas

\footnotetext{
${ }^{183}$ Editor e vendedor de livros alemão, graças à alta vendagem do Universal-Lexiconn Johann Heirich Zedler conseguiu montar sua própria editora.

${ }^{184} \mathrm{Na}$ verdade, o nome Malpighi refere-se a Marcello Malpighi (1628-1694), médico e anatomista italiano, correspondente da Royal Society de Londres, autor de teoria segundo a qual a pele negra conteria uma membrana extra, por onde circularia um líquido denso, de cor escura. Ver CURRAN, A. S. The Anatomy of Blackness: Science and Slavery in an Age of Enlightenment. Baltimore: JHU Press, 2011.

${ }^{185}$ Idem, ibidem.

${ }^{186}$ Filósofo, teólogo, poeta e crítico literário alemão comumente associado ao romantismo: seu encontro com o jovem Goethe em 1770 é reputado como um marco fundador do movimento Sturm und Drang.

${ }^{187}$ Gingrich é enfático ao destacar que o conceito de cultura cunhado por Herder nada trazia de racial, ainda que tenha sido usado a posteriori por diferentes vertentes do nacionalismo alemão com finalidades políticas, inclusive pelo nazismo. Cultura significava, na visão de Herder, língua, costumes e mentalidades compartilhadas por um grupo humano particular, imbricado no conjunto da humanidade. Assim, a máxima desse conceito seria "unidade na diversidade". GINGRICH, A. The German speaking countries. Ruptures, schools and nontraditions: Reassessing the History of Cultural Anthropology in Germany. In: BARTH, F. One Discipline, Four Ways: British, German, French, And American Anthropology. University of Chicago Press, 2005.

${ }^{188}$ BENTHIEN, C. Skin: On the cultural border between self and the world. New York: Columbia University Press, 2002, p. 146.

${ }^{189}$ Gingrich comenta que, a despeito da oposição que se convencionou atribuir a Kant e Herder, ambos os projetos desses teóricos buscaram responder uma questão central: como compreender a humanidade como algo único, ante a variabilidade cultural humana. GINGRICH, op. cit.

190 Blumenbach foi médico, fisiologista, antropólogo e naturalista e professor de medicina da Universidade de Göttingen, onde tornou-se célebre pelos estudos craniométricos e por ter constituído uma vasta coleção de crânios de distintas partes do mundo.
} 
medições craniométricas que realizava em seu laboratório em Göttingen, dissertando sobre aquilo que identificou como as "cinco variedades da espécie humana": caucasóide, mongolóide, etíope, americana e malaia. Autor que raramente utilizou o termo raça, o cientista atribuía as variações a fatores climáticos ${ }^{191}$.

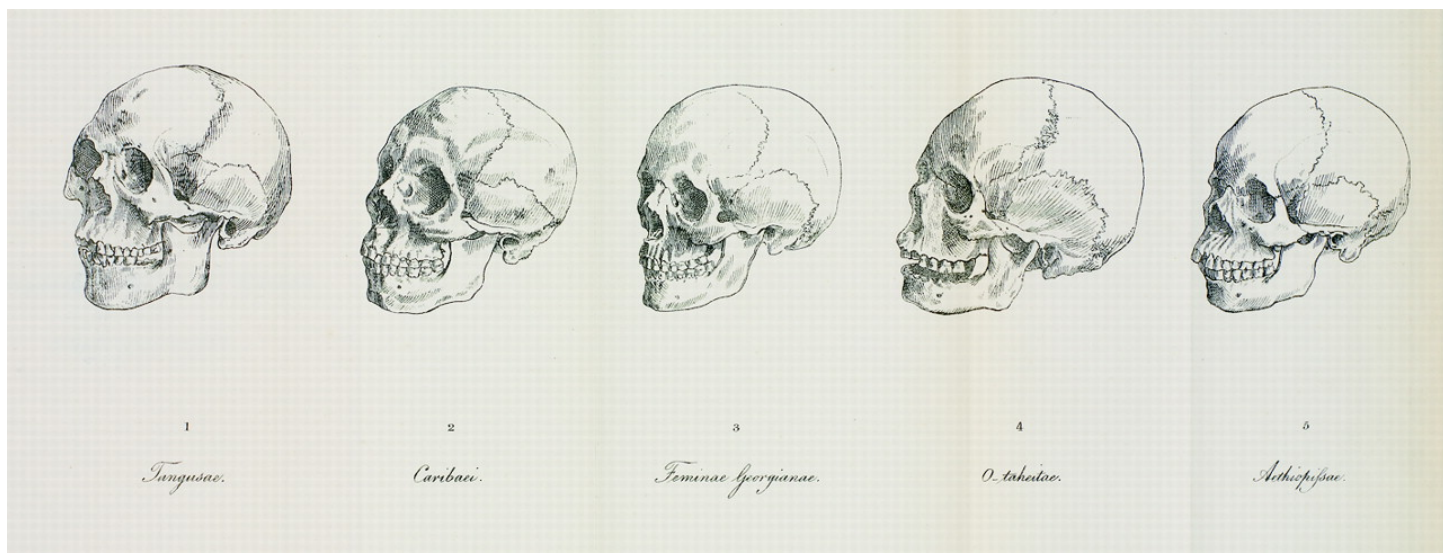

Fig. 32: Crânios estudados por Blumenbach, relativos às cinco variedades da espécie humana por ele definidas. A etíope é a última, da esquerda para a direita.

Prevalece em tais estudos, paralelamente a uma reafirmação da pele branca como o padrão natural, um desejo latente de promover o branqueamento por meio de experimentos, além de compreender em que medida a derme podia de fato mudar de cor. Esse tipo de formulação de base empírica se enquadrava num modelo mais amplo de pensamento, outrora inaugurado com filósofos como Leibniz e Spinoza, em que o mundo era visto como uma série de transformações substanciais entre o conjunto dos seres, imersos numa cadeia gigantesca ${ }^{192}$. Nesse sentido, uma das principais questões que ocupavam as mentes dos pensadores era compreender a ordem por trás dessas transformações, que ligavam a menor das criaturas à divindade - sem deixar de estabelecer hierarquias, inclusive entre os homens ${ }^{193}$.

${ }^{191}$ Cf. JUNGHANS, M. O príncipe e o filho do jardineiro: Maximilian Zu Wied-Neuwied e Friedrich Sellow e a viagem ao Espirito Santo e Bahia (1815-1817). Comunicação apresentada ao PPGHCS/COC/Fiocruz, 2011.

${ }^{192}$ PIMENTEL, M. R. O enigma da cor: dissertação sobre a variedade das cores da espécie humana. In: Ellipsis, 8, 2010, pp. 49-74.

193 De acordo com Gingrich, Herder considerava o grupo dos Kulturevölker (povos com cultura) superior ao dos Naturevölker (povos naturais) - ainda que não tenha levado a extremos seu esforço de hierarquização e que esse relativismo fosse sempre restrito pelo universalismo que lhe era patente. GINGRICH, A. The German speaking countries. Ruptures, schools and nontraditions: Reassessing the History of Cultural Anthropology in Germany. In: BARTH, F. One Discipline, Four Ways: British, German, French, And American Anthropology. University of Chicago Press, 2005.Vale destacar que a sociogênese do conceito de cultura seria alemã, enquanto a do conceito de civilização, francesa e, em 
Os teóricos mencionados até agora se alinharam à tendência que posteriormente se convencionou chamar de monogenista: assentada sobre a Bíblia, essa corrente defendia a origem comum da humanidade. Em oposição - assim como haviam sugerido Paracelso e Giordano Bruno no auge do humanismo -, outros teóricos demonstraram não se convencer quanto à origem comum, caminhando para separar cada vez mais as diferentes raças e posicionando-se contra a interracialidade. Como mostra Roger em seu estudo sobre Buffon, "little by little the idea became accepted that black people and then yellow people formed separate races or even different human species from white people from the very beginning" ${ }^{\text {"194. Um dos }}$ defensores dessa tendência poligenista foi o pensador Voltaire ${ }^{195}$, inclusive em reforço à sua postura anticlerical. O ilustrado é o autor da máxima, publicada em seu Tratado de Metafisica (1734), de que "never as a man with even a little education suggested that unmixed species degenerated"196. Segundo Voltaire, “"a man dressed in a long black cassock' might say about it, 'bearded whites, wooly-haired negroes, yellow people with ponytails and men without beards do not come from the same man",197.

Além dele, lembramos também o germânico Christoph Meiners (17471810) ${ }^{198}$, que publicou em 1785 o estudo Fundamentos da História da Humanidade. $\mathrm{O}$ teórico atribuía a diversidade física da humanidade à sua organização social; afirmava que a mistura de raças levava à degeneração; e argumentava que os germânicos eram superiores a outros povos - inclusive europeus - por terem origens raciais distintas ${ }^{199}$.

É preciso reconhecer a impossibilidade de discutir mais à fundo os elaborados sistemas de pensamento propostos por cada um desses autores, que se dedicaram a uma série de problemas para além do debate que chamamos racial. Também não se pode assumir que este pequeno recorte representa a diversidade de perspectivas teóricas sobre as diferenças que emergiram no período. De qualquer modo, sua menção contribui para perceber que os poligenistas caminhavam para uma

\footnotetext{
menor grau, escocesa, como delimita ELIAS, N. O Processo Civilizador: uma história dos costumes. SP: Companhia das Letras, 1999.

${ }^{194}$ ROGER, J. Buffon. Cornell University Press, 1997, p. 177.

${ }^{195}$ Escritor, historiador e filósofo iluminista francês.

${ }^{196}$ VOLTAIRE. Traité de métaphysique apud Roger, op. cit.

${ }^{197}$ Idem, ibidem.

${ }^{198}$ Meiners, filósofo e historiador, formou-se na Universidade de Göttingen, onde tornou-se professor.

${ }^{199}$ GINGRICH, op. cit.
} 
noção de raça no sentido que hoje atribuiríamos à palavra espécie: usavam o termo para indicar a incompatibilidade da mistura, evidenciando que ela invariavelmente resultava em degeneração (o que nesse ponto se reveste de temores quanto a uma irreversibilidade). Por outro lado, aqueles que chamamos monogenistas não consideravam a união entre raças anti-natural, mas também não negavam a existência de povos, nações ou raças inferiores ou degeneradas (o que, entretanto, seria reversível). Evidentemente, fosse pelo fator climático, o estilo de vida, ou um mal congênito as pessoas de pele negra eram incluídas nesse grupo.

De todo modo, já no final do XVIII o argumento religioso parece perder terreno, enquanto os interesses científicos se voltam com maior entusiasmo para os costumes, o ambiente e o corpo humano, produzindo relatos que não apenas aludiam à moral e à espiritualidade, mas adquiriam solidez material. Adentra-se no século XIX, portanto, com uma perspectiva bastante deslocada no que concerne à crença no mito de Cam e nos argumentos de base escritural. Ao que indicam as fontes, a vinculação entre pele negra e imoralidade converte-se na ideia de degeneração, preservando-se uma tendência a descrever os africanos como inferiores - próximos ao reino animal numa hierarquia ratificada pelas novas descobertas.

A partir desse ponto, a permanência de eventuais alusões ao "povo de Cam", a exemplo daquela empreendida por Ribeyrolles, torna-se devedora de novas formas de identificá-lo, atrelada a esforços de descrição empreendidos por viajantes, naturalistas e missionários que, por vezes em conjunto, procuram comprovação e substrato empírico para as teorias que se produziam nos gabinetes ou fora deles.

\section{Pode o povo de Cam ser branco?}

Tabuada das misturas para ficar branco: 1 branco com 1 negra produz mulato, metade branco, metade preto

1 branco com 1 mulata produz quartão, $3 / 4$ branco e $1 / 4$ negro

1 branco com 1 quartão produz outão 7/8 branco, $1 / 8$ negro

1 branco com 1 outona produz branco, inteiramente branco

Tabuada das misturas para ficar negro: 1 negro com 1 branca produz mulato, metade preto, metade branco 
1 negro com 1 mulata produz quartão, $3 / 4$ negro e $1 / 4$ branco

1 negro com 1 quartão produz outão $7 / 8$ negro, $1 / 8$ branco

1 negro com 1 outona produz negro, inteiramente negro 200

Nesse momento da reflexão, o primeiro ponto que merece atenção é que, se tomarmos uma perspectiva oficial, pode-se dizer que no império português parece nunca ter havido dúvidas quanto à origem única da humanidade ${ }^{201}$. Fortemente católico, este vasto território já lidava, desde o século XV, com a presença de largo contingente populacional de não-brancos, em boa parte escravizados, o que pressupôs desde o começo um aparato jurídico e administrativo próprio para arbitrar o convívio. Era preciso não apenas zelar pelas distinções devidas aos chamados cristãos velhos, mas também preservar o funcionamento do sistema escravista - o que equivalia a empregar todos os recursos para repor continuamente fronteiras étnicas e distinções sociais. A isto serviu o Genesis 9 que, simultaneamente, pretava-se a justificar a escravidão, prover explicação sobre a pele negra e provar que havia uma imoralidade intrínseca aos camitas, sob o olhar da fé. O segundo ponto a destacar é que, ao mesmo tempo, o recurso à escritura produzira a ideia de que a água do batismo tinha o poder de transformar a pele negra em branca, enquanto a mesma transformação epidérmica era alvo de uma série de questionamentos que chamavam a atenção para o lado mais terreno do problema da diferenciação social e racial.

De modo semelhante ao que ocorria também em domínios hispânicos, a perpetuação da desigualdade que hoje tendemos a ver como racial se dava em simultâneo com (e a despeito de) uma multiplicação dos relacionamentos interraciais e de uma vasta população mestiça. Se, como vimos anteriormente, as fontes

\footnotetext{
${ }^{200}$ GAYOSO, Raymundo José de Souza. Tabuada das misturas. In: Compendio HistóricoPolítico dos Principios da Lavoura no Maranhão: suas produç̧ões, e progressos, que tem tido até ao prezente, entraves que a vão deteriorando; e meios que tem lembrado para desvanece-los, em augmento da mesma lavoura, e sem prejuizo do real patrimônio. P. N. Rougeron, 1818.

${ }^{201}$ É bem vinda a ressalva de Luiz Felipe de Alencastro: segundo o historiador, a despeito das tentativas de parte da Coroa de embranquecer a (escassa) população mestiça em Angola, ali prevaleceu a tendência à reafricanização dos mulatos, em decorrência da tradição matrilinear vigente entre grupos locais. Em sua reflexão, Alencastro mostra que a ideia de que a mestiçagem é um padrão comum ao mundo lusófono foi uma invenção, resultante das contribuições de intelectuais como Gilberto Freyre ao colonialismo português do século XX. Ver ALENCASTRO, L. F. Mulattos in Brazil and Angola: A Comparative Approach, from Seventeenth to Twenty-First Century. In BETHENCOURT, F.; PEARCE. A. Racism and Ethnic Relations in the Portuguese-Speaking World. Oxford: British Academy Publications Online, Jan. 2013, pp. 71-96.
} 
missionárias buscavam repor interdições relativas aos descendentes de Cam, aos olhos dos observadores estrangeiros a assiduidade das relações afetivas entre mulheres negras e homens brancos, e a larga variabilidade de tons de pele, parecia ser o principal traço distintivo do mundo ibérico. Assim que, no império espanhol, o conde de Buffon chamava a atenção para a inclassificável gama de cores e fisionomias:

In the present state of these countries, so intermixed are the inhabitants of Mexico and New Spain, that hardly do we meet with two visages of same colour. In the town of Mexico, there are white men from Europe, Indians from the north, and from the south of America, and Negroes from Africa, etc. insomuch, that the colour of the people exhibits every different shade which can subsist between black and white ${ }^{202}$.

O britânico William Dampier (1651-1715) $)^{203}$, de passagem pelo Brasil em 1699, anotou que "vários portugueses que não são casados, tomam essas mulheres negras como suas amantes" ${ }^{204}$. Já o francês Guy le Gentil de la Barbinais (1692$1731)^{205}$, que esteve na América portuguesa entre 1717 e 1718, escreveu que "os portugueses naturais do Brasil preferem possuir uma mulher negra ou mulata à mais bela mulher". O mesmo visitante arrematava: "Sempre lhes perguntei donde procedia um gosto tão bizarro, mas eles mesmos o ignoram. De minha parte, creio que, criados e nutridos por essas Escravas, tomam inclinação pelo leite"206.

A seu turno, ao visitar a metrópole lusitana em 1759, Rhys Udal (s/d $)^{207}$ demonstrava-se perturbado pela dificuldade de compreender sistema de classificação racial adotado naquele reino: "O facto de ter domínios nas duas Índias traz a Lisboa um número de amorenados, negros e mulatos que, quando um português deseja ressaltar a sua condição de nobre, diz que é Branco"208. Assim como ele, em 1747

\footnotetext{
${ }^{202}$ BUFFON, J.-L. L. Comte de. A natural history of the globe and of men, p. 181. London, Thomas Tagg, 1831. Na sequência, o conde discorre sobre a influência do clima na cor da pele.

${ }^{203}$ Dampier é considerado a primeira pessoa a realizar três circunavegações pelo mundo e um desbravador da Austrália. Autor de $A$ new voyage round the world, sua obra influenciou viajantes posteriores, como o capitão Cook e Darwin.

${ }^{204}$ DAMPIER, W. Voyages... aux Terres Australes, à la Nouvelle Hollande, 1699. Amsterdam, 1705 apud FREYRE, G. Casa-Grande \& Senzala. SP: Editora Record, 1994, p. 239.

${ }^{205}$ Pouco se sabe sobre Barbinais. Nascido em Saint-Malo, na Bretanha, ele foi comissário da marinha francesa e um dos primeiros marinheiros franceses a realizar uma viagem ao redor do mundo.

${ }^{206}$ Idem, ibidem

${ }^{207}$ Não há maiores informações sobre Udal. Sabe-se que ele foi autor de A Tour Through Spain and Portugal, Giving an Account Of the Most Remarkable Places and Curiosities In Those Kingdoms (1749-50), tendo supostamente estado nesses lugares.

${ }^{208}$ A sequência de aspas de Trusler se encontra em HOFBAUER, A. Uma história do branqueamento ou o negro em questão. São Paulo: Editora UNESP, 2006, p. 94.
} 
John Trusler (1735-1820) ${ }^{209}$, manifestava desconforto diante da enorme presença de negros em Portugal e, mais ainda, pelo fato de ser-lhes "permitido casar não apenas entre eles, mas também com gente de outra cor" - que considerava o motivo pelo qual o país estava "repleto dos mais diferentes exemplares de monstrengos humanos". O reverendo inglês explicava o processo de maneira didática, para leitores que pudessem desconhecê-lo:

\begin{abstract}
Um branco e um negro geram um mulato. $\mathrm{O}$ mulato une-se então a um negro ou a um branco, e com isso formam mais duas variantes chamadas mestiços. Esses mestiços de brancos, então, unem-se a mestiços de negros, ou brancos, ou mulatos; e assim, são tantos os ramos em que se desdobram em tais cruzamentos, que se torna difícil distingui-los com designações exatas, embora sejam facilmente identificáveis no geral pelos seus tons de pele. A raça portuguesa de origem foi por tal forma degradada que ser um Branco, isto é, um branco de verdade, tornou-se título honorífico: e assim quando um português diz que é Branco, não quer dizer que sua pele o seja, mas apenas que se trata de um nobre ou de famílias de certa importância ${ }^{210}$ (grifos nossos).
\end{abstract}

O uso do termo raça em referência a um grupo humano marcado por características físicas comuns, da parte de Trusler, confrontava com a tendência portuguesa, observada in loco, de definir brancura por distinção. Desse modo, ainda que Trusler pretenda explicar o processo de produção das diferenças raciais, esbarra na dificuldade evidente de traduzir uma cena impensável num sistema de classificação binária (negro e branco). O obstáculo se amplia pelo fato de que ser branco, nesse caso, não implicava ter a cor da pele branca, embora tê-la branca de verdade fosse prova inegável de nobreza.

O que tais relatos indicam é o quão arraigada se encontrava no império português uma noção particular de raça que, à primeira vista, parece pouco sintonizada com uma definição mais propriamente assentada em caracteres biológicos. Aos olhos desses estrangeiros, raça em Portugal era, antes, algo definido pelo critério da honraria. O conceito, portanto, parecia mais afinado com os termos geração, ou qualidade de sangue, guardando ainda uma correlação direta com os

\footnotetext{
${ }^{209} \mathrm{O}$ reverendo Trusler foi um missionário inglês, fundador de uma escola de retórica em Londres, voltada para a aprendizagem da eloquência. Foi autor de escritos diversos, como um guia de Londres para moradores e estrangeiros e livros sobre a língua inglesa. Suas considerações sobre Portugal se encontram em The habitable world described: or the present state of the people in all parts of the globe, from north to south, onde consta que foram extraídas de "Baretti, Fielding and others" - o que serve de indício quanto a uma consolidação da imagem de um reino de população não-branca, onde a mescla era definidora de classificações que desafiavam o sistema binário.

${ }^{210}$ Idem, ibidem.
} 
estatutos de pureza ou limpeza de sangue e os sentidos que evocavam desde o século $\mathrm{XV}$. Tais estatutos eram normas que definiam as posições de cada habitante do império na hierarquia social. Entre os critérios, num primeiro momento, se privilegiou o da ancestralidade genealógica da família na fé católica, a fim de separar os "cristãos velhos" de mouros, judeus, penitenciados e hereges, reconhecendo-se as famílias católicas mais antigas como mais nobres e escalonando-se as demais à luz dessa superioridade secularizada. Entretanto, com a expansão do império português, a figura do gentio $^{211}$ e a evidente mescla entre populações distintas passaram a exigir um alargamento das convenções jurídico-religiosas pré-existentes. Como indica Stolcke, o mesmo acontecia no império espanhol, onde no século XVII o questionamento aos velhos estatutos já se fazia ecoar. Os opositores

\begin{abstract}
Argumentaban que los estatutos eran contrarios a la ley canónica o civil así como la tradición bíblica pues vedaban a los conversos la oportunidad de redimirse a través de la purificación del bautismo. Había opiniones desencontradas asimismo sobre si la limpieza de sangre era un asunto de índole religiosa o si por el contrario se refería a algún tipo de rasgo personal congénito esencial. A pesar de estas disensiones resultó imposible, no obstante, liberar a España de lo que se había convertido en una ansiedad obsesiva sobre honores y distinciones sociales que, a su vez intensificaba la inquietud relativa a los matrimonios y el nacimiento legítimo $^{212}$ (grifos nossos).
\end{abstract}

A antropóloga atribui a persistência da linguagem da "pureza de sangue" no século XVIII, apesar da emergência de debates abertamente raciais, à existência de uma população altamente mesclada, de modo que "los marcadores raciales, como el fenotipo, resultaron ser un indicio muy poco fiable de la ascendencia genealógica y la identidad social de una persona" ${ }^{, 13}$. Dessa maneira, o termo casta - cujo uso se dissemina na América espanhola do século XVIII - adquire conotação de mistura: refere-se a todas as populações cuja classificação se faz mais dificultosa, ao mesmo tempo em que procura endereçar tipos de mistura específicos, recompondo grupos

\footnotetext{
${ }^{211}$ Contrariamente, a definição de gentio significava de "sangue puro... sem mescla ou infecção de nenhuma seita maldita", como explica Stolcke. Assim, se não eram cristãos, os indígenas e africanos não-islâmicos tinham uma oportunidade de integração social, ainda que mediada por condicionantes diversas. No caso dos negros, a escravidão era a mácula maior: "La 'sangre negra' era tenida como impura porque se la asociaba con la esclavitud. Un cuerpo negro o mulato exhibía el signo visible de su genealogía "bárbara", escreve Stolcke. Cf. STOLCKE, V. "Los mestizos no nacen sino que se hacen". In: STOLCKE, V.; COELLO, A. (Ed.) Identidades Ambivalentes en América Latina (Siglos XVIXXI). Barcelona: Bellaterra, 2007, p. 3.

212 Idem, ibidem

213 Idem, ibidem, p. 18.
} 
raciais distintos ${ }^{214}$. O uso da palavra casta sugere que, nos domínios hispânicos, parece prevalecer o intento classificatório racial, marcado pela criação de tipologias que separam diferentes grupos fenotípicos. É o que ilustra de forma didática, por exemplo, a pintura de castas.

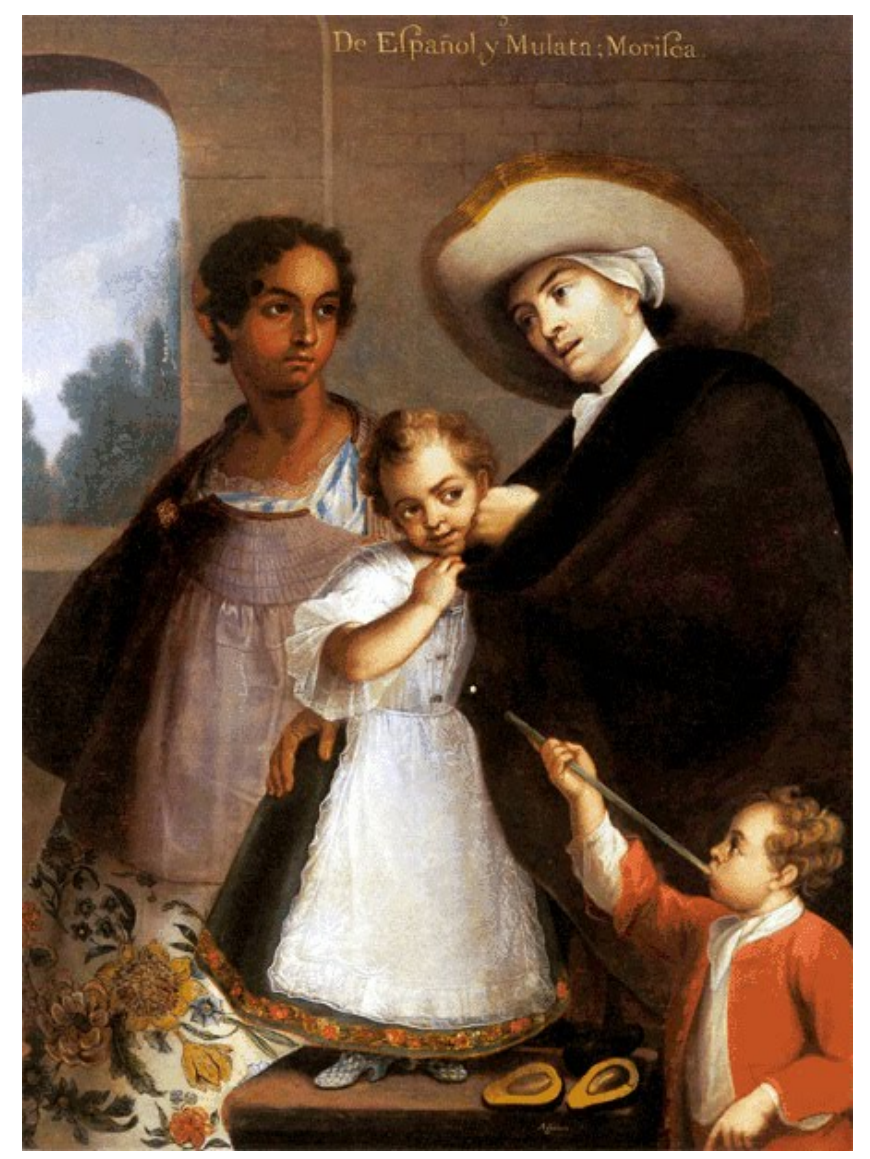

Na pintura de castas, a cor da pele é indexada a sinais de distinção, com o objetivo de fixar posições sociais.

Fig. 33: Miguel Cabrera: De Español y Mulata: Morisca (México, 1763). Óleo sobre tela, $136 \mathrm{~cm} \times 105 \mathrm{~cm}$. Coleção particular.

No império português, a manutenção do vocabulário da "limpeza de sangue" também se combina à análise da aparência no que concerne a delimitar margens de distinção possíveis. Entretanto, cresce em simultâneo uma tendência a apostar na reversibilidade da cor, rumo ao branqueamento, em termos ideológicos ou discursivos. Em estudo sobre as habilitações para o Santo Oficio e outros cargos que garantiam certo grau de ascensão em Portugal, Figueirôa-Rêgo e Olival mostram que, a partir dos séculos XVII e XVIII a cor da pele se transforma em um foco de interesse nos inquéritos promovidos com vistas a outorgar títulos e cargos importantes. Assim,

\footnotetext{
${ }^{214}$ Segundo Stolcke, casta, originalmente sinônimo de linhagem ou ascendência, passa a disseminar-se nos éditos reais espanhóis no século XVIII, começa a adquirir o sentido de mescla, mas também tipos de mistura diferentes.
} 
se no decurso de um testemunho o depoente estabelecesse uma correspondência entre atributos físicos (tez trigueira, nariz chato, beiços largos ou cabelo encarapinhado) e impureza, sem que existisse prova irrefutável, a observação era em geral desvalorizada. Ao contrário, quando o defeito era sugerido sem ser estabelecida qualquer marca fisionómica, os ministros do Santo Ofício atenuavam a nota, com base na inexistência de características étnicas notórias $^{215}$.

De acordo com o excerto, a fisionomia não era em si vista como sinônimo imediato de impureza de sangue. Era, no entanto, levada em conta pelo Santo Ofício, podendo ou não funcionar como elemento decisivo na habilitação do candidato (o que também ocorria nas habilitações para instituições públicas, religiosas e militares, segundo os autores) - o que equivale dizer que havia possibilidades de distinção, ainda que mediadas por uma série de critérios, para não-brancos. Passando aos exemplos citados pelos autores, a investigação que habilitaria Agostinho Medeiros Ferreira, presbítero do hábito de S. Pedro, a servir a Inquisição apontou nota de mulatice. De modo análogo, o escrivão da Provedoria de Guimarães, Carlos António da Costa Cardoso, habilitando-se para o Santo Ofício, também constou nota de mulatice por via de uma avó, neta de escrava negra, emergindo em sua avaliação acusações de manter relações com uma mulher adúltera e descrita como mulata; e observações sobre seu pai, apresentado como o proprietário da chamada Taberna do Negro e descrito como possuidor de cabelo "carapinha". Ambos conseguiram os títulos almejados.

Mais um caso mencionado por Figueirôa-Rêgo e Olival merece atenção, devido à preocupação em detalhar os costados da avó materna do candidato. Trata-se da habilitação do Santo Ofício de António Vieira Rebelo, de 1770:

[a avó materna tem mácula de mulatismo] Por descender de uma preta, que se ignora se foi escrava, e até o grau, em que principiou, sendo já fora do $4^{\circ}$ grau o que lhe dão algumas testemunhas nos quais termos e ainda na opinião dos mais escrupulosos que supõe defeito no mulatismo, que não sigo, mas sim a objecção da escravidão, ainda o verificar-se esta, seria em grau tão remoto, e se acha o habilitando no estado nobre de capitão, em que lhe não podia obstar, como também a falta de notícia do avô materno (...) e de Manuel Ribeiro avô materno de sua mulher nas suas naturalidades, por serem bem reputados nos seus domicílios, e terem a seu favor a presunção de pureza, enquanto se não mostra o contrário ${ }^{216}$.

\footnotetext{
${ }^{215}$ FIGUERÔA-RÊGO, J. e OLIVAL, F. Cor da pele, distinções e cargos: Portugal e espaços atlânticos portugueses (séculos XVI a XVIII). In: Tempo, vol. 16, nº 30, Niterói, 2011, p. 139-140.

${ }^{216}$ Idem, ibidem, pp. 141-142.
} 
Entre as sugestivas informações do trecho, está a de que a escravidão constituiria uma mácula maior do que o defeito do "mulatismo" aos olhos do investigador. Além disso, fica indicado que as habilitações eram permitidas, desde que o candidato cumprisse o requisito geracional previsto - no caso, o de estar comprovadamente além do $4^{\circ}$ grau (portanto, ter o último ancestral mulato e/ou escravo registrado a pelo menos quatro gerações, com todos os demais ancestrais depois dele sendo brancos e cristãos), com chances de atenuação da mácula.

Se foge a nossos limites imediatos um estudo detalhado de tais processos, de qualquer forma é digno de nota, para efeitos desta investigação, a incidência da visualidade das testemunhas sobre o inquérito, orientada a identificar o "defeito do mulatismo" que, ao mesmo tempo, nem sempre inviabilizava a nobilitação do candidato. Talvez porque, como sugere o médico António Ribeiro Sanches (1699$1783)^{217}$, já houvesse certeza quanto ao destino dos negros e mulatos: "vemos todos os dias a raça de negro e mulato extinguir-se em quatro gerações, e no fim delas todos vêm a ser Portugueses" 218 .

A declaração de Sanches indica uma confiança no cálculo geracional rumo ao branqueamento. Na prática, a matemática das transformações raciais se encontrava bastante difundida no século XVIII, tendo aparecido também no comentário de Trusler citado acima - ainda que neste caso em sentido negativo. A previsão de quatro gerações para converter-se de negro em branco (ou vice-versa) teria sido proposta originalmente pelo jesuíta francês M. L'Abbé Prévost $(1697-1763)^{219}$ e adotada por teóricos como DePauw. Buffon, por sua vez, não acreditava na possibilidade de transformação completa entre negro e branco, calculando que levaria entre oito e 12 gerações para que os descendentes de um negro que tivesse sido transplantado à zona temperada se tornassem visivelmente mais claros que seu ancestral ${ }^{220}$.

\footnotetext{
${ }^{217}$ Ribeiro Sanches foi um intelectual ilustrado, tendo colaborado com a Enciclopédia, a pedido de D'Alembert e Diderot. Especializou-se em venereologia, angariando reconhecimento como "o médico dos males de amor". Diz-se que seu pensamento influenciou, entre outros, o Marquês de Pombal.

${ }^{218}$ SANCHES, A. R. Cristãos novos e cristãos velhos em Portugal. Covilhã, Universidade da Beira Interior, 2003 [1748] apud, op. cit. FIGUERÔA-REGÔ, J. e OLIVAL, F. Cor da pele, distinções e cargos: Portugal e espaços atlânticos portugueses (séculos XVI a XVIII). In: Tempo, vol. 16, n 30, Niterói, 2011, p. 139-140.

${ }^{219}$ Romancista francês, o abade Prévost foi originalmente membro da ordem jesuítica, com a qual rompeu, ingressando numa comunidade beneditina em que passou boa parte da vida, exceto pela ruptura de 1728 a 1734, quando passou a viver em Londres.

${ }^{220}$ Sollors e Hofbauer mencionam tais cálculos. Sollors percorre uma série de autores que fizeram suas contagens geracionais, constatando que, invariavelmente, tais cálculos tinham por base um projeto de branqueamento - e nunca o contrário. Cf. SOLLORS, W. Neither black, nor white, yet both.
} 
A versão expressa por Sanches parece mais próxima daquela de Prévost e DePauw, mas também transmite a ideia de que já havia um processo natural em andamento, em que tornar-se branco podia ser visto como uma espécie de regeneração social e racial. Desse modo, o cálculo geracional parece evocar o antigo argumento cristão de que a água do batismo transformava os negros em brancos. Entretanto, sem transparecer qualquer viés religioso, ela se baseia no olhar: a prova do branqueamento era antes a existência de descendentes de negros em que a "nota de mulatice" não se exprimia mais de modo visível. Aquilo que antes poderia ser lido como uma transformação espiritual ou um reconhecimento social adquiria, portanto, materialidade e função prática.

Desenhava-se assim, entre os portugueses, uma tendência a crer no branqueamento. A mesma propensão não encontrava equivalência entre os espanhóis, cujo modelo de castas reforçava a ideia latente de que a condição branca outrora perdida não poderia jamais ser recuperada ${ }^{221}$, a despeito das transformações obtidas por meio da mistura. Assim, se aos olhos de alguns a reversibilidade da cor aparece como total, entre outros era sempre limitada: adicionando outro termo central para resumir as preocupações raciais setecentistas, estes segundos modelos pareciam evidenciar maiores preocupações com o chamado atavismo, qual seja, o retorno, em gerações posteriores, das características de um ancestral. É isso que parece dizer a categoria de "salta atrás", existente em algumas contagens e também na pintura de castas produzida no Peru e México do século XVIII ${ }^{222}$.

Thematic explorations of interracial literature. Cambridge: Harvard University Press, 1999. HOFBAUER, A. Uma história do branqueamento ou o negro em questão. São Paulo: Editora UNESP, 2006.

${ }^{221}$ Cf. SOLLORS, W. Neither black, nor white, yet both. Thematic explorations of interracial literature. Cambridge: Harvard University Press, 1999.

${ }^{222}$ O missionário dominicano Jean-Baptiste Labat (1663-1738) observou a irreversibilidade provocada pela mistura racial em prejuízo do pólo branco, mas não o negro: "se alguém casa Mulatos, macho ou fêmea, com brancos, as crianças emergentes serão muito mais brancas, seu cabelo muito menos enrolado. Na terceira geração, só será possível reconhecê-las pelo branco dos olhos, que sempre tende à parecer um pouco intumescido... Se alguém os unisse novamente a negros, eles retornariam em igual número de gerações à sua negritude" (apud Sollors, op. cit. p. 116). O clérigo foi autor de uma classificação em que o saltatrás era figura recorrente. 


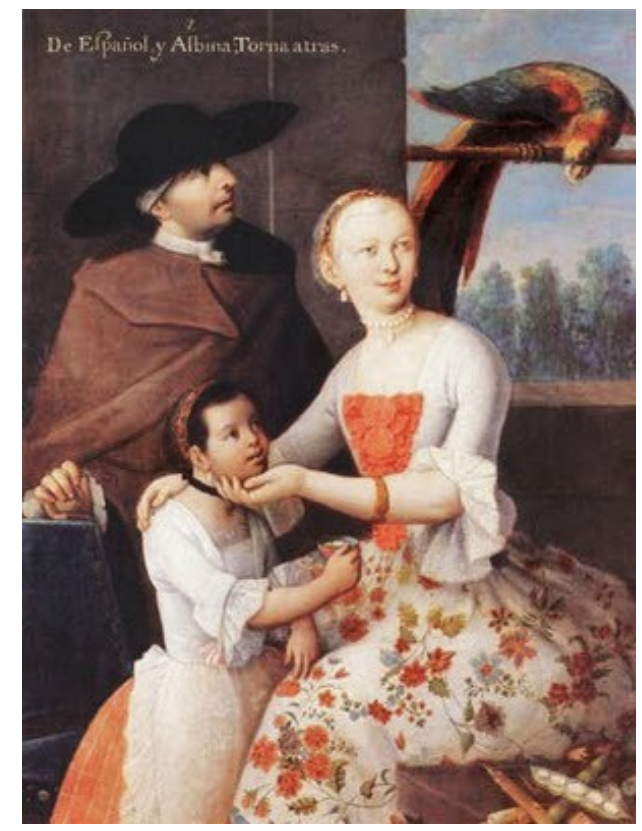

$\mathrm{Na}$ cena, o pai olha preocupado para uma arara especialmente colorida, que observa o casal formado por uma esposa albina e um marido espanhol, cuja filha tem a pele um pouco mais escura que os pais.

Isto porque, a despeito da cor da pele dos pais, os filhos de um albino com branco serão definidos como "salta atras" - atávicos rumo ao pólo negro no modelo de castas espanhol. Assim, trata-se de um sistema em que a brancura nunca é plenamente recuperada.

Fig. 34: Miguel Cabrera. De Español y Albina: Torna atras, (México, 1763). Óleo sobre tela, $136 \mathrm{~cm} \times 105 \mathrm{~cm}$, coleção particular

Por outro lado, é importante reforçar que tal processo não estava de modo algum livre de preocupações de parte das autoridades coloniais lusitanas, que não pareciam nutrir a mesma segurança de Sanches quanto ao futuro (racial) do império português. Aqui o problema parece traduzir-se da seguinte maneira: por um lado, a miscigenação colocava em xeque a existência da escravidão - pois se a conta fechasse, um dia todos deixariam se ser negros, podendo tornar-se livres ${ }^{223}$. Por outro, a frequência das insurreições de escravos e forros e o aumento da violência ameaçava a unidade do império e, para contê-la, seria necessário pensar num sistema de concessões que permitisse amainar tensões, mas sem abalar hierarquias vigentes. Surgia a necessidade de encontrar a justa medida para a gestão das uniões interraciais, inclusive no tocante ao destino de seus descendentes.

Nas palavras de Laura de Mello e Souza: "a metrópole não podia suprir a sua colônia de gente, e no entanto esta necessitava de um povo que a defendesse, que a fizesse funcionar e render. (...) Uma das soluções seria aceitar os casamentos mistos e

\footnotetext{
${ }^{223}$ Estudando as Minas setecentistas, Laura Mello e Souza comenta que a dificuldade para estabelecer o status jurídico dos descendentes de uniões interraciais repercutia na crescente quantidade de forros. Basílio Teixeira de Saavedra, representante de uma elite ilustrada mineira resumia o problema: "Os casamentos e mais ainda as mancebias de proprietários com mulheres pretas, e mulatas têm feito mais de três partes do povo de gente liberta, sem criação, sem meios de alimentar-se, sem costumes e com a louca opinião de que a gente forra não deve trabalhar" SAAVEDRA, B. T. Informação da Capitania de Minas Gerais. RAMP vol. II, 1897 [1805] apud SOUZA, L. M. Os desclassificados do ouro. A pobreza mineira no século XVIII. Rio de Janeiro, Graal, 1990, p. 109. As devassas analisadas pela historiadora detalham casos de concubinato entre portugueses e mulheres negras, que optamos por não mencionar, mas que são bastante ilustrativos do fenômeno em questão.
} 
a sua conseqüência: uma população de mestiços"224. Foi assim que o Marquês de Pombal (1699-1782) $)^{225}$ propôs incentivar os matrimônios entre portugueses e indígenas, "dignando-se Sua Majestade de os habilitar para todas aquelas honras competentes às graduações dos seus postos",226.

É preciso reconhecer que tal aceitação não era isenta de problemas, tanto que, no mesmo Diretório dos Índios (1757), Pombal proíbe os colonos de chamar os indígenas de "negros"227 (leia-se, escravos) e recomenda "muito aos Diretores, que apenas forem informados de que algumas Pessoas, sendo casadas desprezam os seus maridos, ou suas mulheres, por concorrer neles a qualidade de Índios, o participe logo ao Governador do Estado, para que sejam secretamente castigados, como fomentadores das antigas discórdias, e perturbadores da paz, e da união pública",228. Os trechos são sugestivos quanto às diferenças de status já naturalizadas entre indígenas e brancos, indicando que tipo de resistência esperar diante de tais enlaces.

De qualquer maneira, no tocante aos negros, a escravidão sem dúvida representava um impedimento maior. Não só os casamentos com pessoas dessa cor não constavam da recomendação de Pombal, como a fronteira instaurada entre estes e os indígenas fíca explícita na proibição de uso do denominativo "negro" para os segundos. Outro documento sugestivo a esse respeito é uma portaria lançada pelo Marquês de Lavradio (1729-1790) ${ }^{229}$, que rebaixa um indígena do posto de capitãomor por ter casado com uma negra e assim "haver manchado o seu sangue e se mostrado indigno do cargo",230.

\footnotetext{
${ }^{224}$ Idem, ibidem, p. 115.

${ }^{225}$ Nobre, diplomata e estadista português, Sebastião José de Carvalho e Melo, primeiro Conde de Oeiras e Marquês de Pombal, foi secretário de Estado durante o reinado de D. José I (1750-1777). Empreendeu diversas reformas administrativas, com destaque ao fato de ter posto fim à escravidão em Portugal continental em 1751. Também é lembrado pela expulsão dos jesuítas de Portugal e colônias.

${ }^{226}$ MELLO, S. J. de C., Marquês de Pombal. Diretório dos Índios, 1757, §89 apud ALMEIDA, Rita Heloísa de O diretório dos índios: um projeto de "civilização" no Brasil do século XVIII. Brasília, Editora UNB, 1997, p.14.

${ }^{227}$ Idem, ibidem, §10. "Entre os lastimosos princípios, e perniciosos abusos, de que tem resultado nos Índios o abatimento ponderado, é sem dúvida um deles a injusta, e escandalosa introdução de lhes chamarem Negros; querendo talvez com a infâmia, e vileza deste nome, persuadir-lhes, que a natureza os tinha destinado para escravos dos Brancos, como regularmente se imagina a respeito dos Pretos da Costa da África".

${ }^{228}$ Idem, ibidem., $\$ 90$.

${ }^{229}$ Dom Luís de Almeida Portugal Soares de Alarcão d'Eça e Melo Silva Mascarenhas foi o $2^{\circ}$ Marquês de Lavradio, recebendo o título de seu pai, D. Antônio de Almeida Soares Portugal. Dom Luís foi o $11^{\circ}$ vice-rei do Brasil, função que exerceu de 1769 a 1778.

${ }^{230}$ Portaria datada de 6 de agosto de 1771, apud SOUZA, L. M. Os desclassificados do ouro. A pobreza mineira no século XVIII. Rio de Janeiro, Graal, 1990, p. 115.
} 
Contrastadas, as fontes confirmam o escalonamento entre negros e indígenas no interior de um gradiente de cor, envolvendo distinções que pareciam se estruturar a partir da condição escrava. Espraia-se assim um jogo de diferenciação delicado em que, por um lado, cultiva-se um fascínio pelo branqueamento - cuja contrapartida era a negação da pele escura -; por outro, exprime-se o problema pelo vocabulário da liberdade e não da cor. Dessa maneira, ainda que proibir o uso do termo "negro" reforçasse uma inferioridade localizada não só na condição de escravo, mas também na tez, reiterar a escravidão como limite assegurava uma margem para concessões que seria impossível num sistema de classificação binário de cor, de modo que os descendentes de uniões interraciais entre brancos e negros pudessem habilitar-se para cargos e títulos.

Assim, uma combinação entre a matemática geracional da transformação epidérmica, pureza de sangue e escravidão parecia contribuir para um ordenamento complexo entre os portugueses, que jogava com as expectativas de transformação racial e distinção. Somam-se a esse tipo de cálculo estudos que buscam comprovar a reversibilidade da cor.

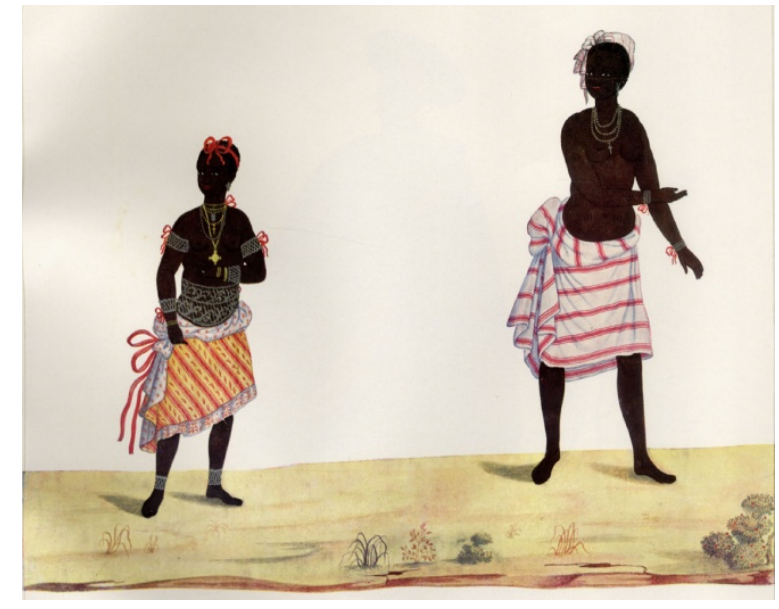

Fig. 35: Carlos Julião. Roupas de mulheres escravas (Rio de Janeiro, c. 1770). Aquarela colorida. Rio de Janeiro:

Biblioteca Nacional. Destaca-se o uso de pano da costa e adornos africanos e jóias pelas figuras.
Se administrar as relações interraciais na colônia representava um desafio, as imagens produzidas por Carlos Julião (1740-1811) parecem reforçar a separação entre senhores e escravos, caracterizados por roupas e costumes distintos, além de um contraste acentuado na cor da pele de uns e outros, sem tons intermediários.

Julião, ítalo-lusitano, serviu ao império português como militar e inspetor de fortalezas não só no Brasil, mas também em Mazagão, Marrocos; Macau, China; e na Índia. Ele recebeu formação em desenho por exigência da função, que envolvia o registro de informação visual sobre os povos e territórios colonizados ${ }^{231}$.

\footnotetext{
${ }^{231}$ Para uma análise das aquarelas de Carlos Julião, ver LARA, S. G. Customs and Costumes: Carlos Julião and the Image of Black Slaves in Late Eighteenth-Century Brazil. In: Slavery \& Abolition: A Journal of Slave and Post-Slave Studies, vol. 23, Issue 2, 2002.
} 


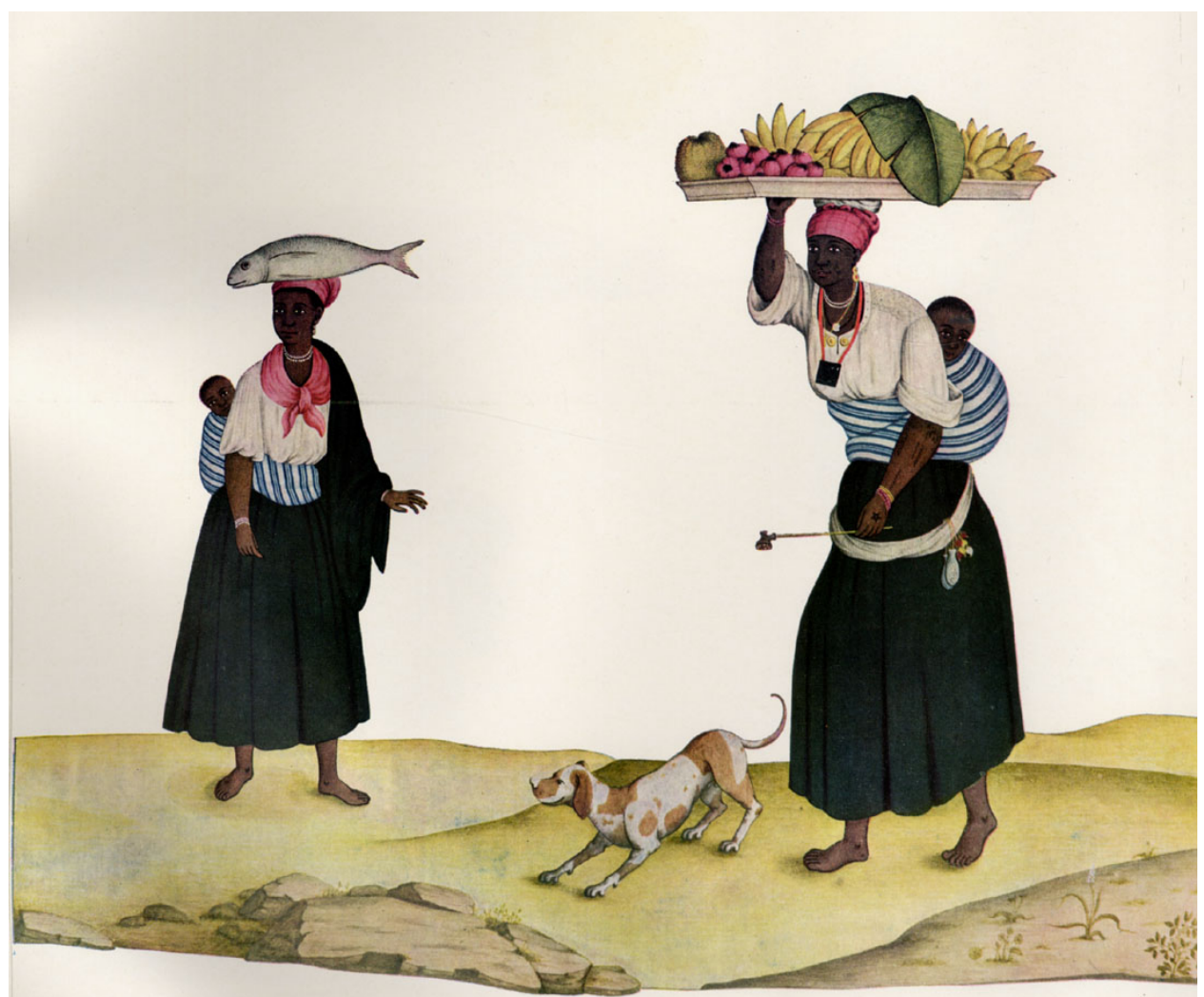

Fig. 36: Carlos Julião. Negras vendedoras (Rio de Janeiro, c.1776). Aquarela colorida. Rio de Janeiro: Biblioteca Nacional. Note-se o uso de patuás e bolsas de mandingas; turbantes; e os pés descalços das mulheres, que usam panos da costa para carregar seus bebês. As crianças são negras, como as mães.

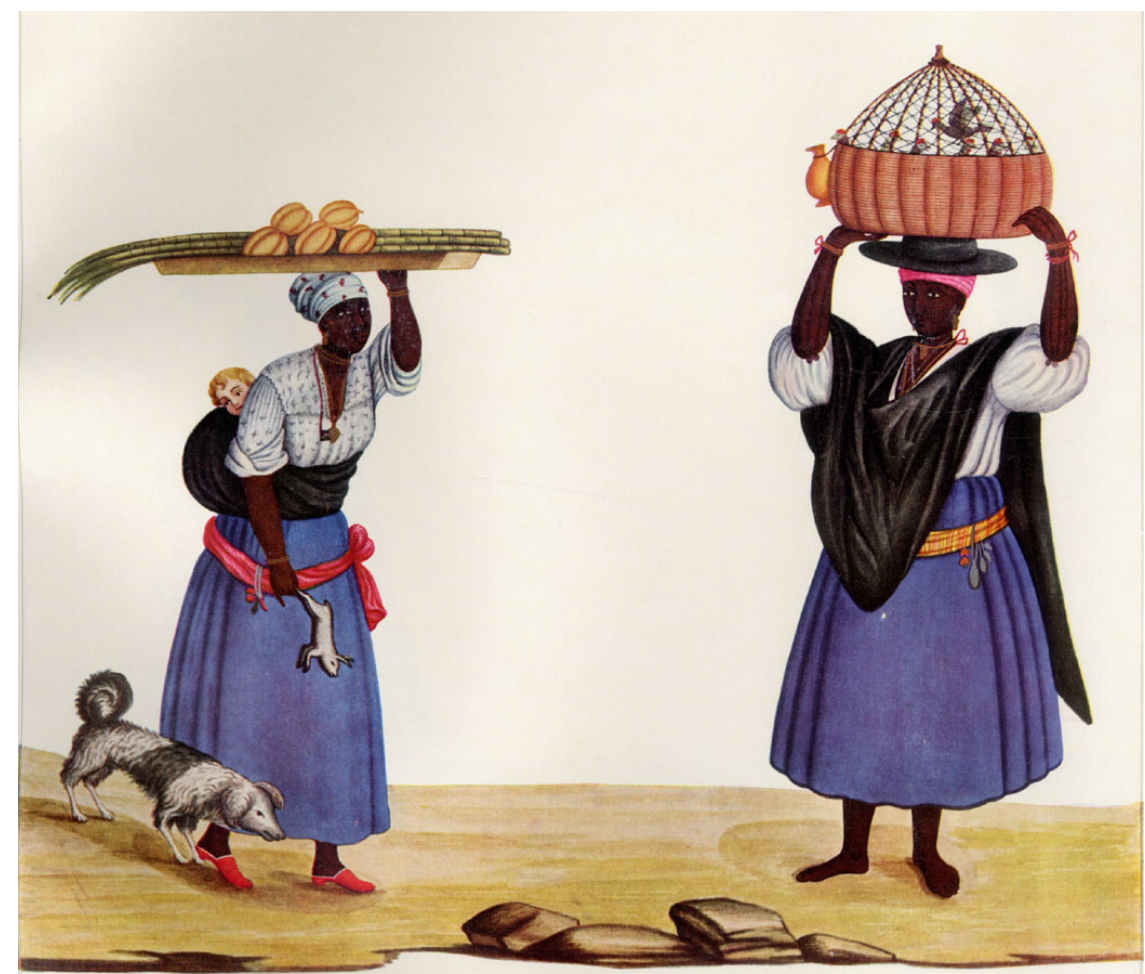

Fig. 37: Carlos Julião. Escravas vendedoras (Rio de Janeiro, c.1776). Aquarela colorida. Rio de Janeiro: Biblioteca Nacional. Com diferenças sutis em relação à imagem anterior, agora uma das mulheres carrega um bebê branco, de cabelos louros e está calçada. Mantém-se, no mais, o contraste de cor branco/negro, sem tonalidades intermediárias de pele. Se ela leva um coelho branco na mão, sua colega tem pássaros negros numa gaiola, talvez, alusões ao fato da primeira ser livre e a outra, escrava. 


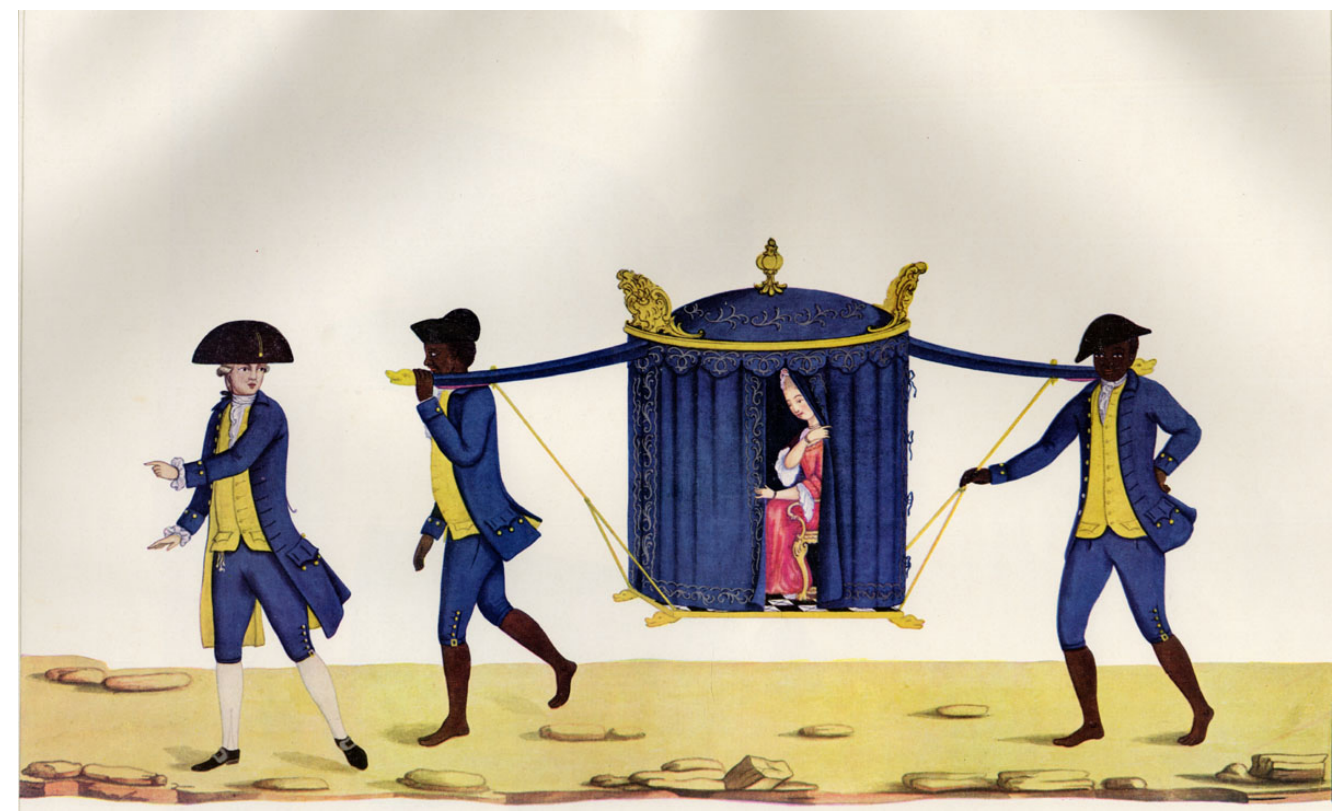

Fig. 38: Carlos Julião. Carregando uma liteira (Rio de Janeiro, c.1776). Aquarela colorida. Rio de Janeiro: Biblioteca Nacional. A diferença de tom de pele entre livres e escravos é marcante na imagem.

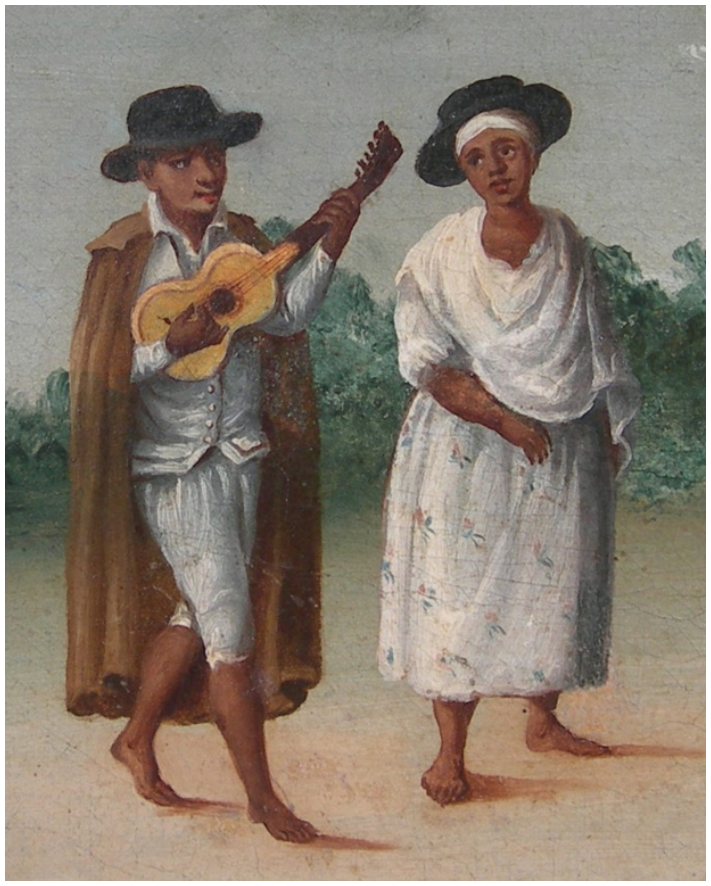

Fig. 39: Leandro Joaquim. Vista da Lagoa do Boqueirão e do Arqueduto de Santa Teresa (Rio de Janeiro, c.1790) [detalhe]. Óleo sobre tela, $86 \mathrm{~cm}$ $105 \mathrm{~cm}$. Rio de Janeiro: Museu Histórico Nacional
Pouco posteriores às aquarelas de Julião, as pinturas de Leandro Joaquim (c.1738c. 1798$)^{232}$, artista fluminense considerado "mulato", mostram a população de pele negra, branca e de tonalidades intermediárias no Rio de Janeiro.

O casal ao lado aparece em meio a outras figuras, com destaque para negros com trouxas de roupas na cabeça, um pastor de bois (negro) conduzindo o rebanho e um grupo de crianças nadando, quatro brancas e uma negra nadando.

É digno de nota que numa obra encomendada pelas autoridades locais, para decorar o Pavilhão de Apolo no futuro Passeio Público do Rio de Janeiro, o artista tenha privilegiado a inclusão dessas figuras - e em primeiro plano -, deixando ao fundo as obras arquitetônicas que mostrariam avanços urbanísticos do Rio de Janeiro de então. Visto que a Lagoa do Boqueirão foi aterrada para dar lugar ao Passeio Público, a imagem indica uma intenção de Leandro Joaquim de preservar a memória do local como uma área de uso comum e lazer da população do $\mathrm{Rio}^{233}$

\footnotetext{
${ }^{232}$ Leandro Joaquim foi pintor oficial do Vice-Reino e retratista de D. Luis de Vasconcelos $-\mathrm{O}$ maior mecenas do pintor, arquiteto e cenógrafo.

${ }^{233}$ Nicolau Sevcenko, anotações de aula. Cambridge, Harvard University, 2011.
} 


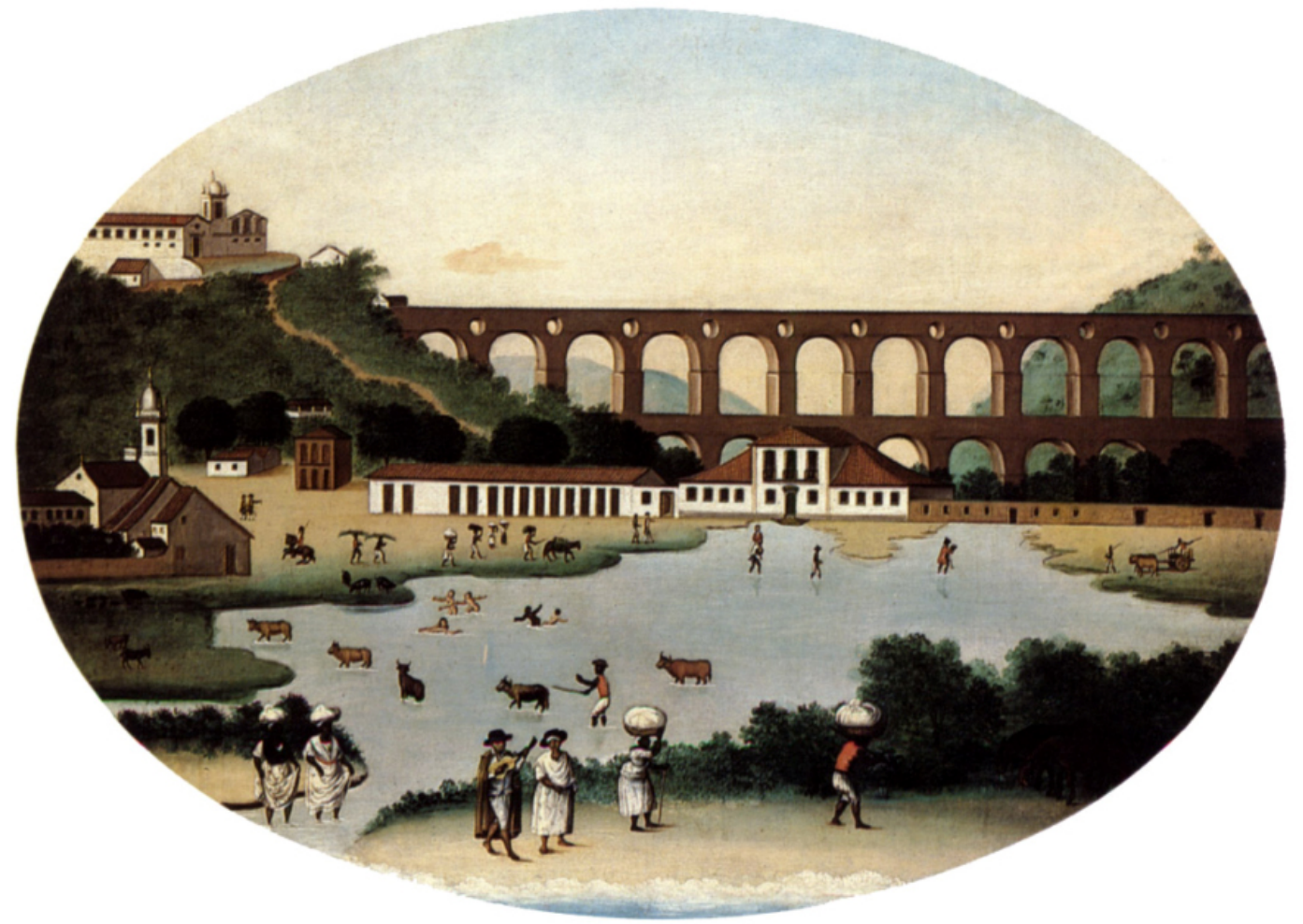

Fig. 40: Leandro Joaquim. Vista da Lagoa do Boqueirão e do Arqueduto de Santa Teresa (Rio de Janeiro, c.1790). Óleo sobre tela, $86 \mathrm{~cm} 105 \mathrm{~cm}$. Rio de Janeiro: Museu Histórico Nacional

Assegurar o equilíbrio político necessário, assim como compreender a complexa gestão da cor nas paragens que assim o exigiam resultou também numa produção científica própria, em que a ideia de degeneração pudesse ser vista como reversível e o atavismo ficasse de fora. Duas teorias merecem atenção a esse respeito. Em primeiro lugar, é digna de nota a tese Disquisitiones Quaedam Physiologicochemicae, de Influentia Oxigenii in Oeconomia Animali, defendida pelo pernambucano Manuel Arruda da Câmara (1752-1811) $)^{234}$ na Faculdade de Medicina de Montpelier, França, em 1791, para obtenção do título de graduado. Câmara discorre sobre os efeitos do oxigênio sobre a pele, argumentando que todas as pessoas nascem brancas e adquirem sua tonalidade característica pela ação desse elemento químico. Desse modo, nos lugares frios, em que o ar é rarefeito, as populações

\footnotetext{
${ }^{234}$ Câmara é considerado por muitos historiadores como um dos maiores divulgadores dos ideais da Revolução Francesa em Pernambuco e fundador da maçonaria local e perseguido pela repressão monarquista por sua participação no movimento revolucionário republicano de 1817. Há, no entanto, versões discordantes, que o definem como monarquista ilustrado e senhor de escravos. Para um panorama geral e reflexões sobre Disquisitiones - tese polêmica no período -, ver ALMEIDA, A. V.; e MAGALHÃES, F. O. As "Disquisitiones" do naturalista Arruda Câmara (1752-1811) e as relações entre a química e a fisiologia no final do século das Luzes. In: Química Nova, vol. 20, n. 4, 1997; e KURY, L. No calor da pátria. IN: Revista USP, São Paulo, nº 72, dez-fev. 2006/2007, pp. 80-89.
} 
respiram menos oxigênio e, por isso, permanecem brancas. Nas latitudes equatoriais e tropicais, é diferente: as pessoas respiram mais oxigênio e se tornam mais escuras. Tudo isso para dizer que, ao contrário do que propunha Buffon, a cor de nascença não corresponde ao padrão da normalidade. Na argumentação de Câmara, a derme normal é morena, não branca ${ }^{235}$. O teórico, aliás, contrapôs-se abertamente ao conde francês, que considerava contaminado demais pelo amor à sua pátria. Para isso lembrou das constatações do botânico e zoólogo Carl Lineu (1707-1778) $)^{236}$, que via o homem tropical em harmonia com um meio ambiente em que tudo florescia e frutificava, não necessitando de recursos artificiais para suprir suas necessidades de "calórico",237. Aqui, portanto, encontramos um trabalho dedicado a mostrar que não havia degeneração na pele morena, contrariamente às teorias científicas produzidas por autores franceses e alemães citadas acima. $\mathrm{O}$ anormal estava nos extremos - o que inclusive retirava do horizonte o debate sobre o atavismo.

A reversibilidade da cor também é ponto passivo no manuscrito Dissertação sobre a variedade das cores da espécie humana, enviado em 1799 à Academia Real das Ciências de Lisboa. Conforme Pimentel $^{238}$, o artigo foi apresentado anonimamente, de acordo com a regra estipulada para submeter trabalhos à instituição, sendo possível atribuir sua autoria a Manuel da Cunha de Azeredo Coutinho $^{239}$.

A Dissertação rejeita a ideia de que as diferentes cores da pele humana se devessem ao mito bíblico sobre a maldição que afetou Canaã, atribuindo-as antes ao fator climático, pois "se não acham os Pretos senão nos climas da terra em que todas as circunstâncias se têm reunido para produzir um calor constante e sempre excessivo"240. Para expor sua teoria, o autor dialoga com uma base empírica já consolidada de investigações, citando estudos anatômicos com a finalidade de

\footnotetext{
${ }^{235}$ Cf. KURY, L. No calor da pátria. IN: Revista USP, São Paulo, nº 72, dez-fev. 2006/2007, pp. 8089.

${ }^{236}$ Lineu, considerado o pai da taxonomia moderna, foi botânico sueco altamente reconhecido em seu tempo. Reconhecido por nomes como Jean-Jacques Rousseau e Goethe como uma grande influência, escreveu também obras de literatura.

${ }^{237}$ Idem, ibidem.

${ }^{238}$ PIMENTEL, M. R. O enigma da cor: dissertação sobre a variedade das cores da espécie humana. In: Ellipsis, 8, 2010.

${ }_{239}$ Possivelmente, Manuel da Cunha de Azeredo Coutinho Souza Chichorro (1774-1839), jusrista, ouvidor da Comarca de São Paulo e sobrinho de José Joaquim da Cunha Azeredo Coutinho, escravista, bispo de Pernambuco (1794) e de Elvas (1806-1818) e membro da mesma Academia.

${ }^{240}$ Anônimo [Coutinho, M. C. A.]. Dissertação sobre a Variedade das Côres da especie humana. Tese apresentada à Academia de Ciências de Lisboa, 1799, Fl. 346. Anexo PIMENTEL, M. R. O enigma da cor: dissertação sobre a variedade das cores da espécie humana. In: Ellipsis, 8, 2010
} 
descobrir "em que parte dos Tegumentos dos Negros residia a Cor" ${ }^{241}$. Ele menciona o anatomista francês Alexis Littré (1654-1726) ${ }^{242}$, que "na Era de 1702 fez uma dissecção em um Negro de pouca idade, o qual não tinha ainda a glande descoberta, e que a porção que ficava coberta com o prepúcio era perfeitamente branca, e a extremidade descoberta negra"243. Cita também monsieur Holbe ${ }^{244}$, naturalista inglês que estudara os hotentotes, observando que seus filhos "nasciam tão brancos como os dos Europeus, e que só depois de adquirirem a amarelhidão que alguns contemplam como uma espécie de Icterícia, passavam à Cor de azeitona madura"245.

O manuscrito prossegue, aludindo a explicações distintas para o fenômeno da pele negra, como a de Torrans ${ }^{246}$, que atribuía esta cor ao sangue, e as de Pierre Barrère (1690-1795) e Jacob B. Winslow (1669-1760) ${ }^{247}$, que a atribuíam à forte presença de bílis no corpo negro. Por fim, o texto critica o último cientista por não ver que se a bílis fosse negra, não haveria pele branca, argumentando que a cor da bílis varia de acordo com a temperatura, tornando-se negra em zonas mais quentes do globo.

Além de sugerir, desse modo, que o branco seria a ausência de cor, ou o matiz original, Coutinho não deixa de reforçar uma associação entre a pele negra e uma moléstia transmitida de geração em geração, anomalia provocada pelo clima e que aos poucos se torna natural. Diz ele que o "clima constantemente quente tem naturalizado nos seus habitantes esta alteração, que bem como uma moléstia hereditária acompanhada sempre das mesmas Causas se perpetua nascer-se das

\footnotetext{
${ }^{241}$ Idem, ibidem, fl. 347 vo.

${ }^{242} \mathrm{O}$ anatomista francês, membro da Academia Real de Ciências de Paris, foi o primeiro a testar a teoria de Malpighi sobre a existência, na pele dos negros, de uma camada de retícula mucosa por onde circulava um liquido negro e denso. No entanto, ele concluiu que a pigmentação negra se devia em parte à existência da membrana, em parte à ação do ar quente. Ver CURRAN, A. S. The Anatomy of Blackness: Science and Slavery in an Age of Enlightenment. Baltimore: JHU Press, 2011.

${ }^{243}$ Idem, ibidem, fl. 346. O mesmo experimento também é citado por Cámara, apud KURY, L. No calor da pátria. IN: Revista USP, São Paulo, n 72, dez-fev. 2006/2007

${ }^{244}$ Não foi possível localizar mais informações sobre Holbe.

${ }^{245}$ Idem, ibidem, fl. 347.

${ }^{246}$ Não foi possível localizar mais informações sobre Torrans.

${ }^{247}$ Pierre Barrère, médico e botânico francês, foi autor de Dissertation sur la cause physique de la couleur des nègres (1741). Anatomista dinamarquês nascido na França, Jacob B. Winslow escreveu Exposition anatomique de la structure du corps humain (1732). O primeiro atribuía o excesso de bílis à sexualidade exacerbada e paixões impetuosas, verificáveis segundo sua teoria pelas temperaturas mais altas do corpo. Quem discordou deste autor foi LeCat, que atribuiu a mudança de pigmentação a doenças dos nervos, como histeria e apoplexia. Segundo Quinlan, ambos desejavam com isso "feminizar o corpo africano". QUINLAN, S. M. The Great Nation in Decline: Sex, Modernity and Health Crises in Revolutionary France C.1750-1850. Hampshire, Ashgate Publishing, 2007, p. 99.
} 
gerações vindo a ser natural” ${ }^{, 48}$. Hereditariedade e fixidez de características físicas, portanto, atrelam-se no trecho.

No entanto, ao contrário do que se poderia imaginar pelas conclusões anteriores, o manuscrito de Coutinho defende a possibilidade de transformação da cor da pele. A fórmula para consegui-lo é mudar de localização geográfica, de atmosfera, de alimentação e, sobretudo, a mistura entre pessoas de cores diferentes, pois a

naturalidade só se pode, e deve perder, pelo misto das naturezas, e é tão certo que por quatro gerações sucessivas de preto e branco, ou vice versa, casando constantemente as filhas com brancos se desvanece esta alteração e ficam absolutamente brancos, como até as nossas Leis parecem considerá-los, isto pois julgo que prova bastante que a Cor é uma coisa acessória e não natural, e que tiradas as causas acidentais, se perde a naturalidade adquirida ${ }^{249}$ (grifos nossos).

À medida que o uso da palavra natureza nesse excerto equivale ao uso do termo raça em sentido propriamente biológico, é interessante perceber que o argumento de Coutinho transita da irreversibilidade para a reversibilidade das qualidades corpóreas que reagem ao meio material, buscando ao final refutar as teses de que determinados atributos são intransponíveis, permanentes. A ideia de degeneração está presente enquanto se fala em uma moléstia hereditária provocada pela naturalização entre organismo e ambiente, mas também o está a de regeneração, que tem como causa maior o "misto das naturezas". Outro aspecto que chama a atenção no argumento é o fato de usar os termos geração e natureza, mas não raça.

Novamente, importa perceber que havia, nas explicações produzidas no seio do império português, uma confiança na reversibilidade da cor da pele e uma tendência a adotar cálculos segundo os quais, na quarta geração, a brancura era dada como um fato. Destoa das demais formulações a teoria de Câmara que, no entanto, também se propõe a legitimar a existência de uma população mesclada, de morenos, vista como padrão de normalidade. De todo modo, parece haver também aqui uma flutuação estratégica no padrão de brancura, tanto no uso do termo em referência à coloração da derme, quanto como sinônimo de distinção.

De toda maneira, onde quer que se localizasse o pólo branco da fórmula, à medida que o Gênesis 9 perde impacto explicativo, uma nova narrativa parece

\footnotetext{
${ }^{248}$ Idem, ibidem, fl. 347.

${ }^{249}$ Fl. 349 vo. Coutinho ainda menciona que a cor decorre da presença de um retículo de fluido oleoso na pele, responsável "pelo cheiro a que os Americanos chamam - Catinga”. Idem, ibidem.
} 
germinar à sua sombra: agora, a ideia de maldição milenar cede espaço à de redenção futura. Contudo, a despeito desta operação ideológica, não se pode ignorar o descompasso entre o discurso de redenção e as enormes contradições impostas pelo preconceito e a escravidão para a vida dos diferentes grupos engendrados neste imbricado sistema de classificação racial.

\section{Há redenção para o povo de Cam?}

Uma população toda mulata, com sangue viciado, espírito viciado e feia de meter medo (...) Nenhum brasileiro é de sangue puro; as combinações de casamentos entre brancos, indígenas e negros multiplicam-se a tal ponto que os matizes da carnação são inúmeros, e tudo isso produziu, nas classes baixas e nas alturas, uma degenerescência do mais triste aspecto.

- Arthur de Gobineau

Iniciava o século XIX no império português ainda escravista, com uma população marcada pela enorme variabilidade de tons de pele e uma confiança reiterada na reversibilidade do negro ao branco. Assim como haviam feito anteriormente Dampier, Barbinais, Udal e Trusler em períodos anteriores, no primeiro oitocentos a mistura observada em domínios lusitanos e as possibilidades de distinção abertas aos filhos de uniões interraciais chamariam a atenção dos ingleses Henry Koster (c.1793-1820) e Thomas Ewbank (1792-1870), do alemão Johann Moritz Rugendas (1802-1858) e do francês Jean Baptiste-Debret (1768-1848) ${ }^{250}$, entre outros viajantes.

Em seu Travels in Brazil (1815), Koster observa que "quando circunstâncias favoráveis, riquezas, relações de família, ou talentos pessoais tornam um homem recomendável, qualquer degradação de cor o faz passar por branco, tanto mais facilmente quanto os próprios brancos são muitas vezes bastante morenos"251 (grifo do autor). Ewbank, por sua vez, viu com admiração que, no Rio de Janeiro de 1846, “jovens de cor entraram e sentaram-se sem hesitação na mesma mesa dos brancos,

\footnotetext{
${ }^{250}$ Koster, um filho de ingleses nascido em Portugal, mudou-se para o Brasil por problemas de saúde. Aqui, tornou-se senhor de um engenho de açúcar. Thomas Ewbank, norte-americano, foi cientista, inventor e ex-fabricante de canos de cobre e chumbo em Nova York. Esteve no Rio de Janeiro durante alguns meses, em 1846, em visita ao irmão, Joseph Ewbank e sua esposa brasileira. Rugendas, alemão, esteve no Brasil de 1822 a 1825, como integrante da missão do Barão de Langsdorff. Debret, francês, era primo e aluno de Jacques-Louis David. Ele veio ao Brasil com o grupo de artistas franceses que aportou no país no início do século XIX e que, no país, deu início à Academia Imperial de Belas Artes. O mesmo grupo incluiu Nicolas-Antoine Taunay, Joachim Lebreton e Grandjean de Montigny.

${ }^{251}$ KOSTER, H. Viagens ao nordeste do Brasil. São Paulo: Ed. Nacional, 1942 apud HOFBAUER, A. Uma história do branqueamento ou o negro em questão. São Paulo: UNESP, 2006, p. 174.
} 
tomando parte na conversação em perfeito pé de igualdade",252 - o que não ocorreria nos Estados Unidos, onde viveu a maior parte da vida.

Rugendas, que esteve no Brasil de 1922 a 1825, observava que no Brasil, "quando circunstâncias favoráveis tornam um homem recomendável, (...) qualquer degradação de cor o faz passar por branco" 253 e comentava:

Por mais estranha que pareça a afirmação que vamos fazer, cabe menos à vista e à fisiologia do que à legislação e à administração resolver sobre a cor de tal ou qual indivíduo. Os que não são de um negro muito pronunciado, e não revelam de uma maneira incontestável os caracteres da raça africana não são, necessariamente, homens de cor; podem, de acordo com a circunstâncias, ser considerados brancos ${ }^{254}$.

O viajante mostrava-se cético quanto ao futuro de um território tão misturado, reconhecia haver transformação de cor entre gerações:

poucas gerações se fazem necessárias para destruir a cor preta, na população livre, em razão dos casamentos entre negras e homens de cor e, em conseqüência das ligações freqüentes entre as negras livres e os brancos. Muitas vezes a cor preta já desaparece com os filhos ou netos, de modo que os descendentes dos negros livres, em vez de aumentar a população negra perdem-se, insensivelmente, na massa dos homens de $\operatorname{cor}^{255}$.

Por fim, Debret - que viveu no país de 1816 a 1831 - perceberia o uso da expressão "Deus te faça balanco [branco]" como equivalente a "Deus te faça santo" 256 , como resposta dos senhores a seus escravos quando estes lhes pediam a benção.

\footnotetext{
${ }^{252}$ Idem, ibidem. Uma leitura detida na fonte pode sempre perguntar-se que tipo de "igualdade". seria.

${ }^{253}$ RUGENDAS, J. M. Viagem pitoresca através do Brasil. SP: Círculo do Livro, s/d, p. 248. A título de ressalva, Slenes recorda que o texto da Viagem passa longe de um relato de um observador em campo: nem foi escrito apenas por Rugendas, nem deixou de plagiar textos similares. De todo modo, a informação indica o quanto as mesmas ideias se propagaram na Europa do período, sob escritos de autores distintos. SLENES, R. W. As provocações de um Abraão africano: a nascente nação brasileira na Viagem Alegórica de Johann Moritz Rugendas. Revista de História da Arte e Arqueologia, n. 2, 1995/96.

${ }^{254}$ Idem, ibidem, p. 126.

${ }^{255}$ Idem, ibidem, p. 247.

${ }^{256}$ DEBRET, J.-B. Rio de Janeiro, cidade mestiça: ilustrações e comentários de Jean-Baptiste Debret. Organização de Patrick Straumann. São Paulo: Companhia das Letras, 2001, p. 24.
} 
Debret e Rugendas buscam evidenciar fisionomias, penteados, marcas corporais - como tatuagens e escarificações -, tipos de roupas e acessórios entre grupos de ascendência africana. Quanto aos chamados mestiços, Rugendas, que afirma não se preocupar com matizes e as subdivisões, estabelece três grupos: mulatos (que define pela ascendência branca e negra); mamelucos (de ascendência branca e indígena); cabras ou caboclos (de ascendência negra e indígena $)^{257}$. Já Debret (Fig. 45), inclui tipos como "Cabra, crioula, filha de mulato e negra" (busto $\mathrm{n}^{\circ} 3$ ); "Crioula" (busto $\mathrm{n}^{\circ}$ 5); e "Mulata, filha de branco com negra" (busto n 12 ).

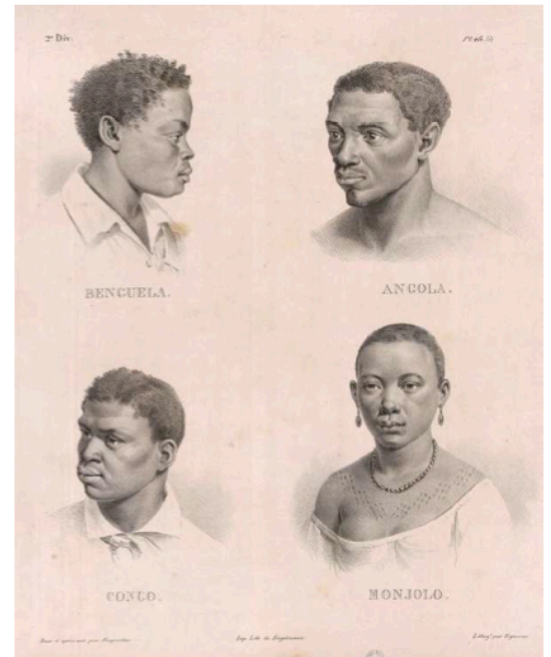

Fig. 41: Johann Moritz Rugendas Benguela/Angola/Congo/Monjolo.

Voyage Pittoresque dans le Brésil. $2^{\mathrm{a}}$ divisão, prancha 9. Biblioteca Nacional Digital.

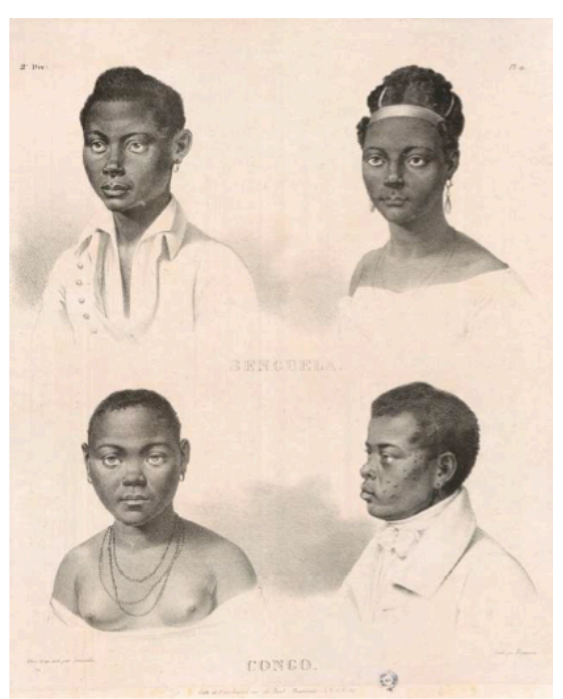

Fig. 43: Johann Moritz Rugendas

Benguela/Congo. Voyage Pittoresque dans le Brésil. $2^{\text {a }}$ divisão, prancha 9. Biblioteca Nacional Digital.

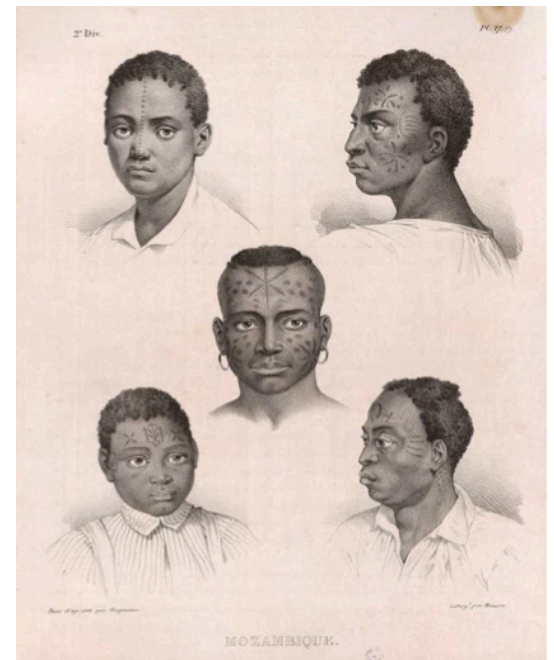

Fig. 42: Johann Moritz Rugendas Mozambique.

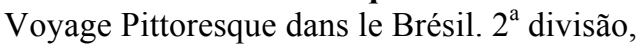
prancha 9. Biblioteca Nacional Digital.

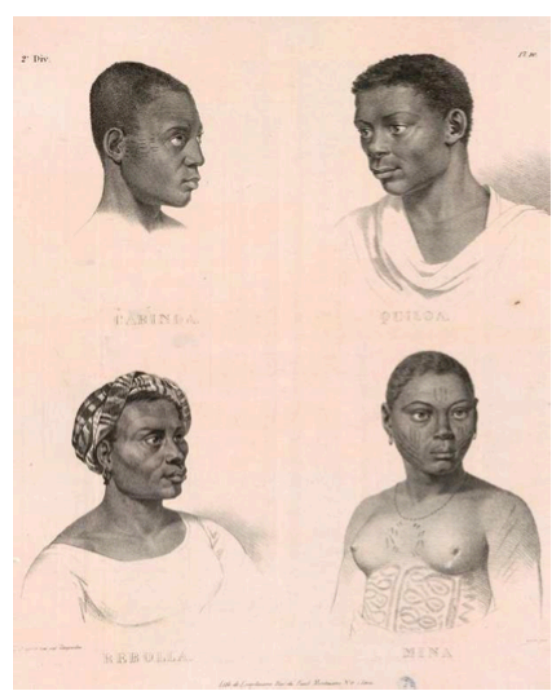

Fig. 44: Johann Moritz Rugendas

Cabinda/Quiloa/Rebolla/Mina.

Voyage Pittoresque dans le Brésil. $2^{\text {a }}$ divisão, prancha 9. Biblioteca Nacional Digital.

\footnotetext{
${ }^{257}$ Para uma análise detalhada, ver FREITAS, I. B. Cores e olhares no Brasil oitocentista: os tipos negros de Rugendas e Debret. Dissertação (História Social). Niterói: Universidade Federal Fluminense, 2009. Sobre Debret, ver também LIMA, V. J.-B. Debret. Historiador e Pintor. Campinas: Editora da Unicamp, 2008; e NAVES, R. A forma difícil: ensaios sobre arte brasileira. São Paulo: Editora Ática, 2007; sobre a Viagem Pitoresca de Rugendas, cf. SLENES, R. W. As provocações de um Abraão africano: a nascente nação brasileira na Viagem Alegórica de Johann Moritz Rugendas. Revista de História da Arte e Arqueologia, n. 2, 1995/96.
} 


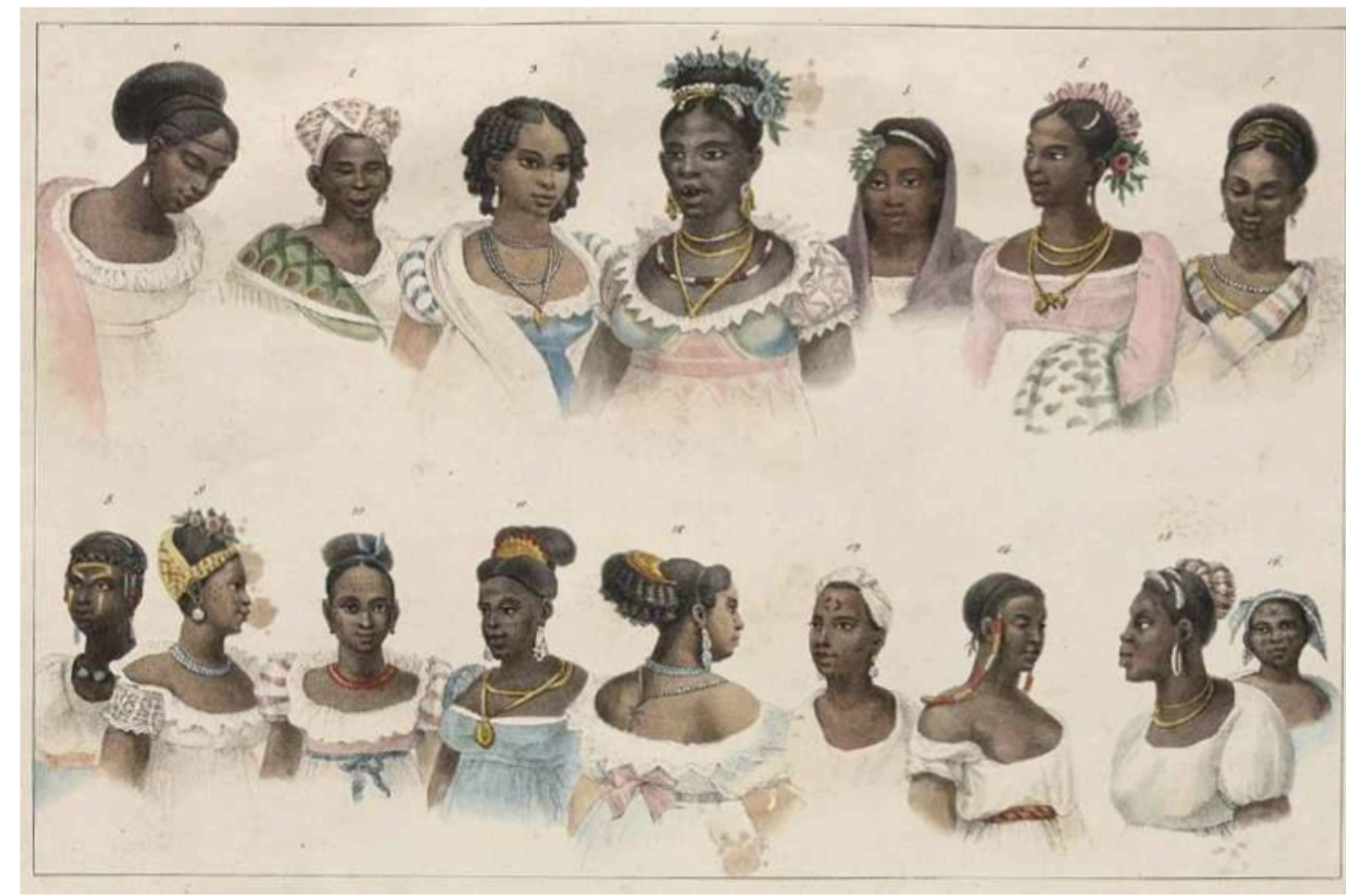

Fig. 45: Jean-Baptiste Debret. Esclaves nègres de differentes nations. Voyage pittoresque et historique au Brésil. Tomo II, prancha 22. Biblioteca Nacional Digital.

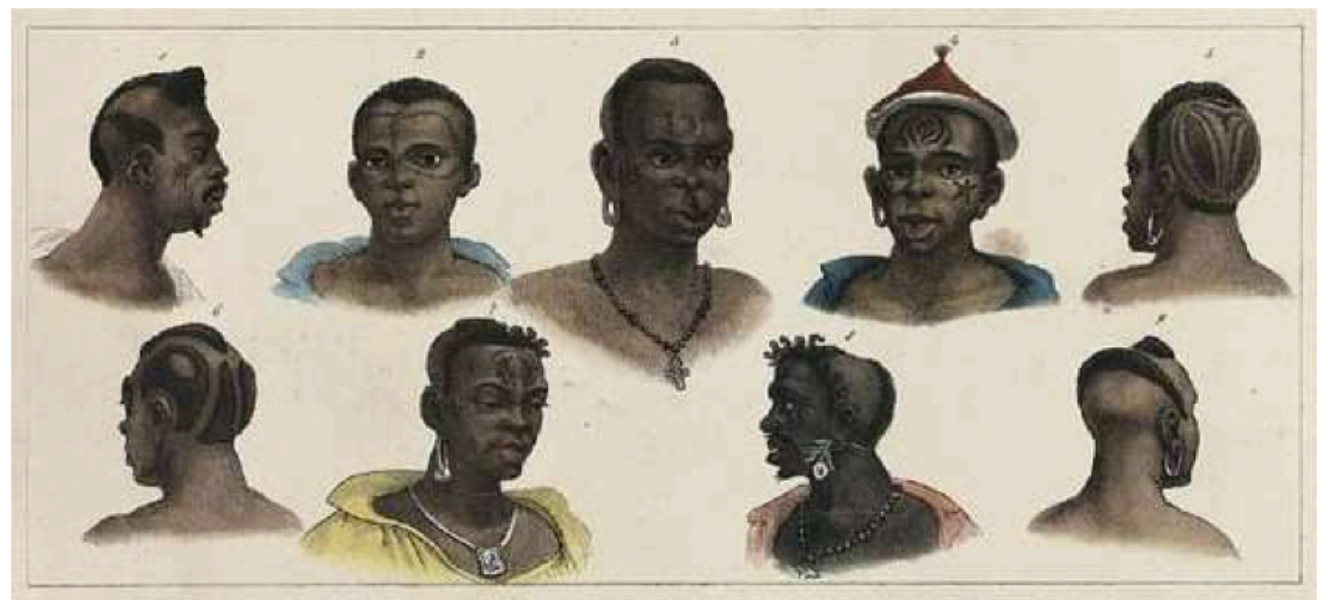

Fig. 46: Jean-Baptiste Debret. Esclaves nègres de differentes nations. Voyage pittoresque et historique au Brésil. Tomo II, prancha 22. Biblioteca Nacional Digital ${ }^{258}$.

Houve, é fato, muitas imagens de negros e grupos de ascendência negra produzidas por viajantes e também artistas no período, bem como narrativas que descreviam a mescla de cor e o perfil da população do Brasil. É interessante notar, a esse respeito, que muitas parecem incorporar à sua fatura alguma posição quanto à

\footnotetext{
${ }^{258}$ Imagens disponíveis em:

$<\mathrm{http}$ //bndigital.bn.br/scripts/odwp032k.dll?t=bs\&pr=fbn_dig_pr\&db=fbn_dig\&ss=new\&disp=card\& use $=$ sh \&arg=debret,\%20jean $\% 20$ baptiste $>$. Consulta realizada a 25/07/2013.
} 
ideia de abolição da escravidão ${ }^{259}$. Nesse sentido, é válido pontuar que, quando tais observações foram feitas, já havia muito a Revolução Francesa difundira os ideais republicanos e também já se presenciara mundialmente um recrudescimento político contrarrevolucionário.

Em 1776, os Estados Unidos declararam sua independência. Em 1804, a emancipação haitiana se obteve graças a uma revolução de escravos. A história da primeira república governada por pessoas de ascendência africana ficou marcada nos pesadelos do colonialismo europeu, que passou a empregar o termo haitismo ao referir-se a tendências políticas com relação aos negros que pudessem representar ameaças à ordem branca e colonial ${ }^{260}$. Desde 1809 , caminhava o processo de fragmentação da América Espanhola, cujas guerras de independência resultariam em uma série de novas repúblicas. Napoleão já havia sido cônsul e imperador, conseguindo impor seu Bloqueio Continental ao comércio com a Inglaterra; o líder francês também destronara o rei espanhol, Carlos IV, nomeando seu irmão, José Bonaparte, como rei de Espanha. Como é sabido, a família real portuguesa aportou no Brasil em 1808, fugindo da invasão francesa. Acontecimento sem precedentes, o deslocamento da capital do império lusitano para as Américas causaria profundas transformações políticas em terras brasileiras - a começar pela montagem de um aparato institucional, administrativo e cultural diferenciado na capital, Rio de Janeiro.

É clave citar que um dos principais impasses vivenciados durante o oitocentos foi a desmontagem do sistema escravista e o destino das populações negras outrora escravizadas - em particular a partir do Congresso de Viena (1814), que impôs como meta a extinção do tráfico negreiro e o fim da escravidão. Após o Congresso, a Inglaterra em particular encampou o controle do tráfico ${ }^{261}$. Mas se as reflexões envolvendo a ideia de liberdade remontavam à tradição iluminista, no novo

\footnotetext{
${ }^{259}$ Voltaremos ao assunto no capítulo 2. Por ora é válido destacar autores que discutem essas conexões. Sobre Debret, ver LIMA, V. J.-B. Debret. Historiador e Pintor. Campinas: Editora da Unicamp, 2008; e NAVES, R. A forma difícil: ensaios sobre arte brasileira. São Paulo: Editora Ática, 2007; quanto a Rugendas, cf. SLENES, R. W. As provocações de um Abraão africano: a nascente nação brasileira na Viagem Alegórica de Johann Moritz Rugendas. Revista de História da Arte e Arqueologia, n. 2, 1995/96. Schwarcz também discute a presença de negros nas pinturas de Taunay, em SCHWARCZ, L. K. M. O sol do Brasil. São Paulo: Companhia das Letras, 2008.

${ }^{260}$ O próprio Rugendas observa que, "se o curso dos acontecimentos, a imprevidência dos partidos ou a imprudência dos governantes provocarem um dia uma revolta de escravos, só seria possível dominá-la mediante o apoio da população livre de homens de cor e negros. É, por conseguinte, muito importante ligá-los definitivamente aos brancos por um interesse comum". RUGENDAS, J. M. Viagem pitoresca através do Brasil. SP: Círculo do Livro, s/d, p. 249.

${ }^{261}$ Ver MORGAN, K. Slavery and the British Empire, from Africa to America. Oxford: Oxford University Press, 2007.
} 
século, frutificaram correntes de pensamento sobre as diferenças raciais, com novos argumentos, teorias e posições que encontravam uma tendência comum a deslocar definitivamente a ideia de um mal da condição de escravo para um mal intrínseco ao corpo negro - e mestiço ${ }^{262}$. É durante o século XIX que ressurge o temor do atavismo e a palavra degeneração ganha força, ao mesmo tempo em que se busca fixar as configurações raciais presentes ao futuro da humanidade e das distintas nações. Dessa forma, o termo raça adquire novos contornos, vinculados à biologia e à natureza, ao mesmo tempo em que se torna uma alargada metáfora, em referência à nação - como observa Schwarcz ${ }^{263}$.

A variedade, detalhamento e multiplicação dos posicionamentos de caráter jurídico, científico, político, literário e religioso sobre as diferenças, que se ramificam a partir dos mesmos troncos estabelecidos anteriormente é de fato assombrosa, no século XIX. De igual tamanho são as disposições políticas que se desdobram entre os abolicionistas no Brasil. Ao reconhecer a importância inegável dos estudos que procuram articular os debates sobre o fim da escravidão tal diversidade de posições políticas que frutificam em diálogo com a ascensão de novas teorias raciais no Brasil, é preciso admitir que foge aos limites de nossa pesquisa uma discussão em detalhe sobre o amplo movimento de ideias que movimentavam as disputas políticas no período $^{264}$. Diante dessa limitação, fica patente reforçar que nosso recorte busca somente evidenciar algumas tendências, de parte da intelectualidade nacional, a articular a ideia de transformação racial (de negro a branco) a projetos de desenvolvimento do país - dando vazão a nosso propósito de perceber formas recorrentes de caracterizar as populações afrodescendentes, as relações raciais e a interracialidade. Assim, procuramos observar a existência e o teor de certas opiniões

\footnotetext{
${ }^{262}$ O antropólogo Louis Dumont avalia que, a partir deste ponto, "o reconhecimento de uma diferença cultural não pode mais justificar etnocentricamente uma desigualdade. Observa-se que (...) uma diferença hierárquica continua a ser colocada, mas que ela se liga desta feita aos caracteres somáticos, à fisionomia, à cor da pele, ao 'sangue'. Sem dúvida, esses sempre foram signos da distinção, mas eles se tornaram sua essência”. DUMONT, L. Homo Hierarchicus. São Paulo, EDUSP, 1992, p. 314.

${ }^{263}$ Cf. SCHWARCZ, L. K. M. O espetáculo das raças. Cientistas, instituições e a questão racial no Brasil - 1870-1930. São Paulo, Companhia das Letras, 2004 e também SCHWARCZ, L. K. M. Questões de fronteira. In: Novos Estudos. São Paulo, Cebrap, nº 72, jul. 2005.

${ }^{264}$ Sobre estas ideias, cf. ALONSO, A. Ideias em movimento. A geração de 1870 na crise do Brasil Império. RJ, Paz e Terra, 2002; BRESCIANI, M.S. Liberalismo: ideologia e controle social (Um estudo sobre São Paulo de 1850 a 1910). Tese de doutorado, Departamento de História,FFLCH/USP, 1976; BRESCIANI, M.S. "O cidadão da República. Liberalismo versus positivismo no Brasil: 18701900". Revista USP, 17, mar.-abr.-maio de 1993; CARVALHO, J. M. A construção da ordem. A elite política imperial. Rio de Janeiro, Campus, 1980; CARVALHO, J. M.. "A ortodoxia positivista no Brasil.Um bolchevismo de classe média”. Revista Brasileira, ano 4, 8, 1989.
} 
como dado relevante para compreender em que medida uma formação discursiva dada $^{265}$ aportou à construção da raça enquanto objeto e que relações estavam em jogo nessa definição, em particular no Brasil.

É viável indicar que, no seio dos debates de um abolicionismo luso-brasileiro no primeiro Oitocentos, destaca-se a mesma confiança no branqueamento observada no período anterior. Além disso, já se faz visível um projeto de introdução de imigrantes europeus como mão-de-obra livre no país. A historiadora Célia Marinho de Azevedo e o antropólogo Andreas Hofbauer citam fontes elucidativas sobre o lugar atribuído ao negro pelo pensamento abolicionista. Em 1811, destaca a autora, o diplomata Hipólito da Costa (1774-1823) $)^{266}$ escrevia de Londres ao Correio Braziliense um artigo em defesa de uma abolição gradual da escravidão, acompanhada pela imigração de mão-de-obra branca. Em1821 - um ano antes da independência do Brasil -, João Severiano Maciel da Costa $(1769-1833)^{267}$, jurista e governador da Guiana de 1809 a 1815, exprimia sua preocupação com a "multiplicação indefinida de uma população heterogênea, inimiga da classe livre"268, ao passo que se somava à defesa da abolição gradual e da introdução de estrangeiros. Em 1826, José Eloy Pessoa da Silva (1792-1841) ${ }^{269}$ comentava que os escravos estavam "sempre em guerra doméstica com a população livre" ${ }^{, 270}$. O cientista e matemático Frederico Leopoldo Cezar Burlamaqui (1803-1866) ${ }^{271}$ considerava os negros "de uma incúria e imprevisão que revolta; eles vegetam no estado o mais vizinho do mais bruto animal"272, enquanto nutria o projeto de devolver os exescravos à África.

\footnotetext{
${ }^{265}$ FOUCAULT , M. A arqueologia do Saber. RJ: Forense-Universitária, 1987.

${ }^{266}$ Hipólito José da Costa Pereira Furtado de Mendonça foi maçom e, como correspondente do Correio Braziliense, defendeu e deu grande visibilidade às ideias liberais - a emancipação entre elas.

${ }^{267}$ O Marquês de Queluz foi também ministro da Fazenda, conselheiro de Estado, presidente da província da Bahia e senador do Império do Brasil.

${ }^{268}$ COSTA, João Severiano Maciel da, et al. Memórias sobre a escravidão. Rio de Janeiro-Brasília: Arquivo Nacional-Fundação Petrônio Portela, Ministério da Justiça, 1988 apud AZEVEDO, C. M. M. Onda negra, medo branco. RJ: Paz e Terra, 1987, p. 40.

${ }^{269}$ Matemático e futuro administrador público, autor de Memória sobre a escravatura (1826). Importante destacar que, neste livro, a despeito de apropriar-se de argumentos usados pelos antiescravistas, procura argumentar pela manutenção do tráfico.

${ }^{270}$ Idem, ibidem, p. 42.

${ }^{271}$ Autor de Memoria analytica a'cerca do commercio d'escravos e a'cerca dos malles da escravidão domestica (1837).

${ }^{272}$ Idem, ibidem, p. 43.
} 
Ainda em 1821, o médico Francisco Soares Franco $(1771-1844)^{273}$ publica seu Ensaio sobre os melhoramentos de Portugal e do Brazil. Nesta obra, alinha-se aos demais autores que defendem a extinção gradual da escravidão e a importação de mão-de-obra branca. Mas à diferença deles, considera que os negros nascidos na colônia devem permanecer livres, enquanto os africanos de nascença têm de continuar escravos; além disso, apresenta um programa para a erradicação da casta negra (e aqui é interessante chamar a atenção ao uso do termo casta conforme a língua castelhana):

Os Africanos sendo muito numerosos no Brazil, os seus mistiços o são igualmente; nestes se deve fundar uma nova origem para a casta branca. A Natureza ensina o meio, vamos a desenvolvello.

Os mistiços convervão só metade, ou menos, do cunho Africano. Sua côr he menos preta, seus cabellos menos crespos e lanudos, os beiços e nariz menos grossos e chatos, etc. Se elles se unem depois á casta branca, os segundos mistiços já têm menos da côr baça, etc. Se inda a terceira geração se faz com branca, o cunho Africano perde-se totalmente, e a côr he a mesma que a dos brancos; ás vezes, inda mais clara; só nos cabellos é que se divisa uma leve disposição para encresparem. ${ }^{274}$

Um pouco mais adiante, o douto detalha sua proposta:

Se pois o Legislador mandar que todos os mistiços não possão casar senão com individuos da casta branca, ou india, e se prohibir sem excepção alguma todo o casamento entre mistiços, e a casta Africana; no espaço de duas gerações consecutivas, toda a geração mistiça estará, para me explicar assim, baldeada na raça branca. E deste modo, teremos outra origem de augmento da população dos brancos, e quasi extincção dos pretos e mistiços desta parte do Mundo; pelo menos, serão tão poucos que não entrarão em conta alguma nas considerações do Legislador. ${ }^{275}$

As palavras de Franco não apenas alimentavam o velho projeto de branqueamento, como deslocavam do horizonte qualquer preocupação política voltada para a integração dos libertos no pós-abolição. Administrando-se com nota da lei os casamentos adequados, a natureza seria responsável pela assimilação.

\footnotetext{
${ }^{273}$ Português, pensador liberal e Deputado pela Estremadura às Cortes Constituintes de 1821.

${ }^{274}$ FRANCO, F. S. Ensaio sobre os melhoramentos de Portugal e do Brazil. Lisboa: Imprensa Nacional apud HOFBAUER, A. Uma história do branqueamento ou o negro em questão. São Paulo: Editora UNESP, 2006, p. 185.

${ }^{275}$ Idem, ibidem.
} 
Também no ano que antecede a independência do Brasil, António d'Oliva de Souza Sequeira (s.d.) $)^{276}$ advoga pela mesma causa, em seu Addição ao projecto para o estabelecimento político do Reino Unido de Portugal, Brasil e Algarves. Este autor calcula um prazo de 100 anos para que, com a introdução dos imigrantes europeus, a mescla racial resulte numa população branca para o Brasil. O plano é transformar não apenas a cor negra, mas também a "côr de cobre" indígena em branca:

e se quizerem apressar a extincção das duas raças, estabeleção-se premios aos brancos, que casarem com pretas, ou indigenas na primeira e segunda geração: advertindo, que se devem riscar os nomes de "mulato, crioulo, cabôco", e "indigena"; estes nomes fazem resistir odios, e ainda têm seus ressaibos de escravidão (...) sejão todos "Portugueses!". 277

Como mencionávamos, é impossível afirmar que estas fontes reflitam disposições gerais no seio do abolicionismo luso-brasileiro do primeiro oitocentos - o que exigiria um levantamento mais abrangente, que foge ao alcance deste trabalho realizar. Entretanto, é digna de nota a existência de tais argumentos e seu teor, em particular ao contrastá-los com um panorama internacional de pesquisas científicas que procuravam descrever as diferenças raciais como intransponíveis.

A esse respeito, é sabido que, desde o início do século XIX, já se põe em prática uma série de métodos que propunham mapear as características e limitações próprias de cada raça - como a antropometria, a frenologia, a fisionomia, a medida do ângulo facial e o índice cefálico -, invariavelmente, reforçando a correlação entre traços distintivos da aparência e qualidades morais. Também há que se destacar um novo uso do termo raça, a exemplo do que propôs Georges Cuvier (1769-1832) ${ }^{278}$, para quem a palavra se referia a grupos com características fisiológicas fixas e imutáveis $^{279}$. O anatomista francês, aliás, foi taxativo ao considerar que os negros não participavam da "igualdade do homem", por estarem mais próximos dos macacos ${ }^{280}$.

\footnotetext{
${ }^{276}$ Português, Sequeira era tenente de infantaria e estudante do $4^{\circ}$ ano de Matemática quando escreveu tal obra. Não encontramos maiores informações a seu respeito.

${ }^{277}$ SEQUEIRA, A. d'O. S. Addição ao projeto para o estabelecimento político do reino-unido de Portugal, Brasil e Algarves apud HOFBAUER, A. Uma história do branqueamento ou o negro em questão. São Paulo: Editora UNESP, 2006, p. 187.

${ }^{278}$ Anatomista e um dos mais renomados naturalistas do século XIX.

${ }^{279}$ SCHWARCZ, L. O espetáculo das raças. Cientistas, instituições e a questão racial no Brasil 1870-1930. São Paulo, Companhia das Letras, 2004.

${ }^{280}$ KEULLER, A. T. A. M. Os Estudos Físicos de Antropologia no Museu Nacional do Rio de Janeiro: cientistas, objetos, ideias e instrumentos (1876-1939). Tese de Doutorado em História Social na Universidade de São Paulo, 2008, p. 33.
} 
Pouco depois dele Julien Joseph Virey (1775-1846) ${ }^{281}$ afirmaria que "todos os povos feios são mais ou menos bárbaros, porque a beleza é inseparável das nações mais policiadas" 282 , associando beleza à raça branca e feiúra, à negra.

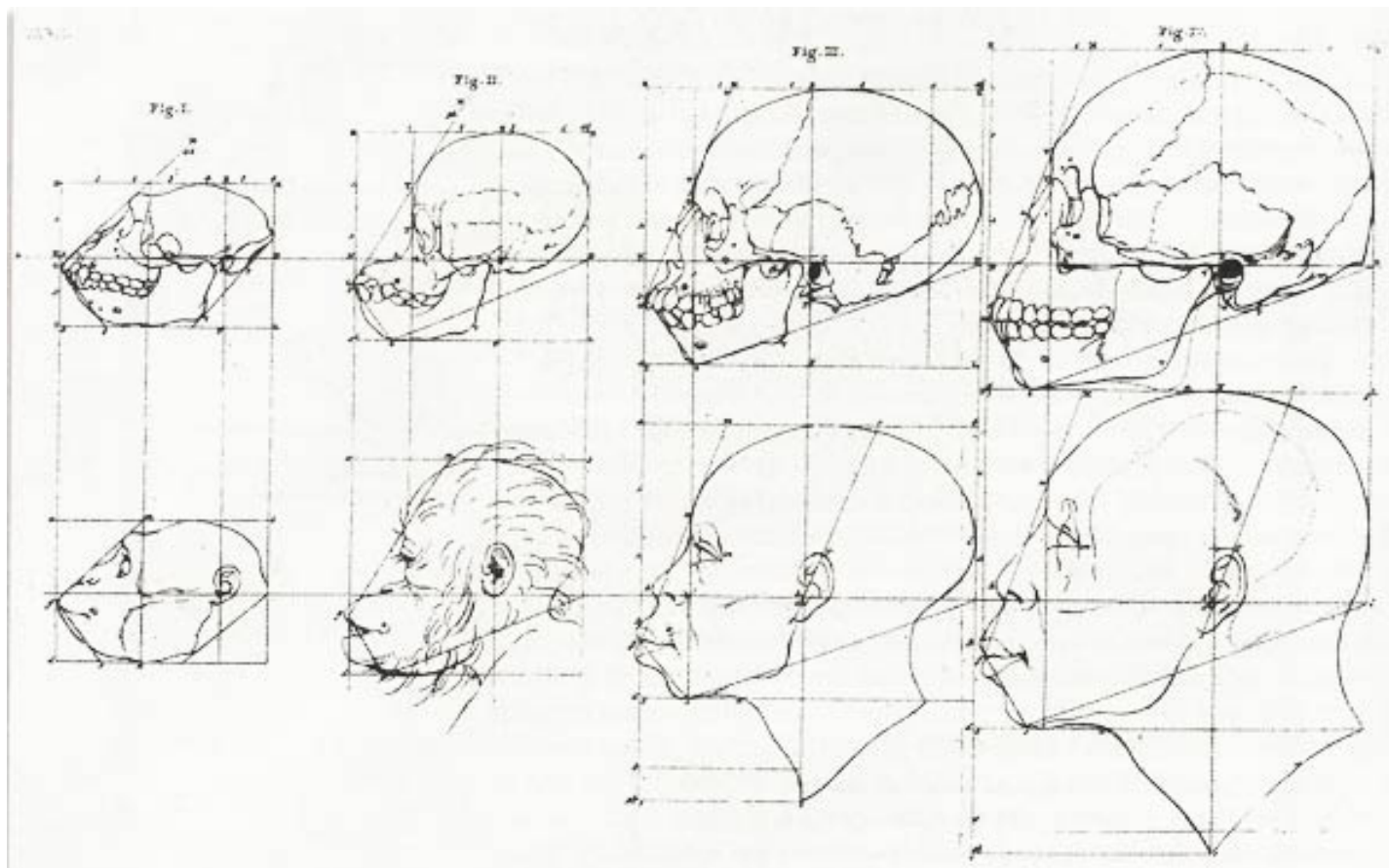

Fig. 47: O ângulo facial de Petrus Camper (1791) - Berigt van den zaaklyken inhoud van twee lessen, Edição póstuma)

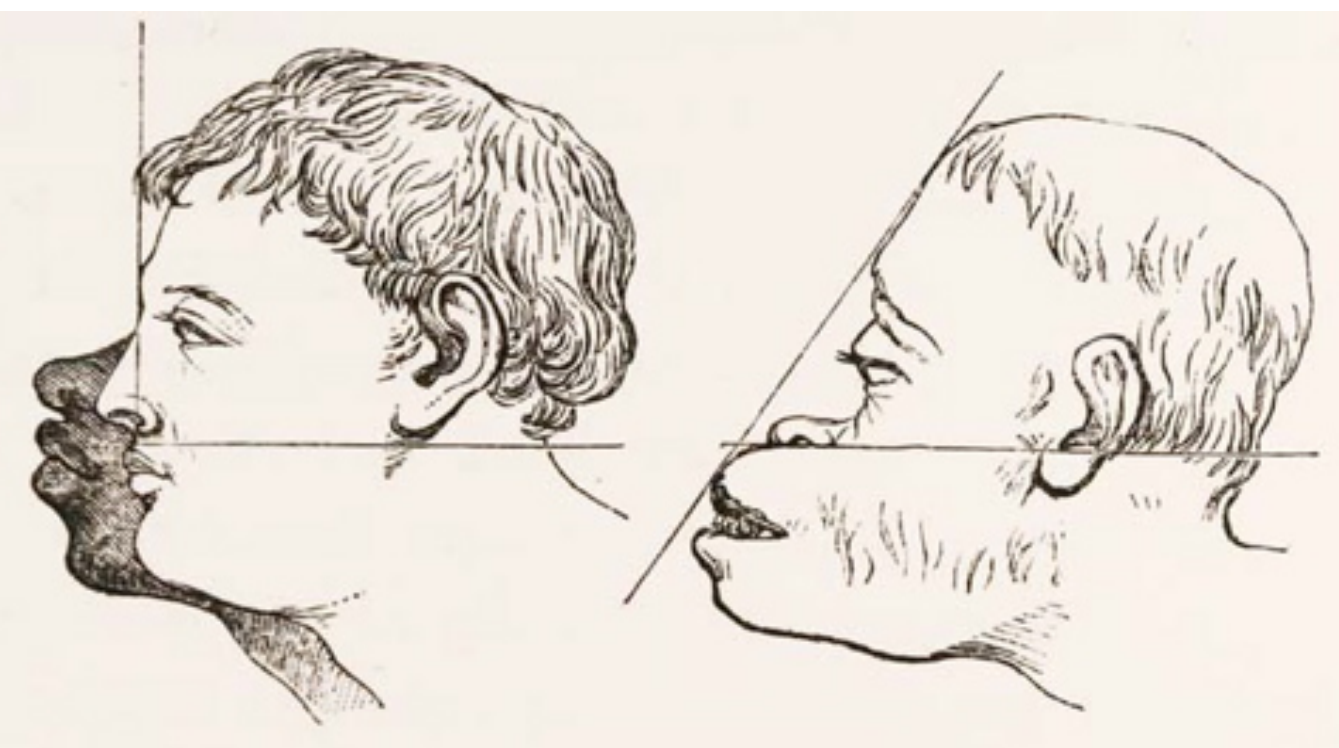

[Profile of Negro, European, and Oran Outan.]

Fig. 48: Profile of Negro, European and Oran Outan. Crania Americana (1831), de Samuel G. Morton.

${ }^{281}$ Naturalista e antropólogo francês.

${ }^{282}$ VIREY J. Histoire naturelle du genre humaine. Vol. I. Paris: 1'Imprimerrie de F. Dupartm IX apud PIMENTEL, M. R. O enigma da cor: dissertação sobre a variedade das cores da espécie humana. In: Ellipsis, 8, 2010, p. 66. 
Virey levava adiante, entre outros argumentos, a teoria do ângulo facial, desenvolvida pelo Petrus Camper (1722-1789) e ilustrada acima. Segundo este médico holandês, os seres humanos teriam um ângulo facial entre 70 e 90 graus, estabelecendo uma escala de beleza que ia das estátuas grecoromanas (com ângulos faciais em torno de 100 graus) aos orangotangos (cujas faces formariam ângulos de 58 graus), passando pelos europeus (ângulos de 90 graus) e os africanos (ângulos de 70 graus). Camper concluía que os africanos, dentre os seres humanos, eram os mais afastados da beleza clássica e bastante próximos aos orangotangos ${ }^{283}$.

A teoria do ângulo facial serviu de inspiração para teóricos influentes como Samuel G. Morton (17991851), fundador da chamada "escola antropológica norte-americana" e estudioso de craniologia ${ }^{284}$, como se pode notar na fig. 48 .
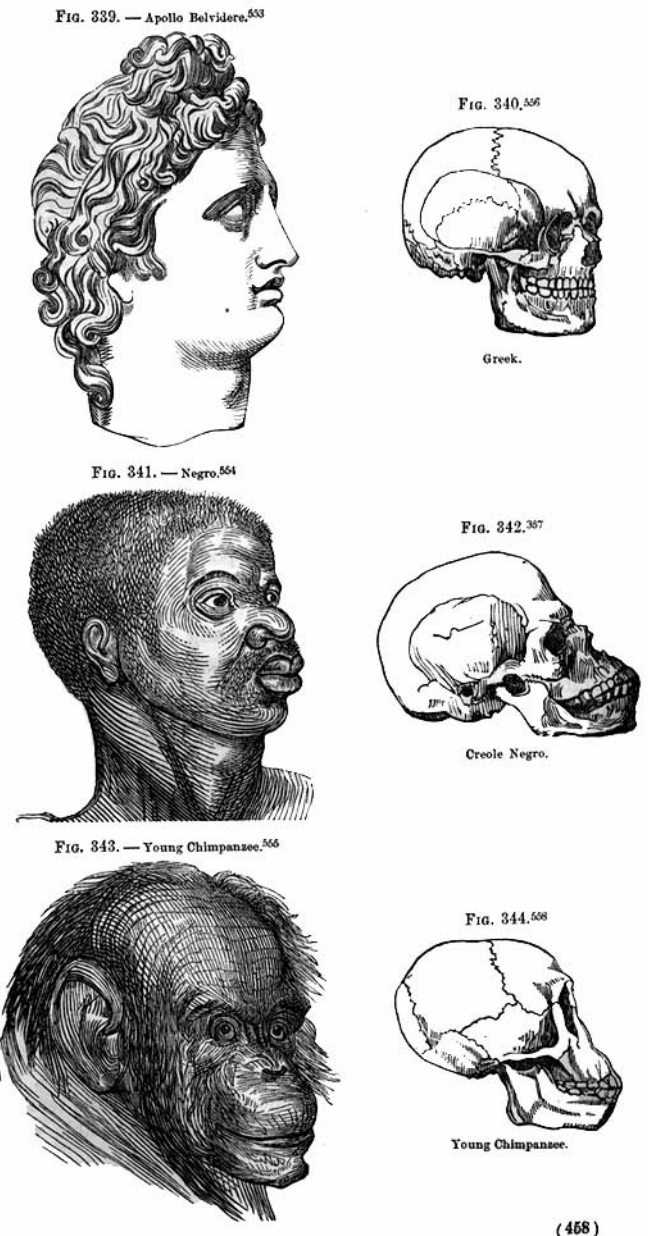

Creole Negro.

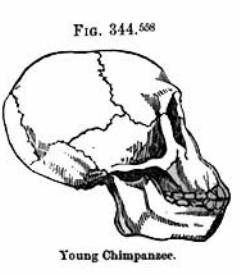

(468)

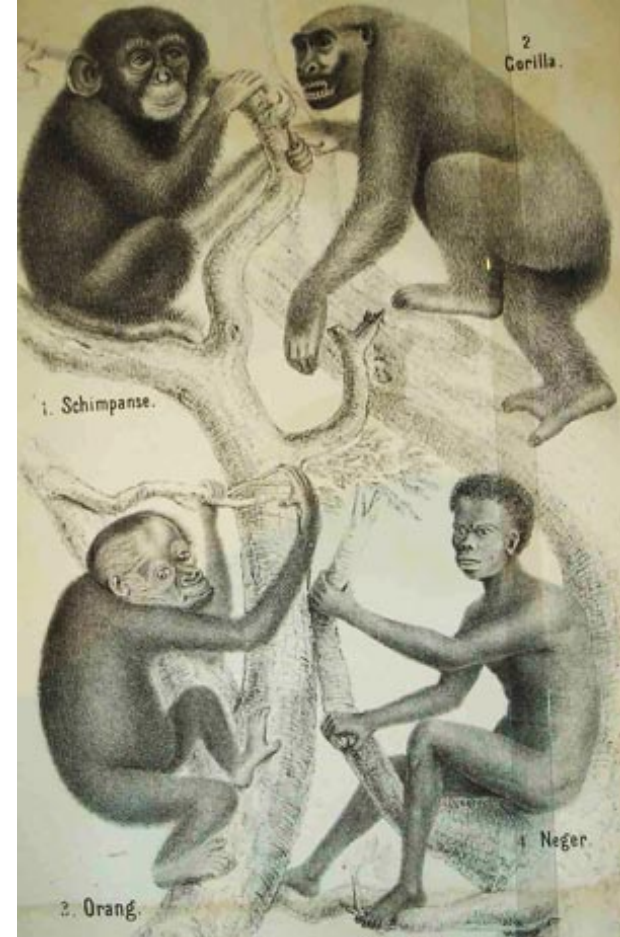

Fig. 49: Acima, prancha extraída de Antropogenia, de Ernst Haeckel (1874).

Fig. 50: À esq., ilustração da obra Types of Mankind (1854), de Josiah Clark Nott (1804$1973)^{285}$ - volume em memória de Samuel Morton.

${ }^{283}$ Para uma análise sobre Camper, ver MEIJE, M. C. Race and Aesthetics in the Anthropology of Petrus Camper (1722-1789). Amsterdam, Rodopi, 1999. Sobre as relações entre raça e estética no século XVIII, cf. Bindman, D. Ape to Apollo. Aesthetics and the Idea of Race in the 18th Century. Ithaca: Cornell University Press, 2002. Agradeço a indicação de leitura a Maria Helena P. T. Machado. ${ }^{284}$ Os estudos de Morton foram decisivos, por exemplo, para a defesa do poligenismo feita pelo naturalista Louis Agassiz - que esteve no Brasil entre 1865-66, com a expedição Thayer, onde registrou a população local em cerca de 200 fotografias, tiradas no Rio de Janeiro e em Manaus. MACHADO, M. H. P. T. E HUBER, S. (T)races of Louis Agassiz: photography, body and science, yesterday and today. SP: Capacete \& 29a Bienal, 2010.

${ }^{285}$ Médico norte-americano e proprietário de nove escravos, Nott foi um defensor da escravidão, que via como um regime em que os negros atingiriam o máximo da perfeição física e moral, bem como a longevidade. 
Em meados do "século da ciência", Joseph Arthur de Gobineau (1816$1882)^{286}$ publicaria seu Ensaio sobre a desigualdade das raças humanas (vol. I, 1853; e vol. II, 1855), onde afirma que o cruzamento de raças produz degenerações irreversíveis. Na perspectiva do teórico, a humanidade é incapaz de evitar tal processo $^{287}$, que se torna particularmente problemático à medida que "algumas 'subraças mestiças não civilizáveis" "288 se mostram incapazes de progredir. Poucos anos depois, a publicação de A Origem das Espécies (1859) produz novos paradigmas. Como se sabe, Charles Darwin (1809-1882) ${ }^{289}$ introduz aí a tese da seleção natural, ou seja, as transformações adaptativas das espécies ao longo de sua história, responsáveis pela preservação das características que as tornam mais aptas para a sobrevivência em meio à natureza; uma evolução contínua, provocada nos organismos viventes pelo instinto de preservação da vida.

Vale pontuar que, se Gobineau parece seguir uma via em certa medida contrária a Darwin - este observando a evolução permanente das espécies, aquele afirmando que a humanidade caminha para a degeneração -, ainda assim, os dois modelos conviveriam até o final do século XIX, por vezes convergindo para um mesmo argumento. Segundo Schwarcz, a partir de Darwin se propagam teorias que fazem uso próprio do marco conceitual cunhado pelo naturalista britânico, com o objetivo de justificar a lógica de um imperialismo europeu que alargava presença na África e em outras partes do globo ${ }^{290}$. A autora situa três categorias de formulações: evolucionismo social; darwinismo social; e antropologia cultural. Segundo ela, o primeiro grupo pressupunha, o uso de termos como competição, seleção do mais forte, evolução e hereditariedade em estudos de diversas áreas (biologia, antropologia e psicologia, entre outras), argumentando que os povos mais adiantados em matéria

\footnotetext{
${ }^{286}$ O Conde de Gobineau foi diplomata e escritor francês. Ele esteve no Brasil em missão diplomática entre março de 1869 e abril de 1870, tornando-se amigo de D. Pedro II, quando também escreveu sobre as benesses que resultariam da imigração branca para o país.

${ }^{287}$ Ensaio sobre a desigualdade das raças humanas se tornaria referência fundamental aos debates raciais no oitocentos tardio: o argumento central do livro era que o desejo de expansão imperialista, marca das raças mais evoluídas, acarretava no inevitável encontro - e miscigenação - com diferentes raças. Desse modo, a degeneração era tida como certa.

${ }^{288}$ GOBINEAU, A. Essai sur l'inegalité des races humaines. Paris, Gallimard-Pleiade (1983 [19853]) apud SCHWARCZ, L. O espetáculo das raças. Cientistas, instituições e a questão racial no Brasil 1870-1930. São Paulo, Companhia das Letras, 2004, p. 64.

${ }^{289}$ Naturalista inglês, autor da teoria da evolução.

290 Schwarcz também aponta para a adesão, tanto de monogenistas, quanto de poligenistas, ao darwinismo, a despeito do naturalista inglês afirmar uma origem comum: "se a adaptação monogenista do darwinismo era mais imediata, (...) para os poligenistas seleção natural implicava pensar na degeneração social". Idem, ibidem, p. 57.
} 
de evolução tinham como prerrogativa conduzir os demais ao mesmo estágio. $\mathrm{O}$ darwinismo social partia dos determinismos geográfico e racial, segundo Schwarcz, alegando que o destino das nações era determinado pela influência do clima e do meio natural, assim pela composição racial. A autora também pontua que, nessas teses, as raças eram vistas como produtos finais e qualquer mistura, como um erro. Por sua vez, a antropologia cultural buscava reafirmar uma humanidade única, porém dividida em diferentes estágios de evolução, no entender da pesquisadora ${ }^{291}$.

De fato, foram inúmeros os teóricos que, na segunda metade do século XIX, procuraram aprofundar-se no tema das diferenças raciais, alinhando-se a modelos evolucionistas sociais e deterministas ${ }^{292}$. Se nos escapa discuti-los a fundo e com justeza, dois pontos importantes sobressaem em tal produção científica, como percebe Schwarcz ${ }^{293}: 1$. Nesse momento, o propósito de naturalizar as diferenças se torna um projeto teórico de pretensão universal e globalizante; diante das verdades ditadas pelas leis da natureza sobre os indivíduos e grupos, parece não haver espaço para o arbítrio individual; 2. Esses debates se inscrevem necessariamente em projetos políticos, que considera a configuração racial de um povo como fator que determina no destino da nação.

Há também uma mudança epistemológica com relação ao pensamento setecentista. No século XIX, como ensina Foucault, "o tema evolucionista se refere menos à constituição do quadro contínuo das espécies que à descrição de grupos descontínuos e à análise das modalidades de interação entre um organismo, cujos elementos são solidários, e um meio que lhe oferece suas condições reais de vida" ${ }^{294}$.

\footnotetext{
${ }^{291}$ Idem, ibidem, pp. 54-64.

${ }^{292}$ Para citar alguns: Lapouge (1854-1936) institui uma Antropossociologia baseada na noção de seleção social e declara que quanto maior o numero de arianos, mais avançada é a nação. Spencer (1820-1903) aposta na aplicação das leis da natureza às sociedades humanas, classificando-as segundo estágios de evolução distintos. Galton (1822-1911) cunha o termo "eugenia" em 1883. Taine (18281893 ) sustenta que toda ação humana é determinada por causas exteriores e estende o conceito de raça às nações, classificadas como inferiores ou superiores. Lombroso (1836-1909) mapeia traços faciais e corporais com a intenção de apontar estigmas atávicos que levariam as pessoas ao crime e à loucura. Cf. STOCKING, G. W. Jr. Victorian anthropology. New York: Free Press, 1987; SEYFERTH, G. A antropologia e a tese do branqueamento da raça no Brasil: a tese de João Baptista Lacerda. In: Revista do Museu Paulista, 30, 1985; SKIDMORE, T. E. Preto no branco. RJ: Paz e Terra, 1989. SCHWARCZ, L. K. M. O espetáculo das raças. Cientistas, instituições e a questão racial no Brasil 1870-1930. São Paulo, Companhia das Letras, 2004. SCHWARCZ, L. K. M. Questões de fronteira. In: Novos Estudos. São Paulo, Cebrap, no 72, jul. 2005. CORRÊA, M. As ilusões da liberdade. A Escola Nina Rodrigues e a antropologia no Brasil. Bragança Paulista: Edusf, 1998.

${ }^{293}$ SCHWARCZ, op. cit.

${ }^{294}$ FOUCAULT , M. A arqueologia do Saber. RJ: Forense-Universitária, 1987, p. 41.
} 
Mudam, portanto, as metáforas e jogos de $\operatorname{conceitos}^{295}$ que viabilizam a produção discursiva sobre as raças - com implicações para aqueles que se tornam os objetos de conhecimento, cuja produção discursiva passa a mobilizar elementos captados por uma nova malha de relações. Assim, a preservação de certos modos antigos de caracterização dos negros e de seus descendentes se faz combinar com um novo aparato de percepção do mundo, em que o corpo é definido como um complexo fechado, dotado de aptidões limitadas para sobreviver no meio natural.

Schwarcz indica que, no Brasil, a entrada das novas teorias raciais se deu com mais força a partir da década de 1870 , em meio a avanços que anunciavam um fim próximo da escravidão, como a Lei do Ventre Livre (1871). Monarquia agora independente, de imperador português e ainda escravista, reconhecida por sua característica fortemente miscigenada e, ao mesmo tempo, marcada por uma confiança antiga no branqueamento, no império tropical o "modelo racial servia para explicar as diferenças e hierarquias, mas, feitos certos rearranjos teóricos, não impedia pensar na viabilidade de uma nação mestiça"296.

Ao percebê-lo, consideramos interessante pensar que, no processo em marcha, metáforas e conceitos extraídos das correntes deterministas atualizavam antigas imagens a respeito dos africanos e seus descendentes, mas a partir de um marco jurídico e científico reformulado. Se nesse movimento, preserva-se a ideia de branqueamento por meio da mistura de raças, mas agora sua compreensão se inscreve no marco da seleção natural e social ${ }^{297}$. A partir deste ponto, o que fora percebido como um fenômeno aleatório passa a esbarrar em mecanismos complexos de diferenciação biológica: cada organismo é visto no particular, cada corpo individualizado, negro, branco ou mestiço, torna-se uma matriz reprodutiva, um conjunto de potencialidades físicas e psíquicas que determinam a qualidade biológica de sua descendência. No que se refere às possibilidades de transformação racial, a admissão da ideia de branqueamento passa a depender de uma série de variáveis inscritas no corpo humano. Aos olhos desta nova ciência, são poucos os indivíduos dotados de aptidão física e psicológica adequada para gerar descendentes brancos e muitas as combinações que levam à degeneração.

\footnotetext{
${ }^{295}$ Sobre o tópico, cf. LENOIR, T. (org.). Inscribing Science: Scientific Texts and the Materiality of Communication. Bloomington: Stanford University Press, 1998.

${ }^{296}$ Idem, ibidem, p. 65.

${ }^{297}$ Cf. SCHWARCZ, L. K. M.. Retrato em negro e branco. Jornais, escravos e cidadãos em São Paulo no final do século XIX. SP: Companhia das Letras, 1987, p. 25.
} 
O impasse trazido por tal configuração não se traduz de forma simples, mas por meio de insinuações e proposições dispersas e de uma variedade de discursos que, como avalia Hofbauer ${ }^{298}$, ora planejam o futuro do país com base em projetos de extermínio da população negra (via branqueamento), ora advogam pela adoção de políticas segregacionistas, assentadas numa combinação entre medidas de tratamento diferencial para os negros e de incentivo à imigração branca. De todo modo, são propostas incapazes de questionar as ideias de atraso e de inferioridade biológica, psicológica e social da população de origem africana.

Assim, mesmo entre os abolicionistas sobressaem escritos que procuram correlacionar a escravidão com a perda da natureza humana - logo, a ver o escravo/negro como um elemento dotado de potencial destrutivo intrínseco, como mostra Azevedo ${ }^{299}$. Ao fazê-lo, Ruy Barbosa (1849-1923) $)^{300}$, em seu Apelo às mães (1870) aposta numa metáfora orgânica:

\begin{abstract}
Vêde a folhagem risonha do laranjal. De dia é toda oxigênio, que aviventa, e perfumes inoffensivos; de noite sob essas exhalações balsamicas insinuase o carbono, que asphyxia.

Assim o homem. Banhado nas ondas luminosas da liberdade, fertilisará o globo. Redusido, na oppressao, ás trevas, encherá de morte em derredor a atmosphera empobrecida. Há nada mais innocente que o lyrio amoravel dos valles? Entretanto, povoae d'elles, á tardinha, a alcova, e... bem póde ser que não acordeis mais ${ }^{301}$.
\end{abstract}

Já o Manifesto da Sociedade Brasileira contra a Escravidão (1880) afirma: "Nós Brazileiros não queremos fechar por mais tempo os olhos á essa monstruosa mutilação do homem, á essa suppressão systematica da natureza humana em um milhão e meio dos nossos compatriotas de outra raça” ${ }^{, 302}$ (grifos nossos). Nos dois casos, parece haver convicção, não apenas de que a escravidão deve acabar, mas de que a condição de escravo desumaniza. No primeiro trecho, o esforço para convencer

\footnotetext{
${ }^{298}$ HOFBAUER, A. Uma história do branqueamento ou o negro em questão. São Paulo: Editora UNESP, 2006.

${ }^{299}$ AZEVEDO, C. M. M de. Irmão ou inimigo: o escravo no imaginário abolicionista dos Estados Unidos e do Brasil. In: Revista USP, São Paulo (28): 96-109, dez/fev 1995-1996, p. 99.

300 Jurista, político, diplomata e escritor, Barbosa foi um dos articuladores da República brasileira, tornando-se ministro da Fazenda no novo regime e coautor de sua primeira Constituição, com Prudente de Morais. Foi federalista e abolicionista.

${ }^{301}$ BARBOSA, Ruy. Pelos escravos ás mães de Família. Diário da Bahia, 1881 apud, AZEVEDO, op. cit.

${ }^{302}$ Idem, ibidem.
} 
sobre sua periculosidade é evidente, no segundo a ênfase recai sobre a distinção racial - posto que esse mal acomete os "compatriotas de outra raça"303.

Ao lado de tal imagem de perigo e desnaturação, os abolicionistas também refletiam sobre o destino dos negros livres e da nação. Na década de 1880, se o positivista Miguel Lemos ${ }^{304}$ (1854-1917), por exemplo, defendia a integração dos exescravos ao operariado brasileiro e afirmava não haver raças superiores ou inferiores, seu colega, o médico Luís Pereira Barreto $(1840-1923)^{305}$, afirmava que os negros possuíam "menor massa de substância cerebral"”306. Este intelectual considerava incerta a possibilidade de alcançar "os mesmo resultados intelectuais e morais do cérebro ariano" ${ }^{307}$. Barreto defendia a abolição e a introdução de mão-de-obra branca, que em sua opinião contribuiria para superar o atraso do país. E não mencionava a miscigenação. O jurista Aureliano Cândido de Tavares Bastos $(1839-1975)^{308}$, por sua vez, defendia que "o europeu deve ser o alvo de nossas ambições, como o africano o objecto de nossas antipathias",309.

Argumentando que o grande mal do Brasil era o escravismo, Joaquim Nabuco (1849-1910) $)^{310}$, fundador da Sociedade Brasileira contra a Escravidão, idealiza "um paiz onde todos sejam livres; onde, atrahida pela franqueza das nossas instituições e pela liberalidade do nosso regimen, a imigração européa traga sem cessar para os trópicos uma corrente de sangue Caucasico vivaz, enérgico e sadio, que possamos absorver sem perigo"311. Em suma, segundo o advogado, "no futuro, só uma operação poderá nos salvar (...) a transfusão do sangue puro e oxygenado de uma

\footnotetext{
${ }^{303}$ Como não pensar também no romance antiescravista As vítimas algozes (1869), de Joaquim Manoel de Macedo que, dizendo contar histórias verdadeiras, narra histórias em que a presença dos escravos na intimidade doméstica colocam em risco a vida e a dignidade de seus senhores?

${ }^{304}$ Formado na Escola Politécnica, Lemos foi um dos fundadores da Sociedade Positivista Brasileira, que posteriormente transformou em Apostolado e Igreja Positivista do Brasil.

${ }^{305}$ Fluminense formado em medicina na Universidade de Bruxelas, Barreto também foi positivista.

${ }^{306}$ BARReTO, L. P. Os Abolicionistas e a Situação do Paiz. In: A Provincia de São Paulo, 20-30 de novembro de 1880, apud AZEVEDO, C. M. M. Onda negra, medo branco. RJ: Paz e Terra, 1987, p. 69.

${ }^{307}$ Idem, ibidem.

${ }^{308}$ Político e escritor liberal, Bastos foi um dos maiores defensores do federalismo e um crítico contumaz do centralismo imperial.

${ }^{309}$ BASTOS, A. C. Tavares. Os males do presente e as esperanças do futuro. São Paulo: Ed. Nacional, 1939 apud HOFBAUER, A. Uma história do branqueamento ou o negro em questão. São Paulo: Editora UNESP, 2006, p. 194.

${ }^{310}$ Diplomata do Império do Brasil, político, jurista e jornalista pernambucano, Nabuco foi um dos fundadores da Academia Brasileira de Letras e, nascido em família escravocrata, converteu-se num dos mais renomados defensores da causa abolicionista.

${ }^{311}$ Idem, ibidem, p. 195.
} 
raça livre" ${ }^{312}$. O político exprime aqui uma visão negativa sobre a raça negra, cuja escravidão atribuía "ao seu desenvolvimento mental atrazado, aos seus instinctos barbaros ainda, às suas superstições grosseiras",313 e a um "sangue" cheio de "vícios"314.

A ideia da África como uma terra de vícios e do africano como seu introdutor no Brasil, de acordo com Azevedo, foi marcante no discurso dos abolicionistas brasileiros - imagem que tendeu a combinar-se com preceitos evolucionistas e o darwinismo social nos meios letrados ${ }^{315}$. Enquanto isso, os negros e mestiços ocupavam as páginas policiais da imprensa. Nos jornais paulistas, Lilia Schwarcz identifica uma propensão a descrever o negro como "elemento perigoso"316.

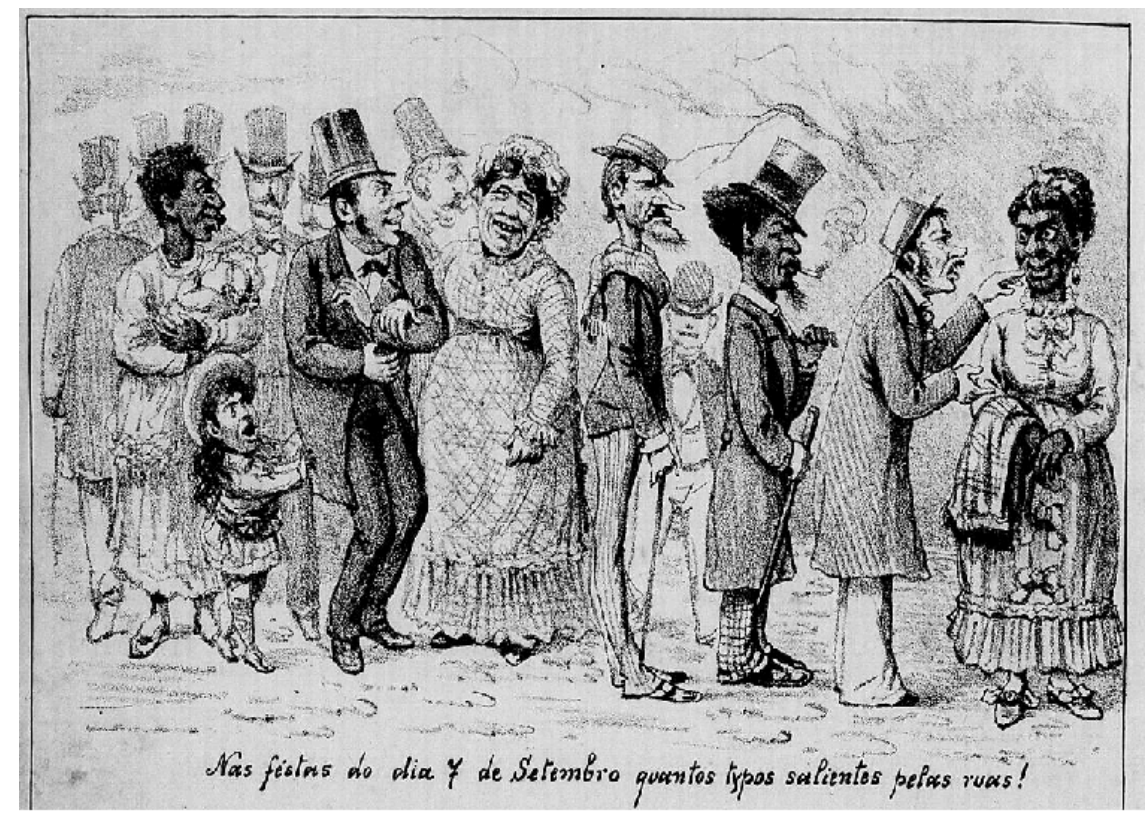

Fig. 51: Ilustração anônima para O Mequetrefe, 10 de setembro de 1885, p. 8. Num momento marcado por clamores republicanos, $O$ Mequetrefe mostra a celebração do 7 de setembro de 1885 como um lugar dos encontros interraciais, como forma de crítica ao Império.

\footnotetext{
${ }^{312}$ Idem, ibidem.

${ }^{313}$ Idem, ibidem.

${ }^{314}$ Não obstante, Nabuco se apresenta como um autor ambíguo com relação aos negros. Descreve, por exemplo, uma abnegação completa dos escravos para o bem de seus senhores, em Minha Formação (1900), que aqui são chamados de "santos negros". A oscilação não deixa de ser sugestiva sobre uma forma de lidar com a população negra por meio de oposições agudas de extremos binários, analisada por Stuart Hall: entre santificação e degeneração, não há espaço para a normalidade. Cf. HALL, S. Representation. Cultural representation and signifying practices. Sage publications, 2009, p. 229.

${ }^{315}$ AZEVEDO, C. M. M. Onda negra, medo branco. RJ: Paz e Terra, 1987. Embora mereça atenção a figura excepcional de Luís Gama (1830-1882), ex-escravo que conseguiu formar-se em Direito e trabalhou a vida inteira em defesa dos cativos que se rebelavam contra seus senhores. O literato morreu antes de ver abolida a escravidão. Sobre este literato, cf. MARTINS, H. Luís Gama e a consciência negra na literatura brasileira. Afro-Ásia, 17, 1996.

${ }^{316}$ O espetáculo das raças. Cientistas, instituições e a questão racial no Brasil - 1870-1930. São Paulo, Companhia das Letras, 2004.
} 
Finda a escravidão, ganham força os debates em torno das possibilidades de embranquecimento. Dois cientistas da República merecem atenção particular, ao resumirem caminhos a que conduziram os dilemas relativos aos negros e ao futuro racial do Brasil. Embora apresentem soluções distintas, nos dois casos a ideia de branqueamento convive com o empenho na fixação de diferenciações biológicas, psicológicas ou sociais entre as raças: os médicos Raimundo Nina Rodrigues (18621906) e João Batista de Lacerda (1846-1915) $)^{317}$. Ambos mostram-se particularmente elucidativos acerca dos mecanismos de fundamentação científica do racismo no Brasil e ilustram um trabalho de produção de modelos originais - como indica Schwarcz ${ }^{318}$ : por um lado, em diálogo com a produção teórica determinista, o darwinismo social e o evolucionismo, seus trabalhos inferiorizam a população negra; por outro, não exprimem acordo total com as teses que consideram tal inferioridade como uma característica biológica inexorável, buscando propor soluções com base em um projeto de civilização possível.

Nina Rodrigues questiona o argumento de Sylvio Romero, que em 1890 publica sua História da Literatura Brasileira, afirmando que no futuro do Brasil, prevaleceria um tipo de mestiço que dificilmente se distinguiria do branco ${ }^{319}$. Em particular, o médico tende a ver a população chamada mestiça como instável e, em sua maior parte, degenerada, com predisposições à violência e a vícios, como o alcoolismo, e aos excessos sexuais. Encarando a mistura racial em solo brasileiro como um problema, ele afirma que:

O que importa ao Brasil determinar é o quanto de inferioridade lhe advém da necessidade de civilizar-se por parte da população negra que possui e se de todo fica essa inferioridade compensada pelo mestiçamento, processo

\footnotetext{
${ }^{317}$ Médico e antropólogo maranhense, Rodrigues foi professor da Faculdade de Medicina da Bahia, primeiro na Cadeira de Clínica Médica e depois, de Medicina Pública. É considerado um grande precursor no desenvolvimento da área de Medicina Legal no Brasil, dedicando-se a estudos frenológicos e craniométricos. Lacerda, fluminense, formou-se em medicina no Rio de Janeiro. Foi diretor do Museu Nacional e presidente da Academia Nacional de Medicina.

${ }^{318}$ Idem, ibidem. Ver também SCHWARCZ. L. K. M. Nem preto, nem branco, muito pelo contrário. Cor e raça na intimidade. In: História da vida privada no Brasil, vol. 4. SP: Companhia das Letras, 2004, pp. 173-244.

319 “O seu número (dos brancos) tende a aumentar, ao passo que os índios e os negros puros tendem a diminuir. Desaparecerão num futuro não muito remoto, consumidos na luta que lhes movem os outros, ou desfigurados pelo cruzamento. O mestiço, que é a genuína formação histórica brasileira, ficará só diante do branco puro, com o qual se há de, mais cedo ou mais tarde, confundir", escreve Romero. (apud RODRIGUES, N. As raças humanas e a responsabilidade penal no Brasil. Companhia Editora Nacional, 1938. Disponível em <http://www.brasiliana.com.br/obras/as-racas-humanas-e-aresponsabilidade-penal-no-brasil/pagina/128/texto>. Consulta: 10/05/2013.
} 
natural por que os negros se estão integrando ao povo brasileiro, para grande massa de sua população de cor.

Capacidade cultural dos negros brasileiros; meios de promovê-la ou compensá-la; valor sociológico e social do mestiço ário-africano; necessidade do seu concurso para o aclimamento dos brancos na zona intertropical; conveniência de diluí-los ou compensá-los por um excedente de população branca, que assuma a direção do país: tal é na expressão de sua rigorosa feição prática o aspecto por que, no Brasil, se apresenta o problema o negro $^{320}$

A partir disto, elabora uma teoria própria, segundo a qual, os perfis psicológicos resultantes da mescla racial são tidos como imprevisíveis, com forte tendência à degeneração, e esta, arriscada. Entretanto, ele também questiona as teses de que os africanos estariam condenados à estagnação física e moral. Atribui, assim, uma "inferioridade social"321 (grifos nossos) à população negra, mas não descarta a possibilidade de que alguns atinjam o mesmo estágio de civilização que os brancos.

É interessante notar que autor adota o termo camita com novo sentido ${ }^{322}$ : segundo ele, os "verdadeiros negros" são distintos dos "povos camitas que, mais ou menos pretos, são todavia um simples ramo da raça branca e cuja alta capacidade de civilização se atestava excelentemente na antiga cultura do Egito, da Abissínia, etc.” ${ }^{323}$ (grifos nossos). No Brasil, segundo ele, se por um lado a existência de sangue camita justificaria a existência de "alguns homens negros de reconhecida superioridade intelectual" ${ }^{\text {"324 }}$, a reduzida presença de camitas puros e larga presença de mestiços camitas, de diferentes partes da África teria resultado num perfil em que estes seriam minoria.

Diante disso, merece atenção o fato de que, ao passo que Rodrigues afirma incerteza quanto a um futuro branco (ou a impossibilidade de atingir-se a homogeneidade racial) para a população nacional ${ }^{325}$, não nega que certos indivíduos negros possam tornar-se brancos e vice-versa, como fica claro em suas definições sobre esses grupos:

\footnotetext{
${ }^{320}$ RODRIGUES, R. N. Os Africanos no Brasil. RJ: Biblioteca Virtual de Ciências Humanas do Centro Edelstein de Pesquisas Sociais, 2010, p. 289.

${ }^{321}$ Idem, ibidem, p. 291.

${ }^{322}$ Idem, ibidem. Interessante notar como a obra de Nina sugere uma sobrevivência do termo camita no discurso científico oitocentista, que introduz o termo numa tipologia em que ora a palavra se vincula a um grupo específico, ora ao conjunto da população de ascendência negra.

${ }^{323}$ Idem, ibidem, p. 295.

${ }^{324}$ Idem, ibidem, p. 296.

325 "Não acredito na futura extensão do mestiço luso-africano a todo o território; considero pouco provável que a raça branca consiga fazer predominar o seu typo em toda a população brasileira”, escreveu. Cf. RODRIGUES , op. cit., 1957, p. 96.
} 
Consideramos assim [brancos] não só os brasileiros descendentes diretos dos europeus que em face das outras duas raças se conservaram puros de toda a mescla, mas ainda aqueles mestiços de qualquer delas que por um cruzamento unilateral com a raça branca conseguiram no fim de um certo número de sangues voltar definitivamente a esta última raça.

(...) Como para os brancos, reunimos sob a denominação de negros não só os descendentes diretos e sem mistura dos africanos importados pelo tráfico, como os seus mestiços que voltam à raça negra; são de todo aplicáveis a este grupo as considerações emitidas sobre o precedente; somente são eles a vítima principal do preconceito seletor (grifos nossos) $)^{326}$.

João Batista de Lacerda, por sua vez, é um expoente daquilo que Rodrigues chamaria de otimismo. Este cientista é reconhecido como o propagador da mesma confiança expressa nas fontes citadas anteriormente sobre o futuro branco da população brasileira - o que advogou por meio de uma teoria favorável à mescla racial, apresentada ao I Congresso Internacional das Raças: "A seleção sexual continua, aperfeiçoando-se sempre ao subjugar o atavismo e ao purgar os descendentes dos mestiços de todos os traços característicos do negro. Graças a este procedimento de redução étnica, é lógico supor que, no espaço de um novo século, os mestiços desaparecerão do Brasil, fato que coincidirá com a extinção paralela da raça negra entre nós ${ }^{\text {”27 }}$. A despeito do jargão evolucionista - exemplificado no uso do conceito seleção sexual, de Darwin -, a tese de Lacerda soa como uma versão renovada da antiga matemática geracional setecentista, evocada por tantos autores que o precederam.

Schwarcz percebe um sinal que denomina como "ambivalência" da perspectiva do médico fluminense: “A mestiçagem surge como um 'mal' (pois o cientista não desfaz ou não desconhece as máximas do darwinismo social e da antropologia física), mas seria também um 'bem', uma vez que sinalizaria um caminho positivo e definitivo para o Brasil”,328. Assim, no dizer do antropólogo, "o cruzamento racial se convertia em solução, e nosso enviado oficial apostava em uma espécie de mestiçagem redentora, que se lograria a

\footnotetext{
${ }^{326}$ RODRIGUES, R. N. As coletividades anormais. Brasília: Ed. do Senado Federal, vol. 76, 2006, p.192.

${ }^{327}$ LACERDA, J. B. Sobre os mestiços no Brasil. Tradução de "Sur le métis au Brésil" (Premier Congrès Universel des Races: 26-29 juillet 1911, Paris, Devouge, 1911). In: Schwarcz, L. K. M. Previsões são sempre traiçoeiras. João Baptista de Lacerda e seu Brasil branco. In: História, Ciências, Saúde Manguinhos. RJ, v.18, n.1, jan.-mar. 2011, p. 228.

${ }^{328}$ Idem, ibidem.
} 
partir de algumas políticas públicas concernentes à imigração; de algumas certezas da ciência que apostava na seleção - branca - dos mais fortes, e com alguma fé",329.

De fato, é interessante notar que a ideia de fé perpassa a teoria do médico. Cristão devoto, este cientista criticava uma ciência que, em sua opinião, não respeitava os princípios de amor ao próximo, propondo "oppôr as alevantadas da moral christian, que manda condoer-se da sorte dos fracos e humildes, e ajudal-os a vencer na senda desta vida" ${ }^{330}$ para fazer frente àquilo que nomeava uma "desesperadora sentença darwínica",331. De fato, na escrita do autor assoma uma tendência a unir fé à reflexão científica, que revela a fluidez de contornos entre estes domínios. Lacerda afirmava que

embora tomada como character differencial de raça, a côr não passa de um character anthropologico accidental, susceptível de modificar-se profundamente sob a influência dos agentes cosmicos; que a superioridade e a inferioridade das raças no sentido absoluto é um facto inveridico; e que no mundo só existem raças adiantadas e atrazadas, devendo ser atribuídas essas differenças às condições do meio physico e social em que o homem evoluio ${ }^{332}$ (grifos nossos).

Seja como for, ao assumir a "seleção sexual" como um princípio, Lacerda mantinha-se invariavelmente alinhado aos autores que viam, em meio ao processo de miscigenação, uma transferência de caracteres negativos do negro ao branco, afirmando, como fizera Buffon, que "o demorado contacto entre duas raças, uma atrazada, outra adiantada, viria [sic.] com o tempo fazer adquirir á raça adiantada muitos dos vícios e defeitos da raça atrazada" ${ }^{, 33}$. De modo análogo, enquanto dizia que a mistura interracial já produzira, em três gerações, crianças brancas, não deixava de ressaltar a permanência de certos traços atávicos em descendentes de negros.

Assim, Lacerda apresentava um plano para o futuro racial do país, cujo foco residia em extinguir a população negra. O que não parece ficar claro na formulação são as mecanismos propícios, na visão do cientista, para levar adiante essa propalada "seleção sexual": por trás de um discurso eminentemente político, escrito com o intuito de traduzir confiança sobre os rumos da nação brasileira aos olhos do estrangeiro, esse conceito de talhe evolucionista insinua que uma distribuição desigual de caracteres biológicos desejáveis é instransponível e que os esforços de gestão da perfectibilidade, no fundo,

\footnotetext{
${ }^{329}$ Idem, Ibidem, p. 230.

${ }^{330}$ LACERDA, J. B. O Congresso das Raças reunido em Londres. 1912, p. 108.

${ }^{331}$ Idem, ibidem.

${ }^{332}$ Idem, ibidem, p. 90.

${ }^{333}$ Idem, ibidem, p. 91.
} 
tornam cada indivíduo responsável pelo resultado das combinações de caracteres em seus descendentes.

Poderíamos citar outros autores de destaque na primeira República entre os expoentes de uma intelectualidade brasileira a incorporar o problema da mestiçagem em suas formulações. Há, é claro, exceções, como o médico Manuel Bomfim (1868-1932), para quem a mescla racial no Brasil era positiva e a educação, o caminho para o desenvolvimento, fazendo uso de metáforas biológicas; Manuel Querino (1851-1923), intelectual negro e abolicionista, que defendeu o valor da contribuição africana para a identidade nacional; e o médico Edgar Roquette-Pinto (1884-1954) - representante de uma geração posterior aos demais -, que procurou negar os efeitos negativos da mistura racial, afirmando a normalidade do mestiço. Também é possível situar especificidades do pensamento de autores como o escritor Euclides da Cunha (1866-1909), que diferencia o "mestiço do litoral" e o "mestiço do sertão" por meio de relações específicas entre homem e meio, percebendo o segundo com maior otimismo. Mas à medida que muitos dos autores do período se fiavam ao prognóstico de que a população negra estaria extinta no futuro, como é o caso de Silvio Romero (1851-1914) ${ }^{334}$, parece haver uma tendência, entre os teóricos dessa geração, a olhar para os negros como indivíduos de corpo problemático, cuja descrição é quase o prenúncio de seu desaparecimento iminente.

No referido Congresso, Lacerda anexou à sua comunicação uma pintura que unia a iconografia religiosa à narrativa de uma transformação racial em três gerações. Naquele contexto, a imagem parecia traduzir perfeitamente seu argumento. Mas ia além: articulava a iconografia religiosa a formas antigas de ver o negro, contando uma história familiar de embranquecimento. Assim, A Redenção de Cam sobrepunha as projeções da ciência ao discurso da fé cristã que, em tempos anteriores, servira ao intuito de eclipsar as desigualdades instauradas pelo modelo escravista. Mas se o quadro fazia ver os esforços da ciência para apagar dos corpos a derme que recordava o passado escravista - e não mais justificá-la no presente -, o tempo já falseara em muito os antigos cálculos geracionais. A legenda dizia que ali estava "o negro passando ao branco em três gerações, por efeito do cruzamento de raças". Mas ainda que a imagem o confirmasse, ao mesmo tempo não deixava de insinuar que a redenção, agora celebrada pela fé e a ciência, talvez fosse a dos brancos.

\footnotetext{
${ }^{334}$ A obra deste literato oscila entre ver o mestiço como produto final e vê-lo como etapa no processo rumo à brancura.
} 


\title{
Capítulo 2. A tela, por seu estilo
}

\author{
Images of violence, in other words, can be violent themselves \\ - violating the subject's illusion of its self as thinking, \\ through the illusionism of the image's resemblance to something, as thinkable. \\ - Hudek, The Sensive Image, 2007.
}

Foi assim [por meio da maldição] que a raça gerada por Cham, na terra adusta da Africa, ficou sendo preta e feia, maltratada e escrava. No grande quadro do meu amado Brocos, aquella admirável preta velha, de mãos erguidas ao céo, é a descendente d'aquelle máo filho, que, tendo visto bebedo o pai, teve a ousadia de achar engraçada a sua patriarchal bebedeira. Alli está ella pagando o crime que não commetteu. Mas Noé, quando condemnou, com a sua maldição, toda a raça do filho máo a ter na pelle, até a consummação dos seculos, a negrura da noite, - não podia contar com uma cousa que succedeu depois.

E a cousa foi esta: descendentes brancos de Sem, fartos de beijar pelles alvas, desandaram a beijar pelles pretas. E começou assim a raça de Sem a redimir a raça de Cham - redempção que Brocos acabou agora. (...)

Na sua grande tela belissima, já a filha da velha preta está meio lavada da maldição secular: já não tem na pelle a lugubre côr da noite, mas a côr indecisa de um crespusculo. E vêde agora aquelle latagão que alli está, ao lado d'ella, branco como o dia: é um Semita puro, que se encarregou de completar a obra da redempção, transformando o crepusculo n'uma aurora radiante. Vêde a aurora-creança como sorri e fulgura, no collo da mulata, aurora filha do dilúculo, neta da noite... Cham está redimido! Está gorada a praga de Noé! $!^{335}$

Cham, toda a tua historia ahi está nessa téla: a negra, a tua macula, mas também o teu primeiro passo no caminho do Perdão. Perdão, a mulata o dilúculo, a criança a claridade resplandecente. A tua raça, mãi negra, entrará pelo Futuro nobre e forte, perdoada do pecado de Cham, teu ancestral tenebroso, que vai baixar ao Esquecimento, redimido para o sempre, porque não ha Redempção como o olvido e a morte é uma substituição. ${ }^{336}$

Dizer que uma pintura é performática é como dizer de sua capacidade para aguçar os sentidos de uma comparação contínua com algo que a extrapola - a existência, do lado de fora do quadro, de uma realidade que o comprove ou refute, ainda que em caráter de projeção imaginária. Logo, a performance pode aqui ser entendida como a provocação que impele o espectador a encontrar na tela algo para além daquilo que ela apresenta.

Assim parece ter sido A Redenção de Cam, desde o momento inaugural. $\mathrm{Ou}$ pelo menos é o que indicam as críticas daquela Exposição Geral de Belas Artes, aberta em setembro de 1895, na Escola Nacional de Belas Artes: mais do que uma

\footnotetext{
${ }^{335}$ BILAC, O. [pseudônimo ass. Fantasio]. “A redempção de Cham”. Gazeta de Noticias, 05/09/1895. Fantasio na Exposição II, p. 1.

${ }^{336}$ NETTO, C. [ass. C. N. ].“A redempção de Cham - Fantasia Symbolista (a proposito do quadro de Modesto Brocos)”. Gazeta de Noticias, 19/9/1895, pp. 1-2.
} 
apreciação de ordem formal, o que a tela provocou foi uma série de preocupações com relação à verdade do fato que encarnava. Seriam os membros da família multirracial em cena legítimos representantes dos grupos que pareciam ter inspirado sua composição? Seria o tratamento do assunto condizente com a realidade nacional? Era legítimo que a pintura abordasse uma temática daquela importância para o país?

É esse o sentido da apreciação publicada no Jornal do Commercio, naquele 7 de setembro:

\begin{abstract}
"A redenção de Cã", de grandes proporções, chama logo a atenção de quem entra. Muito já se tem falado sobre este trabalho; não nos parece, porém, que ele tenha o valor que se quer dar como concepção. No desenvolvimento do assunto, é pouco claro; a ideia que o artista teve em mente traduzir, não transparece à primeira vista, nem se entende sem explicação; quem o observar, não compreenderá que o tema é a redenção de uma raça. Afigura-se-nos que semelhante intuito não se realiza com a transfusão progressiva nela de elementos que lhe são estranhos e a gradual extinção dos seus característicos. Demais, o assunto em si é pouco delicado para ser assim publicamente tratado; envolve fatos sociais que realmente se dão, mas que não são aceitos na ordem geral de coisas. Fere preconceitos ainda arraigados em muitos espíritos e, para ser compreendido, demanda explicações demasiadamente delicadas para serem franca e claramente expostas. Na nossa opinião representa apenas um simples episódio que ocorre na nossa vida social, mas sem constituir normalidade e ao qual se deu um título ruidoso, a nosso ver inadequado. Como estudo de seleção natural, os tipos representados não são dos mais felizes ${ }^{337}$.
\end{abstract}

Como se nota, esse crítico anônimo não compartilhava do entusiasmo expresso por Olavo Bilac (1865-1918) e Coelho Netto ${ }^{338}$ nos trechos destacados mais acima. Entretanto, em todos os excertos prevalece a mesma tendência a transformar a tela numa espécie de subterfúgio para posicionamentos inflamados, que não deixam maior espaço para uma análise do quadro por seus méritos artísticos. Se o teor desses textos merece uma atenção à parte - que lhes dispensaremos mais adiante -, por ora é preciso reconhecer a capacidade de mobilizar reações de $A$ Redenção de Cam, sua provocação contínua e sua força pensante.

As manifestações da crítica mostram que logo de saída o êxito almejado por Brocos parecia ter sido alcançado. Afinal, o artista guardava para si uma definição

\footnotetext{
${ }^{337}$ NOTAS SOBRE ARTE. Jornal do Commercio, Rio de Janeiro, 7 set. 1895, p. 2.

${ }^{338} \mathrm{O}$ escritor brasileiro Olavo Bilac, considerado o "príncipe dos poetas", também é reconhecido por sua atuação em defesa e promoção da República brasileira. Escreveu a letra do Hino à Bandeira. Henrique Maximiano Coelho Netto, escritor, político e professor brasileiro, teve um papel ativo nas campanhas abolicionista e republicana, aliando-se a José do Patrocínio. Tornou-se deputado federal em 1909. Também é digno de nota que este escritor tenha lecionado História da Arte na Escola Nacional de Belas Artes, no ano de 1892.
} 
elaborada do que fosse arte: não importando o gênero da obra, ela deveria “impressionar ao espectador" 339 , sendo esta capacidade sua "qualidade mais alta". E se tal capacidade, escrevia Brocos, estava ligada à fatura apurada - ao domínio de uma retórica pelo artista -, não lhe seria plenamente debitária. Antes, corresponderia àquilo que os modernos retóricos haviam definido como fundo, "a ação moral que se desprende do discurso". Nos termos empregados por Brocos:

Essa ação moral em arte descobre-se pela impressão de alegria ou tristeza que, ante a vista de um quadro, desperta no espectador e que poderemos dar o qualificativo de sentimento. A obra de arte, ou seja, o quadro (...) deverá despertar no espectador um quer que seja de adequado ao assunto, que vai ferir a sua conciência intima, e que, enquanto se encontre diante da obra, não o abandona um segundo ${ }^{340}$.

Dito de outro modo, uma pintura deveria ser composta de modo a arremessar a atenção (ou a sensação) para algo que extrapolasse seu universo diegético - um referente, já decodificado pelos sentidos e anteposto à imagem que se guardava no interior da moldura. A forma, aqui, não deveria servir de obstáculo; antes, necessitava passar até certo ponto incólume pelo crivo do olhar, ajudando-o a tomar o rumo das dimensões não-pictográficas do pensamento. Pois, a partir do momento em que a crítica passava a disputar a realidade vis-à-vis o quadro, já havia abandonado o domínio da obra propriamente dita, deixando intumescer a percepção de estar-se apenas diante daquilo que se via, para avançar em debates sobre a validez de uma realidade exterior e candente. No caso de $A$ Redenção de Cam, a questão dizia respeito ao futuro racial do país.

Ao mesmo tempo, o retoque da realidade à luz da obra era tão almejado quanto inevitável. Ainda em sua Retórica dos Pintores, Brocos explicava aquilo que, a seu entender, deveria ser uma finalidade da arte: a intervenção de um mundo ideal, onde se desejaria viver, no mundo real. Segundo o pintor,

$\mathrm{O}$ artista deverá preocupar-se com as relações que existem entre o mundo em que vive e o que imagina e no qual deseja viver; aquele está cheio de imperfeições, este seguido de grandíssimas dificuldades; o primeiro diz as cousas como elas são, o segundo, como elas deveriam ser.

Deveremos, pois, partir da realidade para elevar-nos ao ideal de beleza a que aspiramos, tal será o resultado de um educado entendimento. ${ }^{341}$

\footnotetext{
${ }^{339}$ BROCOS, M. Retórica dos Pintores. Rio de Janeiro: Typ. D’A Industria do Livro, 1933, p. 19.

${ }^{340}$ Idem, ibidem, p. 19.

${ }^{341}$ Idem, ibidem, p. 40
} 
Assim, a função performática exercida pela obra diante do espectador dependeria de sua capacidade para mobilizar uma ilusão (a da beleza, no entender de Brocos) sobre a forma do real: ao mesmo tempo em que a pintura insinua uma realidade diante do olhar, também lhe devolve a mirada, recolocando os limites de sua capacidade de assimilação do mundo. Olhar, aqui, é processo, uma troca que permite redefinir ou preservar determinadas fronteiras. Ver uma imagem é, nesse sentido, enfrentar o confronto entre aquilo que ela de fato apresenta em seus constrangimentos materiais e aquilo que ela introduz em seus aspectos conceituais - sendo a primeira dimensão passível a observação e esta última, imprecisa e largamente dependente das opiniões emitidas por terceiros sobre a tela e das próprias percepções do espectador.

Há dessa feita uma dialética do ver que o próprio artista admitia como um mecanismo fundante de sua arte. Se a imaginação é posta a procurar referentes externos no momento em que observa a cena, é a própria imagem que recoloca as condições para encarar esse referencial ora chamado de realidade. Ciente deste movimento, A redenção de Cam ganhava contornos de um paradoxo: jogava com os limites entre o que poderia ser visto como ideal e o que poderia ser visto como real. Assim, a tela trazia para dentro da moldura um debate candente, apelando para algo que era tido por muitos como novidade última da genealogia nacional - o embranquecimento. Com isto, elaborava um nível de realismo próprio, assentado sobre uma hipótese, uma conjectura e uma crença: uma sorte de realismo idealista e, evidentemente, racista.

Neste capítulo, procuraremos discutir precisamente a construção desse jogo do estilo na obra de Brocos, a partir de considerações sobre um conjunto de telas, livros de autoria do pintor e outras fontes documentais - notadamente, a crítica de arte. A partir do debate sobre estilo, será possível delinear padrões de intenção ${ }^{342}$ nessa amostra de fontes de autoria do artista. Segundo Baxandall,

todo ator histórico, todo objeto histórico têm um propósito - ou um intento, ou, por assim dizer, uma 'qualidade intencional'. Nessa acepção, a qualidade caracteriza tanto o ator, quanto o objeto. A intenção é a peculiaridade que as coisas têm de se inclinar para o futuro.

Portanto, a intenção não é um estado de espírito reconstruído, mas uma relação entre o objeto e suas circunstâncias (...)

342 BAXANDAlL, M. Padrões de intenção: a explicação histórica dos quadros. São Paulo: Companhia das Letras, 2006. 
Assim, meu conceito de 'intenção' aplica-se mais aos quadros que aos pintores $^{343}$.

Como ensina o historiador, a obra de arte resolve um problema. Logo, seus padrões de intenção podem ser apreendidos pela observação do objeto artístico - que constitui um resultado da interação entre aquele problema e um conjunto de "possibilidades culturalmente determinadas" $" 344$. A dificuldade do analista é que nem sempre estes dois últimos aspectos são evidentes ou disponíveis ao pesquisador - o que exige a recriação de metodologias de observação que possibilitem contornar certas lacunas, a fim de elucidar a trama da imagem em suas articulações formais e conceituais.

A procura por padrões de intenção se completa no capítulo 3, quando passaremos a uma análise do quadro $A$ redenção de Cam, a partir do contraste com outras modalidades de caracterização de personagens negras, não-brancas e das relações raciais na pintura.

Para efeitos da análise proposta, o que parece especialmente convidativo sobre a ideia de padrões de intenção é sua capacidade de encontrar na obra uma propriedade particular, qual seja, a de emitir pensamento. Coli explica bem essa qualidade: "A obra de arte, como pensamento material e objetivado, deixa de ser objeto e se torna sujeito, sujeito pensante, como o é um tratado filosófico, apenas com uma diferença fundamental de meios. O artista, portanto, introduz um ser pensante no mundo, ser autônomo em relação a seu próprio criador",345.

Partimos do pressuposto de que um estilo presente na obra de Brocos - e ora chamado de realismo idealista - é fundamental para sua capacidade pensante e performática e permite vislumbrar, nas imagens e em sua recepção, uma série de aspectos particulares sobre a questão racial no Brasil do último Oitocentos.

\footnotetext{
${ }^{343}$ Idem, ibidem, p. 81. Ver também: "Explicar uma intenção não é contar o que se passou na cabeça do pintor, mas elaborar uma análise sobre seus fins e meios, conforme os inferimos a partir da observação da relação entre um objeto e algumas circunstâncias identificáveis" (idem, ibidem, p. 162).

${ }^{344}$ Idem, ibidem, p. 69. Baxandall não define o termo "cultura", mas parece empregá-lo com o sentido de um conjunto de traços diferenciadores de uma determinada configuração social, encerrada numa dada temporalidade e espaço geográfico.

${ }^{345}$ COLI, J. O corpo da liberdade. São Paulo: CosacNaify, 2010, p. 281.Ver também SAMAIN, E. (org.). Como pensam as imagens? Campinas: Editora Unicamp, 2012; HUTCHET, S. (org.). Fragmentos de uma Teoria da Arte. São Paulo: Edusp, 2012; Idem, Image and Narrative [ejournal], $\quad$ n. $18, \quad 2007, \quad$ s.p. 20 Disponível $<$ http://www.imageandnarrative.be/thinking_pictures/hudek.htm>. Consulta: 01/05/2013.
} 
Contudo, antes de partir para as reflexões propostas, vale uma ressalva, que diz respeito à nossa posição, enquanto espectadores extemporâneos a Brocos e definitivamente afastados de suas motivações: os limites desta análise dizem respeito ao fato de que já não basta compreender e justificar o projeto artístico que resultou nas obras abordadas. Se lida na chave de uma intervenção no mundo por meio da beleza, tal como proposto pelo pintor, o quadro que se tornou um emblema dos projetos racialistas de embranquecimento é a antítese do belo - é, sem dúvida, como avaliaram alguns críticos, preconceituoso ${ }^{346}$, e esta é sua performance, diante de nossos olhos.

Tal como as imagens da violência analisadas por $\operatorname{Hudek}^{347}$, a imagem preconceituosa também é uma visão do impensável, por duas razões. A primeira diz respeito à sua própria existência, que aponta para uma validez do projeto de embranquecimento do lado de fora da tela, no momento de sua composição. A segunda refere-se à elevação desta ideia à categoria de algo que merece ser admirado por seu efeito estético, vez que a imagem evidencia um desejo de constituir como belo algo que emerge como inaceitável, sob o olhar contemporâneo: através da pintura, o embranquecimento não apenas ganha uma visibilidade privilegiada, mas é alçado à condição do memorável - digno de figurar numa galeria ou coleção ${ }^{348}$.

Segundo Didi-Huberman: "Devant une image - si ancienne soit-elle -, le présent ne cesse jamais de se reconfigurer [...]. Devant une image - si récent, si contemporaine soit-elle - le passé en même temps ne cesse jamais de se reconfigurer, puisque cette image ne devient pensable que dans une construction de la mémoire, si n'est pas de la hantise" ${ }^{, 34}$. Assim, discutir a proposição de que A Redenção de Cam é preconceituosa, reagindo à provocação presente desta cena, é reencontrar formas que possibilitem reconfigurar o passado, de modo a iluminar novos problemas no presente. Para isto, é preciso compreender determinadas obras como sintomas, nos

\footnotetext{
${ }^{346}$ Cf. LEITE, J.R.T. Dicionário crítico da pintura no Brasil. RJ: Artlivre, 1988, p. 177; NAVES, Rodrigo. Almeida Júnior: o sol no meio do caminho. In: Seminários CEBRAP, 2003, p. 138; e LOURENÇO, M. C. F. Debates e posturas - Tempo humano. In: Almeida Júnior: um criador de imaginários. Catálogo da exposição na Pinacoteca do Estado. São Paulo, 25 jan.-15 abr. de 2007, p. 95. ${ }^{347}$ HUDEK, A. The Sensive Image. De-Thinking the Figure with Bataille and Levinas. Image [\&] Narrative [e-journal], n 18, 2007, s.p. Disponível em: $<$ http://www.imageandnarrative.be/thinking_pictures/hudek.htm>. Consulta: 01/05/2013.

${ }^{348}$ Evidentemente, ao propor uma discussão sobre a memória, é preciso ter em conta que não se trata de extirpar a obra de uma coleção. Antes, acreditamos que é preciso reconhecer seu caráter documental e definir novas formas para introduzi-la ao público, abrindo caminhos para sua revisão crítica.

${ }^{349}$ DIDI-HUBERMAN, G. Devant le temps. Histoire de l'art et anachronisme des images. Paris: Minuit, 2000, p. 10.
} 
termos de Didi-Huberman ${ }^{350}$, cuja função se refere à possibilidade de desencadear reações a partir de um substrato material conforme.

Quais as implicações desse reconhecimento para a análise proposta? A principal é admitir a riqueza do anacronismo, como propõe Didi-Huberman. Partimos do entendimento de que $A$ redenção de Cam evidencia um passado que parece revelar-se hoje insuficiente à sua própria compreensão: afinal, se o racialismo oitocentista encontra o rechaço das gerações atuais, o racismo é ainda presente ${ }^{351}$, convidando a questionar determinados aspectos dessa memória.

\section{Do estilo como um problema e do problema por trás do estilo}

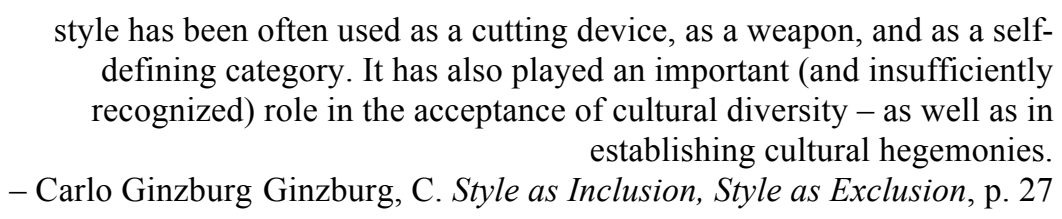

Em 1894, logo depois de uma viagem a Diamantina, Modesto Brocos exibiu uma série de quadros na Exposição Geral de Belas Artes, grande evento promovido anualmente na capital brasileira, entre os meses de setembro e novembro. A visão das imagens produziu sobre a crítica a sensação de estar diante de um estilo genuinamente realista. "Não é, como geralmente não são os bons artistas, fanático de alguma maneira de arte ou de algum gênero estereotípico de efeitos naturais. É realista enragé. Todos os tipos, todas as cenas, todos os efeitos lhe servem: o que importa é que os tenha diante dos olhos", escrevia o comentarista da Gazeta de Notícias ${ }^{352}$.

Se essa característica percorreria o conjunto das cenas expostas - fossem retratos, paisagens ou pintura de costumes, a descrição da tela Garimpeiros é significativa. Segundo o crítico, "nos Garimpeiros a paisagem, animada por duas figuras de trabalhadores, assume a feição duma cena zoliana: a tristeza do ambiente está em relação com a das figuras e o drama cotidiano do trabalho se revela em toda a sua crueza, despido daquela auréola sentimental que o idealismo necessariamente lhe

\footnotetext{
${ }^{350}$ DIDI-HUBERMAN, G. O que vemos, o que nos olha. São Paulo: Editora 34, 2010; e Idem. Quadro = Corte - Experiência visual, forma e sintoma segundo Carl Einstein. In: HUTCHET, S. (org.). Fragmentos de uma Teoria da Arte. São Paulo: Edusp, 2012, pp. 61-96.

${ }^{351}$ Para uma discussão aprofundada sobre essa questão, ver GUIMARÃES, A. S. A. Racismo e AntiRacismo no Brasil. São Paulo: Editora 34, p. 62.

${ }^{352}$ EXPOSIÇÃO GERAL DE BELAS ARTES. MODESTO BROCOS. Gazeta de Noticias, Rio de Janeiro, 12 out. 1894, p.2.
} 
dá ${ }^{353}$. Hoje não sabemos o paradeiro da pintura, mas a descrição é ainda marcante ao sugerir que, por seu teor, a cena mantinha-se em conformidade com um tipo de realismo ou naturalismo bastante em voga na Europa do período. Harmonizados com o meio, esses operários dedicados à extração de minérios (riqueza alheia) parecem servir de mote ao testemunho documental sobre a vida e as condições de trabalho naquele lugar afastado dos grandes centros e, no entanto, crucial para o seu desenvolvimento.

O realismo tende a ser associado à imagem do pintor francês Gustave Courbet (1819-1877) e ganha força na década de 1850 como uma das tendências que se opunham ao idealismo em pintura: Courbet defendia que a arte deveria ocupar-se precisamente daquilo que se via, o que implicava num compromisso com a pintura ao ar livre (plein air) $)^{354}$ - e na decorrente fuga dos ateliês, vistos a partir de então como ambientes artificiais -; no anti-academicismo; e na recusa veemente a formar escola o que não significou, evidentemente, que à sombra do Realismo não houvesse florescido uma tradição. Um ponto caro ao sistema de notação realista era a dupla renúncia, tanto ao passado greco-romano/renascentista dos neoclássicos, quanto ao medievalismo e orientalismo que povoavam as imagens românticas - ambas as

\footnotetext{
${ }^{353}$ EXPOSIÇÃO GERAL DE BELAS ARTES. MODESTO BROCOS. Gazeta de Noticias, Rio de Janeiro, 12 out. 1894, p.2.

${ }^{354}$ A valorização da pintura ao ar livre (plein air) representa uma transformação fundamental na pintura do século XIX e remonta à chamada Escola de Barbizon. Tal agremiação que, durante décadas, acolheu artistas de distintas gerações numa propriedade rural na cidade de Barbizon, França, próxima à floresta de Fontainebleau, inicia seu projeto na década de 1820, inspirada pela exposição de telas do pintor inglês John Constable no Salão de 1824, em Paris. Se a princípio, os preceitos de Barbizon foram voltados às cenas de paisagem, o clareamento das palhetas evidenciado nos quadros dos expoentes dessa escola costuma ser lembrado pelos críticos como marca de uma influência decisiva do grupo sobre a pintura francesa oitocentista - reconhecidamente, o impressionismo -, expandindo-se para outros gêneros. O realismo e o naturalismo logo adotaram o pleinarismo como fundamento da prática pictórica. Um pintor considerado naturalista, que se associou ao grupo de Barbizon em 1849 é Jean-François Millet (1914-1975), autor de Les glaneuses (1857). Outros expoentes marcantes são Jean-Baptiste Camille Corot (1796-1875), Théodore Rousseau (1812-1867), Constant Troyon (18101865), Jules Dupré (1811-1889) e Charles-François Daubigny (1817-1878). Cf. MOLLET, J. The painters of Barbizon: Corot, Daubigny, Dupré (1890). London: Kessinger Publishing, 2010; BOURET, J. The Barbizon School and 19th century French landscape painting. Greenwich: Thames and Hudson, 1973; ADAMS, S. The Barbizon School and the origins of Impressionism. London: Phaidon, 1994; TURNER, J. (ed.). From Renaissance to Impressionism: Styles and movements in Western Art, 1400-1900. The Grove Dictionary of Art. London: Macmillan Reference Ltd., 2000. Sobre a influência dessa escola no Brasil, cf. SOUZA, G. M. Pintura Brasileira Contemporânea: os Precursores. In: Discurso, n. 5, São Paulo, 1974; e ZILIO, C. A modernidade efêmera: anos 80 na Academia. In: 180 anos de Escola de Belas Artes. Anais do seminário EBA 180, 20-11 de nov., 1996, Rio de Janeiro; e TORAL, A. A. No limbo acadêmico: comentários sobre a exposição "Almeida Júnior - um criador de imaginários". ARS (São Paulo) [online]. 2007, vol.5, n.10, p. 43. Disponível em: <http://www.scielo.br/pdf/ars/v5n10/05.pdf >. Última consulta: 22/07/2013.
} 
tradições, consideradas idealistas ${ }^{355}$. Mas na medida em que tais preceitos se espalhavam pela Europa com rapidez, antes e depois de Courbet, o realismo não ficou restrito a este artista canônico.

Visto por alguns como uma derivação do Realismo das décadas de 1840 e 1850 - e por vezes definido enquanto tal -, o naturalismo começa a aparecer com força nos Salões da Escola de Belas Artes francesa em finais da década de 1870. Não obstante, trata-se de um estilo largamente presente na pintura europeia da segunda metade do século XIX - e portanto, internacional -, que se faz discernir sobretudo pelo interesse temático. Coli sintetiza seu caráter: "Não buscando inovar no plano do 'fazer artístico' mas, ao contrário, tentando dispor instrumentos picturais perfeitamente adquiridos e dominados ao serviço da intenção de 'descrever' a 'realidade', os naturalistas apresentam um métier anônimo, quase intercambiável. Que se distingue, no entanto, das outras técnicas picturais da época” ${ }^{, 356}$.

É um tanto difícil discernir essa tendência do realismo e por vezes os dois nomes são aplicados para uma mesma obra. Os estilos coincidem ao procurar expor aquilo que consideram a realidade das coisas. Seus temas prioritários envolvem as condições de trabalho na sociedade industrial, de modo que tais quadros primam por evidenciar a exiguidade das condições de vida da classe trabalhadora. Do ponto de vista do assunto, como descreve Coli,

O inventário é completo: trabalho industrial pesado (siderurgias, minas), obras públicas, indústrias mais específicas (o vidro, o metal, o tecido), trabalho feminino (rendeiras, costureiras, lavadeiras, passadeiras...), trabalho nos campos, nos barcos fluviais e marítimos, no comércio, nos espetáculos populares (atores e músicos ambulantes, lutadores, circo). A vida dos trabalhadores é detalhada: acidentes profissionais, miséria das habitações, despejos, hospital, o desemprego com a vagabundagem e as prisões, as revoltas sociais - greves, comícios. A infância, com o trabalho em baixa idade e o orfanato, a escola, depois o exército, o casamento, a velhice, os momentos de repouso, de descontração, as distrações ${ }^{357}$.

\footnotetext{
${ }^{355}$ Sem dúvida, seria possível alargar o debate sobre os sentidos particulares do realismo de Courbet e de sua proposta individualizante de arte. Coli (op. cit.), por exemplo, pontua a frase preferida do artista - "eu pinto o que vejo" - como uma afirmação dotada do sentido oposto àquele buscado por Zola, que procurava explorar temas desconhecidos, sobre os quais era importante instruir-se. Para Courbet, a ideia seria afirmar o artista através da pintura, aquilo que ele tinha diante de seus olhos e conhecia bem. Logo "os camponeses de Courbet não são importantes porque são camponeses, mas porque existem artisticamente por um ato instaurador do artista" (Coli, op. cit., p. 149).

${ }^{356}$ COLI, J. O corpo da liberdade. São Paulo: CosacNaify, 2010, p. 287.

${ }^{357}$ Idem, ibidem, p. 289. Toral reforça e complementa a definição, indicando também a presença de pintura de paisagem - urbana e rural - e do tema bíblico, no naturalismo. TORAL, A. No limbo Acadêmico. Comentários sobre a exposição "Almeida Júnior - um criador de imaginários". ARS, vol. 5, n. 10, São Paulo.
} 
A contrapartida do enfoque nas condições de vida é a redução das personagens aos elementos mais significativos de sua inserção no meio e à modelagem particular que o trabalho, o clima e as dificuldades da existência infligem sobre a musculatura, a postura, a pele de corpos submetidos às rotinas mais aviltantes. Segundo Coli, são figuras "definidas por traços gerais: idade sexo, compleição física, classe social a que pertencem. Pouca vontade de caracterização psicológica: as crianças, os velhos que vemos são, antes de tudo tipos sociais determinados pelas funções que exercem"358.

Pois segundo o crítico da Gazeta de Notícias, todos esses elementos parecem constar do quadro Garimpeiros. A alusão ao escritor Émile Zola (1840-1902), o pai do naturalismo francês ${ }^{359}$ na literatura, tanto quanto a ênfase no anti-idealismo da cena, são aqui indicadores explícitos a esse respeito. $\mathrm{O}$ autor de Germinal reapareceria num texto de Carlo Parlagreco ${ }^{360}$, de 1895, sobre a arte de Brocos: "Uma collecção de quadros feitos em Diamantina (...) apresenta com evidencia verdadeiramente zoliana as scenas que encerram as maiores riquezas do solo, as pedras rijas e tristes, que dão a medida exata da energia brutal que deve empregar o

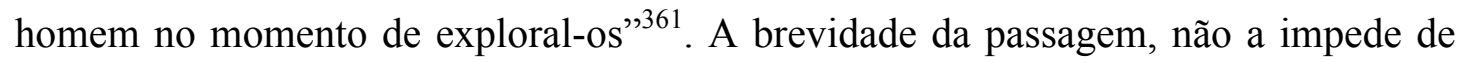
comunicar um confronto cotidiano entre a força do homem do garimpo e a resistência e solidez da rocha, expresso na tela.

No mesmo comentário, Parlagreco citava também Engenho de Mandioca, quadro exposto por Brocos em 1892 e premiado na Exposição Universal de Chicago ${ }^{362}$, como uma amostra do mesmo tipo de compromisso com a realidade.

${ }^{358}$ COLI, J. O corpo da liberdade. São Paulo: CosacNaify, 2010, p. 289 .
${ }^{359}$ É digno de nota que o escritor considerasse Édouard Manet (1832-1883) um artista com capacidade
aguda de observação da realidade, identificando-se com sua arte. Zola foi primeiro um defensor
entusiasta de Manet e depois, um amigo do pintor. Em 1866 e 1867 , escreveu comentários elogiosos ao
artista, que considerava um pintor do futuro: o inventor de uma nova maneira de pintar, livre das
convenções acadêmicas. Cf. LETHBRIDGE, R. Zola and contemporary painting. In: NELSON, B.
(ed.). The Cambridge Companion to Zola. Cambridge: Cambridge University Press, 2007; YEE, J.
The black maid and her mistress in Manet e Zola. In: DAMLE, A.; L'HOSTIS, A. (eds.) The
Beautiful and the Monstrous: Essays in French Literature, Thought and Culture. Bern: Peter Lang,
2010 ; BERG, W. J. Émile Zola and the art of his times. University Park, Pennsilvanya: Pennsilvanya
State University Press, 1992 .
360 Carlo Parlagreco foi um artista italiano, professor de História da Arquitetura na Escola Nacional de
Belas Artes. É autor de Questões de arte (1895).
361 PARLAGRECO, C. Revista Brazileira, 1895 , anno I, tomo I, p. 50.
362 Conforme anunciava a Gazeta de Notícias no dia $29 / 07 / 1893$, p. 1 . Nos Estados Unidos, o crítico
William Walton o elogiou: "Professor Brocos is one of the most industrious and versatile of these
painters, his contributions including portraits, landscapes and figures, though from an inspection of our
illustration of his 'Manioc' it would be difficult to conceive that the painter of this excellent
composition, with its demonstration of artistic judgment and sound academical training ever occupied
himself with other methods. These dusky workers, a succession of admirable studies from life, are 


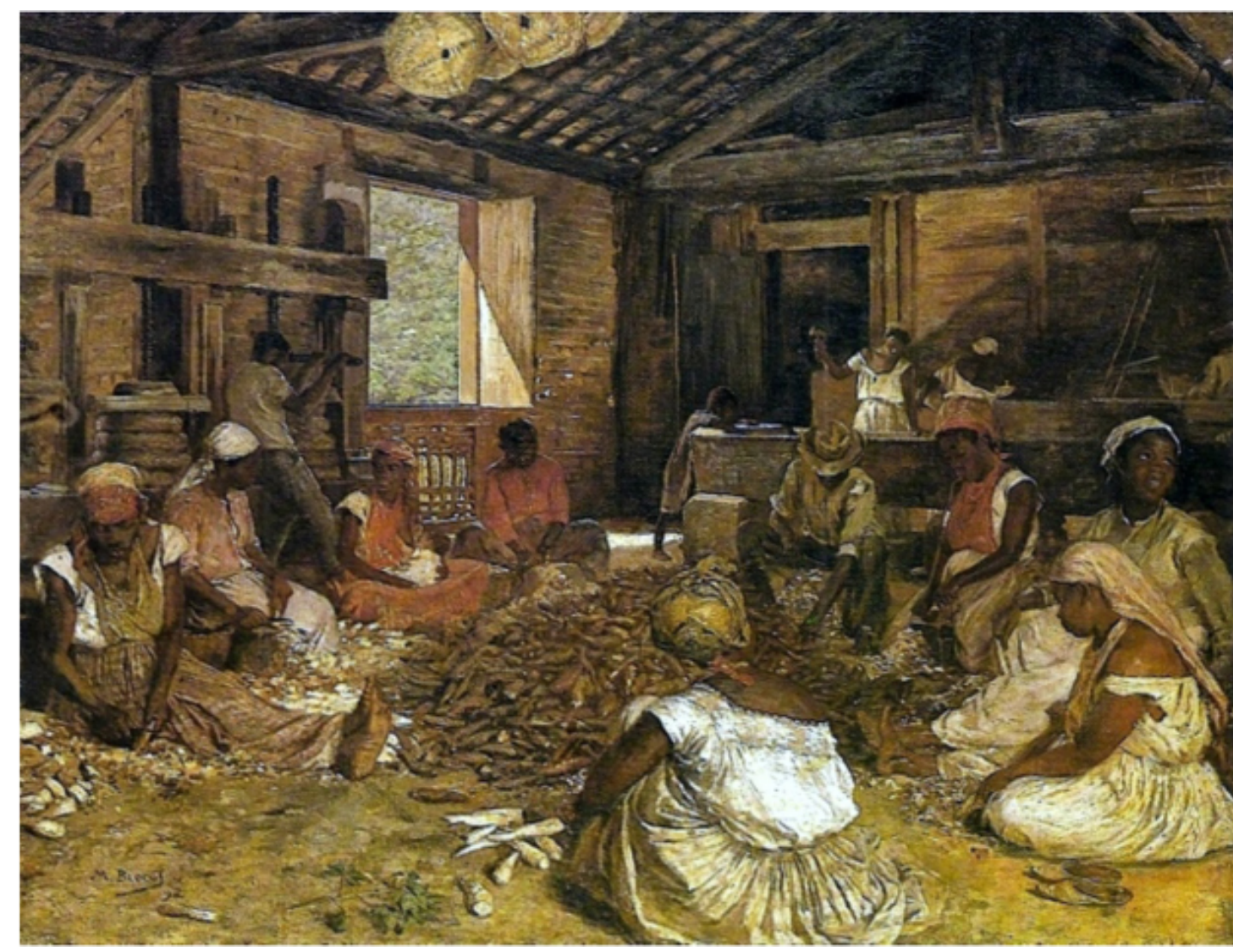

Fig. 52: Modesto Brocos. Engenho de mandioca (1892). Óleo sobre tela, $58,6 \mathrm{~cm}$ x 75,8cm. Rio de Janeiro: Museu Nacional de Belas Artes.

No interior do Engenho de mandioca, trabalham dez mulheres negras e três homens, enquanto um menino acompanha o labor dos adultos e se distrai, mexendo no tanque ao fundo. Em primeiro plano, as mulheres sentadas ao chão descascam o tubérculo, que jaz numa pilha ao centro da roda, da qual participa apenas um homem. Uma delas amamenta seu bebê. Em pé, outro homem à esquerda faz girar uma

occupied in scraping the stems of this plant for the purpose of extracting the faecula contained in them, tapioca being one of its products". WALTON, W. Art and Architecture. v. II. Brazil and Mexico. Art and Architecture. Philadelphia: G. Barrie, 1893, p. 93-96. Disponível em: http://columbus.gl.iit.edu/artarch/00254007.html. Consulta: 01/05/2013. Sobre a Exposição, cf. também BANCROFT, Hubert Howe. "Chapter the Twenty-First: Fine Arts". In: The Book of The Fair. Chicago, San Francisco: The Bancroft Company, 1893. Disponível em: $<$ http://columbus.gl.iit.edu/bookfair/ch25.html. Consulta: 01/03/2013>. Para um comentário sobre a participação dos artistas brasileiros na feira, ver DAZZI, C. C. Relações Brasil-Itália na arte do segundo Oitocentos. Dissertação de Mestrado (História), Instituto de Filosofia e Ciências Humanas da Universidade Estadual de Campinas, sob orientação de Luciano Miggliaccio, 2006. Idem. A Produção dos Professores e Alunos da Escola Nacional de Belas Artes na Exposição de Chicago de 1893. 19\&20, Rio de Janeiro, v. VI, n. 4, out./dez. 2011. Disponível em: $<$ http://www.dezenovevinte.net/obras/chicago_1893.htm>. Consulta: 01/03/2013. O pintor teve sua obra exposta nos Estados Unidos novamente na Louisianna Purchase Exposition, em St. Louis, em 1904. Um dos quadros expostos foi $A$ descascar goiabas. O livro desta mostra está disponível em $<$ http://www.ebooksread.com/authors-eng/louisiana-purchase-exposio-brazil-commisso/brazil-at-thelovisiana-pvrchase-exposition-st-louis-1904-hci/page-8-brazil-at-the-lovisiana-pvrchase-exposition-stlouis-1904-hci.shtml>. Consulta: 01/03/2013. 
manivela, ativando a moenda que tritura a mandioca. Nas fileiras de trás, duas pessoas alimentam o forno, onde se torra a farinha, enquanto uma mulher martela os pedaços de aipim mais resistentes ao processo de trituração.

O artista optou por constituir o espaço do engenho a partir de um gradiente equilibrado de variações de tons terrosos, com o marrom puxando ao vermelho e, principalmente, ao amarelo. O contraste fica por conta da alvura da mandioca descascada e das roupas brancas de várias personagens, realçada pela luz quente que rebate na persiana da janela à esquerda e forma um retângulo de calor no chão de terra. A tendência é o equilíbrio entre as cores - marrons e brancos -, reforçando o marasmo da rotina de trabalho e a monotonia das figuras cabisbaixas, de postura curvada. O silêncio é quebrado por três exceções: a lactante, que parece conversar com a colega ao lado; e a mulher à direita, que olha para fora com ares de quem responde a um chamado. Fora isso, somente os sons do trabalho e da moenda em operação se fazem pressentir em imagem. Apesar de algumas poucas expressões sugestivas, de modo geral a falta de nitidez dá o tom aos rostos das personagens, distanciando-as da minúcia de detalhes nas feições. Predominam as figuras de perfil, com sombras no rosto, que curvam a cabeça para baixo ou cujas faces estão cobertas pela aba do chapéu, o que reforça a indefinição e aproxima todas as personagens do engenho, criando uma atmosfera de comunhão. Às vezes, os corpos refletem a luz que entra pela esquerda, mas também pela frente, transformando-se por manchas claras e sugestão de suor; o branco das roupas é reluzente e, no entanto, não fere os olhos.

A cena de trabalho parece responder às motivações do naturalismo. No entanto, Engenho de mandioca encara um assunto que não constava como pauta do movimento europeu naquele momento. Aos quatro anos de promulgada a Lei Áurea, o destino da população afrodescendente pós-emancipação era evidenciado numa imagem que, em tudo, evocava a escravidão.

$\mathrm{O}$ ambiente do engenho, a totalidade de trabalhadores negros, suas roupas e adereços, tudo na cena parece transmitir a mensagem de que a vida das populações outrora escravizadas não mudara desde os tempos em que o cativeiro era lícito. E se o quadro pode ser visto como um registro de condições de trabalho localizadas, e nunca gerais, assim como no caso de Garimpeiros há ali drama humano, um quê de denúncia, voltado a mostrar a inviabilidade de uma condição que parece remanescer de outros tempos. Não obstante, a pintura dá sinais de estar lidando com o problema 
sob um novo viés, que reaparecerá em imagens futuras do mesmo autor: a cena do engenho pergunta-se sobre as condições de incorporação da população afrodescendente à República brasileira.

A questão vai ao encontro de dilemas comuns aos contextos coloniais de incidência do escravismo. Observando a arte norte-americana do século XIX, Boime identifica a recorrência de três grandes temas que se desenvolvem sob a arbitragem de uma tensão dialética entre a escravidão e sua abolição: "firstly, the inhumanity of the system and its dehumanizing effect on both slave master and slave; secondly, the question of black people's competency and their capacity to integrate into the dominant society; thirdly, their potential to rise above their "brute" status and attain the level of 'spiritual' enlightenment" ${ }^{363}$. Familiares tanto aos simpatizantes, quanto aos oponentes da prática escravista, no entender de Boime, tais eixos temáticos encontram vazão do ponto de vista conceitual, tanto quanto formal. Nos Estados Unidos, pintores como John Singleton Copley (1738-1815), William Sidney Mount (1807-1868), Eastman Johnson (1824-1906), Thomas Eakins (1844-1916) e Henry Ossawa Tanner (1869-1937), estariam, cada qual a seu modo, buscando responder a pelo menos uma dessas problemáticas.

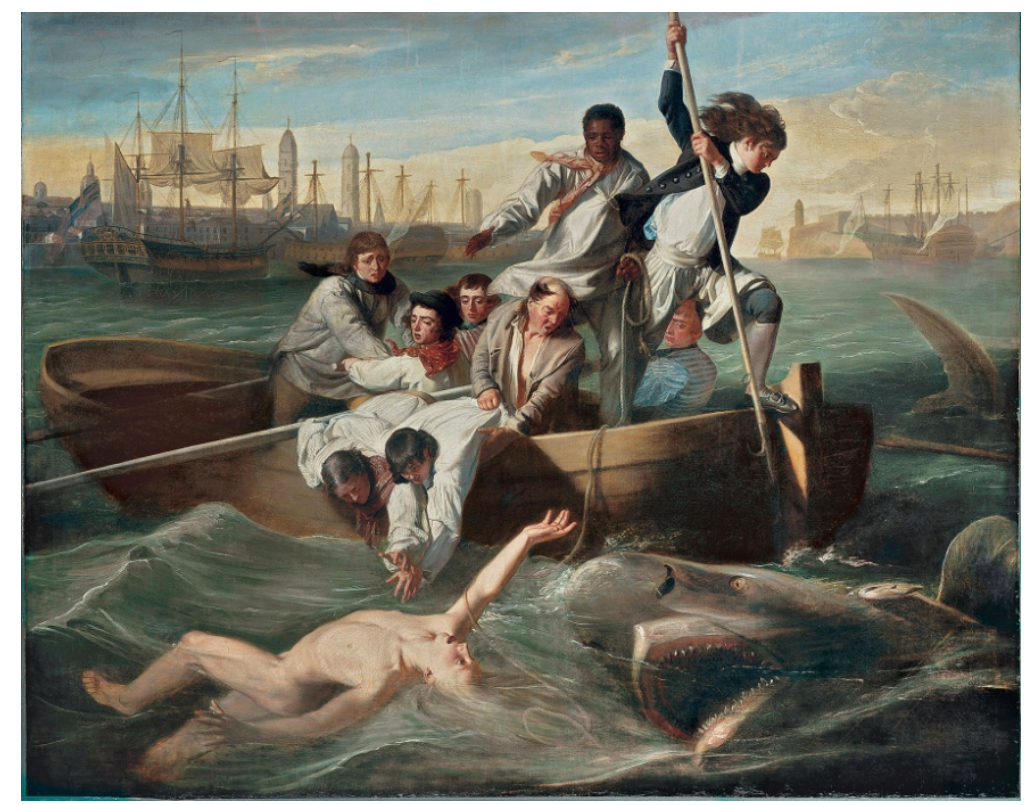

As pinturas a seguir mostram a diversidade de soluções pictóricas encontradas por artistas norte-americanos, em resposta à questão da incorporação do negro à ordem livre no marco dos debates sobre a emancipação. Para uma análise detalhada, ver Boime $^{364}$.

Fig. 53: John Singleton Copley. Watson and the Shark (1778). Óleo sobre tela, $182,2 \mathrm{~cm} \mathrm{x} 229.9 \mathrm{~cm}$. Washington, D.C.: National Gallery of Art

\footnotetext{
363 BOIME, A. The art of exclusion. Representing blacks in the Nineteenth Century. Washington\&London: Smithsonian Institution Press, 1990, p. xiv.

${ }^{364}$ Idem, ibidem.
} 

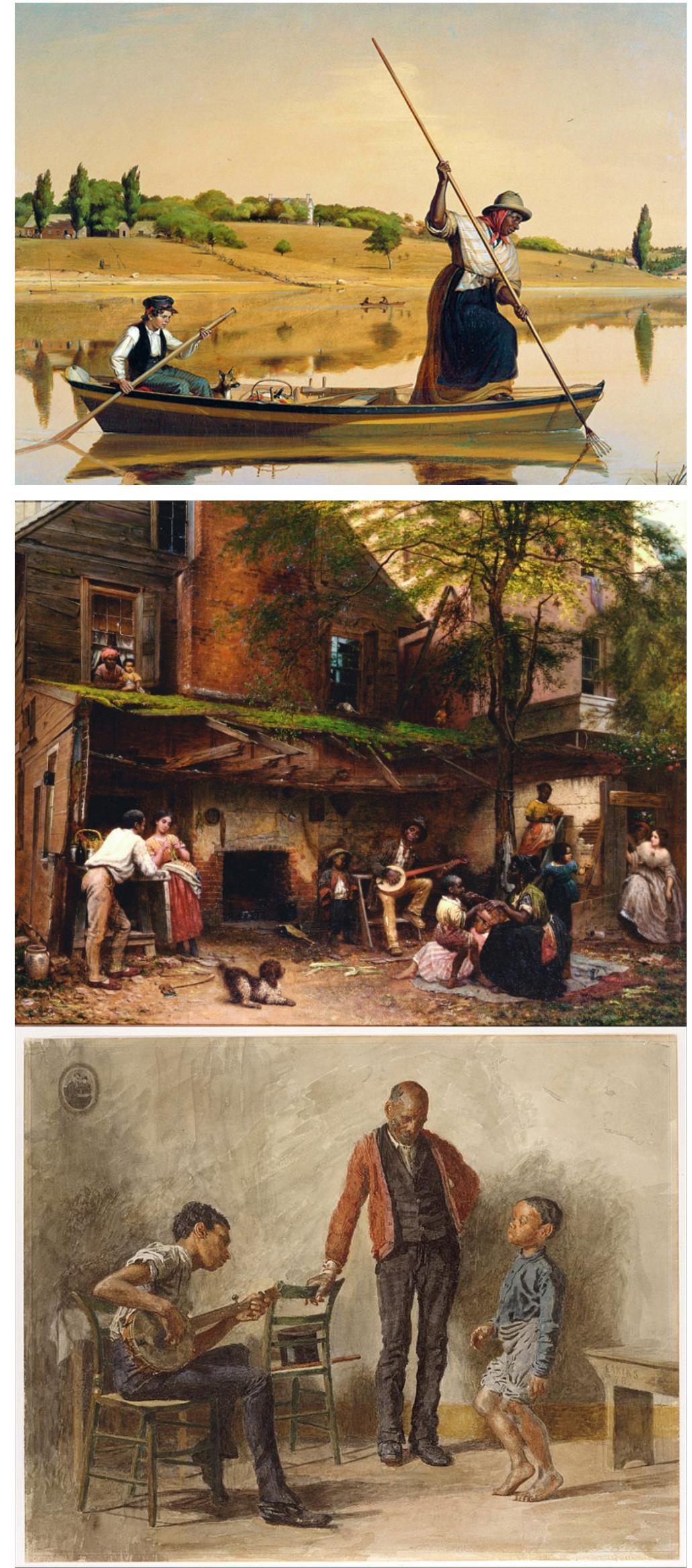

Fig. 54: William Sidney Mount.

Eel Spearing at Setauket (1845).

Óleo sobre tela, $72,4 \mathrm{~cm} \mathrm{x}$ $91,4 \mathrm{~cm}$.

Cooperstown: Fenimore Art Museum

Fig. 55: Eastman Johnson. Negro Life at the South (1859).

Óleo sobre tela, $91,4 \mathrm{~cm} \mathrm{x}$ $114,9 \mathrm{~cm}$.

Coleção particular

Fig. 56: Thomas Eakins.

The Dancing Lesson [Negro Boy Dancing] (1878).

Aquarela sobre papel, $45,9 \mathrm{~cm} \times 57,3 \mathrm{~cm}$. Nova York: Metropolitan Museum of Art 


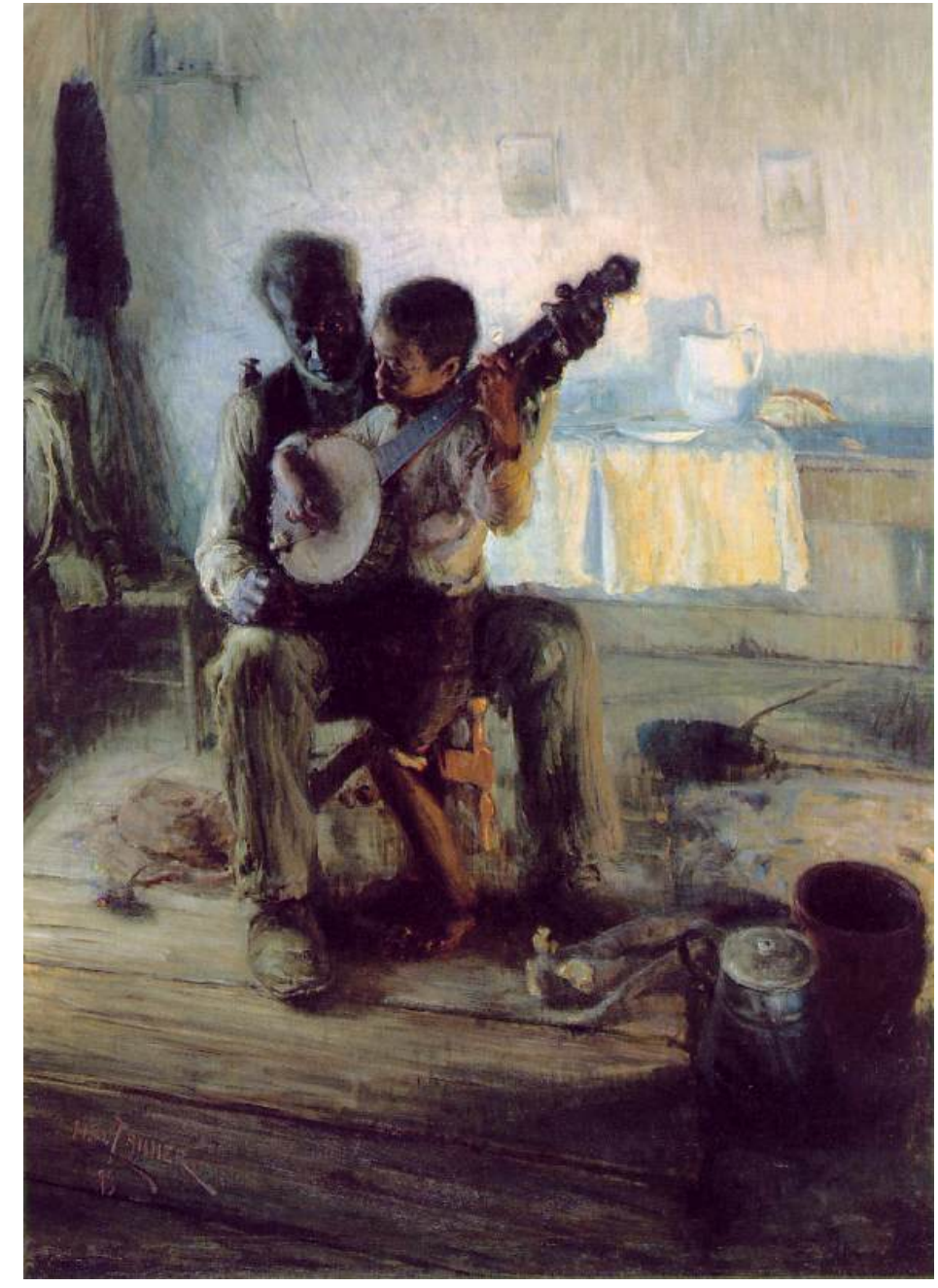

Fig. 57: Henry Ossawa Tanner. The Banjo Lesson (1893). Óleo sobre tela, $124,5 \mathrm{~cm} \mathrm{x}$ $90,2 \mathrm{~cm}$

Hampton: Hampton University Museum

No Brasil, os impasses trazidos pela escravidão para as relações entre brancos e não-brancos já haviam sido tratados por outros artistas e viajantes europeus que estiveram no país no primeiro Oitocentos - ainda na vigência do regime escravista. É particularmente interessante, sob esse aspecto, perceber como cada um parece ter encontrado suas próprias soluções, do ponto de vista formal e conceitual, para enfrentá-los.

Conforme mostram Naves $^{365}$ e Schwarcz ${ }^{366}$, até meados do século a escravidão era o principal elemento a desafiar a formação neoclássica dos artistas franceses no país - leia-se, um compromisso que assumiam, quer por força do estilo ou da convicção, com os valores republicanos franceses ${ }^{367}$. Nicolas-Antoine Taunay

\footnotetext{
${ }^{365}$ NAVES, R. A forma difícil: ensaios sobre arte brasileira. São Paulo: Editora Ática, 2007. ${ }^{366}$ SCHWARCZ, L. K. M. O sol do Brasil. São Paulo: Companhia das Letras, 2008.

${ }^{367}$ Grosso modo, se a forte conotação moral, heróica e republicana, calcada nos valores da liberdade, igualdade e fraternidade propagados pela Revolução Francesa viram nascer na Europa o estilo neoclássico, as mesmas
} 
(1755-1830), como pontua Schwarcz ${ }^{368}$, achava que nos trópicos “o verde era forte demais; o céu, muito radiante; a luz do sol brilhante em excesso"369, enquanto se valia de seu talento como miniaturista para apequenar senhores e escravos em meio à exuberância da natureza em suas paisagens. Jean-Baptiste Debret (1768-1848), em suas aquarelas sobre escravos, teria optado por dar-lhes feições e contornos indefinidos, subvertendo o princípio da limpidez do desenho. Segundo Naves, a decisão pela aquarela e outras opções formais do artista serviriam como indícios de que a técnica aprendida na Europa já não era suficiente para traduzir em termos pictóricos os modos e costumes que via no Brasil. $\mathrm{O}$ problema da forma é, aqui, crucial: embora não se trate de uma abdicação do paradigma neoclássico - suficientemente elaborado para embasar as decisões e o ofício de Debret, como argumenta Coli $^{370}$-, ele adquire toda sua complexidade no jogo ideológico, no modo de exprimir uma convicção política na aparência das coisas na França e também no Brasil.

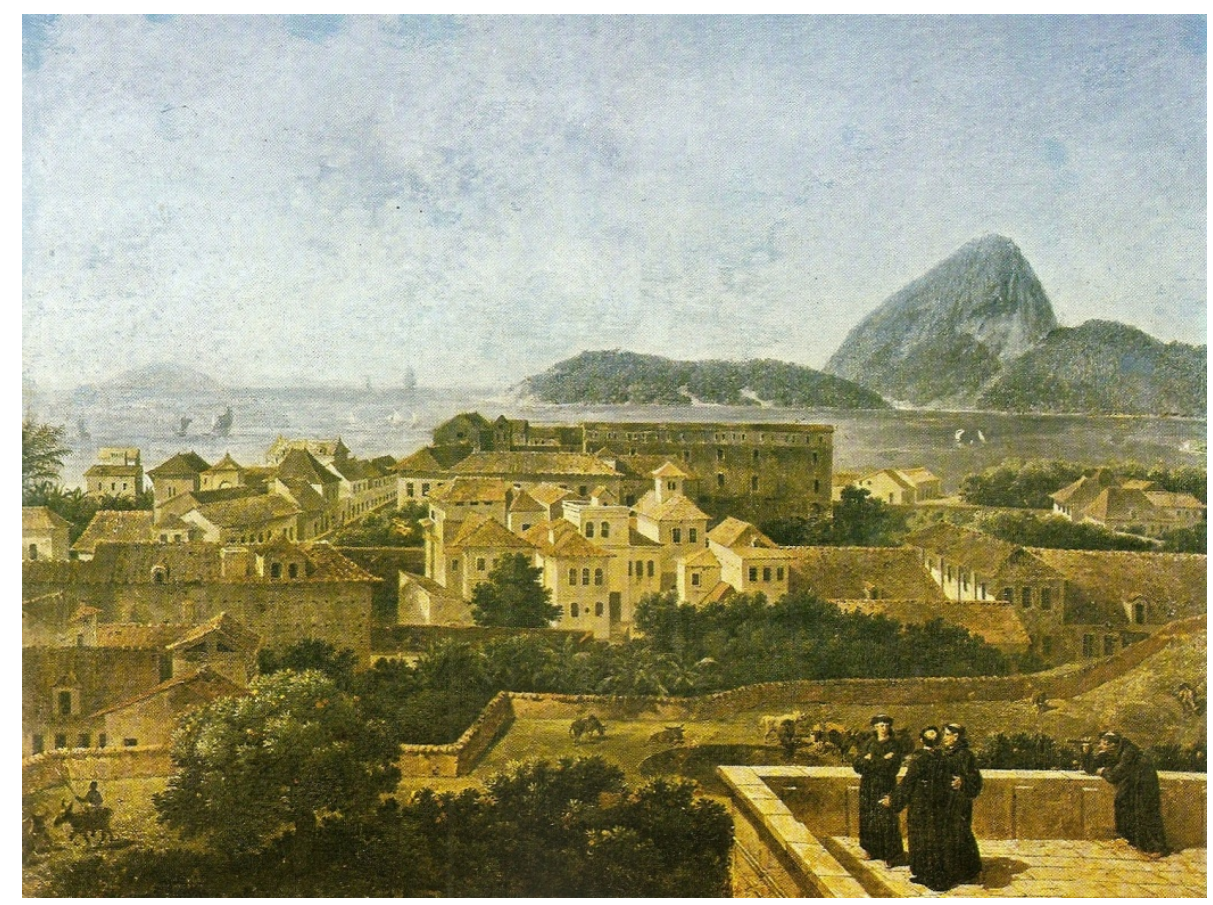

Fig. 58: Nicolas-Antoine Taunay. Entrée de la baie et la ville de Rio, de la terrasse du Convent de SaintAntoine en 1816 (c.1818). Óleo sobre tela, $45 \mathrm{~cm}$ x 56,5cm. Rio de Janeiro: Museu Nacional de Belas Artes. À esquerda de uma imagem grandiosa, um escravo de pequenas dimensões pastoreia um animal. Como analisa Schwarcz, ambos seriam vistos à época como "bens semoventes",371.

diretrizes estilísticas não podiam ser transpostas à realidade de uma monarquia escravista nos trópicos, em que tais valores estavam evidentemente ausentes. Cf. NAVES, op. cit. e SCHWARCZ, op. cit.

${ }^{368}$ Idem, ibidem.

${ }^{369}$ Idem, ibidem, p. 19.

${ }^{370}$ COLI, J. O corpo da liberdade. São Paulo: CosacNaify, 2010. Ver também STAROBINSKI, J. Os emblemas da razão. São Paulo: Companhia das Letras, 1988, para uma compreensão da relação dialética de luz e sombra que perpassa e desafia os limites do estilo neoclássico.

${ }^{371}$ SCHWARCZ, L. K. M. O sol do Brasil. São Paulo: Companhia das Letras, 2008. 


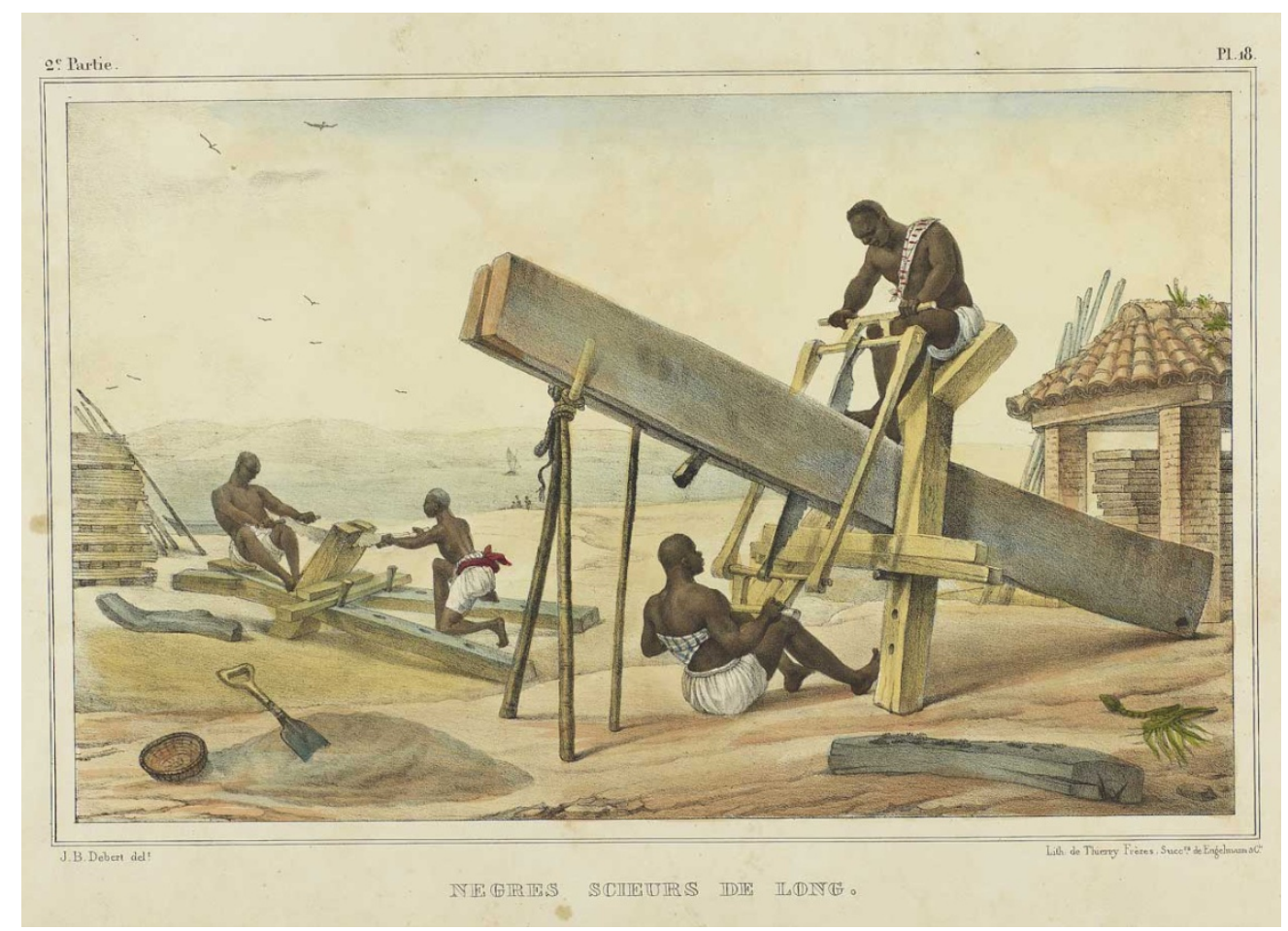

Fig. 59: Jean-Baptiste Debret. Negres scieurs de long. Voyage pittoresque et historique au Brésil.

Tomo 2, prancha 20 (1834). Biblioteca Nacional Digital ${ }^{372}$. Na análise de Naves, "o esforço dos escravos serradores, ao invés de retesar seus músculos e definir seus contornos, produz uma indefinição dos corpos"373.

Ambos os casos ilustram o paradoxo de artistas estrangeiros que, formados nos cânones rígidos e específicos de um estilo, se viram frente a frente com as idiossincrasias de um império escravista nos trópicos: ao encontrar no Brasil um contexto tão avesso ao ideal revolucionário francês, com uma natureza em tudo distinta da europeia, já não podiam pintar o que viam sem antes reposicionar as lentes e enquadramentos de que estavam imbuídos. Os casos são exemplares de um movimento do estilo que, mais que um rótulo $a$ priori, mostra-se em constante transmutação no confronto com uma dada percepção de realidade.

Mais distantes do modelo neoclássico e comumente vistas como fontes etnográficas por excelência, as gravuras que compõem a Viagem Pitoresca através do Brasil (1827-1835), de Johann Moritz Rugendas, teriam buscado explorar ao máximo a dimensão mais ideológica do estilo, lançando uma hipótese interpretativa sobre o país. De acordo com Slenes,

\footnotetext{
${ }^{372}$ Disponível em:

$<\mathrm{http}$ ://bndigital.bn.br/scripts/odwp032k.dll?t=bs\&pr=fbn_dig_pr\&db=fbn_dig\&ss=new\&disp=card \& use $=$ sh\&arg=debret,\%20jean\%20baptiste $>$. Consulta realizada a 25/07/2013.

${ }^{373}$ NAVES, R. A forma difícil: ensaios sobre arte brasileira. São Paulo: Editora Ática, 2007, p. 94.
} 
Seu trabalho, longe de ser um retrato, 'tomado' no Brasil, desenvolve como aspecto central uma tese a respeito da formação da Nação brasileira (...) Rugendas procura mostrar a formação no Brasil de um povo "mestiço", incorporado ao modo de vida europeu. Mais especificamente, ele afirma aqui a capacidade no negro de se integrar, futuramente, numa sociedade "civilizada" e de incorporar plenamente a religião cristã. Para construir esse argumento, Rugendas suaviza os efeitos desumanizantes da escravidão no País, embora sua condenação da instituição não fique em dúvida $^{374}$.

O viajante bávaro teria visto no Brasil um pretexto para a persecução de esquemas $^{375}$ consagrados da iconografia cristã, desde que a serviço daquela comprovação. É interessante notar que, para tanto, "Rugendas estava disposto até a sacrificar a autenticidade do detalhe em seus desenhos para ilustrar o que ele percebia como uma 'verdade maior",376, conforme Slenes. Assim, as litografias cuidadosamente planejadas do autor explorariam um jogo de diálogos silenciosos com imagens de episódios da Bíblia e um reforço ao argumento textual de Viagem... ${ }^{377}$.

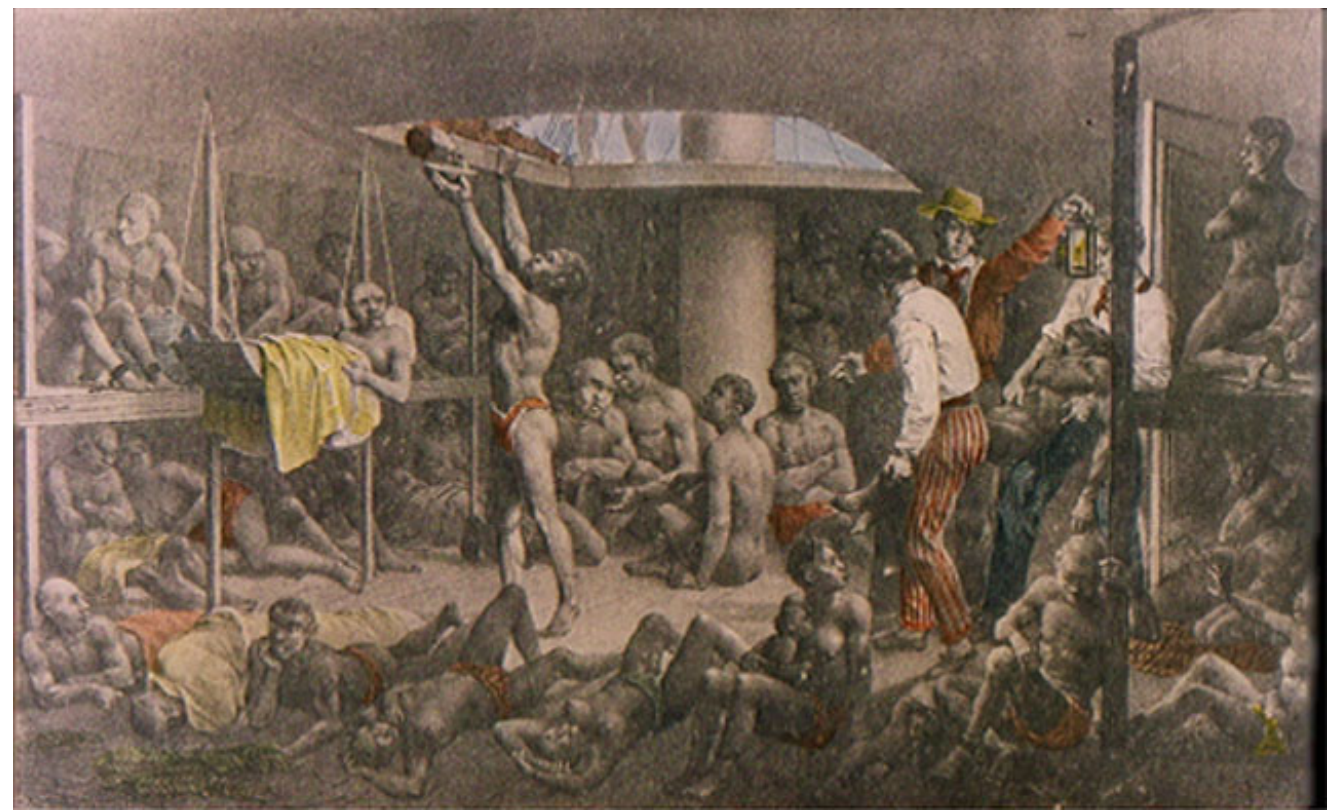

Fig. 60: Johann Moritz Rugendas. "Negres a fond de calle" (c.1830). Voyage pittoresque dans le Brésil. Paris: Engelmann, 1835. Divisão 4e, prancha 1. Rio de Janeiro: Biblioteca Nacional.

Slenes argumenta que o corpo do escravo morto na gravura de Rugendas utiliza esquemas de representação do corpo de Cristo em gravuras de Albert Dürer e Mattheus Meriam, entre outros ${ }^{378}$.

${ }^{374}$ SLENES, R. W. As provocações de um Abraão africano: a nascente nação brasileira na Viagem Alegórica de Johann Moritz Rugendas. Revista de História da Arte e Arqueologia, n. 2, 1995/96, pp. 273-274

${ }^{375}$ GOMBRICH. E. Arte e Ilusão. Um estudo da psicologia da representação pictórica. SP: Martins Fontes, 2007.

${ }^{376}$ SLENES, R. W. op. cit., p. 273.

${ }^{377}$ Se o texto de Rugendas possui autoria duvidosa, é interessante perceber a importância das imagens para atestar-lhe veracidade. Cf. Idem, ibidem.

${ }^{378}$ Idem, ibidem. 
Qualquer que tenha sido a saída adotada, a caracterização imagética das personagens não-brancas nas produções dos três estrangeiros encerra um desconcerto: os corpos retratados parecem referir-se, o tempo todo, a algo que escapa à assimilação imediata. Há ali uma incontinência da forma, espécie de indefinição incômoda de figuras que não podem ser vistas em concretude; daí o subterfúgio, o desvio de percurso do corpo para as insinuações metafóricas. São personagens que adquirem, em cada composição, uma visibilidade instável, alheia ao referente: em Debret, a indefinição dos traços e da musculatura aludiria ao horror ao sistema; em Taunay, a miniaturização faria com que se perdessem na paisagem; em Rugendas, a dimensão pessoal e corporal teria sido preenchida pelo motivo cristão - ganhando ares de transcendência. Eis o trabalho de idealização por sobre a forma supostamente extraída da natureza - quer em consonância com a tradição neoclássica ou não.

Nesse sentido, Engenho de mandioca revela-se distinto. Há evidentemente que se creditar o grande impacto do realismo e do naturalismo no intervalo que separa o quadro de Brocos daquelas obras - evitando-se assim o risco de atribuir ao passado uma estética então inexistente. De todo modo, faz-se agora marcante um compromisso com a visibilidade mais terrena das figuras da cena, que à primeira vista não mostra o intento de avançar para a elaboração metafísica. Antes, o autor lhes confere uma corporalidade supostamente exata e jamais minimizada, em que o grau de deformação aceitável assenta-se sobre a noção de mimese, bem sintetizada por Flechter: "the aim of mimetic art, in Aristotles' view, is to follow the variable course of nature, and if nature should (...) turn out to be invariable the mimetic art will collapse in an excess of liveliness by portraing that insane nature",379.

A precisão dos corpos do Engenho fala ao compromisso com a acurácia da descrição, enquanto a diluição calculada e jamais excessiva de certas fisionomias contribui para o propósito de tornar o trabalho, e não os indivíduos, o mote do quadro. As figuras humanas têm o tamanho exato e se encontram perfeitamente adaptadas ao ambiente, prontas para responder aos esforços exigidos para pôr em marcha a casa de farinha. O trabalho, talvez, seja aqui a única força transcendente, mas ainda não se constitui necessariamente como um ideal - visto que alude à escravidão, que a esta altura já deixara de ser vista enquanto tal.

\footnotetext{
${ }^{379}$ FLETCHER, A. Allegory. The Theory of a Symbolic Mode. Ithaca and London: Cornell University Press, 1995, p. 67.
} 
Assim, para além das diferenças nítidas de formação, origem e geração entre os autores - e sem nenhuma intenção de perder de vista as particularidades que os distanciam -, a tela de Brocos é fruto de um contexto já distinto. A imagem do engenho, embora alusiva ao passado escravista, inscreve-se nos primeiros anos de uma República pós-emancipação, que encarava os impasses da igualdade sob outras condições $^{380}$. Se a desumanidade do sistema terá sido um mote para Debret, Taunay e Rugendas, Engenho de mandioca parece apostar no segundo tema apontado por Boime. Mas desta vez, a inquietude quanto à integração dos não-brancos à sociedade brasileira não se entrega à visão por força de maiores elaborações sobre sua própria capacidade para incorporar-se ao mundo livre. Antes, torna-se explícita na referência à manutenção das antigas relações de trabalho - e este é o idioma que permite ao quadro modular a ideia de "competência", citada por Boime. Tem-se toda a contradição nesta fórmula: o trabalho é visto como forma de integração e, entretanto, alude ainda ao tempo da escravidão. Para o realismo/naturalismo, bastaria torná-la evidente.

Em consonância, a precisão no cuidado das figuras recebeu atenção da crítica, que procedeu pelo elogio. Vejamos, por exemplo, o que diz Gonzaga Duque:

\begin{abstract}
A raspa do engenho, em pleno dia, o circulo de negras fechando o amontoado da mandióca. Esta, cabeceante e sórna de velhice, abatida de nadegas sobre o chão, pernas estiradas, torso contorcido á direita, descasca a raiz parda que a terra alimentou e inchou; aquela, encarapitada a um tóro, vai dando conta do serviço, ventre enchumaçado e mamas pelleguentas, em accuso derreado, d'uma flacidez gasta de aleitamentos longos, sob o lenço d'estamparia, que pende do pescoço á cinta.

Vê-se bem que esse trabalho requereu grande paciencia observadora, e cada uma das figuras desse bello quadrinho, valioso tanto por seu merecimento de arte transportadora como pelo assumpto, é um estudo de typos conseguido com o mais feliz exito e constitue um excellente producto do que, na sediça terminologia dos velhos pintores, se chamava estudo de costumes. ${ }^{381}$
\end{abstract}

O crítico é sensível ao apuro com que o quadro registra o peso da vida de trabalho sobre o físico das operárias do Engenho. Duque fala de corpos exauridos

\footnotetext{
${ }^{380}$ A esse respeito, é preciso sublinhar que Brocos deixa claro que considerava a escravidão "um resto de barbaria" na época do Império, quando chegou pela primeira vez ao Brasil. BROCOS, M. A questão do ensino de Bellas Artes, seguido de critica sobre a direção de Bernardelli e justificação do autor. Rio de Janeiro, 1915, p. 95.

${ }^{381}$ GONZAGA DUQUE. "Exposição Brocos". In: Contemporâneos (Pintores e Escultores). Rio de Janeiro, Typografia Benedicto de Souza, 1929, pp. 88-89. Crítica originalmente publicada no Diario do Commercio, em 1892.
} 
pelos anos empenhados na consecução de antigas tarefas. Nas mulheres, sobretudo, a musculatura cansada alude às relações construídas pela vida na casa de farinha, a dependência que se assenta sobre o trabalho feminino: seus corpos contam o lugar a partir do qual experimentam a existência, dedicada à purificação e moagem da mandioca, e denotam os anos passados em função do sustento alheio, evocando presenças ausentes do campo visual imediato - eis, por exemplo, a força da menção aos seios flácidos pelo esforço contínuo de amamentação de uma das figuras. A descrição traz à tona outra dimensão de um realismo/naturalismo pictórico, qual seja, o poder de condensar um universo social no gesto ou no corpo das figuras. Não se procura o embelezamento, mas a valorização de uma forma de distorção mimética sutil, em graus bem dosados, coextensíveis com a composição do universo que se apresenta como natural - ou, como diria Fletcher ${ }^{382}$, uma vitalidade que angaria a identificação do público, mesmo que apresente apenas ideias fixas sobre a natureza; assim, a forma procura afirmar-se coerente com materialidades possíveis, evitando-se os elementos capazes de introduzir estranhamentos ao domínio dos conformes.

Crítica publicada em $O$ Paiz tecia um elogio à veracidade do Engenho, destacando a exatidão no desenho das personagens negras, consideradas difíceis de pintar, e elogiando a expertise técnica de Brocos neste quesito:

(...) o quadro n. 26, intitulado Engenho de Mandioca, verdadeiro tour de force e attestado do alto valor deste artista professor da Escola Nacional de Bellas-Artes.

(...) Os pretos são modelos difficilimos e poucos pintores tem conseguido pintal-os sem artificios mais ou menos engenhosos, mas Brocos attaca o assumpto em um quadro com 14 figuras, e consegue um effeito verdadeiramente admiravel.

(...)

Entre as pretas empregadas na raspa, ha tres que são dignas de attenção dos visitantes.

A primeira, de costas, está n'uma posição difficil e é de desenho altamente correcto; segue-se uma outra, pensativa, em um momento não de repouso, mas de pausa; e mais além a terceira, alegre e risonha, traduz bem o contraste de sua visinha.

Conseguir pintar essa raça com tal perfeição, dar-lhe movimento na physionomia e vida, é o mais que se pode exigir de um pintor.

Cresce o merecimento deste quadro pelo facto de ser um interior, cujo aspecto sombrio augmenta com o monte das raízes escuras; mas o artista vence todas as difficuldades e o quadro impõe-se verdadeiramente bello ${ }^{383}$.

\footnotetext{
${ }^{382}$ FLETCHER, A. Allegory. The Theory of a Symbolic Mode. Ithaca and London: Cornell University Press, 1995.

383 “MODESTO BROCOS". O Paiz, 27/07/1892. Artes e artistas, p. 2
} 
À primeira vista, portanto, Engenho de mandioca confirma a mesma propensão ao realismo/naturalismo que estaria presente em Garimpeiros. Entretanto, há certos indícios nesta pintura que a tornam refratária a tal classificação, por exemplo, o modo sugestivo de explorar o contraste entre o branco luminoso das roupas e a pele negra de algumas personagens, por vezes fazendo com que a luz que entra pela janela imprima manchas brancas sobre o corpo das figuras, por efeito do rebatimento. Trajes e luminosidades concorrem para que prevaleça a insistência no contraste de marrom e branco, que aparece inclusive na escolha da mandioca como o centro do processo: tubérculo de casca marrom, mas alvo em seu interior e que, naquela usina, se torna definitivamente uma substância clara - farinha ou polvilho -, por meio de um processo purificador ${ }^{384}$.

Tais elementos saltam aos olhos como discretas contrariedades e tornam Engenho uma espécie de equação complexa, que aproxima o registro mimético do realismo a um idealismo que se nutre das formas naturalizadas. A mandioca como metáfora não alude à ordem cósmica, mitológica ou religiosa, mas localiza-se ao nível da natureza - possibilitando uma inscrição realista/naturalista a seu idealismo. Desse modo, é possível pensar que o quadro explora princípios de determinação da pessoa pelo meio.

Acoplado como traço documental do cotidiano de trabalho, sob um tratamento condizente com o realismo/naturalismo, o contraste presente nos corpos e cenário resvala pois na finalidade metafórica. Sabe-se do peso dos debates sobre a imigração de mão-de-obra europeia naquele período e o papel que ela cumpriu para as políticas de corte racialista que advogavam pelo embranquecimento da população brasileira; diante de tal associação, motivada pelo dado de contexto, parece lícito nos perguntarmos outra vez sobre o tipo de realismo da composição: tudo ali é factível, mas ao mesmo tempo meticulosamente calculado. $\mathrm{O}$ elemento branco, assumindo a função de trazer luminosidade ao interior e permitindo uma apreciação mais nítida de

\footnotetext{
${ }^{384} \mathrm{O}$ engenho da imagem, próprio para a produção de farinha, é onde se processa a variedade "amarga" do tubérculo, de grande concentração de ácido cianídrico e, portanto, venenosa - adquirindo, portanto, o sentido de uma usina purificadora, que habilita o alimento para o consumo. Além disso, a mandioca é uma planta tipicamente brasileira, que nasce e se reproduz com facilidade em todas as condições de terreno, cultivo e clima. Sobre isto, cf. SOARES, M. C. Engenho sim, de açúcar não. O engenho de farinha de Frans Post. In: Vária história, Belo Horizonte, vol. 25, nº 41: p 61-83, jan-jun 2009, p. 74; e SILVA, H. A. Mandioca, a rainha do Brasil? Ascensão e queda da Manihot esculenta em São Paulo. Dissertação (Mestrado em História Social) - Programa de Pós Graduação em História Social, Universidade de São Paulo, São Paulo, 2008, p. 37.
} 
todos os detalhes do desenho, provoca a pergunta: poderia esta solução aparentemente técnica vir carregada de um sentido conceitual mais alargado? Estaria Brocos ensaiando uma insinuação ao embranquecimento, que trataria de modo mais direto em A redenção de Cam?

Engenho de mandioca, isoladamente, não permite ultrapassar tal conjectura. Por outro lado, uma tela como A descascar goiabas, que guarda correspondências com aquela pintura, pode ser particularmente sugestiva a esse respeito. Passemos a uma apreciação da cena.

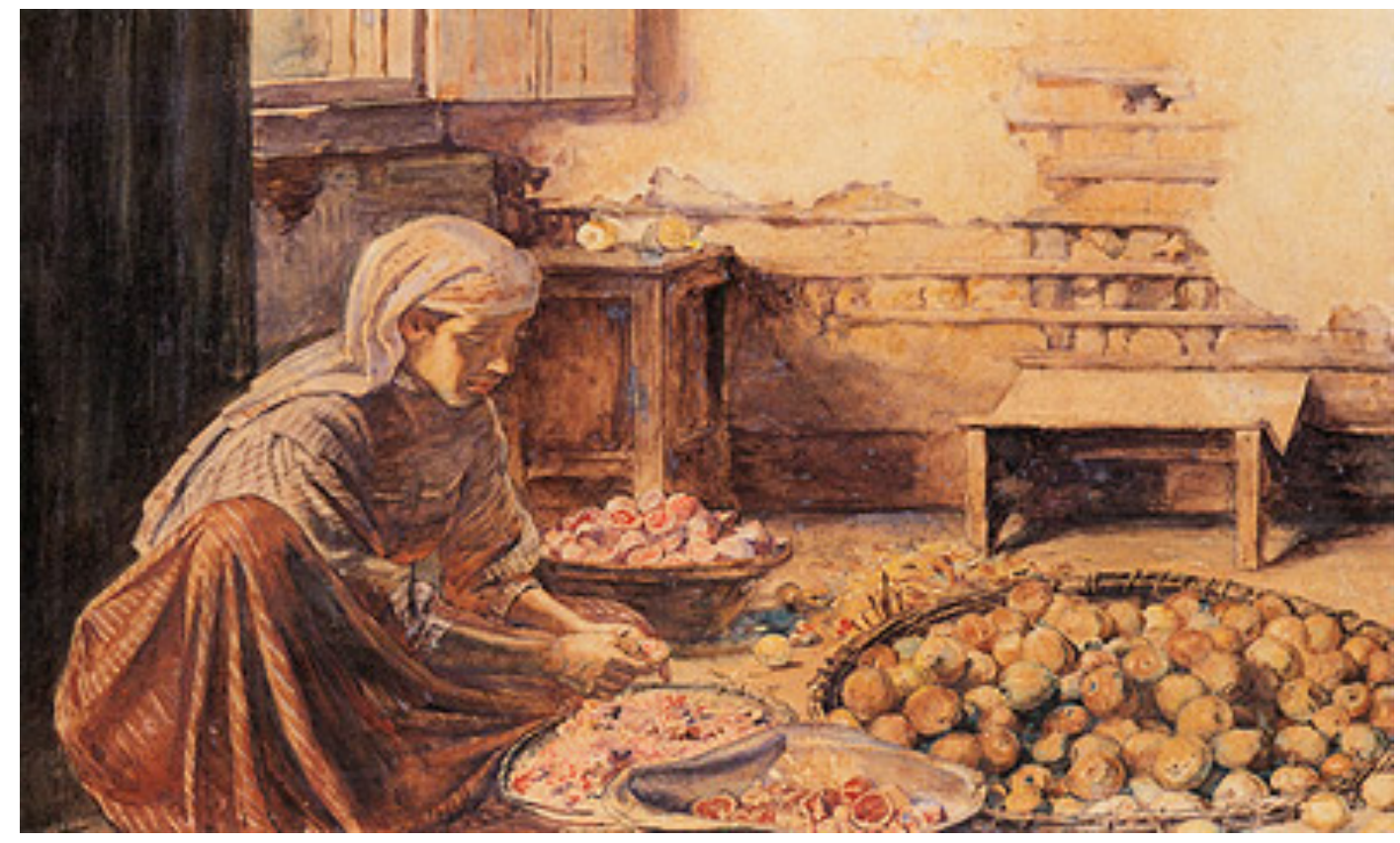

Fig. 61: Modesto Brocos. A descascar goiabas (1901). Aquarela sobre papel, $36 \mathrm{~cm}$ x 58,5cm. Coleção particular. Esta imagem também existe na forma de gravuras em que é possível perceber o uso do contraste acentuado de branco e negro no rosto da figura ${ }^{385}$.

O interior é claro. A tom vem por força do branco semi-rosado de uma luminosidade capaz de amanhecer a luz mais alva do dia. Sentada no chão, diante de um enorme cesto de goiabas, uma jovem descasca fruta por fruta, de maneira cuidadosa. O invólucro é descartado num cesto menor, enquanto a polpa vai repousar numa bacia de metal. O trabalho se faz na quietude, prenúncio de monotonia. Vestindo as listras do uniforme de trabalho, a cabeça coberta, ela imprime a curvatura obrigatória da coluna em direção ao cesto. Na fisionomia, a concentração ganha ares de sonolência. O ambiente simples se faz notar sobretudo pela caiação gasta das

\footnotetext{
${ }^{385}$ A seção de iconografia da Biblioteca Nacional, no Rio de Janeiro, dispõe de uma dessas gravuras.
} 
paredes, que revela sua estrutura de pau-a-pique. Tudo indica que a porta esteja aberta, tal como a janela que deixa entrar a iluminação pelas costas da personagem. $\mathrm{O}$ refresco da sombra no rosto serve de refúgio dos raios à visão, evitando a cegueira, e desenha uma máscara de sombra sobre na face, dividindo-a em duas manchas de cor uma mais escura, outra mais clara. O corpo é estável, maciço: ombros roliços, quadris largos, pernas fortes. Por baixo da saia, se faz ver um pé descalço. As mãos, delicadas, combinam com a suavidade dos frutos, mas não dizem trabalho. Extremidades estranhas aos próprios braços, que nascem na carnatura muscular ostensiva, parece curiosamente faltar-lhes o calejamento do cotidiano - e com isto, tornam-se uma curiosa antítese do corpo, talhado para resistir ao impacto do esforço mais desgastante.

A descascar goiabas veio a lume em 1901. Brocos, desenhista já experiente, não parece ter pintado aquelas mãos - de traçado rigoroso - por ignorância do ofício. Antes, elas apontam para uma hibridez aparentemente proposital no traçado da figura e denuncia os limites do realismo na cena. Por um lado, mostram quase que uma aposta na transcendência por meio do labor, a suavidade do espiritual em lugar da aspereza da matéria. Por outro, indicam um segundo problema encerrado na fatura. Acompanhemos a crítica do Jornal do Commercio: “A descascar goiabas', não gostamos, nem das goiabas, que são muito mirradas e informes, nem da mulata que as descasca, que tem uma orelha fora do lugar, e é desagradável na impressão geral" ${ }^{386}$ (grifos nossos).

O comentário nos obriga a olhar mais uma vez para a mulher branca em cena. Será uma "mulata"? Há um afastamento evidente entre modos de ver e, graças à declaração do articulista, somos levados a imaginar que este não é apenas o registro de um momento de trabalho, mas também uma reflexão sobre a cor da pele/caracterização racial: o quadro deflagra impasses próprios à classificação do que é ser branco, ou do que torna alguém branco, na pintura.

Chama a atenção uma proximidade com Engenho de mandioca. Repetem-se em ambas as imagens o tema do trabalho feminino, no meio rural; a sintonia de cor entre a personagem, os objetos do entorno e o meio; o fato de estar-se num interior banhado de luz; a goiaba/mandioca como um produto da terra, perfazendo na pintura o lugar da parte que concentra a direção geral do colorido do todo, além de

\footnotetext{
${ }^{386}$ NOTAS SOBRE ARTE. Jornal do Commercio, Rio de Janeiro, 10 set. 1901, p.3.
} 
estabelecer uma relação de homologia entre o humano e o natural; a posição da personagem, sentada no chão e ligeiramente curvada para a frente como algumas das figuras de Engenho. Porém, tem-se uma inversão entre as duas: a pele das trabalhadoras é marrom com contraste de branco, num caso; e "branca", com contraste de marrom no outro. A distância temporal que separa a realização das pinturas, entre 1892 e 1901, não as impede de estabelecer entre si um diálogo circunstanciado; na oposição negro/branco, construída no espaço pictórico sobretudo por meio da forma de aplicação da cor - e por extensão, luz - ambas as imagens internalizam um dilema relativo à composição racial do país e sinalizam que este talvez fosse um problema recorrente a Brocos.

Se em separado as telas não apontam para a questão, é no conjunto que ela se torna mais explícita: lado a lado, elas sugerem que, num contexto de aderência à defesa da eliminação progressiva da população de ascendência negra por meio de casamentos interraciais branqueadores e da entrada de imigrantes brancos europeus no país ${ }^{387}$, o que Brocos talvez estivesse buscando desenvolver fosse um sistema de notação capaz de problematizar os limites do embranquecimento, ou seja, a própria definição de "branco". Desse modo, o artista combinava um problema pictórico (e particularmente relativo ao uso da cor, embora não apenas), com uma preocupação que poderíamos chamar social; buscava fixar, por meio da convenção, um conceito que permitisse identificar distintos grupos raciais - e principalmente, estabelecer um parâmetro para o que poderia ser considerado a aparência de cada um, explorando no trajeto similitudes e diferenciações.

Nesse sentido, não parece fortuito que o desenho dos corpos das mulheres de Engenho de mandioca e $A$ descascar goiabas parta de esquemas similares. No segundo caso, o corpo parece desenhado para atestar sua própria capacidade de transmigração entre pólos de cor diferentes, de acordo com a incidência dos raios do sol.

\footnotetext{
${ }^{387}$ Como vimos no capítulo 1.
} 

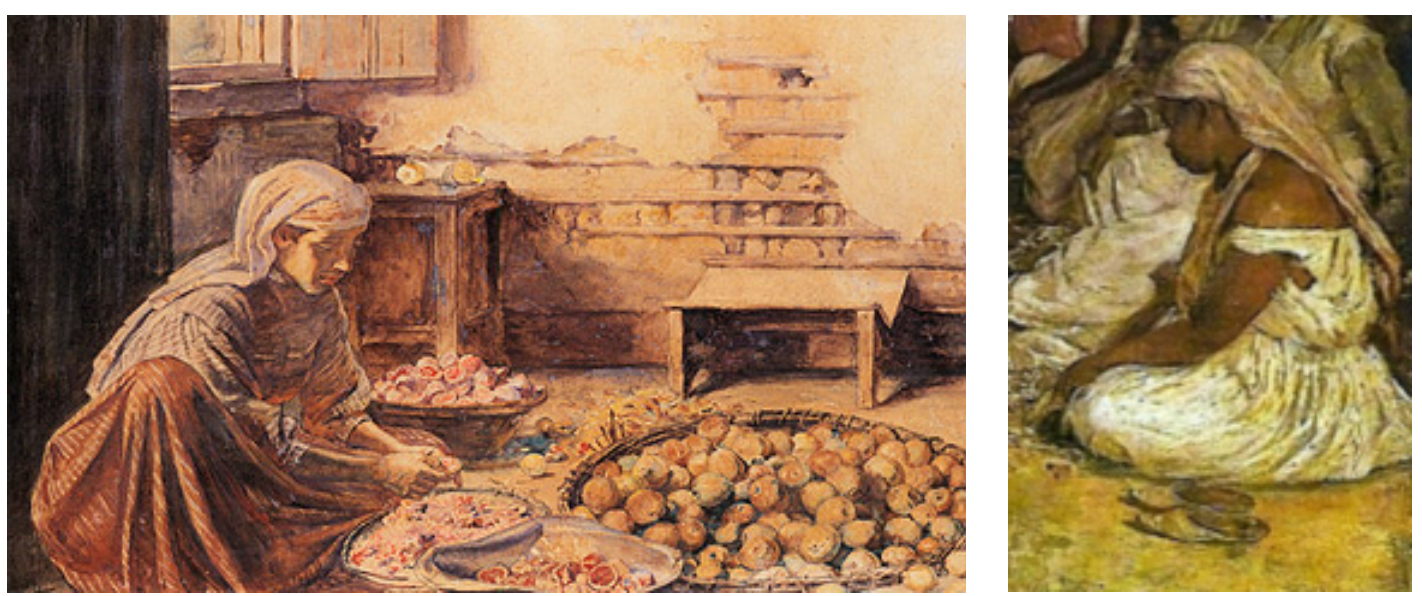

Da esq. para a dir.: Fig. 62: Modesto Brocos. A descascar goiabas (1901) [detalhe]. Aquarela sobre papel, $36 \mathrm{~cm}$ x 58,5cm. Coleção particular; Fig. 63: Modesto Brocos. Engenho de mandioca (1892) [detalhe]. Óleo sobre tela, 58,6cm x 75,8cm. Rio de Janeiro: Museu Nacional de Belas Artes

Estamos, em suma, buscando compreender se no conjunto das telas escolhidas existem indícios que apontam para um problema pictórico comum, nos termos propostos por Baxandall ${ }^{388}$. A esse respeito, as reflexões sobre Engenho de mandioca e $A$ descascar goiabas ajudam a vislumbrar os temas da classificação da cor da pele e do embranquecimento como elementos que perpassam as duas telas. Como mencionamos acima, tais escolhas formais são parte da constituição de um estilo que habilita o duplo reconhecimento das obras como frutos do realismo/naturalismo e também de um idealismo, conforme definido pelo próprio Brocos. Se a primeira pintura é elogiada pelos críticos por sua verossimilhança, também codifica no uso da cor um contraste alusivo aos dilemas raciais do país. Na segunda imagem, a incompatibilidade entre nossa própria percepção da cor da personagem e a do crítico citado serve como um alerta da existência de uma zona de incerteza que faz com abandonemos o terreno da cena realista, perguntando-nos em que medida não se trata de uma imagem de uma mulher não-branca, mas branqueada, ou seja, idealizada nos moldes do pensamento racialista.

Ainda que os dois quadros apresentados possam passar apenas como cenas de trabalho sem nenhuma relação com o tema do branquamento, há em ambos os casos elementos que permitem extrapolar tais limites. A mesma aproximação a um estilo

388 BAXANDALL, M. Padrões de intenção: a explicação histórica dos quadros. São Paulo: Companhia das Letras, 2006. 
que combina realismo e idealismo está presente na única pintura de Brocos que trata abertamente do tema do embranquecimento, qual seja, A redenção de Cam.

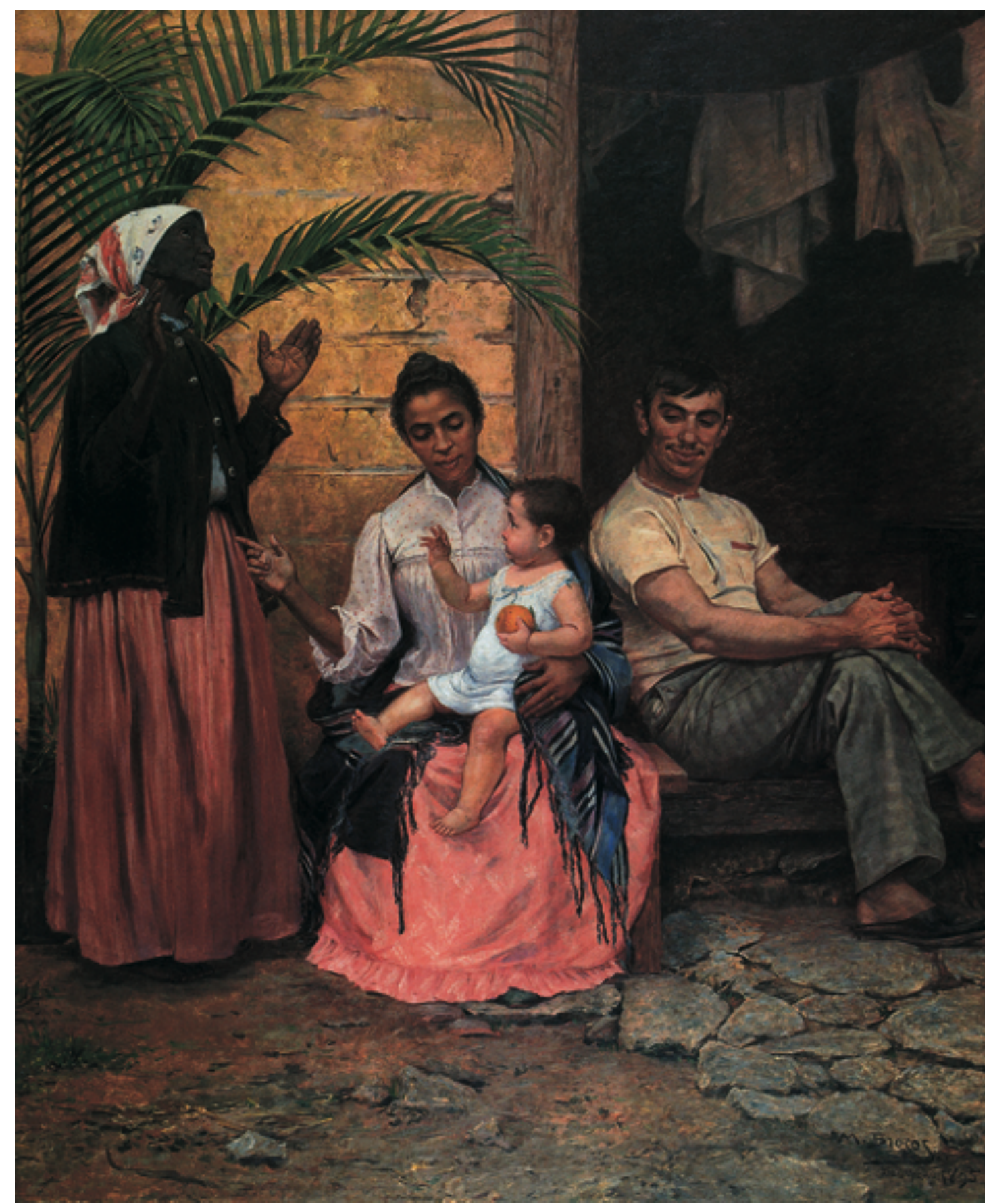

Fig. 64: Modesto Brocos. A redenção de Cam (1895). Óleo sobre tela, $199 \mathrm{~cm}$ x $166 \mathrm{~cm}$. Rio de Janeiro: Museu Nacional de Belas Artes.

Como mencionamos anteriormente, a obra premiada em 1895 explora a transformação genealógica de uma família por meio das diferenças na cor da pele de seus membros - da avó, negra, ao neto, branco. Por um lado, o quadro manifesta o 
intento de mostrar um aspecto mais sociológico, por assim dizer, da vida de uma família rural, ao gosto do realismo/naturalismo: as figuras se apresentam diante de sua casa de taipa, vestindo as roupas do campo e o hábito simples de sua característica corporal mais evidente - sendo a cor da pele um dado da maior importância. Por outro, trata-se de uma visão que se procura edificante; a mesma família é flagrada no momento singular de uma prece, cuja importância se desenha no intervalo exato da correspondência gestual entre avó e neto, fazendo a imaginação vislumbrar a criança como o motivo da oração. É verdade que a tela pode ser vista como um registro visual da religiosidade popular, expresso pelo flagrante do cotidiano. Porém, trata-se de um flagrante ensaiado, com o propósito de transmitir a ideia de que aquela senhora celebra a brancura do menino e, sobretudo, um flagrante no qual o uso da iconografia religiosa aponta para uma dimensão transcendente.

Logo, A redenção de Cam apresenta uma capacidade única de estabelecer uma cisão de caráter ambíguo entre realidade e ficção - constituindo um caso exemplar para compreender o jogo de estilo adotado por Brocos: em que medida a cena exibe um fato rotineiro no cotidiano brasileiro? Em que medida é alimentada pela projeção imaginária de um futuro branco, pelo artista e por gerações que, como vimos no capítulo 1, fiaram-se a projeções de embranquecimento que embaralhavam, elas próprias, sentidos concretos e figurados, ciência e religião?

Compreendemos, portanto, que $A$ redenção de Cam constitui uma solução original para um problema que se encontra codificado, de modos distintos, em outras pinturas do mesmo autor e torna mais evidente o estilo adotado por ele em certas cenas de costumes: um tipo de realismo idealista, que dota de verossimilhança ou reveste com ares de cotidianidade uma disposição imaginária e/ou introduz, por meio de certos recursos formais, pistas que apontam para um ideal. Numa pintura como $A$ redenção de Cam, tal dimensão ideal ou imaginária é a crença na diluição do negro em branco, elevada à condição de uma verdade futura ou possibilidade aberta. Dessa forma, a pintura serve de elemento constitutivo para uma narrativa que alimenta um racismo à brasileira - este, bastante real - e se torna uma obra paradigmática ao recobrir o incerto com o véu da certeza; mostra o embranquecimento - disposição ideológica -, por meio da impressão de naturalidade que é própria à convenção documental. 
A esse respeito, é importante aprofundar a definição realismo/naturalismo. Sob tal denominativo, como pontua Pellegrini ${ }^{389}$, entende-se a forma de exprimir uma relação particular entre indivíduo e sociedade, uma postura e método adotado em artes e literatura que, no século XIX, passa a apresentar-se como um estilo comprometido com a acuidade da representação das coisas em sua materialidade imanente, rompendo-se com as aspirações teleológicas que costumam caracterizar a arte dita idealista. É do realismo/naturalismo o apreço pela temática de costumes, que procura dotar de interesse artístico o fato comum do dia-a-dia da classe burguesa e/ou operária, com base num reconhecimento de que esse tipo de evento tem algo de urgente a oferecer à compreensão histórica.

Conforme desenvolvido por Auerbach, no clássico Mimesis, é no Oitocentos que se constitui o chamado realismo moderno, que restitui a importância do factual e do particular por sobre o perene e universal, inserindo, como marca indelével, a estória das pessoas anônimas à história geral e empregando o "tratamento sério da realidade quotidiana, a ascensão de camadas humanas mais largas e socialmente inferiores à posição de objetos de representação problemático-existencial, por um lado - e, pelo outro, a estreita vinculação de personagens e acontecimentos quotidianos quaisquer ao decurso geral da história contemporânea”390.

Tal definição contribui para pensar que, em seu realismo, $A$ redenção de Cam introduz aquela família anônima na história nacional, atribuindo a seus membros um papel social ativo na manutenção de um ideal racista. Não obstante, a obra se afasta do realismo/naturalismo, na medida em que tal história se refere a uma projeção que ora parece estranho às personagens: determinadas por uma espécie de lei geral que lhes escapa (o embranquecimento), mediante uma abordagem enaltecedora, tais figuras também permitem pensar que a ação expressa como episódio do cotidiano só pode ter pertinência como obra do acaso. No entanto, trata-se de um evento que, no marco da obra, torna-se modelar.

No capítulo seguinte, trataremos do quadro por seus aspectos formais. Por ora, é importante situar, a partir dos escritos de Brocos e de sua formação, os elementos que reforçam uma tal predisposição estilística particular de sua produção.

\footnotetext{
${ }^{389}$ PELLEGRINI, T. Realismo: Postura e método. In: Letras de Hoje. Porto Alegre, v. 42, n. 4, dezembro 2007, pp. 137-155.

${ }^{390}$ AUERBACH, E. Mimesis. São Paulo: Perspectiva, 1976, p. 440.
} 


\title{
Da arte e seus atributos: referenciais
}

O apreço de Modesto Brocos pelo idealismo torna-se evidente em seu livro Retórica dos pintores, pulicado em 1933 $3^{391}$. O volume apresenta-se como um instrumento de utilidade para o jovem artista, por meio do qual ele aprenderá a planejar seus quadros com base nos princípios das retóricas antigas - perfazendo assim um paralelo entre discurso textual/oral e pintura. Explica o autor:

\begin{abstract}
Os antigos dividiam a Retórica em quatro partes, ás quais os modernos acrescentaram uma quinta. Estas se denominavam: invenção, disposição, elocução, pronunciação e o fundo, que vinha a ser a quinta parte do discurso.

$\mathrm{Na}$ Retórica do pintor entram todos estes tratados: a invenção corresponde ao pensamento ou idéa nova que represente o quadro; a disposição é a maneira de distribuir e colocar os personagens e que o assunto esteja bem composto; a elocução refere-se á boa execução do quadro, que, na plástica, a habilidade do pincel e o colorido vai de acordo com o assunto; a pronunciação corresponde à maneira de desenhar as figuras e demais objétos que entrem no assunto e que se achem não só bem desenhados, como bem proporcionados e corretos de forma; e o fundo poderemos substituir pelo sentimento que se destaque da obra, todo em si subjetivo e que nos emociona internamente, sendo esta emoção a qualidade superior a todas as outras. E de todas as qualidades acima expressadas, quando bem executadas e harmonicamente compostas, resultará o estilo ${ }^{392}$.
\end{abstract}

Esta retórica segue ainda outras regras: a primeira delas, que "o ideal de toda obra, tanto artística como literária, deve ser o mais perfeito, ou bem a exteriorização do belo"393. Em segundo lugar, a persecução desta beleza ideal dependeria da seleção de um assunto da predileção do pintor, que lhe permitisse explorar os mais nobres sentimentos e pensamentos e tornar explícitas suas convicções. Não é fortuita, portanto, a coincidência entre fundo, "sentimento" e "assunto" no correr do texto: "O fundi, ou seja, o assunto, compreende tudo o quanto o homem pode expressar com o pensamento, sem mais limite algum que o de fazer o belo"394, escreve Brocos.

\footnotetext{
${ }^{391}$ Brocos afirma estar escrevendo essa obra desde o período que passou em Roma, pensionado pela província de A Corunha (1883-1887). Segundo conta o pintor, naquele momento seus colegas do Círculo Artístico Internacional queixavam-se de não encontrar livros de pintura para principiantes. Foi quando, passeando no Campo dei Fiori, encontrou uma antiga Retórica, cujos princípios considerou válidos para a pintura. BROCOS, M. Retórica dos Pintores. Rio de Janeiro: Typ. D’A Industria do Livro, 1933, p. 2

${ }^{392}$ Idem, ibidem, pp.10-11. Ecos de Leon Battista Alberti, sem dúvida, que adotou princípios das retóricas antigas, em particular, de Cícero e Quintiliano, em seu tratado sobre a pintura, De Pictura (1435). Ver GRAFTON, A. Leon Battista Alberti: Master Builder of the Italian Renaissance. Cambridge: Harvard University Press, 2002.

${ }^{393}$ Idem, ibidem, p. 24.

${ }^{394}$ Idem, ibidem, p. 12.
} 
Sentimento e assunto adquirem aqui a dimensão de partes indissociáveis de uma qualidade artística superior. Não há limitação temática para a pintura, desde que a obra manifeste um compromisso do artista com o valor elevado.

Mas como se definiria essa beleza, que encontra no sentimento seu lugar de expressão? Mais adiante, descobrimos que esta é uma força transcendente - espécie de lei universal captada a partir da experiência sensível, que o artista é impelido a revelar mediante um trabalho de elaboração racional. "O belo", define o texto, "é uma aspiração da nossa alma para um fim indefinido e absoluto, que não nos dá proveito imediato, mas que nos proporciona um gozo íntimo, só comparável com as cousas divinas" ${ }^{395}$. Posto que o belo ideal é tão inefável, quanto inatingível, o belo artístico constitui uma versão decantada, à luz de procedimentos específicos:

Consiste o belo em um engenhoso artifício para entresacar as partes mais perfeitas da realidade e com elas formar um todo perfeito que se aproxime da beleza, por cuja razão dão a estes [os pintores que se filiam a esse propósito] o título de seleptistas ou idealistas. (...) o idéal só pode conseguir-se comparando o que sucede com o que deve acontecer, ou seja, o mundo do sentido com o da razão ${ }^{396}$.

Há nessas sequências uma fórmula que permite compreender critérios que poderiam embasar a produção artística de Brocos. Ao aplicar à pintura o método retórico, ele se aproximava de uma tradição pictórica que prezava o modelo clássico e certos valores universais. A obra, segundo tal filosofia, tornava-se um objeto de investigação sobre o mundo sensível - um esforço calculado para torná-lo inteligível à luz de critérios éticos determinados. Mas ao propor uma transformação do mundo do sentido à luz do mundo da razão - o que sucede e o que deve suceder - este idealismo revestia-se de um desejo de moralização, de introdução, naquilo que

\footnotetext{
${ }^{395}$ Idem, ibidem, p. 25. A Retórica estipula que as demais dimensões de uma pintura encontram-se subordinadas a tal elaboração: o melhor assunto é "aquele que fale á nossa alma" e, portanto, o que é sentido pelo artista; a invenção deve "reunir todo o sabor e a expressão da verdade" - categoria que encontra a de beleza e que, como ela, transcende o universo racional -, ainda que submetida ao crivo da razão; a disposição é a origem da clareza no tratamento do assunto, contribuindo para sua verdade; por sua vez, "a elocução é a faculdade de apresentar no discurso, com facilidade e justeza, os conceitos, a fim de persuadir o auditorio e convencê-lo das verdades expressadas com alma e exaltação pelo orador" (itálico nosso); por fim, a pronunciação no discurso está para o desenho na arte: é elemento que comove o espectador, fazendo-o compartilhar da mais contundente sensação de verdade do orador/artista. O autor ainda acentua que "a invenção, a disposição e a elocução se tocam tão de perto que nos faz difícil encontrar a diferença”.

${ }^{396}$ Idem, ibidem, p. 24, grifos nossos.
} 
poderia ser registro realista, de uma projeção julgada necessária pelo artista; esta seria a condição para que um quadro pudesse aproximar-se da beleza ideal.

A noção de idealismo, como é sabido, remonta a Platão e encontra-se em conformidade com o modelo exposto acima. Grosso modo, ela parte do princípio da existência de ideias universais, independentes dos objetos em que são percebidas, e portanto transcendentes ${ }^{397}$.

No que se refere à elaboração formal, um exemplo notório de arte idealista é o estilo neoclássico da escola de Jacques-Louis David (1748-1825), que nasce como um produto da Revolução Francesa e em conformidade com os mesmos ideais. Trata-se de um tipo de produção que encontra seus modelos de verdade e beleza em certas formas recuperadas de um passado greco-romano e renascentista, que poderíamos resumir à simplicidade e retidão da linha, exatidão nas proporções do desenho, equilíbrio e força geométrica. É comumente atribuída, na explicação do estilo neoclássico, a metáfora de elaboradas edificações pictóricas, lineares, econômicas e funcionais, em cujo interior se procura conter as manchas de cor e domesticar a aplicação das sombras - vistas como qualidades alusivas ao sentimento e, portanto, avessas à razão ${ }^{398}$. Schwarcz, em diálogo com uma vasta tradição de autores que se dedicaram ao estudo do gênero, resume a fórmula: para os neoclássicos, "a arte deveria ser lógica, emocionalmente pura e moralmente elevada, assim como as qualidades estéticas tinham conotações éticas precisas: verdade, pureza, honestidade"399.

Retórica dos pintores exprime a seu modo, portanto, uma afinidade direta com o idealismo, traço caro ao modelo neoclássico. Em contraposição, nas páginas daquele livro realismo e naturalismo se tornam tendências equivocadas, que teriam aberto mão da beleza ideal para assumir "como finalidade a imitação servil da natureza"400, admitindo "indistintamente o belo como o disforme, o bom como o mau"401. Essa posição desafia as apreciações dos críticos, que tenderam a ver a pintura de Brocos como realista - a exemplo daqueles que citamos mais acima.

\footnotetext{
${ }^{397}$ Evidentemente, o debate sobre as definições do realismo e do idealismo pode ser bastante aprofundado - o que foge aos limites deste trabalho. É irresistível, por exemplo, citar a definição de Hegel, para quem "o belo se determina desse modo como aparência [Scheinen] sensível da Ideia". HEGEL, G. W. F. Cursos de Estética. São Paulo: Edusp, 2001, p. 126.

${ }^{398}$ STAROBINSKI, J. Os emblemas da razão. São Paulo: Companhia das Letras, 1988.

${ }^{399}$ SCHWARCZ, L. K. M. O sol do Brasil. São Paulo: Companhia das Letras, 2008, p. 57.

${ }^{400}$ BROCOS, M. Retórica dos Pintores. Rio de Janeiro: Typ. D’A Industria do Livro, 1933, p. 22.

${ }^{401}$ Idem, ibidem, p. 24.
} 


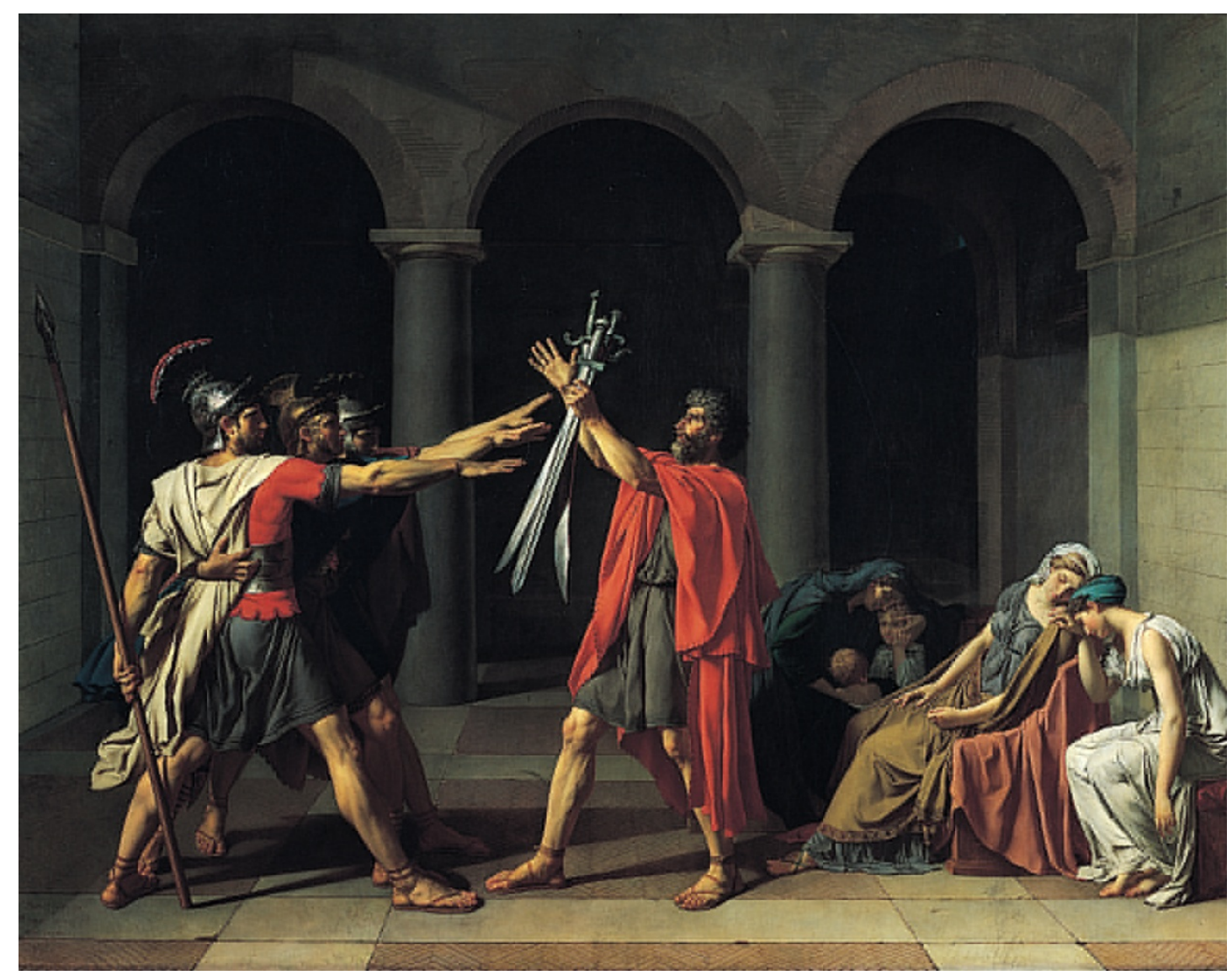

Fig.65: Jacques-Louis David. Le serment des horaces. 1784/5. Óleo sobre tela, 3,3m x 42m. Paris: Musée du Louvre.

Obra que sintetiza a fusão entre qualidades morais e pictóricas no estilo neoclássico, O juramento dos Horácios mostra os irmãos da família dos Horácios jurando fidelidade a Roma, que partirão para defender em guerra contra a cidade de Alba Longa, segundo narra Tito Livro. Tem-se uma ação concentrada no núcleo formado pelos irmãos e seu pai, que segura as espadas dos três, em contraste com o retraimento das mulheres inconsoláveis. Em termos formais, destaca-se a geometria precisa da construção arquitetônica, que demarca os lugares dos jovens Horácios, do velho e das mulheres e crianças; e o peso do ângulo preciso, da linha reta na caracterização da postura das figuras masculinas, de pernas abertas em "V" e tronco ereto; e os braços que conduzem em linha reta para a mão que segura as espadas, uma delas formando um ângulo de 90 graus. Enquanto isso, as posturas e desenho das mulheres valorizam as linhas curvas. Os Horácios, por sua corporalidade e postura, se aproximam à ideia de racionalidade e equilíbrio da arquitetura romana. A palheta é suave e valoriza as cores da bandeira da França, sendo que uso do vermelho no pai e no irmão mais à frente contribuem para tornálos pólos de atração para o olhar, em torno das espadas ${ }^{402}$.

\section{É preciso reconhecer o lapso de quase 40 anos que separa Retórica dos} pintores de telas como Engenho de mandioca e Garimpeiros, por exemplo. Dada a distância, seria legítimo pensar numa fase realista/naturalista de Brocos, entre a década de 80 e o início dos anos 90 . De outro modo, como avaliar o impacto, sobre o artista, da tradição que se tornaria marcante em seu país de nascimento? Falamos de

\footnotetext{
${ }^{402}$ Para citar duas análises, confira STAROBINSKI, J. Os emblemas da razão. São Paulo: Companhia das Letras, 1988; e COLI, J. O corpo da liberdade. São Paulo: CosacNaify, 2010.
} 
uma Espanha que, como aponta Leonard Williams (1871-?) $)^{403}$, se consagrava como "a terra dos realistas":

\begin{abstract}
Spain is above all other lands the land of realists; that is, in art, of painters of the actual. From first to last, the life work of Velazquez, which consists of portraits, ladscapes, genre, and renderings of so-called mythological or sacred subjects, is real and therefore actual. It is completely and consistently non-retrospective, non-archaic. All of it is truthfully to be defined as portraiture, using this term not in the circumscribed and ordinary sense, but as it was pointed out by Bastien-Lepage, who wisely said: "I believe that everything in nature, even a tree, even still-life, should be treated as a portrait. For so it is, a portrait; and all painting is or should be portraiture" ${ }^{404}$.
\end{abstract}

A citação alude ao caráter particular assumido pelo realismo em território espanhol. Ali, o estilo tornou-se a forma da arte mais genuinamente nacional, passando a ser definido por sua capacidade de incorporar tendências, como as experimentações de luz e cor do impressionismo, por exemplo, mas sempre com os pés fincados no solo da tradição velazquista e goyesca - sorte de realismo de origem, avant la lettre, segundo o analista. Tudo, em função de expressar o prosaico, o atual. É digno de nota, a tal respeito, que próprio Williams reconhecerá o caráter assombrosamente palpável das criaturas mitológicas e dos anões de Velásquez (15991660) - que parecem passar ao longe do universo fantástico, para impor-se como evidências cruas da realidade. É este o artista matriz de uma linhagem de pintores que assumiam a temática de costumes como um compromisso urgente, fortemente representados nas últimas décadas do Oitocentos e as primeiras do Novecentos.

Segundo Fernandez e Pena ${ }^{405}$, dita tradição é fruto da oposição fundante entre centro e periferia, que marca os dilemas da modernização do país: Madrid - e, por extensão, Castela -, tornava-se aos olhos das províncias o lócus de uma modernidade artificial, enquanto as segundas seriam a verdadeira Espanha, cada qual auto-definida como detentora de uma identidade regional singular e autêntica. No que se refere à arte, na segunda metade do século XIX ganha força a ideia dos grandes centros como

\footnotetext{
${ }^{403}$ Leonard Williams foi um pesquisador norte-americano dedicado à arte e cultura espanholas e membro ativo da Hispanic Society of America, com base em Nova York.

${ }^{404}$ WILLIAMS, L. Introduction. In: Catálogo de exposição de Joaquin Sorlla Y Bastida. Exhibited by The Hispanic Society of America, February 8 to March 8, 1909, p. 47.

${ }^{405}$ PENA, C. Presentación. In: PENA, C. (org.) Centro y Periferia en la Modernización de la Pintura Española. Catálogo de Exposição. Madrid, Palácio de Velázquez, Bilbao, Museo de Bellas Artes, 1993-1994. Ver também os demais ensaios desta coletânea e FERNÁNDEZ, X. J. B El Contexto Cultural Gallego (1880-1914) (La cultura urbana). In: Isidoro Brocos (1841-1914). Catálogo de exposição. Museu de Bellas Artes de A Coruña, 24/11/1989.
} 
espaços dominados pela influência francesa, entregues ao artificialismo importado dos estilos neoclássico e romântico. Em contraposição, o realismo, verdadeiro estilo espanhol, só poderia sobreviver nas paragens mais recônditas do país, redutos dos costumes nacionais mais legítimos.

É expressiva a maneira com que o crítico galego Chamoso Lamas (19091985), por exemplo, exalta o nascimento do realismo: a seus olhos, esta é uma corrente que, surgida na década de 1850, “condena todo aquél arte de guardarropía, de bambalinas historicistas, falsamente evocadoras de un pasado sepultado y yerto que habían aportado las trasnochadas aúras románticas"406. Segundo Lamas, com o realismo "se impuso, con suave decesión primero, pero con inusitada fuerza después el grito de retorno al presente y al verdadero, a la naturaleza y a la realidad" ${ }^{\$ 07}$. Segundo tal perspectiva, o realismo é visto como um fenômeno nacional, e não como uma importação estrangeira falsa ou inadequada à realidade (como acontecia com o neoclássico e o romantismo); para o autor, seu diferencial residiria na liberdade formal e num anti-academicismo escancarado. Agora, tinha-se um estilo que parecia brotar da própria existência e, portanto, o único genuinamente espanhol ${ }^{408}$.

A conexão de Modesto Brocos com tais tendências pode ser compreendida no contexto de suas relações familiares, em particular no convívio próximo com o irmão, Isidoro. O escultor e gravurista, onze anos mais velho que Modesto, é considerado um dos expoentes do chamado rexurdimento (renascimento) galego na pintura, um movimento que buscou afirmar o valor das tradições e da identidade local, em contraposição a Madrid. Nesse sentido, o rexurdimento se constituiu como um dos braços da tendência mais geral à eclosão, na Espanha, de uma série de regionalismos artísticos que se opunham ao centralismo castelhano. Conforme explicam Pena e Fernande ${ }^{409}$, tais movimentos tinham em comum o propósito de afirmar identidades locais, questionando a adoção do tipo sevillano como a síntese do caráter espanhol.

\footnotetext{
${ }^{406}$ Idem, ibidem, p. 59.

${ }^{407}$ Idem, ibidem, p. 59.

${ }^{408}$ Como não pensar em Courbet, cuja definição de realismo dizia respeito não ao conjunto do mundo visível, mas àquela parte mais fortemente ligada à experiência do artista - o mundo que ele conhecia? Tal mensagem parece ter ganhado enorme adesão na Europa e seu valor estava em afirmar que a arte prescindia do rigor acadêmico, chamado o artista para uma atitude sobretudo política, comprometida com seu povo e/ou classe. Ver COLI, J. O corpo da liberdade. São Paulo: CosacNaify, 2010.

${ }^{409}$ PENA, op.cit.; FERNÁNDEZ, X. J. B. El Contexto Cultural Gallego (1880-1914) (La cultura urbana). In: Isidoro Brocos (1841-1914). Catálogo de exposição. Museu de Bellas Artes de A Coruña, 24/11/1989.
} 
Ao comentar os impasses da modernização galega, Fernandez ${ }^{410}$ sublinha que a reação cultural dessa província ao centralismo de Madrid se deu mais fortemente na cidade de A Corunha, núcleo urbano mais populoso da região, em torno de um grupo de intelectuais que incluía escritores como Rosalía de Castro, Manuel Murguía e Eduardo Pondal; e artistas como Dionísio Fierros, somado a Isidoro Brocos ${ }^{411}$.

Expoente da tendência, a obra escultórica de Isidoro é tida como um retrato fiel da vida da população mais simples e dos hábitos do campo. O escultor mantinha um compromisso realista, no dizer dos críticos, na medida em que se colocava em pé de igualdade com seus modelos, compartilhando com eles um gosto especial pelo prosaico que parecia resumir também a própria existência. Nesse sentido, é exemplar a observação de Balsa de la Vega $(1859-1913)^{412}$, para quem o artista,

viviendo la vida de sus modelos, connaturalizado con ellos, aprecia y siente hasta el detalle más insignificante de la vida campesina (...) Porque [Isidoro] Brocos es un labriego gallego. Su temperamento es de aquellos que aguanta a pie firme todo un palique de cualquiera de sus modelos, respecto del tiempo, de la cosecha, de la vaca; y se interesa en la conversación, mientras tanto trabaja con el palillo al barro y da forma al tipo $^{413}$.

O texto remete imediatamente a obras como $O$ cego dos monifates (1909); $O$ velho da sanfona (s.d); e A parva (s.d). Mas se de fato Isidoro dedicou-se ao regionalismo, há certos elementos que parecem emblemáticos em sua trajetória, ao sugerir o peso da emergência e afirmação dos regionalismos - e da memória construída em torno do realismo na Espanha - por sobre os caminhos percorridos pelo artista. Assim, o principal conflito experimentado por Isidoro parece ter sido o de conciliar a necessidade de formação em centros como Paris e Roma, além de Madrid, com a ascensão destas tendências regionalistas. O próprio Manuel Murguía recorda as enormes dificuldades enfrentadas por Isidoro (e também Modesto Brocos) na Galícia:

\footnotetext{
${ }^{410}$ Idem, ibidem.

411 Justamente por seu caráter de crítica à modernidade, uma das metáforas mais presentes nesta recuperação é a da escravidão que, sobretudo na produção literária, fazia referência a uma Galícia idílica, que se via escravizada por uma Castela tirânica e individualista. Um exemplo é o poema Cantares gallegos, de Rosalía de Castro, diz: "Castellanos de Castilla/tratade ben ós gallegos/cando van, van como rosas; cando véná vén como negros".

${ }^{412}$ Rafael Balsa de la Vega, crítico de arte, contribuiu para a exaltação do realismo espanhol.

${ }^{413}$ VEGA, R. B. de la. Artistas y críticos españoles - siluetas de pintores, esculptores y críticos. Barcelona, 1891, 161-169.
} 
Si se necesite todavía, algo que de manera palpable y como quien dice, terminante, nos diece a conocer, no solo lo imperfecto, sino lo inútil de la actual enseñanza artística en las cuatro províncias hermanas, bastaria el ejemplo de los dos hermanos Brocos para probar de uma vez para siempre que nuestros artistas no encuentran en su pátria los elementos necesarios para su educación y adelanto en el difícil camino del arte ${ }^{414}$.

O trecho sintetiza o conflito entre um compromisso do artista com sua terra natal (visto quase como uma obrigação) e a impossibilidade de receber ali mesmo a formação adequada, indicando a precariedade das instituições de ensino artístico locais e a necessidade de buscar o aperfeiçoamento no exterior. Mas Murguía também deixa entrever a dificuldade de desenvolver um estilo propriamente realista em meio à formação no estrangeiro. No caso de Isidoro Brocos, essa experiência é recontada por seus biógrafos como a fonte de um episódio significativo: ao regressar de um período de estudos na Escola de Belas Artes de Paris e de uma passagem pela Itália, o escultor trouxe à Espanha, para a Exposição Nacional de Belas Artes, a obra de inspiração clássica intitulada Os últimos momentos de Herodes (1878), que recebeu os elogios do júri da capital e a terceira medalha do concurso. Apesar da recepção calorosa do centro do país, ao chegar à Galícia a mesma escultura foi tomada com rechaço pelos críticos, que a consideraram artificial. Chamoso Lamas eternizou o episódio como uma prova de que, por força da experiência parisiense de Isidoro, "su arte se había desgalleguizado, se había sumido en los arcanos de la erudición, de los conceptos que solamente hablan a la mente y no a los sentimientos"

Por trás da recusa, os comentaristas reafirmavam a um só passo o gosto pelo realismo e a discordância do aval recebido em Madri, afirmando que a verdadeira arte deveria nutrir um compromisso com sua terra. Fica patente o episódio, portanto, como um exemplo de como a polarização centro-periferia podia inviabilizar certas opções estilísticas para um artista que se propusesse a ficar na província, como fez o Isidoro

\footnotetext{
${ }^{414}$ MURGUÍA, M. Nuestro pensamiento. La Illustración Gallega y Asturiana, no 1, Madrid, 20 de marzo de 1879.

${ }^{415}$ LAMAS, M. C. "Isidoro Brocos". In: Isidoro Brocos (1841-1914). Catálogo de Exposição, Museu de Bellas Artes de A Coruña, de 24 de nov. a 22 de dez., 1989, p. 66. Isidoro é conhecido como um dos primeiros professores de Pablo Picasso, que este artista gostava de lembrar por seu vanguardismo: graças à formação em Paris, Brocos lhe transmitia ensinamentos sobre tendências ainda negligenciadas na Galícia, como o impressionismo, e por isso era bastante criticado por alguns colegas da Academia de Belas Artes de A Coruña. Ver Picasso Joven. A Coruña: Fundación Pedro Barrié de la Maza, Conde de Fenosa, 2002. Chan, V. Rubens to Picasso: Four Centuries of Master Drawings. Catálogo de Exposição: Fine Arts Building Gallery, University of Alberta, Sept. 16 - Oct. 30, 1995; Richardson, J., McCully, M. A life of Picasso (1881-1906), vol. 1. Knopf, 2007.
} 
Brocos - e isto sem discutir o mérito de seu entusiasmo com o projeto de valorização da cultura galega, a que se dedicou ao longo da vida.

Como se pode observar nas Figs. 66 e 67, as diferenças de temática, material e estilo entre $A$ parva e Os últimos momentos de Herodes, de Isidoro Brocos, são marcantes:

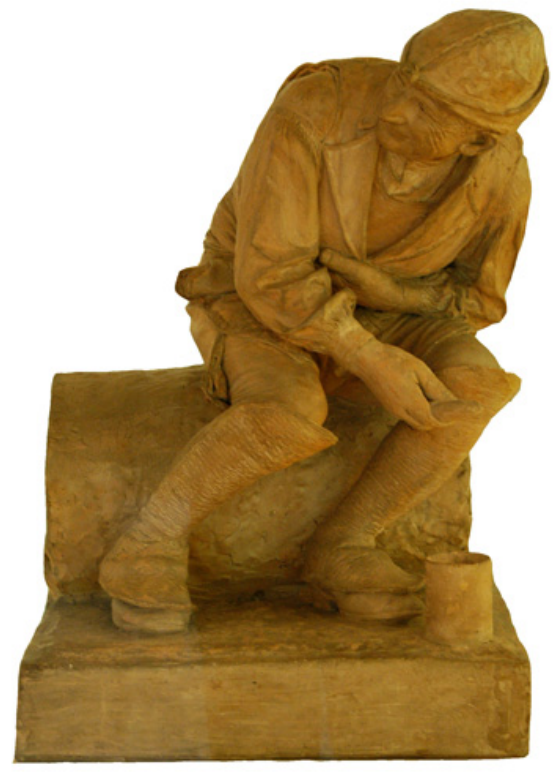

Fig. 66: Isidoro Brocos. La parva (c. 1887). Escultura em terracota e gesso, $60 \mathrm{~cm} \mathrm{x} 42 \mathrm{~cm} \mathrm{x}$ $43 \mathrm{~cm}$. A Corunha: Museu de Belas Artes

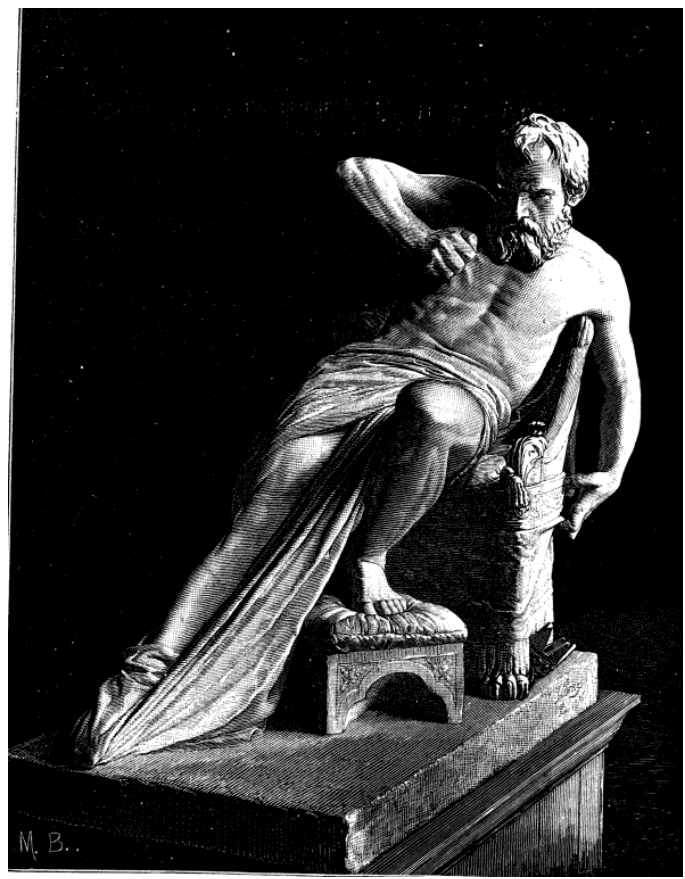

Fig. 67: Isidoro Brocos. Os últimos momentos de Herodes (1878). Ilustração de Modesto Brocos para A illustración Gallega y Asturiana, n. 8, 20 de março de 1979 , p. 1 .

Não há como auferir com precisão o impacto do realismo espanhol, de modo geral, e do regionalismo galego, em particular, sobre Modesto Brocos, mas é possível imaginá-lo. Encontramos ainda hoje a atribuição ao pintor, por parte da crítica da Espanha, do estilo naturalista: de acordo com Massé, “o vemos [a Modesto Brocos] posicionarse a carón dun grupo de pintores que rexeitando as propostas máis novidosas do momento prefieren actitudes realistas máis conservadoras, que amosan interese por unha pintura máis centrada na comunicación directa coa natureza e o achegamento á vida cotia"416. A pesquisadora segue os passos de López Vázquez, para quem "Modesto Brocos é un naturalista ecléctico, que recolle as diversas tendencias vixentes na pintura oficial europea nos anos finais do século XIX"417.

\footnotetext{
${ }^{416}$ MASSÉ, M. C. Modesto Brocos. Artistas Galegos, Ed. Nova Galícia, 2000/1, p. 9.

${ }^{417}$ VÁZQUEZ (s/referência) apud MASSÉ, op. cit., p. 8.
} 
De fato, há certas telas produzidas pelo artista na Galícia que demonstram afinidade com o projeto de recuperação da identidade regional, por exemplo, Retrato de Rosalía de Castro (1880) e Velha galega (s.d., c. 1880). Entretanto, ao lado de um quadro como $A$ redenção de Cam, estas pinturas parecem ser fruto de um momento distinto e talvez possam ser vistas como uma tentativa de enquadrar-se ao modelo de regionalismo em voga naquela região. É válido lembrar que Modesto Brocos cogitou permanecer na Galícia após concluir sua formação em Roma e em Paris. Por volta de 1888, candidatou-se ao posto de professor na Espanha. Foram as pressões financeiras, segundo conta, que o motivaram a voltar para "a terra do Cruzeiro" ${ }^{418}$, onde já estivera entre 1872 e 1877 - quando trabalhou como gravurista e frequentou como aluno livre o curso de Victor Meirelles na Academia Imperial de Belas Artes.
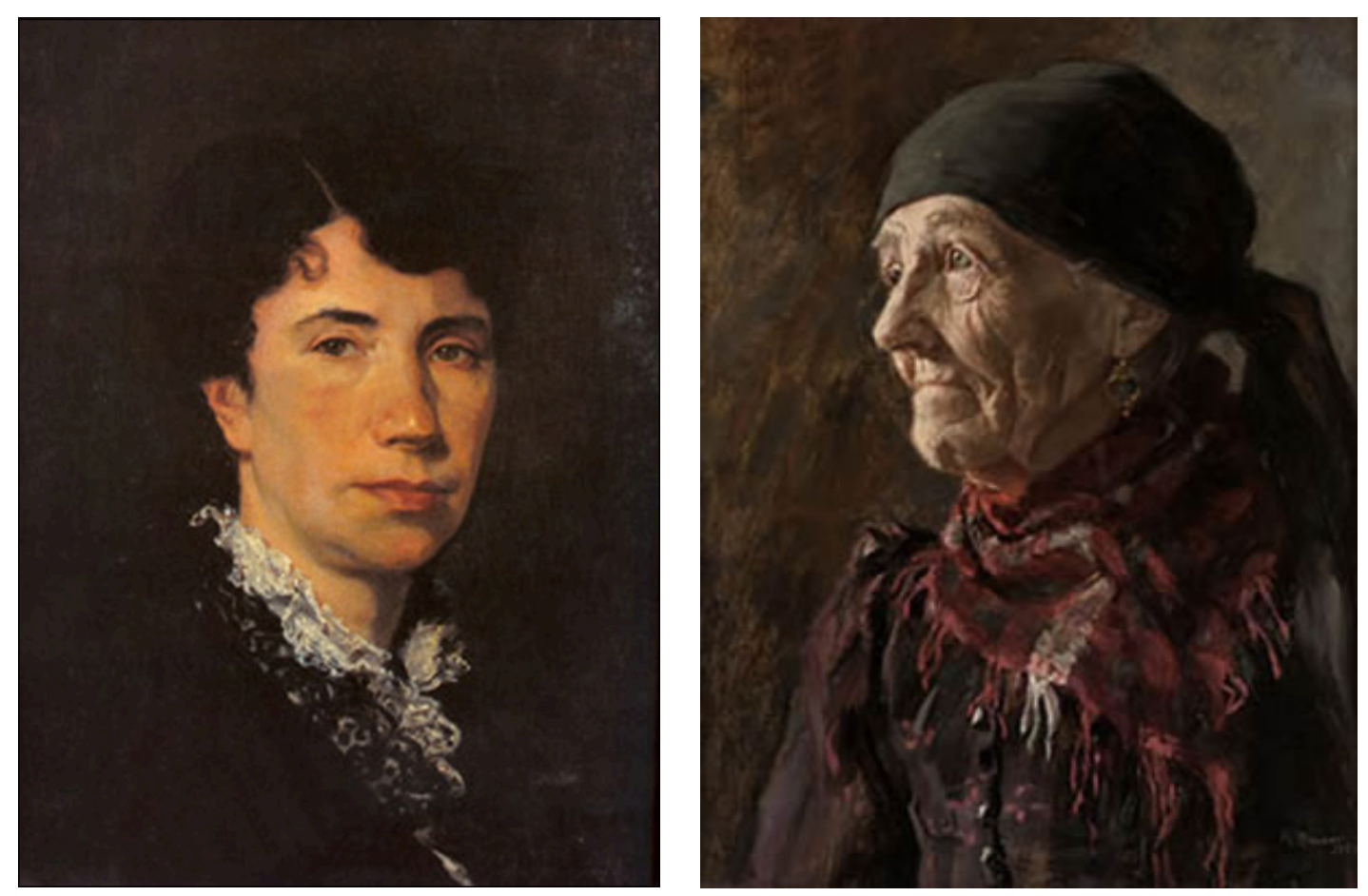

Fig. 68: Esq. Modesto Brocos. Retrato de Rosalía de Castro (1880). Óleo sobre tela, dimensões não informadas. Xunta de Galicia

Fig. 69: Dir. Modesto Brocos. Galega (c.1880). Coleção particular. A última imagem mostra a tendência a valorizar os tipos locais.

\footnotetext{
${ }^{418}$ Conforme Brocos: "Ao mesmo tempo, preparava-me para ir concorrer aos cargos de professor na Hespanha; com este fim, mandei o programma. A este proposito, fui frequentar os cursos nas escolas communaes de ville de Paris, entrando como principiante para estudar a disposição das aulas e como eram feitos os estudos; pondo-me assim ao corrente da pedagogia artística. (...) Cansado de esperar pelo concurso e sem recursos, vivendo com o producto de meu trabalho, e farto de luctar em Paris, decidi voltar á terra do Cruzeiro". BROCOS, M. A questão do ensino de Bellas Artes, seguido de critica sobre a direção de Bernardelli e justificação do autor. Rio de Janeiro, 1915, p. 98
} 
Para além das notas biográficas, talvez o maior legado deixado pela dimensão particular do realismo em território espanhol para a trajetória de Brocos seja a consciência nítida de uma relação intrínseca entre estilo e realidade nacional. É desta fórmula que talvez se possa depreender o sentido maior que o artista buscou conferir à sua pintura, já no Brasil, à luz de uma confluência de estilos própria, capaz de exprimir os dilemas específicos da modernização naquele país.

Não obstante, é preciso buscar compreender ainda a relevância que a formação no exterior pode ter tido sobre Brocos. É sem dúvida significativo que, poucos anos antes de executar o retrato de Rosalía, o pintor se encontrasse em Paris, matriculado como aluno regular da École des Beaux-Arts, sob orientação de Henri Lehmann (1814-1882) - formado pela tradição idealista de herança neoclássica, no ateliê de Jean-Auguste Dominique Ingres (1780-1867) -, onde conviveu com artistas das mais diversas orientações. Como exemplos, há Georges Seurat (1859-1891) e Edmond Aman-Jean (1858-1936), também alunos de Lehmann, com quem Brocos afirmava ter aprendido técnicas e princípios impressionistas de uso da $\operatorname{cor}^{419}$. Com aquele professor, Brocos estuda de 1877 a 1879. Dali, o jovem parte para Madri, onde passa a frequentar a Academia de San Fernando - maior expressão da arte oficial produzida no centro do país -, e o ateliê de Federico de Madrazo y Kuntz (1815-1894), outro pintor que fora discípulo de Ingres em Paris, visto como um dos grandes expoentes da tradição idealista na Espanha ${ }^{420}$.

Neste trajeto, uma série de elementos reforçam uma certa homogeneidade na formação acadêmica de Brocos, em que o acento neoclássico daqueles professores serviria de linha mestra ${ }^{421}$. Professor dos dois, é válido lembrar que Ingres é um dos mais célebres discípulos de David ${ }^{422}$. Porém, ao mesmo tempo em que estudava sob a égide de uma tradição idealista de molde neoclássico, Brocos mantinha estreitas relações com o grupo artístico da província de A Corunha - deputação que custearia

\footnotetext{
${ }^{419}$ Ver BROCOS, M. Retórica dos Pintores. Rio de Janeiro: Typ. D’A Industria do Livro, 1933; e CAMPOFIORITO, Q. Modesto Brocos. Rio de Janeiro: Bolsa de Arte, 1977.

${ }^{420}$ O pai de Madrazo, o também pintor José Madrazo, era amigo próximo de Ingres, com quem estudara no ateliê de Jacques-Louis David, e figura proeminente no meio artístico espanhol.

${ }^{421}$ Campofiorito, op. cit., relembra o orgulho expresso por Brocos por pertencer à tradição que remontava a Ingres - e o próprio pintor espanhol reafirma, em sua Retórica, a lição deste artista, que dizia ser o desenho "a probidade da arte". A máxima foi repetida pelo próprio Brocos em sua Retórica. BROCOS, M. Retórica dos Pintores. Rio de Janeiro: Typ. D’A Industria do Livro, 1933, p. 18.

${ }^{422}$ Discípulo de David, "Ingres é o guardião do belo ideal, é aquele que intitulava Géricault e Delacroix de 'apóstolos do feio' e julgava o romantismo francês insuportavelmente carregado de realismo". Coli, op. cit., p. 26.
} 
seus estudos em Roma em 1883. Envolvido com o projeto do rexurdimento, como vimos, ele colaborava assiduamente, ao lado do irmão, com a Illustración GallegoAsturiana - periódico que procurava valorizar esta identidade regional. À primeira vista, estes dois universos de formação, inconciliáveis no contexto espanhol, parecem curiosamente ter-lhe resultado, no correr dos anos, um estilo da conciliação, que combinava métodos e sobretudo conceitos de um sistema de notação pictórico neoclássico, de origem francesa, com uma propensão especial para as cenas costumistas, como queria o realismo/naturalismo espanhol - e por isto comprometido com problemas nacionais.

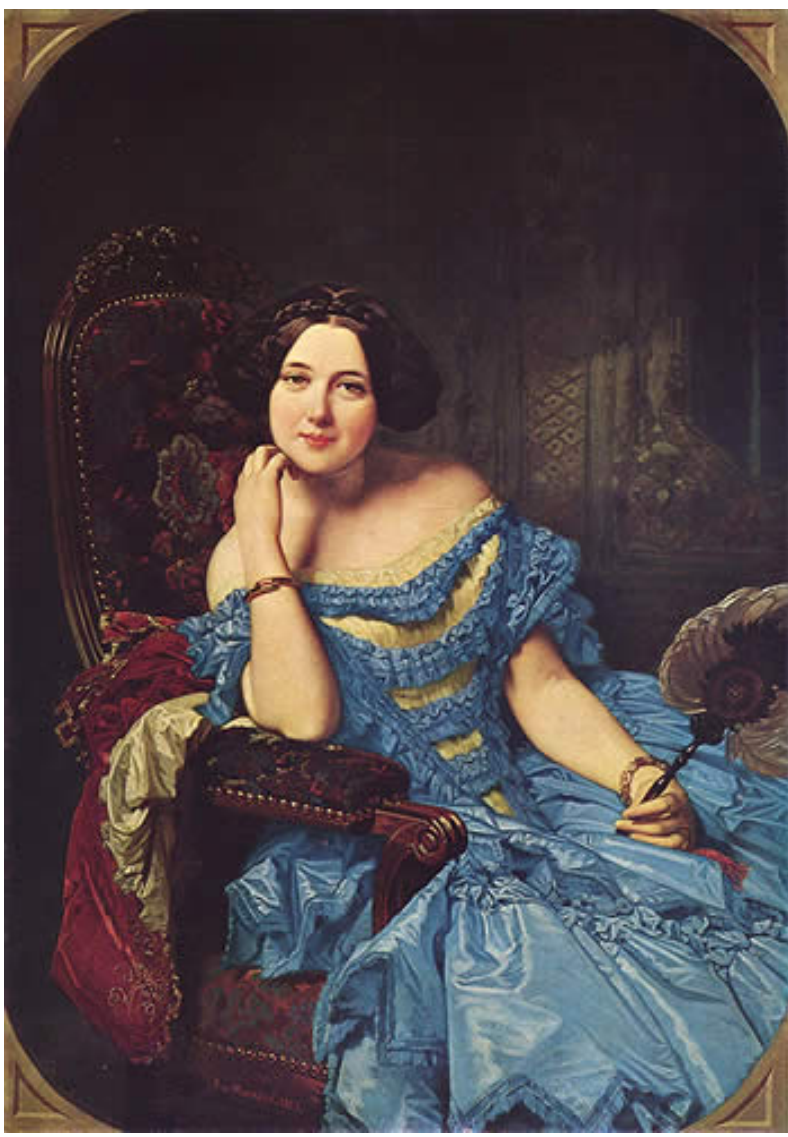

Fig. 70: Federico de Madrazo Amalia de Llano y Dotres, condesa de Vilches (1854) Óleo sobre tela $126 \mathrm{~cm}$ x $89 \mathrm{~cm}$ Madri: Museo del Prado
Há notáveis semelhanças de estilo entre os retratos pintados por Madrazo e Ingres. A similaridade no tratamento da pele, no desenho da expressão facial, no modo de projetar o rosto ligeiramente para a frente por meio de sombras marcadas, no desenho dos braços e mãos e na caracterização do tecido são aproximações possíveis.

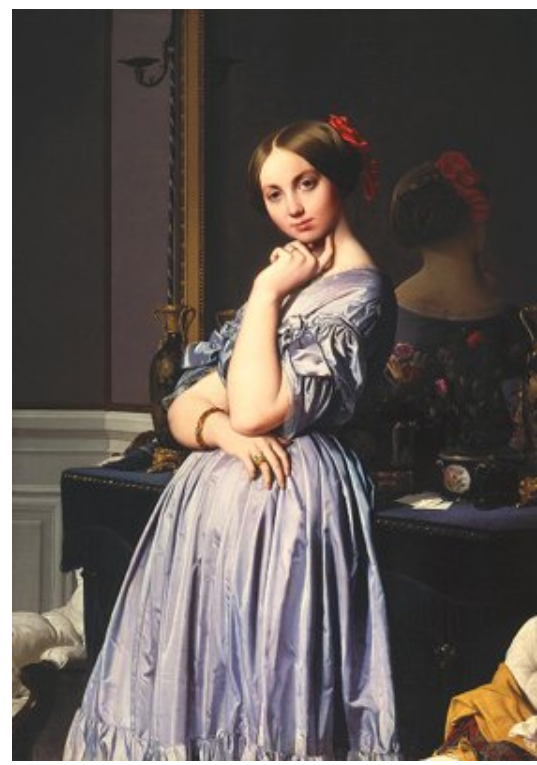

Fig. 71: Jean-Auguste Dominique Ingres. Comtesse D'Haussonville (1845). Óleo sobre tela, $131,8 \mathrm{~cm} \times 92,1 \mathrm{~cm}$ Nova York: Frick Collection

O legado de Ingres é fortemente presente na obra de Madrazo, que dedicou-se com enorme afinco aos retratos da aristocracia espanhola, tornando-se o grande retratista oficial da época isabelina. Tais imagens destacam-se pela força do desenho e pelo equilíbrio geral da composição. Há ali uma combinação de herança ingreana, 
entre os rostos plácidos das figuras e uma série de microdetalhes do cenário, com destaque para o estudo das roupagens e tecidos. As cores, se bem possam adquirir tons brilhantes ou chamativos, tendem a um equilíbrio que sabe valorizar o tratamento conferido ao rosto e corpo do modelo. Exibe-se uma inclinação para a pose, somada à idealização cristalina de uma pele que remete à beleza sobrehumana do mármore polido, evitando-se cautelosamente as imperfeições. Não obstante, são retratos que exprimem uma relação de cumplicidade do pintor com seus modelos - vide, por exemplo, o retrato de Doña Amalia de Llano y Dotres, Condessa de Vilches (1854).

Não há, na obra de Madrazo, maior disposição para a temática de costumes, com exceção de alguns poucos desenhos. Lehmann, por sua vez, se dedicou ao costumismo, em particular nas pinturas produzidas na Itália. Ainda assim, estas obras preservam uma fidelidade à tradição idealista de fundo neoclássico - vide, por exemplo, Le repos (s.d., c. 1863); Portrait de paysanne italienne (1863); e Portrait de paysan italien (1863).

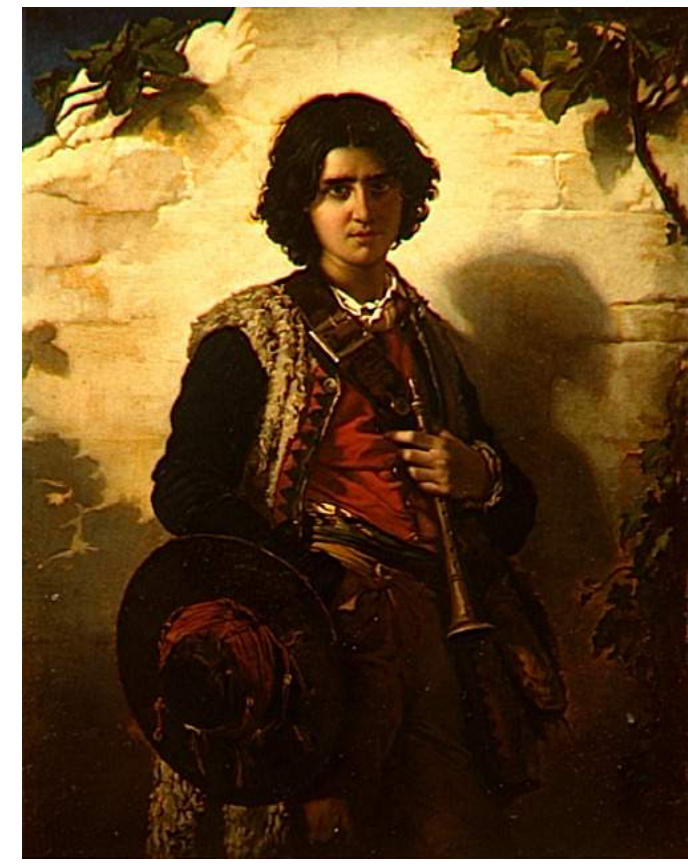

Fig. 72: Henri Lehmann. Portrait de Paysan italien (s.d.). Óleo sobre madeira, $26,5 \mathrm{~cm} \mathrm{x}$ 20,5cm. Bayonne: Musée Bonnat

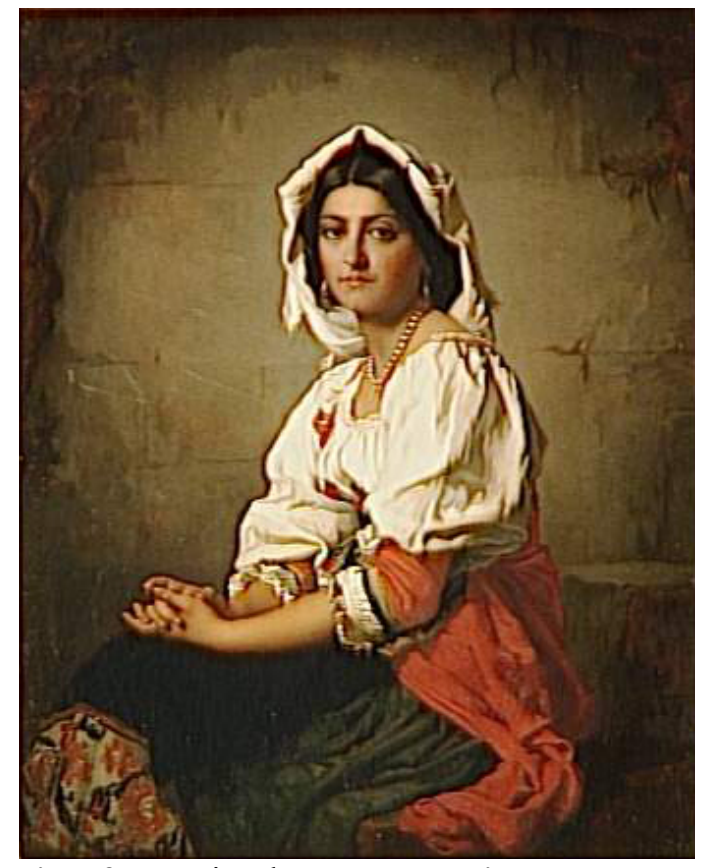

Fig. 73: Henri Lehmann. Portrait de Paysanne italienne (1863). Óleo sobre madeira, $26,5 \mathrm{~cm} \mathrm{x}$ 20,5cm. Bayonne: Musée Bonnat 


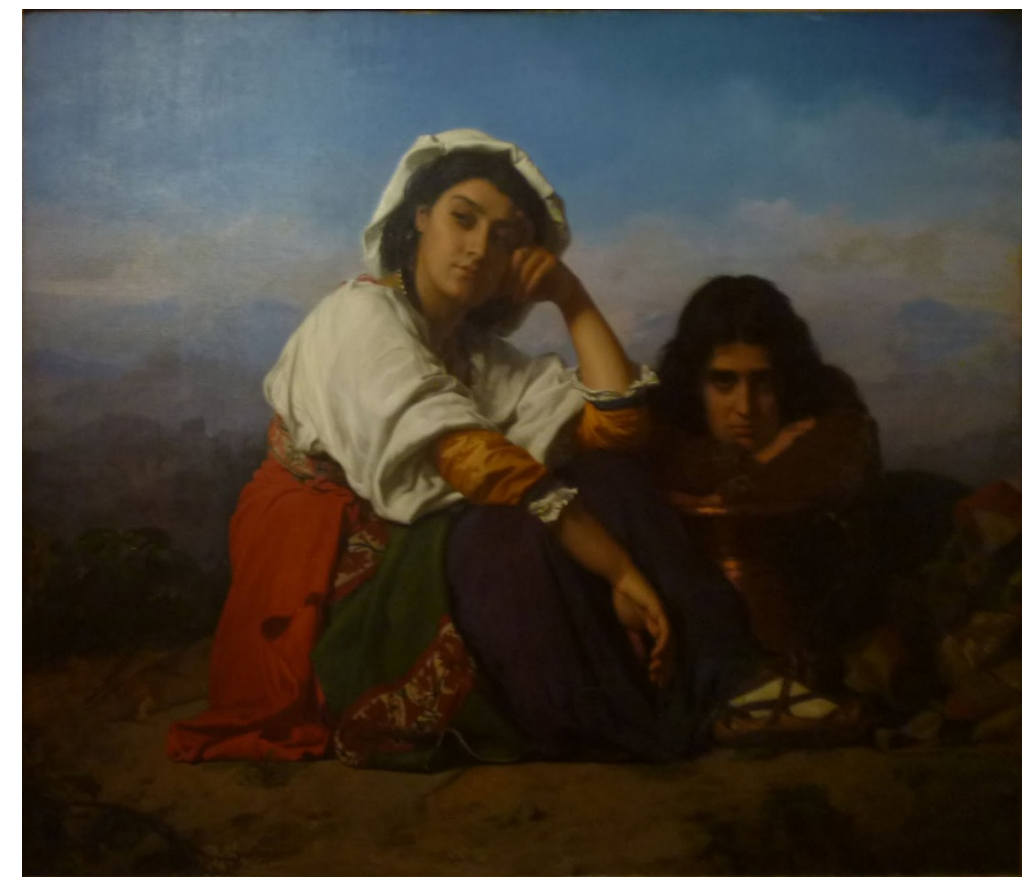

Fig. 74: Henri Lehmann. Le repos (1864). Óleo sobre madeira, $31,7 \mathrm{~cm} \times 23,6 \mathrm{~cm}$. Montauban: Musée Ingres.

Os retratos de camponeses são construídos na contenção do gesto e na pose de estúdio. A imagem da camponesa, a despeito do aprumo no estudo da indumentária e do desenho cuidadoso, inspira um conflito latente entre a modelo e a postura ensaiada do retrato. A cena opera uma transposição da forma clássica a uma personagem típica, que parece desafiar a rigidez da convenção, impondo um certo desconforto e/ou inadequação à modalidade pictórica proposta. Tem-se de todo modo um interessante estudo de cor, particularmente no que se refere à pele morena da figura.

$O$ descanso preserva o mesmo pendor geral, ao exigir dos retratados uma pose incompatível com o momento de repouso que deseja mostrar. A tendência à encenação também se faz presente no terceiro retrato, que mostra um jovem camponês encarando o espectador no olho, com certa timidez. Não há despojamento nessas caracterizações, como ocorreria com uma pintura de molde realista/naturalista; há, isto sim, uma espécie de cerimoniosidade ensaiada, em que tudo parece organizado para corresponder ao projeto previamente traçado pelo artista. De todo modo, são telas que tornam visível o processo de preparação, permitindo vislumbrar a força do planejamento sobre a produção de Lehmann, ou seja, a existência de um projeto estético que se impõe, deixando com que as contingências cedam lugar a permanências e às constantes de uma forma idealizada.

Cada qual a seu modo, Madrazo e Lehmann são artistas que seguem de perto o cânone neoclássico, preservando um sentido de beleza que se traduz no trabalho de 
produção da imagem, a partir de esquemas e tópicas consagradas por esta tradição. É contra elas que o realismo/naturalismo se levantará, desejando uma arte que parte de outros esquemas e concepções sobre a pintura.

É preciso não perder de vista que os anos 1840 e, sobretudo, os 1850 são marcos de um processo de emergência de uma série de estilos e tendências do fazer pictórico, vinculados com maneiras de definir as relações do artista com o a chamada realidade - ela própria, podendo ser vista como um conceito em transformação. Se em períodos anteriores fora marcante a oposição entre Ingres - o mestre da linha e do desenho, formado na escola de David - e Delacroix - o colorista, reconhecido como artífice do romantismo na pintura ${ }^{4}{ }^{423}$, em meados do Oitocentos toda uma geração de pintores acadêmicos já encontra uma série de referenciais cruzados em sua formação, deixando trabalhos que articulam tendências herdadas das duas tradições, mesclam estilos alheios na constituição de seus próprios, exploram o espectro das técnicas disponíveis para, por fim, fazerem suas escolhas. É assim que neoclássico, romantismo, realismo/naturalismo e, posteriormente, impressionismo, conviverão com um sem-número de outras modalidades artísticas, figurando ora como modos de resolução de problemas, ora como sistemas de pensamento ou modelos de aprendizagem sobre o real, ora como exercícios incorporados ao ofício, rumo ao virtuosismo da forma.

O terceiro professor marcante na vida de Brocos parece já formado nos moldes dessa confluência de estilos e, assim, aproxima-se com maior assiduidade daquele que o artista espanhol desenvolveria no Brasil para a pintura de costumes. Pois em 1881, o encontramos mais uma vez na École des Beaux-Arts de Paris, desta vez como aluno de Ernest Hébert (1817-1908), pintor formado nos ateliês do escultor David d'Angers (1788-1856), do pintor neoclássico Benjamin Rolland (1777-1855) e de Paul Delaroche (1797-1856), reconhecido operador de uma fusão entre neoclassicismo e romantismo ${ }^{424}$. Hébert foi ainda amigo próximo de Ingres na Itália $^{425}$ - que o fascinava -, tendo incorporado à sua pintura todas essas influências,

\footnotetext{
423 Para uma boa síntese da propalada rivalidade entre os artistas, tornada paradigmática, cf. ROSEMBLUM, R.; JANSON, H. W. El arte del siglo XIX. AKAL/Arte y Estética, 1984.

${ }^{424}$ Ver, por exemplo, STRIETER, T. W. Nineteenth-century European Art: A Topical Dictionary. Greenwood Publishing Group, 1999; MURRAY, C. J., Encyclopedia of the Romantic Era, 17601850. Routledge, 2012.

${ }^{425}$ Hébert era influente no meio artístico: retratista de prestígio da alta sociedade parisiente do Segundo Império e Terceira República, foi duas vezes diretor da Académie de France (1867-1873 e 1885-1890).
} 
sem aderir completamente nenhuma delas. Primo de Stendhal ${ }^{426}$, ele declarou-se, ao final dos anos 40, enfastiado com a clausura do estúdio, entregando-se à pintura ao ar livre e ao novo sentido de realidade que ela propiciava: "J'ai résolu de ne plus peindre que la chose ou le fait qui m'aura ému. Je crois que c'est le meilleur moyen de rester vraiment artiste et de marcher dans la voie de l'originalité" ${ }^{427}$, escreveria a um amigo - o paisagista Jules Dupré, expoente da Escola de Barbizon.

Foi, destarte, o único dentre os professores de Brocos que, num momento de ebulição do realismo e rápida propagação do pleinarismo, manifestou interesse imediato por um tipo de pintura que desafiava os cânones neoclássico e romântico, quer pela atualidade no tratamento de seus temas, quer por uma busca da naturalidade das coisas - sem passadismo, nem exotização, ainda que preservando uma tendência neoclássica a valorizar as belas formas. Tal como fizera seu professor, Delaroche, Hébert parece ter procurado operar uma fusão entre estilos: reúne o romantismo neoclássico daquele pintor ao neoclássico de Benjamin Rolland, com influência de Ingres, em particular na valorização do desenho, mas sobretudo na pesquisa de formas antigas que se amoldam à composição de certas telas. De todo modo, tal fusão de tendências se coloca a serviço de uma arte que se deleita nas cenas de trabalho e tipos populares e assim confere seus próprios contornos ao realismo. Por fim, há um Hébert simbolista $^{428}$, que flerta com a estética pré-renascentista das catedrais bizantinas.

As telas produzidas na Itália pelo artista demonstram preocupação com a luminosidade natural, um clareamento da palheta e uma intenção de representar as personagens com maior naturalidade. As jovens vendedoras de feno que pintou guardam correspondências com as respigadeiras, de Jules Breton - e são quase contemporâneas: Le rapel des glaneuses, por exemplo, é de 1859, enquanto Les fienaroles de Sant'Angelo, de 1854. Ainda assim, há no quadro de Breton um pesar mais intenso que na pintura de Hébert - uma rigidez nos corpos das trabalhadoras, a

\footnotetext{
${ }^{426} \mathrm{O}$ escritor e crítico de arte Henri Beyle, conhecido como Stendhal (1784-1842), tornou-se célebre pelo romance $O$ vermelho e o negro. Atribui-se a ele um estilo que rejeita o primeiro romantismo em função da crítica de costumes, sendo o autor considerado um precursor do realismo literário. Stendhal conviveu intensamente com o primo Hébert na Itália, onde foi embaixador. Ali, cultivaram um círculo de amizades que incluía a princesa Mathilde e o pintor Ingres, Anatole France e Marcel Proust.

${ }^{427}$ Cf. HÉRBERT, E. Les fienaroles de San Germano. Comentário critico. Paris, Musée D’Orsay. Disponível em: $\quad<$ http://www.musee-orsay.fr/fr/collections/oeuvrescommentees/peinture/commentaire id/the-haymakers-of-san-germano21454.html?tx_commentaire_pi1[pidLi] $=509 \&$ tx_commentaire_pi1[from] $=841 \& \mathrm{cHash}=\mathrm{a} 59 \mathrm{ccb} 33 \mathrm{~d} 7>$. Acceso: 10/05/2013.

${ }^{428} \mathrm{O}$ autor de telas como La musique, de 1880.
} 
tensão nos rostos, sua aparição num bloco sólido e compacto, a incomunicabilidade individual ou solidão em meio ao conjunto, a resistência do físico em conflito latente com o meio que, em contraposição ao céu do entardecer, confere um peso terreno à cena. O traço aprendido na escola holandesa dá o tom, em particular na composição dos corpos e posturas ${ }^{429}$. Já as fienaroles apresentam sinais de cansaço especialmente aquelas que se apóiam nos montes de feno e repousam durante o expediente -, mas também exprimem um ar de leveza quase etéreo, acentuado pela suavidade das formas, os corpos pequenos e rostos que se diluem sob a sombra dos lenços que trazem na cabeça. O estilo de pincelada que tende à atenuar os contornos, dotando a composição de uma delicadeza que remete à aquarela - técnica que Hébert aprendeu na Itália com Dominique Papety (1815-1849), outro artista neoclássico francês. O reflexo dos tecidos brancos sob o sol e a textura com ares de maciez do feno também contribuem para o aspecto singelo da composição em que, ao mesmo tempo, o desenho e a proporção se revelam fundamentais.

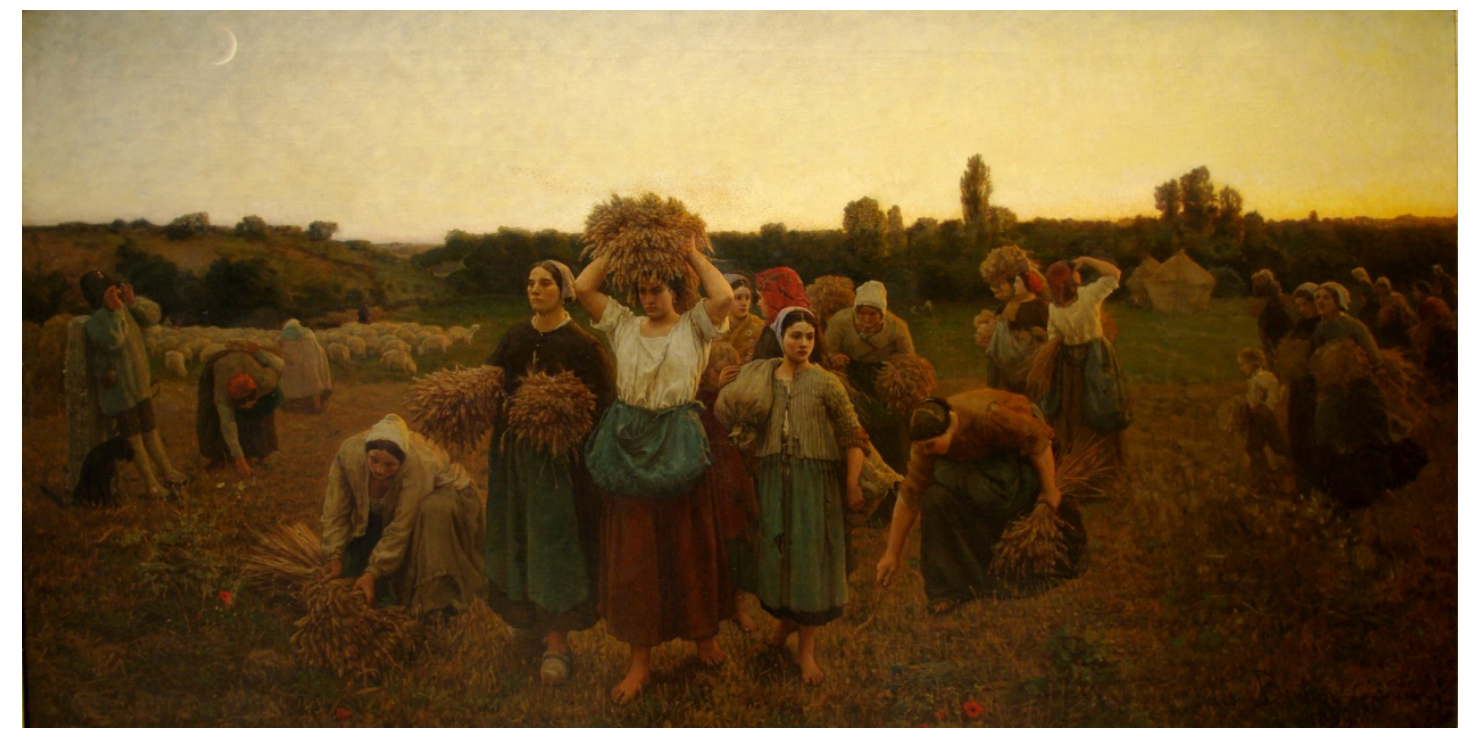

Fig. 75: Jules Breton. Le rapel des glaneuses (1859). Óleo sobre tela, $90 \mathrm{~cm}$ x 117,6cm. Paris: Musée d'Orsay.

\footnotetext{
${ }^{429}$ Breton na Academia de Belas Artes de Ghent e também na Antuérpia antes de concluir sua formação na Escola de Belas Artes de Paris. Cf. LACOUTURE, A. B. Jules Breton: painter of peasant life. New Haven, Yale University Press, 2002.
} 


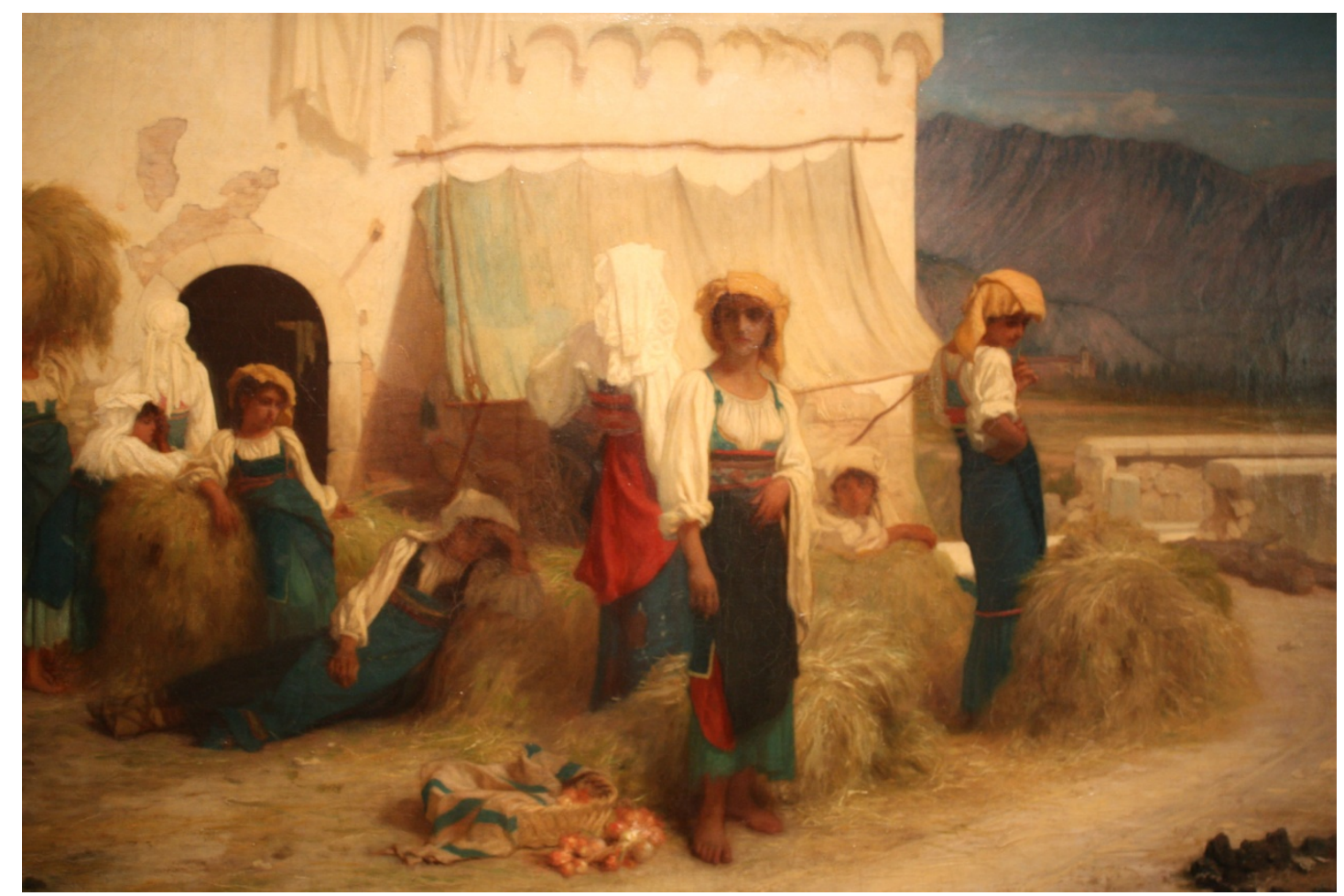

Fig. 76: Ernest Hébert. Les Fienaroles de Sant'Angelo vendant du foin à l'entrée de la ville de San Germano (1854). Óleo sobre tela, $50 \mathrm{~cm}$ x $75 \mathrm{~cm}$. Paris: Musée National Ernest Hébert

Tresseuses des cordages (s.d., $2^{\mathrm{a}}$ metade do século XIX) e La mal'aria (1848) guardam a mesma tendência à diluição dos contornos em função do tratamento da luz e da cor - a segunda tela, explorando o contraste complementar do vermelho e verde e, desse modo, experimentando a luminosidade própria do colorido, nos moldes do romantismo, em evocação sutil a Delaroche. Já Les filles d'Alvito (1855) evidencia o legado do desenho de influência clássica, especialmente nas feições simétricas e algo frias da jovem da frente, em sua postura ereta e equilibrada de estátua, e no caimento das pregas das roupas, mas não deixa de explorar um jogo de luminosidades diurnas sobre seu corpo, que extrapolam o limiar de sombra contida do neoclassicismo. É válido pontuar o despojamento das imagens produzidas pelo pintor, que tende gradativamente a eliminar a pose dessas cenas italianas. A esse respeito, é válido vislumbrar o peso da fotografia na produção pictórica de Hébert, visto que várias destas telas foram elaboradas a partir de fotos tiradas por sua esposa, Gabrielle Hébert - o que possivelmente repercutiu sobre os quadros do artista na naturalidade do movimento e na forma dissoluta e luminosa de equacionar contornos ${ }^{430}$.

${ }^{430}$ É irresistível não pensar em Delaroche, que declarou-se um entusiasta da fotografia em seus
primórdios, afirmando que ali estava anunciado o fim da pintura. Este pintor também explorou o 

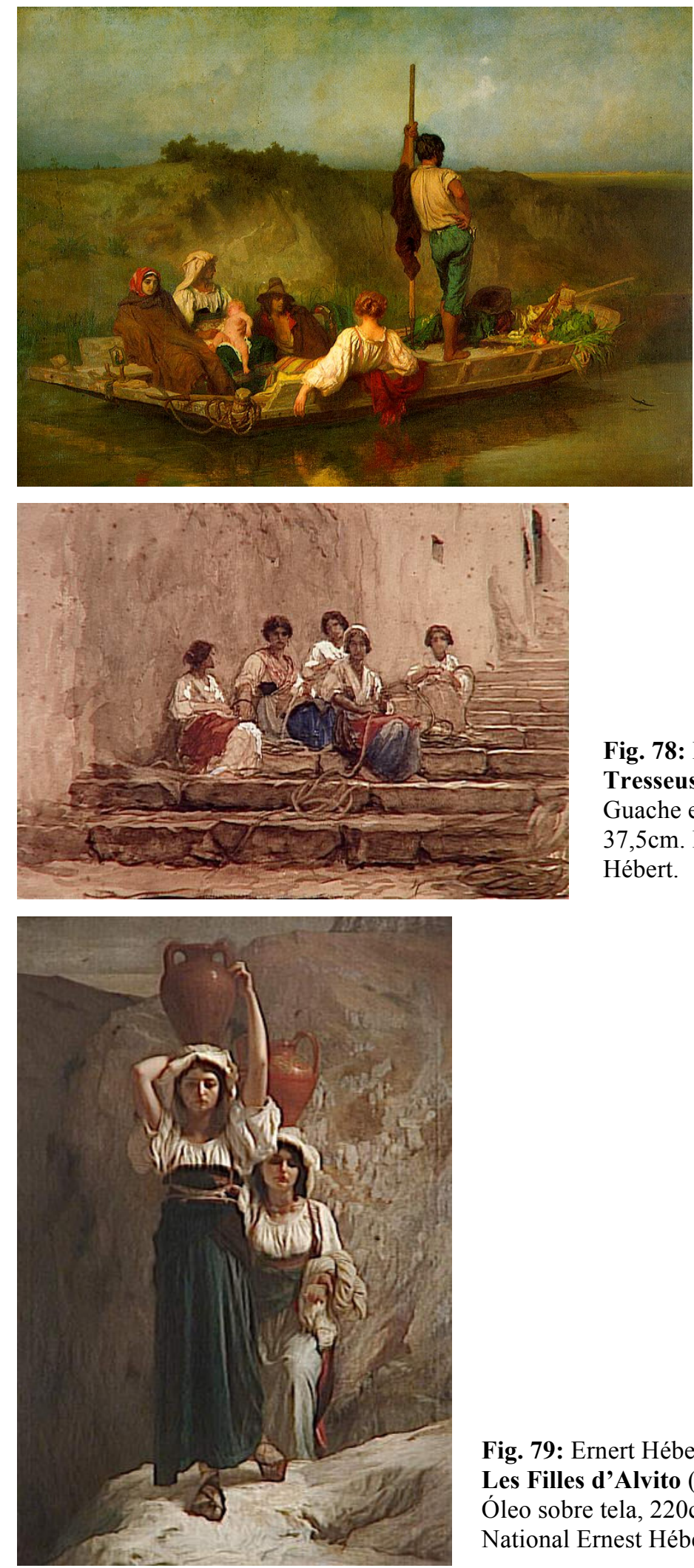
Hébert.

Fig. 79: Ernert Hébert.

National Ernest Hébert.
Fig. 77: Ernest Hébert. La Mal'aria (1848-49).

Óleo sobre tela, $135 \mathrm{~cm}$ x 193 $\mathrm{cm}$.

Paris: Musée d'Orsay.

Fig. 78: Ernert Hébert.

Tresseuses des cordages (s.d.).

Guache e aquarela sobre papel, $27 \mathrm{~cm} \mathrm{x}$ $37,5 \mathrm{~cm}$. Paris: Musée National Ernest

Les Filles d'Alvito (1855).

Óleo sobre tela, $220 \mathrm{~cm}$ x $152 \mathrm{~cm}$ Paris: Musée

mesmo tipo de contorno difuso, que que o rigor do desenho é combinado com a descontração promovida pela luminosidade que ofusca os domínios da matéria. 


\section{Do estilo}

Passamos rapidamente, nas páginas precedentes, por uma questão que se anuncia quase que contraditória, qual seja, a da atribuição de um estilo para a pintura de Brocos. Como, afinal, classificar a obra de um artista que, formado num ambiente de ascensão do realismo na Espanha e reconhecido como um expoente desse tipo de pintura pela crítica, estuda com professores alinhados com a escola neoclássica e se afirma idealista?

Longe de pretender realizar um estudo de trajetória em profundidade sobre Modesto Brocos, buscamos destacar alguns elementos que permitem compreender a conformação de seu estilo, que viemos denominando como realismo idealista. Nota-se que a formação do artista entre escolas e referências cruzadas resulta num projeto de conciliação entre um tipo de realismo ascendente na Galícia e um idealismo mais próximo da inspiração neoclássica. Esta região se convertia numa espécie de dupla periferia - de Paris, centro emanador de tendências, mas também de Madri, capital que se guia pelo modelo francês. Poderíamos acrescentar que Brocos, através de seu estilo, expressa a condição de entremeio, a oscilação própria da experiência de um pintor marginal na periferia do centro artístico mundial. Nesse sentido, é interessante notar que a oscilação entre realismo e idealismo do artista termina encontrando lugar no centro de uma periferia longínqua, o Brasil. Nestes páramos, ele encontra espaço para construir uma obra que incorpora o problema do embranquecimento. Sem mais, a análise do estilo dá vazão para pensar em que medida esse realismo idealista não seria próprio à condição periférica, que necessita encontrar sua identidade no recurso a diferentes sistemas de notação e mesclando espectativas em torno da beleza com imagens capazes de incitar reflexão sobre a vida mais crua.

O realismo idealista, como vimos, procura explorar temas caros ao realismo/naturalismo, subvertendo a lógica mais característica deste estilo: trata-se de uma arte que pode ser vista tanto por sua intenção de documentar a vida das camadas populares - finalidade própria à tradição realista/naturalista -, quanto pelo viés ideológico, na medida em que procura explorar certas formas indicativas de uma suposta qualidade intrínseca das coisas para espelhar transcendências - por exemplo, quando exalta noção de belo ideal como finalidade da arte, na Retórica dos pintores. Argumentamos que certas telas produzidas por Brocos no Brasil elabora um código próprio, através do qual adquirem a capacidade de sugerir transformações raciais de 
negro a branco. No próximo capítulo, procuraremos mostrar como $A$ redenção de Cam se torna capaz de adaptar convenções pictóricas vigentes em seu tempo, de modo a apresentar uma tese sobre o embranquecimento. Antes de passar a este ponto, no entanto, gostaríamos de tecer mais algumas observações.

O debate sobre o estilo, evidentemente, tem o potencial único de se renovar, à luz de redefinições operadas no interior das próprias historiografias da arte, ou dos próprios recortes que se aplicam na construção da memória. Carlo Ginzburg ${ }^{431}$ mostra que a resistência dos objetos a enquadrar-se num determinado complexo estilístico - a aparência da forma absoluta em si mesma - deve ser posta em diálogo permanente com nosso interesse em atribuir-lhes sentido social. Há uma advertência nesta constatação: o pensamento sobre estilo, lembra o autor, possui uma história particular no ocidente - a história da exclusão, que culmina na própria fusão entre raça e estilo, tornada um dos pilares do regime nazista.

Se o próprio Hitler celebrou o trabalho de ideólogos como H. F. K. Gunther, autor de Rasse und Stil (1926), como menciona Ginzburg ${ }^{432}$, algumas décadas antes a ideia de que os estilos possuíam sua própria raça tornava-se um consenso na Europa. Na mesma Espanha que afirmava o realismo à luz de aspirações ao desenvolvimento de uma arte genuinamente nacional, o fim de século viu ganhar força o uso do termo "arte racial", como forma de referir-se à produção que ansiava por exaltar o tipo humano que Miguel de Unamuno $(1864-1936)^{433}$ definia como castizo: este, dizia o escritor "viene a ser puro y sin mezcla de elemento extraño... Lo castizo es lo de pura raza..." ${ }^{״ 34}$. Assim, a história do realismo naquele país é indissociável de certas conexões com uma inclinação à descoberta e afirmação da existência de uma raça espanhola pura.

$\mathrm{O}$ que isso nos informa sobre uma pintura como $A$ redenção de Cam? Talvez, que a preocupação expressa tematicamente por esta tela e sua configuração de estilo pudessem encontrar uma confluência silenciosa e que o realismo idealista tivesse sido

\footnotetext{
${ }^{431}$ GINZBURG, C. Style as Inclusion, Style as Exclusion In: JONES, C. A., GALISON, P. (ed.). Picturing Science, Producing Art. Routledge, pp. 27-54.

${ }^{432}$ Idem, ibidem.

${ }^{433}$ Escritor, ensaísta, romancista, dramaturgo e filósofo nascido em Bilbao, Espanha, Unamuno foi um dos intelectuais que se dedicaram à reflexão sobre a identidade espanhola entre finais do Oitocentos e sobretudo nas primeiras décadas do século XX.

${ }^{434}$ UNAMUNO, M. En torno al casticismo. Biblioteca Nueva, 1996 [1895] apud PENA, C. Presentación. In: _ (org.) Centro y Periferia en la Modernización de la Pintura Española. Catálogo de Exposição. Madrid, Palácio de Velázquez, Bilbao, Museo de Bellas Artes, 1993-1994, p. 22.
} 
uma forma de enfrentar a questão da "raça" brasileira, cuja essência se definia na ideia de "mestiçagem".

A esse respeito, Brocos deixou ainda outro indício, que permite compreender sua maneira particular de lidar com a realidade por meio da ficção: no livro chamado Viaje a Marte (1930), publicado somente na Espanha, ele se torna personagem e narrador ${ }^{435}$. Recém-chegado ao planeta vermelho, é recebido por um padre chamado Feijóo $^{436}$, que lhe apresenta o local. O visitante destaca aquilo que considera avançado na modernidade marciana; Brocos, impressionado, exalta a adoção de medidas eugênicas entre os alienígenas: descreve, entre outros aspectos, o trabalho de uma junta de higiene, responsável pelas políticas de esterilização de mulheres desviantes dos padrões de beleza/saúde vigentes; esterilização das pessoas com males congênitos e/ou incuráveis; e triagem das crianças logo após o nascimento, além do afogamento das que apresentassem quaisquer defeitos físicos. Fala também de uma política de reprodução controlada, rumo ao "aperfeiçoamento da raça":

Siguiendo, pues, la humanidad marciana en esa aspiración fatal y constante, después de alcanzar un perfeccionamiento nunca hasta entonces imaginado, aquella humanidad no estaba satisfecha, pensaron que aún faltaba una gran reforma a introducir en el planeta, cual era la de unificar las razas fundiéndolas en una sola para que la desigualdad desapareciera al menos en el aspecto exterior de las gentes. Ya se había conseguido mucho en tiempos anteriores mejorando las razas separadamente, de modo que la raza blanca con la amarilla fue fácil el mestizaje. No aconteció lo mismo con la raza negra, que si bien se había tenido anteriormente cuidado de seleccionar, ofrecía dificultades por el color. De esta tan ardua tarea se encomendó de llevar a feliz término al Ejército Agrícola y a las Hermanas Humanitarias.

(...)

Introdújose entre aquellas razas al ejército y a las Hermanas como principal elemento durante una generación, juntándose a éstos los voluntarios y voluntarias que se ofreciesen a ir con el mismo laudable fin, y pasado ese tiempo se dejaban abandonadas a sí mismas durante dos generaciones. En este espacio de tiempo las razas inferiores se iban perfeccionando entre sí, hasta quedar confundida la primera inoculación. Luego volvíase a enviar los soldados y las Hermanas Humanitarias para renovar la sangre de aquellas razas, y por dos generaciones se las dejaba

\footnotetext{
435 "C'est une comparaison curieuse et ingenieuse entre les Martiens, qui representent notre avenir, et nous", diz VERSINS, P. Encyclopédie de l'utopie, des voyages extraordinaires et de la science fiction. L'Age d'Homme, 2000, p. 289. Outras análises deste livro se encontram em JAUREGUíZAR, A. El viaje a Marte de Modesto Brocos. In: Ciencia, Pensamiento y Cultura, CLXXXV 740, noviembre-diciembre (2009); CAPEL, H. S. F., JUNIOR, G. W. Performances híbridas no pensamento utópico de Modesto Brocos y Gomez (1852-1936). In: Estudos Ibero-Americanos, PUCRS, v. 38, n. 2, jul./dez. 2012, pp. 363-380.

${ }^{436}$ E que Brocos identifica como Benito Jerónimo Feijóo, frei da ordem de São Benito, autor do Teatro Crítico e precursor da Enciclopédia. Feijóo (1676-1764) de fato existiu e é considerado um iluminista avant la lettre, na Espanha. BROCOS, M. Viaje a Marte. Valencia, Editorial Letras y Artes, 1930.
} 
aisladas. Y continuando periódicamente estas medidas la piel se fue aclarando hasta llegar por último a quedar del color de los otros habitantes. Este trabajo fue largo, cerca de mil años tardó en realizarse, pero la unificación fue un hecho real, y hoy la raza que en algunas comarcas quedó sin mezcla no le es superior a esta conseguida artificialmente ${ }^{437}$.

Se tudo poderia ser apenas uma ficção, algo desmente uma tal possibilidade: em nota introdutória ao texto, assinada em primeira pessoa, Brocos explica a intenção de transmitir seus ideais às gerações futuras, na esperança de que possam inspirá-las. O autor declara:

Estoy en una edad avanzada, cercana del sepulcro y a mis años me será permitido decir algunas verdades en el curso de este trabajo, verdades que ningun joven escritor se atrevería a emitir por temor a la critica y que están infelizmente en oposición a la manera de ser actual del mundo. Este hasta ahora ha sido gobernado por los intereses materiales y mientras estos intereses dominen, la pobre humanidad no podrá vivir tranquila. (...)

Ahora, en los postrímeros años de mi vida, cuando ya las ilusiones y las esperanzas han muerto, doy a la publicidad estas ideas por si pueden ser aprovechadas algún dia ${ }^{438}$.

A dedicatória, deixada ao neto Péricles, confirma o caráter profético de Viaje a Marte: "Es bien posible que tú lo leas como si fuera un romance, tus hijos también lo leerán como un pasatiempo, pero tus nietos tengo la certeza de que lo leerán con más atención que tú (...) y aun cuando lo que digo aquí no pase de un sueño, será muy posible que en el fin de tu vida veas realizadas algunas de las utopías que presento en este libro" ${ }^{439}$.

Sob um estilo que chamamos realismo idealista, talvez Brocos estivesse buscando conceber uma forma de "arte racial" para o Brasil, que apresentasse a população do país sob o espectro de um futuro imaginário, produto direto do pensamento racista do período. É nesse sentido que se pode pensar que o estilo, nas mãos do artista, se tornava uma arma: do realismo, explorava a capacidade de alargar possibilidades de perceber o real, revelando a fragilidade da fronteira que separava o aceitável do inadmissível; já do idealismo, guardava uma propensão à violência latente, traduzida na aversão a tudo aquilo que pudesse escapar à perfectibilidade de seus modelos.

\footnotetext{
${ }^{437}$ Idem, ibidem, p. 182-183.

${ }^{438}$ Idem, ibidem, p. 10.

${ }^{439}$ Idem, ibidem, p. 7.
} 


\section{Capítulo 3. A tela, por seus esquemas}

O homem da crença prefere esvaziar os túmulos de suas carnes putrescentes, desesperadamente informes, para enchê-los de imagens corporais sublimes, depuradas, feitas para confortar e informar - ou seja, fixar - nossas memórias, nossos temores e nossos desejos.

- Georges Didi-Huberman, O que vemos, o que nos olha, p. 48

$\mathrm{Na}$ tradição ocidental, o pensamento sobre o corpo é mediado pelas imagens. Como explica Schaeffer, trata-se de uma homologia que, "loin d'être universelle, est un trait historique de la civilisation chrétienne" ${ }^{\text {"40 }}$, cuja realização plena remonta à articulação de três paradigmas fundantes: o dualismo ontológico da contraposição entre corpo, de um lado, e alma, do outro; o criacionismo monoteísta, ou seja, a crença de que o homem se constituiu à imagem e semelhança de uma entidade divina inacessível; e a doutrina da encarnação, que torna possível vislumbrar a possibilidade de transição entre Deus - a forma espiritual inalcançável - e corpo humano, material.

O corpo-imagem - o corpo tornado inteligível em imagem - é pensado através de linhas de força que, não raro, parecem sobrepor-se à sua ancoragem histórica, religiosa ou filosófica. Segundo Schaeffer ${ }^{441}$, tudo se passa como se ele pudesse ser definido por sua relação com um modelo que lhe serve de matriz e ideal ao mesmo tempo; é análogo (cópia) e impressão (evidência) de algo que o extrapola - imanência e transcendência, determinação e revelação; e sempre imperfeito, não-conforme ao modelo. Logo, a representação imagética do corpo no mundo euro-americano é a interface mediadora estratégica ou plataforma de contato entre duas realidades incomensuráveis; em decorrência, o processo de fabricação social do corpo está intimamente ligado à imitação ou recusa de imagens-conformes (representações), vistas como canais que habilitam uma aproximação ao modelo, ou seja, à perfeição.

La tension entre modèle et copie permet de comprendre l'ambivalence de notre attitude face aux images. Tantôt nous les célébrons comme ce qui nous donne accès au modèle, tantôt nous les condamnons comme vaines apparences qui nous en détournent. Notre iconodulie est ainsi toujours prête à verser dans l'iconophobie, pour peu que ce que l'image donne à voir nous paraisse traduire l'éloignement plutôt que la proximité du modèle. (...) La même ambivalence structurelle permet aussi de comprendre la tension

\footnotetext{
${ }^{440}$ SCHAEFFER, J.-M. Le corps est image. In: Image [\&] Narrative, 15, Battles around Images: Iconoclasm and Beyond, nov. 2006, s.p. Disponível em: http://www.imageandnarrative.be/inarchive/iconoclasm/schaeffer.htm. Consulta a 10/05/2013.

${ }^{441}$ Idem, ibidem.
} 
bipolaire qui est inhérente à notre pensée du corps et dont les images n'ont cessé d'être le véhicule. Le corps glorieux s'opposera ainsi au corps souffrant et la beauté idéale à la contingence biologique. La chair conçue comme manifestation de l'intériorité spirituelle trouvera sa négation dans l'obscénité de la chair sexuée et animale. Le corps géométrisé sera déstabilisé par le fouillis des organes. Le corps conforme sera subverti par le corps grotesque, voire monstrueux. Et ainsi de suite, selon des déclinaisons innombrables de la même opposition entre image conforme et image non conforme ${ }^{442}$.

Entretanto, o modelo é sempre uma incerteza e, dado seu caráter inefável, torna-se ele próprio a fonte de uma série de questionamentos e investigações de ordem específica. A mesma ideia de encarnação que funda a existência do modelo é fonte de seu abalo profundo: o corpo de Cristo torna-se não apenas o sinal da divindade, mas do humano, com sua falibilidade imanente, e por isso incita a transformar a forma ideal em espelho do homem. Schaeffer aponta para o caso exemplar de Dürer, cujo passo decisivo percorre duas etapas: primeiramente, a utilização de uma imagem de Cristo na composição de seu autorretrato de 1500; logo, a utilização do mesmo autorretrato como o esquema que lhe permite recompor aquela imagem, em Veronica, treze anos depois ${ }^{443}$. Ambas são obras inaugurais de uma modernidade que, desse modo, aborda o corpo humano à luz da tensão crescente entre a força orgânica pulsante da matéria e os sonhos de perfectibilidade que, aos poucos, passam a assentar-se sobre sistemas de harmonia e proporções. Redefine-se, na fórmula mesma da imagem, a noção de belo.

A tensão é fundante do dilema do corpo no ocidente. $\mathrm{O}$ corpo belo é belo em si, ou porque anuncia algo que o extrapola? Encarando o mesmo problema, DidiHuberman identifica, na relação do ocidente com suas imagens, uma relação dialética entre crença e tautologia. O homem da tautologia, como o denomina esse autor, "terá feito tudo (...) para recusar as latências dos objetos ao afirmar como um triunfo a identidade manifesta - minimal, tautológica - desse objeto mesmo: 'Esse objeto que vejo é aquilo que vejo, um ponto, nada mais",444, eliminando da imagem qualquer transbordamento de sentidos ocultos. Contrariamente, para o homem da crença "o que vemos (o triste volume) será eclipsado, relevado pela instância legiferante de um invisível a prever; e o que nos olha se ultrapassará num enunciado grandioso de

\footnotetext{
${ }^{442}$ Idem, ibidem.

443 Ver também PANOFSKY, E. The Life and Art of Albrecht Dürer. New York: Princeton University Press, 2005.

${ }^{444}$ DIDI-HUBERMAN, G. O que vemos, o que nos olha. São Paulo: Editora 34, 2010, p. 39.
} 
verdades do além, de alhures hierarquizados, de futuros paradisíacos e de face a face messiânicos"

Daí os túmulos vazios - visão frequente na iconografia cristã -, impossíveis de olhar por meio de uma visão puramente objetiva (tautológica). São volumes que devolvem um olhar, tornando visível não o túmulo, mas a morte e, além dela, a ressurreição. Ao lado destas imagens, estão os corpos recompostos, embelezados, que engendram modos possíveis de aludir à capacidade de existência imaterial, contrapondo-se à visão das formas cadavéricas:

\begin{abstract}
a iconografia cristã terá inventado todos os procedimentos imagináveis para fazer imaginar, justamente, a maneira como um corpo poderia se fazer capaz de esvaziar os lugares - quero dizer esvaziar o lugar real, terrestre, de sua última morada. Vemos então por toda parte os corpos tentando escapar, em imagens, evidentemente, aos volumes reais de sua inclusão física, a saber, as tumbas: essas tumbas que não mais cessarão de reproduzir a sinistra, a sórdida presença dos cadáveres, em representações elaboradas que declinam todas as hierarquias ou então todas as fases supostas do grande processo de Aufhebung [superação] gloriosa, de ressurreição sonhada ${ }^{446}$.
\end{abstract}

Tem-se, portanto, uma ideia de beleza que engana a visão, tornando a morte uma espécie de tradução e confirmação do que é verdadeiramente belo. As reflexões de Didi-Huberman sobre a incidência do princípio da crença, em seu embate fundamental com o da tautologia, e de Schaeffer, sobre a centralidade das imagens para os processos de fabricação do corpo na cosmologia ocidental, convidam a pensar sobre $A$ redenção de Cam, desdobrando um segundo nível de manifestação de seu realismo e idealismo.

Sob o prisma da crença, a tela introduz a ideia de um esvaziamento alegórico do corpo como chave da composição da avó, vista como objeto da redenção. E se por um lado o quadro poderia ser encarado como a visão de um flagrante da religiosidade popular, por outro ele também perfaz uma encenação da morte, segundo um viés cristão: a velha senhora recebe ali uma benção divina como recompensa pelo sacrifício de sua "raça". A redenção é efeito da negação do corpo - a recusa da negritude -, tratada como condição obrigatória para acessar o paraíso. Explora-se, assim, uma indexação entre corpo branco e salvação. A oposição que se anuncia na tela deixa de ser entre um corpo inatingível (divino) e outro imperfeito (humano), mas

\footnotetext{
${ }^{445}$ Idem, ibidem, p. 41.

${ }^{446}$ Idem, ibidem, p. 42.
} 
entre dois corpos supostamente imperfeitos: o branco e o negro. É o primeiro que assume a posição de modelo - ou “corpo conforme", para adotar o termo empregado por Schaeffer $^{447}$.

Há portanto, nessa imagem, uma transformação fundamental na maneira de conceber a transcendência: atingir o paraíso é tornar-se branco e este é também um fim em si mesmo, que se baseia num modelo ao alcance dos olhos. Se no episódio bíblico o castigo decorre da intervenção divina, a redenção resulta da ação humana, produzida a partir do próprio corpo que se considera imperfeito. No entanto, ao mostrar que a vida passa ao largo da determinação da divindade, A redenção de Cam não abandona a ideia de sacralização. Antes, faz o sagrado coincidir com o ideal embranquecedor.

Partindo-se dessas reflexões, que situam a imagem do corpo no marco definitivo da iconografia cristã, procuraremos nas páginas seguintes pensar sobre os corpos fabricados por A redenção de Cam. Buscaremos argumentar que é por meio da fatura que o quadro procura reforçar um argumento favorável ao embranquecimento. Para isto recorreremos à observação dos esquemas empregados para a composição de personagens negras - sobretudo mulheres - na pintura e também na literatura do período, evidenciando as decisões de ordem formal tomadas pelo artista e seu diálogo original com determinados contextos mentais ${ }^{448}$ correntes à época. Dois elementos serão merecedores de atenção redobrada: do ponto de vista do desenho, a tela abre mão de formas consagradas de percepção e caracterização de mulheres não-brancas na pintura europeia Oitocentista e também na literatura nacional; já no uso da cor, explora modelos conhecidos - o que dá vazão a percepções contraditórias de parte do público do período.

\footnotetext{
${ }^{447}$ Como não lembrar também de Deleuze e Guattari? "If the face is in fact Christ, in other words, your average ordinary, White Man, then the first deviances, the first divergence-types, are racial: yellow man, black man, men in the second or third category. They must be Christianized, in other words, facialized. European racism as the white man's claim has never operated by exclusion (...). Racism operates by determination of degrees of deviance in relation to the White-Man face". DELEUZE, G.; e GUATTARI, F. Year zero, faciality. A Thousand Plateaus. London: Continuum, 2004, p. 197.

${ }^{448}$ Este termo, originário da psicologia, é utilizado por Ernst Gombrich em referência às predisposições do público receptor de uma dada obra de arte para mobilizar através da memória o reconhecimento de certas formas convencionais empregadas na fatura desse objeto. Gombrich ensina que a arte joga continuamente com a expectativa do público de encontrar essas formas ou esquemas. Cf. GOMBRICH, E. Arte e Ilusão. Um estudo da psicologia da representação pictórica. São Paulo: Martins Fontes, 2007.
} 


\title{
Da mulher negra na pintura da Europa oitocentista: alguns exemplos
}

\author{
White is the symbol of Divinity or God; \\ Black is the symbol of the evil spirit or the demon. \\ White is the symbol of light... \\ Black is the symbol of darkness and darkness expresses all evils. \\ White is the emblem of harmony; \\ Black is the emblem of chaos. \\ White signifies supreme beauty; \\ Black ugliness. \\ White signifies perfection; \\ Black signifies vice. \\ White is the symbol of innocence, \\ Black that of guilty, sin, and moral degradation. \\ White, a positive color, indicates happiness. \\ Black, a negative color, indicates misfortune. \\ The battle between good and evil is symbolically expressed \\ By the opposition of white and black \\ - Paillot de Montabert, $1838^{449}$
}

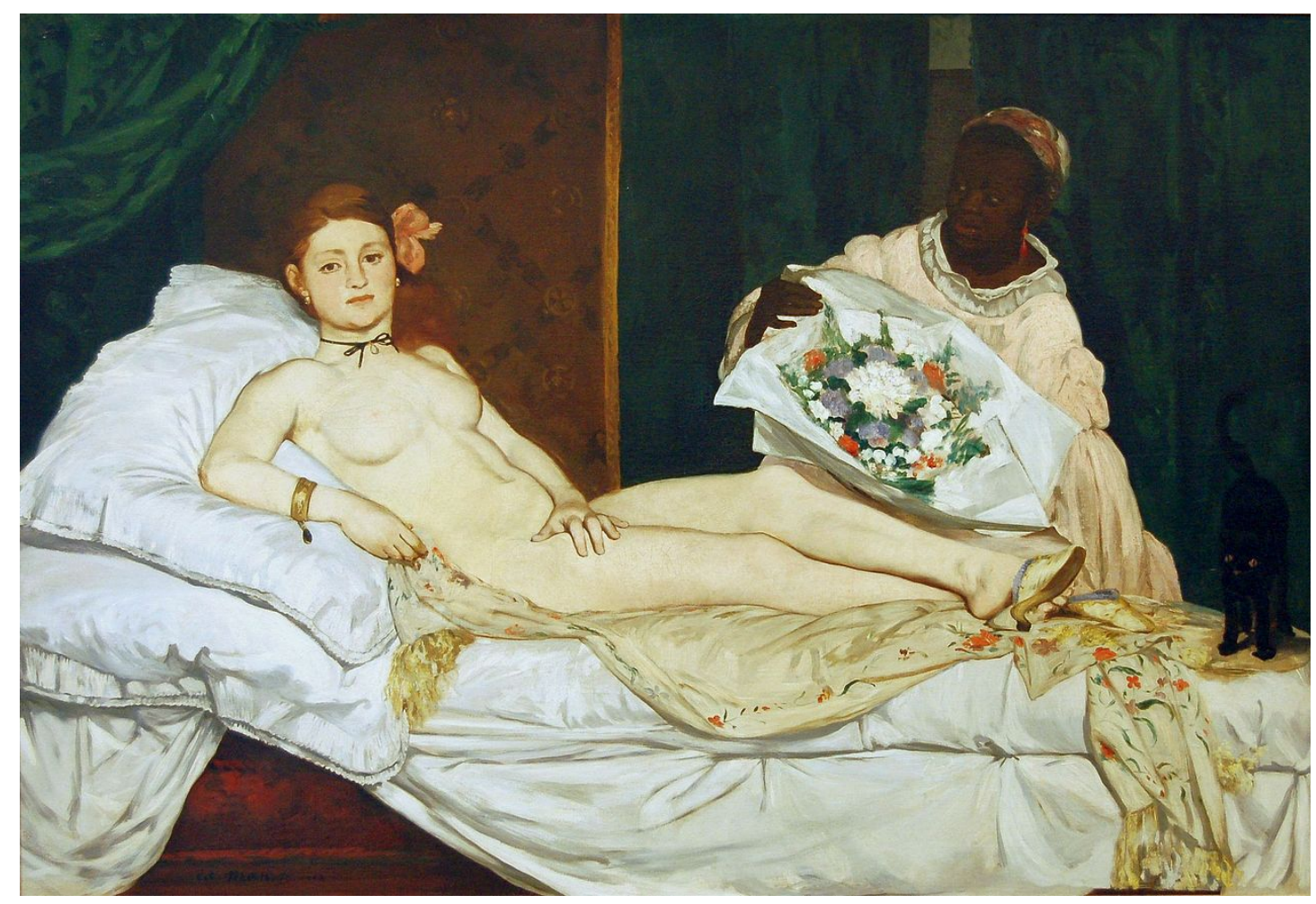

Fig. 80: Édouard Manet. Olympia (1863).

Óleo sobre tela, $130,5 \mathrm{~cm}$ x 190cm. Paris: Musée d'Orsay.

Talvez um dos quadros mais célebres do Oitocentos ${ }^{450}$, Olympia, de Édouard Manet (1832-1883), coloca lado a lado uma mulher branca e uma negra - a primeira,

449 Apud BOIME, A. The art of exclusion. Representing blacks in the Nineteenth Century.Washington\&London: Smithsonian Institution Press, 1990, p. 2. 
uma prostituta; a segunda, sua criada ${ }^{451}$. Exibida pela primeira vez no Salão de 1865 , em Paris, o quadro explora de modo original um topos caro à pintura e ao pensamento ocidental, qual seja, a oposição entre negro e branco, tornada evidente por autores como Paillot de Montabert, conforme a epígrafe acima. O que este crítico de arte, influente na primeira metade do século XIX, exprime em seus versos é uma polarização de cor que terá servido de fundamento para a produção artística europeia não apenas do período, mas ao longo de séculos de história do continente. Boime o explica:

The confusion of formalistic categories with ideological biases is a singular phenomenon in the history of art that has been sorely neglected. The racial opposition of black and white derives from the color scale; the famous chiaroscuro, or light and dark polarity, is intimately associated with the religious dualism of Good and Evil ${ }^{452}$.

Branco e negro são categorias formais, mas sua contraposição é fruto de uma convenção de contornos ideológicos explícitos. A aparição de tal contraste na pintura adquire, inevitavelmente, significações que ultrapassam a simples apreensão objetivosensorial das cores. Tendo tal perspectiva em vista, encontramos em Olympia um problema a um só passo formal e conceitual: por um lado, "Manet, anxious to eliminate shadow from his painting space, hit upon an ingenious solution for

\footnotetext{
${ }^{450}$ Se não o mais ultrajante aos olhos dos críticos e o público de arte do período, como mostram CLARK, T. J. The Painting of Modern Life: Paris in the Art of Manet and His Followers. New York: Knopf, 1985; e BERNHEIMER, C. Manet's Olympia: The Figuration of Scandal. In: Poetics Today, Vol. 10, No. 2, Art and Literature II (Summer, 1989), pp. 255-277.

${ }^{451}$ Morais segue a afirmação de Antonio Bento, para quem a criada teria sido inspirada numa negra carioca, Laura, que trabalhou para Manet quando ele esteve no Rio. MORAIS, F. O Brasil na visão do artista. São Paulo: Prêmio Editorial, 2002. No entanto, a maioria dos analistas considera tratar-se de uma negra das Índias Orientais. Para uma discussão sobre a personagem, ver também HONOUR, H. L'image du noir dans l'art occidental. Paris: Gallimard, 1989. Tome 2, pp.159-160; e FLOYD, P. A. The Puzzle of Olympia. In: Nineteenth-Century Art Worldwide, v. 3, Issue 1, Spring 2004. Disponível em: <http://www.19thc-artworldwide.org/spring-04/index.html $>$. Consulta: 10/05/2013.

${ }^{452}$ BOIME, A. The art of exclusion. Representing blacks in the Nineteenth Century. Washington \& London: Smithsonian Institution Press, 1990, p. 2.
} 
achieving dramatic contrast without chiaroscuro ${ }^{453}$, by the interaction of the maid and the courtesan" 454 .

Por outro, um tal procedimento atesta o quanto, naquele momento, já era convencional a vinculação ideológica entre "raça" e "cor". Preto e branco extrapolavam o rótulo das tonalidades, indexando sentidos raciais consolidados num imaginário desdobrado das relações coloniais.

If nothing else, the maid indicates the status of her mistress, which is always a notch above her own. Secondly, the dialectic of Manet's black and white symbolism inevitable points to the colonial enterprises of the Second Empire. The West Indian maid (identified by her headdress) has been induced to come to Paris for work, and she has been impressed into the service of a high-class prostitute whose very existence depends upon the signs of status that go right to the heart of imperial darkness. The juxtaposition of the courtesan and the exoticized black servant point inescapably to a world-embracing political system. Olympia is not only triumphant over her admiring client presenting the floral gift, but also over the colonialized Other who mediates between them ${ }^{455}$.

Mas além da sobreposição entre raça e cor, Olympia também explora uma segunda problemática, igualmente fundante para o colonialismo europeu: a vinculação entre raça e gênero/sexualidade. Num primeiro momento, basta recordar que a cena empreende uma inversão, pois a representante da brancura - cor imediatamente associada à pureza, na perspectiva mais convencional expressa pelos versos de Montabert e por outros críticos - é uma prostituta. Daí sua ironia, que procuraremos compreender melhor adiante.

Mas antes disso, é preciso pontuar que a conjunção entre gênero e raça/cor é recorrente na pintura Oitocentista e ganha alento especial com a pintura orientalista produzida a partir do início do século XIX. Não raro, tal articulação engendra a interlocução entre a auto-percepção do homem branco europeu (o artista e seu suposto público) e a legitimação da empreitada colonialista: num sistema que se desdobra das fantasias brancas e masculinas, as mulheres, assim como as populações que habitam

\footnotetext{
${ }^{453}$ Chiaroscuro é o nome dado, em pintura, ao uso de contrastes acentuados de luz e sombra, a fim de conferir profundidade aos corpos e volumes pintados e dramatismo às feições. A técnica é associada ao Renascimento e, de costume, aplica-se uma grande quantidade de tinta preta na produção das áreas sombrias, buscando-se obter uma transição gradual até o tom mais claro. Um pintor exemplar no uso do chiaroscuro é Michelangelo Merisi da Caravaggio (1571-1610), como se pode ver em telas como David con la testa di Golia (1606-07), pertencente à Galeria Borghese, em Roma.

${ }^{454}$ Idem, ibidem, p. 3. Sobre isto, é válido lembrar, como aponta Guimarães, que a ideia de "cor" faz sentido "no interior de ideologias raciais". GUIMARÃES, A. S. A. Racismo e Anti-Racismo no Brasil. São Paulo: Editora 34, pp. 44-45.

${ }^{455}$ Idem, ibidem, p. 4.
} 
as colônias, são vistas como propriedades ou espólios, e colocadas em posição subordinada ${ }^{456}$.

Se muitos nomes poderiam ser citados, como Jean-Léon Gerôme (1824-1904); Théodore Chasserieau (1819-1856); Alexandre Gabriel Decamps (1803-1860); e Eugène Fromentin (1820-1876) ${ }^{457}$, outro artista francês é exemplar: Eugène Delacroix (1798-1863), que perseguiu a fantasia de adentrar no harem algeriano - compartilhada com o público masculino francês ${ }^{458}$-, e a tornou visível através de seu Femmes d'Algier dans leurs appartements (1834). Aliado a isto, no que concerne a Delacroix destaca-se sobremaneira o reconhecimento deste artista como o autor de um sistema de notação de cor específico para a pintura orientalista, alinhado a um conceito particular de primitivismo, com grande influência sobre gerações posteriores.

Os dois aspectos são debitários da viagem do artista ao norte da África: em 1832, ele acompanhou o conde de Mornay - enviado especial do rei francês, Louis Philippe - em missão diplomática ao Marrocos, onde foram recebidos pelo sultão Abd-er-Rahman, permanecendo nas cidades de Tanger e Meknès durante dois meses. Ao deixar o Marrocos, os viajantes passaram por Cádiz e Sevilha (Espanha) e, após poucos dias em Oran, na Argélia, retornaram à França ${ }^{459}$. Na Argélia, o pintor recebeu uma esperada autorização para visitar o harem de um corsário turco - o que o inspirou a compor a famosa pintura das mulheres argelinas em seus aposentos, de 1834 .

\footnotetext{
${ }^{456}$ Ver DYER, R. White. London and New York: Routledge, 1997. T. J Clark menciona a ênfase na associação entre sexualidade e classe feita pelos críticos de Olympia - reforçando a relação mercantil e de posse que envolvia a percepção das relações sexuais, do ponto de vista masculino, francês e branco disseminado na imprensa do período. O autor também destaca as associações feitas pelos críticos do período entre o corpo de Olympia, o de um cadáver, sujeira e doenças, o que seria visto como uma espécie de código cifrado para sua sexualidade. CLARK, T. J. The Painting of Modern Life: Paris in the Art of Manet and His Followers. New York: Knopf, 1985. Cf. também BERNHEIMER, C. Manet's Olympia: The Figuration of Scandal. In: Poetics Today, Vol. 10, No. 2, Art and Literature II (Summer, 1989), pp. 255-277.

${ }^{457}$ Também é preciso lembrar artistas pioneiros, como Horace Vernet (1789-1863) e o próprio Ingres, este último célebre por suas cenas com odaliscas. Evidentemente, a tradição orientalista também esteve presente fora da França. Mas é sobretudo a partir da década de 40 que um orientalismo francês marcado por tendências de uso da cor específicas se propaga.

${ }^{458}$ NOCHLIN, L. The imaginary Orient. In: The politics of vision: essays on Nineteenth century art and society. New York: Harper \& How Publisher, 1983; POLLOCK, G. Differencing the Canon. Feminist Desire and the Writing of Art's Histories. London and New York: Routledge, 1999; GRIGSBY, D. G. Orients and Colonies: Delacroix's Algerian Harem. In: The Cambridge Companion to Delacroix. Cambridge: Cambridge University Press, 2001; ALLOULA, M. The Colonial Harem. Minneapolis: University of Minnesota Press, 1986; PLATO, J. D. Multiple Wives, Multiple Pleasures: Representing the Harem, 1800-1875. Madison: Fairleigh Dickinson University Press, 2002; KALMAR, I. The Houkah in the Harem: On Smoking and Orientalist Art. In GILMAN, S.; ZHOU, X. (ed.). Smoke. London: Reaktion Press, 2004.

${ }_{459}$ Cf. GUARALDO, L. Delacroix no Marrocos e a inversão do exótico. In: Projeto História n. 42, jun. 2011.
} 
Sabe-se que a colonização francesa da África do Norte - iniciada pela ocupação do Egito pelas tropas napoleônicas em 1801 - marca o desenvolvimento de um novo paradigma orientalista na pintura ${ }^{460}$. De acordo com Miller ${ }^{461}$, o orientalismo elegeu, redefiniu certos matizes, vistos como exóticos e exuberantes, transformandoos num topos central e desafiando no uso da cor o primado do desenho estabelecido pelas diretrizes neoclássicas como padrão estético e moral de valor superior ${ }^{462}$. Delacroix, tido como um grande expoente dessa tendência, ficou marcado pela experiência da viagem, que o motivou a seguir trabalhando, nas décadas subsequentes, para desenvolver seu modelo de aplicação da cor que logo se tornou paradigmático.

Um insumo importante para as reflexões do artista teria sido a teoria das cores elaborada pelo químico Michel-Eugène Chevreul (1786-1889), diretor da manufatura têxtil de Gobelins, em Paris ${ }^{463}$. Diante das críticas dos consumidores ao padrão tonal dos produtos da tecelagem - as cores originais se alteravam em contato umas com as outras -, o químico empreendeu estudos sobre a percepção óptica e concluiu que cores chapadas em contraste complementar, como vermelho e verde; laranja e azul; e amarelo e violeta equilibram-se mutuamente quando contrapostas, podendo ser visualizadas sem alterações. No uso dos contrastes complementares, Delacroix encontrou um modelo para suas produções de temática orientalista, capaz de dotá-las de um caráter "primitivo" - com sentido de puro, ou sem mescla.

\footnotetext{
${ }^{460}$ Para uma síntese, ver MEAGHER, J. "Orientalism in Nineteenth-Century Art". In: Heilbrunn Timeline of Art History. New York: The Metropolitan Museum of Art, 2004. Disponível em: $<$ http://www.metmuseum.org/toah/hd/euor/hd_euor.htm>. Última consulta: 26/07/2013. Cf também NOCHLIN, L. The imaginary Orient. In: The politics of vision: essays on Nineteenth century art and society. New York: Harper \& How Publisher, 1983; POLLOCK, G. Differencing the Canon. Feminist Desire and the Writing of Art's Histories. London and New York: Routledge, 1999; e LEMAIRE, G.G. L'Univers des Orientalistes. Paris: Éditions Place des Victoires, 2000.

${ }^{461}$ MILLER, P. B. "Des couleurs primitives": Miscegenation and French Painting of Algeria. In: Visual Resources, 24:3, 2008, pp. 273-298.

${ }^{462}$ Diz-se que Jacques-Louis David, o maior expoente do neoclassicismo, esforçava-se para manter seu talento de colorista sob controle em detrimento da linha, entendida como a expressão do domínio racional das emoções. Cf. STAROBINSKY, J. Os emblemas da razão. São Paulo: Companhia das Letras, 1989; FRIEDLANDER, W. De David a Delacroix. São Paulo: CosacNaify, 2001; e PREVSNER, N. Academias de arte: passado e presente. São Paulo: Companhia das Letras, 2005.

${ }^{463}$ Cf. Ver BIRREN, F. History of colour in painting. NY: Van Nostrand Reinhold Corp., 1965. Introduction. IN: The principles of harmony and contrast of colours and their application to the arts, by Michel Chevreul. NY: Reinhold Publishing Corporation, 1967; GAGE, J. Color and meaning: art, science, and symbolism. Berkeley: University of California Press, 2000; Color and culture: practice and meaning from antiquity to abstraction. Berkeley: University of California Press, 1999. Dentre os autores consultados, Chu é a única a considerar que Delacroix já vinha trabalhando para desenvolver seu sistema de cores, antecipando muito do que foi proposto por Chevreul. CHU, P. T. A science and an art at once: Delacroix's pictorial theory. In: WRIGHT, Beth S., The Cambridge Companion to Delacroix. Cambridge: Cambridge University Press, 2001.
} 
800. Chevreul's classification of colors, and chromatic diagram.-The chromatic diagram, of Cherreul, fig. 441, greatly

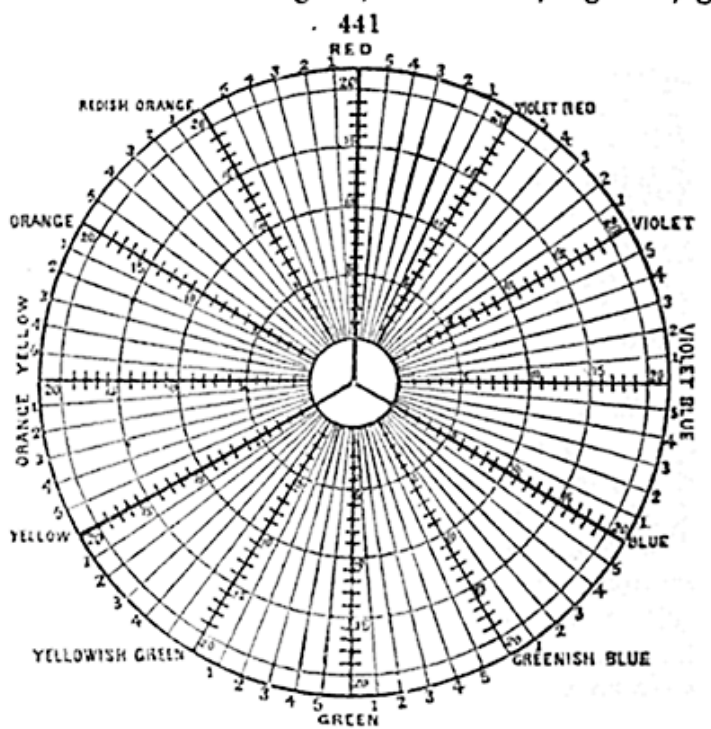

facilitates the study of complementary colors, and the modifications produced by their mutual proximity.
Fig. 81: O diagrama elaborado pelo químico Chevreul esquematiza a teoria dos contrastes complementares. A partir de três pares principais - verde/vermelho e amarelo/violeta, laranja/azul -, se desdobram outros contrastes no círculo cromático. Note-se que a proximidade entre violeta, azul e laranja, amarelo torna tais cores quase que intercambiáveis entre si.

Extraído de First principles of physics: or Natural philosophy, designed for the use of schools and colleges (1859), de autoria de Benjamin Silliman, que reimprimiu o diagrama de 1855 .

Como mostra Miller ${ }^{464}$, Delacroix e outros artistas que acompanhavam expedições oficiais ao norte da África ${ }^{465}$ encontravam ali um problema comum na dificuldade de reproduzir, do ponto de vista formal, a luminosidade e os tons de pele dos nativos da região. Na busca de soluções, iam desenvolvendo um sistema de notação "etnográfica" em franco diálogo com os esforços da Sociedade Etnológica de Paris, empenhada em "distinguir tipos puros dos miscigenados" 466 em solo colonial na prática, com uma grande propensão a valorizar os primeiros. Na Argélia, por exemplo, se o etnógrafo D'Omalius d'Halloy (1783-1875) admitia que as cores nos nativos forçavam "às vezes, a classificar numa categoria racial homens cuja pele não estava de acordo ao caráter de sua raça"467, é interessante notar que na pintura, a palheta de Delacroix, entre outros artistas, era "a antítese da mistura característica da geografia racial" $" 468$ local, de modo que "a teoria das cores adaptada à representação dos argelinos, ao final da década de 1840, reflete tropos discursivos centrais para a

${ }^{464}$ MILLER, P. B. "Des couleurs primitives": Miscegenation and French Painting of Algeria. In: Visual Resources, 24:3, 2008, pp. 273-298.

${ }^{465}$ Ele discute mais detidamente Delacroix e Théodore Chasserieau (1819-1856).

${ }^{466}$ Idem, ibidem, p. 276. O autor comenta o quanto, do ponto de vista dos antropólogos franceses, a imensa variabilidade de tons de pele encontrados entre os africanos representava uma ameaça ao modelo classificatório que privilegiava a ideia de tipos puros ou primitivos.

${ }^{467}$ MILLER, P. B. "Des couleurs primitives": Miscegenation and French Painting of Algeria. In: Visual Resources, 24:3, 2008, p. 280.

${ }^{468}$ Idem, ibidem, p. 281. 
prática da etnologia” ${ }^{469}$ francesa: a busca por tipos puros e os olhos fechados para a miscigenação em curso $^{470}$.

A ruptura operada pelo artista implicou na revisão do conceito pictórico de “cor local", à luz do debate etnológico francês: se até então a "cor local" era a cor predominante ou principal de um corpo ou objeto - e as "cores secundárias" aquelas que perfaziam sua transição para outros objetos -, agora ela ganhava também o sentido de "assunto pitoresco, uma cena ou um detalhe concentrando o sabor único ou essencial de um lugar ou cultura"471. Além disso, o domínio na aplicação da cor local virava agora o "elemento-chave do processo de pintura dos coloristas" deveriam dedicar-se uma série de estudos para capturar a um só passo uma aparência e uma caráter das coisas, por meio de um matiz dominante. Dessa forma, em seu Dicionário de Belas Artes ${ }^{473}$, Delacroix associa cor local a "localidade"; em seus diários, discute de que maneiras a cor local pode ajudá-lo a encontrar uma solução técnica para simplificar sua linguagem, permitindo-lhe libertar suas figuras de detalhes desnecessários e concentrar-se no essencial. Além disso, nomeia a "cor local" como "cor primitiva", criando assim uma relação direta entre o despojamento de nuances e o caráter dos norte-africanos que buscava representar. De acordo com Miller, isto ocorreu em sintonia com investigações que procuravam isolar tipos puros (primitivos) dos miscigenados ${ }^{474}$.

Do ponto de vista técnico, a mudança operada por Delacroix consistiu em produzir a transição entre elementos em cena por meio de uma fusão das cores principais (que ele chamou de "cores primitivas") com matizes secundários

\footnotetext{
${ }^{469}$ Idem, ibidem, p. 281.

${ }^{470}$ Grigsby chama a atenção para a gama reduzida de termos para a classificação de cor e grupos étnicos, no diário de Delacroix: "Four terms alone, Moors, Negroes, mulattoes and Jews, fonctioned as his primary ethnic categories; not, one should notice, Berber or Bedouin or Kabyle. Often Negro and mulatto seemed to signify color as much as ethnic or racial identity" (p. 74). Além disso, ela comenta que "only occasionally does a notation like 'black moor squatting - small negro nose' indicate some attention to the subtle 'mixing' of racial codes and to physiognomic traits associated with race" (p. 75). Tais informações sugerem um processo de simplificação, possivelmente necessário para a produção pictórica do artista no Marrocos. GRIGSBY, D. G. Orients and Colonies: Delacroix's Algerian Harem. In: The Cambridge Companion to Delacroix. Cambridge: Cambridge University Press, 2001.

${ }^{471}$ Idem, ibidem, p. 281.

${ }^{472}$ Idem, ibidem, p. 281.

${ }^{473}$ Delacroix jamais conseguiu lançar o Dicionário, iniciado em 1857. No entanto, diversos verbetes foram sendo anotados em seus diários, que manteve ao longo da vida, a partir de 1822. HANOOSH, M. Histoire d'une édition: le Journal de Delacroix, archéologie et reconstitution d'un document. In: RIHA Journal, 0001, 14 de abril de 2010. Disponível em: <http://www.rihajournal.org/articles/2010/hannoosh-histoire-d-une-edition>. Última consulta: 26/07/2013.

${ }_{474}$ MILLER, P. B. "Des couleurs primitives": Miscegenation and French Painting of Algeria. In:
} Visual Resources, 24:3, 2008, p. 280. 
(complementares) destas tonalidades, evitando o uso do preto (e o efeito chiaroscuro), tão presente na pintura produzida até então. Em decorrência, suas telas primavam pela homogeneidade na pele de figuras representativas de grupos humanos, mas também segundo os preceitos de Chevreul - pela estabilidade na percepção da "cor primitiva", que se via sem mescla, nem mutação.

Merece atenção a articulação de ambos os modelos: enquanto o artista tornouse paradigmático, a respeito do químico é preciso destacar a ampla difusão de sua $D e$ la loi du contraste simultané des couleurs (1839), que como assinala Gage ${ }^{475}$, talvez tenham sido o manual sobre cor mais utilizado no século XIX, com traduções ao inglês e alemão. Assim, os sistema desenvolvidos por Delacroix, tanto quanto por Chevreul podem ter sido responsáveis pela profusão no uso de contrastes complementares de verde e vermelho; amarelo e azul; e laranja e violeta, em especial, que parece ter se tornado uma espécie de marca distintiva da pintura orientalista e, assim, entrado definitivamente para o paradigma constitutivo do olhar europeu sobre os não-brancos - que carregava consigo a ideia de primitivismo, envolvendo a noção de raças puras, mas também as ideias circulantes sobre uma suposta superioridade racial dos brancos ${ }^{476}$.

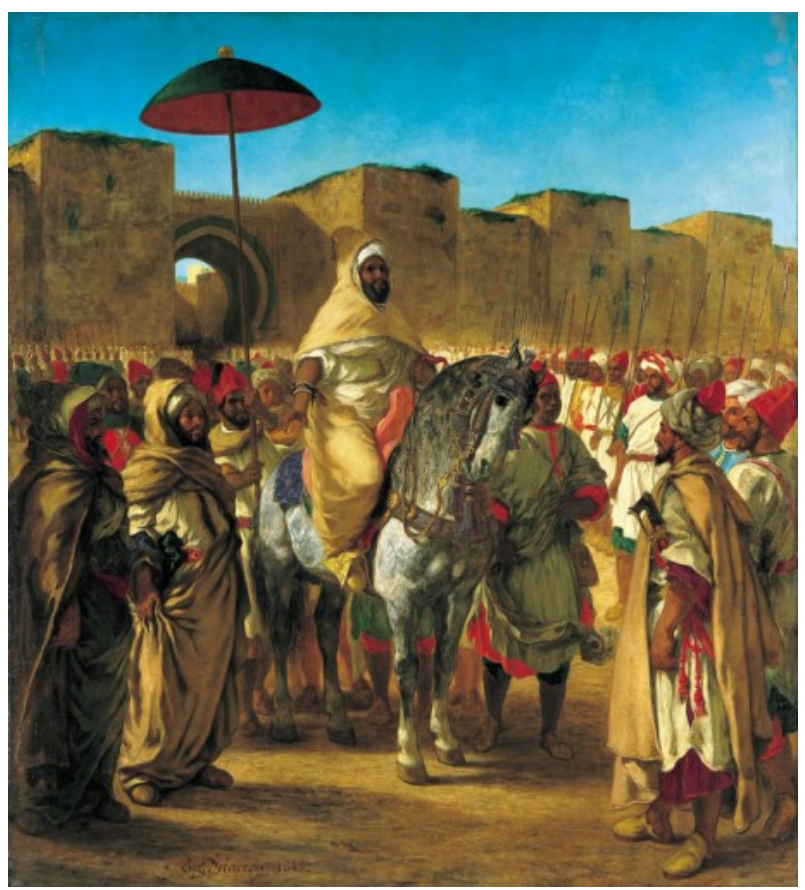

Os contrastes complementares marcam as telas orientalistas de Delacroix, com destaque para a polarização entre vermelho, verde, amarelo e azul.

Fig. 82: Eugène Delacroix.

Moulay Abd er-Rahman, sultão do Marrocos (1845)

Óleo sobre tela, $377 \mathrm{~cm} \times 340 \mathrm{~cm}$ Toulouse: Musée des Augustins

\footnotetext{
${ }^{475}$ GAGE, J. Color and meaning: art, science, and symbolism. Berkeley: University of California Press, 2000.

${ }^{476}$ Como vimos no capítulo 1 .
} 


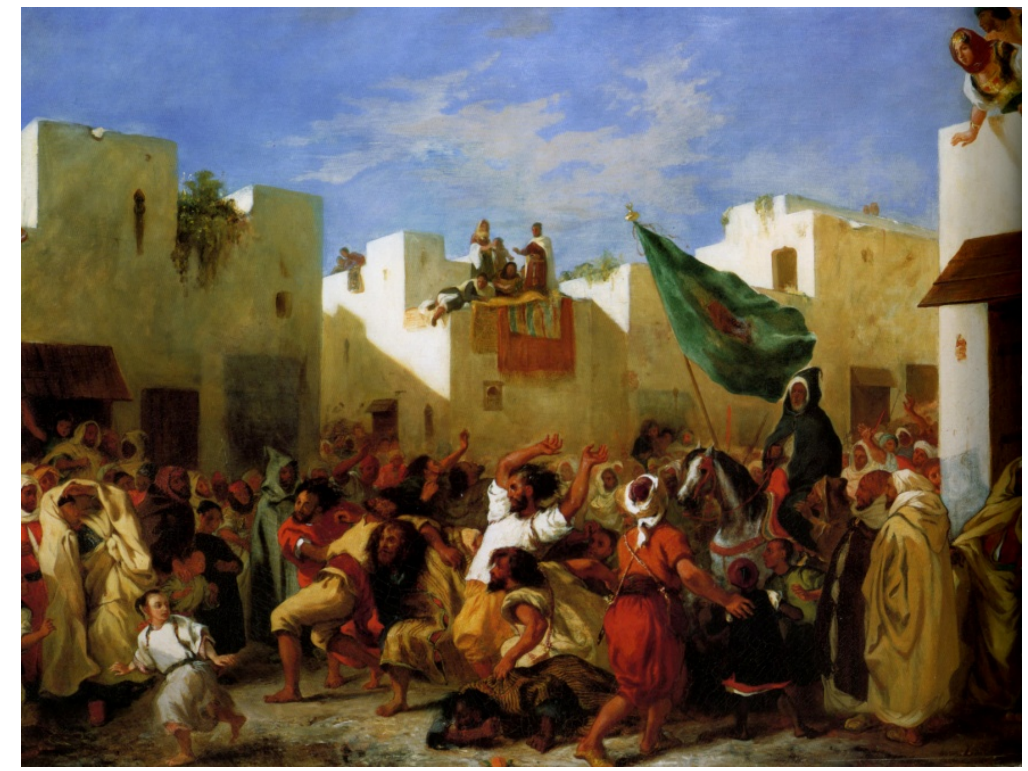

Fig. 83: Eugène

Delacroix.

Os convulsionários

de Tanger (1837-8).

Óleo sobre tela,

$100 \mathrm{~cm} \times 135 \mathrm{~cm}$

Toronto: Musée des

Beaux-Arts

d'Ontario à Toronto

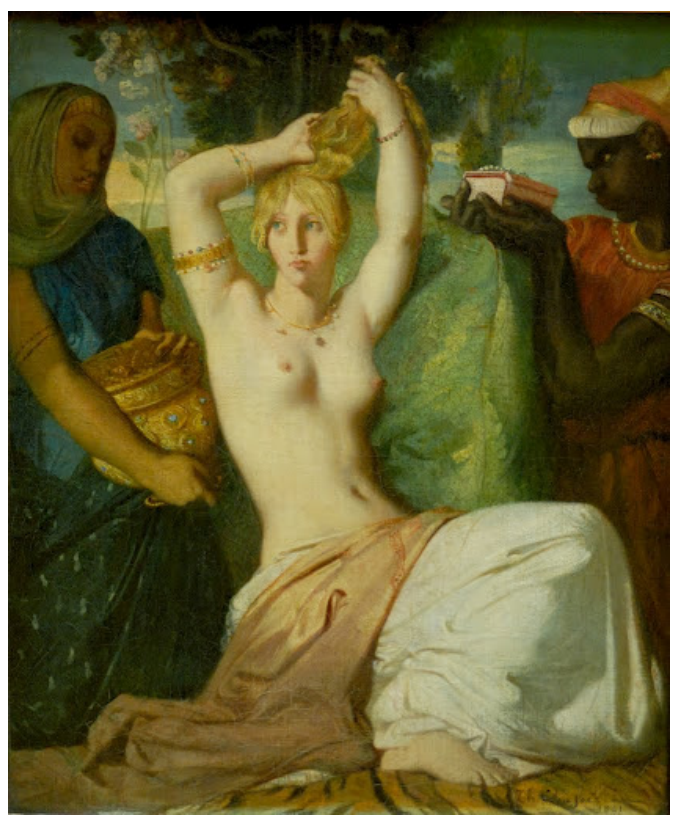

Outro artista que esteve no norte da África foi Théodore Chasserieau. Na pintura ao lado, ele faz largo uso dos contrastes complementares e explora três tonalidades de pele distintas.

Fig. 84: Théodore Chassériau.

La toilette d'Esther (1841).

Óleo sobre tela, $45,5 \mathrm{~cm} \times 35,5 \mathrm{~cm}$

Paris: Musée Du Louvre

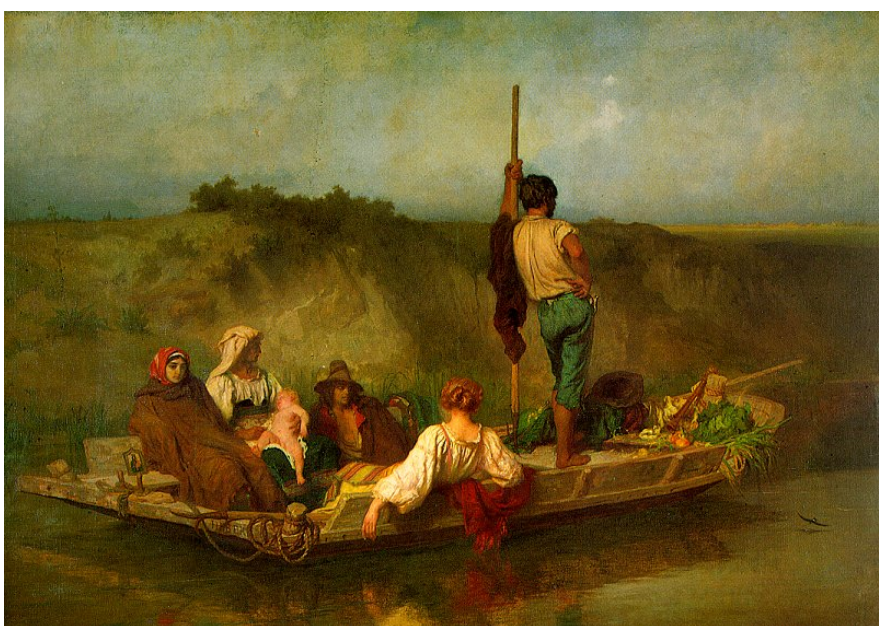

Os contrastes complementares, colocados em uso por Ernest Hébert. Seu professor, Paul Delaroche, foi próximo a Chevreul.

Fig. 85: Ernest Hébert. La Mal'aria (1848-49).

Óleo sobre tela, $135 \mathrm{~cm} \mathrm{x} 193 \mathrm{~cm}$. Paris: Musée d'Orsay 
Se os especialistas identificam nos anos 40 a maturidade da produção orientalista de Delacroix, em Femmes d'Algiers dans leurs appartements o uso de sua modalidade de "cor local" já se torna explícito na aplicação de uma palheta de tons em que predomina a visão contrastiva do verde, vermelho, amarelo, azul, laranja e roxo. No quadro, essas cores se destacam como contrapontos sobre a superfície pintada, entre o fundo do salão e a luminosidade dourada que vem pela janela. Além disso, a despeito da sombra intensa que ocupa grande proporção do quadro, o corpo das personagens usa apenas um ou dois tons da mesma cor predominante, sem apelar para um contraste mais evidente que pudesse aludir à ideia de mistura racial.

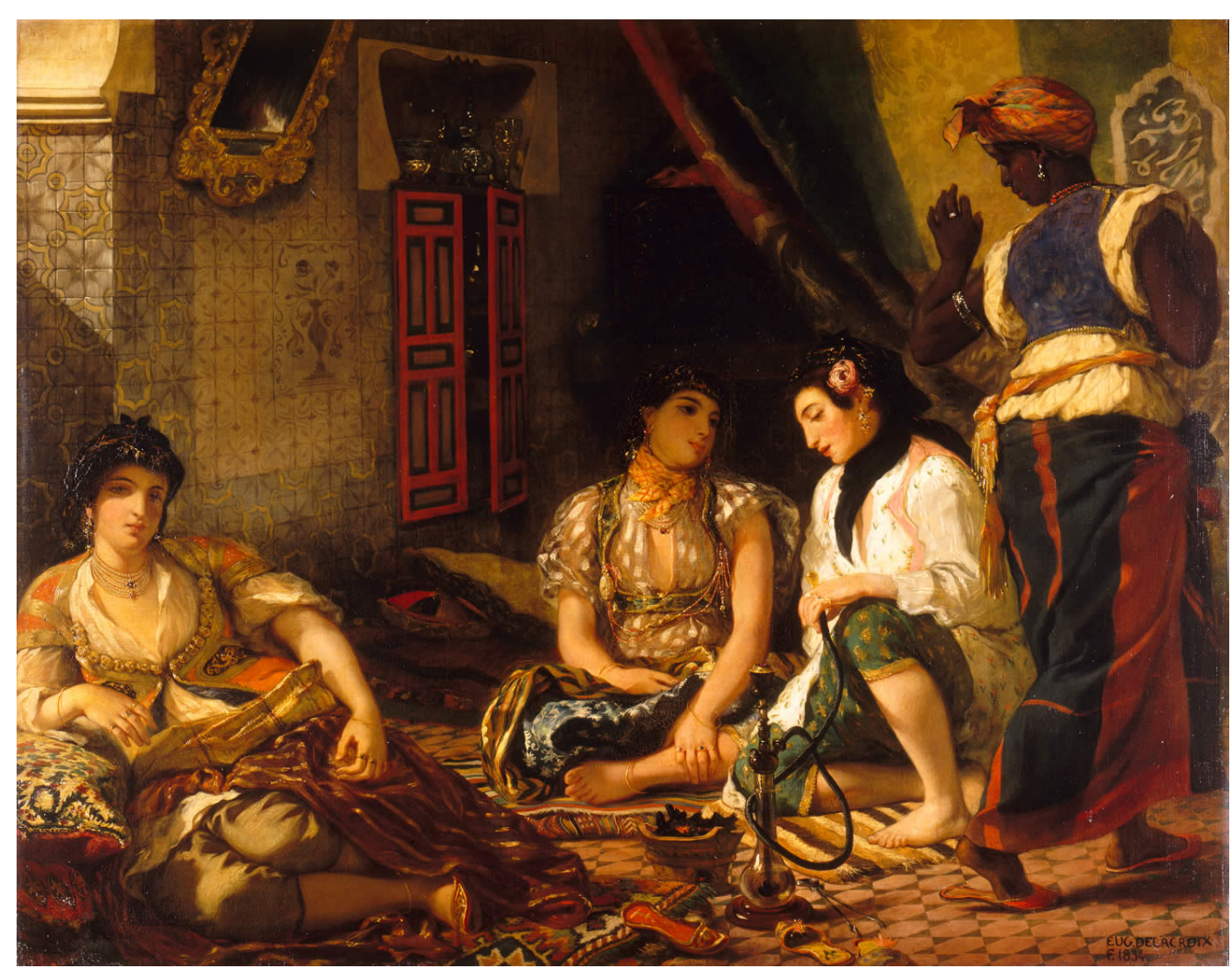

Fig. 86: Eugène Delacroix. Les femmes d'Algers dans leurs appartements (1834). Óleo sobre tela, 1,80m x 2,29m. Paris: Musée du Louvre.

Pode-se dizer, assim, que a obra de Delacroix representa um caso exemplar para um aprofundamento da ideia, apresentada por Boime ${ }^{477}$, de uma confusão entre categorias formais e fundamentos ideológicos que marca a aplicação e percepção dos códigos de cor na pintura. E se tais opções vão ao encontro dos interesses coloniais franceses no norte da África, a mesma afinidade transparece por meio de outra

\footnotetext{
${ }^{477}$ BOIME, A. The art of exclusion. Representing blacks in the Nineteenth Century. Washington \&
} London: Smithsonian Institution Press, 1990. 
dimensão marcante no orientalismo e muito presente em seus quadros: vejamos como o artista lida com a articulação entre os marcadores de gênero/sexualidade e raça.

Grigsby comenta os impasses por trás da elaboração de Femmes d'Algier: Delacroix, que convencionara definir sua pintura como a prática do intercurso (hetero)sexual, opondo-se à cultura homossocial do estúdio de David ${ }^{478}$, parte para sua celebrada viagem pelo norte da África munido de uma curiosidade particular pelas mulheres muçulmanas que habitavam aqueles territórios. Ao chegar, depara com uma situação adversa e inesperada: estas não apenas são inacessíveis, como também não se deixam ver, uma vez que afeitas à clausura de seu ambiente doméstico. Já as negras aparecem nas páginas de seu diário como criaturas servis e, em geral, descritas de modo pejorativo: de traços disformes, elas são mostradas como as ríspidas criadas que barram o acesso do pintor ao interior do harem. Como pontua Grigsby, "if he had repeatedly noted 'negrèsses' in his voyage sketchbooks, pausing to describe in both text and image a black woman running toward him with 'tits' [tétons] visible beneath her blouse, he chooses in his Salon painting to turn her away from the viewer" ${ }^{\prime 79}$.

Em decorrência, as femmes d'Algier pintadas por Delacroix seriam uma metamorfose operada a partir de alguns estudos realizados pelo artista em suas viagens, sobretudo no Marrocos (e não apenas na Argélia, portanto). Se as muçulmanas não the abriam as portas, as judias se tornavam seu modelo feminino prioritário no oriente. "Of course, the painter had immediatly recognized that Jewish women were no more sexually accesible than 'Moorish' women”, pontua Grigsby, "but at least (...) they were visible to him" $" 480$. Além delas, havia evidentemente os homens que, em troca de dinheiro, aceitavam posar no estúdio do artista. $\mathrm{Na}$ imaginação de Delacroix, ambos os tipos de modelos eram pouco a pouco postos a encenar o papel das argelinas muçulmanas, ou seja, das mulheres consideradas as habitantes típicas de uma colônia que a França lutava para conquistar. Como resultado, o harem visto de seu interior é antes uma forma fabricada - o produto de uma operação imaginária do pintor, que o compôs a partir dos modelos disponíveis e jamais daqueles que a princípio desejava.

\footnotetext{
${ }^{478}$ GRIGSBY, D. G. Orients and Colonies: Delacroix's Algerian Harem. In: The Cambridge Companion to Delacroix. Cambridge: Cambridge University Press, 2001.

${ }^{479}$ Idem, ibidem, p. 82.

${ }^{480}$ Idem, ibidem, p. 78.
} 
Por um lado, a pintura dava vazão às fantasias colonialistas dos franceses, em que os haréns emergiam como lugares povoados de mulheres brancas e sempre dispostas a realizar seus desejos sexuais ${ }^{481}$. Por outro lado, na metamorfose do corpo masculino em feminino, estava uma afirmação velada de superioridade do homem branco em relação aos demais ${ }^{482}$. Por sinal, os homens argelinos jamais apareciam nessas imagens, consideradas eróticas, ao lado das mulheres, a não ser como eunucos.

Tudo iria mudar, pois em 1834 o sultão da Argélia é deposto pela França. O evento é celebrado pela imprensa francesa por meio de uma metáfora já previsível: nas páginas dos jornais, "as popular prints continually emphasized, to wrest Algeria away from its ruler was to claim his harem, his property", diz Grigsby. A despeito da pintura de Delacroix, recém-lançada, ter sido vista como uma amostra verídica do interior do harem, não tardou para que periódicos de seu país passassem a estampar charges e caricaturas, com grande assiduidade, ridicularizando o colonialismo - e, por tabela, a visão fantástica do artista - por meio da mesma metáfora.

In such caricatures, Frenchmen simpleminded risked life and limb to grab what they were told was their reward and found only old, fat, or motley white women, or large full-breasted, sometimes shockingly denigrated black women, or, in one especially disturbing image, a monkey instead. In many prints, the harem, like Algeria, seemed to have promised the Orient, but delivered in its place a devalued repugnant black Africa. Algeria, in such racist anticolonial images, was a degraded black woman rather than the traditionally prized white harem woman ${ }^{483}$.

Como amostra de um modelo arraigado, que aproximava raça e gênero para reafirmar um ideal de superioridade branca e masculina, as charges são emblemáticas.

\footnotetext{
${ }^{481}$ NOCHLIN, L. The imaginary Orient. In: The politics of vision: essays on Nineteenth century art and society. New York: Harper \& How Publisher, 1983; POLLOCK, G. Differencing the Canon. Feminist Desire and the Writing of Art's Histories. London and New York: Routledge, 1999; GRIGSBY, D. G. Orients and Colonies: Delacroix's Algerian Harem. In: The Cambridge Companion to Delacroix. Cambridge: Cambridge University Press, 2001; ALLOULA, M. The Colonial Harem. Minneapolis: University of Minnesota Press, 1986; PLATO, J. D. Multiple Wives, Multiple Pleasures: Representing the Harem, 1800-1875. Madison: Fairleigh Dickinson University Press, 2002; KALMAR, I. The Houkah in the Harem: On Smoking and Orientalist Art. In GILMAN, S.; ZHOU, X. (ed.). Smoke. London: Reaktion Press, 2004.

${ }^{482}$ Poderíamos citar aqui, dentre os estudos que apontam para a construção deste discurso sobre o desejo no mundo ocidental oitocentista, POLLOCK, G. "A Tale of Three Women: Seeing in the Dark, Seeing Double, at least, with Manet". In: Differencing the Canon. Feminist Desire and the Writing of Art's Histories. London and New York: Routledge, 1999; MCCLINTOCK, A. Couro Imperial. Editora Unicamp, Campinas, 2010; sobre o Brasil, ver MOUTINHO, L. Razão, “cor" e desejo. Unesp, São Paulo, 2003; MISKCOLCI, R. O desejo da nação. Masculinidade e branquitude no Brasil de fins do século XIX. Annablume, São Paulo, 2012.

${ }^{483}$ GRIGSBY, D. G. Orients and Colonies: Delacroix's Algerian Harem. In: The Cambridge Companion to Delacroix. Cambridge: Cambridge University Press, 2001, p. 79.
} 
Mas se a pintura de Delacroix não encarnava seriedade sob a égide do discurso anticolonial, seus pressupostos não divergiam daqueles de seus críticos quanto às relações raciais e de gênero: tais caricaturas mantinham-se afeitas a cânones vigentes de branquitude e a um ponto de vista eminentemente masculino ${ }^{484}$. Como vimos, na descrição do pintor, as negras marroquinas não ocupavam o lugar da fantasia; antes, eram definidas por atributos físicos considerados anormais, como os seios exagerados e expostos sem pudor. Não por acaso, ao retratar as mulheres argelinas de pele mais clara, ele as dotou de seios pequenos, trabalhando as transparências e tecidos de modo sugestivo, sem qualquer traço de nudez explícita. Mas nem por isto deixou de acentuar o contraste com a mulher negra, disposta em cena de costas para exibir o volume dos quadris e nádegas sob a saia, mas jamais o peito nu.

A introdução da mulher negra junto às brancas merece maior atenção, na medida em que tal combinação parece ter mobilizado a imaginação europeia ao longo do século XIX - e aqui voltamos ao exemplo de Olympia. Juntas, como mostra Gilman, essas figuras femininas eram tomadas como uma espécie de alusão pictórica à sexualidade irrefreada, configurando uma forma de reapropriação específica de um preconceito nutrido ao longo de séculos pelo pensamento europeu com relação aos africanos. Segundo o autor,

by the eighteenth century, the sexuality of the black, both male and female, becomes an icon for deviant sexuality in general (...) By the nineteenthcentury, as in the Olympia, or more crudely in one of a series of Viennese erotic prints entitled The Servant, the central female figure is associated with a black female in such a way as to imply their sexual similarity ${ }^{485}$.

Tratar-se-ia, assim, de um topos recorrente para uma imagística evidentemente masculina e atormentada pela ideia do desejo sexual feminino. Segundo a observação de Gilman, nas obras afeitas à temática, a figura da negra é comumente inspirada por

\footnotetext{
${ }^{484}$ Idem, ibidem.

${ }^{485}$ GILMAN, S. Black Bodies, White Bodies: Toward an Iconography of Female Sexuality in Late Nineteenth-Century Art, Medicine and Litterature. In: GATES, H. L. (ed.). "Race", Writing and Difference. Chicago and London: University of Chicago Press, 1985, p. 228. Vale a ressalva de Pollock, que adverte para o risco da análise de Gilman de reduzir a criada negra a "um atributo exótico da sexualidade venal", recomendando situá-la no marco conceitual do orientalismo para interpretar o quadro. Contudo, reconhecemos também o mérito de Gilman ao apontar para esquemas pictóricos centrais a um sistema de notação voltado para a classificação visual da mulher negra e da prostituta, em diálogo com a ciência e a opinião pública do período. A identificação desses esquemas é valiosa para a análise dos papéis de gênero e raça na pintura oitocentista. Ver POLLOCK, G. "A Tale of Three Women: Seeing in the Dark, Seeing Double, at least, with Manet". In: Differencing the Canon. Feminist Desire and the Writing of Art's Histories. London and New York: Routledge, 1999, p. 285.
} 
uma mesma modelo: Sara Bartmaan. Esta africana, escalada pela indústria do entretenimento colonial, foi exposta pela primeira vez em Londres, em 1810, quando recebeu o apelido de "Vênus Hotentote",486, e logo passou também a Paris, em 1814. O traço diferencial de Sara era a hipertrofia das nádegas - ou steatopygia, nome científico dado ao excesso de gordura nesta região do corpo, nas coxas e quadris. Graças a tal característica, Bartmann atrairia não apenas a atenção do público de seus shows, mas também a de cientistas como Georges Cuvier e J. J. Virey que, como apontam Jay-Gould e Gilman ${ }^{487}$, atribuíram a ela uma sexualidade patológica, cujos sintomas seriam o tamanho das nádegas e uma segunda hipertrofia, a do órgão genital.

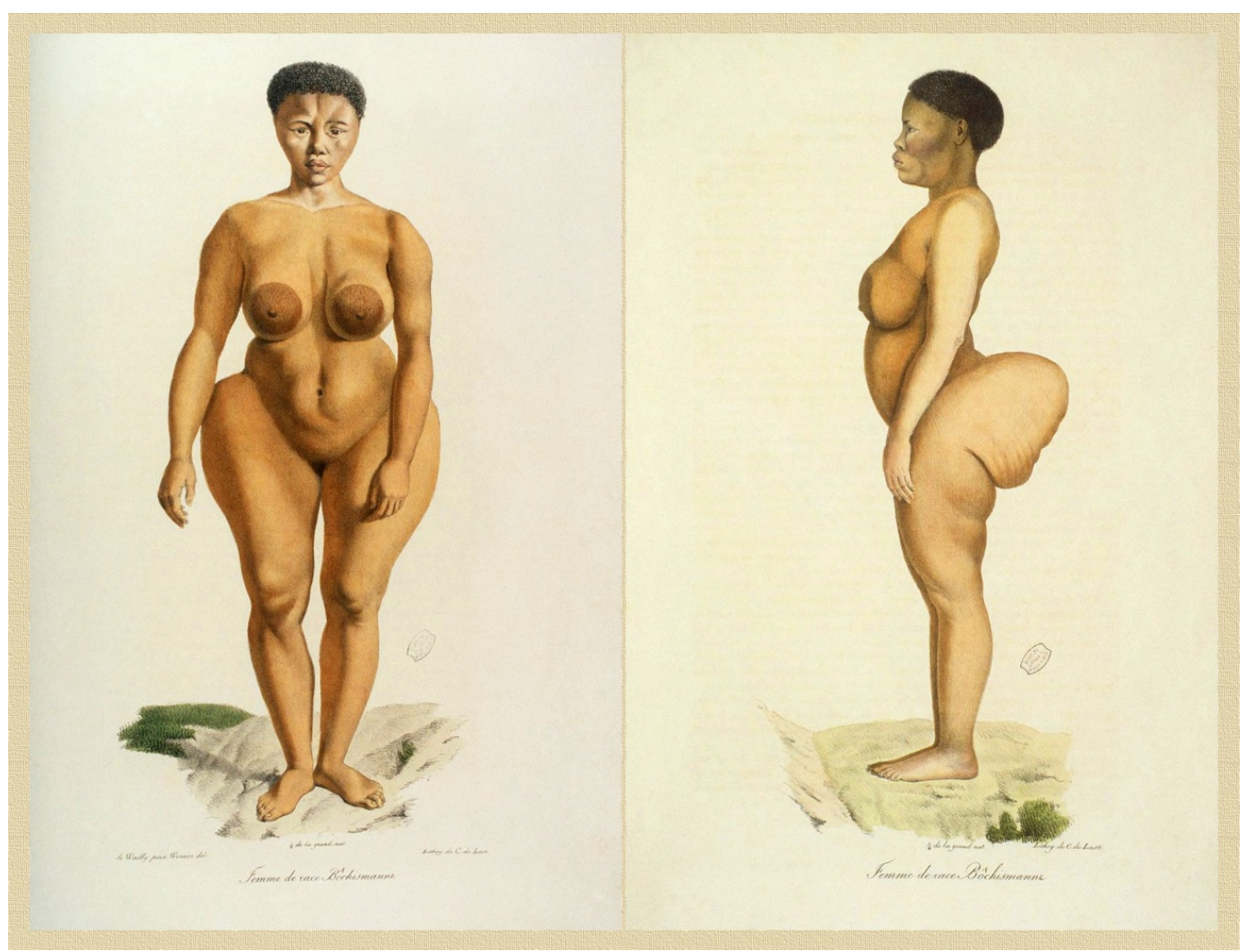

Fig. 87: Sara Baartman, a Vênus Hotentote. Imagens extraídas do Tomo II de "Illustrations de l'Histoire Naturelle des Mammifères" (1815), de Etienne Geoffroy Saint-Hilaire e Frédéric Cuvier. Desenho de Werner; litografia de C. de Lasteyrie. Fonte: Biblioteca Nacional da França.

\footnotetext{
${ }^{486}$ Hotentote teria sido o nome dado pelos holandeses, no século XVII, ao grupo conhecido como khoikhoi, que habitava a área entre o norte de Botswana e o Cabo da Boa Esperança. O termo seria uma referência à língua local, que aos ouvidos dos europeus soava como um gaguejar. Cf. STROTHER, Z.S. Display of the Body Hottentot. In LINDFORS, B., (ed.), Africans on Stage: Studies in Ethnological Show Business. Bloomington, Indiana, Indiana University Press, 1999, pp. 1-55.

${ }^{487}$ GILMAN, S. Black Bodies, White Bodies: Toward an Iconography of Female Sexuality in Late Nineteenth-Century Art, Medicine and Litterature. In: GATES, H. L. (ed.). "Race", Writing and Difference. Chicago and London: University of Chicago Press, 1985. GOULD, S. J. The Flamingo's Smile: Reflections in Natural History. W. W. Norton \& Company, 1987.
} 
Gilman afirma que o sistema de notação científico foi essencial para a disseminação da imagem de Sara Baartman como a mulher negra sexualizada. Se "the physical appearance of the Hottentot is, indeed, the central nineteenth-century icon for the sexual difference between the european and the black" ${ }^{\prime 48}$, isto ocorre com o aval da ciência. Em paralelo, estudos científicos começam a identificar os mesmos atributos físicos em mulheres brancas que, na visão dos cientistas, seriam acometidas por "patologia" sexual similar. O suposto desvio estaria inscrito na corporalidade.

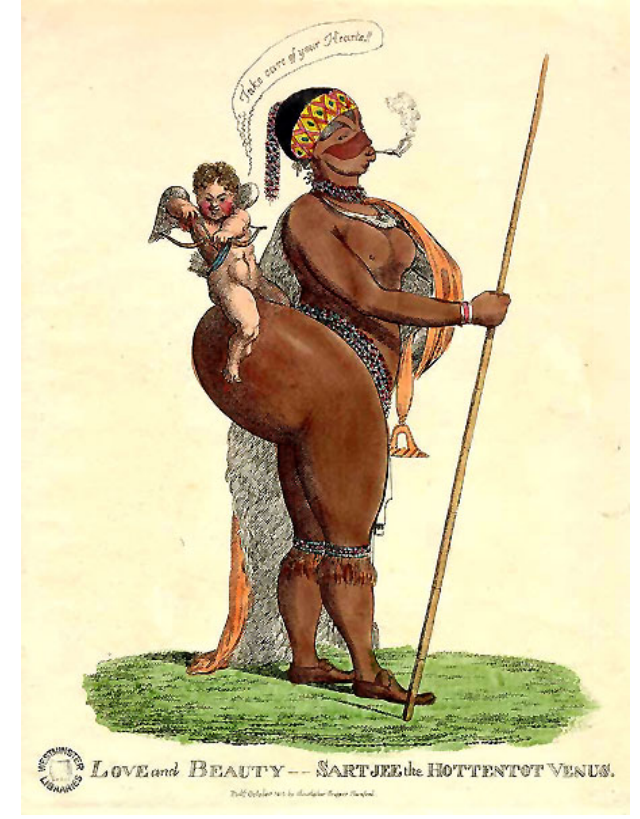

Uma série de pesquisas sobre prostituição - empreendidas por diferentes
Fig. 88: à dir.: Human Ear, modelled and drawn by Mr. Woolner. Ilustração de The descent of men (1871). A "orelha de Darwin" passaria a ser vista, no Oitocentos, como um sinal de degeneração feminina.

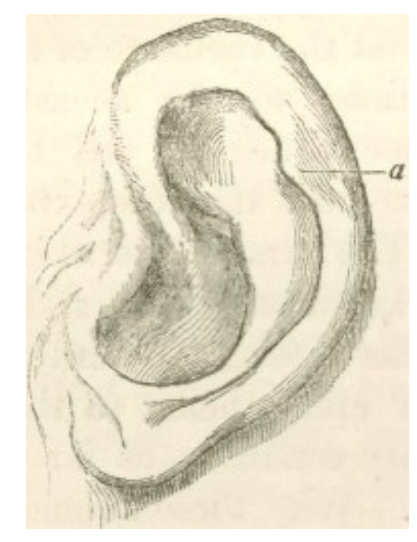

Fig. 89: À esq.: Christopher Crupper Rumford. Love and beauty - Sartjee the Hottentot Venus (1811). Gravura colorida à mão. Washington, D.C.: Library of Congress. As alusões à sexualidade de Sara Baartman são ironizadas na frase do Cupido, que mira o observador e diz "Take care of your hearts". Quase nua, ela fuma cachimbo e segura um longo bastão. pesquisadores que seguiam na esteira de Parent-Duchatelet ${ }^{489}$, com destaque para Cesare Lombroso - encontrava um padrão fisionômico e anatômico comum para as mulheres que se dedicavam a tal ofício: elas seriam gordas, de rostos assimétricos, narizes desfigurados, apresentavam uma hipertrofia do crânio na região parietal e a

\footnotetext{
${ }^{488}$ GILMAN, op. cit. p. 231. Strother chama a atenção para os distintos papéis assumidos pela imagem dos hottentot no pensamento europeu ao longo dos séculos. Diferentemente de Gilman, a historiadora indica que Baartman não foi considerada sexy pelo público londrino e parisiense que assistiu a suas performances nos anos 1810, mas sim "anti-erótica" e lembra que, ao longo de séculos (inclusive no XVIII), os hotentote foram vistos como quase assexuados. STROTHER, Z.S. Display of the Body Hottentot. In Lindfors, B., (ed.), Africans on Stage: Studies in Ethnological Show Business. Bloomington, Indiana, Indiana University Press, 1999, p. 2. Ressalva aceita, a análise de Gilman nos parece interessante por seu potencial de revelar as reapropriações icônicas assumidas pela imagem de Sara, que a partir de meados do século XIX passa a condensar um modelo de sexualidade tida como desviante, associado às negras e a certas mulheres, brancas ou não.

${ }^{489}$ Este médico higienista francês é autor do estudo De la Prostitution dans la ville de Paris (1835), considerado pioneiro no assunto e umas das primeiras pesquisas de sociologia empírica do período.
} 
orelha de Darwin (fig. 87). Outros estigmas da degeneração criminal, segundo tais pesquisas, seriam os cabelos escuros e grossos, as mandíbulas fortes e um olhar fisgado. Ao mencionar a gordura como um sintoma, indicava-se que o tamanho acentuado dos quadris e nádegas era determinante ${ }^{490}$, embora por vezes se pudesse substituir esse traço por seios fartos. Segundo tais estudos, tanto as prostitutas (outras mulheres que apresentassem essas características), quanto Sara Baartman, possuiriam a mesma anomalia sexual e, além disso, seriam inférteis.

Interessa perceber que tais referências não estão ausentes do universo pictórico, como Gilman procura mostrar. No mercado babilônio do casamento pintado por Edward Long (1734-1813) segundo texto de Heródoto, por exemplo, a negra que exibe a mulher à venda não por acaso está de costas, com as nádegas projetadas para o espectador da cena. Enquanto isso, as mulheres à frente são perfiladas segundo tais parâmetros: as da esquerda são mais brancas e correspondem aos traços considerados belos pelos europeus; progressivamente, as mulheres em cena adquirem fisionomias mais asiáticas e, por fim, negras - ainda que nenhuma possua a pele tão negra quanto a escrava de costas e não participa da cena como candidata ao casamento.

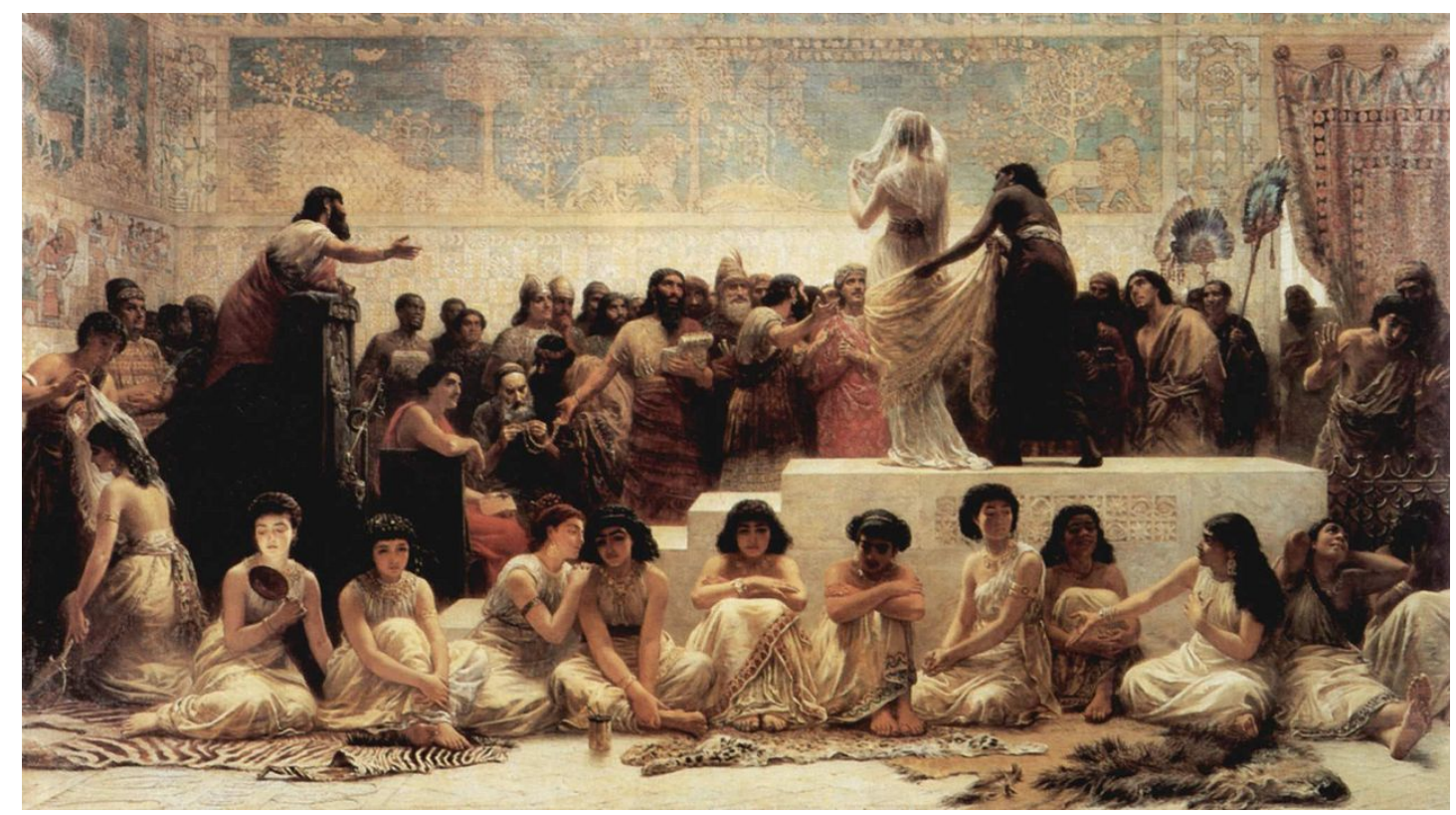

Fig. 90: Edwin Long. The Babylonian Marriage Market (1875). Óleo sobre tela, 172,6cm x 304,6 cm. Londres: Royal Holloway College. A pintura é, além disso, um exemplo do orientalismo inglês.

\footnotetext{
${ }^{490}$ Gilman acrescenta que as prostitutas gordas eram uma convenção do período, bem expressa por Madam's Birthday (1879), de Edgar Degas.
} 
Logo, essa imagem - assim como Les femmes d'Algier dans leurs appartements - posiciona a mulher negra de modo a mostrar as nádegas, numa possível alusão a Sara Baartman. Mas não é tudo:

The only black female is associated with sexualized white women as a signifier of their sexual availability. Her position is her sign and her presence in the picture is thus analogous to the figure of the black servant, Laura, in Manet's Olympia. Here the linkage between two female figures (...) represents the internalization of this [the sexual] perversity in one specific aspect of human society, the sexualized female, in the perception of late nineteenth-century Europe ${ }^{491}$.

Floyd reforça tal argumento, perfazendo uma linhagem de pinturas que apresentam esta temática desde o século XVIII:

As is now well established, pictorial precedents existed for women, usually nude, attended by a black maid, such as the eighteenth-century painting by Jean-Marc Nattier, Mlle De Clermont en Sultane of 1733, The Odalisque, by Charles Jalabert of 1842 or Esther with Odalisque by Léon Benouville. During the nineteenth century an odalisque and later a courtesan with an attendant negress usually designated unbridled eroticism. In his Dictionnaire des idées reçues Gustave Flaubert declared that the negress was "more amorous than white women." The stereotype inspired early erotic photographs, such as F. J. A. Moulin's of 1853, one of many sources identified for Olympia ${ }^{492}$.
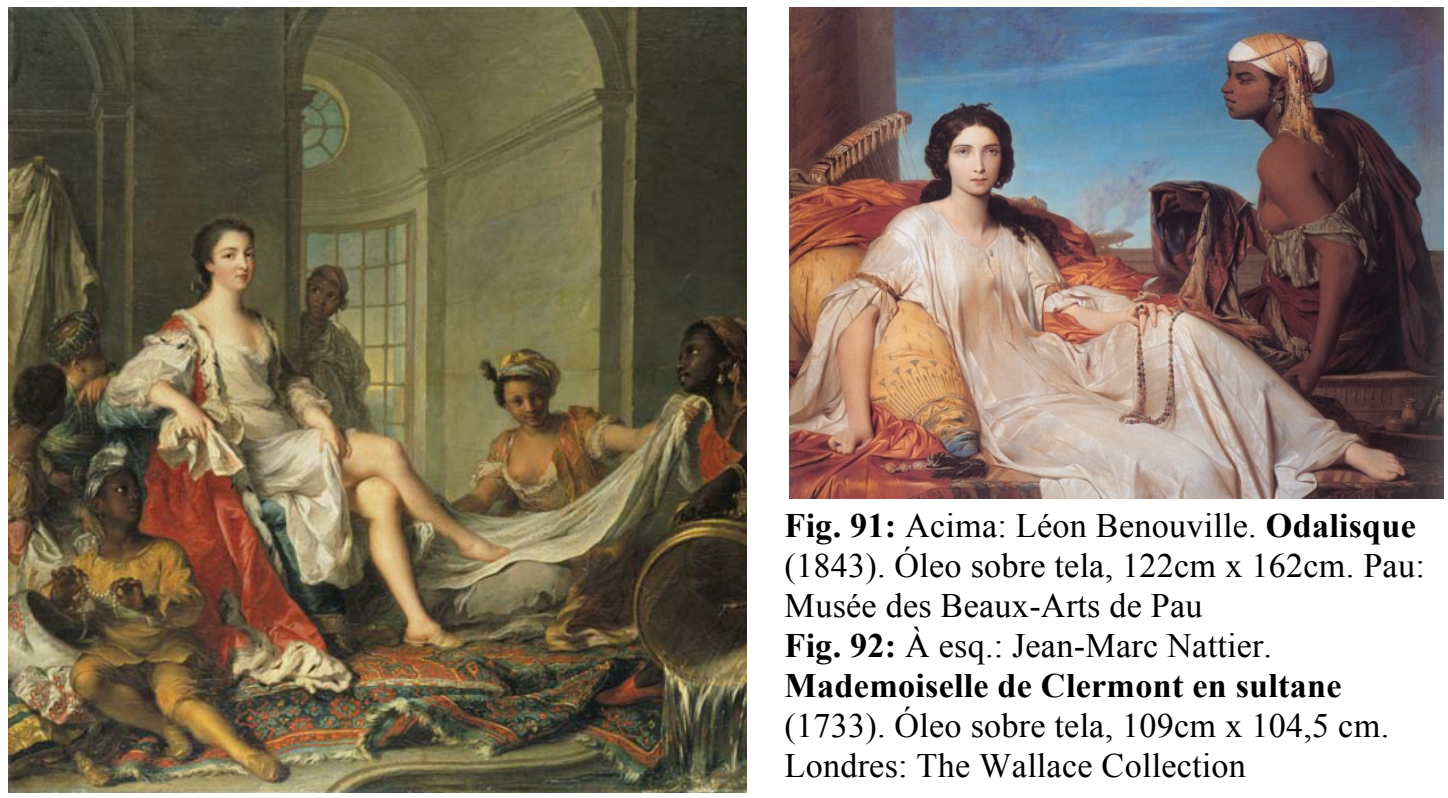

Fig. 91: Acima: Léon Benouville. Odalisque (1843). Óleo sobre tela, $122 \mathrm{~cm} x 162 \mathrm{~cm}$. Pau: Musée des Beaux-Arts de Pau

Fig. 92: À esq.: Jean-Marc Nattier.

Mademoiselle de Clermont en sultane (1733). Óleo sobre tela, $109 \mathrm{~cm} \times 104,5 \mathrm{~cm}$. Londres: The Wallace Collection

${ }^{491}$ GILMAN, S., op. cit, p. 240.

${ }^{492}$ FLOYD, P. A. The Puzzle of Olympia. In: Nineteenth-Century Art Worldwide, v. 3, Issue 1, Spring 2004. Disponível em: <http://www.19thc-artworldwide.org/spring-04/index.html>. Consulta: $10 / 05 / 2013$. 


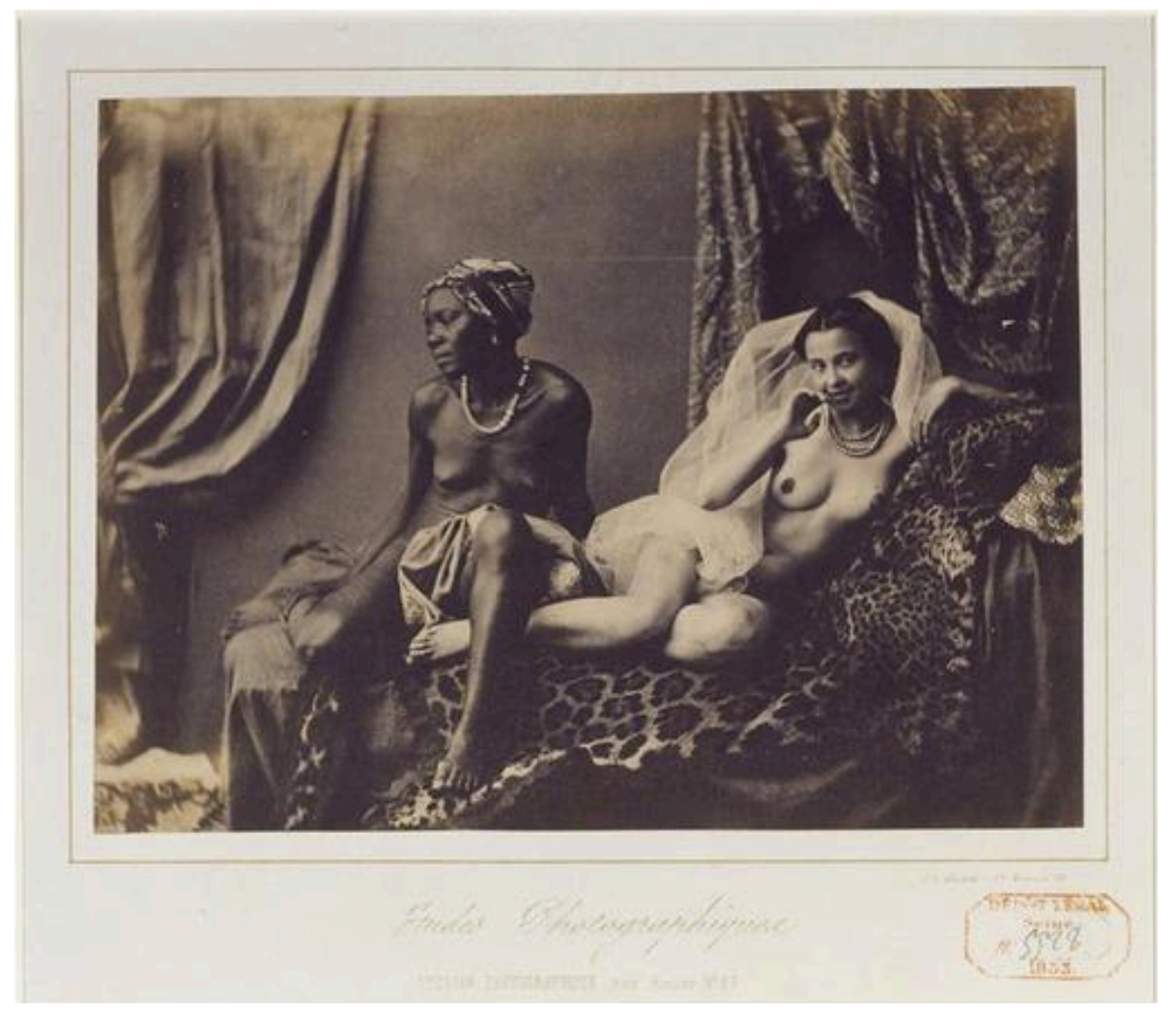

Fig. 93: Félix Jacques Antonin Moulin. Odalisque (1853). Impressão sobre papel com sal. Paris: Bibliotèque National de France

$\mathrm{Na}$ pintura de Manet, a branca é representada como uma figura esguia, de quadris estreitos, que cobre as intimidades com as mãos, enquanto a negra apresenta todos os "sintomas" da sexualidade patológica: é gorda, tem a orelha de Darwin à mostra e uma fisionomia de traços exagerados. Ao separar do corpo da prostituta os sinais daquilo que era tomado como degeneração, o artista coloca Olympia $^{493}$ a meio caminho entre a exaltação e a condenação da sexualidade feminina, no dizer de Gilman.

O mesmo não acontecerá em Nana (1877). Desta vez, o recurso adotado por Manet é fundir, na mesma personagem, a criada e a prostituta. Também conhecida como Citron (Limão), Henriette Hauser era amante do príncipe d’Orange (Laranja, em francês). Na imagem, ela se faz ver parcialmente vestida, com um homem elegante que passa ao lado e de perfil, de modo a tornar evidentes o contorno de suas nádegas - volumosas - e a orelha esquerda - darwínica. Ao fundo, a imagem de uma

\footnotetext{
${ }^{493}$ Olympia, por sinal, é um dos nomes "de guerra" adotados pelas prostitutas de luxo, conforme o estudo de Parent-Duchâtelet. Cf. FLOYD, op. cit. e CLARK, T. J. The Painting of Modern Life: Paris in the Art of Manet and His Followers. New York: Knopf, 1985.
} 
garça evoca a palavra grue - o nome da ave em francês, que serve de gíria do momento para prostituta.

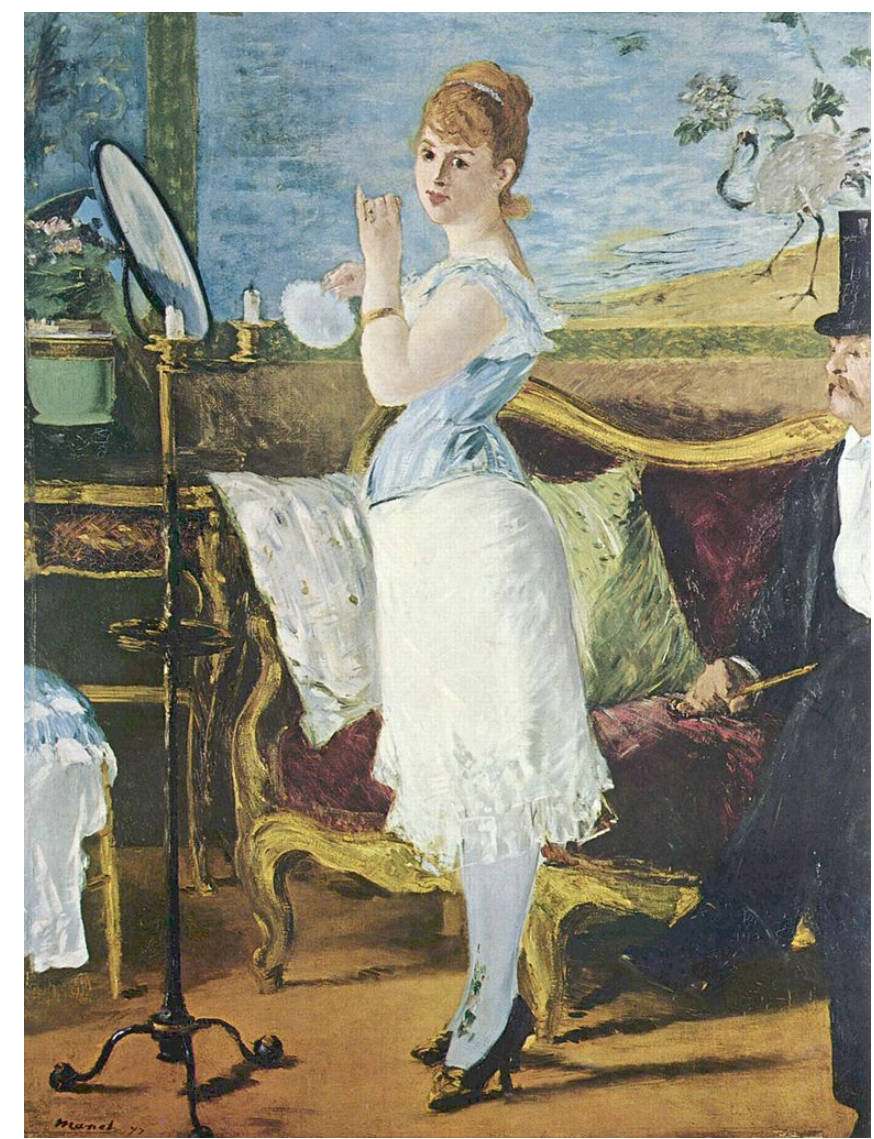

Fig. 94: Édouard Manet. Nana (1877). Óleo sobre tela, $154 \mathrm{~cm}$ x $115 \mathrm{~cm}$. Hamburg: Kunsthalle

Nana incorporou, na constatação de Gilman, o físico de Sara Baartman: internalizou o protótipo da prostituta e criada negra, num único corpo feminino. Amigo próximo de Manet, que o elegeu como expoente do naturalismo, Émile Zola inclui a personagem Nana em romance homônimo. Nas páginas do livro, a descrição da jovem é sugestiva:

\footnotetext{
Nana was in the nude: naked with a quiet audacity, certain of the omnipotence of her flesh. She was wrapped in a simple piece of gauze: her rounded shoulders, her Amazon's breasts of which the pink tips stood up rigidly like lances, her broad buttocks which rolled in a voluptuous swaying motion, and her fair, fat hips: her whole body was in evidence and could be seen under the light tissue with its foamy whiteness ${ }^{494}$.
}

\footnotetext{
${ }^{494}$ Apud GILMAN, S. Black Bodies, White Bodies: Toward an Iconography of Female Sexuality in Late Nineteenth-Century Art, Medicine and Litterature. In: Gates, H. L. (ed.). "Race", Writing and Difference. Chicago and London: University of Chicago Press, 1985, p. 240., op. cit., p. 253 (grifos nossos).
} 


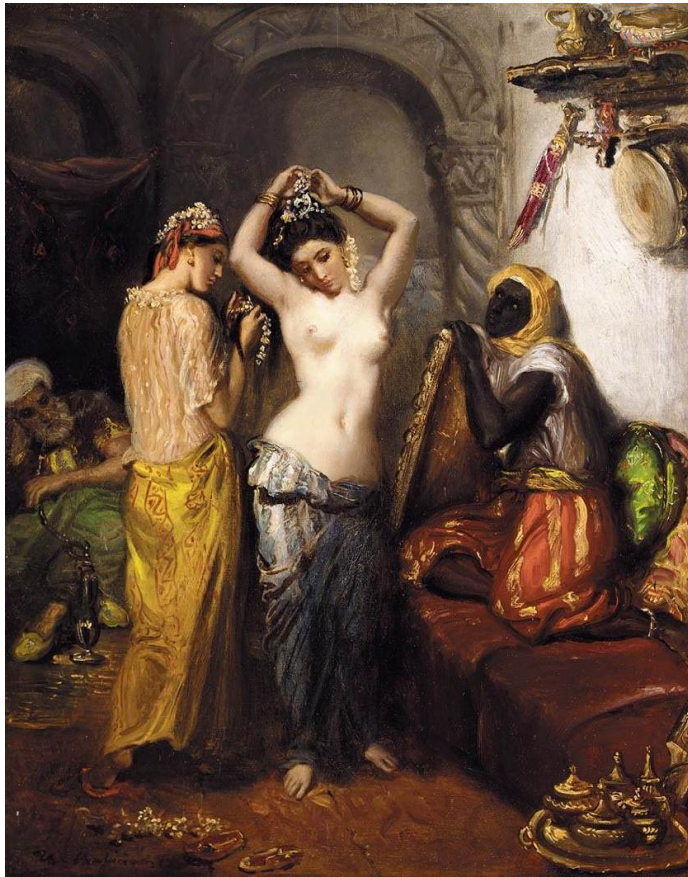

Fig. 95: Théodore Chassériau. Intérieur oriental (c. 1850-52). Óleo sobre tela, $46 \mathrm{~cm} \mathrm{x}$ $38 \mathrm{~cm}$. Coleção privada.

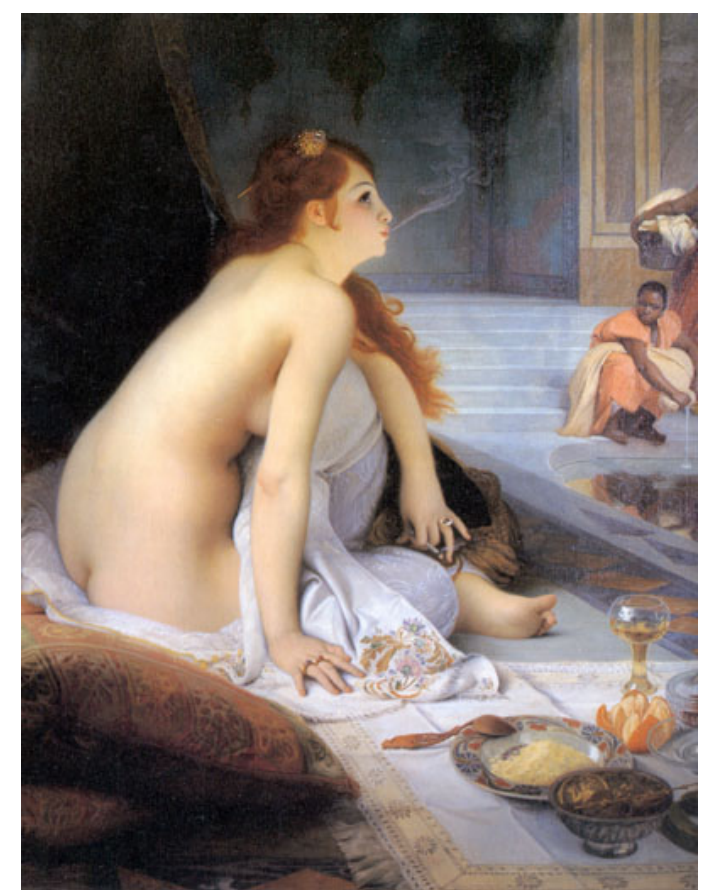

Fig. 97: Jules Jean Antoine Lecomte du Noüy. L'esclave blanche (1888). $146 \mathrm{~cm} \times 118 \mathrm{~cm}$. Nantes: Musée des Beaux-Arts

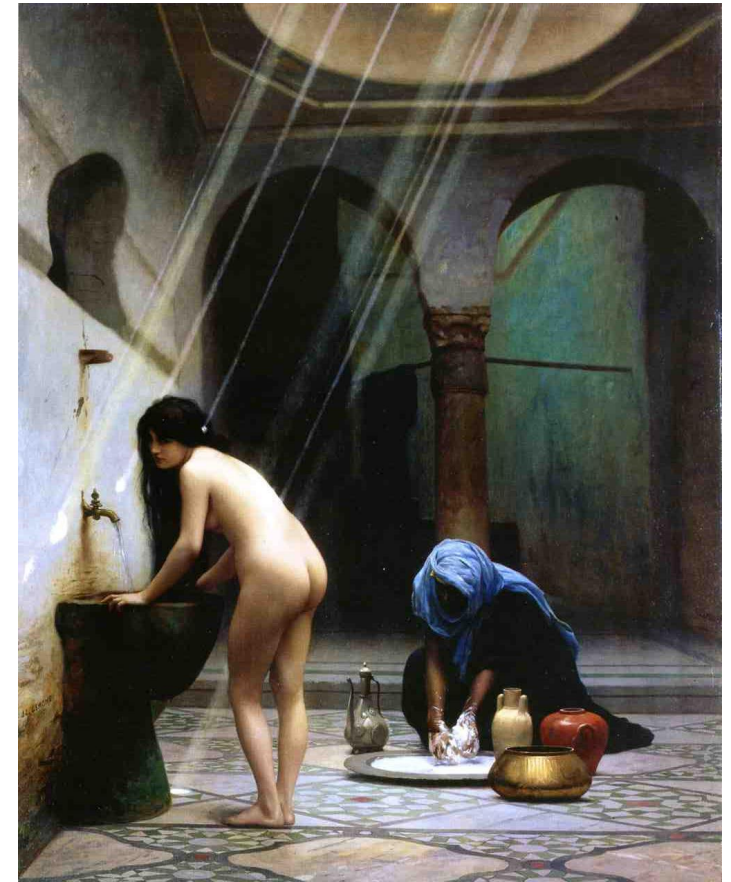

Fig. 96: Jean-Léon Gérôme. Le bain maure (c. $1874-77)$. Óleo sobre tela, $81,5 \mathrm{~cm}$ x $65,5 \mathrm{~cm}$. Coleção privada.

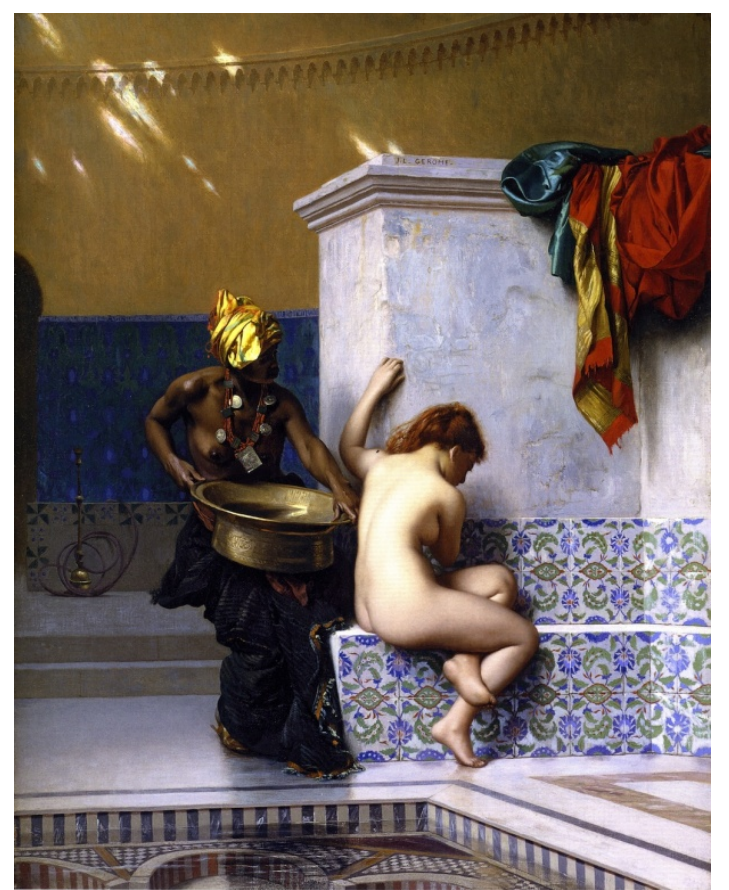

Fig. 98: Jean-Léon Gérôme. Bain turc ou bain maure (1870). Óleo sobre tela, 50,8cm x 40,6 cm. Boston: Museum of Fine Arts

Como se pode notar, nas pinturas orientalistas destacadas [Figs. 95 a 101], certas tópicas e esquemas são recorrentes. Guardadas as particularidades, tem-se o uso dos contrastes complementares; o desenho similar do corpo das odaliscas (brancas), sobretudo nas telas de Gérôme e Noüy; a presença de pelo menos uma mulher virada de costas ao espectador e/ou de mulheres em que se valoriza o tamanho dos quadris, nádegas e coxas; a diluição ou ocultação das feições das mulheres negras (exceto pelo quadro de Nouÿ, que opta pela nitidez, contra a idealização da odalisca branca); a musculatura masculina dos braços da mulher negra e/ou uma pose simiesca (exceto pela tela de Bazille). 


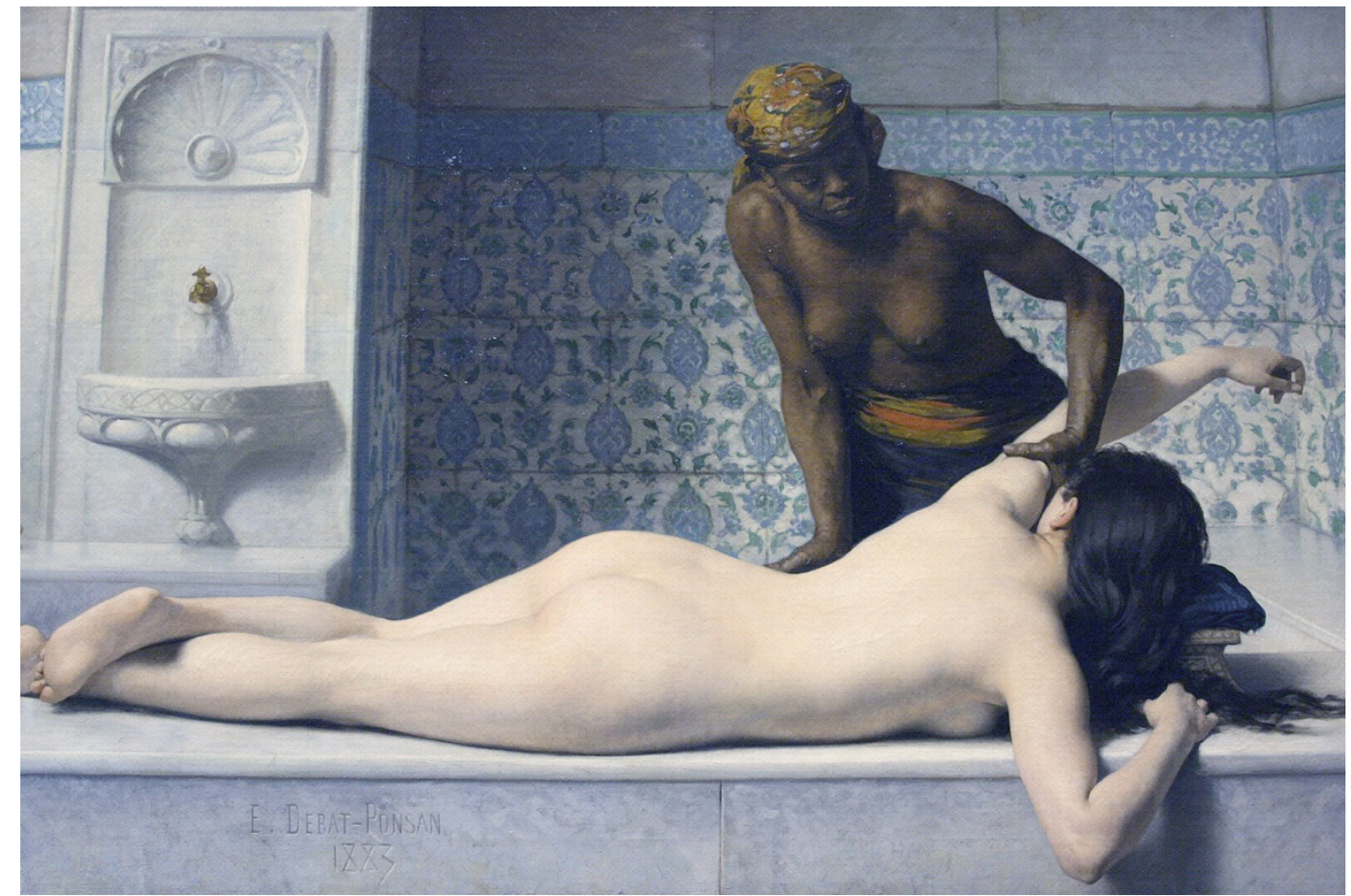

Fig. 99: Édouard Debat-Ponsan. Le massage au Hamman (1883). Óleo sobre tela, $127 \mathrm{~cm} \times 150 \mathrm{~cm}$. Toulouse: Musée des Augustins.

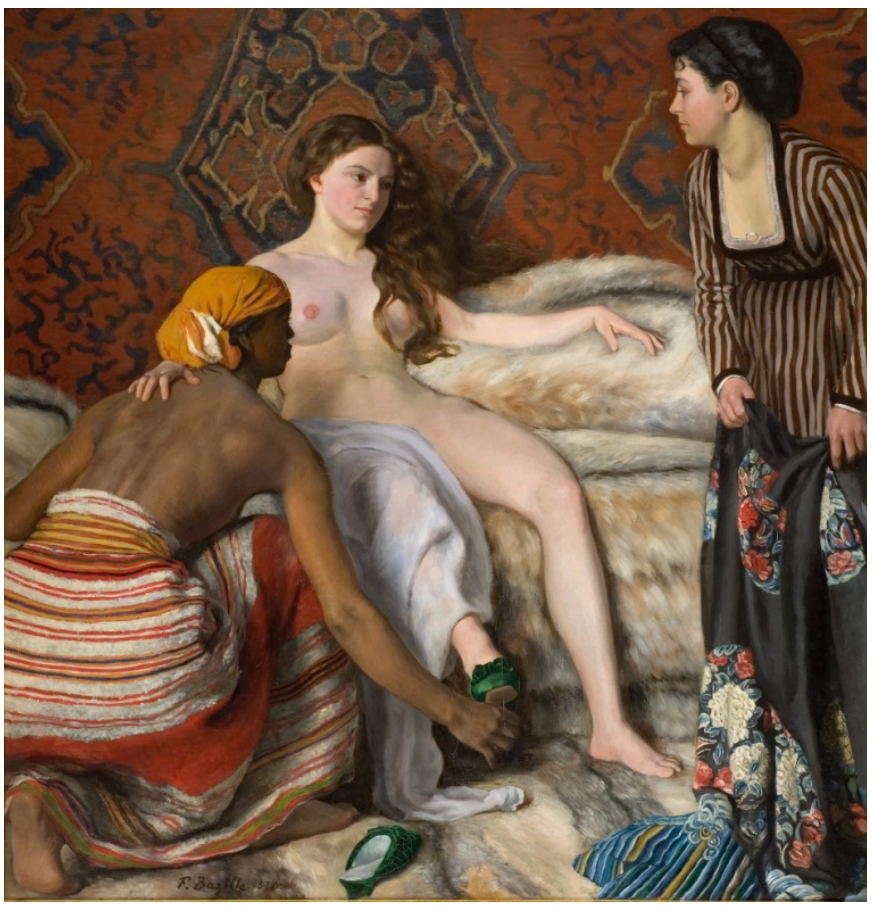

Fig. 100: Frédéric Bazille.

La toilette (1869-70).

Óleo sobre tela, $132 \mathrm{~cm} \times 169 \mathrm{~cm}$.

Montpellier: Musée Fabre

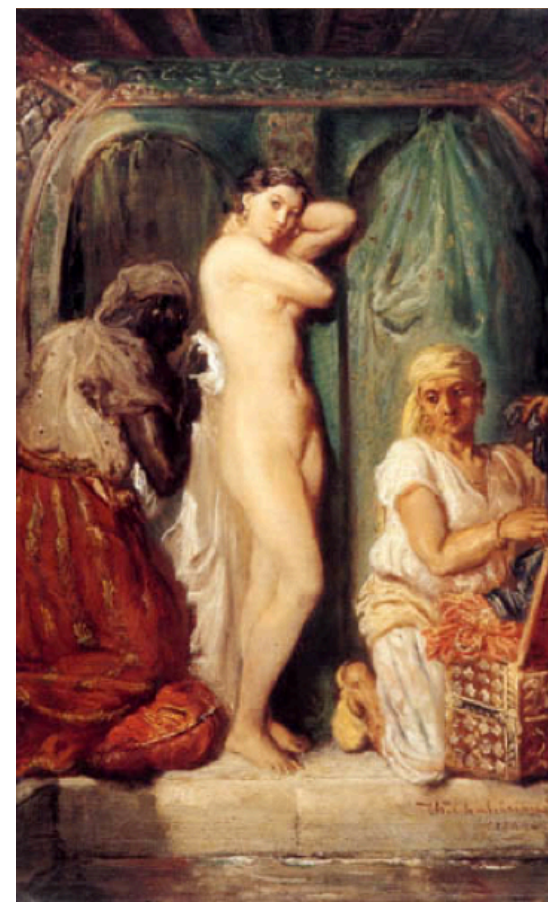

Fig. 101: Théodore Chassériau. Bain au serail (1849). Óleo sobre madeira, $50 \mathrm{~cm} \times 32 \mathrm{~cm}$.

Paris: Musée du Louvre

É interessante perceber o quão espraiado foi o uso dessa tópica na pintura oitocentista. Se por um lado os exemplos de Delacroix e Chassérieau mostram que já 
nos anos 1830 e 1840 se explorava uma imagem da mulher negra de costas e/ou o desenho da mulher branca com os quadris acentuados - o que corresponde a um marco cronológico posterior à chegada de Sara Baartman à Europa, é preciso reconhecer que, com Manet, ela parece ter adquirido sentidos mais alargados. Bernheimer e $\mathrm{Yee}^{495}$, assim como Gilman, apontam para a presença da criada negra ao lado das mulheres brancas como um elemento cênico que indica o tipo de sexualidade de Olympia, mas Yee procura avaliar as diferenças entre o momento orientalista, bem expresso por Delacroix, e os anos 70, quando Manet realizou suas pinturas. Ela afirma a particularidade de Olympia com relação às pinturas orientalistas, como aquelas feitas por Delacroix: se nestas o plano era realçar a brancura (e seus atributos) a partir do contraste com a negritude (relação de oposição), naquela a mulher branca se torna menos branca porque figura ao lado da negra (relação de exemplificação). Segundo a autora, isto se deveria ao fato das leituras contemporâneas a Olympia apontarem para a sujeira como um traço distintivo desta figura. Segundo ela,

The association of Olympia with África was apparent in contemporary responses which describe her as 'that Hottentot Venus', exposed like a discoloured corpse, 'a sort of female gorilla, a grotesque in India rubber outlines in black' and 'a sort of monkey'. So the black maid can be seen as compromising her mistress's own whiteness ${ }^{496}$.

Seria possível pensar, a partir do comentário, que a relação de oposição preserva a desejabilidade da mulher de pele clara em cena, enquanto a de exemplificação a transforma numa figura grotesca e desagradável. É digno de nota, no entanto, que em ambos os casos, a mulher negra continue sendo associada ao aspecto negativo da relação: é o contrário da virtude, por um lado, e o mau exemplo, por outro, além de constituir o avesso do desejo do homem branco europeu.

Pollock observa que, na arte ocidental, as mulheres negras costumam representar "a space in the text of a masculinist modernist culture in which flourishes an Orientalizing, Africanist fantasy that circulates between artists, their models, and

\footnotetext{
${ }^{495}$ BERNHEIMER, C. Manet's Olympia: The Figuration of Scandal. Poetics Today, Vol. 10, No. 2 , Art and Literature II (Summer, 1989), pp. 255-277. YEE. J. The black maid and her mistress in Manet and Zola. In: Damle, A. L'Hostis, A. (ed.). The Beautiful and the Monstrous: Essays in French Literature, Thought and Culture. Bern: Peter Lang, 2010.

${ }^{496}$ Idem, ibidem, p. 171. Para uma análise dessa recepção, ver BERNHEIMER, op. cit.; e CLARK, T. J. The Painting of Modern Life: Paris in the Art of Manet and His Followers. New York: Knopf, 1985.
} 
contemporary art historians" ${ }^{497}$, também no século XX. Manet e Delacroix, nas análises citadas, são vistos como autores paradigmáticos que espelham um mesmo olhar - branco, masculino - em suas pinturas, coincidindo numa certa maneira de subordinar a figura da mulher negra à da branca, ao mesmo tempo em que ambas se tornam objetos sob a mirada do espectador branco, do sexo masculino ${ }^{498}$. Mulvey ${ }^{499}$ diria tratar-se de um olhar voyeurista e, nesse sentido, seu estudo sobre o cinema de Hitchcock e Sternback se torna uma importante referência para a compreensão de certas estruturas de poder em jogo na composição e apreciação desse tipo de imagens.

Segundo a autora, as mulheres nesses filmes desempenham a função de objetos do desejo masculino e jamais aparecem no papel de agentes da trama. Os personagens do sexo oposto assumem o papel protagônico no desenrolar das ações e decisões tomadas no decorrer da história, ao mesmo tempo em que dispõem de uma figura feminina que lhes serve ao deleite visual/fantasia sexual - ato este que é feito em cumplicidade com o diretor, a câmera e o público imaginário do filme supostamente masculino. Isto significa que a obra tem gênero definido e é isto que dá o tom em sua recepção. Logo, "the place of the look defines cinema, the possibility of shifting it, varying it and exposing it. (...) Going far beyond high-lighting a woman's to-be-looked-at-ness, cinema builds the way she is to be looked at into the spectacle itself",500.

As mulheres que assistem aos filmes, segundo Mulvey, estão sujeitas a compartilhar do olhar masculino numa espécie de identificação transsexuada. Olham

\footnotetext{
${ }^{497}$ POLLOCK, G. "A Tale of Three Women: Seeing in the Dark, Seeing Double, at least, with Manet". In: Differencing the Canon. Feminist Desire and the Writing of Art's Histories. London and New York: Routledge, 1999, p. 287.

${ }^{498}$ Merece menção o clássico Orientalismo, de Edward Said, que observa em autores como Delacroix e Flaubert uma relação quase uniforme entre o oriente e o sexo. SAID, E. W. Orientalismo: o oriente como invenção do ocidente. São Paulo, Companhia das Letras, 2003.

${ }^{499}$ MULVEY, Laura. "Visual pleasure and narrative cinema". In: Visual and other pleasures. Indianápolis: Indiana University Press, 1989. Para debates correlatos, ver NOCHLIN, L. Women, Art, and Power: And Other Essays. Boulder: Westview Press, 1989; e LAURETIS T. D. Technologies of Gender: Essays on Theory, Film, and Fiction. Bloomington: Indiana University Press, 1987.

${ }^{500}$ Idem, ibidem, p. 25. Poderíamos acrescentar, aqui, a referência ao trabalho pioneiro de Teresa de Lauretis sobre as perspectivas de gênero no cinema, em que ela define a importância de reformular a relação entre espectador e imagem: é preciso substituir a ideia de que as imagens retratam mulheres pelo reconhecimento de que elas lidam com a construção de um protótipo de feminidade, de um ponto de vista masculino. LAURETIS, T. D. Figures of Resistance: Essays in Feminist Theory. Urbana and Chicago: University of Illinois Press, 2007; e LAURETIS T. D. Technologies of Gender: Essays on Theory, Film, and Fiction. Bloomington: Indiana University Press, 1987. No Brasil, Simioni tem desenvolvido interessantes estudos em torno da pergunta sobre o gênero das obras de arte. Cf. SIMIONI, A. P. C. Bordado e transgressão: questões de gênero na arte de Rosana Paulino e Rosana Palazyan. In: Revista Proa, $\mathrm{n}^{\circ}$ 02, vol. 01, 2010. Disponível em: $<\mathrm{http} / / /$ www.ifch.unicamp.br/proa/ArtigosII/PDFS/anasimioni.pdf>. Última consulta: 27/072013.
} 
para as personagens femininas assim como os homens as vêem: no papel de objetos eróticos cobiçados pelo prazer do homem heterossexual. É preciso acrescentar que as figuras tornadas objetos do desejo em cena são brancas. bell hooks dará vazão à análise de Mulvey pelo viés racial. Segundo a autora, uma pessoa negra experimenta uma relação particular com os filmes produzidos sob uma perspectiva branca, qual seja, a do olhar trans-racializado: é impelida a ver do ponto de vista dos brancos ${ }^{501}$. Mas a mulher negra, ao assistir a tais filmes, experimenta a um só tempo um olhar trans-racializado e transsexuado. Daí a importância do "oppositional gaze" (olhar oposicional), conceito através do qual a autora aponta para a possibilidade da visão crítica:

Looking at films with an oppositional gaze, black women were able to critically assess the cinemas construction of white womanhood as object of phallocentric gaze and choose not to identify with either the victim or the perpetrator. Black female spectators who refused to identify with white womanhood, who would not take on the phallocentric gaze of desire and possession, created a critical space where the binary opposition Mulvey posits of "woman as image, man as bearer of the look" was continually deconstructed $^{502}$.

O que essas análises tornam evidente é que certos pressupostos que embasam a produção de determinadas obras traduzem a forma visual assumida por um tipo de sistema de dominação assentado sobre a imagem; e que tais obras, ao espelharem o padrão dominante, também se convertem em imposições de um modelo de visão sobre o público. Tornam-se "imagens padrão de referência"503, como as define Menezes, que exploram formas "naturalizadas" com o propósito de expressar "os atributos do olhar de quem olha como se fossem expressão cultural do outro que é olhado"504.

\footnotetext{
${ }^{501}$ Compreender o que seria um olhar branco implica em perceber, como propõe Dyer, os "white makings of whiteness within Western culture, because white people have had so very much more control over the definition of themselves and indeed of others than have those others". DYER, R. White. New York and London: Routledge, 1999, p. xiii. O paradigma da brancura, segundo Dyer, opera em larga medida de modo inconsciente, mas a definição de quem é branco tende a ser prerrogativa dos próprios brancos.

502 HOOKS, b. "The oppositional gaze: Black female spectators". In:_ Black looks: race and representation. Boston, South End Press, 1992, pp. 122-123. Disponível em:

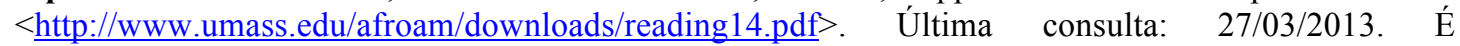
interessante notar as possibilidades abertas por essas reflexões para outros níveis possíveis de percepção dos filmes, por exemplo, pelo viés da classe, da orientação sexual, da etnicidade e da deficiência. O entrecruzamento entre esses níveis é inevitável.

${ }^{503}$ MENEZES, P. R. A. O nascimento do cinema documental e o processo não civilizador. In: MARTINS, J. S.; ECKERT, C.; NOVAES, S. C. (orgs.). O imaginário e o poético nas ciências sociais. Bauru, EDUSC, 2005 , p. 73

${ }^{504}$ Idem, ibidem, p. 73.
} 
Se Delacroix e boa parte dos pintores orientalistas estão mais imediatamente próximos - porque à serviço - da empreitada colonial francesa, colocando os corpos das mulheres brancas e das personagens não-brancas (de ambos os sexos) na posição de objetos do desejo (as primeiras) e dominação (todos), o naturalismo de Manet aponta para uma tendência crescente à patologização, em chave científica, da modernidade, em que a anomalia encontra sua forma ideal no corpo negro e no feminino. Ambos os modelos mobilizam uma aproximação entre mulheres brancas e as populações representativas de um universo não-branco, articulando a representação fisionômica/anatômica e um trabalho de uso da cor/luz: em Manet, vimos a renúncia ao chiaroscuro; em Delacroix, um método próprio de classificação de cores, em diálogo com um espectro que poderia ser definido como etnológico, que encerra em si alusões ao caráter "primitivo" dos norte-africanos, e com o modelo de contrastes complementares desenvolvido por Chevreul e amplamente difundido no Oitocentos. Além disso, estes e outros artistas exploram o uso de um esquema ${ }^{505}$ fundamental para a composição corporal das mulheres: os contornos inspirados em Sara Baartman e outros elementos considerados naquele tempo como indícios físicos da patologia sexual.

É o momento de voltar à pintura de Modesto Brocos, a fim de compreender em que medida elas dialogaram com esses modelos. Como argumentamos, o artista se propôs a abordar, por meio da pintura, o problema do embranquecimento - e se isso procede, ele deverá ter procurado formas capazes de fazer um elogio à mescla racial, explorando um modelo capaz de atender suas intenções - o que definiria, de início, escolhas distintas daquelas expressas por Delacroix e os orientalistas franceses no uso da cor, por exemplo, mas também a construção de corpos dotados de qualidades diferentes daquelas de Sara Baartman - que, conforme comentamos, foi diagnosticada pela ciência racialista do período como infértil. Voltaremos agora para as telas selecionadas - todas povoadas de mulheres negras ${ }^{506}$-, com o intuito de compreender melhor seu projeto.

\footnotetext{
${ }^{505}$ GOMBRICH. E. Arte e Ilusão. Um estudo da psicologia da representação pictórica. SP: Martins Fontes, 2007.

506 Não foram encontradas pinturas executadas pelo artista em que apareçam homens negros. Entretanto, uma crítica da Exposição Geral de Belas Artes de 1895 indica que um estudo de cabeça intitulado Negro foi adquirido na ocasião pelo Barão de Quartin. NOTAS SOBRE ARTE. Jornal do Commercio, Rio de Janeiro, 15 set. 1895, p.2.
} 


\section{Da mulher negra nas telas de Brocos: algumas observações}

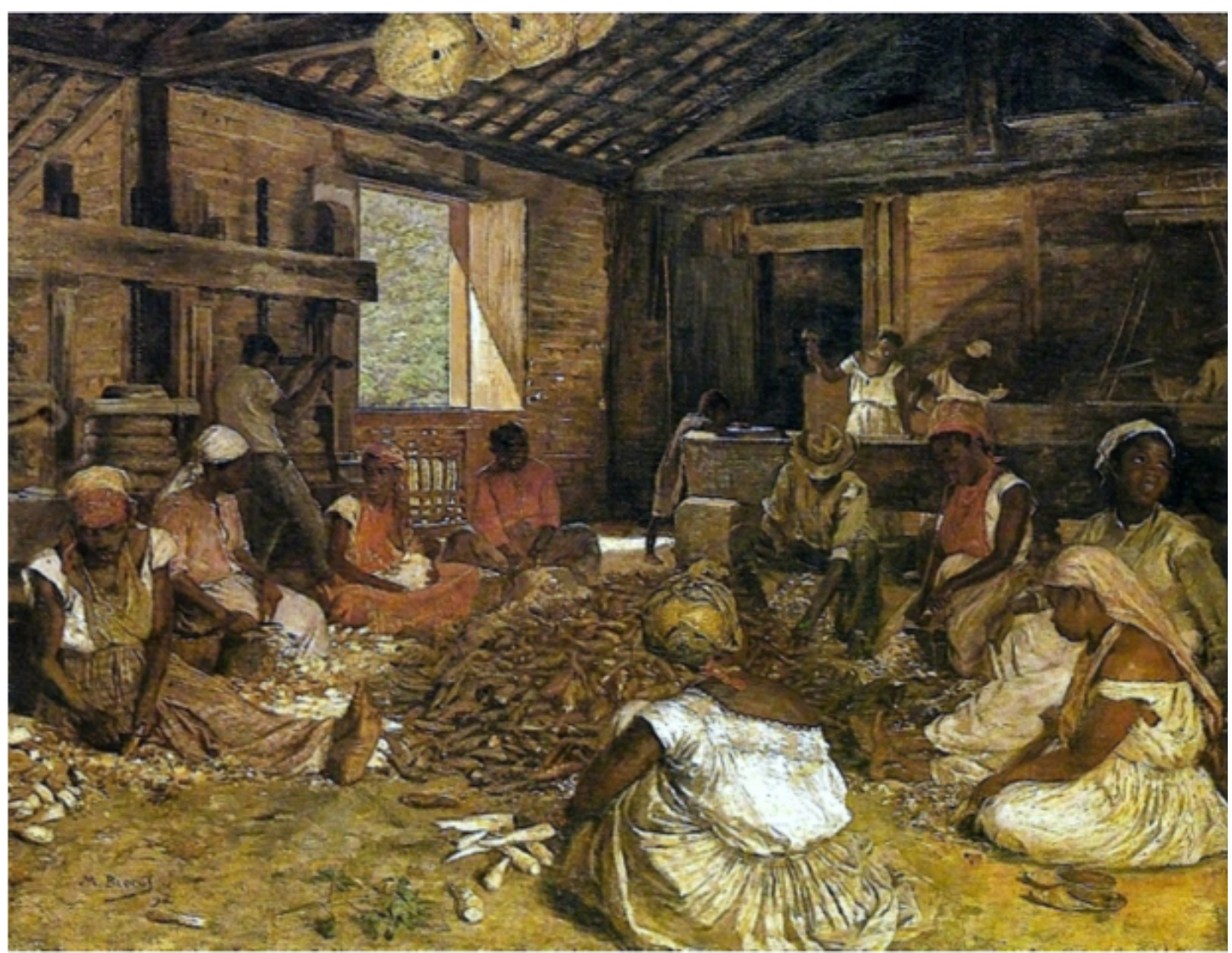

Fig. 102: Modesto Brocos. Engenho de mandioca (1892). Óleo sobre tela, 58,6cm x 75,8cm. Rio de Janeiro: Museu Nacional de Belas Artes.

Há diversos tipos de mulheres negras em Engenho de mandioca. Não parece haver entre elas grandes coincidências fisionômicas e anatômicas, mas sim um desejo de particularizar cada personagem. As duas à direita, em primeiro plano, têm formas arredondadas; uma delas está de costas, a outra, de perfil. Quanto à primeira, não transparece qualquer interesse de tornar evidentes os contornos de suas nádegas, dada a posição sentada e o volume das saias. A segunda é composta de modo a evidenciar tais contornos (e o corpo de perfil como um todo), assim como a orelha esquerda, grande e podendo corresponder ao modelo de orelha de Darwin. Outras mulheres também têm as orelhas expostas, mas estas não necessariamente seguem o mesmo padrão. Aquela que volta a cabeça para a margem direita do quadro também tem o corpo mais redondo. As demais são magras, algumas com os braços fortes. Uma parece estar grávida. Outra amamenta um bebê. 
Como se pode perceber, Brocos foge a associações obrigatórias das negras com a prostituição e/ou a sexualidade patológica; e ao uso de cores que pudessem ser vistas como rótulos de primitivismo. A presença de uma grávida e duas crianças na cena é um índice que aponta para a possibilidade de uma vida reprodutiva saudável das mulheres negras, desfazendo possíveis atribuições de infertilidade. Se uma pode ter os estigmas indicados por Gilman, à primeira vista eles não representam um padrão geral entre as figuras em cena. Ao mesmo tempo, todas possuem o mesmo tom de pele - o que poderia indicar uma preocupação com a pureza racial da amostra de parte do artista, embora ele não utilize os contrastes complementares para insinuá-lo. Ao invés disso, privilegia a harmonia entre tons terrosos, que tendem ao equilíbrio. Além do sol que chega da janela, é o uso estratégico da cor branca que ilumina o interior, contribuindo para realçar a pele marrom das personagens. Ambos os homens presentes, um deles bastante jovem (o que mexe a manivela), são negros. No mais, a tela explora o virtuosismo do desenho, visto que privilegia o detalhe, a minúcia, seja nas roupas extremamente elaboradas, do maquinário, da edificação, das posturas e do manejo dos intrumentos de trabalho.

As referências possíveis para a composição merecem observações mais detidas. Silva encontra, em Engenho de mandioca, uma evocação a litografias de Victor Frond - que ilustram o álbum Brazil Pitoresco, com texto de Charles de Ribeyrolles $^{507}$. Ela argumenta que esse tipo de álbum ilustrado, produzido por viajantes estrangeiros, se torna uma referência, a partir dos anos 1880, para artistas acadêmicos dedicados à pintura de costumes - como Almeida Júnior - e que o realismo/naturalismo dessas imagens se tornava um estilo cada vez mais apreciado no fim de século. De fato, o quadro de Brocos acentua um tipo de postura feminina curvada, sentada no chão, como aparece nas litografias Descascadoras de mandioca (1858-1861); e Rendeiras (1858-1861), de Frond. Já em Produção de farinha e mandioca (1858-1861), do mesmo autor, as posturas de todas as personagens resvalam na pose ensaiada e a mulher agachada lembra uma figura greco-romana, no jeito de equilibrar-se sobre os pés e na roupagem, de modo que a composição como um todo flerta com o equilíbrio geométrico de molde neoclássico.

\footnotetext{
${ }^{507}$ SILVA, M. A. C. Imagens de permanência: considerações acerca do álbum Brasil Pitoresco de Charles Ribeyrolles e Victor Frond. In: Revista de História da Arte e Arqueologia, n. 10, jul.-dez. 2009.
} 

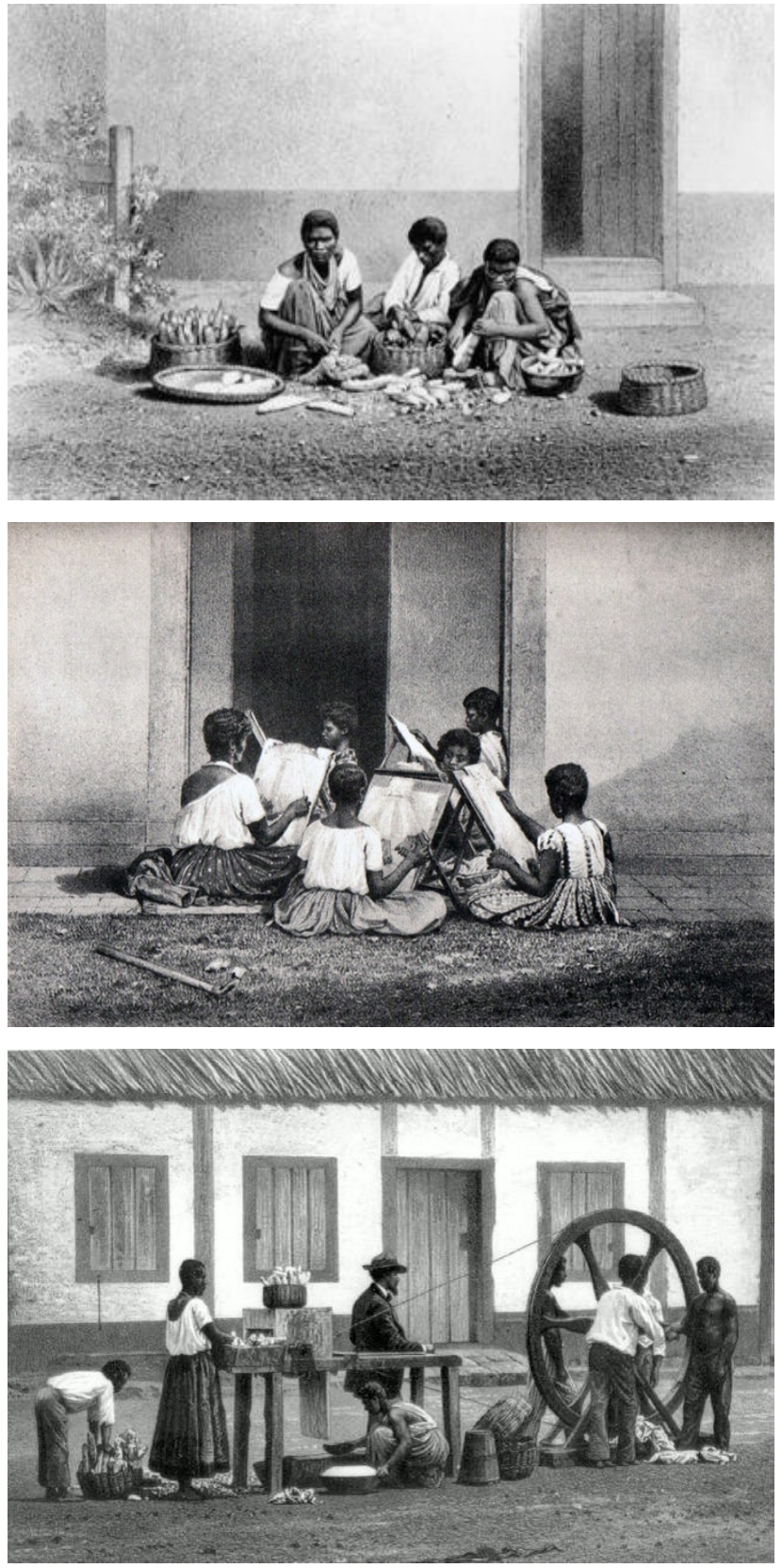

Fig. 103: Victor Frond. Descascadoras de mandioca (1858-1861).

Litografia a partir de fotografia. Litógrafo: Duruy.

Procedência: RIBEYROLLES, Charles. Brasil Pitoresco. Ilus. por Victor Frond. São Paulo : Livraria Martins, 1941.

Fig. 104: Victor Frond. Rendeiras (1858-1861). Litografia a partir de fotografia. Litógrafo: Duruy.

Procedência: RIBEYROLLES, Charles. Brasil Pitoresco. Ilus. por Victor Frond. São Paulo : Livraria Martins, 1941.

Fig. 105: Victor Frond. Produção de farinha e mandioca (1858-1861). Litografia a partir de fotografia. Litógrafo: Duruy.

Procedência: RIBEYROLLES, Charles. Brasil Pitoresco. Ilus. por Victor Frond. São Paulo : Livraria Martins, 1941.

Mas para além da referência a Frond, o esquema utilizado na composição das figuras mantém correspondências diretas com alguns estudos feitos por Hébert para suas cenas de trabalho com camponesas italianas, com coincidências sugestivas entre posturas, corte e caimento das roupas. A possibilidade de ter-se aí um substrato comum para a composição das brancas e negras nos dois países indica uma eventual percepção de compatibilidade entre as condições de vida e ocupação dessas mulheres. 


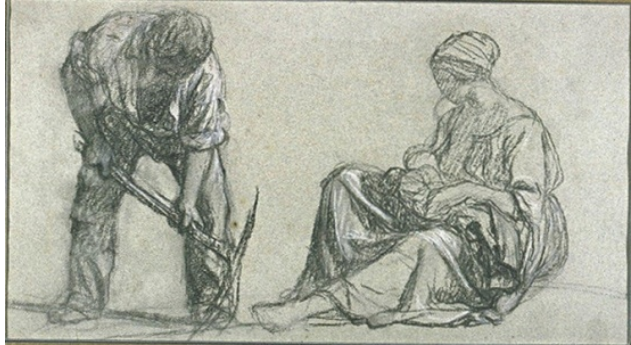

Fig. 106: Ernest Hébert. Homme piochant, et femme allaitant son enfant (s.d.).

Desenho sobre papel, $29,7 \mathrm{~cm}$ x $47,5 \mathrm{~cm}$. Paris: Musée du Louvre.

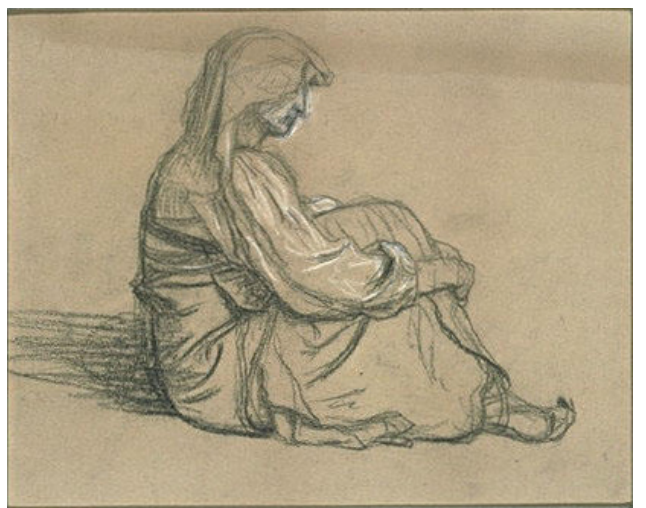

Fig. 107: Ernest Hébert. Paysanne italienne assise à terre, de profil (s.d.). Desenho sobre papel, 25,9cm x 23,9cm. Paris: Musée du Louvre

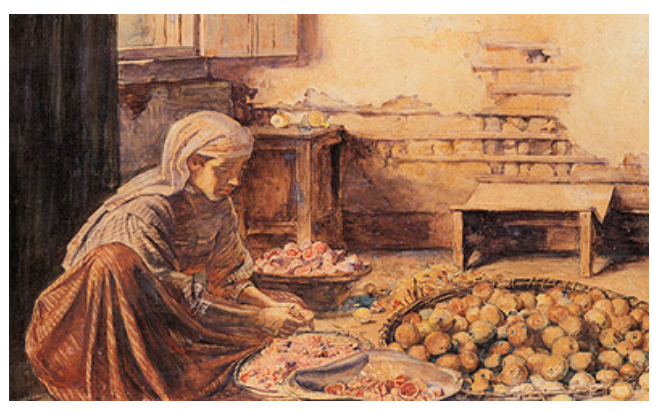

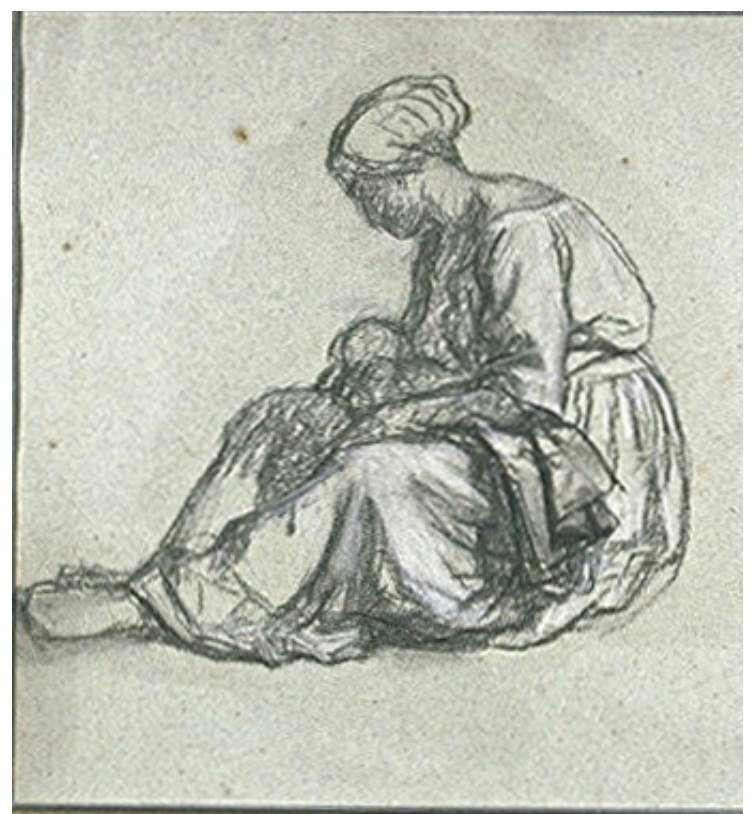

Fig. 108: Ernest Hébert. Femme assise allaitant un enfant, et étude d'homme piochant (s.d.) [detalhe]. Desenho sobre papel, $31,2 \mathrm{~cm}$ x 47,3cm. Paris: Musée du Louvre

Fig. 109: Modesto Brocos. Engenho de mandioca (1892) [detalhe]. Óleo sobre tela, $58,6 \mathrm{~cm} \times 75,8 \mathrm{~cm}$. Rio de Janeiro: Museu Nacional de Belas Artes.

Fig. 110: Modesto Brocos. A descascar goiabas (1892).

Óleo sobre tela, $58,6 \mathrm{~cm} \times 75,8 \mathrm{~cm}$. Rio de Janeiro: Museu Nacional de Belas Artes.
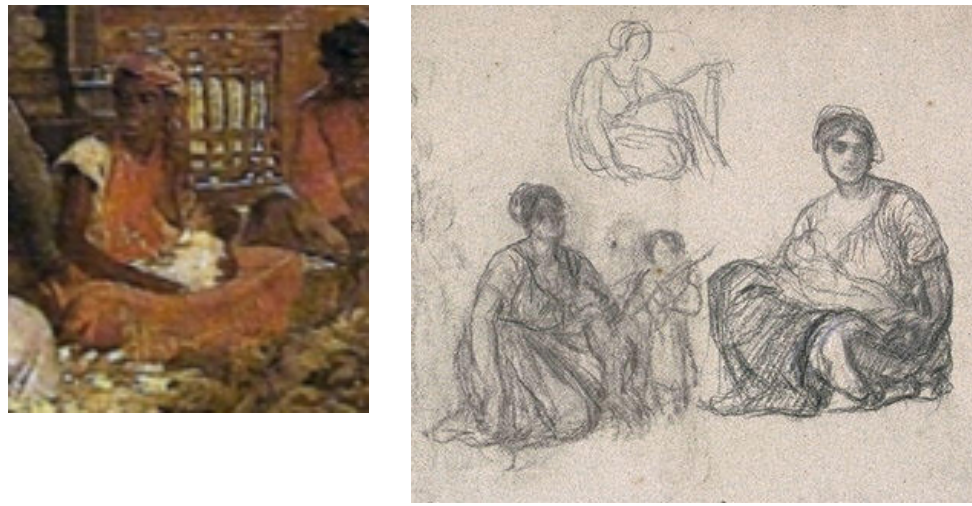

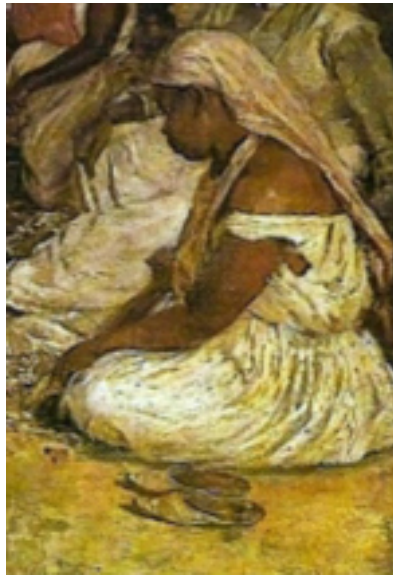

Fig: 111: à dir.: Modesto Brocos. Engenho de mandioca (1892) [detalhe]. Óleo sobre tela, $58,6 \mathrm{~cm} \mathrm{x}$ $75,8 \mathrm{~cm}$.Rio de Janeiro: Museu Nacional de Belas Artes.

Fig. 112: à esq: Ernest Hébert. Quatre études de femme, assise, avec leurs enfants (s.d.). Desenho sobre papel, $31,5 \mathrm{~cm}$ x $48 \mathrm{~cm}$. Paris: Musée du Louvre. 
No uso da cor, seu contraste entre branco e marrom encontra correspondências na tradição neoclássica - vide o Portrait d'une negrèsse $(1800)^{508}$, de Benoist. A mesma sintonia de cor, somada à predileção pela monotonia harmônica dos tons terrosos, à afinidade temática e à busca pela expressividade fisionômica remetem ao realismo de Velázquez, expresso em La mulata (c. 1620), também conhecido como Escena de Cocina. Note-se, entretanto, que diferentemente desses artistas, Brocos descarta o uso do chiaroscuro, aproximando-se de uma palheta solar, que remete à tradição pleinarista.

Na versão pertencente à National Gallery de Dublin, Irlanda, do quadro de Velázquez, a cozinha abre uma janela para a sala de jantar, onde se vê uma imagem de Cristo à mesa, conversando com um homem. Por esse motivo, essa versão também é conhecida pelo nome de Escena de Emaús - referindo-se ao local onde, segundo a Bíblia, um grupo de apóstolos teve a visão de Cristo ressuscitado, que lhes benzeu o pão ${ }^{509}$. Desse modo, a imagem adquire uma dimensão que poderia ser vista como irônica, do ponto de vista da pintura religiosa: é a criada, possivelmente escrava, quem aparece em primeiro plano e não os ícones cristãos.

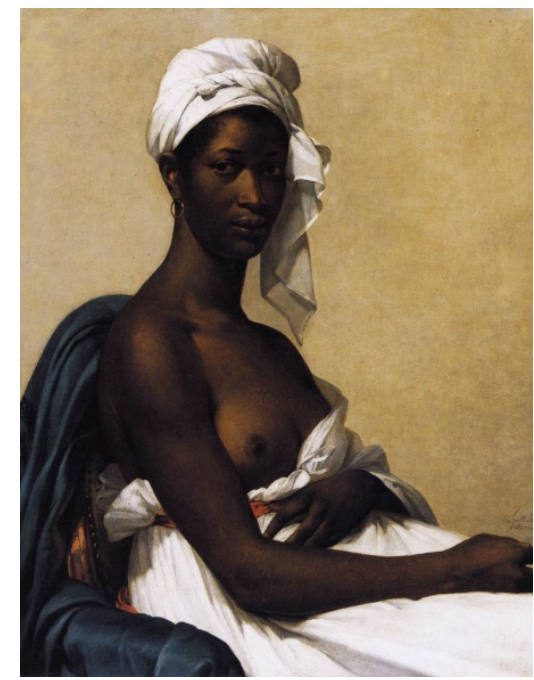

Fig. 113: Marie-Guillemin Benoist. Portrait d'une Negrèsse (1800). Óleo sobre tela, $65 \mathrm{~cm}$ x $81 \mathrm{~cm}$. Paris: Musée du Louvre.

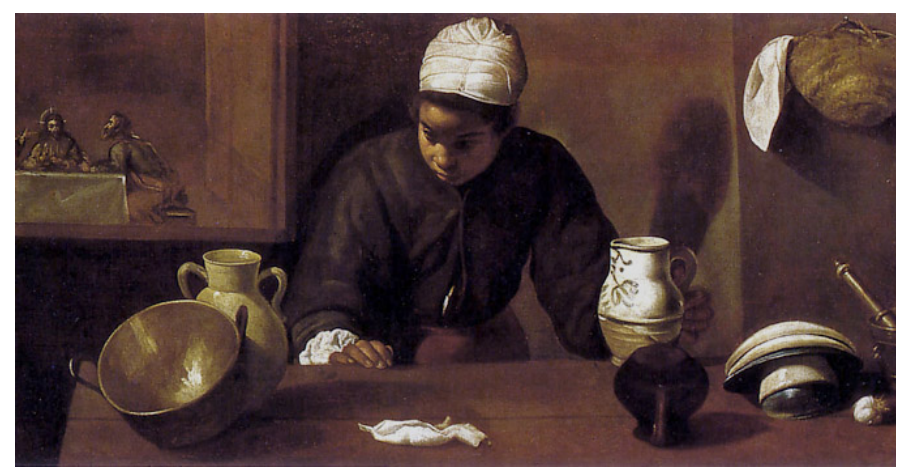

Fig. 114: Diego Velázquez. La escena de Emaús. La mulata (c.1618-1622) Óleo sobre tela, $55 \mathrm{~cm} \times 118 \mathrm{~cm}$. Dublin: National Gallery.

\footnotetext{
${ }^{508}$ Smalls faz uma interessante análise da tela. SMALLS, J. Slavery is a Woman: "Race," Gender, and Visuality in Marie Benoist's Portrait d'une negrèsse (1800). In: Nineteenth-Century Art Worldwide, vol. 3, issue 1, Spring 2004.

${ }^{509}$ Uma outra versão dessa tela pertence ao Instituto de Arte de Chicago e não traz a imagem de Cristo e seu interlocutor à mesa.
} 
De todo modo, se essas constituem referências possíveis, não há como articulá-las de modo consistente com possíveis intenções do artista, que não legou documentação confirmando suas referências na elaboração da pintura, nem comentando o processo de confecção da obra. Tudo indica que a tela procura dialogar com as tendências em voga no meio artístico brasileiro naquele momento - a se julgar pelo interesse despertado na imprensa por esse tipo de pintura $^{510}$.

Outra tela que repete certas tendências presentes em de Engenho de mandioca é Crioula de Diamantina, de 1894. Desta vez, trata-se de uma imagem externa. A tela apresenta uma figura feminina negra que foge tanto ao padrão corporal de Sara Baartman, discutido por Gilman, quanto ao sistema de "cor local" de Delacroix.

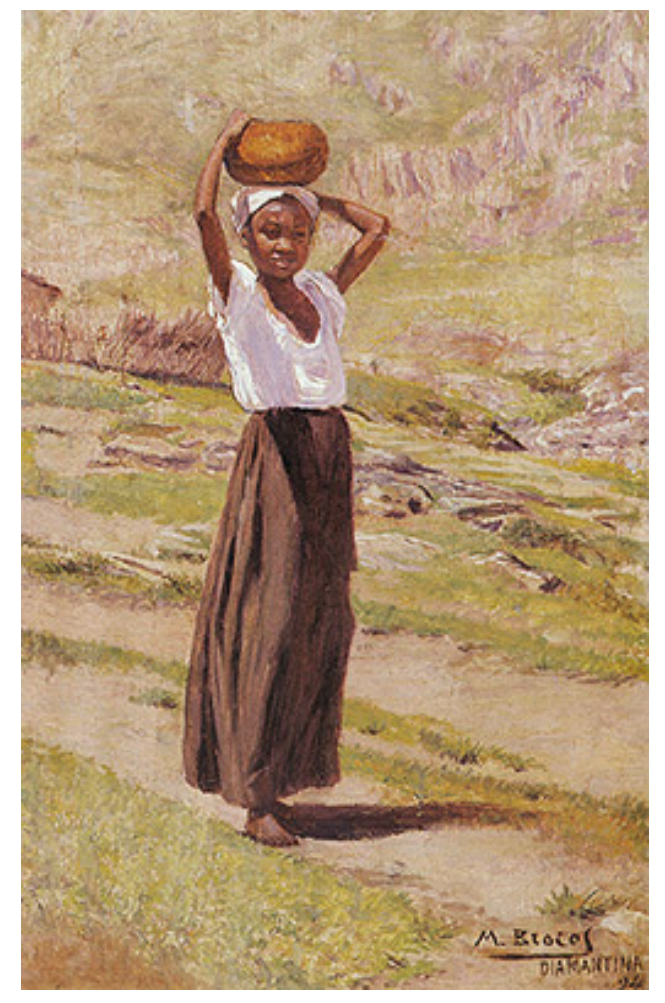

Fig. 115: Modesto Brocos

Crioula de Diamantina (1894)

Óleo sobre madeira, $37 \mathrm{~cm}$ x 27,5 cm Coleção Particular.

Não obstante, a cor adquire destaque na tela por sua proximidade com o impressionismo, que Brocos afirma ter aprendido com Seurat ${ }^{511}$ - um dos artistas que

\footnotetext{
${ }^{510}$ Referimo-nos às críticas de jornal publicadas em torno das exposições de belas artes e individuais de artistas que, com frequência, destacavam as cenas de gênero, em particular pelo interesse na caracterização dos chamados "tipos" nacionais.

511 "Meu companheiro da Escola de Belas Artes de Paris, Seurat, um dos chefes da escola impressionista, foi quem me iniciou no impressionismo" (Bocos, 1915, op. cit., p. 104). Segundo Campofiorito, Brocos fez "amizade com Seurat e Sorolla, de ambos trazendo impressões sobre novos caminhos da pintura, tendo mesmo em suas aulas desta matéria feito demonstrações do Divisionismo, exaltando as teorias de Seurat" CAMPOFIORITO, Q. História da pintura brasileira no século XIX. RJ:
} 
transformaria o modelo proposto por Chevreul em cartilha ${ }^{512}$ - e Aman-Jean. Alguns trechos de Retórica dos pintores mostram familiaridade do pintor espanhol com técnicas impressionistas e outras modalidades de uso da cor em voga no fim de século, como o divisionismo: “como já dissemos, um tom não se faz ou não se rompe na palheta de primeira intenção: todos os tons que entram no quadro deverão ser divididos por três e colocados separadamente, para se chegar a obter, por meio do mélange óptico a cor desejada" ${ }^{213}$, diz ele.

Além disso, o artista também apresenta outra solução derivada da primeira. Ele propõe uma variação da mesma técnica, o chamado "impressionismo disfarçado", obtido pela justaposição de tons quentes e frios:

\begin{abstract}
Para equilibrar as côres num quadro precisará pôr ao lado de um tom frio um tom quente e ao lado do quente uma mancha fria: esta é a maneira moderna de pintar e harmonizar as cores num quadro, e todos os tons deverão seguir este processo para que o colorido vibre e tenha vida (...) Será preciso, para que a côr vibre, decompor o tom em dois: de um lado a parte quente e do outro a fria, colocando uma ao lado da outra e deixando a vista casá-las à distância, produzindo-se o tom desejado: isto vem a ser o impressionismo disfarçado. Esta é a maneira moderna de pintar, maneira racional, porque com a vibração que produzem as tonalidades frias e quentes ao lado umas das outras, fazem vibrar e dar vida aos objétos que o artista reproduz na téla. ${ }^{514}$
\end{abstract}

Brocos já estaria aplicando essas técnicas no final dos anos 1880. Ele relata, por exemplo, que em visita a seu estúdio em 1887, Aman-Jean surpreendeu-se com o uso da cor na figura do cordeiro do quadro $A$ defesa de Lugo, que atualmente se encontra no Centro Galego de Habana, $\mathrm{Cuba}^{515}$. "De todos os tons que tem seu quadro, só acho justo o do cordeiro" ${ }^{, 16}$, teria dito o francês. Brocos, então, explica ao leitor:

Pinakotheke, 1983, p. 112. Cf. também EXPOSIÇÃO MODESTO BROCOS (RETROSPECTIVA).Ministério da Educação e Saúde, Museu Nacional de Belas Artes. Rio de Janeiro, Fev. 1952., (s/p).

${ }_{512}$ Cf. BIRREN, F. Introduction. IN: The principles of harmony and contrast of colours and their application to the arts, by Michel Chevreul. NY: Reinhold Publishing Corporation, 1967. CHU, P. T. A science and an art at once: Delacroix's pictorial theory. In: WRIGHT, Beth S., The Cambridge Companion to Delacroix. Cambridge: Cambridge University Press, 2001.

${ }^{513}$ BROCOS, M. A questão do ensino de Bellas Artes, seguido de critica sobre a direção de Bernardelli e justificação do autor. Rio de Janeiro, 1915, p. 105.

${ }^{514}$ Idem, ibidem, pp. 96-103.

${ }^{515}$ Para uma apreciação crítica da tela no momento de seu lançamento, ver RIBALTA, A. Galicia en la Actual Exposición de Bellas Artes. In: Revista Regional, n. 8, ago. 1887. Além da pintura, o Centro Galego de Habana guarda uma série de correspondências entre Modesto e Isidoro Brocos.

${ }^{516}$ BROCOS, M. Retórica dos Pintores. Rio de Janeiro: Typ. D’A Industria do Livro, 1933, p. 75. 
"Quando pintava o quadro, não acertava com o tom do cordeiro; sempre saía-me sujo. Decidi aplicar o que sabia do impressionismo. Havia dois tons, um terroso e outro gris. Fui colocando-os ao lado um do outro sem os misturar e assim pude ir formando a lã, que no arranque da pele é terrosa e nas extremidades, gris $^{517}$.

Em Crioula de Diamantina, o contraste de marrom e branco presente em Engenho de mandioca reaparece, mas agora o pintor opta por explorar as distintas luminosidades que incidem na blusa e no turbante brancos, no corpo da jovem e na saia marrom; a aparência do branco sob a luz do sol, emanando matizes resplandecentes, lembra o brilho que essa cor, aplicada à indumentária, adquire em certos quadros impressionistas, como Femme au jardin (1866), de Monet.

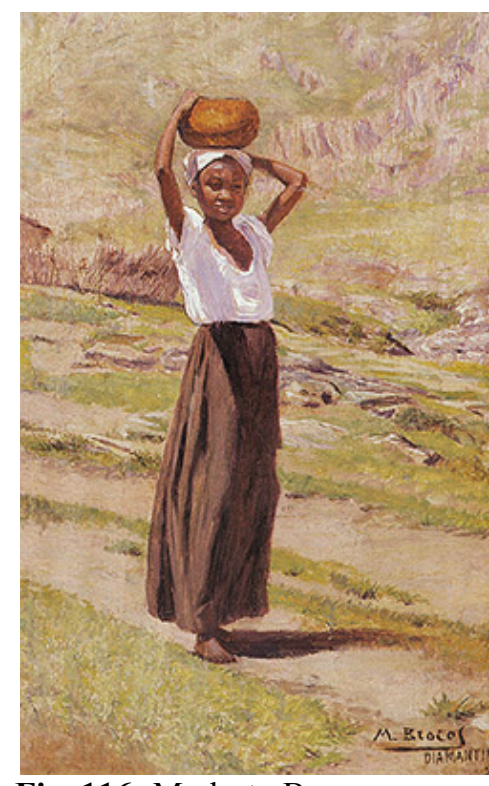

Fig. 116: Modesto Brocos.

Crioula de Diamantina (1894). Óleo sobre madeira, $37 \mathrm{~cm}$ x 27,5 cm. Coleção Particular

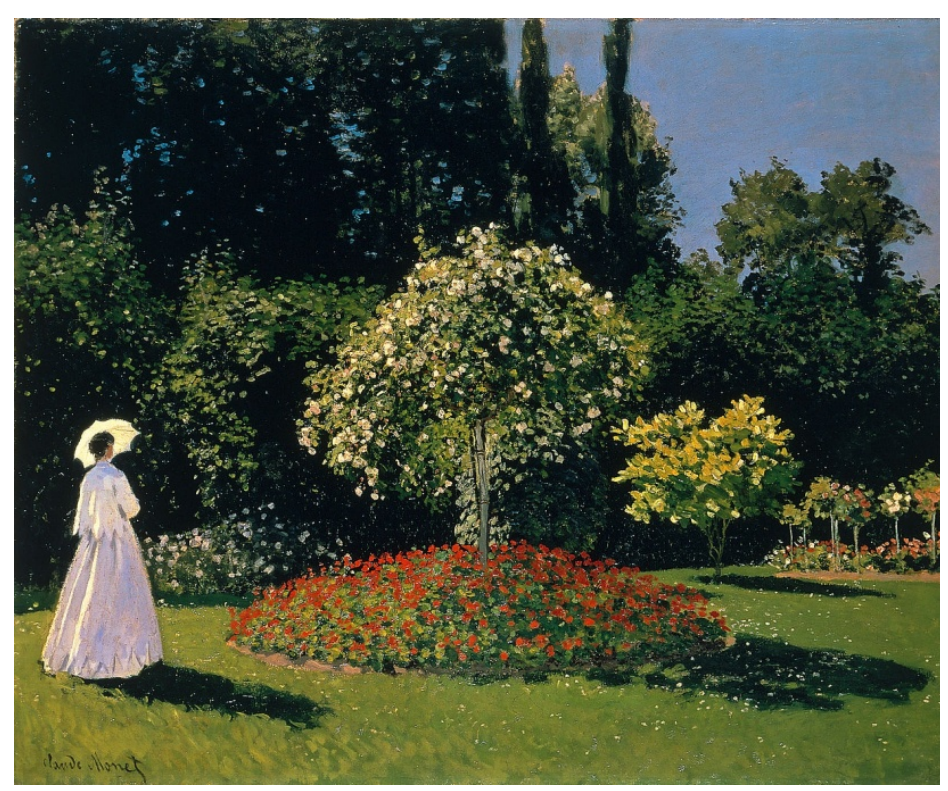

Fig. 117: Claude Monet.

Femme au jardin (1866).

Óleo sobre tela, $255 \mathrm{~cm}$ x $205 \mathrm{~cm}$.

Paris: Musée d'Orsay

Nas pinturas acima, guardadas as diferenças gerais, destaca-se um uso de branco marcado pela luminosidade resplandecente, além de uma palheta clara.

A pincelada é solta, especialmente nas pedras e no gramado. A personagem é pequena e magra, tem a saia rasgada e uma fisionomia bem desenhada. A posição dos braços e do tronco, para equilibrar a cumbuca na cabeça, é similar à da figura da frente na tela Les filles d'Alvito, de Hébert, bem como o caimento da saia. As rochas

\footnotetext{
${ }^{517}$ Idem, ibidem, p. 75.
} 
ao fundo talvez assinalem um possível diálogo entre as telas - o que sugeriria uma proximidade entre a trabalhadora de Diamantina e a italiana.

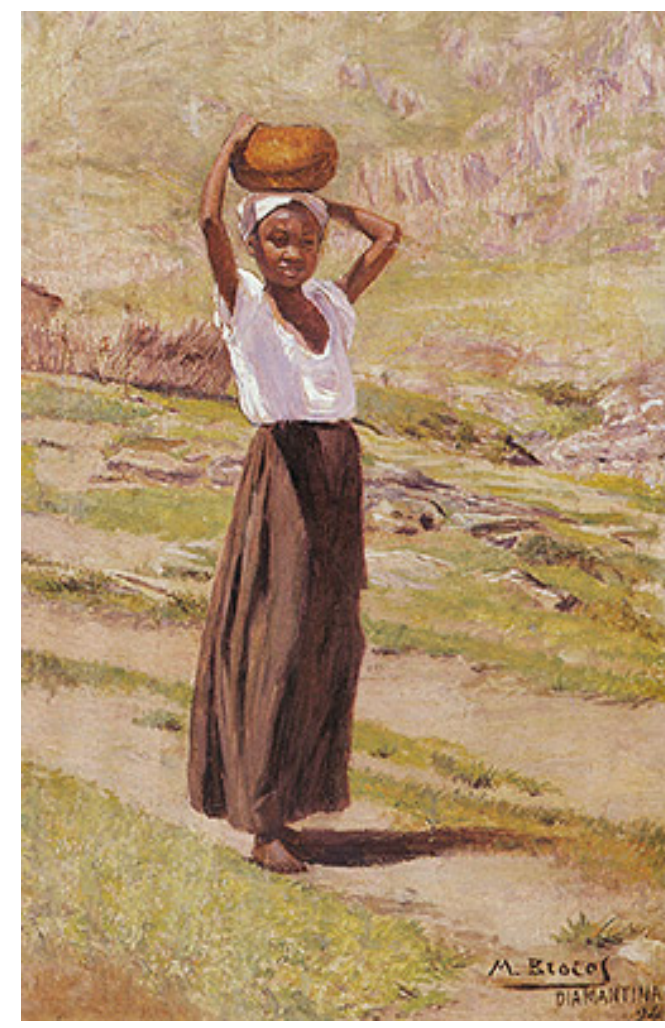

Fig. 118: Modesto Brocos.

Crioula de Diamantina (1894).

Óleo sobre madeira, $37 \mathrm{~cm} \mathrm{x} 27,5 \mathrm{~cm}$. Coleção Particular.

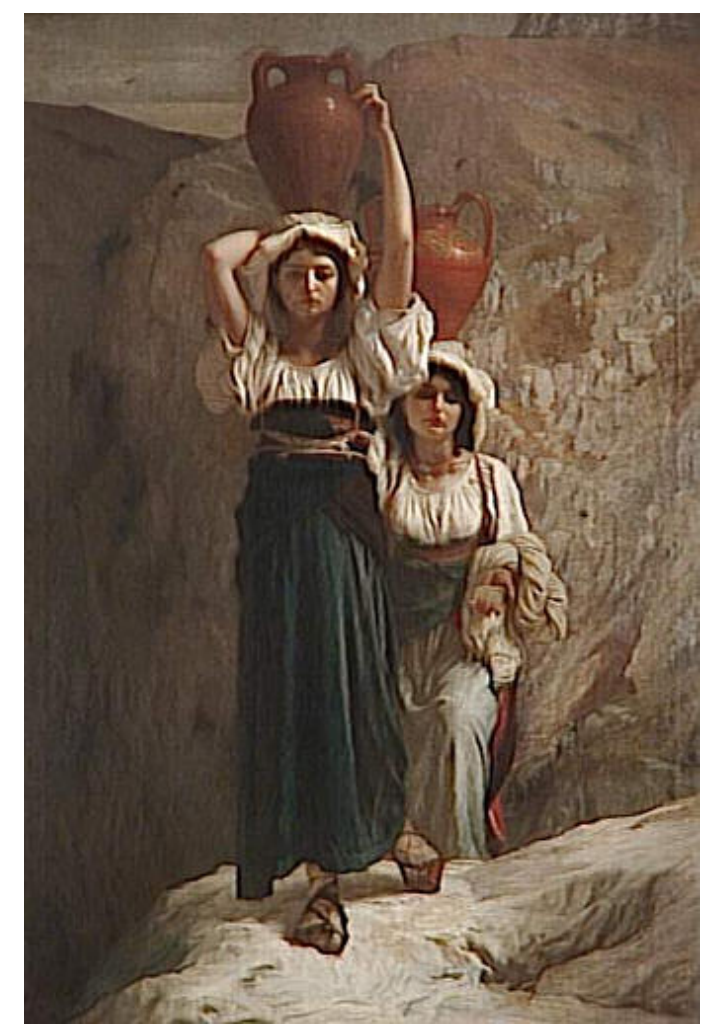

Fig. 119: Ernert Hébert. Les Filles d'Alvito (1855).

Óleo sobre tela, $220 \mathrm{~cm}$ x $152 \mathrm{~cm}$ Paris: Musée National Ernest Hébert.

Mulher (s.d.) é o retrato de uma jovem, aparentemente mestiça. Não há, nessa imagem, contraste de cor: o rosto da modelo, sua blusa e o fundo, tudo na cena é colorido por um alaranjado caramelo, com variações sutis de tom. Os cabelos sobrancelhas, cílios e alguns outros detalhes são traçados num marrom mais escuro. Ela tem o rosto simétrico e usa uma camisa xadrez, fechada, que não deixa ver os ombros ou o colo de modo explícito. Os olhos fechados da figura sugerem ao mesmo tempo o sono e a morte - ambas as condições respaldadas por seu rosto sereno e contraditas pelo fato dela estar diante de uma janela fechada e não apoiar as costas no batente, como quem estivesse desacordada ou desfalecida. 


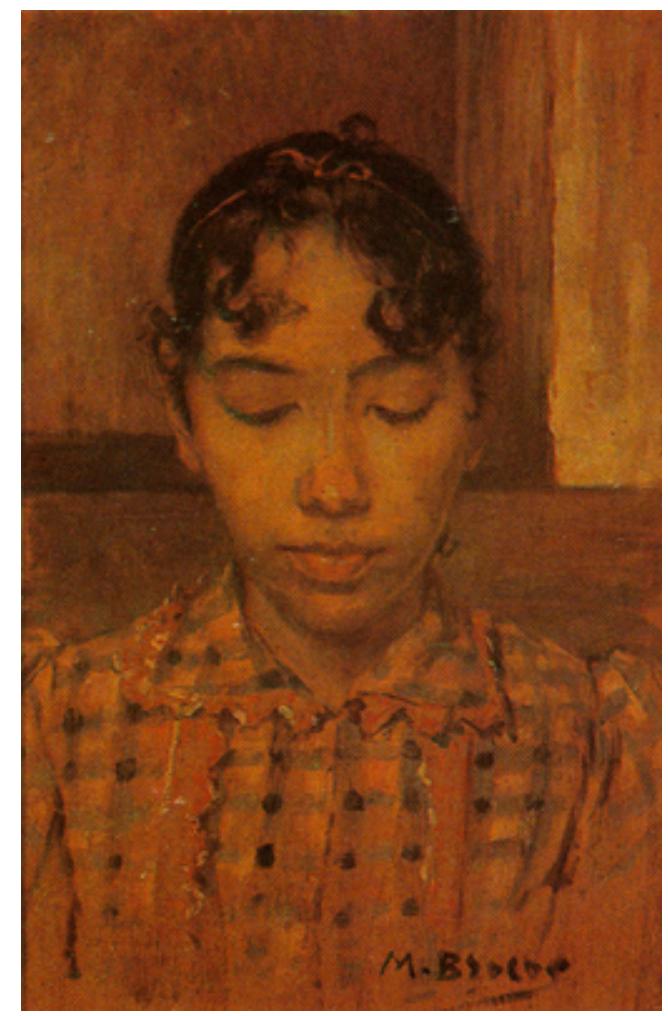

Fig. 120: Modesto Brocos

Mulher, s.d.

Óleo sobre tela, $25 \mathrm{~cm} \times 16 \mathrm{~cm}$ Coleção particular.

Dentre as pinturas escolhidas, Feiticeira (c.1895), é a mais próxima do padrão orientalista: o xale vermelho vivo no corpo da negra e o turbante de um amarelo, intenso, em sua cabeça, assim como a saia listrada de vermelho, azul e amarelo relembram Delacroix, assim como a combinação de tons das penas coloridas por sobre a bancada, nas cores verde, vermelho, amarelo, laranja e azul. O próprio Brocos afirmou, na Retórica dos pintores, que o pintor francês foi o "grande observador e colorista" que, assim como observara o crítico Charles Blanc (1813-1882), conseguia criar a ilusão de luz em ambientes fechados apenas pelo uso das cores - caso verificado pela cúpula central da biblioteca do Palácio de Luxemburgo ${ }^{518}$.

Cerca de quatro décadas após as primeiras experimentações de cor realizadas por Chevreul e Delacroix, o que representara uma novidade no passado já se tornara um procedimento de rotina para os jovens artistas: uma ferramenta que tinham à mão na hora de realizar suas telas ${ }^{519}$. Os modelos desenvolvidos na manufatura de Gobelins e no norte da África haviam, ademais, estimulado experimentações

\footnotetext{
${ }^{518}$ BROCOS, M. Retórica dos Pintores. Rio de Janeiro: Typ. D’A Industria do Livro, 1933. A cúpula traz uma imagem do Inferno, de Dante, pintado por Delacroix, em que os contrastes de vermelho vivo, verde, laranja, azul (o tom celeste e um tom mais escuro), amarelo, roxo e branco são fundamentais para o efeito de luminosidade apontado.

${ }_{519}$ CARDOSO, Rafael \& TRODD, Colin. Art and the academy in the nineteenth century. Manchester, Manchester University Press, 2000.
} 
inovadoras, dentre as quais as mais célebres foram levadas a cabo pelos impressionistas a partir da na década de $60^{520}$. Assim, é importante notar o quanto a influência da lei dos contrastes e harmonias complementares de Chevreul - chamado por Brocos de "o sabio" e "o grande químico",521 - e da teoria das cores de Delacroix sobre o pintor espanhol e sua geração já estiveram presentes no interior das próprias academias de arte onde ele estudou e que naquele momento o convívio entre artistas possibilitava debates, intercâmbios e novas experimentações de uso da cor (como no exemplo citado por Brocos, sobre o dialogo com Aman-Jean) ${ }^{522}$.

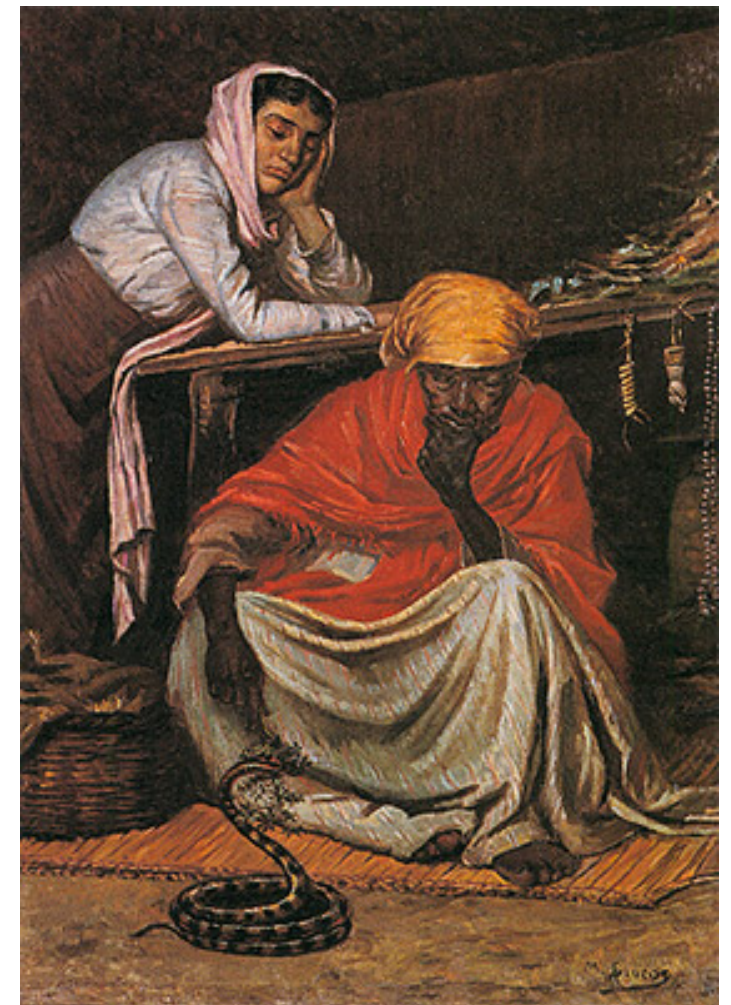

Fig. 121: Modesto Brocos.

Feiticeira (c.1895)

Óleo sobre tela, $45 \mathrm{~cm} \times 34 \mathrm{~cm}$

Coleção Particular.

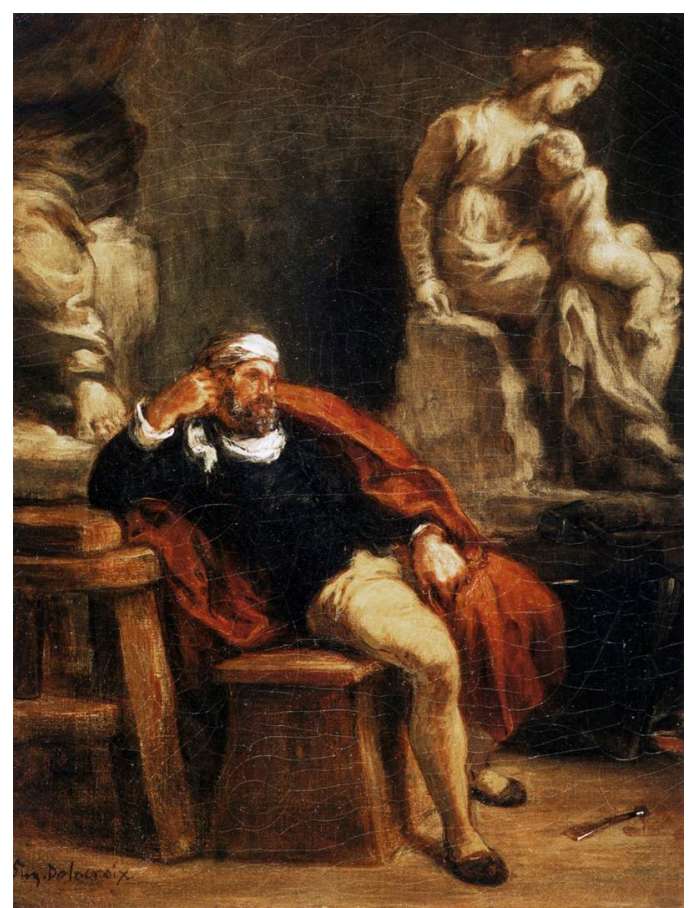

Fig. 122: Eugène Delacroix.

Michelangelo in his studio (1850).

Óleo sobre tela, $40 \mathrm{~cm}$ x $32 \mathrm{~cm}$

Montpelier: Musée Fabre

O interior em tom marrom, presente nos dois quadros, recebe uma luminosidade especial pela combinação de beges, marfins, branco (especialmente luminoso na tela de Delacroix) e o toque de vermelho, vivo na tela de Brocos que também incorpora o amarelo brilhante do lenço da mulher negra e o rosa claro do da branca.

${ }^{520}$ BIRREN, F. History of colour in painting. NY: Van Nostrand Reinhold Corp., 1965. Introduction. IN: The principles of harmony and contrast of colours and their application to the arts, by Michel Chevreul. NY: Reinhold Publishing Corporation, 1967; GAGE, J. Color and meaning: art, science, and symbolism. Berkeley: University of California Press, 2000;

Color and culture: practice and meaning from antiquity to abstraction. Berkeley: University of California Press, 1999.

${ }_{521}^{52}$ BROCOS, M. Retórica dos Pintores. Rio de Janeiro: Typ. D’A Industria do Livro, 1933.

${ }^{522}$ Idem, ibidem. 
As personagens da tela Feiticeira encontram-se num porão claustrofóbico, de teto baixo, onde as cores vivas são responsáveis pela iluminação do interior. É digno de nota que esses tons vibrantes e largamente presentes na pintura orientalista estejam nas roupas da mulher negra, visto que a branca, apoiada sobre a mesa, usa roupas em cores mais discretas: lenço rosa claro na cabeça, saia marrom e blusa de um azul claro suave, quase branca, mesclada por tons róseos que insinuam a transparência do tecido. O uso das cores parece sinalizar a intenção de diferenciar as duas mulheres.

Do ponto de vista do desenho, as duas têm os traços exagerados. A negra é corpulenta, de quadril largo e pernas fortes, com pés grandes e descalços que, deformados, lembram patas. O fato de tratar-se de uma banca de venda de ervas e talismãs aparentemente clandestina (o lugar de teto baixo parece claustrofóbico, como um porão), cuja proprietária (a negra) brinca com uma serpente de estimação tirada do cesto a seu lado, concorre para uma visão negativa desta personagem e de suas práticas religiosas. Como mostra Sampaio ${ }^{523}$, na década de 1880 e até o final do século XIX, uma série de acusações a feiticeiros e curandeiros ocuparam as páginas da imprensa carioca que imprimia nesses artigos uma preocupação com a existência dessas práticas, consideradas superstições imorais e contrárias aos valores da medicina científica e da higiene. A maioria, dentre esses feiticeiros, era negra.

O caso de Juca Rosa, estudado pela autora, é ilustrativo do tratamento concedido pelos jornais ao assunto. Procurado por suas curas espirituais, esse filho de africana foi preso por charlatanismo no Rio de Janeiro, num momento em que o fim iminente da escravidão era remediado pelo pensamento racialista. Entre as acusações feitas contra Rosa - e na denúncia anônima que levou à sua prisão -, estava a de abusar da "ignorância" das mulheres, induzindo-as a práticas recriminadas na época não apenas do ponto de vista espiritual, mas também sexual, como a prostituição. Segundo os jornais, os seguidores de Rosa vinham de todas as "raças" e classes sociais. Aparentemente, a maior parte eram mulheres - e Rosa teria uma predileção pelas brancas -, o que certamente representaria um problema aos olhos do público leitor desses diários.

Interessante notar que, a despeito da alusão frequente na imprensa do período aos feiticeiros - do sexo masculino -, personagem pintada por Brocos é uma mulher

\footnotetext{
${ }^{523}$ SAMPAIO, G. R. Juca Rosa e as relações entre crença e cura no Rio de Janeiro Imperial. In: CHALHOUB, S.; MARQUES, V. R. B.; SAMPAIO, G. R.; SOBRINHO, C. R. G. (orgs.). Artes e ofícios de curar no Brasil. Campinas, Editora Unicamp, 2003.
} 
que, entretanto, é masculinizada pelas dimensões corporais e traços da fisionomia. Assim seu desenho se ajustaria mais uma convenção vigente na pintura europeia, destacada por Gilman ${ }^{524}$, quando comenta que a presença da mulher negra junto à branca era, comumente, vista como um sinal de lesbianismo das duas, reforçamdo a ideia de uma sexualidade anormal sob o olhar da época. Poderíamos aqui retomar a análise de Olympia feita por Yee ${ }^{525}$, indicando uma relação de exemplificação entre as mulheres em cena, em que a branca se tornaria menos branca ao lado da negra. Talvez por isso seus traços sejam tão acentuados, seja pelo rosto redondo, a testa curta ou o desenho do nariz, alusivos ao tipo físico negro segundo os parâmetros estipulados pela ciência do período $^{526}$.

A mulher branca de $A$ descascar goiabas, assim como a que figura em Feiticeira, é envolvida em dúvidas sobre sua cor/raça. Conforme apontado anteriormente, ela foi descrita como mulata em crítica publicada no Jornal do Commercio. Sua orelha, segundo o mesmo comentário, estaria "fora do lugar" - o que pode ser um indício de que Brocos estivesse explorando o modelo indicado por Gilman no desenho de seu corpo: ela tem os quadris largos e a deformação na orelha pode servir de alusão à orelha de Darwin.

Chama a atenção uma similitude de tipo físico, postura e modo de sentar entre a personagem dessa pintura e algumas das mulheres negras de Engenho de mandioca e camponesas italianas pintadas por Hébert [figs. 105 a 107], enquanto seu modo de posicionar as pernas é similar ao da Feiticeira. Se essas observações procedem, a tela de 1901 acrescentar à série um desfecho aparentemente paradoxal, com a possível insinuação quanto à sexualidade da mulher em cena que, entretanto, é uma camponesa de corpo completamente coberto - e portanto, sem nenhuma correlação mais explícita com uma imagem como Nana, de Manet, ou com uma insinuação de caráter erótico.

\footnotetext{
${ }^{524}$ GILMAN, S. Black Bodies, White Bodies: Toward an Iconography of Female Sexuality in Late Nineteenth-Century Art, Medicine and Litterature. In: GATES, H. L. (ed.). "Race", Writing and Difference. Chicago and London: University of Chicago Press, 1985

${ }^{525}$ YEE. J. The black maid and her mistress in Manet and Zola. In: Damle, A. L'Hostis, A. (ed.). The Beautiful and the Monstrous: Essays in French Literature, Thought and Culture. Bern: Peter Lang, 2010.

${ }^{526}$ Sob esse aspecto, parece lícito lembrar os manuais de fisionomia, largamente circulantes no Oitocentos e cuja leitura fazia parte da formação dos artistas nas academias. Como explica Cowling, em tais manuais, a testa curta e o nariz chato, entre outros aspectos, eram vistos como traços distintivos das classes baixas e das "raças" consideradas inferiores. COWLING, M. The artist as anthropologist. The representation of type and character in Victorian art. Cambridge: Cambridge University Press, 1989. Ver também HARTLEY, L. Physiognomy and the meaning of expression in nineteenthcentury culture. Cambridge: Cambridge University Press, 2001; e PEARL, S. About faces: physiognomy in nineteenth-century Britain. Cambridge: Harvard University Press, 2010.
} 
Como entender, desse modo, a existência de tais sinais num corpo que não parece ter sido desenhado para ser visto como objeto do deleite voyeurista masculino?

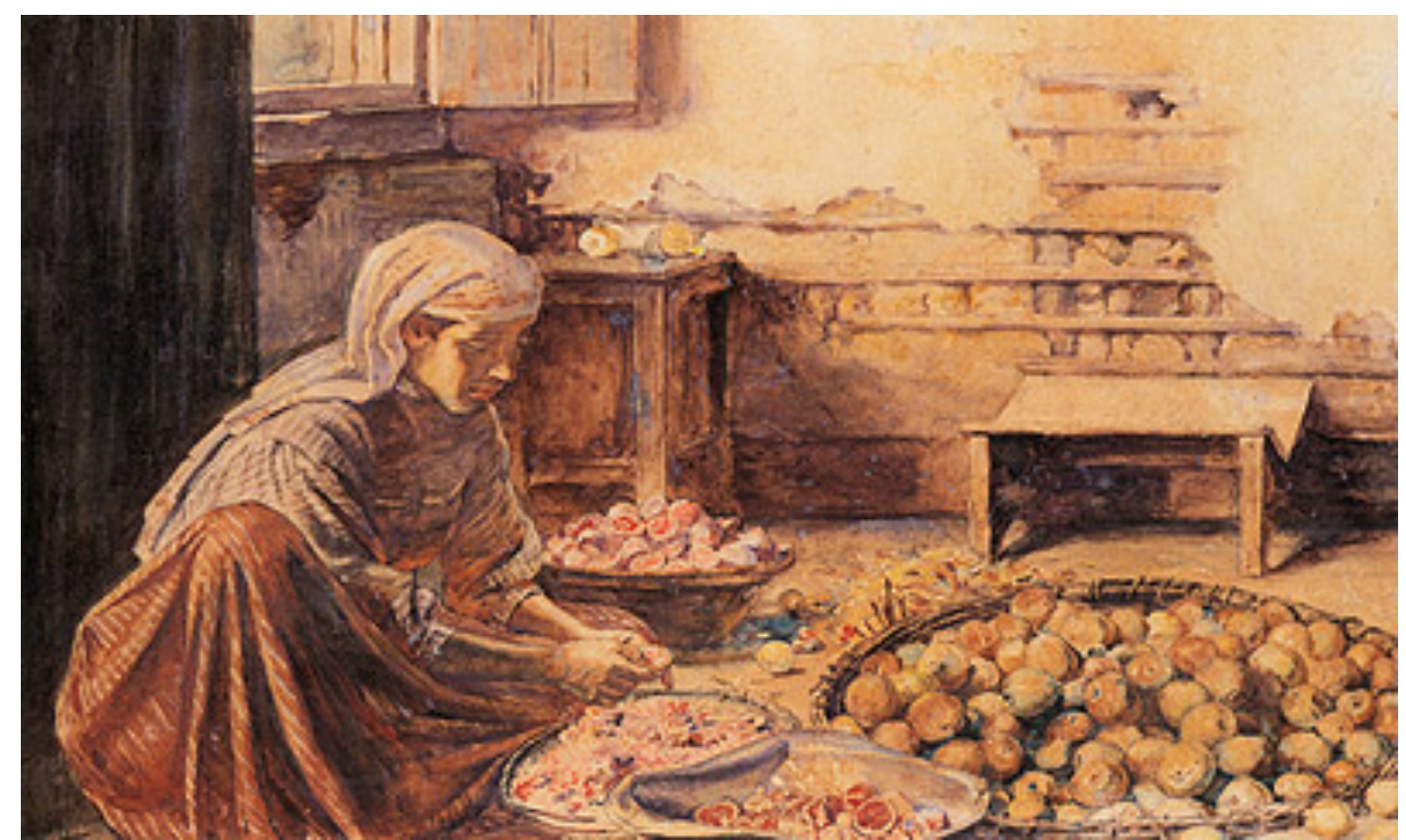

Fig. 123: Modesto Brocos. A descascar goiabas (1901). Aquarela sobre papel, $36 \mathrm{~cm}$ x $58,5 \mathrm{~cm}$. Coleção particular.

Por um lado, há que considerar a possibilidade da pintura mobilizar outros esquemas, constituindo apenas uma cena de trabalho como tantas outras correntes no período. Por outro, não deixa de ser interessante pensar no projeto eugênico descrito por Brocos em Viaje a Marte, pois nesse livro, ele vislumbra uma função lícita e central para as mulheres consideradas "histéricas", as de "temperamento ardente" e as "voluntariosas" (nesta ordem) ${ }^{527}$, que se tornariam peças-chave em seu projeto de “seleção sexual”. No livro, estas seriam as chamadas Irmãs Humanitárias, mulheres que se dedicaram à vida pública e ao "aperfeiçoamento da espécie" das $2 \mathrm{~h}$ às $22 \mathrm{~h}$, em "conventos" onde receberiam os homens "como esposas carinhosas". Diferentemente do que ocorria com a prostituição na época, que como mostra Gilman ${ }^{528}$ era condenada, em Viaje a Marte esta seria uma opção profissional das mais dignas para as mulheres que não se casassem, nem seguissem os estudos até determinada idade.

\footnotetext{
${ }^{527}$ BROCOS, M. Viaje a Marte. Valencia, Editorial Letras y Artes, 1930.

${ }^{528}$ GILMAN, S. Black Bodies, White Bodies: Toward an Iconography of Female Sexuality in Late Nineteenth-Century Art, Medicine and Litterature. In: GATES, H. L. (ed.). "Race", Writing and Difference. Chicago and London: University of Chicago Press, 1985.
} 
Desse modo, seria possível pensar que tal imagem, composta segundo a perspectiva do pintor, pudesse reunir, na figura de uma mulher branqueada, em plena vivência de seu dia-a-dia de trabalho rural, as características próprias desse tipo de sexualidade de modo não-contraditório, uma vez que acenasse para a finalidade eugênica que Brocos almejava ${ }^{529}$. Do ponto de vista da cor, não há apelo na tela para o uso de contrastes complementares de verde e mermelho; azul e amarelo; laranja e roxo, mas sim a manutenção de uma claridade expressa na monotonia de tons rosados e amarelos, com aplicação de matizes mais escuros na porta e em certos sombreamentos dos móveis.

Sem dúvida, é preciso admitir a impossibilidade de comprovar esse tipo de observação, visto que Brocos não deixou documentação específica sobre essas telas sejam rascunhos ou declarações. De todo modo, é interessante notar como cada uma procura unir a figura feminina a uma série de qualidades formais, indicativas de uma experimentação de um modelo de representação da mulher negra, que é testado junto à opinião pública brasileira. É elucidativo, a esse respeito, o fato de Engenho de mandioca, Feiticeira e Crioula de Diamantina terem sido produzidas em períodos próximos, assim como $A$ redenção de Cam, exibida na Exposição Geral de Belas Artes no mesmo ano que o segundo desses quadros.

A recepção das pinturas dá pistas quanto à aceitação dessas composições e, com isso, ajuda a visualizar também uma vigência do modelo francês exemplificado por Olympia e Delacroix no imaginário dos críticos dos anos 1890. Feiticeira, por exemplo, é considerada uma tela bem pintada e "com muito character" ${ }^{\text {"530 }}$. Engenho de mandioca recebeu elogios, ao mesmo tempo em que as figuras femininas que mais agradaram são precisamente, aquelas mais próximas do esquema corporal de Sara Baartman. O crítico da coluna Artes e artistas, em O Paiz, escreve:

Entre as pretas empregadas na raspa, ha tres que são dignas de attenção dos visitantes.

A primeira, de costas, está n'uma posição difficil e é de desenho altamente correcto; segue-se uma outra, pensativa, em um momento não de repouso,

\footnotetext{
${ }^{529}$ Note-se que ele preserva um olhar masculino, nos moldes da época, especialmente porque em suas telas e na ficção científica, as mulheres são sempre os alvos de intervenções eugênicas comandadas pelos homens - sobretudo, intervenções de cunho estético. Os únicos homens que entram na lista dos passíveis de são aqueles acometidos por epidemias em Viaje a Marte, esterilizados em caráter de emergência.
}

${ }^{530}$ NOTAS SOBRE ARTE. Jornal do Commercio, Rio de Janeiro, 1 set. 1895, p.2. 
mas de pausa; e mais além a terceira, alegre e risonha, traduz bem o contraste de sua visinha.

Conseguir pintar essa raça com tal perfeição, dar-lhe movimento na physionomia e vida, é o mais que se pode exigir de um pintor $^{531}$.

Já Crioula de Diamantina foi vista como motivo de piada - o que pode indicar uma baixa aceitação da forma adotada na caracterização da jovem negra. A Gazeta de Notícias publicou a seguinte caricatura do quadro, acompanhada dos versos:

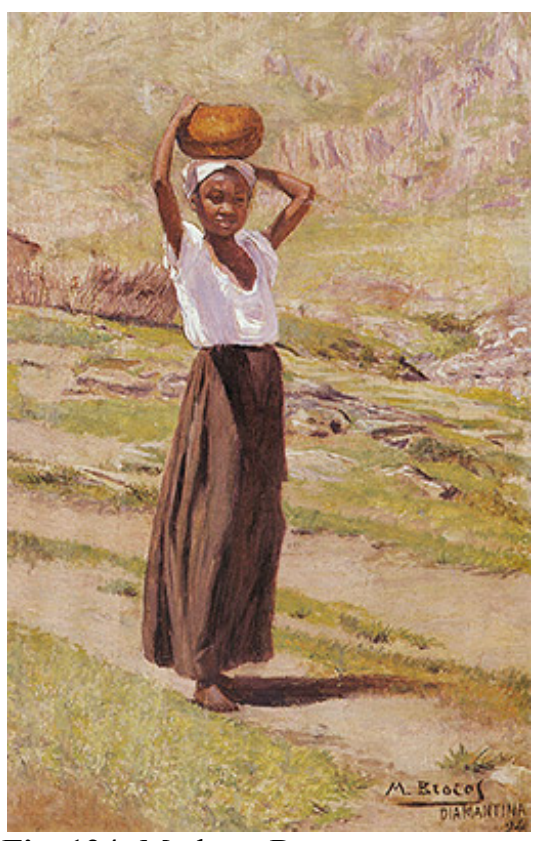

Fig. 124: Modesto Brocos.

\section{Crioula de Diamantina (1894).}

Óleo sobre madeira, $37 \mathrm{~cm}$ x $27,5 \mathrm{~cm}$.

Coleção Particular

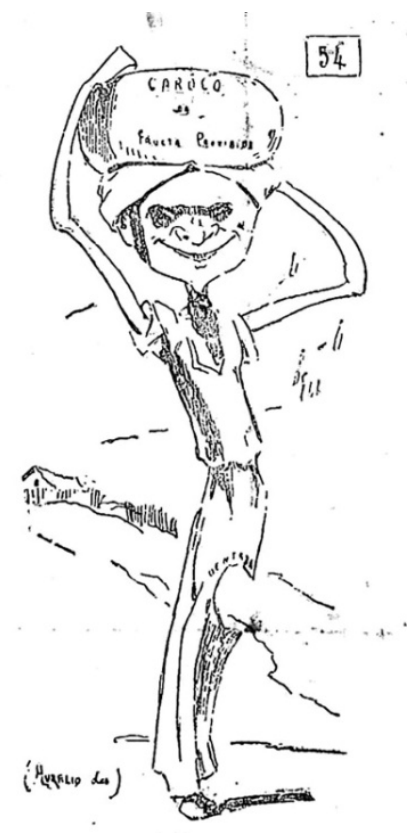

Fig. 125: UM QUADRO

DE BROCOS

Mulatinha Delambida

Mulatinha do caroço

Que da fruta proibida

Vais carregando o

destroço...

Quem te deu essa dentada

Com tal fúria de molosso;

Quem te fez tão descarnada

- Que te roa agora o osso!

Fonte: GAZETA DE

NOTÍCIAS, Rio de Janeiro, 1 nov. 1894, p. 1 .

Na cumbuca que a jovem leva à cabeça, o chargista Aurélio Dias escreveu "Caroço da favela proibida". Na parte rasgada da saia, lê-se "dentada".

Como se pode perceber, critica-se a magreza da figura - o contrário da imagem de Sara Baartman. O autor do texto faz uma alusão de caráter sexual, ao sugerir que a jovem, definida como "mulata", leva o "caroço da fruta proibida" (que já teria sido consumida), mas no contexto da charge ela se torna uma forma de ironia, como se essa figura pudesse ser sexualizada, mas não sensual - com destaque ao fato de que a mulher em cena é vista pelo autor como um objeto apreendido pelo viés da desejabilidade sexual.

Por fim, é válido lembrar outra vez o crítico já citado de 1901, que não demonstrou apreço por A descascar goiabas, descrevendo a personagem como "mulata": talvez se possa pensar que, em seu ponto de vista, o corpo desenhado 
daquela maneira fosse inadmissível na representação de uma mulher branca - o que respaldaria a ideia de que Brocos opera ali uma fusão entre cor da pele (branca) e esquema corporal (negro).

Se juntas, essas pinturas perfazem uma amostra de soluções formais distintas a partir das quais Brocos procurou responder ao problema da incorporação da população não-branca à sociedade brasileira, elas também ajudam a compreender melhor a resposta encontrada em $A$ redenção de Cam - pintura que, de todas as mencionadas, recebeu a aclamação pública, com a medalha de ouro na Exposição Geral de Belas Artes, em 1895. A premiação, é preciso reforçar, não significa que o quadro tenha passado ao largo de questionamentos, conforme discutiremos mais adiante. Mas primeiro, é preciso compreender em que medida Brocos dialogou com as imagens de mulheres negras e "mulatas" circulantes junto à opinião pública do período para equacionar seu problema ${ }^{532}$ do ponto de vista pictórico.

\section{Da mulher negra, segundo a opinião pública nacional: diálogos possíveis}

O primeiro diferencial mais evidente entre $A$ Redenção de Cam e as demais telas apontadas é a temática bíblica e o emprego de recursos formais que permitem dar vazão a tal gênero. Como apontaram Bueno e Jimenez ${ }^{533}$, trata-se de uma natividade; ou, poderíamos pensar, de uma imagem alegórica da sagrada família, que no quadro aparece metamorfoseada em família interracial. Estão ali a mãe que segura o bebê no colo, ao centro; o pai, à direita; e a avó, à esquerda.

No primeiro capítulo, vimos a sobrevivência, ao longo de séculos, do episódio bíblico em que Noé amaldiçoa o filho, Cam (e/ou o neto Canaã). Se no Genesis 9, o castigo transforma Cam em escravo de Sem e Iafet, procuramos mostrar como, durante o período medieval, essa mesma passagem passou a ser interpretada como um mito sobre a origem das diferenças que hoje chamamos de raciais. Em tais exegeses, a maldição impetrada por Noé resulta no escurecimento da pele de Cam e de seus descendentes, associados aos negros. Logo, o mesmo episódio adquire uma função

\footnotetext{
532 BAXANDALL, M. Padrões de intenção: a explicação histórica dos quadros. Companhia das Letras, São Paulo, 2006.

${ }_{533}$ BUENO, F.; JIMÉNEZ, J. A Redención de Cam de Modesto Brocos. Estudios Migratórios, n. 9, 2000 .
} 
essencial ao longo da era moderna, como justificativa para a escravização de distintas populações africanas.

Ao traçar um percurso de reapropriações dessa forma discursiva resistente, observamos que, em meados do século XIX, ela já convive com um tipo de pensamento científico que procura identificar as diferenças entre brancos e negros com base na ideia de "raça" - largamente utilizada como parte fundamental do discurso de afirmação de uma pretensa superioridade branca. Por fim, percebemos que no império português - e também no Brasil independente e, depois, republicano foram amplamente difundidas as teorias que defendiam a possibilidade da transformação racial, do ponto de vista biológico, por meio de uniões sexuais entre negros, brancos e mestiços - potencial este que, no plano discursivo foi mobilizado por meio de um acento no pólo branco ${ }^{534}$. Isto deu o tom particular ao racismo praticado nesses territórios, com a decorrente valorização daqueles indivíduos considerados mais claros, em detrimento dos mais escuros.

Datada de finais do Oitocentos, A redenção de Cam aborda diretamente o tema do branqueamento e, portanto, não pode se desvencilhar desses debates. Não por acaso, a pintura tornou-se a ilustração do artigo Sur les mêtis au Brésil, de João Batista de Lacerda. Não obstante, ela é, indubitavelmente, uma pintura alegórica - e isto a diferencia das demais telas mencionadas. Fletcher define alegoria:

Whenever a literary work is dominated by its theme, it is likely to be called an allegory, on the grounds that thematic content is not usually so free of logical control that it could be there by accident. The contrary assumption that mimetic art resists thematic excess follows from the way Aristotle defined mimesis, namely as an "imitation of an action," since "action" (praxis) in Aristotle's sense can and does exist without any extra help from secondary rationalization, that secondary level which we called "thought" (dianoia). Such is not the case with allegory, where the secondary meaning arises immediately from the primary surface of literal narration or drama, and constitutes the raison d'être of the primary surface. Allegorical stories exist, as it were, to put secondary meanings into orbit around them, and the primary meaning is then valued for its satellites ${ }^{535}$.

\footnotetext{
${ }^{534}$ Ainda que, na prática, pudesse haver dinâmicas populacionais distintas. ALENCASTRO, L. F. Mulattos in Brazil and Angola: A Comparative Approach, from Seventeenth to Twenty-First Century. In Bethencourt, F.; PEARCE. A. Racism and Ethnic Relations in the Portuguese-Speaking World. Oxford: British Academy Publications Online, Jan. 2013, pp. 71-96

${ }^{535}$ FLETCHER, A. Allegory. The Theory of a Symbolic Mode. Ithaca and London: Cornell University Press, 1995, pp. 220-221.
} 
Ainda que se refira à literatura, o conceito aplica-se perfeitamente à pintura. A definição vai ao âmago do debate sobre os caminhos que diferenciam, na tradição ocidental, realismo e idealismo - o segundo, aproximando-se do modo alegórico, o primeiro, do mimético. Como pudemos perceber, essa cisão é estratégica para a compreensão do jogo operado por Brocos com o estilo realista, ao compor suas imagens de negros e do embranquecimento - com a ressalva de que, ao anunciar-se afeito ao idealismo, Brocos tendeu a ser visto como realista.

As reflexões anteriores, que procuraram vislumbrar o uso, em telas de Brocos, de esquemas e topoi pictóricos consagrados pela pintura europeia para a composição de personagens negras, indicam as particularidades desses quadros, elaborados num Brasil republicano, em resposta ao problema relativo à incorporação dos não-brancos na ordem livre. São imagens que assumem um viés de gênero explícito, povoadas por mulheres negras (e ora brancas), cuidadosamente estudadas e pintadas por meio de uma variedade de recursos técnico-formais e conceituais: para elas, Brocos fabricou corporalidades conformes, mas também inconformes aos sistemas de notação que aludissem, de modo mais óbvio, a um tipo de sexualidade então tomada como patológica $^{536}$.

Viaje a Marte, sua obra de ficção científica, parece confirmar intenções, ao elogiar políticas eugênicas, visando ao que ele considerava um aperfeiçoamento da raça. No livro, o corpo feminino é o alvo primordial das intervenções: ali as mulheres têm o dever de casar-se ou voluntariar-se numa irmandade, colocando-se a serviço do prazer masculino e da reprodução da espécie; caso não correspondam aos modelos de beleza e saúde estabelecidos (pelos homens), são submetidas à esterilização. Além disso, todas as ameaças ao ideal de perfectibilidade defendido no livro precisam ser eliminadas e, por esse motivo, os marcianos afogam as crianças consideradas imperfeitas numa piscina, logo após o nascimento.

Buscamos argumentar que, ao afastar-se dos modelos de representação da mulher negra convencionais na Europa, o artista terá buscado constituir padrões visuais capazes de aludir a processos de "seleção sexual" ${ }^{\text {"537 }}$ condizentes com suas

\footnotetext{
${ }^{536}$ GILMAN, S. Black Bodies, White Bodies: Toward an Iconography of Female Sexuality in Late Nineteenth-Century Art, Medicine and Litterature. In: GATES, H. L. (ed.). "Race", Writing and Difference. Chicago and London: University of Chicago Press, 1985.

${ }^{537}$ Empregamos o termo usado por João Batista de Lacerda. LACERDA. J. B. Sobre os mestiços no Brasil. Tradução de "Sur le métis au Brésil" (Premier Congrès Universel des Races: 26-29 juillet 1911,
} 
projeções racistas de embranquecimento. Dessa feita, uma tela como Engenho de mandioca é uma cena de trabalho, ao mesmo tempo em que mostra uma variedade de tipos femininos, cuja corporalidade poderá atender a distintos papéis numa ordem sexual voltada à gestão do futuro racial do país. Duas ressalvas são necessárias: 1 . evidentemente, uma tal leitura só se faz possível no entrecruzamento das obras do mesmo autor; 2. não se pode perder de vista que aquilo que encaramos como o racialismo de Brocos pode ter passado por diferentes etapas de amadurecimento entre 1892 e 1933 - anos de lançamento de Engenho de mandioca e Viaje a Marte e que isto serve de explicação para possíveis variações. Entretanto, quadro e livro respondem ao mesmo problema, qual seja, o de propor modelos para um suposto "aperfeiçoamento da raça" (leia-se, embranquecimento).

Não obstante as intenções de Brocos, também percebemos que certos críticos de Engenho de mandioca - assim como os de Feiticeira e de Crioula de Diamantina - deixam entrever contextos mentais ${ }^{538}$ mais afeitos aos esquemas europeus citados anteriormente: elogiam a caracterização de mulheres negras, cujos corpos têm formas arredondadas e quadris largos, como no caso de Engenho, ou traços deformados e o uso de cores ao gosto do orientalismo, como ocorre em Feiticeira. Logo, há motivos para pensar que tais quadros ainda não haviam alcançado os objetivos propostos por Brocos, revelando-se em certa medida incapazes de traduzir suas convicções.

Conforme mostra Gilman, na Europa a interpenetração de convenções médicas no domínio da pintura resultou na produção de um sistema de notação pictórico capaz de evidenciar, na forma de caracterização do corpo feminino (de brancas e negras), certas qualidades morais das personagens - em particular, as relativas à sexualidade. Tal sobreposição se tornava possível porque, naquele momento, o status da ciência enquanto via de acesso à realidade era incontestável: este seria um sistema de notação capaz de impor seus esquemas por sobre o pictórico.

Mas Brocos procurou explorar um modelo próprio, voltado à ideia de embranquecimento - e, no contexto do Brasil republicano, isto dependia de representações alternativas do corpo feminino, que pudessem indicar preceitos morais distintos. Longe dos domínios da ficção científica passada em marte (e publicada

Paris, Devouge, 1911). In: História, Ciências, Saúde - Manguinhos. Rio de Janeiro, v.18, n.1, jan.mar. 2011, p. 228.

${ }^{538}$ GOMBRICH. E. Arte e Ilusão. Um estudo da psicologia da representação pictórica. SP: Martins Fontes, 2007. 
somente em 1933), no Brasil dos anos 1890 o sucesso de um projeto embranquecedor dependia de um reconhecimento da mulher negra como uma esposa em potencial - e não apenas como objeto sexual. Não obstante, ao que tudo indica, não havia, ainda, na medicina ou antropologia brasileira, um esquema corporal definido para a mulher negra que pudesse ser considerada capaz de dar à luz uma descendência branca. Destarte, como procuramos mostrar no capítulo 1, muitas incertezas rondavam as teorias do embranquecimento.

Isto não quer dizer que Brocos tenha antecipado preocupações inéditas ao Brasil de seu tempo. É de 1890, por exemplo, a História da Literatura Brasileira de Sylvio Romero, em que ele afirma que, no futuro do Brasil, prevalecerá um tipo de mestiço que dificilmente se distinguirá do branco ${ }^{539}$. Como se sabe, os mesmos debates também eram frequentes na imprensa nacional e modulavam o texto de folhetins como O mulato (1881) e O cortiço (1890), de Aluísio de Azevedo; ou ainda, Escrava Isaura (1872) - romance abolicionista, bastante anterior - e a esse respeito, é importante lembrar que, como indica Schwarcz, a literatura antecipa a "moda cientificista" no país, em romances como O Chromo (Horácio de Cavalho, 1888); e $A$ Carne (Júlio Ribeiro, 1888). Com personagens “condicionadas pelas máximas deterministas, os enredos terão seu conteúdo determinado pelos princípios de Darwin e Spencer, ou pelas conclusões pessimistas das teorias raciais da época" ${ }^{\# 40}$. Mas enquanto essas obras tendiam a reforçar determinados traços do modelo europeu, $A$ redenção de Cam parecia propor um modelo diferente.

Bertoleza, em $O$ Cortiço, é "crioula trintona" 541 , gorda, de pernas curtas e grossas e "cachaço" largo. Note-se de saída que o termo cachaço - sinônimo de nuca

\footnotetext{
539 “O seu número (dos brancos) tende a aumentar, ao passo que os índios e os negros puros tendem a diminuir. Desaparecerão num futuro não muito remoto, consumidos na luta que lhes movem os outros, ou desfigurados pelo cruzamento. O mestiço, que é a genuína formação histórica brasileira, ficará só diante do branco puro, com o qual se há de, mais cedo ou mais tarde, confundir", escreve ROMERO, apud RODRIGUES, N. As raças humanas e a responsabilidade penal no Brasil. Companhia Editora Nacional, 1938, p. 128. Disponível em <http://www.brasiliana.com.br/obras/as-racas-humanas-e-aresponsabilidade-penal-no-brasil/pagina/128/texto>. Consulta: 10/05/2013.

${ }^{540}$ SCHWARCZ, L. K. M. O espetáculo das raças. Cientistas, instituições e a questão racial no Brasil - 1870-1930. São Paulo, Companhia das Letras, 2004, p. 32.

${ }^{541}$ Note-se que, em determinado momento, ela também é descrita como "cafuza" - termo usado por Nina Rodrigues para referir-se à mistura de indígena com negro. Valeria um debate, para discutir o uso da palavra: ver Bertoleza como cafuza é reforçar o argumento do médico maranhense Nina Rodrigues, para quem os mestiços (de todos os graus) representam um mal; já vê-la como "crioula" - descendente de africanos, nascida no Brasil - é reforçar-lhe a negritude. O uso concomitante dos dois adjetivos parece indicar uma intenção de afirmar a desclassificação de Bertoleza que, não obstante, era escrava (o que a aproxima da imagem de negra).
} 
- é normalmente usado na descrição do pescoço atarracado de certos animais, como as vacas e ovelhas. A companheira de João Romão está sempre suja, cheirando a peixe e este português agradece aos céus por não terem filhos: “Abençoadas drogas que a Bruxa dera à Bertoleza nas duas vezes em que esta se sentiu grávida!", diz ele. Bertoleza é explorada pelo trabalho aviltante e tem um final trágico: ao descobrir que sua carta de alforria é falsa, a personagem se mata. Já Leonor, criada da personagem Miranda no romance, é "uma negrinha virgem (...) muito ligeira e viva, lisa e seca como um moleque, conhecendo de orelha, sem lhe faltar um termo, a vasta tecnologia da obscenidade"; o narrador completa a insinuação de que a menina teria uma predisposição precoce à sexualidade, ao lembrar que ela se deixa apalpar por mãos masculinas, ainda que sempre repetindo o bordão: "Óia, que eu me queixo ao juiz de orfe!”. Em O mulato, o personagem-título - o herói da trama, visto como uma figura de elevados padrões morais, inteligente e bonito -, descobre a identidade de seus pais: um português e uma negra, que fora sua escrava. A mãe do personagem, chamado Raimundo, é uma figura que confunde os moradores daquelas paragens, pois eles crêem tratar-se de uma assombração. Mais adiante, ela é apresentada como uma velha louca, descrita no trecho:

Raimundo, ao chegar à sacristia, estacou e estremeceu todo: o vulto esquelético e andrajoso, que lhe aparecera à noite, como um fantasma, ali estava naquela meia escuridão, a dançar uns requebros estranhos, com os braços magros levantados sobre a cabeça. O rapaz sentiu gelar-lhe a testa um suor frio e conservou-se estático, quase duvidoso de que aquilo que tinha defronte de si fosse uma figura humana.

Todavia, a múmia se aproximava dele, a dar saltos, estalando os dedos ossudos e compridos. Viam-se-lhe os dentes brancos e descarnados, os olhos a estorcerem-se-lhe convulsivamente nas órbitas profundas, e a caveira a desenhar-se em ângulos através das carnes. Ora erguia as mãos, descaindo a cabeça; ora fazia voltas, sapateando e dando pungas no $\mathrm{ar}^{542}$.

Descrita como um vulto "esquelético e andrajoso" e reduzida ao corpo deformado, a negra possui trejeitos alusivos à ideia de crise histérica ${ }^{543}$, como o riso e

\footnotetext{
${ }^{542}$ AZEVEDO, A. O mulato. São Paulo: Montecristo Editora, 2013, (s/p).

${ }^{543}$ Demoraria alguns anos para que João Batista de Lacerda e Nina Rodrigues protagonizassem um debate público sobre a histeria, que o primeiro afirmaria acometer somente as mulheres brancas (visto que, na opinião do médico, produto da "civilização") e o segundo - discípulo de Lombroso sustentaria a tese de que as negras também podiam ser acometidas pelas crises histéricas, refutando com isto também as teses defendidas na Europa. A histeria entre as negras (e que também poderia ser observada nos homens negros), segundo Rodrigues, seria decorrência dos estados de possessão e transe das religiões africanas. Cf. CORRÊA, M. Sobre a invenção da mulata. In: Cadernos Pagu, 6-7, 1996, pp. 35-50.
} 
os olhos que se agitam em convulsão. Não por acaso, o leitor é induzido a pensar, o pai da mocinha a impede com tamanha veemência de casar-se com Raimundo, ainda que o primeiro afirme que a negativa decorre do fato do segundo ser filho de escrava. É digno de nota que, assim como Bertoleza, a mãe de Raimundo tenha tido um fim trágico.

A corporalidade da mulher negra é constituída, em todos os casos, como algo anormal: é gorda como Bertoleza - que remete a Sara Baartman - ou magra demais, esquelética, hiperexcitada e/ou à beira da loucura, caso de Leonor e da mãe de Raimundo. Merece atenção, além disso, a tendência dessas personagens a terminar em tragédia, como se elas já nascessem fadadas à destruição.

Como mostra Verona ${ }^{544}$, a mulher "normal”, segundo os padrões do período, é definida como uma criatura frágil, delicada, de nervos à flor da pele; intelectualmente inferior ao homem, visto que vítima de emoções descontroladas; e cujo corpo possui todas as características físicas e psíquicas que resultem na satisfação de sua finalidade e vocação única na vida: a procriação e a maternidade, entendidas como evidências de uma sexualidade e um perfil psicológico saudável. A descrição de Ana Rosa, heroína branca de $O$ mulato, se ajusta ao perfil. Leitora de romances românticos, ela bordava, tocava um pouco de piano e cantava na procissão, enquanto sonhava com um marido:

Agora, só o que lhe convinha era um marido! O seu, o verdadeiro, o legal! O homem da sua casa, o dono do seu corpo, a quem ela pudesse amar abertamente como amante e obedecer em segredo como escrava. Precisava de dar-se e dedicar-se a alguém; sentia absoluta necessidade de pôr em ação a competência, que ela em si reconhecia, para tomar conta de uma casa e educar muitos filhos.

(...) E sonhava o noivado: um banquete esplêndido! e junto dela, ao alcance de seus lábios, um mancebo apaixonado e formoso, um conjunto de força, graça e ternura, que a seus pés ardia de impaciência e devorava-a com o olhar em fogo.

Depois via-se dona de casa; pensando muito nos filhos; sonhava-se feliz, muito dependente na prisão do ninho e no domínio carinhoso do marido. E sonhava umas criancinhas louras, ternas, balbuciando tolices engraçadas e comovedoras, chamando-lhe mamã!

- Oh! Como devia ser bom!... E pensar que havia por ai mulheres que eram contra o casamento!... Não! Ela não podia admitir o celibato, principalmente para a mulher!... Para o homem ainda passava... viveria triste, só; mas em todo o caso era um homem... teria outras distrações! Mas uma pobre mulher, que melhor futuro poderia ambicionar que o casamento?... que mais legítimo prazer do que a maternidade; que

${ }^{544}$ VERONA, E. M. O romance, a mulher e o histerismo no século XIX brasileiro. In: Histórica Revista Eletrônica do Arquivo Público do Estado de São Paulo, n. 32, 2008. Disponível em $<$ http://www.historica.arquivoestado.sp.gov.br/materias/anteriores/edicao32/materia06/texto06.pdf $>$. Consultta: 10/05/2013. 
companhia mais alegre do que a dos filhos, esses diabinhos tão feiticeiros?.. Além de que, sempre gostara muito de crianças: muita vez pedira a quem as tinha que lhas mandasse a fazer-lhe companhia, e, enquanto as pilhava em casa, não consentia que mais ninguém se incomodasse com elas; queria ser a própria a dar-lhes a comida, a lavá-las, a vesti-las, e acalentá-las. E estava constantemente a talhar camisinhas e fraldas, a fazer toucas e sapatinhos de lã, e tudo com muita paciência, com muito amor, justamente como, em pequenina, ela fazia com as suas bonecas $^{545}$.

A maternidade, nessa passagem, é tratada como uma espécie de dom. Do outro lado da moeda, era frequente encontrar nesses romances as personagens femininas que não conseguiam se casar, ora acometidas por surtos de histeria, ora mobilizando a preocupação da família e dos médicos por crises nervosas que culminassem na doença. A própria Ana Rosa tem uma crise, em determinada altura da narrativa. Nesse quesito, como explica Verona,

Receitas para o sucesso matrimonial não faltam na ficção brasileira oitocentista. Cada escritor encontrou o seu modo de reforçar essa instituição social chamada casamento, abordando-a sempre pelas suas vantagens. O "casamento é a base de toda sociedade civilizada", é a mais "nobre de todas as instituições". O celibato é, freqüentemente, caracterizado por seus incontáveis prejuízos e frustrações, que vão desde o estar só até, no caso das mulheres, a uma doença nervosa (...). Legitimavase, dessa forma, a idéia de que o casamento, se é importante para o homem, é indispensável para a mulher, pela necessidade que ela tem da proteção desse "ente superior" que toma por marido, que lhe dá "firme garantia à sua fraqueza e ao seu pudor" ${ }^{, 546}$.

A autora lembra que, "no que tange à questão do histerismo, o coro dos doutores das páginas da ficção era uníssono: nem xarope de 'Easton', nem 'Pravaz', nem ‘bromureto de potassium', o casamento era o melhor remédio",547.

Mas se uma tal solução podia estar ao alcance das brancas, as personagens negras não apareciam casadas ou realizadas como mães nos romances. Dentre nossos exemplos, Bertoleza, possuidora de um tipo físico próximo ao modelo representado por Baartman, vive em concubinato com João Romão, enquanto a união que resulta

\footnotetext{
${ }^{545}$ AZEVEDO, A. O mulato. São Paulo: Montecristo Editora, 2013, (s/p).

${ }^{546}$ VERONA, E. M. O romance, a mulher e o histerismo no século XIX brasileiro. In: Histórica Revista Eletrônica do Arquivo Público do Estado de São Paulo, n. 32, 2008. p. 7. Para uma discussão sobre as relações entre masculinidade e branquitude no período, ver MISKOLCI, R. O desejo da nação. Masculinidade e branquitude no Brasil de fins do século XIX. São Paulo: Annablume, 2012.

${ }^{547}$ VERONA, op. cit., p. 7. Schwarcz comenta que a tendência a ver certas mulheres como dadas a vícios já estava presente no trabalho de Jean-Martin Charcot (1825-1893), neurologista e professor de anatomia patológica francês célebre no Oitocentos. SCHWARCZ, L. K. M. O espetáculo das raças. Cientistas, instituições e a questão racial no Brasil - 1870-1930. São Paulo, Companhia das Letras,
} 2004. 
no nascimento de Raimundo também é ilícita - com o agravante de que a personagem feminina enlouquece.

Além disso, é importante perceber nesses enredos a presença de uma segunda figura exemplar para o pensamento racial do Brasil oitocentista: a "mulata" que, como a imagem de Nana, pintada por Manet, une no mesmo corpo atributos de branca e de negra. Rita Baiana, de $O$ cortiço, é um exemplo clássico na literatura sobre o assunto. Esta personagem é descrita pelo narrador como mulher bela e perfumada - ao contrário de Bertoleza -, dotada de uma sensualidade incontrolável e destrutiva: Jerônimo, português casado, apaixona-se por Rita e, obcecado, mata seu amante, o capoeirista Firmo. Em seguida, abandona a família; sua ex-esposa torna-se alcoólatra. É ainda digno de nota que a vida sexual ativa de Rita Baiana jamais resulte em gravidez - aludindo às teorias que, na época, apregoavam a infertilidade dos mestiços $^{548}$. Entretanto, à diferença das personagens negras citadas acima, a mulata empurra aqueles que estão a seu redor à fatalidade, mas jamais se destrói com eles.

Corrêa mostra que, "no discurso de alguns críticos literários (José Veríssimo, Silvio Romero), no de alguns historiadores (Capistrano de Abreu), no discurso médico (Raimundo Nina Rodrigues e muitos outros) e no literário (repito, de Gregório de Matos a Guimarães Rosa) que serviu de lastro para a construção dessa figura mítica, a mulata é puro corpo, ou sexo, não 'engendrado' socialmente" ${ }^{, 549}$. A autora também observa que:

\begin{abstract}
No campo do debate sobre as relações raciais, a feminilidade da mulata era também definida por contraste (aproximações e afastamentos) com a da branca. Nada exemplifica mais graficamente este modo de raciocínio do que a classificação das formas de hímem feita por Nina Rodrigues em suas análises médico-legais. Embora as mulheres mestiças apresentassem, como as brancas, as formas "mais variadas" de hímem, "as recém-nascidas, negras ou mestiças" apresentavam com freqüência uma forma de hímem que facilmente se confundia com o hímem rompido. (Essa classificação parece ter facilitado enormemente seu trabalho como perito nos casos em que meninas negras ou mulatas violadas eram examinadas por ele - e sua queixa desqualificada.) No que diz respeito às negras, as formas de hímem são mais simplificadas. ${ }^{550}$
\end{abstract}

\footnotetext{
${ }^{548}$ Nina Rodrigues se destaca como um autor que tendia a ver os mestiços como anormais, degenerados e estéreis. CORRÊA, M. As ilusões da liberdade. A Escola Nina Rodrigues e a antropologia no Brasil. Bragança Paulista: Edusf, 1998.

549 Idem, ibidem, p. 40. Vale citar o estudo de Teófilo de Queirós Júnior que, entretanto, erra ao colocar-se na posição de estabelecer hierarquias e juízos estéticos totalizantes com relação à aparência da negra, da mulata e da branca, em procedimento similar ao adotado por Gilberto Freyre. Cf. JÚNIOR, T. Q. Preconceito de cor e a mulata na Literatura Brasileira. São Paulo: Ática, 1975.

${ }^{550}$ CORRÊA, op. cit., pp. 44-45.
} 
O próprio Nina Rodrigues é o autor de um trecho que resume bem as qualidades atribuídas à figura da mulata pelos intelectuais de fim de século:

\begin{abstract}
Nunca se frisou bastante, diz o Sr. José Verissimo (“A educação nacional”, Pará, 1890), a depravada influência deste característico tipo brasileiro, a mulata, no amolecimento do nosso caráter. "Esse fermento do afrodisismo patrício", como the chama o Sr. Sylvio Romero, foi um dissolvente da nossa virilidade física e moral. A poesia popular brasileira no-la mostra, com insistente preocupação apaixonada, em toda a força dos seus atrativos e da sua influência. O povo amoroso se não fatiga em celebrar-lhe, numa nota lúbrica, os encantos, que ele esmiuça, numa sofreguidão de desejos ardentes. Canta-lhe a volúpia, a magia, a luxúria, os feitiços, a faceirice, os dengues, os quindins, como ele diz na sua linguagem piegas, desejosa, sensual ${ }^{551}$.
\end{abstract}

Assim como Rita Baiana, houve antes Vidinha, de Memórias de um Sargento de Milícias. Por outro lado, tem-se Escrava Isaura, romance abolicionista que aposta na descrição idealizada de uma personagem não-branca - mas quase - a fim de angariar a identificação do público branco. Isaura era

uma bela e nobre figura de moça. As linhas do perfil desenham-se distintamente entre o ébano da caixa do piano e as bastas madeixas ainda mais negras do que ele. São tão puras e suaves essas linhas que fascinam os olhos, enlevam a mente e paralisam toda análise. A tez é como o marfim do teclado, alva que não deslumbra, embaçada por uma nuança delicada que não sabereis dizer se é leve palidez ou cor de rosa desmaiada. O colo donoso e do mais puro lavor sustenta com graça inefável o busto maravilhoso (...) $\mathrm{Na}$ fronte calma e lisa como mármore polido, a luz do ocaso esbatia um róseo e suave reflexo ${ }^{552}$.

Conforme Bosi, "toda a beleza da escrava é posta no seu não parecer negra, mas nívea donzela (...) o que explica a beleza 'branca' de Isaura é a permanência de padrões estéticos europeus" ${ }^{\$ 553}$. Por conseguinte, Isaura era a exceção entre as escravas - nunca a regra -, o que se confirma em distintos momentos da narrativa. Carvalho observa a recorrência dessa distinção, assentada na pele mais clara:

Note-se a importância da "tez branca" de Isaura. Ela "era bonita demais para mucama” (GUIMARÃES, s/d, p. 42). Dizia-se dela: “Ó céus! É possível que uma moça tão linda seja uma escrava", pois era "bonita e civilizada como qualquer moça branca" (GUIMARÃES, s/d, pp. 105, 52). Certa vez, Leôncio disse a Malvina: "É preciso primeiro assegurar-lhe uma

\footnotetext{
${ }^{551}$ RODRIGUES, R. N. As raças humanas e a responsabilidade penal no Brasil. Rio de Janeiro, Guanabara, 1957, pp. 199-200.

${ }_{552}$ GUIMARÃES, B. A escrava Isaura. São Paulo: Klick Editora, s/d, p. 14.

${ }^{553}$ BOSI, A. História concisa da literatura brasileira. São Paulo: Cultrix, 2004, p. 144.
} 
posição decente, honrosa e digna de sua beleza e educação, procurando-lhe um bom marido"; enfim, era uma "escrava excepcional" (GUIMARÃES, $\mathrm{s} / \mathrm{d}$, pp. 61, 66). (...) Isaura, no meio das outras escravas, "parecia uma garça real, alçando o colo garboso e altaneiro, entre uma chusma de pássaros vulgares" (GUIMARÃES, s/d, p. 53) ${ }^{554}$.

Os exemplos são infindáveis: "És formosa e tens uma cor linda, que ninguém dirá que gira em tuas veias uma só gota de sangue africano" ${ }^{\text {"55 }}$, diz Malvina, sua senhora, a Isaura. Vale destacar que até mesmo os outros escravos, no romance, contribuem para reconhecer a diferença marcante entre Isaura e as demais nãobrancas. É o caso de André, que lhe diz: “dói-me deveras dentro do coração ver aqui misturada com essa corja de negras beiçudas e catinguentas uma rapariga como tu, que só merece pisar em tapetes e deitar em colchões de damasco" ${ }^{, 556}$. Por fim, a caracterização de Isaura não poderia estar completa se a aparência branqueada não encontrasse referência explícita em um tipo europeu. Em determinada altura da narrativa, ela é "uma andaluza de Cadiz, uma napolitana"557 - ao mesmo tempo em que ainda é chamada de "mulata" ou "mulatinha" pelo narrador. No entanto, a personagem criada por Bernardo Guimarães é uma mulata que se diferencia também pelo comportamento, pois longe de exibir uma sexualidade patológica, é vista como moça para casar. Assim, a figura não pode ser entendida senão como um produto das intenções abolicionistas do autor, que procurava por meio da caracterização de Isaura cativar a simpatia do público pela personagem.

Foge às pretensões e limites desta dissertação empreender um estudo mais detalhado sobre as personagens não-brancas na literatura e no pensamento social brasileiro $^{558}$. Os exemplos aqui citados importam na compreensão de modelos vigentes na segunda metade do século XIX, com os quais Brocos - e seus críticos pudessem dialogar. Ao lado das demais personagens descritas, a pintura de Brocos oferece um contraponto interessante.

\footnotetext{
554 CARVALHO, C. A. A imagem do negro na literatura brasileira do século XIX. In: Ciências Humanas em Revista, São Luís, v. 4, n.2, dez. 2006, pp. 59-60.

${ }_{555}$ Apud QUEIROZ JR., T. Preconceito de cor e a mulata na Literatura Brasileira. São Paulo: Ática, 1975., p. 82.

${ }^{556}$ GUIMAR $\tilde{E} E S$, op. cit., p. 56.

${ }^{557}$ Apud QUEIROZ JR, op. cit. p. 84. Nesse sentido, a existência de uma figura como Isaura ajuda a compreender por que, por exemplo, a mulher do quadro A descascar goiabas pode ser compreendida como "mulata" - e isto já em 1901.

${ }^{558}$ Ver QUEIROZ JR, op. cit.; PROENÇA FILHO, D. A trajetória do negro na literatura brasileira. Estudos Avançados, São Paulo, v. 18, n. 50, Abr. 2004. Disponível em: $<$ http://www.scielo.br/scielo.php?script=sci_arttext\&pid=S010340142004000100017\&lng=en\&nrm=is o>. Consulta: 10/05/2013.
} 
Bertoleza e Rita Baiana, a mãe de Raimundo e Leonor encarnam figuras de uma sexualidade destrutiva, que jamais poderiam ser vistas como mães de família - e portanto, não correspondem à imagem de mulher que desejaria uma tela como $A$ Redenção de Cam. Isaura é branca demais, idealizada demais e, assim, não pode figurar como exemplo capaz de afirmar a viabilidade do embranquecimento, seja porque figura como uma exceção, seja porque ela mesma ainda não chega a ser branca. De um lado, tem-se uma amostra de excesso de realismo, entendido por sua aproximação com o sistema de notação científico vigente; do outro, um exemplo do idealismo exacerbado.

De todo modo, a existência desse espaço propício para imaginar representações possíveis de negras, conformes ao pensamento e aos sistemas de notação científicos da época, é o que permite a Brocos colocar em prática seu projeto pictórico. Como vimos, A redenção de Cam pode ser vista como exceção, tanto se comparada aos modelos estrangeiros disponíveis, como dos nacionais. Resta compreender melhor os aspectos que marcam e reforçam essa diferença.

\section{A redenção de Cam, por suas particularidades}

Paradoxalmente, numa era marcada pela disseminação de sistemas de notação científicos na esfera pública, pelo positivismo, evolucionismo, darwinismo social que coloriam inclusive as páginas dos folhetins ${ }^{559}$, para fazer jus a seu ponto Brocos precisou recorrer à iconografia cristã. Ao fazê-lo, o quadro sem dúvida se aproxima da combinação de fé e ciência levada adiante por João Batista de Lacerda - que comentamos no capítulo 1. Entretanto, a tela antecede em 16 anos o artigo em que o médico tornaria evidentes tais correlações ${ }^{560}$, configurando-se, possivelmente, numa

\footnotetext{
${ }^{559}$ SEYFERTH, G. A antropologia e a tese do branqueamento da raça no Brasil: a tese de João Baptista Lacerda. In: Revista do Museu Paulista, 30, 1985; SKIDMORE, T. E. Preto no branco. RJ: Paz e Terra, 1989; SCHWARCZ, L. K. M. Retrato em negro e branco. Jornais, escravos e cidadãos em São Paulo no final do século XIX. SP: Companhia das Letras, 1987; SCHWARCZ, L. K. M. O espetáculo das raças. Cientistas, instituições e a questão racial no Brasil - 1870-1930. São Paulo, Companhia das Letras, 2004. SCHWARCZ, L. K. M. Questões de fronteira. In: Novos Estudos. São Paulo, Cebrap, $n^{\circ}$ 72, jul. 2005; Schwarcz, L. K. M. Previsões são sempre traiçoeiras. João Baptista de Lacerda e seu Brasil branco. In: História, Ciências, Saúde - Manguinhos. RJ, v.18, n.1, jan.-mar. 2011; CORRÊA, M. As ilusões da liberdade. A Escola Nina Rodrigues e a antropologia no Brasil. Bragança Paulista: Edusf, 1998; HOFBAUER, A. Uma história do branqueamento ou o negro em questão. SP: Editora UNESP, 2006.

${ }_{560}$ É fato que o artista trabalhou durante um tempo como ilustrador na revista do Museu Nacional, mas fora isso, não restam maiores informações que possibilitem contectá-lo a Lacerda.
} 
das primeiras tentativas de explorar por meio de imagem uma hipótese sobre o embranquecimento. Como veremos, isto é possível porque a tela estabelece um diálogo seletivo com determinadas convenções. A primeira delas, apontada anteriormente, é a forma da pintura bíblica, que reforça o título do quadro: estão ali a mãe que segura o filho no colo, no centro da cena, ladeada por duas outras figuras - $\mathrm{o}$ pai da criança e a avó. Por sua disposição na economia do quadro, essas personagens lembram respectivamente a madonna que carrega o menino Jesus no colo; José; e o anjo que intermedeia, na iconografia religiosa, as relações entre o plano terreno e a divindade, ao estabelecer algum tipo de conexão gestual mais direta com uma dimensão ausente da cena.

A sutileza desse artifício, toda ela produto da concepção da tela, é explorar uma religiosidade estendida à própria personagem da avó que, desse modo, aproxima o ideal expresso pela obra - o embranquecimento - à factibilidade de um cotidiano reconstruído. Logo, tudo se passa como se houvesse (ou devesse haver) voluntarismo dos próprios afrodescendentes no projeto branqueador que visava extingui-los - um auto-sacrifício, como Coelho Netto expressou em crônica inspirada pela tela - e citada no início do capítulo 2 . A dúvida quanto à natureza da imagem (ela vislumbra a transcendência, ou apenas reforça a presença da religiosidade popular na vida prosaica?) coloca o interlocutor frente a um imbricado jogo entre crença e tautologia $^{561}$.

De todo modo, é graças à referência bíblica em primeiro lugar que as figuras femininas do quadro escapam à modelagem então vigente na representação de negras e mulatas, quer na pintura europeia, ou na literatura nacional: agora, elas são mães de família, que afirmam sua religiosidade cristã. Além disso, a própria corporalidade de cada uma dessas figuras explora certas minúcias em que o acento religioso - intenção moralizante - é reforçado. Vejamos melhor.

${ }^{561}$ DIDI-HUBERMAN, G. O que vemos, o que nos olha. São Paulo: Editora 34, 2010. 


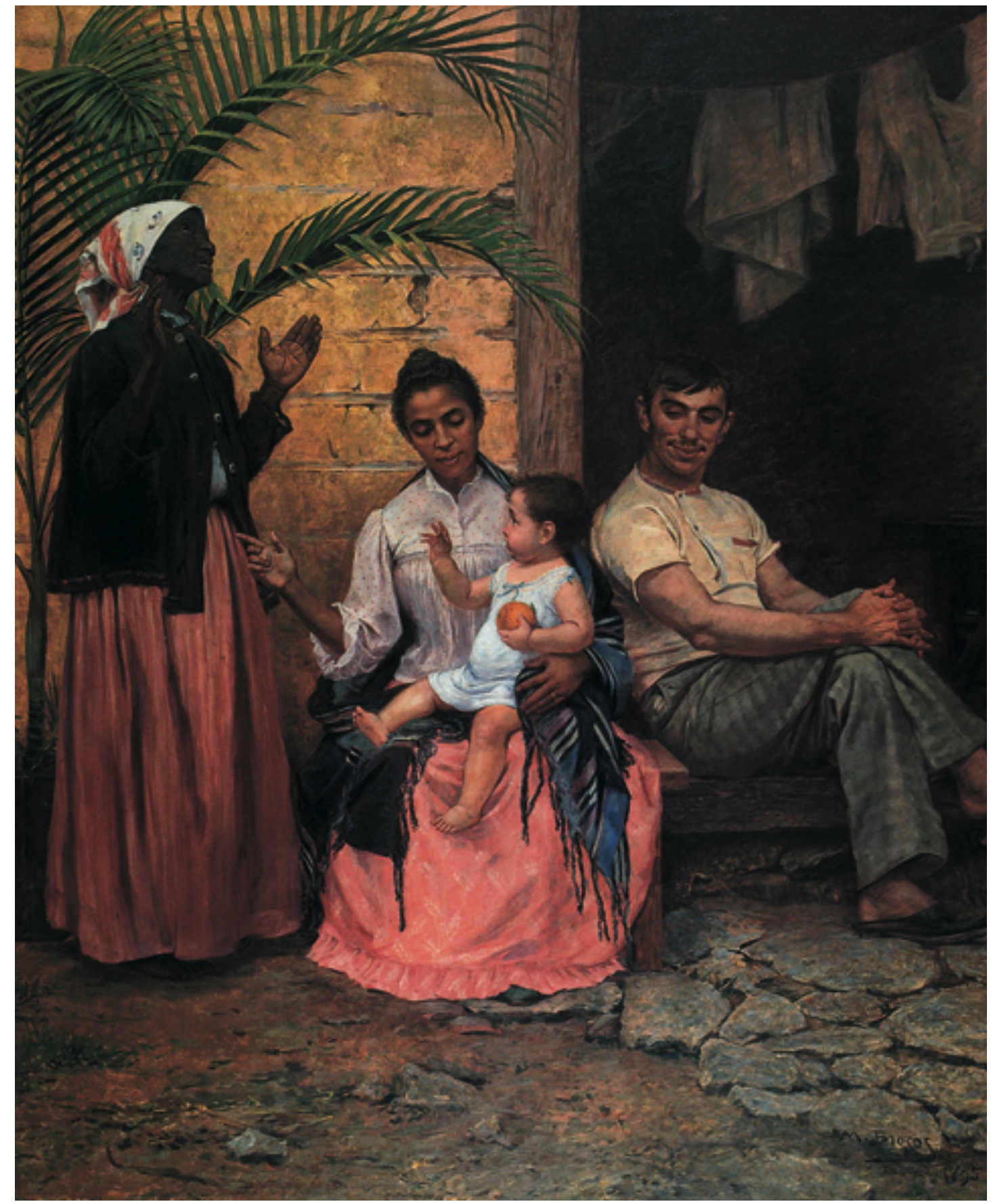

Fig. 126: Modesto Brocos. A redenção de Cam (1895). Óleo sobre tela, $199 \mathrm{~cm}$ x $166 \mathrm{~cm}$. Rio de Janeiro: Museu Nacional de Belas Artes.

Em primeiro lugar, à esquerda de quem olha, está a avó, negra, que se sobressai por sua pose de estátua. A rigidez postural encontra complementaridade na própria pigmentação da pele, pois seu rosto é uma mancha de cor uniforme, marrom escura, que se justapõe ao fundo da cena e cria a impressão de estar-se diante de uma figura de argila, lembrando a qualidade rústica de algumas santas populares. 
No desenho desse corpo, destacam-se correspondências possíveis com certos esquemas bem estudados por Hébert, em suas incursões às igrejas italianas. A Vierge orant (Virgem orando), do pintor francês, incorpora o gestual das mãos e o corpo coberto e petrificado, que percorre uma linha reta, assim como sua Sainte debout et deux figures à sés pieds (Santa em pé e duas figuras a seus pés). O caimento da saia das figuras é também retilíneo e suas vestes quase recobrem a totalidade dos pés. Os mesmos elementos também se fazem presentes na avó negra pintada por Brocos ainda que esta última se encontre voltada para a direita.
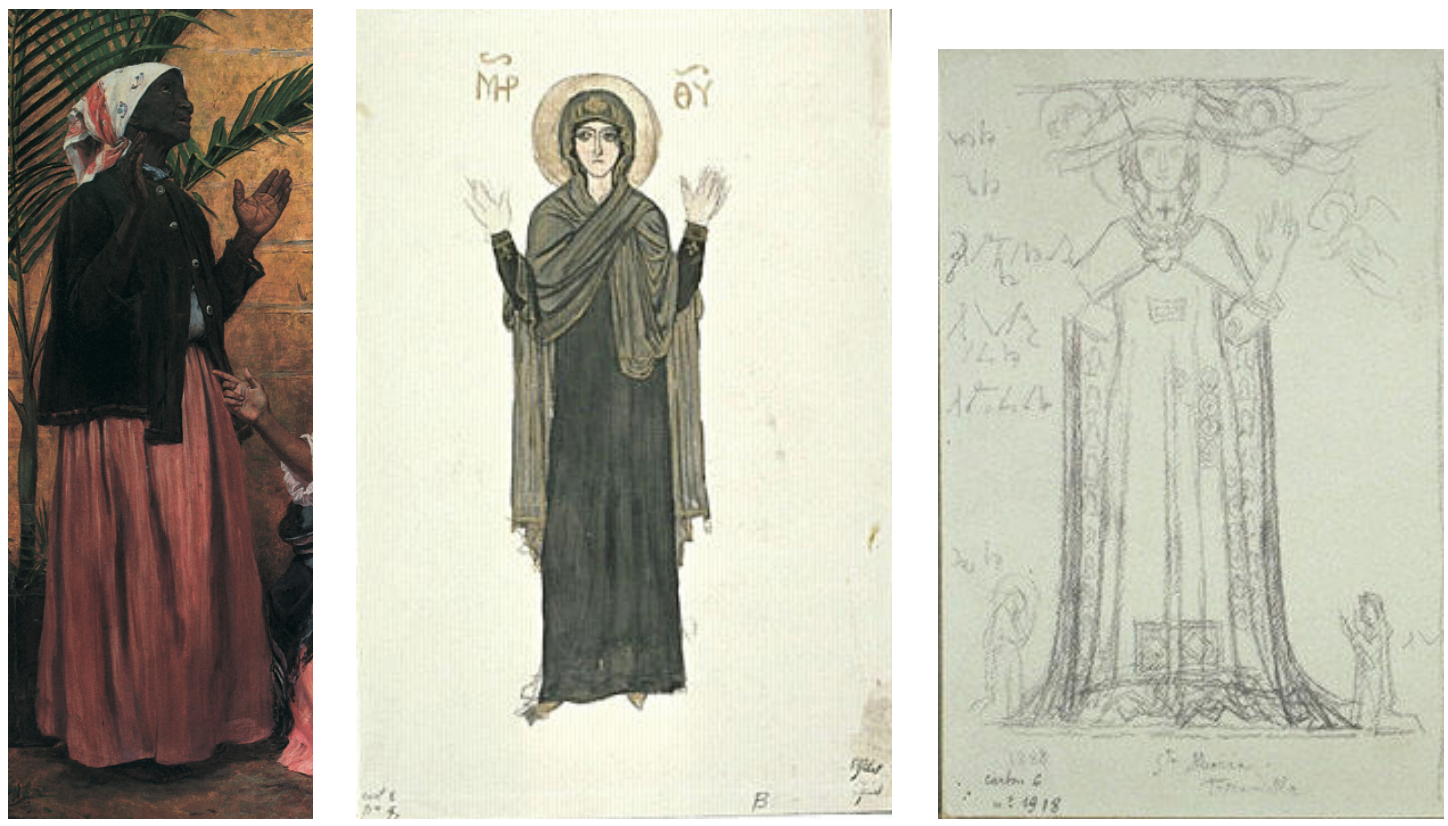

Da esq. para a dir.: Fig. 127: A redenção de Cam (detalhe); Fig. 128: Ernest Hébert. Vierge orant (s.d.). Desenho. Paris: Musée du Louvre. Fig. 129: Ernest Hébert. Sainte debout et deux figures à ses pieds (s.d.). Desenho. Paris: Musée du Louvre.

A ideia de uma virgem negra merece atenção redobrada, pois afasta-se das imagens correntes, que buscavam indicar uma sexualidade patológica, sem com isto tirar de cena a vinculação sexual que caracteriza a percepção dos europeus sobre a mulher negra. Segundo Knight, é em pleno século XIX e lado a lado com a aparição da vênus negra como objeto da ciência (e da curiosidade pública) europeia, que a madonna negra, cultuada durante séculos pelos cristãos, é reinventada como a patrona da fertilidade. Conforme a autora, ambas as imagens podem ter convivido como pontas complementares dos mesmos interesses do colonialismo europeu na África. No Oitocentos, 
the association of blackness in Africa with primitive insticts, animals and fertile landscapes served to enliven the European imagination about the Black Madonna's powers of fertility. Perhaps the Black Madonna's association with earthly power, fertility and miracles only enhanced stereotypes about Africans as being closer to nature, without civilization and primitive.

(...) it is probable that the image of Black Madonna as having extraordinary power in relation to fertility and miracles was and still is mutually reinforcing of stereotypes of black women as primitive and highly sexual. Ironically, although the Black Madonna is also called the "Black Virgin," her relationship with fertility and her connection with the power of the earth could easily connect in the subconscious minds of worshippers with their stereotypes of the black women as highly sexualized $^{562}$.

Logo, a virgem negra torna-se uma presença fundamental para refutar suspeitas de infertilidade: a associação entre a avó da pintura e a santa como essa pode servir como garantia, na imagem, de que o embranquecimento via união interracial é possível. Além disso, também é importante perceber que, no catolicismo brasileiro, a virgem negra é considerada a protetora dos escravos - como discute Knight. Os pés descalços da velha senhora, nesse sentido, são índices importantes, pois sugerem que ela própria teria sido escrava ${ }^{563}$.

Mas não apenas a avó é moldada pela imagem da santa. A mesma ideia de divindade embasa a composição de sua filha em cena, que de todas as personagens é a que mais se aproxima da representação canônica da madonna com o menino Jesus no colo $^{564}$. Todavia, não deixa de ser surpreendente que Brocos tenha ativado essa

${ }^{562}$ KNIGHT, J. S. Feminist Mysticism and Images of God: A Practical Theology. Chalice Press, 2011, pp. 122-124. A mesma autora também aponta para uma associação com uma orixá, mas não dá maiores detalhes. Segundo ela comenta, se acredita que a primeira estátua negra de Nossa Senhora de Aparecida como negra emergiu na rede de peixes de um grupo de pescadores. Ver também SOUZA, J. B. A. de. Mãe negra de um povo mestiço: devoção a Nossa Senhora Aparecida e identidade nacional. Estudos Afro-Asiáticos (29), março de 1996.

${ }^{563} \mathrm{O}$ viajante Jean-Baptiste Debret foi um dos autores que estabeleceu a associação entre pés descalços e escravidão. Em 1816, ele surpreendeu-se com a quantidade de sapatarias do Rio de Janeiro, cidade onde 5/6 da população eram escravos que andavam descalços. DEBRET, J.-B. Viagem pitoresca e histórica ao Brasil. Belo Horizonte/São Paulo: Itatiaia/EDUSP, 1978, vol. 1. Souza comenta que, nos anúncios de escravos fugidos publicados na imprensa oitocentista, por vezes apareciam descrições de problemas nos pés ou de pés fortes demais para terem andado calçados em algum momento da vida. A despeito da associação visual, a autora mostra que, já nos anos 1870, boa quantidade de escravos, fugidos e forros andava calçada. SOUZA, P. M. Visualidade da Escravidão: representações e práticas de vestuário no cotidiano dos escravos na cidade do Rio de Janeiro oitocentista. Tese (Doutorado em História da Cultura), Departamento de História da PUC-Rio, Rio de Janeiro, 2011.

${ }^{564}$ Isto parece perfeitamente factível no contexto brasileiro, onde a virgem negra (Nossa Senhora de Aparecida), como observa Schwarcz, assumirá futuramente uma "identidade mestiça": "Tal qual um Macunaíma às avessas, nesse caso, a imersão nas águas do Rio Paraíba do Sul teria escurecido a Virgem e sua "súbita aparição" feito dela uma legítima representante da nacionalidade", comenta SCHWARCZ, L. K. M. Nem preto, nem branco, muito pelo contrário. Cor e raça na intimidade. In: História da vida privada no Brasil, vol. 4. SP: Companhia das Letras, 2004 p. 197. 
sobreposição estratégica, contrapondo-se com isso à ideia da mulata de sexualidade exacerbada e destrutiva, presente em escritos da ciência e literatura brasileiras.

A esse respeito, outros aspectos da caracterização das duas figuras femininas merecem atenção. Um deles é o fato da avó ser magra, com quadris e ombros de largura similar - fugindo ao padrão físico de Sara Baartman -, ao mesmo tempo em que não apresenta uma magreza extrema, como a mãe de Raimundo em $O$ mulato. Já o corpo de sua filha tem formas arredondadas e cintura fina, sendo que o contorno de seus quadris é calculadamente coberto pelo xale e pelo bebê, de modo a evitar a visibilidade do desenho. Ela tem mãos pequenas e delicadas, em comparação com as da mulher mais velha ${ }^{565}$. Ambas as personagens estão extremamente vestidas, com os corpos completamente cobertos. Mãe e filha usam roupas à moda ocidental - evitando trajes comumente associados à identidade étnica como, por exemplo, aqueles utilizados pelas trabalhadoras do Engenho de mandioca.

Como indica Souza ${ }^{566}$, as vestimentas usadas pelas persongens do quadro eram comuns no vestuário feminino das mulheres negras já nos anos 1870. A autora destaca a combinação de saia e camisa ou vestido com um paletó nos anúncios de fuga de escravos do período e encontra também confecções especializadas em roupas para escravos, cujo chamariz é a praticidade e liberdade de movimentos para o trabalho. Merece atenção também o uso de tecidos com listras ou riscadinho pela população escrava, notado pela autora; as mulheres também usariam estampas de flores, salpicos, pintas redondas e xadrez. Segundo observa, xale, lenço (equivalente a turbante) - comumente associados à população negra do Rio de Janeiro pelos viajantes - não aparecem com assiduidade entre as escravas fugidas nesse período. No uso de turbante/lenço - categorias que se confundem também das fontes analisadas por Souza -, a cor branca (como a do adereço usado pela avó da tela) é frequente. A historiadora cita trabalho da pesquisadora de cultura material de povos africanos Elise Renne, para quem o tecido branco (àki) usado ao redor da cabeça, na cultura iorubá

\footnotetext{
${ }^{565}$ A primeira, poderia ter mãos de serva (ou escrava), ao contrário da segunda. McClintock e Pearl, analisando a relação afetiva entre uma mulher das classes populares e um advogado na Inglaterra vitoriana, apontam para o fetiche que ele nutria pelas mãos de trabalhadora de sua amada: mãos grandes, que ele fazia questão de fotografar. MCCLINTOCK, A. Couro Imperial. Editora Unicamp, Campinas, 2010; PEARL, S. About faces: physiognomy in nineteenth-century Britain. Cambridge: Harvard University Press, 2010.

${ }^{566}$ SOUZA, P. M. Visualidade da Escravidão: representações e práticas de vestuário no cotidiano dos escravos na cidade do Rio de Janeiro oitocentista. Tese (Doutorado em História da Cultura), Departamento de História da PUC-Rio, Rio de Janeiro, 2011.
} 
tem a função de induzir à possessão espiritual, propiciando visão sobrenatural. Sem condições de avaliar o conhecimento de Brocos sobre esta tradição, podemos pensar que o uso cotidiano tenha tornado o lenço branco um distintivo da mulher negra no período $^{567}$.

Mais um ponto a observar sobre a pintura é que, a despeito do cuidado extremo com o desenho do corpo e rosto da jovem - bastante simétrico e proporcional, ou seja, sem deformação -, sua mão esquerda é exageradamente maior que a direita e foge à justeza das medidas anatômicas. No dedo anular dessa mão, desenhada para ser vista, repousa uma aliança que indica tratar-se de uma mulher casada e, portanto, em conformidade com a moral sexual vigente. $\mathrm{O}$ azul do xale, por sinal, também serve de referência à Virgem Maria, cujo manto tem a mesma cor nas representações mais canônicas ${ }^{568}$. Por fim, não há intenção de mostrar as orelhas de nenhuma das mulheres em cena, visto que esses órgãos aparecem parcialmente cobertos em ambas as personagens.

Por todos esses motivos, são imagens distanciadas dos modelos citados anteriormente: as figuras femininas de $A$ redenção de Cam afastam-se da criada que entrega flores a Olympia, de Nana, Bertoleza, Rita Baiana, Leonor e Vidinha, mas também de Isaura, vez que não há nenhuma preocupação em retratar nenhuma delas com traços e tom de pele que as confundissem com mulheres brancas. Entretanto, a transformação não é livre de preconceitos, pois agora, o corpo dessas mulheres se torna veículo de questionamentos de outra ordem: ao aproximar mãe e filha das virgens negras, a tela restaura o problema da igualdade entre brancos e negros perante a Deus - e propõe uma solução singular, assentada sobre a reprodução.

Dyer chama a atenção ao fato de que, sob o olhar da branquitude, "black people can be reduced (in white culture) to their bodies and thus to race, but white people are something else that is realised in and yet is not reducible to the corporeal, or racial" ${ }^{, 569}$. Essa distinção, diz ele, remonta a um entrelaçamento singular entre o

\footnotetext{
${ }^{567}$ Idem, ibidem.

${ }^{568}$ Gage avalia que, desde o período medieval, o azul ultramarino do manto de da Virgem Maria adquiriu significados que o tornaram axiomático para a iconografia cristã. Em geral, esse azul era obtido a partir de pigmento extraídos de metais nobres e preciosos, como o lápis-lázuli - daí a aplicação comedida essa cor, reservada à imagem sagrada da santidade. GAGE, J. Color and meaning: art, science, and symbolism. Berkeley: University of California Press, 2000.

${ }^{569}$ DYER, R. White. London and New York: Routledge, 1997, pp. 14-15.
} 
imaginário cristão e a construção de uma "estrutura de sentimentos da branquitude" na Europa. O autor explica que

\begin{abstract}
not only Christianity became the religion and the religious export, of Europe, indelibly marking its culture and consciousness, it has also been thought and felt in distinctly white ways for most of its history, seen in relation to, for instance, the following: the persistence of the Manichean dualism of black:white that could be mapped on to skin color difference; the role of the Crusadesin racialising the idea of Christendom (making national/geographic others into enemies of Christ); the gentilising and whitening of the image of Christ and the Virgin in painting; the ready appeal to the God of Christianity in the prosecution of doctrines of racial superiority and imperialism ${ }^{570}$.
\end{abstract}

Se as imagens santificadas da Cristandade são mormente brancas, a aparição dessas virgens não-brancas fala ao problema da existência da alma negra. Os questionamentos sobre a existência dessa dimensão extra-corpórea nos não-brancos é central para as discussões estabelecidas, do ponto de vista europeu, sobre as diferenças entre negros e brancos. Segundo Boime, o argumento da igualdade espiritual é um dos pontos caros ao abolicionismo, nos Estados Unidos: "early objections to black subordination derived not from ideas about earthly qualities, but from the concept of equality before God. Central to religious egalitarianism was the idea that blacks were ultimately the equals of whites because they possessed immortal souls, and although skin color showed otherwise, 'black' souls were 'white",571.

Ao longo do Oitocentos, diz Boime, isto se traduziu em imagens que condicionavam a incorporação dos não-brancos à ordem livre à comprovação - pelos brancos - de sua capacidade de adquirir "iluminação espiritual". Na visão do autor, este é o problema abordado por diversas pinturas, ilustrações e esculturas que mostram personagens não-brancas em momentos de aprendizagem - ensaios musicais ou artísticos, leitura, estudos -, mas também sua participação em rituais cristãos ou pagãos. As imagens deste tipo convergem para uma mesma questão, pois especulam sobre a existência intelectual dos afrodescendentes, ora vistos como corporalidades puras.

Como se pode notar, o mesmo tipo de questionamento parece presidir a fatura de $A$ redenção de Cam: visto que uma das figuras, a avó, é mostrada num momento

\footnotetext{
${ }_{570}^{570}$ Idem, ibidem, pp. 17-18.

571 BOIME, A. The art of exclusion. Representing blacks in the Nineteenth Century. Washington\&London: Smithsonian Institution Press, 1990.p. 121.
} 
de oração, é lícito pensar que isto atestaria sua capacidade de iluminação espiritual. Mas a correlação não termina aí, pois trata-se de uma imagem que cultua a morte - e nesse sentido, a tela quiçá procure ultrapassar os limites da tautologia, explorando a ideia de crença como aspecto fundamental à sua compreensão ${ }^{572}$. Coelho Netto capturou esta dimensão do quadro e a exaltou em sua crônica à Gazeta de Notícias, em que afirmava tratar-se de uma "fantasia simbolista":

És a sombra e espias, como uma noite que escôa o primeiro stratus doirado que lhe saiu flanco. És a maldição e olhas o teu peccado lentamente redimido; és a repudiada e vês que tua alma, através do primeiro amor, vai se approximando da Luz; és a podridão e floresces; és a melancolia e dás o sorriso.

Graças, mãi negra, olhos no céo, mãos postas, rende graças a Deus e ao que te fecundou o ventre para o primeiro fructo. Rende graças, figura martyr, pela redempção da tua alma, alma que é dote do teu maior: Chan.

(...) pode sossobrar agora: teu coração amou, todos os teus sentimentos foram acatados, beijaste, abençoaste, sorriste, redimida.

A morte é o Esquecimento que amnistia; na vida ficas perpetuada e immaculada no teu neto. O teu perdão é esse que balbucia, o filho de tua filha. Descança, alma soffredora. Pódes sossobrar agora.

Ha n'esse quadro um doce e enternecido poema em quatro cantos: a oração de graças da Redimida, a glória de um velho tronco appodrecido, que ainda vê rebentar n'um galho subsistente a flôr anunciadora da vida; a enternecida contemplação materna, a vaidade do homem, olhando-se no espelho humano, o filho, e a innocencia feliz da criança.

Acham-se alli, em representação symbollica, as estações da Vida, a Primavera infante, o Estio que fecunda, o Outono productivo e o merencorio inverno.

A Redempção de Cham é o Natal do Salvador da raça dos opprimidos - é a morte d'Alma negra e o desabrochamento do lyrio do Perdão, o claro infante louro, louro como os que vêm do Caucaso bemdito onde Jafet descançou abençoado e feliz ${ }^{573}$ (grifos nossos).

Analogamente, Boime percebe que, na pintura oitocentista, "most high art examples of black spiritual participation focused on funeral rites" ${ }^{\$ 74}$, acenando para uma combinação particular entre a ideia de morte e a questão da incorporação espiritual/intelectual dos descendentes de escravos à ordem livre. Essas imagens, que exprimem um ponto de vista branco, colocam os negros à prova, ao evidenciar o

\footnotetext{
572 DIDI-HUBERMAN, G. O que vemos, o que nos olha. São Paulo: Editora 34, 2010.

${ }^{573}$ NETTO, C. A redempção de Cham - Fantasia Symbolista (a proposito do quadro de Modesto Brocos). Gazeta de Notícias, Rio de Janeiro, 19 de setembro de 1895, pp. 1-2. Note-se que Coelho Netto é autor de "Rei Negro", peça que conta a história de um escravo que vendia escravos em nome do dono, supostamente escrita com base em um amplo levantamento sobre os africanos no Brasil e baseada em história verídica.

${ }^{574}$ BOIME, A. The art of exclusion. Representing blacks in the Nineteenth Century. Washington \& London: Smithsonian Institution Press, 1990, p. 122.
} 
momento de sua eventual passagem para uma existência descarnada e, portanto, aquele em que é possível revelar-lhes a presença da espiritualidade.

Em complementariedade a tais pontos, poderíamos acrescentar que essas são cenas em que a alma não apenas é vista como via de acesso à vida pós-morte, mas também como habilitadora de uma entrada no mundo dos brancos, apontando para a coincidência criada pela imagística ocidental entre brancura e vida espiritual. Reatualiza-se, assim, a relação entre as imagens brancas do sagrado indicadas por Dyer $^{575}$ - Virgem Maria e Jesus Cristo, além dos demais santos -, sendo que a semelhança entre ditos ícones e a divindade imaginária é crucial para o processo de reafirmação de uma superioridade branca, que a partir do marco das emancipações passa a dominar a esfera pública. Não por acaso, as madonnas negras seriam, nesse momento, atreladas a uma função particular, ligada à fertilidade e, no caso brasileiro, à escravidão: elas jamais poderão ocupar, segundo tal etnogênese, o lugar privilegiado da virgem branca.

Não obstante, o que é digno de nota em $A$ redenção de Cam é que a tela indexa uma transformação corporal - branqueamento - à descoberta da espiritualidade e, com isso, inverte de certa forma o argumento: se por um lado o quadro pode ser entendido como a encenação de um milagre realizado, também sugere que o reconhecimento da espiritualidade ou dimensão intelectual dos nãobrancos passa a depender de uma atestada capacidade corporal - feminina - de geração de descendentes de pele mais clara. Não bastaria, portanto, seguir os preceitos da fé ou dedicar-se à leitura e aos estudos, como sugerem os abolicionistas norteamericanos: o elemento que faz a diferença está inscrito no corpo ou, poderíamos pensar, é biologicamente programado. A fabricação imagética do corpo negro, portanto, introduz determinados sinais - em termos de forma, postura e gestual, simetria dos traços, decoro na maneira de se vestir, similitude com as imagens sagradas, como vimos - que permitem identificar seu potencial branqueador, tal como faria uma ciência racial assentada sobre os princípios da antropometria.

É desse modo que $A$ redenção de Cam deposita, sobre a mulher negra outrora associada à sexualidade ilícita e patológica, o peso da maternidade orientada ao embranquecimento, dependente dos auspícios da moral cristã, mas também de uma constituição biológica supostamente decisiva - fé e ciência, crença e tautologia,

\footnotetext{
${ }^{575}$ DYER, R. White. London and New York: Routledge, 1997.
} 
idealismo e realismo atravessam a cena. Por todos os ângulos, uma tal função social é vista pelas lentes do sacrifício heróico: para ser aceita nesse universo nacional, ela deve abrir mão de sua cor ou raça, deixando a vida terrena para os brancos.

Um elemento é particularmente sugestivo: o indicador da mão direita da mãe que, estranhamente, aponta para a avó, ao mesmo tempo em que não aponta exatamente para ela. Do ponto de vista da crença, o gesto é análogo ao dos anjos que, na imagística cristã indicam algo que não se encontra na imagem - presença na ausência, ou uma dimensão invisível (e mesmo incrível ou fantástica), fora da moldura, que somente se torna plausível sob o prisma da fé. Do ponto de vista da tautologia, é o corpo, carnalidade, configuração racial da velha senhora, e nada mais, o que o indicador quer mostrar. Igualmente, o gesto da mão direita do bebê se assemelha à benção do menino Jesus em algumas imagens cristãs, mas também pode ser apenas um movimento aleatório em reconhecimento à avó. Em contraposição, a laranja que ele carrega na mão esquerda pode ser interpretada à luz de estudos sobre a pintura Renascentista, que encontram na fruta referências ao paraíso, mas também à fertilidade ${ }^{576}$ - engendrando novamente um sentido celestial e outro, mundano.

Por fim, vale atentar para a nota evolucionista do quadro, que imprime sobre as personagens diferenças de coloração, posicionamento na cena e desenho como se quisesse aludir a uma inevitável teleologia racialista nesse caminho que anuncia a desaparição progressiva da raça negra.

Comecemos pela avó. Como mencionamos, o tipo de postura adotada para desenhá-la guarda correspondências com as ilustrações, de autoria de Hébert, da Vierge orant e da Sainte debout et deux figures à sés pieds, que por sua vez também constituem interessantes registros de um tipo de arte de inspiração pré-Renascentista, pois foram feitos a partir de estudos dos mosaicos bizantinos do século XI da Basilica de San Marco, em Roma ${ }^{577}$. Desse modo, adotá-las poderia contribuir para um certo ar de primitivismo na composição da personagem.

\footnotetext{
${ }^{576}$ Analisando Primavera (1478), de Sandro Boticelli, Gibson considera que "oranges can be equated to the golden apples of Classical mithology, notably those that grew in the garden of Hesperides, and consequently often denote paradise". GIBSON, C. The hidden life of Renaissance art. Scotland: Saraband, 2007, p. 125. Harbison considera as laranjas que repousam em uma cesta no retrato do casal Arnolfini (1435), pintado por Van Eyck, com símbolos de fertilidade, "connected in numerous ways to marital and fertility rituals". HARBISON, C. "Sexuality and Social Standing in Jan van Eyck's Arnolfini Portrait.” Renaissance Quarterly, 43.2 (summer 1990), pp. 249-291.

577 O pintor francês dedicou-se aos estudos da arte bizantina do século XI em igrejas italianas. Uma consulta à base Joconde, catálogo digital das coleções dos museus franceses, permite visualizar outras
} 
Este aspecto é redobrado pelo uso da cor: vimos como Delacroix procurou explorar contrastes complementares na caracterização de suas imagens africanas, constituindo as zonas de transição entre os corpos e elementos cênicos pela mescla de tons primários e secundários e evitando a mediação de chiaroscuro: em decorrência, não raro as figuras humanas se tornavam manchas de cor, justapostas ao fundo e a outros corpos e objetos em cena, nesses quadros. Se por um lado esse modelo tornouse paradigmático, por outro mesmo em telas que apostavam em sistemas de notação de cor distintos a presença de contrastes complementares de vermelho e verde; azul e amarelo; laranja e violeta marcou a pintura orientalista francesa, sobretudo a partir dos anos 1840.

Antes de 1895, como discutimos, Brocos já havia explorado modos diferentes de pintar mulheres negras, pelo menos com Engenho de mandioca e Crioula de Diamantina. A velha senhora de $A$ redenção de Cam ingressa no conjunto como um novo experimento compositivo, assim como Feiticeira, do mesmo ano. A encantadora de serpente desta última tela é, dentre todas, a que mais se aproxima do cânone orientalista e, até mesmo por seu métier, indexa à imagem a ideia de primitivismo. Contudo, não se pode perder de vista que a avó do penúltimo quadro incorpora todos os contrastes complementares em torno de si: o detalhe vermelho do lenço, contra o verde da palmeira e do casaco (que é do mesmo tom de musgo do manto que recobre a Vierge orant); e na blusa azul contra a parede amarela. Além disso, seu rosto é de fato uma mancha de cor sólida, colocada contra o fundo sem mediação, em que a simplificação das feições e a justaposição do tecido branco do lenço sobre a pele escura são marcantes. Além disso, o recurso ao lenço branco reelabora o contraste primordial no ocidente entre branco e negro, aludindo às antigas associações resumidas por Montabert, e envolve o mesmo tipo de jogo presente no manejo de cores alusivas à moral de Olympia, de Manet - ainda que com intenções distintas: agora se trata de coroar a cabeça da ex-escrava com um elemento branco, quiçá reforçando o simbolismo da tela.

A mãe em cena é desenhada de modo a valorizar a simetria dos traços e apresenta-se harmônica. Curvilínea, ela foge ao excesso de retidão medievalista

aquarelas e desenhos de Hébert que envolveram o estudo da iconografia gótica e bizantina. Um exemplo são as aquarelas que reproduzem cenas da abside, da Catedral de Trieste. Disponível em: $<$ http://www.culture.gouv.fr/public/mistral/joconde_fr?ACTION=NOUVEAU\&USRNAME=nobody\& USRPWD=4\%24\%2534P $>$. Última consulta: $27 / 07 / 2013$. 
presente na corporalidade da avó, exceto talvez pelo braço e mão direita que aponta para a esquerda de quem olha o quadro, de uma métrica precisa. Merece atenção, além disso, o fato desta mulher sentar-se no centro da imagem, precisamente no ponto em que o chão de pedra - alusiva ao trabalho humano de pavimentação, à modernidade - e o de terra se encontram. Seu único pé visível pisa em terreno rochoso e está calçado, enquanto a avó do quadro está sobre o chão de terra. Em termos de cor, a mãe mobiliza contrastes complementares de azul, violeta e rosa (as roupas) com amarelo e laranja (a parede e o fruto na mão do bebê) que, conforme mencionado, também foram transformados pela pintura orientalista em indicadores de primitivismo. Logo, a jovem se encontra a meio caminho entre a avó e seu marido.

O pai da criança, de pele clara, é o único que não se vê envolvido por contrastes complementares. Veste calça azul, mas porque se encontra em frente à área interna da casa, apoiado no batente da porta, é resguardado da contraposição com a parede amarelada. Bem desenhado, com traços bastante nítidos, ele pisa o chão de pedra com os dois pés.

Por fim, o bebê é o ponto mais alvo da cena. Não obstante sua cor, este personagem, que conforme comentamos faz um aceno alusivo à benção do menino Jesus em certas imagens da iconografia cristã, introduz uma série de paradoxos na composição: é branco, mas envolto por contrastes complementares de azul (detalhes da roupa) e laranja (fruta), além daqueles que marcam a caracterização de sua mãe; fica no meio do caminho, entre o lado esquerdo da tela e a direita e está voltado para a avó, de costas para o pai. A posição da criança, à esquerda deste personagem, parece contradizer o movimento que vai do negro ao branco, colocando-o um degrau para trás do homem adulto numa possível teleologia racialista.

Por um lado, o menino é espelho do pai: branco e do sexo masculino, ele reafirma, nos quesitos cor e gênero, um afastamento da linhagem materna, que reforça o sentido da filiação predominante. Por outro, está no colo da mãe e compartilha com ela um lugar intermediário no quadro e uma inserção em meio a indicadores de cor primitiva. Com isto, a pintura adquire uma carga irônica, que reforça as oscilações da pintura entre crença e tautologia, introduzindo a dúvida no seio do pensamento tautológico. Afinal, a tela demanda do espectador que decida a cor/raça da criança: será ela branca? 
$\mathrm{Na}$ medida em que joga o peso de qualquer decisão final sobre quem a observa, A redenção de Cam mobiliza expectativas de embranquecimento correntes, tangencia os temores do período quanto ao atavismo e atinge o problema da classificação cromática/racial no Brasil em seu âmago, na medida em que obriga a rever a definição de quem é - ou quem pode ser - branco, para além da etiqueta da “cor" aplicada à pele.

No quadro, a senhora negra e o menino são os extremos: pontas reversas de uma mesma ordem genealógica, opõem-se entre si em termos de cor da pele, idade e sexo. Contudo, se a avó constitui uma certeza aos olhos dos críticos, a imagem da criança se constituiu como interrogação. Ávidas por atestar a veracidade da imagem, as análises que esses comentaristas publicavam nos jornais e outros documentos do período se desencontram no que concerne à cor do bebê. Arthur de Azevedo, na coluna Palestra, que manteve em O Paiz, dirá tratar-se de um "menino louro":

O bello quadro de Modesto Brocos - A redempção de Cham, que figura na exposição da Escola Nacional de Bellas Artes, poderia intitular-se, para melhor comprehensão do vulgo, $O$ aperfeiçoamento da raça.

Representa uma familia composta de quatro pessoas: uma preta velha, uma mulata moça, um rapaz branco e um menino louro. A mulata é filha da velha, esposa do rapaz e mãi da criança.

Estão sentados á porta de uma casinha o marido e a mulher, esta com o menino no colo, emquanto a velha, com as máos e os olhos levantados para o céo, parece agradecer ao Altissimo a felicidade da filha.

O rapaz, forte e vigoroso - typo accentuado de colono trabalhador - a mulata em cuja physionomia transparecem a intelligencia e a meiguice de sua raça, - e a criança, lindo producto daquelle cruzamento de sangue, brincando despreocupada com uma laranja, - estão muito bem pintados; mas a grande figura da tela, a figura que mais impressiona, a figura inolvidável, é a da velha africana macerada pelo captiveiro.

$\mathrm{O}$ artista, que já n'outros quadros mostrara uma especialidade do seu talento com a pintura das negras, nunca nos pareceu mais humano e commovedor" ${ }^{\prime \prime 78}$ (grifos nossos).

Sem comprometer-se com uma atribuição de cor para a criança, Fantasio (Olavo Bilac) o descreve como uma aurora radiante. É também digno de nota que ele atribua a responsabilidade pela transformação racial ao pai, que vê como atestadamente branco ("como o dia") e descreve como um "semita puro":

\footnotetext{
578 "PALESTRA". O Paiz, 02/09/1895, p. 1., ass. A.A. Segundo Bueno e Jimenez, o jurista Rodrigo Octavio teria afirmado, que seu filho posara para a tela de Brocos: "meu filho, com alguns meses de idade, linda criança, transpirando no ouro dos cabelos e no rosado das faces a exuberancia do seu sangue escandinavo, serviu de modelo" (OCTAVIO apud BUENO, F.; JIMÉNEZ, J. A Redención de Cam de Modesto Brocos. Estudios Migratórios, n. 9, 2000, p.113-127). No entanto, não encontramos tal afirmação nas memórias do jurista, tal como indicado pelos autores.
} 
Na sua grande tela belissima, já a filha da velha preta está meio lavada da maldição secular: já não tem na pelle a lugubre côr da noite, mas a côr indecisa de um crespusculo. E vêde agora aquelle latagão que alli está, ao lado d'ella, branco como o dia: é um Semita puro, que se encarregou de completar a obra da redempção, transformando o crepusculo n'uma aurora radiante. Vêde a aurora-creança como sorri e fulgura, no collo da mulata, - aurora filha do dilúculo, neta da noite... Cham está redimido! Está gorada a praga de Noé! ${ }^{579}$ (grifos nossos).

Coelho Netto inverte a fórmula, exaltando o sacrifício da mulher negra como responsável pelo processo branqueador. Sem menção explícita à cor do menino, ele fica no plano hipotético, tratando a aspiração contida na tela antes como um desejo, do que como um fato: "Para sagrar-te só a benção multiplicada até que o gesto vindo da grenha encaracolada do teu filho descanse sobre os cabellos louros do teu neto" ${ }^{, 580}$ (grifos nossos).

Em contraposição, um crítico anônimo de O Jornal do Commercio considera o bebê "quase branco":

Entre os quadros de genero, merecem menção: do Sr. Broccos, o quadro n. 101, 'A Redempção de Cham', de grandes proporções em que ha quatro figuras, uma preta velha, uma mulata sua filha, e seu netinho já quasi branco e o pai d'este, de pura raça caucassica e no qual o artista procurou mostrar as gradações do cruzamento da raça branca com a raça de côr, bem pintado e bem desenhado, sobresahindo a figura da preta, feita com grande verdade ${ }^{581}$ (grifos nossos).

A mesma suspeita em torno da cor do menino embasa outro texto de 1895 . Não obstante, o comentário publicado no mesmo Jornal do Commercio adota um tom mais crítico e, desqualificando o argumento do quadro, evita qualquer atribuição de cor à criança:

Quanto à fatura, as figuras são regularmente desenhadas, principalmente a da preta, tronco da família retratada na tela. $\mathrm{Na}$ escolha do tipo do primeiro cruzamento das raças, o artista não foi feliz, pois que essa mulata não é dos mais belos espécimes que aqui se encontram. No desenho da criança notam-se certas durezas em alguns pontos, como sejam nas pernas e no braço direito ${ }^{582}$ (grifos nossos).

\footnotetext{
579 “A REDEMPÇÃO DE CHAM”. Gazeta de Noticias, 5/9/1895. Fantasio na Exposição II, p. 1.

${ }^{580}$ NETTO, C. "A redempção de Cham - Fantasia Symbolista (a proposito do quadro de Modesto Brocos)". Gazeta de Noticias, 19/9/1895., pp. 1-2, ass. C. N. [Coelho Netto].

${ }_{581}^{581}$ NOTAS SOBRE ARTE. Jornal do Commercio, Rio de Janeiro, 1 set. 1895, p. 2.

582 NOTAS SOBRE ARTE. Jornal do Commercio, Rio de Janeiro, 7 set. 1895, p. 2. Ainda merece citação comentário publicado no jornal The Rio News, voltado a um público estrangeiro, que diz:
} 
Sobressaem no trecho alguns pontos: há o desejo de questionar a legitimidade do quadro de duas formas: afirma-se sua inintelegibilidade; e desqualifica-se o próprio princípio do embranquecimento. Em adição, há também um nítido desconforto com o tratamento direto do tema pelo quadro; por fim, critica-se a caracterização dos "tipos" à luz das leis da "seleção natural" - o que parece contradizer a crítica anterior à validade do embranquecimento. Esse argumento sugere que, tivesse Brocos seguido à risca a cartilha do darwinismo social, poderia ter chegado a uma fórmula plausível para a finalidade proposta. Não há informação sobre a autoria do comentário, mas é digna de nota a convicção no uso do jargão científico na análise, que sugere a possibilidade de tratar-se de um escrito de um homem de sciencia, que também desejaria resguardar seu campo de especialidade. Note-se, além disso, que a única figura que recebe alguma aprovação do crítico é a avó, visto que nem a "mulata" - definida como um "espécime" pelo autor -, nem o menino o convencem, apesar do desenho regular.

Por fim, no ano de 1896, a tela voltava a aparecer na crítica de Cosme de Moraes para a seção Folhetim, do jornal A Liberdade, que lembra: "Brocos, que é pintor scientifico, e já em tela memoravel e anthropologica nos explicou como do branco e do preto sae o amarello" ${ }^{, 53}$ (grifos nossos), enquanto critica retratos pintados pelo artista que, em sua opinião, tornava todos os modelos parecidos.

As apreciações recebidas por $A$ redenção de Cam a seu tempo confirmam que, de fato, o quadro não autorizava o consenso quanto à cor/raça do menino. Ao mesmo tempo, indicam que não há maiores objeções à maneira de caracterizar imagem da senhora negra, que é alvo de elogios. Ponderamos que, do ponto de vista formal, o fato da criança situar-se na zona de intersecção entre as figuras do pai e da avó (junto da mãe no que diz respeito à posição numa espécie de linha evolutiva do negro ao branco, ao gosto das teses racialistas) e o fato de polarizar em sua caracterização e entorno direto contrastes de cor complementares, associados ao primitivismo pela tradição orientalista europeia tornam a figura do bebê contraditória, colocando propositadamente em dúvida sua evidente brancura.

\footnotetext{
"Neither does it $\left[\begin{array}{l}A \text { redenção de } \\ \mathrm{Cam}\end{array}\right]$ convey the idea of the delivrance of any particular race, but simply represents an episode common wherever slavery has existed". THE RIO NEWS, Rio de Janeiro, 17 de setembro de 1895 , s.p.

${ }^{583}$ COSME DE MORAES. Folhetim: o salão de 1896 II. Liberdade, 20 set. 1896, p. 1.
} 
Isto não significa que o mecanismo empregado por Brocos, ao introduzir a criança no centro, pudesse ter influenciado diretamente a apreciação dos críticos, mas antes indica uma possível intenção do artista de confundir seu público, ou melhor, de jogar com as expectativas desses apreciadores de arte que, mesmo que não se ativessem à análise da forma em seus escritos, reagiam de modo a confirmar a dificuldade de classificação racial do menino. Nesse sentido, o quadro se torna uma espécie de indagação sobre a cor/raça no Brasil.

Comentamos no capítulo 2 a posição eugênica de Brocos, à luz da ficção científica Viaje a Marte. Tal livro mostra o quão afeito era o pintor à ideia de embranquecimento, que ele via como uma forma de "aperfeiçoamento da raça". Também pontuamos que ele levou a cabo em suas pinturas uma série de experimentos artísticos com o intuito de resolver o problema da "cor", recebendo elogios dos críticos quando se tratava de pintar figuras evidentemente negras, mas também reprovação quando pintava tipos populares aparentemente brancos. Comentamos que, de modo similar ao que acontece com o bebê de $A$ redenção de Cam, a personagem do quadro $A$ descascar goiabas pôde ser vista por um crítico como mulata, a despeito de sua brancura a nossos olhos.

Buscamos compreender em que medida $A$ redenção de Cam poderia ser encarada como obra de um realismo idealista, que introduzia as projeções de um futuro branco feitas pelo artista a uma notação da forma que, na aparência, conferia ares de cotidianidade e verossimilhança à cena. Isso foi conseguido por meio da ruptura com formas convencionais de representar mulheres não-brancas na pintura ocidental e através do recurso à iconografia cristã.

Contudo, ao final do percurso, encontramos não uma criança indubitavelmente branca, mas uma incógnita, tanto por sua dimensão formal, quanto em termos de recepção da tela. Tal presença parece contradizer as convicções expressas por Brocos em Viaje a Marte. No entanto, gostaríamos de pensar que as opções feitas pelo artista na confecção de sua obra tinham um propósito claro: ao questionar a própria indefinição de brancura que percebia existir no Brasil, também poderia estar tentando propor e/ou explorar a necessidade de uma definição mais precisa, como medida para a viabilização ações concretas rumo ao embranquecimento. O cerne da questão, para que se pudesse comprovar os resultados do processo, seria saber quem era branco - e 
isto dependia de um consenso que, afinal, jamais parece ter havido diante das telas do pintor.

Ao mesmo tempo, tal experimentação pictórica tornava-se uma indagação sobre a natureza dos sistemas de notação disponíveis e sua eterna limitação: a pintura não poderia jamais ser apreciada ao largo do sistema que se dizia científico - o único tido como capaz de auferir realismo -, ao passo que a própria ciência racial tornava-se instável diante da evidência propiciada pelo código pictórico, demonstração de que a cor não era critério suficiente para definir a brancura. Esta era transformada, assim, na qualidade estética mais desejada no marco dos projetos racistas do período, mas também a mais inefável: longe de dado científico, ela era contextual.

Do ponto de vista da pintura, existiam formas consagradas para enquadrar as personagens negras - como o sistema de notação de cor "primitiva" e o modelo que buscava esquemas desdobrados de Sara Baartman, mas também a busca por inspiração iconográfica cristã, uma determinada maneira de sentar-se no chão e os pés descalços. A cor escura da pele vinha como um sinal inegável, que marcava determinados papéis e indicava a existência de um problema social, ou moral na cena. Por outro lado, tendo em vista que as personagens brancas podiam fazer-se ver sob uma enorme variedade de recursos, pesava o fato de que, fossem retratadas por meio dos mesmos mecanismos que as negras, a cor de sua pele e/ou sua moral tornava-se passível de ser posta à prova.

De todo modo, é importante notar que o branco continua sendo alçado à posição de futuro ideal, tanto pelo quadro, quanto por seus críticos - o que impede de vê-lo como uma obra capaz de confrontar o racismo. Em 1912, Brocos levou à Exposição Geral de Belas Artes a tela As hamadríades e a civilização ${ }^{584}$. Na crítica de Gonçalo Alves para o periódico A Noite, ressurgia o problema da cor, que acompanhara o artista durante boa parte de sua carreira. O texto, que mostra o acirramento das tensões raciais e a forte penetração do pensamento eugênico nas primeiras décadas do século XX, sugere que o pintor continuava testando os limites do conceito de brancura. Mas agora, seus esforços já não recebiam os mesmos elogios de outrora:

\footnotetext{
${ }^{584}$ A pintura não foi localizada por esta pesquisa.
} 
Houve uma época em que o Sr. Modesto Brocos se devotou incondicionalmente aos quadros de costumes populares, e deu para pintar casas de taipas e desvãos de senzalas.

(...)

O certo é que o Sr. Modesto Brocos fabricou um sem número de caboclos mais ou menos desengonçados, e só deixou de fabricá-los quando o público compreendendo afinal o patriótico embuste fechou os olhos ao esforçado pintor.

O Sr. Modesto Brocos precisava de novos motivos picturais, e apelou resolutamente para a mitologia grega.

(...)

Mas como "o uso do cachimbo fez a boca torta" as hamadríades eram legítimos caboclos, e a "civilização" nada mais do que uma formidável e complicada maxambomba transportada para o seio da floresta virgem por algum guindaste que o autor teve o paciente cuidado de ocultar, para maior tortura do observador ${ }^{585}$.

${ }^{585}$ ALVES, Gonçalo. Notas do "Salon" - Modesto Brocos e Aurelio Figueiredo. A Noite, Rio de Janeiro, 18 set. 1912, p. 1. 


\title{
Contornos do (in)visível: considerações finais
}

\author{
Subordinates in relations of power learn experientially that there is a \\ critical gaze, one that "looks" to document, one that is oppositional. In \\ resistance struggle the power of the dominated to assert agency by \\ claiming and cultivating "awareness" politicizes looking relations - one \\ learns to look a certain way in order to resist \\ - bell hooks, The oppositional gaze, 1992, p. 116
}

Nos três capítulos que constituem esta dissertação, procuramos articular elementos para uma compreensão mais detida da tela $A$ redenção de Cam, tomando como ponto de partida a proposição segundo a qual esta é uma pintura preconceituosa $^{586}$.

No primeiro capítulo, buscamos recuperar a longevidade de um imaginário pautado pela vinculação entre a pele negra e a maldição impingida por Noé sobre o filho Cam e descendentes, mas também a emergência e consolidação da crença de que o embranquecimento poderia ser viabilizado por meio de uniões interraciais. Isto habilitou uma compreensão da problemática evocada no título da pintura, bem como sua inserção numa topografia espaço-temporal particular, constitutiva de uma tradição luso-brasileira de pensamento sobre as diferenças ditas raciais, em longa duração.

O trajeto possibilitou observar, ainda, a emergência de um conjunto de imagines agentes e, com isso, trouxe à tona um universo de caminhos possíveis, que culminaram na fixação de visões sobre a noção de embranquecimento. Entre possibilidades ainda não consolidadas e uma série de indefinições, tornou-se mais evidente a especificidade da tela de Brocos: ela conferiria forma definida àquilo que até então dizia respeito ao domínio di inefável. Ao fazê-lo, a obra conquistou não só uma medalha de ouro, mas também chamou a atenção de João Batista de Lacerda - o artífice de uma das teorias mais célebres sobre o embranquecimento no Brasil -, tornando-se ilustração do artigo Sur les Métis au Brésil ${ }^{587}$. O percurso mostrou o quanto o embranquecimento se constituiu ao longo do tempo como um jogo de

\footnotetext{
${ }^{586}$ LEITE, T. J. R. Dicionário Crítico da Pintura no Brasil. RJ: Artlivre, 1988; NAVES, R. Almeida Jr. O sol no meio do caminho. Novos Estudos-CEBRAP, 73, nov. 2005; LOURENÇO, M. C. F. Debates e posturas - Tempo humano. In: Almeida Júnior: um criador de imaginários. Catálogo da exposição na Pinacoteca do Estado. São Paulo, 25 jan.-15 abr. de 2007.

${ }^{587}$ Sob esse ponto, é interessante notar que a história se incumbiu de fortalecer a união entre quadro e teoria, de modo que hoje as duas peças costumam ser vistas quase que como extensão uma da outra. Entretanto, como observamos no capítulo 3, a tela insere o bebê em meio a uma série de incertezas e, assim, afasta-se da tese que o cientista defenderia anos adiante.
} 
expectativas invariavelmente marcadas por distintos graus de incerteza. Daí a dificuldade do artista: qualquer imagem que se propusesse realista deveria mostrar-se capaz de revelar as contrariedades e indefinições que permeavam as próprias teorias do embranquecimento: longe de fatos, estas constituíam modelos largamente especulativos.

À luz dessas perspectivas, no capítulo 2 empreendemos uma discussão acerca do estilo do quadro, concluindo que ele adere a um tipo de realismo idealista, ou seja, um sistema de notação assentado na impressão de estar-se diante de um trabalho documental, mas colocado a serviço de uma especulação sobre um futuro indeterminado, qual seja, branco. Argumentamos que a qualidade intencional ${ }^{588}$ de $A$ redenção de Cam emerge de uma contradição aparente: por um lado, a pintura se propôs a defender uma tese sobre o embranquecimento como via de incorporação de populações de ascendência negra à sociedade brasileira, num período pouco posterior à assinatura da Lei Áurea; por outro, ela foi incapaz de superar as dúvidas que cercavam as próprias teorias do embranquecimento. Há, desse modo, uma coincidência entre forma pictórica e tradição de pensamento, pois ambas oscilam entre idealismo e realismo, crença e tautologia, para empregar os termos de DidiHuberman $^{589}$. É através do estilo, um realismo idealista em que as referências bíblicas se combinam a formas da vida prosaica, que $A$ redenção de Cam pode exprimir uma gama de variações possíveis em torno da ideia de branqueamento - de um nível anedótico, em que este pode constituir um fenômeno isolado e aleatório, a um nível extremo, envolvendo as políticas de extermínio "racial", às quais o próprio Brocos demonstra ter aderido em seu Viaje a Marte ${ }^{590}$. Seja como for, o preconceito da tela é marcado pela exaltação em torno do nascimento de uma criança de pele clara, do sexo masculino - como seu pai: tais atribuições racial e de gênero continuam alçadas ao horizonte desejável, por mais que a tela suscite dúvidas.

Procuramos elucidar melhor esse ponto no terceiro capítulo, em que discutimos mais propriamente a caracterização das personagens de ascendência negra

\footnotetext{
588 BAXANDALL, M. Padrões de intenção: a explicação histórica dos quadros. São Paulo: Companhia das Letras, 2006.

${ }^{589}$ DIDI-HUBERMAN, G. O que vemos, o que nos olha. São Paulo: Editora 34, 2010.

${ }^{590}$ Que como vimos, foi publicado em 1930 na Espanha, mas escrito ao longo de décadas de trabalho. Segundo Brocos, o livro reflete os projetos e reflexões que ele acalentou e desenvolveu ao longo da vida, enquanto preparava gravuras e pinturas em seu ateliê. BROCOS, M. Viaje a Marte. Valencia: Arte y Letras, 1930.
} 
em $A$ redenção de Cam, em comparação com outras imagens produzidas no período incluindo-se quadros de Brocos. Buscamos sobretudo mostrar como determinadas maneiras de articular gênero e raça/cor no plano pictórico revelam direcionamentos que a pintura deseja impor ao olhar: nas telas e textos analisados no capítulo, as imagens de mulheres negras e das chamadas "mulatas" acusam perspectivas brancas, masculinas e heterossexuais, expressas tanto nos esquemas empregados para caracterizar o corpo feminino, quanto naqueles de uso da cor. Sobre este último ponto, notamos que no registro pictográfico, a cor também faz as vezes de código cifrado para $r a c ̧ a^{591}$. Ao mesmo tempo, a articulação entre marcadores de gênero e cor em $A$ redenção de Cam revela-se particularmente interessante, pois explicita um artifício capaz de adensar, no plano das opções formais, o jogo de expectativas instaurado pela tela - e a figura do bebê em cena cristaliza esta precipitação. Por um lado, trata-se de um menino de pele clara que, assim, anuncia-se pela similitude com o pai; por outro, sua brancura é incerta, ou envolta em aplicações de contrastes complementares de azul e laranja, caros à noção de primitivismo e pela posição ele que ocupa, ao centro do quadro e voltado de frente para a avó e de costas para o pai. Logo, a figura mobiliza todas as tensões de um impasse para o pensamento racialista e, ao fazê-lo, impele o espectador a tirar suas próprias conclusões, como fica patente nas críticas que recebeu.

A navegação em três níveis interconectados de apreciação do quadro, inspirada pela metáfora sobre os palácios da memória ${ }^{592}$, abriu, em nosso entender, perspectivas para alargar o debate sobre o preconceito e sua expressão estética, do ponto de vista pictográfico, a partir de diversas imagens às quais, cada qual a seu modo, articulavam esquemas e tópicas pictóricas em função de produzir determinadas formas de ver as diferenças ditas raciais. Permitiu também vislumbrar articulações entre a pintura e certas construções discursivas de forte apelo imagético. O princípio da rememoração, neste caso, aliou-se a um esforço para evidenciar o quanto o

\footnotetext{
${ }^{591}$ Dialogamos aqui com a constatação de Guimarães, para quem a ideia de "cor" faz sentido "no interior de ideologias raciais". Ainda segundo este autor, "com a substituição da ordem escravocrata por outra ordem hierárquica, a 'cor' passou a ser uma marca de origem, um código cifrado para 'raça". GUIMARÃES, A. S. A. Racismo e Anti-Racismo no Brasil. São Paulo: Editora 34, pp. 44-45. Vale lembrar que na pintura, como mostra Boime, é marcante a confusão entre categorias formais e predisposições ideológicas. The art of exclusion. Representing blacks in the Nineteenth Century. Washington \& London, Smithsonian Institution Press, 1990.

${ }_{592}$ Tal qual evocada por WISEMAN, B. 2007. Ideas in Context. Lévi-Strauss, Anthropology, and Aesthetics. Cambridge University Press.
} 
preconceito está inscrito nos sentidos, ou seja, nas formas assumidas pela percepção, nos modos de ver e de relacionar-se com imagines agentes. Daí a centralidade dos mecanismos adotados pela pintura para posicionar o olhar do espectador, de modo a enredá-lo numa determinada trama diegética capaz de mobilizar preconceitos.

À luz dos caminhos percorridos, estas considerações finais procuram abrir espaço para novas questões, na expectativa de sugerir discussões sobre como determinadas disposições pictóricas podem elucidar mecanismos constitutivos de uma estética, servindo de via de acesso a modos de ver historicamente situados e profundamente imbricados em processos de consolidação dos fenômenos que hoje entendemos como preconceito e racismo. Para isto, procederemos por meio de uma análise preliminar de outras telas produzidas no Brasil por artistas da mesma geração de Brocos e da geração seguinte, em que figuram personagens de ascendência negra. A ideia é, sobretudo, suscitar reflexões. Sendo assim, é importante reforçar que, evidentemente, não há qualquer pretensão de realizar uma análise em profundidade sobre essas pinturas - o que demandaria novos estudos, fugindo aos limites deste trabalho. Guardadas as ressalvas, esperamos que essa primeira interpretação de tais telas possa ajudar a iluminar futuras abordagens. Partimos de um marco comum: a ideia de que elas possam procurar responder a preocupações com a incorporação da população de ascendência negra à ordem livre e republicana brasileira, no pósemancipação, mas sempre reconhecendo a preeminência de cada obra na elaboração de hipóteses próprias em torno da mesma questão ${ }^{593}$.

Além disso, o exercício parte de uma pergunta-chave: será possível encontrar, nessas pinturas, elementos que apontem a articulação de disposições estéticas comuns àquelas presentes em $A$ redenção de Cam? Em que medida o preconceito deixa de estar presente nas pinturas selecionadas? O que caracterizaria, nesse momento, marcado pela mais ampla difusão do racialismo na esfera pública, uma imagem nãopreconceituosa?

Recuperamos, para levar adiante tais considerações, a ideia de uma estética expressa no posicionamento do olhar oferecido pela pintura, perguntando-se sobre as

\footnotetext{
${ }^{593}$ Mantemos nosso alinhamento com o modelo proposto por BOIME, A. The art of exclusion. Representing blacks in the Nineteenth Century. Washington \& London, Smithsonian Institution Press, 1990.
} 
possibilidades abertas pela imagem para fixar ou deslocar perspectivas ${ }^{594}$ sobre as personagens de ascendência negra - sobretudo as mulheres, que são mais presentes nas telas conhecidas do período.

A seguir, passamos à análise preliminar das telas: Negra (1891), de Almeida Júnior; A Quitandeira (s.d.) ${ }^{595}$, Nativa (s.d.) e Monjolo (c. 1895), de Antonio Ferrigno; Feiticeira (1890); Cabeça de homem (1891); Moça sentada (1886); e Jovem adormecida (1891), de Antônio Rafael Pinto Bandeira (1863-1896); e Cabeça de menino (1918); Ziza no atelier (1919); e Alguns colegas (1921), de Arthur Timotéo da Costa. Em contraponto, introduzimos na seleção a obra Caipira picando fumo (1893) e mais algumas telas de Almeida Júnior, de modo a dar seguimento às discussões propostas por Rodrigo Naves e Daniela Perutti ${ }^{596}$, apontadas na apresentação da presente dissertação.

\section{Negra como exceção, na obra de Almeida Júnior}

Sentada à soleira da porta, a mulher negra parece desfazer-se no ambiente ${ }^{597}$, mesclando-se à própria sombra. Tem o corpo encolhido e um olhar oblíquo de tristeza, com a cabeça ligeiramente inclinada para a direita. O rosto é pensativo e ganha ares de receio ou preocupação. Já a mão esquerda que envolve a boca assume a aparência de uma garra de dedos magros e compridos. O corpo é um volume disforme, inteiramente coberto pelo traje escuro que lhe esconde até os pés. A figura ocupa o limiar entre a casa e a rua, com a porta entreaberta - como é frequente nos quadros de Almeida Júnior ${ }^{598}$. A despeito da diluição dos contornos (o que também pode decorrer do suporte escolhido para a pintura - a madeira), nota-se as maçãs do rosto rotundas e salientes, os olhos pequenos e o nariz arredondado, configurando

\footnotetext{
${ }^{594}$ Conforme as reflexões elaboradas por HOOKS, b.The oppositional gaze. Black female spectators. In: __. Black Looks: Race and representation. Boston: South End Press, 1992, pp. 115-131; MULVEY, Laura. "Visual pleasure and narrative cinema". In:_ Visual and other pleasures. Indianápolis, Indiana University Press, 1989; LAURETIS, T. D. Technologies of gender. Essays on theory, film and fiction. Bloomington, Indiana University Press, 1987; MENEZES, P. R. A.. O nascimento do cinema documental e o processo não civilizador. In: MARTIS, J. S.; ECKERT, C.; NOVAES, S. C. (orgs.). O imaginário e o poético nas ciências sociais. EDUSC, Bauru, 2005.

${ }^{595}$ Também conhecida como Mulata quitandeira.

596 NAVES, R. Almeida Jr. O sol no meio do caminho. Novos Estudos-CEBRAP, 73, nov. 2005; PERUTTI, D. C. Considerações sobre a representação do negro na obra de Almeida Júnior. Paper para o GT Pensamento Social Brasileiro, no XIV Congresso Brasileiro de Sociologia. RJ, 2009.

${ }^{597}$ Como também observa PERUTTI, D. C. Considerações sobre a representação do negro na obra de Almeida Júnior. Paper para o GT Pensamento Social Brasileiro, no XIV Congresso Brasileiro de Sociologia. RJ, 2009.

${ }^{598}$ Cf. PERUTTI, D. C. Almeida Júnior, gestos feitos de tinta. São Paulo, Alameda, 2011.
} 
feições marcadas pelo exagero de alguns contornos. A cabeça é envolta por um lenço de coloração branco-dourada, próxima à cor das paredes da casa, mas este parece avesso a qualquer caimento natural, servindo como uma espécie de auréola que destaca o desenho da face, ao mesmo tempo em que produz a sensação de disjunção entre rosto e corpo da figura. A luminosidade da cena sugere o entardecer, enquanto a cor privilegia tons terrosos, somente contrastados pelo azul profundo dos trajes da personagem.

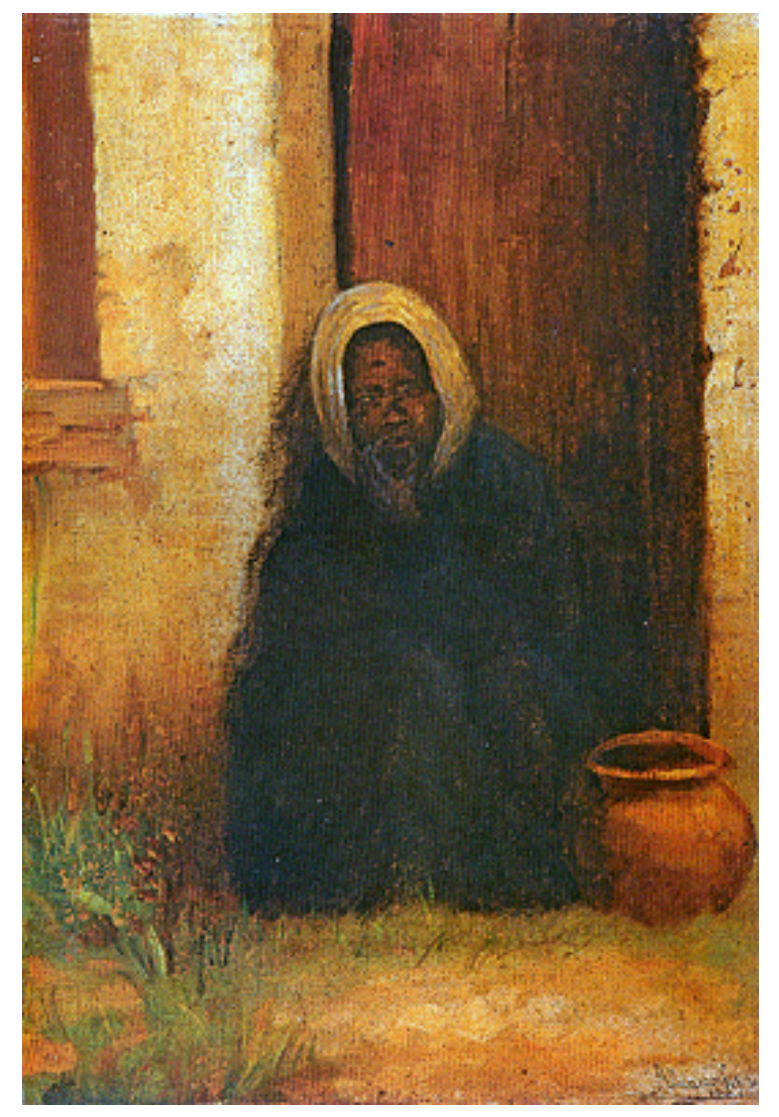

Fig. 130: José Ferraz de Almeida Júnior. Negra (1891). Óleo sobre madeira, $37 \mathrm{~cm} \mathrm{x}$ $25 \mathrm{~cm}$. Coleção particular

Pintada três anos após a proclamação da Lei Áurea, a tela Negra parece lidar com o problema da incorporação dos ex-escravos à ordem livre. Tem-se, neste óleo sobre madeira de tamanho pequeno $-37 \mathrm{~cm}$ x $25 \mathrm{~cm}$ - uma figura feminina que foge a certos padrões correntes de caracterização de personagens negras pela pintura europeia, como a silhueta marcada pela alusão a Sara Baartman ${ }^{599}$ e o uso de

\footnotetext{
${ }^{599}$ Como vimos no capítulo 3, esta sul-africana que se tornou conhecida como Vênus Hotentote na Europa inspirou um esquema pictórico bastante difundido para o desenho do corpo feminino (sobretudo da mulher negra) em que as nádegas voltadas para o espectador e os quadris largos tornavam-se alusivos à sexualidade tida como patológica ou exacerbada, no período. Baartman tinha steatopygia, ou hipertrofia das nádegas e coxas. Cf. GILMAN, S. Black Bodies, White Bodies: Toward
} 
contrastes complementares de inspiração orientalista. Antes, a figura em cena parece marcada pelo retraimento da postura, acuada, e a pose de gárgula, acentuada pela mão que lembra uma garra, bem como por uma diluição dos contornos em sombras em certa medida inusitadas. Ao mesmo tempo, o uso de um lenço que se confunde com uma espécie de halo sugere a ideia de redenção, aproximando a figura de uma imagem cristã, em sobreposição semelhante àquela operada por $A$ redenção de Cam, quando insinua correlações entre suas personagens e santas negras - o que confere ao quadro uma sugestão à transcendência. Em tom de algum modo pessimista, quase que acenando para a impossibilidade de incorporação dessa estranha figura à ordem livre, a pintura em si também não permite avançar para outras conclusões. Por outro lado, sua inserção em meio ao conjunto da obra do artista abre espaço para alguns questionamentos.

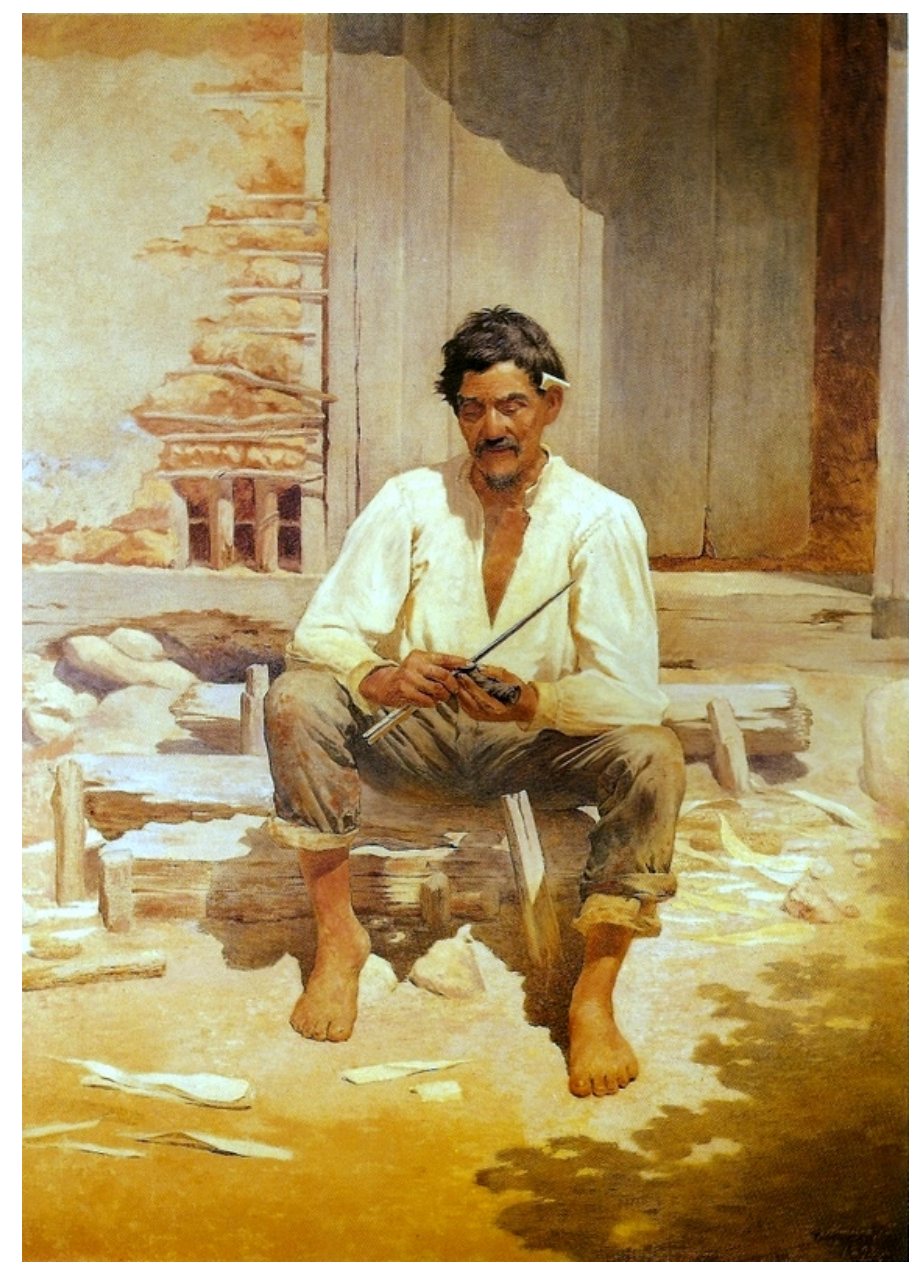

Fig. 131: José Ferraz de Almeida Júnior. Caipira picando fumo (1893).

Óleo sobre tela, $70 \mathrm{~cm} \times 50 \mathrm{~cm}$.

São Paulo: Pinacoteca do Estado

an Iconography of Female Sexuality in Late Nineteenth-Century Art, Medicine and Litterature. In: GATES Jr., Henry Louis. (ed.). "Race", Writing and Difference. Chicago and London, University of Chicago Press, 1985. 
$\mathrm{Na}$ apresentação de nosso trabalho, indicamos um problema enfrentado por Rodrigo Naves em sua análise sobre Caipira picando fumo ${ }^{600}$ : em que medida a obra de Almeida Júnior teria sido capaz de ultrapassar os determinismos de seu tempo? Para discuti-la, nos parece fundamental uma articulação com a análise de Daniela Perutti, para quem o artista ituano evitou pintar personagens negras (como exceções, ela destaca Negra e Partida da Monção), ao mesmo tempo em que se dedicou com afinco às imagens de caipiras paulistas de pele clara. Repetimos duas citações elucidativas: Almeida Júnior valorizou "um certo tipo de caipira, mais produto do cruzamento do branco com o indígena do que o caipira negro ou mulato" "601; e "não esteve vinculado explicitamente a discursos sobre o branqueamento por meio de suas pinturas, tal como Brocos em seu Redenção de Cam (...). Mas também optou por não representar o negro, mantendo apenas alguns discretos traços indígenas em seus caipiras ${ }^{602}$.

É certo que compreender o peso dessas constatações para a análise da tela Negra e tecer possíveis relações com a ideia de preconceito demandaria um estudo mais aprofundado. Os dois autores citados, por exemplo, apontam para fatores como as relações com os comandatários paulistas, ávidos pela construção de uma imagem regional enaltecedora, como um dos motivos que justificam a recorrência e a forma de caracterização do caipira nos quadros do pintor. Contudo, seguir os passos dessas análises, que identificam limitações da obra de Almeida Júnior, pode abrir portas para a reflexão sobre o preconceito na pintura brasileira do último Oitocentos. Com isso em mente, consideramos importante estabelecer diferenças entre a imagem do caipira almeidiano e a personagem negra em questão.

Por um lado, há sem dúvida uma prevalência, nas telas do artista, de caipiras e caboclos de pele clara - o que críticos do período já percebiam, embora nem sempre com apreço. O comentário de Félix Ferreira sobre a tela $O$ derrubador brasileiro (1875) é sugestivo a esse respeito: segundo ele, "o Caboclo em descanso só ressentese da falsidade do colorido da epiderme; vê-se que o Sr. Almeida Júnior teve por modelo um europeu e não um indígena puro ou mesmo mestiço do Brasil”,603.

\footnotetext{
${ }^{600}$ NAVES, R. Almeida Jr. O sol no meio do caminho. Novos Estudos-CEBRAP, 73, nov. 2005.

${ }^{601}$ PERUTTI, D. C. Considerações sobre a representação do negro na obra de Almeida Júnior. Paper para o GT Pensamento Social Brasileiro, no XIV Congresso Brasileiro de Sociologia. RJ, 2009. ${ }^{602}$ Idem, ibidem, pp. 9-10.

${ }^{603}$ FERREIRA, Félix. Exposição do Sr. Almeida Júnior em 1882 - II. In: Belas Artes: Estudos e Apreciações. Rio de Janeiro: Baldomero Carqueja Fuentes Editor, 1885. Texto com ortografia
} 
Almeida Júnior compôs a figura a partir de um modelo italiano, de nome Mariscalo $^{604}$. Já em telas posteriores, os modelos dos caipiras foram figuras ituanas, conhecidas do pintor: "modelos, contratados ou amigos, às vezes nem mesmo brasileiros" ${ }^{\prime 605}$, segundo Coli.

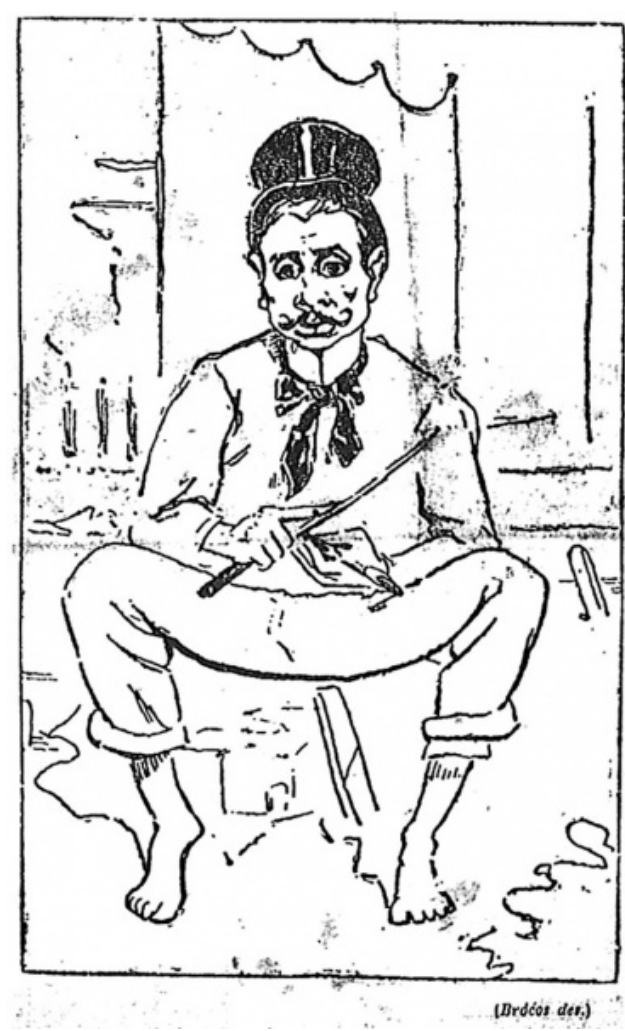

Fig. 132: Modesto Brocos. Charge publicada na Gazeta de Notícias em 1894, com a legenda:

Na Exposição de Belas Artes

PICANDO FUMO

QUADRO DE ALMEIDA JÚNIOR

O modelo parece-nos com o artista, que é um modelo de qualidades artísticas... e paulistas ${ }^{606}$.

Chama a atenção, no mais, uma charge do próprio Brocos sobre Caipira picando fumo, publicada na Gazeta de Notícias em 1894, na medida em que ela parece ter captado uma certa inclinação do quadro para nobilitar o caipira, aludindo,

atualizada, disponível no site:

$<$ http://www.dezenovevinte.net/artigos_imprensa/felixferreira_ba_arquivos/felixferreira_aj.htm>. Última consulta: 14/07/2013.

${ }^{604}$ Cf. SILVA, G. P. da. Almeida Júnior, sua vida, sua obra. São Paulo: Editora do Brasil, 1946; e DAZZI, C; VALlE, A. Comentários. In: FERREIRA, Félix. Belas Artes: Estudos e Apreciações. Rio de Janeiro: Baldomero Carqueja Fuentes Editor, 1885. Texto com ortografia atualizada, disponível no site: < http://www.dezenovevinte.net/artigos_imprensa/felixferreira_ba_arquivos/felixferreira_aj.htm>. Última consulta: 14/07/2013.

${ }^{605} \mathrm{O}$ historiador também cita Caipiras negaceando (1888) como obra que usou modelos estrangeiros. COLI, J. A violência e o caipira. In: Estudos Históricos, vol. 2, No 30 (2002): Arte e História, p. 25.

606 Gazeta de Noticias, Rio de Janeiro, 25 out. 1894, p. 1. Disponível em: $<$ http://www.dezenovevinte.net/egba/index.php?title=Gazeta_de_Noticias\%2C_Rio_de_Janeiro\%2C_2 5_out._1894\%2C_p.1>. Digitalização de Mirian Nogueira Seraphim; Transcrição de Arthur Valle. Consulta: 21/07/2013. 
no texto ao fato dele se parecer com o $\operatorname{artista}^{607}$. O pintor estrangeiro, que na época vinha se dedicando à temática de costumes em telas marcadas pela presença de personagens negras brasileiras, parece discordar da veracidade da figura posta em cena pelo ituano. Tanto uma rusticidade do pintor, quanto uma sofisticação de seus caipiras, ficam implícitas na imagem. Além disso, a legenda destaca a especificidade paulista da personagem, de forma irônica.

Por outro lado, há diferenças fundamentais nos modos de caracterização das personagens negras, com relação à desses caipiras, largamente presentes na obra de Almeida Júnior, e o primeiro passo para compreender essas diferenças é olhar com maior atenção para a imagem do caipira elaborada pelo artista.

Comecemos pelos argumentos de Naves com relação à tela Caipira picando fumo. Em primeiro lugar, trata-se de uma pintura marcada por um "duplo movimento em princípio paradoxal - a ênfase negativa no determinismo do meio e a apreciação positiva desse mesmo ambiente e de seus personagens" ${ }^{\text {,60 }}$, ou seja, uma pintura de viés determinista que, no entanto e ao mesmo tempo, procura revelar a capacidade de adaptação do caipira a seu entorno ${ }^{609}$. Tal disposição, conforme o autor, favorecerá a aceitação do artista aos olhos do público paulista, mas ao mesmo tempo “impedirá que as suas telas radicalizem sem piedade a ação do sol sobre as figuras humanas, esgarçando-as e reduzindo-as a verdadeiros farrapos humanos, com o que certamente sua arte ganharia em qualidade e mesmo em verossimilhança" ${ }^{\natural 10}$.

De fato, o caipira em cena parece completamente ajustado ao meio. Sentado numa espécie de banco improvisado com troncos, ele manuseia a faca com precisão, compenetrado $^{611}$. Como aliás percebe $\mathrm{Naves}^{612}$, o sol e o calor que castigam o

\footnotetext{
${ }^{607}$ Merece atenção aqui o fato de Almeida Júnior ter encarnado, aos olhos dos críticos do período, a persona do caipira. Ver PERUTTI, D. C. Almeida Júnior, gestos feitos de tinta. São Paulo: Alameda, 2011.

${ }^{608}$ NAVES, R. Almeida Jr. O sol no meio do caminho. Novos Estudos-CEBRAP, 73, nov. 2005, p. 142 .

${ }^{609}$ A mesma conclusão também aparece no trabalho de Perutti, para quem Almeida Júnior "fez um esforço de positivá-lo [o caipira], valorizando a figura humana em relação aos demais elementos da cena". PERUTTI, D. C. Almeida Júnior, gestos feitos de tinta. São Paulo, Alameda, 2011, p. 199.

${ }^{610}$ NAVES, R. Almeida Jr. O sol no meio do caminho. Novos Estudos-CEBRAP, 73, nov. 2005, p. 143.

${ }^{611}$ Nisto vale lembrar a análise de Coli: o recurso à precisão do ângulo reto na caracterização de toda a cena, contra a perpendicular desenhada pela posição da faca, sintetiza toda a violência das relações que envolvem o caipira. COLI, J. A violência e o caipira. In: Estudos Históricos, vol. 2, No 30 (2002): Arte e História.

${ }^{612}$ NAVES, R. Almeida Jr. O sol no meio do caminho. Novos Estudos-CEBRAP, 73, nov. 2005, p. 143.
} 
ambiente não parecem incomodá-lo. Os pés descalços mostram-se fortes, desacostumados ao uso dos sapatos ${ }^{613}$. Pela barra dobrada da calça, manchada nas pernas, vê-se também a ceroula. Apoiada na orelha, uma folha de papel indica que o fumo picado é para consumo imediato: o trabalho segue o ritmo da necessidade. A parede gasta da casa, revelando a estrutura de pau-a-pique, mostra despojamento. Longe de posar como vítima de determinismos, no entanto, o homem é dono de si, mesmo altivo, e parece viver a contento. A ação do meio e do clima não provoca drama. Assim, a tela parece de fato desviar-se de um tipo de naturalismo de crítica social. Ao mesmo tempo, tampouco procura tornar a vida no campo uma espécie de idílio.

Nesse sentido, o quadro poderia ser considerado expoente de um realismo ou naturalismo brasileiro nos moldes definidos por Toral: estilos que "tenderam a mesclar-se numa produção de caráter quase sempre descritivo, desengajado, porém atento a temas ligados à contemporaneidade" ${ }^{\prime 14}$. O mesmo autor considera que os interesses de Almeida Júnior no caipira eram "registrar o verdadeiro Brasil (que se confunde com o interior paulista), com suas particularidades, investindo num gênero pitoresco, atraente aos compradores e politicamente desengajado, porque objetivo"615.

Em adição, se há uma objetividade particular na caracterização do caipira, talvez ela tenha sido responsável por um dos aspectos mais marcantes da obra de Almeida Júnior. Como analisa Gilda de Mello e Souza, o pintor foi capaz de

surpreender a verdade profunda de um novo personagem; não apenas a aparência externa, os traços do rosto ou a maneira peculiar de se vestir, mas a dinâmica dos gestos (...) o jeito do homem se apoiar no instrumento, sentar-se, segurar o cigarro entre os dedos, manifestar no corpo largado a impressão de força cansada ${ }^{616}$.

\footnotetext{
613 Se nas personagens negras, eles referiam-se à escravidão, tem-se no caipira um elemento interessante, completamente ressignificado em contraste com a pele clara da figura.

${ }^{614}$ TORAL, A. A. No limbo acadêmico: comentários sobre a exposição "Almeida Júnior - um criador de imaginários". ARS (São Paulo) [online]. 2007, vol.5, n.10, p. 43. Disponível em: $<$ http://www.scielo.br/pdf/ars/v5n10/05.pdf $>$. Última consulta: 22/07/2013; Ver também CHIARELLI, T. Um Jeca nos vernissages. São Paulo: EDUSP, 1995.

${ }^{615}$ TORAL, A. A., op. cit.

${ }^{616}$ SOUZA, G. M. Pintura brasileira contemporânea: os precursores. In: Discurso. São Paulo, Faculdade de Filosofia, Letras e Ciências Humanas da Universidade de São Paulo, ano V, n. 5, 1974, p. 120. Também Coli aponta para o fato do caipira estar sempre desempenhando uma ação, destacando o interesse do pintor pelas relações culturais, pelos gestos, pelo meio e pelos objetos característicos. COLI, J. A violência e o caipira. In: Estudos Históricos, vol. 2, No 30 (2002): Arte e História, p. 25.
} 
O que sobressai, no caipira, não é o drama social, a pobreza ou a configuração racial, mas a imanência, o tratamento minucioso e capaz de dotar o indivíduo em cena de um "caipirismo imanente" 617 , no dizer de Arantes, que ao mesmo tempo lhe resulta numa profundidade singular: é, talvez, por meio dele que o caipira ingressa definitivamente na categoria de brasileiro $^{618}$.

Mas se é assim com o caipira, será possível dizer o mesmo com relação à Negra? Alguns elementos formais adotados em sua caracterização sugerem que não. Em primeiro lugar, não há nesta figura uma preocupação em revelar qualquer dinâmica dos gestos que lhe confira uma qualidade singular. A personagem não se dedica a um afazer em especial; suas formas, conforme indicado, se dissolvem na sombra que a rodeia; trata-se, além disso, de um corpo desconjuntado, volume coberto pelo traje escuro e marcado por dois elementos centrais: a mão, alusiva a uma garra; e a cabeça, aparentemente descolada do corpo e do lenço que a circunda, feito auréola. A expressão temerosa completa a composição, que no todo sugere o desajuste da figura com relação ao meio, ou a retração alusiva a uma inabilidade ou resistência a incorporar-se, contrária ao que ocorre com o caipira, que se mostra altivo. O personagem que pica fumo exibe, além disso, o domínio do corpo, o equilíbrio da postura ereta e na construção da estabilidade do joelho que apóia o braço, realçada pelo ângulo das pernas e a posição dos pés ${ }^{619}$. Assim, se o caipira parece controlar o meio na medida de suas ambições, a personagem negra causa a impressão de estar arredia, subordinada ao ambiente.

\footnotetext{
${ }^{617}$ ARANTES, O. B. F. Notas sobre o método crítico de Gilda de Mello e Souza. In: Discurso, n. 35, 2005 , p. 20.

${ }^{618}$ Gilda de Mello e Souza dirá que "É com ele [Almeida Júnior] que ingressa pela primeira vez na pintura o homem brasileiro". SOUZA, G. M. Pintura brasileira contemporânea: os precursores. In: Discurso. São Paulo, Faculdade de Filosofia, Letras e Ciências Humanas da Universidade de São Paulo, ano V, n. 5, 1974, p. 120.

${ }_{619}$ Novamente, devemos a Coli essa observação. COLI, J. A violência e o caipira. In: Estudos Históricos, vol. 2, No 30 (2002): Arte e História.
} 


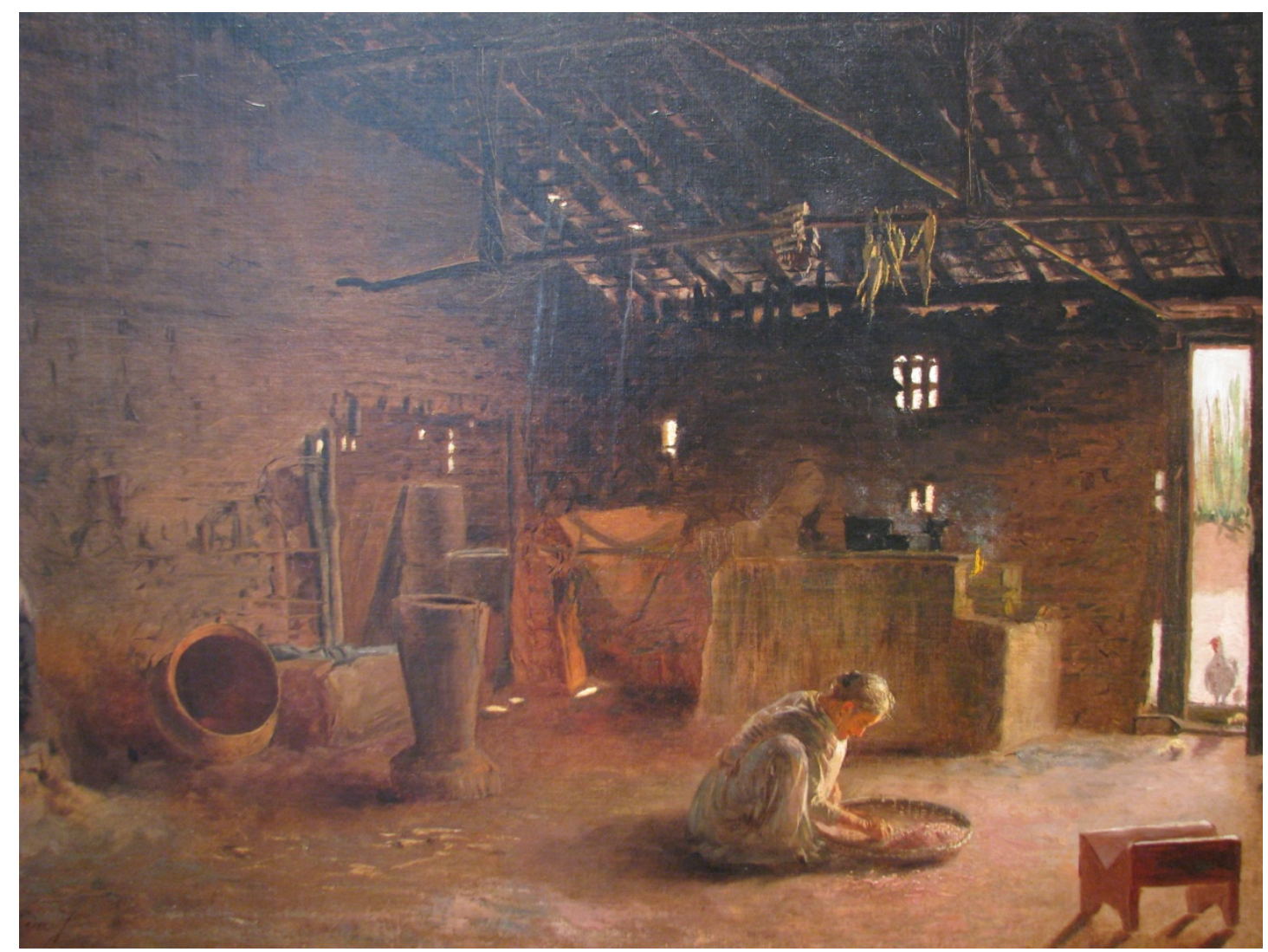

Fig. 133: José Ferraz de Almeida Júnior. Cozinha caipira (1895). Óleo sobre tela, $53 \mathrm{~cm}$ x $87 \mathrm{~cm}$. São Paulo: Pinacoteca do Estado.

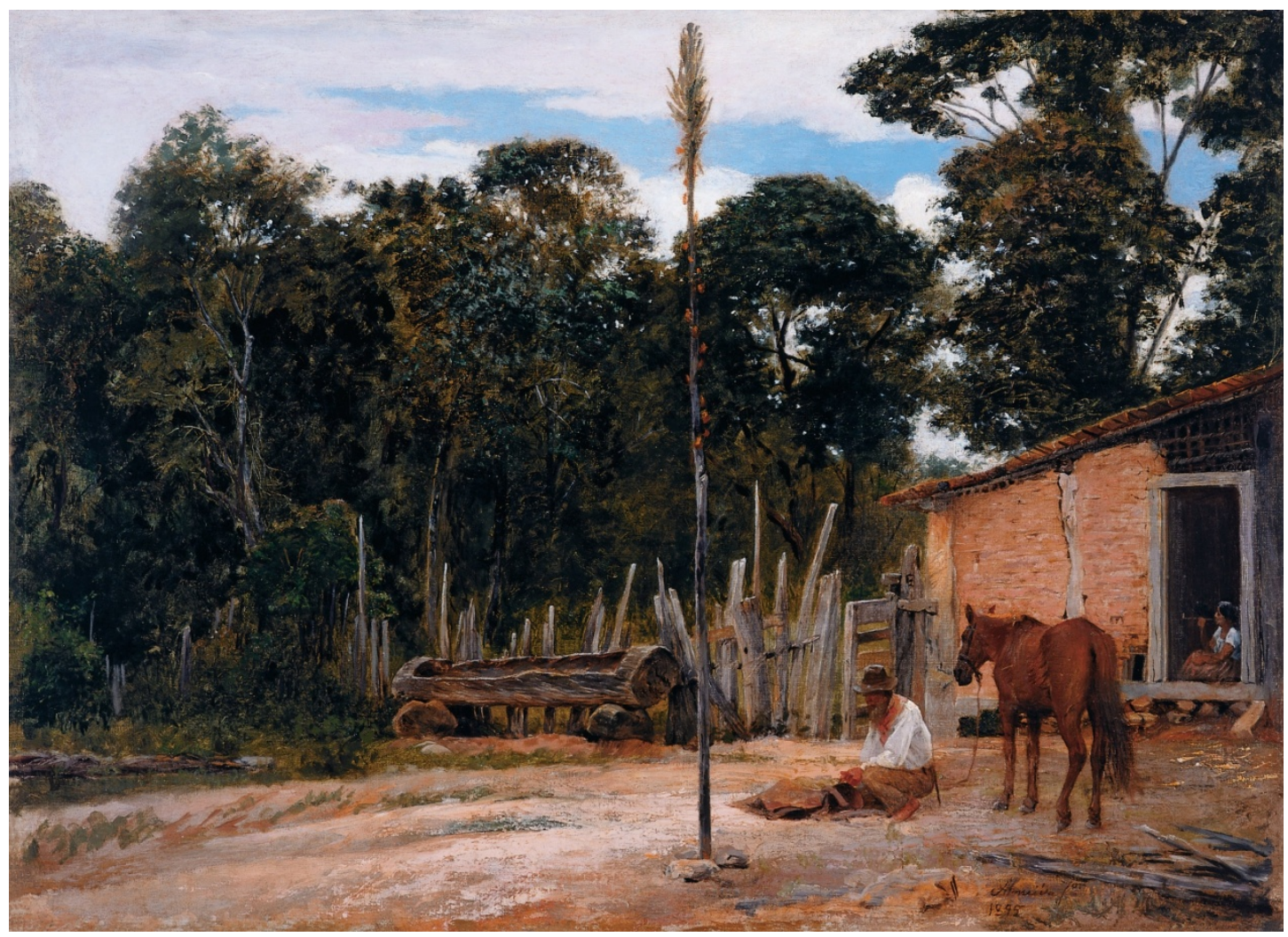

Fig. 134: José Ferraz de Almeida Júnior. Apertando o lombilho (1895). Óleo sobre tela, 64cm x $88 \mathrm{~cm}$. São Paulo: Pinacoteca do Estado. 
Poder-se-ia ainda argumentar sobre o peso das diferenças de gênero na caracterização dessas figuras. A esse respeito, vale introduzir, somente a título de contraponto, a tela Cozinha caipira (1895), do mesmo pintor. A imagem mostra uma mulher de pele clara, sentada de cócoras numa enorme cozinha, escolhendo grãos de feijão. A figura está completamente integrada ao ambiente e absorta pelo trabalho, sobre o qual demonstra propriedade - e aliás, em postura bastante parecida com a de algumas trabalhadoras do Engenho de mandioca e a da protagonista de $A$ descascar goiabas, de Modesto Brocos. Nisso, a cozinheira é bastante diversa da Negra. De todo modo, vale uma ressalva: no que concerne às possibilidades de adotar o quesito gênero como definidor das diferenças entre Caipira picando fumo, Negra e Cozinha caipira, é digno de nota que os homens caipiras de Almeida Júnior não apareçam sentados diretamente no chão, como acontece com a mulher desta cozinha da roça - o que serve de indício quanto à posição diferencial de homens e mulheres em sua pintura. Mesmo em Apertando o lombilho (1895), tem-se um tropeiro em posição agachada: próximo ao chão, mas ainda assim preservando a distância necessária para evitar o contato. Isto lhe confere num certo lugar de superioridade, bem como de protagonismo.

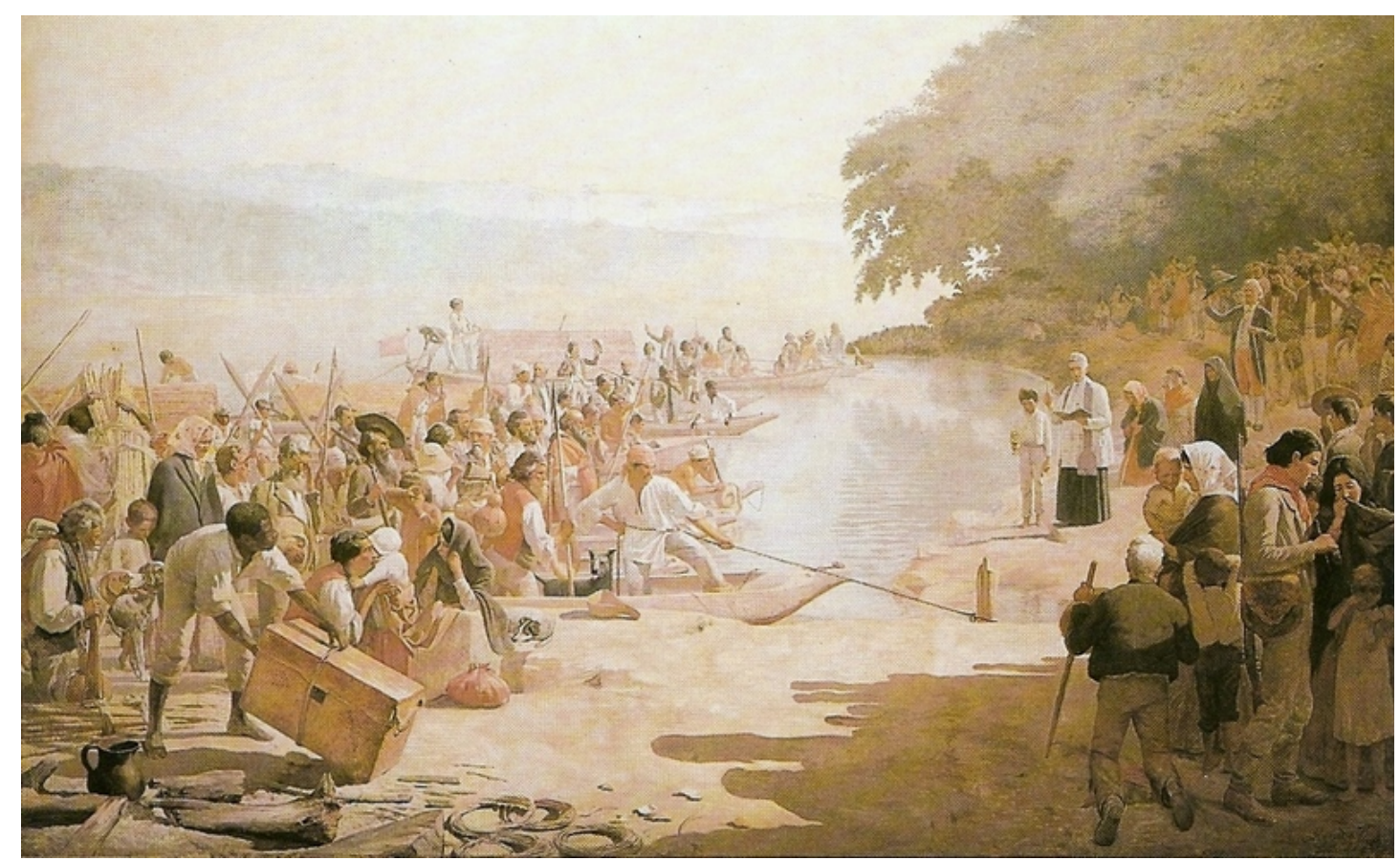

Fig. 135: José Ferraz de Almeida Júnior. Partida da monção (1897). Óleo sobre tela, $73 \mathrm{~cm}$ x $120 \mathrm{~cm}$. São Paulo: Pinacoteca do Estado. 
Também é válido comentar rapidamente a posição do homem negro que aparece em Partida da monção (1897), do pintor ituano. Tem-se, neste caso, uma caracterização interessante: o personagem, em primeiro plano, é uma espécie de auxiliar, carregando um caixote que será levado na expedição dos bandeirantes em cena. É a única figura que desempenha um trabalho braçal desse tipo na pintura. Ele está curvado - coloca-se abaixo dos demais - e parece assistir à ação de um dos núcleos, qual seja, o do padre que reza uma oração para familiares dos desbravadores ${ }^{620}$. Além disso, tem-se aqui uma caracterização de movimento que sugere inabilidade para o trabalho, como observou o crítico Oscar Guanabarino à época do lançamento do quadro: "Veja-se, por exemplo, o negro que no primeiro plano procura carregar uma canastra, que evidentemente está vazia, e indague-se se aquela é a posição que tomaria um homem em tal mister" ${ }^{\text {"621 }}$. De todo modo, merece atenção que a personagem masculina esteja em pé e não sentada ou ajoelhada no chão, como fazem, aliás, algumas figuras femininas em cena, mas não os homens.

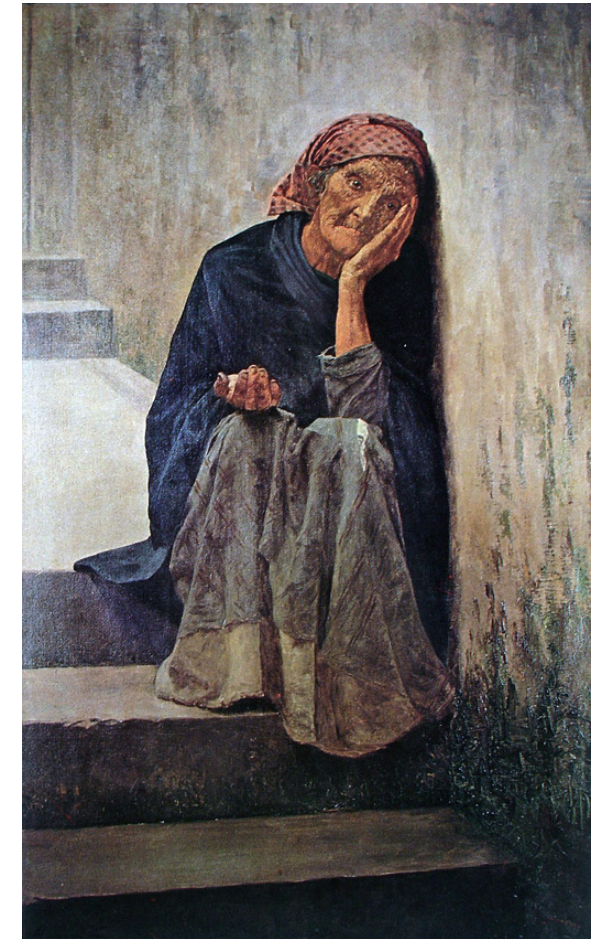

Fig. 136: José Ferraz de Almeida Júnior. Mendiga (1899). Óleo sobre tela, $144 \mathrm{~cm}$ x $88 \mathrm{~cm}$. Coleção particular.

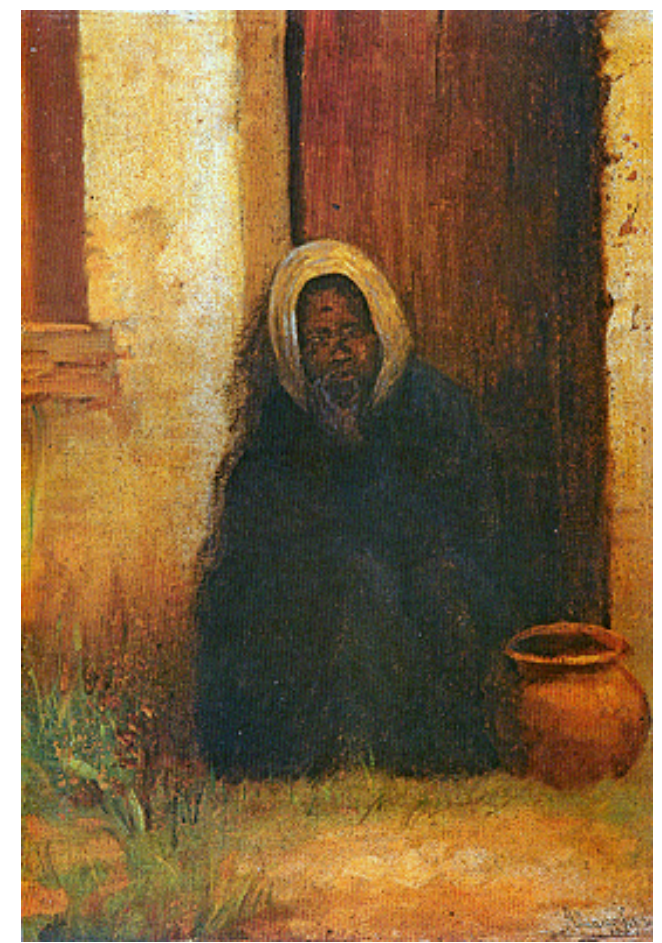

Fig. 137: José Ferraz de Almeida Júnior. Negra (1891). Óleo sobre madeira, $37 \mathrm{~cm}$ x $25 \mathrm{~cm}$. Coleção particular.

\footnotetext{
${ }^{620}$ Lembrando um pouco o caipira que assiste à declaração de independência na tela Independência ou morte!, de Pedro Américo (1888). Ver MATOS, C. V. de. Independência ou Morte! O Quadro, a Academia e o Projeto Nacionalista do Imperador. In: OLIVEIRA, C. H. S. O.; MATTOS, C. V. de (orgs.). O brado do Ipiranga. São Paulo, Edusp, 1999.

${ }^{621}$ GUANABARINO, Oscar. ARTES E ARTISTAS. O Paiz, Rio de Janeiro, 4 set. 1898, p.2.
} 
Por fim, é preciso destacar, em Negra, a tristeza e consternação que parecem anunciar fatalidade. Sob esse aspecto, há correlações possíveis com Mendiga (1899), do mesmo pintor $^{622}$. Em idade já avançada - sinal de proximidade da morte - e com uma sombra que trabalha para diluir seus contornos de forma análoga, esta senhora de pele clara parece no entanto muito mais realista e simétrica, com um lenço avermelhado que se ajusta ao contorno da cabeça, corpo e rosto proporcionais. A solidão ${ }^{623}$ que se desprende das duas figuras também possibilita diálogos com outras imagens de mulheres na pintura. Uma correlação interessante, nesse sentido, é entre Negra e A quitandeira, de Ferrigno, pois ambas preservam um marcador racial comum. Passemos à interpretação deste último quadro que, à sua maneira, também assume características divergentes com relação às imagens de caipiras de Almeida Júnior.

\section{A quitandeira e o modelo naturalista}

O lampião aceso ajuda a enxergar os produtos à venda e sugere que já anoiteceu. O interior, escuro como o breu, guarda um tabuleiro de ervas. Do lado de fora, recostada à parede, está a dona da banca. A mulher negra encontra-se sentada no chão de terra e adormecida, com ares de cansaço. Trata-se de uma figura de traços extremamente nítidos e corpo desenhado segundo os cânones da precisão anatômica. Nada, em seu físico, parece desproporcional: as mãos e pés são grandes, mas não exagerados. De formas opulentas e pescoço largo, ela tem a orelha esquerda à mostra, embora não haja na cena intenção de ressaltar-lhe os contornos do quadril ou das nádegas. A vendedora está descalça e tem as chinelas atiradas ao lado do corpo. $\mathrm{Na}$ saia azul de tecido modesto, destaca-se a barra puída, que deixa uma parte da perna direita da mulher à mostra. No mais, ela veste blusa branca decotada e sem mangas. A vendedora também usa (deixa pender ao chão) o pano da costa estampado de branco, vermelho e ocre e tem como adereços o turbante branco, pulseira e bracelete de metal, um crucifixo e um cordão que parece levar uma espécie de patuá. A pintura prima

\footnotetext{
${ }^{622}$ O paralelo é bem apontado por LOURENÇO, M. C. F. Debates e posturas - Tempo humano. In: Almeida Júnior: um criador de imaginários. Catálogo da exposição na Pinacoteca do Estado. São Paulo, 25 jan.-15 abr. de 2007. Para um estudo de fôlego sobre Almeida Júnior, ver LOURENÇO, M. C. F. Revendo Almeida Júnior, (Dissertação de Mestrado). São Paulo: ECA/USP, 1980.

${ }^{623}$ É preciso reforçar também que o caipira constitui um tipo solitário, no entender de Perutti. A autora mostra que o isolamento marca tanto as descrições textuais de caipiras feitas por viajantes e observadores externos, quanto as imagens produzidas por Almeida Júnior. PERUTTI, D. C. Almeida Júnior, gestos feitos de tinta. São Paulo, Alameda, 2011. No entanto, poderíamos acrescentar, no caso do caipira, a solidão não vem acompanhada da tristeza das personagens Negra e Mendiga.
} 
pela minúcia nos detalhes, ao mesmo tempo em que adere a preocupações naturalistas em expor a vida da população trabalhadora, ressaltando a exiguidade e a pobreza que circundam essa figura marcada por elementos associados à indumentária africana. $\mathrm{O}$ contraste de amarelo e azul está presente, assim como a nota de vermelho e o branco luminoso, ainda que predominem os tons terra.

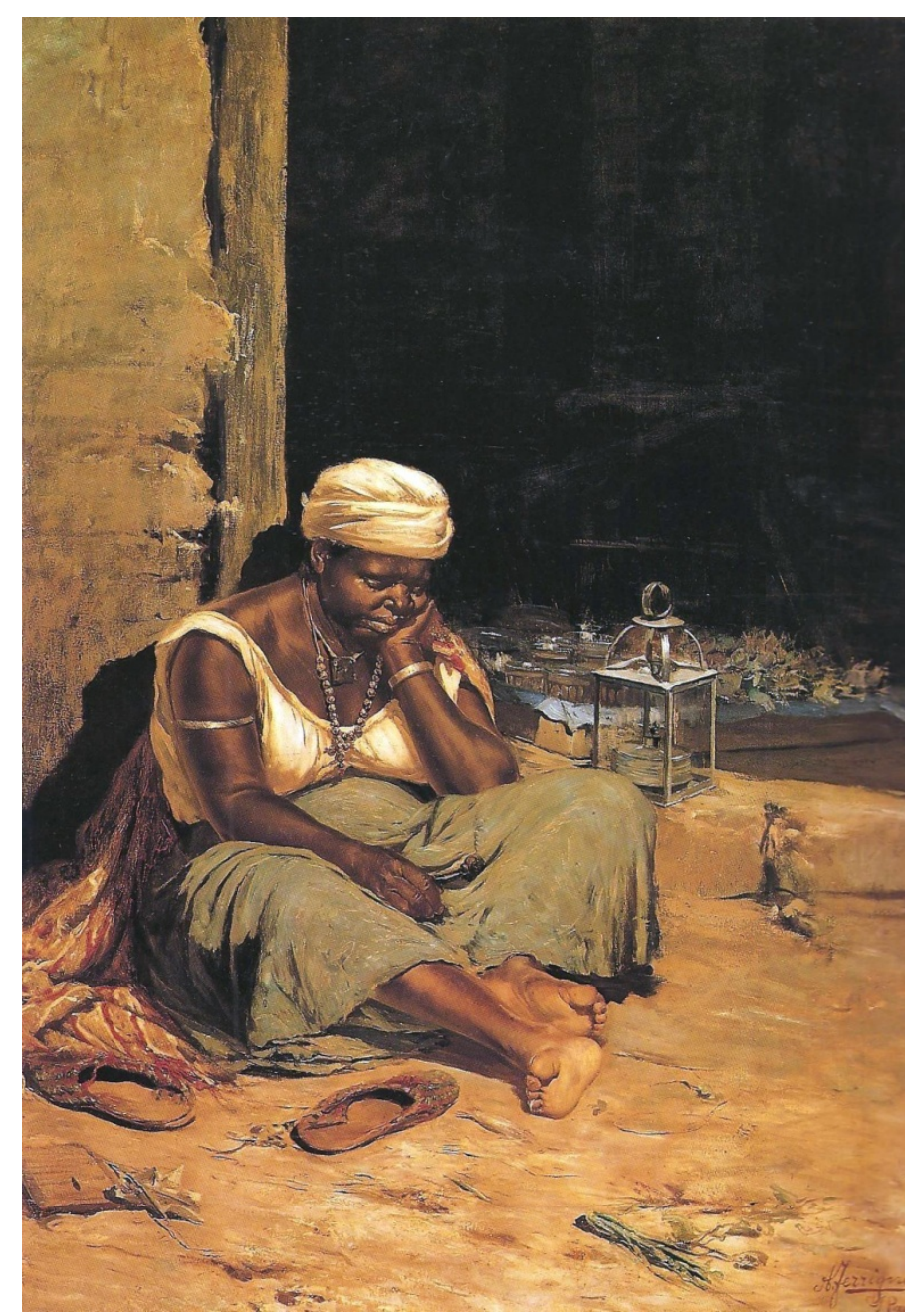

Fig. 138: Antonio Ferrigno.

A quitandeira (s.d.)

Óleo sobre tela, $179 \mathrm{~cm} \times 125 \mathrm{~cm}$.

São Paulo: Pinacoteca do Estado.

Por um lado, é inegável que se trate de uma imagem capaz de mostrar o trabalho aviltante da figura que ganhou o nome de quitandeira: labor inclusive noturno, que a obriga a intercalar o atendimento aos clientes com as horas de sono. A casa é uma espécie de barracão sem porta - e não há como saber se serve ou não de habitação à personagem. Aqui, em primeiro lugar, não há temor ou receio, apenas cansaço. Mas ao mesmo tempo, o trabalho não entretém, como acontece nas atividades do caipira. A negra de Ferrigno não demonstra a preocupação daquela pintada por Almeida Júnior, nem a altivez de seus homens do campo. Assim, a tela 
parece enquadrar-se num modelo naturalista que prima por esmiuçar em detalhes a vida do trabalhador urbano, tornando evidente miséria das condições. Trata-se, desse modo, de uma imagem marcada pelo viés da crítica social, que parece constituir o DNA de sua resposta ao problema da incorporação do negro à ordem livre. A mulher em cena, longe de diluir-se em sombras, como acontece na tela do pintor ituano, não poderia ser mais visível ${ }^{624}$, presença esta que é acentuada pela grandeza do corpo exausto.

Sob esse aspecto, é preciso retomar uma questão levantada por Naves: na visão do crítico, A quitandeira - assim como A redenção de Cam - é uma amostra do pitoresco, que serve para "fixar acontecimentos ao mesmo tempo singulares e

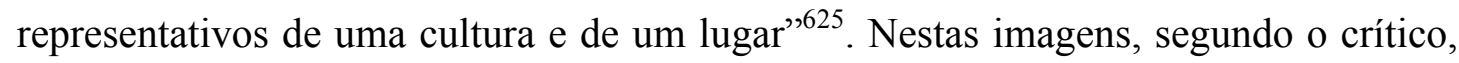
"nada revela a aridez que rege a tela de Almeida Júnior. Ao contrário, uma diversidade miúda apenas nos distrai e enleva, afastando-nos da pobreza que lavra entre aquela população",626. Assim, a quitandeira seria marcada por uma "paradoxal exuberância modesta, na qual a figura de uma negra escrava se vê adornada pelos detalhes saborosos que a envolvem" ${ }^{\prime 627}$ - e a tal respeito, é preciso notar que muitos desses detalhes constituem indicadores de sua africanidade ${ }^{628}$.

A comparação parece desenhar uma equação entre duas variáveis: pobreza e raça, como se, na tela de Ferrigno, os adereços associados a uma identidade africana entorpecessem a percepção da escassez que marca a sobrevivência da quitandeira. Logo, convida a discutir mais a fundo a presença desses elementos. Por um lado, eles apontam para uma intenção da pintura de vincular as duas variáveis. Por outro e tendo-se em vista o momento de produção do quadro, época de grande aceitação do pensamento racialista, parece-nos importante aventar a hipótese de que tal articulação indique um olhar determinista: talvez, o que se anuncie por meio dela, seja antes a

\footnotetext{
${ }^{624}$ A análise de Perutti estabelece essa contraposição. A autora também considera que tal corpo pode exprimir trabalho físico, braçal, sexualidade, ou amamentação de crianças brancas, sendo aquilo que primeiro chama a atenção na figura. PERUTTI, D. C. Considerações sobre a representação do negro na obra de Almeida Júnior. Paper para o GT Pensamento Social Brasileiro, no XIV Congresso Brasileiro de Sociologia. RJ, 2009.

${ }^{625}$ NAVES, R. Almeida Jr. O sol no meio do caminho. Novos Estudos-CEBRAP, 73, nov. 2005, p. 137.

${ }^{626}$ Idem, ibidem, p. 138.

${ }^{627} \mathrm{Idem}$, ibidem, p. 137.

${ }^{628} \mathrm{O}$ que também fica patente na análise de Perutti quando a autora descreve esses itens, associados à imagem de escrava. Segundo a autora, a intenção da tela é tornar exótica a figura em cena. PERUTTI, D. C. Considerações sobre a representação do negro na obra de Almeida Júnior. Paper para o GT Pensamento Social Brasileiro, no XIV Congresso Brasileiro de Sociologia. RJ, 2009.
} 
ideia de fatalidade, tão presente nos romances de Aluísio de Azevedo comentados no capítulo 3 - a esse respeito, merece atenção o físico da figura, similar a Bertoleza, de O cortiço.

Também é importante sublinhar que a imagem da quitandeira parece bastante alinhada com algumas construções feitas por viajantes, como Charles de Ribeyrolles, quando destaca o uso dos andrajos pelas negras que trabalham na zona portuária, ou mesmo Rugendas e Debret em suas pinturas que buscam catalogar indumentária e acessórios típicos das mulheres negras de grupos e ocupações distintas - ainda que na tela de Ferrigno se destaque a solidão de seu cotidiano laboral, ou sua desarticulação de um conjunto que possa ser visto como social. De qualquer maneira, ao explorar uma equação raça/pobreza, a pintura não parece estabelecer contrariedade entre os termos: antes, eles reforçam-se mutuamente.

A solidão também é marcante em Negra, de Almeida Júnior. Já $A$ redenção de Cam é distinta, pois discute a questão embranquecimento como solução possível para a incorporação da população de ascendência negra à República nascente. Em decorrência, neste quadro, a mulher negra está integrada a um núcleo familiar. Contudo, mesmo nesta pintura é preciso notar a manga puída do casaco da avó, bem como seus pés descalços e a vivenda simples como indícios de pobreza, a despeito do acento alegórico da cena.

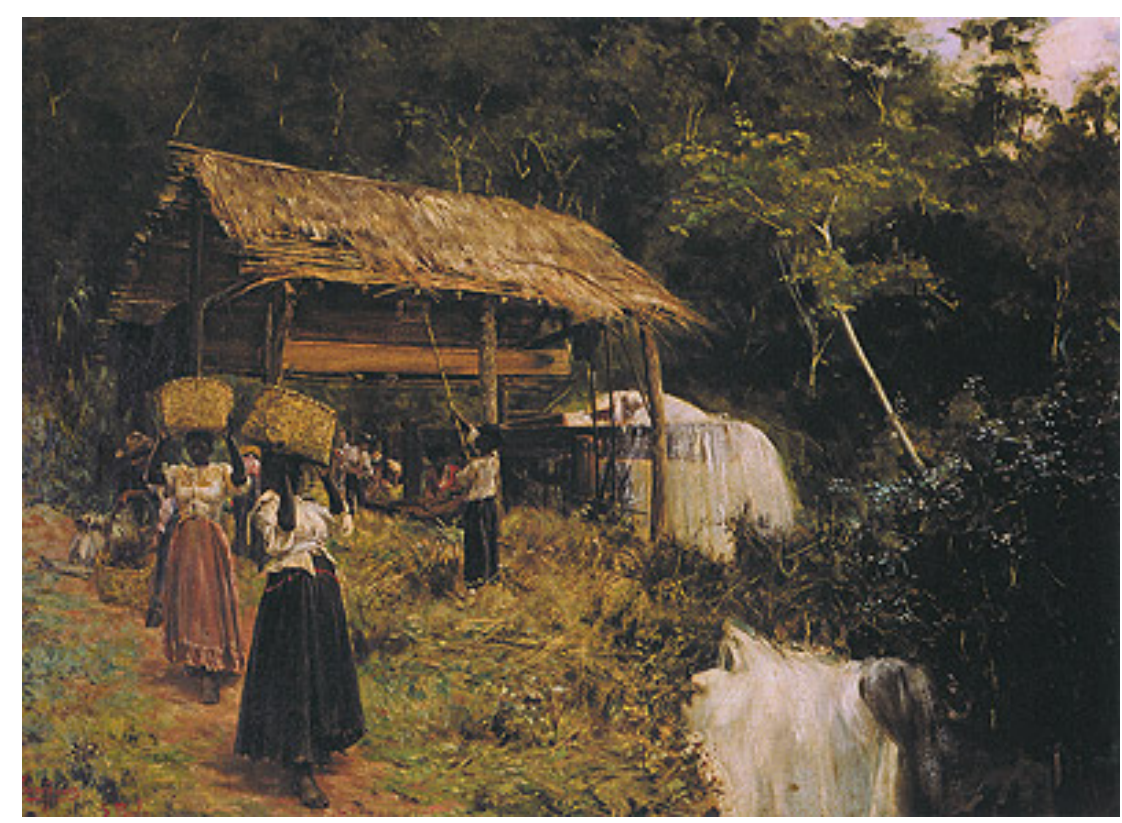

Fig. 139: Antonio Ferrigno. Monjolo (c. 1895). Óleo sobre tela, $47 \mathrm{~cm} \times 47 \mathrm{~cm}$. Coleção particular. 
Voltando a Ferrigno, há motivos para pensar que sua obra explore uma teoria própria sobre a integração dessa parcela da população nacional à fração branca: em algumas telas pintadas por ele em fazendas no interior paulista, há personagens negras mais integradas ao meio. Monjolo, cena da Fazenda Vitória, em Botucatu, mostra um grupo de mulheres negras e dois homens trabalhando. Um deles, de chapéu, parece uma espécie de capataz que brinca com um cão. $\mathrm{O}$ outro bombeia o monjolo para encher de água os cestos que elas levam apoiados na cabeça, para abastecer a fazenda. Todas caminham com postura ereta e equilibrada, usando roupas comumente associadas à moda ocidental, com os cabelos presos. Aqui, os pés descalços podem indicar que, apesar de abolida a escravidão no plano oficial, este ainda seja o caráter do trabalho naquelas terras.

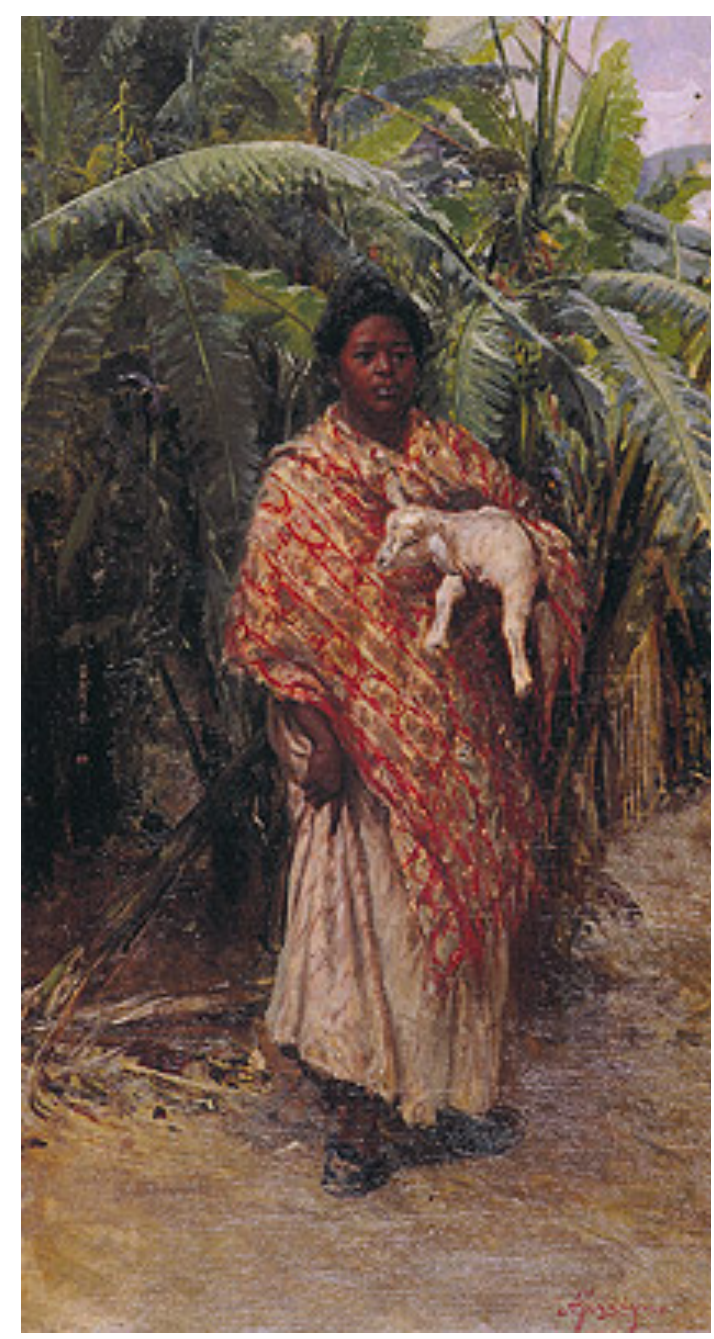

Fig. 140: Antonio Ferrigno. Nativa (s.d.).

Óleo sobre tela, $45 \mathrm{~cm}$ x $25 \mathrm{~cm}$.

Coleção particular.

Na tela Nativa, pintada na Fazenda Santa Gertrudes, município de Araras, vêse uma mulher negra que carrega um cordeiro branco. Ela tem o rosto sereno. De 
cabelo preso em coque, está completamente vestida e tem os pés calçados. Usa um enorme xale estampado de vermelho e amarelo, que contrasta com a folhagem verde ao fundo - combinação que, como vimos, alude ao primitivismo. A primeira imagem mostra um grupo; a segunda, uma mulher sozinha, mas feliz - e em pé. Logo, nas pinturas de Ferrigno no interior paulista parece haver maior integração das pessoas com o ambiente. Destaca-se a similitude nas vestimentas e cabelos entre as mulheres destas pinturas e a jovem mãe do quadro $A$ redenção de Cam.

Em contraposição, A quitandeira combina o terço cristão a adereços que podem ser vinculados às religiões afro-brasileiras. Tendo-se em vista essa sobreposição de elementos e também a corporalidade extremamente visível e pormenorizada da personagem, a imagem também evoca as tendências da imagística ocidental do período a reduzir as personagens negras a seus corpos, questionando a existência da alma negra, bem apontada por Boime e Dyer ${ }^{629}$. Ao mesmo tempo, se lido na chave do modelo proposto por Boime ${ }^{630}$, o uso do terço combinado ao patuá sugere confusão, aludindo a uma dificuldade de atingir a iluminação espiritual, de um ponto de vista cristão e branco.

\section{Aproximações e distanciamentos}

Tem-se, até o momento, dois tipos de imagens de mulheres negras produzidas no período ${ }^{631}$. Negra e $A$ quitandeira são telas que apontam para a solidão, o isolamento e a tristeza. A Redenção de Cam e as cenas pintadas por Ferrigno no interior paulista mostram possibilidades de incorporação à ordem livre, seja via casamento (branqueador), ou trabalho rural, respectivamente. A mulher da tela Negra não aparece num momento de labor $^{632}$; a personagem quitandeira, por sua vez, trabalha, mas está só e apresenta sinais de esgotamento. As figuras das primeiras telas

\footnotetext{
${ }^{629}$ BOIME, A. The art of exclusion. Representing blacks in the Nineteenth Century. Washington \& London, Smithsonian Institution Press, 1990; DYER, R. White. NY, London: Routledge, 1999.

${ }^{630}$ BOIME, op. cit.

${ }^{631}$ E certamente o recorte poderia se ampliado, para incluir questões trazidas por telas como Fascinação (1902), de Pedro Peres; Mãe Preta (1912), de Lucílio de Albuquerque; Tarefa pesada (1913), de Gustavo Dall'ara; e Limpando Metais (1923), de Armando Vianna; e Zumbi (s.d.), de Antônio Parreiras. Algumas desses telas são comentadas por CHRISTO, M. C. V. Algo além do moderno: a mulher negra na pintura brasileira no início do século XX. In: 19\&20, Rio de Janeiro, v. IV, n.2, abr. 2009. Disponível em: <http://www.dezenovevinte.net/obras/obras_maraliz.htm>. Consulta: 22/07/2013.

${ }^{632}$ Sobre isto, Lourenço pergunta-se: "estaria mendigando ou esperava na porta a comida esfriar?". LOURENÇO, M. C. F. Debates e posturas - Tempo humano. In: Almeida Júnior: um criador de imaginários. Catálogo da exposição na Pinacoteca do Estado. São Paulo, 25 jan.-15 abr. de 2007, p. 96
} 
têm a postura ereta, enquanto as das últimas estão curvadas ou largadas, sendo que a negra de Almeida Júnior é marcada pela disjunção corporal e os contornos dissolutos.

No que concerne às discussões inauguradas por Boime ${ }^{633}$, que discute as possibilidades de acesso à iluminação espiritual das personagens de ascendência negra como um dos eixos que assinalam sua presença na pintura oitocentista, os quadros de Brocos e Almeida Júnior se aproximam - ambos exploram um jogo de equivalências, em que elementos cênicos alusivos ao prosaico também se tornam alusivos à fé cristã (respectivamente, similitude com as santas negras e lenço branco que se confunde com auréola). Tais elementos apontam para a constituição de uma dimensão extraterrena para as personagens, ao mesmo tempo em que insinuam a ideia da morte (e do perdão) - o que talvez seja reforçado pela diluição de contornos, em Negra, mas também porque as duas mulheres pintadas têm idade já avançada. Já no caso de A quitandeira - que também engloba elementos alusivos à fé, como vimos -, tudo se passa na imanência da rotina aviltante de um cotidiano que parece não deixar escapatória.

Há que reconhecer nessas pinturas uma tendência ao afastamento com relação a modelos de corporalidade da mulher negra inspirados em Sara Baartman e no orientalismo - que se restringem ao uso seletivo de alguns elementos, como a aplicação das cores em certos quadros. A única figura corpulenta é $A$ quitandeira, que constitui a tela mais ajustada à convenção naturalista europeia do conjunto. Logo, é antes por meio de outros esquemas e tópicas que cada imagem busca responder de maneira diferenciada à questão relativa ao destino dos não-brancos numa nação marcada pela difusão do racialismo ${ }^{634}$, em que a afirmação da branquitude é anunciada como necessidade urgente ${ }^{635}$. Nesses quadros, a presença da mulher negra

\footnotetext{
${ }^{633}$ BOIME, A. The art of exclusion. Representing blacks in the Nineteenth Century. Washington \& London, Smithsonian Institution Press, 1990.

${ }^{634}$ SEYFERTH, G. A antropologia e a tese do branqueamento da raça no Brasil: a tese de João Baptista Lacerda. In: Revista do Museu Paulista, 30, 1985; SKIDMORE, T. E. Preto no branco. RJ: Paz e Terra, 1989; SCHWARCZ, L. K. M. Retrato em negro e branco. Jornais, escravos e cidadãos em São Paulo no final do século XIX. SP: Companhia das Letras, 1987; SCHWARCZ, L. K. M. O espetáculo das raças. Cientistas, instituições e a questão racial no Brasil - 1870-1930. São Paulo, Companhia das Letras, 2004. SCHWARCZ, L. K. M. Questões de fronteira. In: Novos Estudos. São Paulo, Cebrap, $n^{\circ}$ 72, jul. 2005; Schwarcz, L. K. M. Previsões são sempre traiçoeiras. João Baptista de Lacerda e seu Brasil branco. In: História, Ciências, Saúde - Manguinhos. RJ, v.18, n.1, jan.-mar. 2011; CORRÊA, M. As ilusões da liberdade. A Escola Nina Rodrigues e a antropologia no Brasil. Bragança Paulista: Edusf, 1998.

${ }^{635}$ DYER, R. White. NY, London, Routledge, 1999; BEDERMAN, G. Manliness \& Civilization. A cultural history of gender and race $\mathbf{n}$ the United States, 1880-1917. Chicago, The University of Chicago Press, 1996; MCCLINTOCK, A. Couro Imperial. Editora Unicamp, Campinas, 2010;
} 
pode servir para acusar a existência de um problema social ou moral e acenar para projetos que visam à sua incorporação ao mundo dos brancos via trabalho e aceitação de certos preceitos da moral cristã, branca, masculina e ocidental - inclusive, em $A$ redenção de Cam, pelo voluntarismo no processo de embranquecimento. Por fim, seu próprio corpo pode converter-se numa interrogação sobre a morte e as possibilidades de redenção.

Em todos os casos, sua integração social parece ser tomada de antemão como incerta ou problemática, prevalecendo uma tendência a dotá-la de elementos alusivos à ideia de primitivismo - seja no modo de sentar no chão, num traço deformante do corpo, que o afaste dos princípios da anatomia humana, no uso dos contrastes complementares de cor, ou mesmo nos adereços étnicos, que mostram uma certa resistência a aderir ao estilo de vida branco, cristão e ocidental, então tomado como o único caminho para a civilização, ou no mínimo para uma incorporação possível. Se evidentemente, qualquer afirmação mais taxativa sobre as possíveis intenções dessas telas dependeria de um estudo em maior detalhe sobre cada uma, uma primeira visada sobre o conjunto revela uma tendência a instituir o olhar do espectador em posições de distanciamento com relação às personagens em cena.

Resta, portanto, a pergunta: ao lado dessas pinturas, haverá espaço para telas que exprimam uma visão diferente para a mulher negra no período? Na dissertação, destacamos a importância do olhar e das disposições particulares que ele assume de acordo com certos lugares sociais, bem como a centralidade de definir novos modos de ver - incluindo-se aí os olhares oposicionais, como define bell hooks ${ }^{636}$. A questão diz respeito às possibilidades de, por meio da pintura, habilitar estéticas capazes de deslocar percepções correntes e, portanto, de oferecer modelos distintos a partir dos quais compreender e experimentar relações constitutivas de subjetividades.

Gostaríamos de pensar, a partir das telas escolhidas de Antônio Rafael Pinto Bandeira e Arthur Timótheo da Costa, num processo de construção de olhares

\footnotetext{
MISKOLCI, R. O desejo da nação. Masculinidade e branquitude no Brasil de fins do século XIX. Annablume, São Paulo, 2012.

${ }^{636}$ bell hooks, como vimos, destaca o papel das formas de olhar numa aprendizagem da resistência. A autora estabelece um diálogo importante, do ponto de vista de uma mulher negra, com os estudos feministas que procuraram endereçar o problema da fixação de posições do olhar/papéis sociais no cinema. Ver bell hooks. The oppositional gaze. Black female spectators. In: Black Looks: Race and representation. Boston: South End Press, 1992, pp. 115-131; e também MULVEY, Laura. "Visual pleasure and narrative cinema". In: Visual and other pleasures. Indianápolis, Indiana University Press, 1989; LAURETIS, T. Technologies of gender. Essays on theory, film and fiction. Bloomington, Indiana University Press, 1987.
} 
oposicionais na pintura brasileira produzida entre os anos 1880 e as primeiras décadas do século XX. Argumentaremos que, longe de partirem do entendimento de que a integração da população de ascendência negra constitui um problema para o desenvolvimento do país, as telas indicadas dos dois artistas deslocam enquadramentos. Com isto, se tornam capazes de evidenciar o preconceito presente em outras miradas pictóricas ou não, mas também dotar de uma nova dimensão a construção estética do cotidiano dessas populações.

\section{O preconceito, ao alcance do olhar}

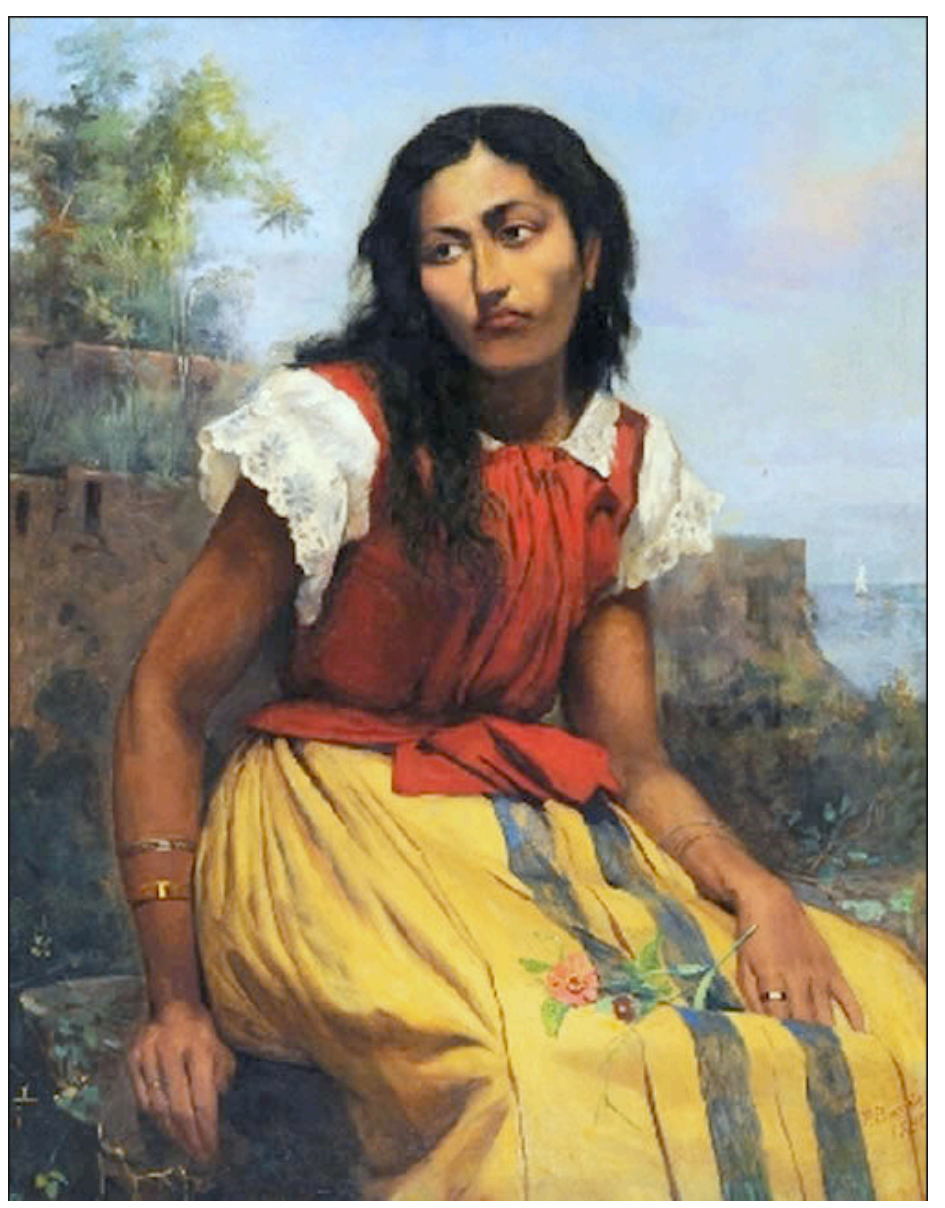

Fig. 141: Antônio Rafael Pinto Bandeira. Moça sentada (1866). Óleo sobre tela, $84 \mathrm{~cm} \times 66,2 \mathrm{~cm}$. Niterói: Museu Antônio Parreiras.

Uma jovem está sentada sobre um banco de pedra. Ao fundo, um veleiro singra as ondas do mar tranquilo. No topo do planalto à suas costas, a vegetação é abundante. No céu azul, as nuvens variam entre tonalidades de roxo e dourado. Ela usa traje colorido: blusa vermelho-viva sem decote, de gola e mangas curtas em tecido branco, com detalhes em renda. Saia amarela, com algumas pregas e duas listras azuis na frente. Tem também adereços: brinco pequeno, dois braceletes, um 
dourado, outro prata, no braço direito; uma aliança dourada no anular na mesma mão - sinal de noivado; algumas pulseiras finas no braço esquerdo e uma aliança mais larga, também dourada, no indicador dessa mão. Seus cabelos, compridos, estão soltos. Sobre o colo, ela traz duas margaridas. A posição do corpo indica que está prestes a levantar: a cabeça virada e ligeiramente inclinada para a direita dá a impressão de que ela acaba de avistar alguém que esperava, talvez o noivo - mas também permite imaginar que tenha desistido de esperar. $\mathrm{O}$ rosto exprime um certo desapontamento. A aliança de noivado constrói uma trama em torno da figura que poderia ser definida, nos moldes da época, como "mulata": contrapõe-se ao uso dos contrastes complementares de cor na caracterização mais geral da narrativa e ao desenho do corpo da personagem, em que sobressai o ângulo perfilado que busca valorizar o contorno dos quadris largos, sob a saia volumosa. Tem-se, portanto, um jogo de sinais contraditórios, como se o artista brincasse com a imaginação de seu público - masculino e voyeurista -, questionando possíveis julgamentos apressados por meio do anel que indica casamento vindouro.

A tela chama-se Moça sentada e traz a data de 1886 - dois anos antes da promulgação da Lei Áurea. Seu autor, Antonio Rafael Pinto Bandeira, um descendente de escravos, é então aluno da Academia Imperial de Belas Artes ${ }^{637}$. Obra de um artista no começo da carreira, portanto, a pintura é dotada a seu modo de uma espécie de contrariedade formal que, como veremos, também esteve presente em quadros posteriores e mostram que ele parece ter levado adiante o projeto de elaborar imagens originais para a mulher de ascendência negra, a despeito das possíveis imposições de tópicas e esquemas consagrados na academia, que vinham carregadas de juízos de valor: junto dos contrastes complementares, uma figura bem vestida, à ocidental, e de certas posses, expressas no uso de jóias; de cabelos soltos, mas recaindo sobre os ombros; em paralelo à visibilidade não perpendicular do quadril, usa uma aliança de noivado.

\footnotetext{
${ }^{637}$ Após completar a formação, em 1884, ele se torna professor do Liceu de Artes e Ofícios em Salvador, Bahia. Retorna em 1890 ao Rio, com o sonho de fundar uma Escola de Belas Artes em Niterói, sua cidade natal, que no entanto, não consegue realizar. O pintor suicida-se em 1896, aos 33 anos. BARDI, P. M. Arte no Brasil. São Paulo: Abril Cultural, 1979; ARAÚJO, E. A mão afrobrasileira. Significado da contribuição artística e histórica. SP, Imprensa Oficial, 2011 e LEITE, J. R. T. Pintores negros do Oitocentos. Mww Motors, 1988.; Lopes, N. Dicionário Escolar AfroBrasileiro. SP: Selo Negro, 2006.
} 
Já Feiticeira, tela de 1890, é um retrato - o que já constitui uma exceção, num momento em que as personagens não-brancas tendiam a aparecer apenas em cenas de costumes. A mulher encara o espectador com olhar firme. Ela tem o cabelo preso em coque, no alto da cabeça, com um laço de fita vermelha. Usa um colar discreto e um pequeno brinco de pérolas, além da blusa branca decotada. A composição como um todo adquire tom perolado. Nota-se neste quadro uma transformação do estilo do pintor, que adere à pincelada mais solta e abandona os contrastes complementares. A mulher, que poderia ser definida como "mulata" nos moldes da época, é composta para cativar a admiração voyeurista masculina sem, no entanto, a quase obrigatória exibição de seu corpo. Desse modo, há um empenho em fugir de um modelo de corporalidade que reduz a mulher negra em cena ao papel de símbolo de uma sexualidade patológica, optando-se, ao invés disto, por individualizar as feições e expressão da personagem. O retrato também escapa à cena de costumes, afastando a figura das associações com o trabalho, com paisagens exuberantes e ambientações modestas ou exóticas. Assim, inaugura um espaço aberto para que a imaginação do espectador possa definir o lugar e a origem dessa figura misteriosa, ao mesmo tempo em que estes se tornam dados de importância menor para a economia da imagem.

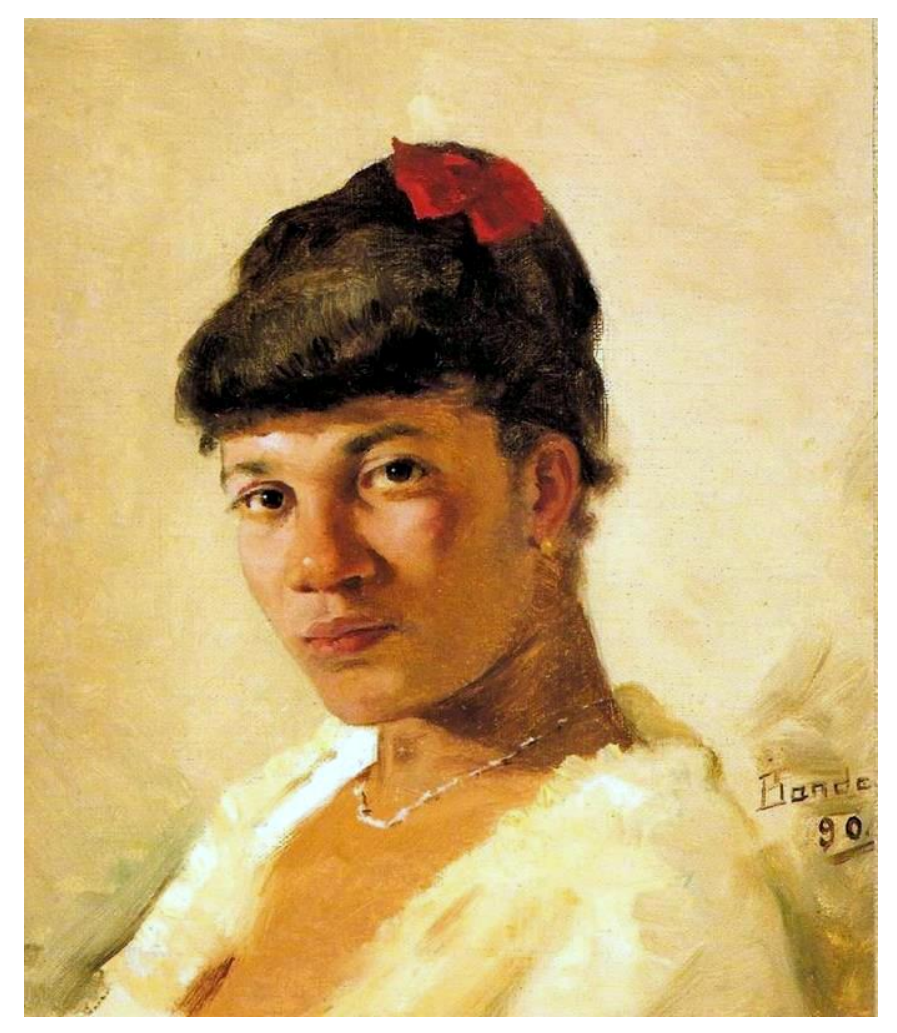

Fig. 142: Antônio Rafael Pinto Bandeira. Feiticeira (1890). Óleo sobre tela, $33 \mathrm{~cm}$ x $30 \mathrm{~cm}$. São Paulo: Coleção particular. 
Um pouco mais adiante, no ano seguinte, encontramos Jovem Adormecida, cena que valoriza a riqueza de detalhes de um interior em que uma menina que também poderia ser definida como "mulata" se deixa vencer pelo sono em meio à leitura de um livro. Ela está sentada de pernas cruzadas, recostada numa almofada de tom marfim e tem a publicação aberta sobre o colo. Usa um vestido azul de gola branca, com uma faixa branca na barra, meias listradas e sapatos pretos, além de um colar em tom rosa. Tem os cabelos soltos. Sobre o aparador ao lado, uma luminária e três outros livros reforçam a ideia do estudo. Destaca-se, na composição, a pincelada livre e uma aplicação de cores que privilegia a sensação de diferentes luminosidades e transparências, recobertas pelo tom dourado para a cena. Chama a atenção o desenho dos motivos no papel de parede, que privilegia um traçado simples, de contornos similares a rabiscos de lápis, lembrando certas tendências de vanguarda. O quadro é original, pois mostra uma personagem extremamente bem vestida e intelectualizada, num interior requintado - e não mais, portanto, em meio à paisagem exuberante, ou numa casa de taipa. Bandeira retoma, nessa tela, o uso do contraste complementar de amarelo e azul - o que resulta numa espécie de ironia, tal como acontece de modo sutil pela combinação entre aliança e demais elementos em Moça sentada: o elemento alusivo ao primitivismo envolve uma figura perfeitamente integrada aos modos de vida das elites intelectuais. Além disso, como naquela pintura ele pode denotar um ajuste do artista a certas tópicas vigentes no período - de todo modo, acatadas de modo criativo e questionador. 


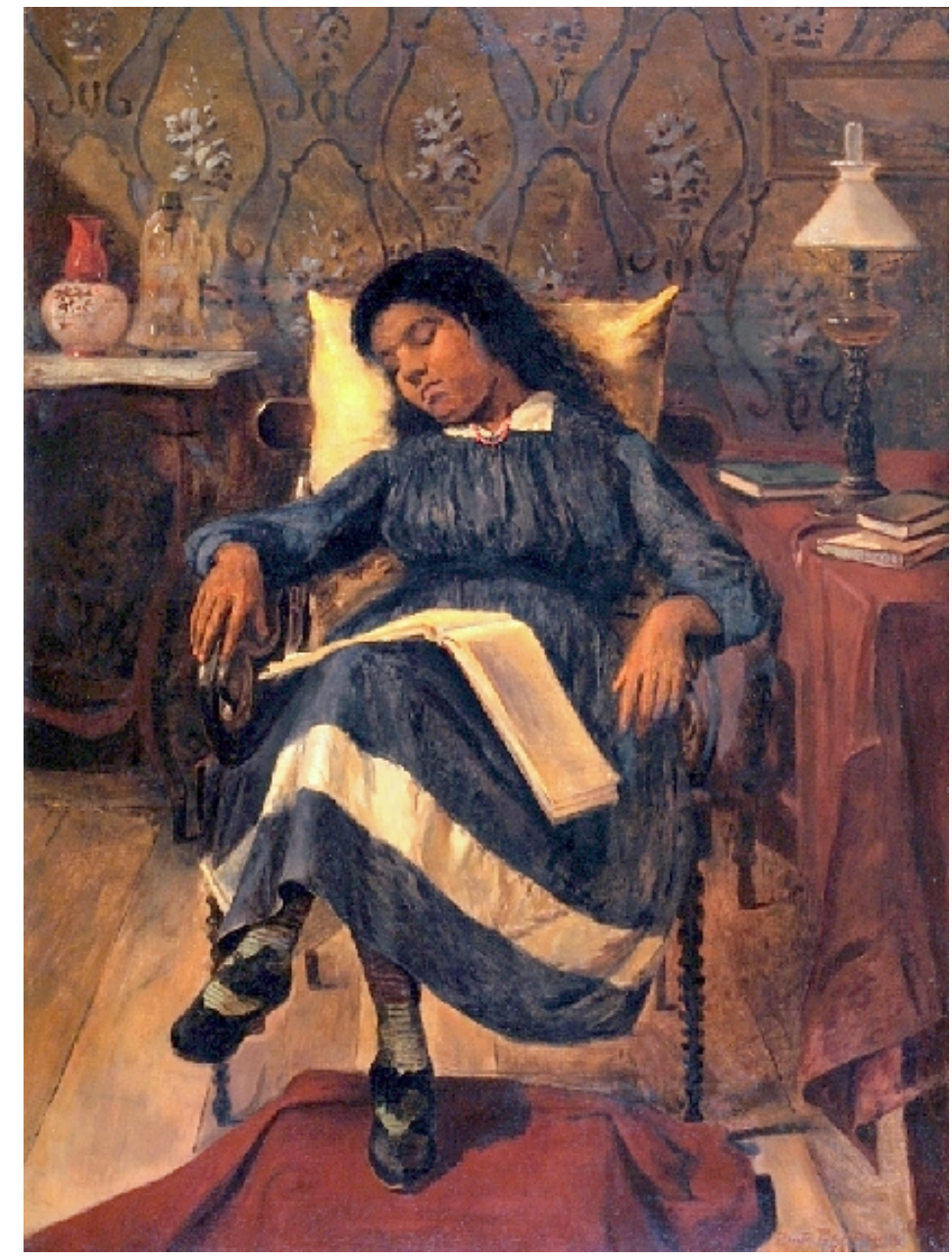

Fig. 143: Antônio Rafael Pinto Bandeira.

Jovem adormecida (1891).

Óleo sobre tela, $83,5 \mathrm{~cm}$ x $62 \mathrm{~cm}$. Niterói: Museu Antônio Parreiras.

Por fim, temos Cabeça de homem, de 1881, expoente de um tipo de imagem dificilmente encontrada para a arte do período. Isto porque ela mostra um homem negro - o que parece contrariar certos parâmetros de afirmação da branquitude e da masculinidade então vigentes ${ }^{638}$. Trata-se de um estudo, exercício frequente na

\footnotetext{
${ }^{638}$ Moutinho e Miskolci, no Brasil; e Dyer, McClintock e Bederman, no exterior, entre outros autores, apontam para a constituição, no mundo ocidental do Oitocentos, de uma ordem dos afetos em que o homem branco e heterossexual era alçado à posição de homem universal, onipresente nas narrativas então constituídas sobre o desejo. Enquanto esse perfil masculino é descrito pela possibilidade ilimitada de enlaces afetivos (no quesito raça/cor, mas também segundo outras variáveis), o homem negro é praticamente ausente das narrativas sobre o desejo. Autoras como Pollock e Grigsby observam algo semelhante na pintura. $\mathrm{O}$ estudo de cabeça é talvez o gênero em que mais aparecem homens negros. As críticas de arte do período mostram que outros artistas - Brocos entre eles - realizaram estudos similares que, infelizmente, não puderam ser localizados, o que inviabiliza qualquer comparação mais aprofundada. Ver DYER, R. White. NY, London, Routledge, 1999; BEDERMAN, G. Manliness \& Civilization. A cultural history of gender and race $n$ the United States, 18801917. Chicago, The University of Chicago Press, 1996; MCCLINTOCK, A. Couro Imperial. Editora Unicamp, Campinas, 2010; MISKOLCI, R. O desejo da nação. Masculinidade e branquitude no Brasil de fins do século XIX. Annablume, São Paulo, 2012; POLLOCK, G. "A Tale of Three Women: Seeing in the Dark, Seeing Double, at least, with Manet”. In: Differencing the Canon. Feminist Desire and the Writing of Art's Histories. Routledge, London and New York, 1999; GRIGSBY, D. G. Orients and Colonies: Delacroix's Algerian Harem. In: WRIGHT, B. S. The Cambridge
} 
formação artística, que valoriza o uso da pincelada solta. $\mathrm{Na}$ aplicação de azul e amarelo, o quadro assume uma tonalidade esverdeada, mais do que escancara o contraste complementar. O personagem tem olhar firme, rosto sério e postura imponente.

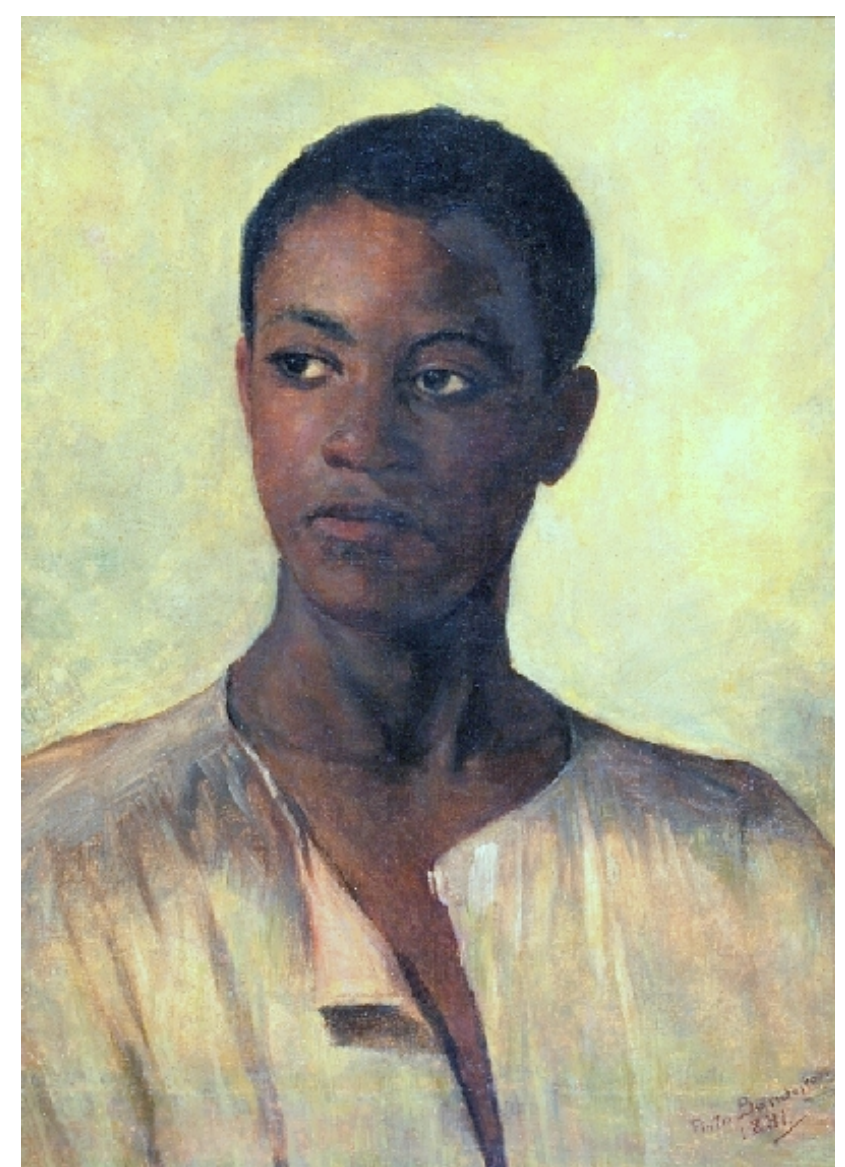

Fig. 144: Antônio Rafael Pinto Bandeira. Cabeça de homem (1891). Óleo sobre tela, $54 \mathrm{~cm} \times 39 \mathrm{~cm}$. Niterói: Museu Antônio Parreiras.

Tal sequência de quadros de Antonio Rafael Pinto Bandeira oferece formas de ver singulares em comparação com as telas mencionadas mais acima. As imagens adotam de forma criativa determinadas tópicas e esquemas correntes na caracterização de personagens de ascendência negra no período e com isso, elaboram questionamentos sobre os lugares que a pintura do período destinava a elas. Não obstante, é preciso reconhecer que se tratam de pinturas que também lidam com limitações. Nesse sentido, é válido destacar que as três mulheres em cena corresponderiam antes à definição de "mulata", do que à de negra - informação que pode indicar tanto uma opção do pintor, quanto a incidência de constrangimentos 
impostos pelo meio acadêmico e o público do período sobre sua produção. Se foge ao alcance destas considerações finais avançar em conclusões sobre o trabalho do artista, especialmente diante da ausência de estudos sobre sua obra, tem-se de todo modo um conjunto de telas instigante, que convida a estudos futuros de maior densidade. O que é digno de nota, aqui, é o uso de tópicas e esquemas consagrados em função de soluções pictóricas originais, sobretudo porque conferem novos papéis à mulher de ascendência negra na pintura do período - o que aponta para um movimento de constituição de formas renovadas de ver essas figuras.

Assim como Bandeira, algumas décadas depois encontramos outro pintor negro que angaria reconhecimento no meio artístico carioca. Arthur Timotéo da Costa inicia sua formação no curso de desenho da Casa da Moeda e, pouco depois, matricula-se na Escola Nacional de Belas Artes (ENBA). Em 1907, recebe o prêmio de viagem e vai estudar em Paris e em 1911, viaja à Itália como integrante da delegação de artistas convocados para decorar o pavilhão brasileiro na Exposição Universal de Turim. Em 1919, funda a Sociedade Brasileira de Belas Artes e inicia uma campanha para que as pinturas produzidas por seus membros possam participar das Exposições Gerais promovidas pela ENBA. O artista enfrenta inúmeras dificuldades em vida, até seu falecimento em 1922, no Hospício dos Alienados do Rio de Janeiro ${ }^{639}$.

${ }^{639}$ VALLE, A. “Artur Timotheo da Costa”, Jornal Rio Informa, Rio de Janeiro, 01 fev. 2004, p. 8; Pinacoteca do Estado de São Paulo. Pintores negros no século XIX. Folheto de Exposição, 26 de fevereiro de 1992 a 20 de fevereiro de 1993. Ver também ARAÚJO, E. A mão afro-brasileira. Significado da contribuição artística e histórica. SP, Imprensa Oficial, 2011; e LEITE, J. R. T. Pintores negros do Oitocentos. Mww Motors, 1988. 

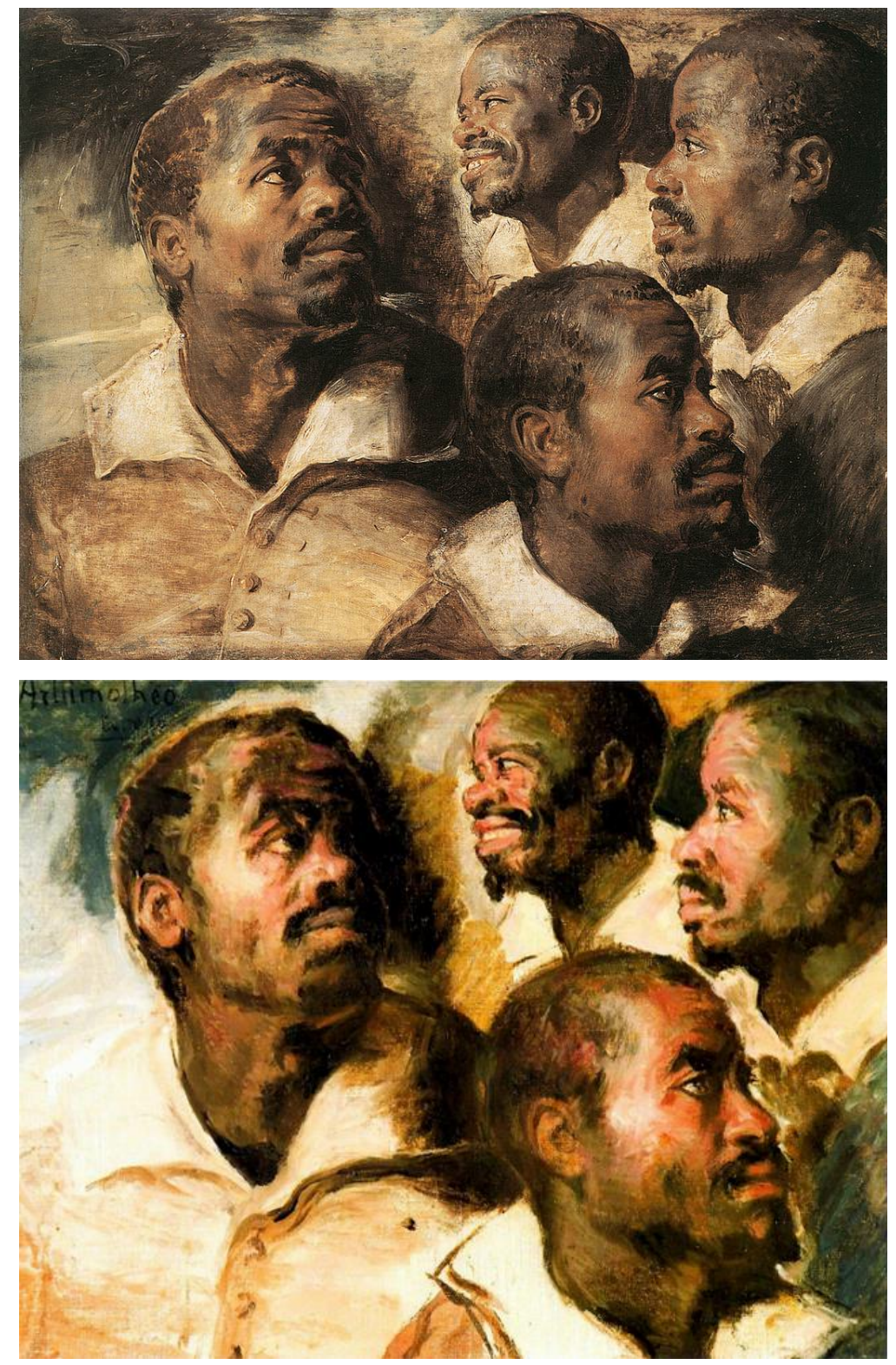

Fig. 145: Peter Paul Rubens Studies of a Male Head (c. 1617). Óleo sobre cartão. Bruxelas: Musée d'Art Ancien.
Fig. 146: Arthur Timótheo da Costa

Estudo de cabeças, d'après Peter Paul Rubens, (s.d.). Óleo sobre tela, $30 \mathrm{~cm} \mathrm{x}$ $36 \mathrm{~cm}$. Coleção particular.

A produção deste pintor e cenógrafo figura como expoente da passagem entre a tradição acadêmica da ENBA e as correntes modernistas e, portanto, já vem marcada pela proposta de remodelação de cânones mais convencionais, à luz de uma liberdade maior na experimentação e emprego de distintas referências pictóricas ${ }^{640}$. Assim, é digno de nota que ele tenha procurado modelos distintos daqueles adotados por outros pintores na composição de personagens negras, como se quisesse romper com a tradição vigente a seu tempo. Arthur Timotéo empenha-se nas investigações sobre a pintura holandesa renascentista, adotando contrastes de claro-escuro

\footnotetext{
${ }^{640}$ Na opinião de Valle, "podemos reconhecer em sua obra objetivos expressivos afinados com aquilo muitos estudiosos reconheceram como o que de mais 'moderno' produziu a arte brasileira do século passado".
} 
impensáveis para gerações anteriores que haviam aderido à influência da pintura plein-air e do orientalismo, entre outras. Inscreve-se nessas investigações, por exemplo, sua cópia de um estudo de cabeças de Peter Paul Rubens (1577-1640), em que é notável a capacidade de dotar de profundidade as diversas expressões da personagem.

A mesma qualidade encontra-se no estudo Cabeça de menino, exposta ao público por Arthur Timotéo em 1918. A imagem de uma criança negra é quase ausente na obra dos artistas citados anteriormente - Brocos, por exemplo, introduz essas personagens como figurantes em cenas maiores, como Engenho de mandioca. Já o quadro de Timotéo confere centralidade ao menino de rosto sério e extremamente bem desenhado, graças ao emprego do chiaroscuro. O fundo, em amarelo e azul, parece dotar a composição do mesmo tipo de contrariedade apontada para certas telas de Bandeira: visto que não se trata de uma figura em cuja aplicação de cor se optou por simplificações primitivistas, ele permite vislumbrar uma espécie de ironia fina do ponto de vista pictórico, ou no mínimo apontar criticamente um paradoxo produzido pela preeminência de um olhar branco na tradição pictórica. Assim, o pintor insinua uma ruptura.

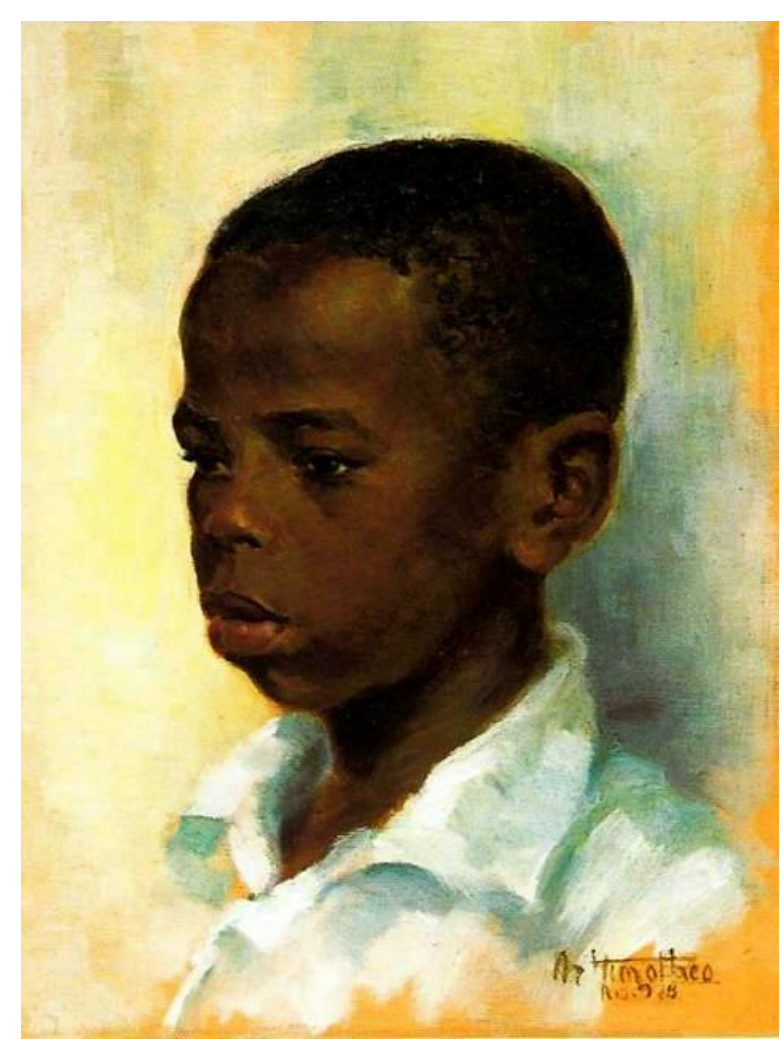

Fig. 147: Arthur Timótheo da Costa Retrato de menino (1916).

Óleo sobre cartão, $41 \mathrm{~cm} \times 33 \mathrm{~cm}$.

Coleção particular. 


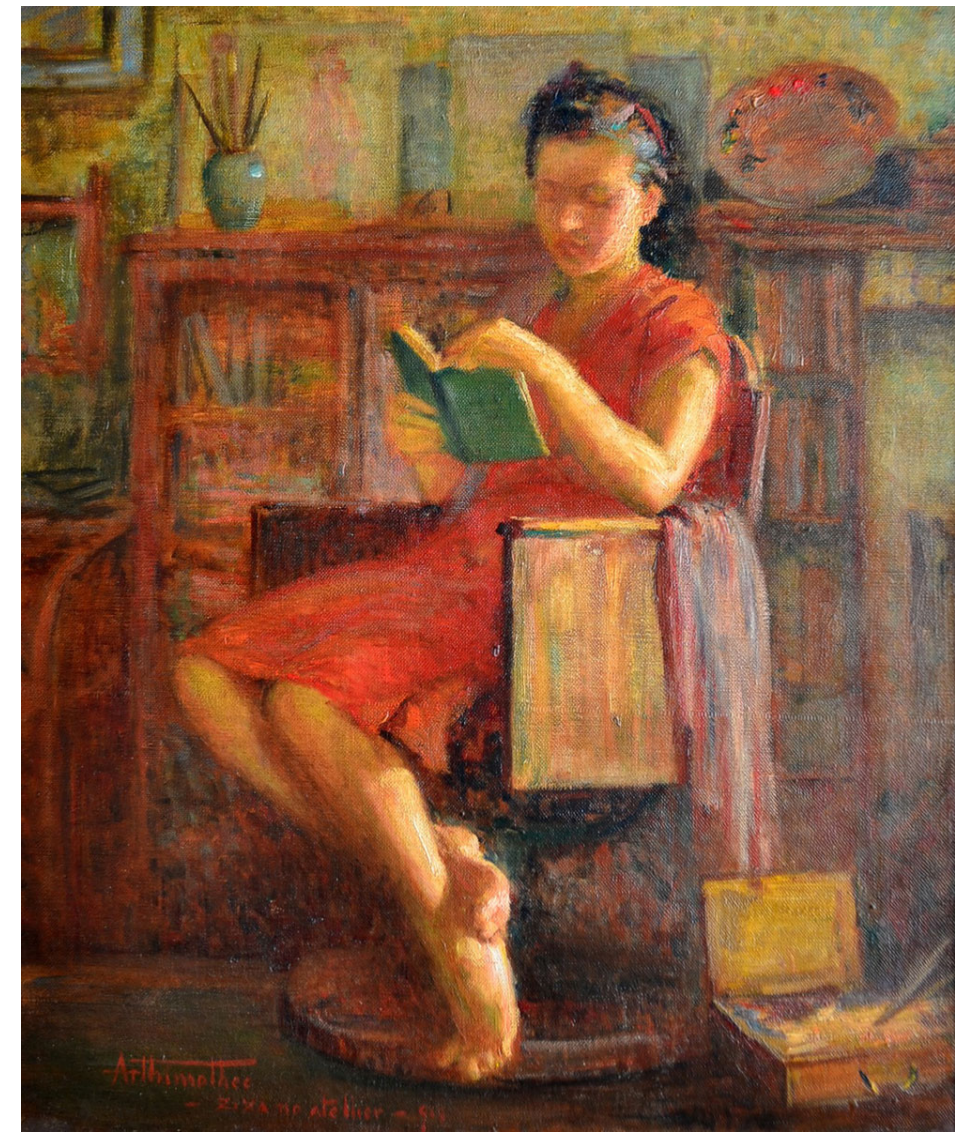

Fig. 148: Arthur Timótheo da Costa

Ziza no ateliê (1919).

Óleo sobre tela, $65 \mathrm{~cm} \times 54 \mathrm{~cm}$. Coleção particular.

Com relação à imagem da mulher negra, o quadro Ziza no ateliê aposta em temática similar à de Jovem adormecida, de Bandeira. Ziza, que na tela faz o papel de modelo, lê um livro. Ela está sentada numa cadeira, estrategicamente posicionada em frente a uma estante cheia de outros títulos. A composição é engenhosa, uma vez que a locação do ateliê fala não apenas sobre a erudição da modelo, mas também do apreço do artista pela leitura. Há novamente o emprego inventivo dos contrastes complementares de verde e vermelho, amarelo e azul, que se aproxima do uso desse recurso na tela Jovem adormecida. Em ambas as obras, tem-se um papel pouco frequente para a mulher de ascendência negra na pintura brasileira da Primeira República. É preciso notar que, a exemplo do que ocorria com os quadros de Bandeira, Ziza é uma negra de pele clara, que poderia ser definida como "mulata" e que, além dela, que é vista com um misto de intimidade e voyeurismo, tem-se notícia de um que o mesmo pintor compôs diversas telas com mulheres consideradas brancas $^{641}$. Frente ao interesse despertado pelas telas de Timotéo, novamente, é preciso reforçar, no entanto, que elucidar e dar vazão a análises sobre as intenções de

\footnotetext{
${ }^{641}$ Listamos: Dama de verde (1908); Dama de branco (s.d.); Nu feminino (s.d.); e Cigana (1910).
} 
sua obra, sem dúvida, dependeria de estudos em maior profundidade, de modo que ficamos aqui limitados por primeiras observações, com o intuito de abrir algumas perspectivas de abordagem.

Seria, evidentemente, possível e desejável alargar a seleção de trabalhos de artistas negros atuantes no período, incluindo nomes como Antônio Firmino Monteiro (1855-1888), que faleceu no momento em que pintava uma composição alegórica sobre a assinatura da Lei Áurea; João Timotéo da Costa (1879-1932), irmão de Arthur que, como ele, também viu o fim da vida como interno no Hospício dos Alienados; Emmanuel Zamor (1840-1917), adotado por franceses na infância e formado em Paris, na Academia Julian; Estevão Roberto da Silva (1845-1891), lembrado como o autor de um esboceto sobre a Lei do Ventre Livre, de 1871, e por um talento singular para a natureza-morta ${ }^{642}$. Contudo, trata-se de uma tarefa que foge ao alcance desta dissertação. Ao incluir algumas telas em meio a estas páginas, nosso objetivo foi antes introduzir paralelos possíveis ${ }^{643}$.

De qualquer maneira - e à luz do trajeto percorrido -, esperamos ter contribuído, ao menos através da remissão à obras produzidas em momentos paralelos e em condições distintas, para introduzir elementos que porventura possam sinalizar o caminho de futuras análises, mais abrangentes e comparativas. Ao transitar pelas pinturas de alguns contemporâneos de Modesto Brocos, observando que tipo de escolhas elas revelam sobre a caracterização das personagens de ascendência negra, o problema que nos colocamos ganhou novos contornos: deslocou-se de uma pintura, cuja tese é o embranquecimento - e que culmina, afinal, no mesmo impasse enfrentado pelas teorias que a antecederam e sucederam -, para telas que exemplificam outras modalidades de caracterização, ainda marcadas por distanciamentos, para por fim encontrar uma série de quadros que partem de pressupostos distintos na construção de seus modos de ver e, por isso, tornam-se capazes de revelar limitações no horizonte de abrangência das imagens anteriores.

Contrastar tais modelos permitiu confirmar que o preconceito, afinal, está ao alcance do olhar: engendra, em seu modus operandi, estéticas que ora definem os caminhos para o consumo de convenções, ora contribuem para mobilizar resistências,

\footnotetext{
${ }^{642}$ Pintores negros no século XIX. Folheto de Exposição, Pinacoteca do Estado de São Paulo, 26 de fevereiro de 1992 a 20 de fevereiro de 1993.

${ }^{643} \mathrm{O}$ que também poderia ser enriquecido por análises comparadas envolvendo telas de outros pintores, produzidas a partir do início do século XX.
} 
por meio de sua reapropriação crítica. As pinturas de Antônio Rafael Pinto Bandeira e Arthur Timotéo da Costa parecem mostrar que os elementos envolvidos na produção dessas estéticas - esquemas e tópicas, entre outros - não constituem soluções fechadas. Antes, exigem escolhas e combinações profundamente imbricadas em formas de sentir e relacionar-se com o mundo, que por isso problematizam continuamente os lugares ocupados por diferentes sujeitos, dentro e fora da tela. São, afinal, artistas de uma obra provocadora, cuja observação pode abrir espaço para indagações sobre a diversificação posterior das formas de inserção das personagens negras na pintura do modernismo. Mas em que medida seus questionamentos foram capazes de influenciar as gerações seguintes, por ora só nos cabe perguntar.

Ao longo da dissertação, privilegiamos mostrar distintos enquadramentos e abordagens oferecidos por artistas brancos para a visualização de personagens de ascendência negra. Para finalizar, parece-nos importante introduzir um último deslocamento de perspectiva, a partir da tela Alguns colegas (1921), de Arthur Timótheo da Costa.

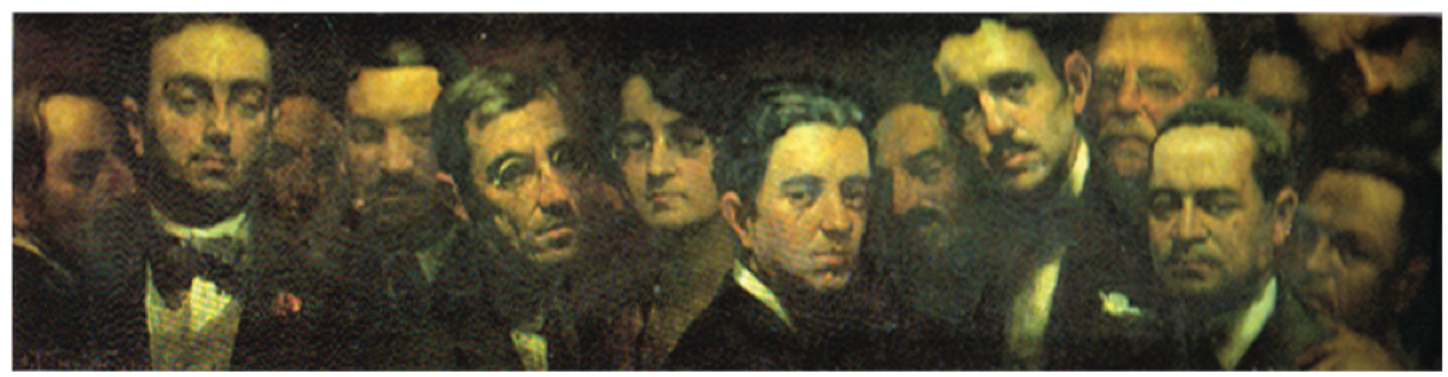

Fig. 149: Arthur Timótheo da Costa. Alguns Colegas (1921). Óleo sobre tela, $455 \mathrm{~cm}$ x 1,7m. Rio de Janeiro: Museu Nacional de Belas Artes

Olhamos a tela e somos olhados por grupo de cavalheiros e uma senhora, que está ao centro ${ }^{644}$-, cujas expressões variam entre curiosidade, embaraço, desconforto, pretensa naturalidade, hostilidade e desprezo. O senhor à esquerda, em primeiro plano, parece não nos ver, desconfortável. Ao lado dele, um homem tem o rosto lúgubre. Em seguida, um cavalheiro de óculos tem ar desapontado. Na sequência, a senhora da cena tem uma expressão enigmática e um ligeiro sorriso. À sua direita, outro senhor exprime desconfiança no olhar. Logo, um homem alto, de bigodes

\footnotetext{
${ }^{644}$ As personagens são colegas de Arthur Timótheo na Escola Nacional de Belas Artes. A mulher ao centro é a pintora Georgina de Albuquerque. À direita, vê-se João Timótheo da Costa, irmão do artista. Não foi possível identificar os demais retratados.
} 
parece ter pena, ou estar gravemente preocupado, prestes a nos dizer alguma coisa. Por fim, tem-se uma figura que olha firme e tenta fingir naturalidade. Enquanto isso, figuras ao fundo parecem disputar espaço para nos ver, o que reforça a sensação de exposição completa, vulnerável aos olhares e julgamentos dessas figuras de olhos fincados em nossos corpos.

A tela foi exposta em 1921, na Exposição Geral de Belas Artes - pouco antes da morte do pintor -, e desafia sentidos correntes do ver na pintura do período. Agora somos observados, submetidos à vigilância invasiva de um grupo, vestindo na pele o sentir do artista negro. A pintura torna-se assim veículo de um questionamento estético singular, desconstruindo posições convencionais. A crítica de Mario da Silva para $O$ Jornal deixa patente a provocação contida nessa única imagem:

\footnotetext{
"Alguns colegas", do sr. Arthur Thimoteo da Costa, é inteiramente falho de qualquer espiritualidade ou caráter. Seriam cabeças de homens, se o homem fosse constituído unicamente por elementos materiais. Mas o homem, para o artista, deve dizer sempre qualquer coisa, ter um caráter, uma espiritualidade, coisas que, bem entendido, lhe são conferidas pelo próprio artista, porque, como já dissemos alhures, o universo é mudo se o homem o não faz falar ${ }^{645}$.
}

Não obstante, ao privar as figuras em cena do tratamento de praxe, o pintor talvez revelasse algo que via como traço genuíno de seu caráter. Aqueles rostos, munidos de tal o qual expressão, quiçá tivessem, ali, a exata profundidade daquilo que lhe comunicavam. Ao mesmo tempo, a tela guardava o potencial de uma eficácia sutil, pois colocava o observador no lugar certo para avaliar, por suas próprias impressões, os olhares em cena. Mas ia além, pois também lhe abria a possibilidade de devolver uma mirada e, assim, construir seu espaço particular de resistência.

\footnotetext{
${ }^{645}$ SILVA, M. da. BELAS ARTES. Impressões sobre o salão deste ano. A PINTURA. O Jornal, Rio de Janeiro, 20 ago. 1921, p. 3.
} 
Bibliografia:

ADAMS, S. The Barbizon School and the origins of Impressionism. London: Phaidon, 1994.

ALBERTI, L. B. Da Pintura. Campinas: Editora da Unicamp, 1999

ALlOUlA, M. The Colonial Harem. Minneapolis: University of Minnesota Press, 1986.

ALMEIDA, A. V. e MAGALHÃES, F. O. As "Disquisitiones" do naturalista Arruda Câmara (1752-1811) e as relações entre a química e a fisiologia no final do século das Luzes. In: Química Nova, vol. 20, n. 4, 1997

ALMEIDA, R. H. de. O diretório dos índios: um projeto de "civilização" no Brasil do século XVIII. Brasília, Editora UNB, 1997.

ALONSO, A. Ideias em movimento. A geração de 1870 na crise do Brasil Império. RJ, Paz e Terra, 2002.

ALVES, C. F. Benedito Calixto e a construção do imaginário republicano. Bauru: EDUSC, 2003.

ARANTES, O. B. F. Notas sobre o método crítico de Gilda de Mello e Souza. In: Discurso, n. 35, 2005, p. 20.

AUERBACH, E. Mimesis. São Paulo: Perspectiva, 1976.

AZEVEDO, C. M. M. Irmão ou inimigo: o escravo no imaginário abolicionista dos Estados Unidos e do Brasil. In: Revista USP, São Paulo (28): 96-109, dez/fev 1995-1996.

AZEVEDO, C. M. M. Onda negra, medo branco. RJ: Paz e Terra, 1987.

BARLOW, P. Fear and loathing of te academic, or Just what is it that makes the avant-garde so different, so appealing? In: CARDOSO, Rafael \& TRODD, Colin. Art and the academy in the nineteenth century. Manchester, Manchester University Press, 2000

BAXANDALL, M. Padrões de intenção: a explicação histórica dos quadros. São Paulo: Companhia das Letras, 2006.

BEDERMAN, Gail. Manliness \& Civilization: a cultural history of gender and race in the United States, 1880-1970. Chicago: University of Chicago Press, 1995.

BENCI, J. Economia Cristã dos Senhores no Governo dos Escravos. São Paulo: Grijalbo, 1977 [1700], pp. 64-65.

BENTHIEN, C. Skin: On the cultural border between self and the world. New York: Columbia University Press, 2002.

BERG, W. J. Émile Zola and the art of his times. University Park, Pennsilvanya: Pennsilvanya State University Press, 1992.

BERNHEIMER, C. Manet's Olympia: The Figuration of Scandal. In: Poetics Today, Vol. 10, No. 2, Art and Literature II (Summer, 1989).

BHABHA, H. K. Interrogationg identity: The postcolonial prerrogative. In: GOLDENBERG, D. T. Anatomy of racism. Minneapolis: University of Minnesota Press, 1990. 
BIRREN, F. History of colour in painting. New York: Van Nostrand Reinhold Corp., 1965.

BIRREN, F. Introduction. In:_ The principles of harmony and contrast of colours and their application to the arts, by Michel Chevreul. New York: Reinhold Publishing Corporation, 1967.

BITTENCOURT, R. Modos de negra e modos de branca: o retrato "Baiana" e a imagem da mulher negra no século XIX. Dissertação de Mestrado em História da Arte e da Cultura apresentada ao Departamento de História do Instituto de Filosofia e Ciências Humanas da Universidade Estadual de Campinas, 2005.

BOIME, A. The art of exclusion. Representing blacks in the Nineteenth Century. Washington \& London: Smithsonian Institution Press, 1990.

BOSI, A. História concisa da literatura brasileira. São Paulo: Cultrix, 2004

BOURET, J. The Barbizon School and 19th century French landscape painting. Greenwich: Thames and Hudson, 1973.

BRESCIANI, M.S. Liberalismo: ideologia e controle social (Um estudo sobre São Paulo de 1850 a 1910). Tese de doutorado, Departamento de História, FFLCH/USP.

BRESCIANI. O cidadão da República. Liberalismo versus positivismo no Brasil: 1870-1900. Revista USP, 17, mar.-abr.-maio de 1993.

BRODY, J. D-V. Impossible purities: Blackness, femininity and Victorian culture. Duke University Press, 1998

BUENO, F.; JIMÉNEZ, J. A Redención de Cam de Modesto Brocos. Estudios Migratórios, n. 9, 2000.

CAMPOFIORITO, Q. História da pintura brasileira no século XIX. RJ: Pinakotheke, 1983.

CAMPOFIORITO, Q. Modesto Brocos. Rio de Janeiro: Bolsa de Arte, 1977.

CAPEL, H. S. F., JUNIOR, G. W. Performances híbridas no pensamento utópico de Modesto Brocos y Gomez (1852-1936). In: Estudos Ibero-Americanos, PUCRS, v. 38, n. 2, jul./dez. 2012, pp. 363-380.

CARVALHO, C. A. A imagem do negro na literatura brasileira do século XIX. In: Ciências Humanas em Revista, São Luís, v. 4, n.2, dez. 2006.

CARVALHO, J. M. A construção da ordem. A elite política imperial. Rio de Janeiro, Campus, 1980.

CHAN, V. Rubens to Picasso: Four Centuries of Master Drawings. Catálogo de Exposição: Fine Arts Building Gallery, University of Alberta, Sept. 16 Oct. 30, 1995.

CHRISTO, M. C. V. Algo além do moderno: a mulher negra na pintura brasileira no início do século XX. 19\&20, Rio de Janeiro, v. IV, n.2, abr. 2009. Disponível em: $<$ http://www.dezenovevinte.net/obras/obras_maraliz.htm $>$.

CHU, P. T. A science and an art at once: Delacroix's pictorial theory. In: WRIGHT, B. S., The Cambridge Companion to Delacroix. Cambridge: Cambridge University Press, 2001. 
CLARK, T. J. The Painting of Modern Life: Paris in the Art of Manet and His Followers. New York: Knopf, 1985.

COLI, J. A pintura e o olhar sobre si: Victor Meirelles e a invenção de uma história visual no século XIX brasileiro. In: FREITAS, M. C. (org.).

Historiografia brasileira em perspectiva. SP: Editora contexto, 1998.

COLI, J. Um corpo da liberdade. São Paulo: CosacNaify, 2010.

CORRÊA, M. As ilusões da liberdade. A Escola Nina Rodrigues e a antropologia no Brasil. Bragança Paulista: Edusf, 1998.

CORRÊA, M. Sobre a invenção da mulata. In: Cadernos Pagu, 6-7, 1996, pp. 35-50.

COWLING, M. The artist as anthropologist. The representation of type and character in Victorian art. Cambridge: Cambridge University Press, 1989.

CURRAN, A. S. The Anatomy of Blackness: Science and Slavery in an Age of Enlightenment. Baltimore: JHU Press, 2011.

DAZZI, C. C. A Produção dos Professores e Alunos da Escola Nacional de Belas Artes na Exposição de Chicago de 1893. 19\&20, Rio de Janeiro, v. VI, n. 4, out./dez. 2011. Disponível em:

$<$ http://www.dezenovevinte.net/obras/chicago_1893.htm>. Consulta: 01/03/2013.

DAZZI, C. C. Relações Brasil-Itália na arte do segundo Oitocentos. Dissertação de Mestrado (História), Instituto de Filosofia e Ciências Humanas da Universidade Estadual de Campinas, 2006.

DELEUZE, G. e GUATTARI, F. Year zero, faciality. In: London: Continuum, 2004, p. 197.

DENIS, R. C. A arte brasileira em 25 quadros. SP, Record, 2008.

DIDI-HUBERMAN, G. Devant le temps. Histoire de l'art et anachronisme des images. Paris: Minuit, 2000.

DIDI-HUBERMAN, G. O que vemos, o que nos olha. São Paulo: Editora 34, 2010.

DIDI-HUBERMAN, G. Quadro = Corte - Experiência visual, forma e sintoma segundo Carl Einstein. In: HUTCHET, S. (org.). Fragmentos de uma Teoria da Arte. São Paulo: Edusp, 2012, pp. 61-96.

DUMONT, L. Homo Hierarchicus. São Paulo, EDUSP, 1992.

DYER, R. White. London and New York: Routledge, 1997.

FERNÁNDEZ, X. J. B. El Contexto Cultural Gallego (1880-1914) (La cultura urbana). In: Isidoro Brocos (1841-1914). Catálogo de exposição. Museu de Bellas Artes de A Coruña, 24/11/1989.

FERREIRA, Orlando da Costa. Imagem e Letra: introdução a bibliologia brasileira a imagem gravada. SP: Edusp, 1994.

FIGUERÔA-REGÔ, J. e OLIVAL, F. Cor da pele, distinções e cargos: Portugal e espaços atlânticos portugueses (séculos XVI a XVIII). In: Tempo, vol. 16, no 30, Niterói, 2011, p. 139-140.

FLETCHER, A. Allegory. The Theory of a Symbolic Mode. Ithaca and London: Cornell University Press, 1995. 
FLOYD, P. A. The Puzzle of Olympia. In: Nineteenth-Century Art Worldwide, v. 3, Issue 1, Spring 2004. Disponível em: <http://www.19thcartworldwide.org/spring-04/index.html>. Consulta: 10/05/2013.

FOUCAULT , M. A arqueologia do Saber. RJ: Forense-Universitária, 1987.

FREITAS, I. B. Cores e olhares no Brasil oitocentista: os tipos negros de Rugendas e Debret. Dissertação (História Social). Niterói: Universidade Federal Fluminense, 2009.

FREYRE, G. Casa-Grande \& Senzala. SP: Editora Record, 1994.

FRIEDLANDER, W. De David a Delacroix. São Paulo: CosacNaify, 2001

GAGE, J Color and culture: practice and meaning from antiquity to abstraction. Berkeley: University of California Press, 1999.

GAGE, J. Color and meaning: art, science, and symbolism. Berkeley: University of California Press, 2000.

GIBSON, C. The hidden life of Renaissance art. Scotland: Saraband, 2007

GILMAN, S. Black Bodies, White Bodies: Toward an Iconography of Female Sexuality in Late Nineteenth-Century Art, Medicine and Litterature. In: GATES, H. L. (ed.). "Race”, Writing and Difference. Chicago and London: University of Chicago Press, 1985.

GINGRICH, A. The German speaking countries. Ruptures, schools and nontraditions: Reassessing the History of Cultural Anthropology in Germany. In: BARTH, F. One Discipline, Four Ways: British, German, French, And American Anthropology. University of Chicago Press, 2005.

GINZBURG, C. Style as Inclusion, Style as Exclusion In: JONES, C. A., GALISON, P. (ed.). Picturing Science, Producing Art. Routledge, 1998.

GOLDENBERG, D. M. The Curse of Ham: Race and Slavery in Early Judaism, Christianity, and Islam. NY: Princeton University Press, 2003.

GOMBRICH. E. Arte e Ilusão. Um estudo da psicologia da representação pictórica. SP: Martins Fontes, 2007.

GRIGSBY, D. G. Orients and Colonies: Delacroix's Algerian Harem. In: The Cambridge Companion to Delacroix. Cambridge: Cambridge University Press, 2001.

GUARALDO, L. Delacroix no Marrocos e a inversão do exótico. In: Projeto História n. 42, jun. 2011.

GUARILHA, Hugo. A questão artística de 1879: um episódio da crítica de arte do II Reinado. 19\&20, Rio de Janeiro, v. I, n. 3, nov. 2006. Disponivel em: $<$ http://www.dezenovevinte.net/criticas/questao_1879.htm $>$. Consulta: 27/07/2013

GUIMARÃeS, A. S. A. Preconceito e discriminação. Queixas de ofensas e tratamento desigual dos negros no Brasil. Salvador: Novos Toques, 1998.

GUIMARÃES, A. S. A. Racismo e Anti-Racismo no Brasil. São Paulo: Editora 34, 1999.

HALL, S. Representation. Cultural representation and signifying practices. Sage publications, 2009 
HANOOSH, M. Histoire d'une édition: le Journal de Delacroix, archéologie et reconstitution d'un document. In: RIHA Journal, 0001, 14 de abril de 2010

HARBISON, C. "Sexuality and Social Standing in Jan van Eyck's Arnolfini Portrait." Renaissance Quarterly, 43.2 (summer 1990), pp. 249-291.

HARTLEY, L. Physiognomy and the meaning of expression in nineteenthcentury culture. Cambridge: Cambridge University Press, 2001.

HEGEL, G. W. F. Cursos de Estética. São Paulo: Edusp, 2001.

HÉRBERT, E. Les fienaroles de San Germano. Comentário critico. Paris, Musée D’Orsay. Disponível em: <http://www.museeorsay.fr/fr/collections/oeuvres-commentees/peinture/commentaire_id/thehaymakers-of-san-germano-

21454.html?tx_commentaire_pi1[pidLi] $=509 \&$ tx_commentaire_pi1[from ] $=841 \& \mathrm{cHash}=\mathrm{a} 59 \mathrm{ccb} 33 \mathrm{~d} 7>$. Acceso: $10 / 05 / 2013$.

HIRANO, L.F.K. O imaginário da branquitude à luz da trajetória de Grande Otelo: raça, persona e estereótipo em sua performance artística. In: Afro-ásia, n. 48, no prelo.

HOFBAUER, A. Uma história do branqueamento ou o negro em questão. São Paulo: Editora UNESP, 2006.

HONOUR, H. L'Image du noir dans l'art occidental. Paris: Gallimard, 1989

HOOKS, b. "The oppositional gaze: Black female spectators". In: Black looks: race and representation. Boston, South End Press, 1992, pp. 122-123. Disponível em: $<$ http://www.umass.edu/afroam/downloads/reading14.pdf $>$. Última consulta: 27/03/2013.

HUTCHET, S. (org.). Fragmentos de uma Teoria da Arte. São Paulo: Edusp, 2012 HUTCHET, S., Image and Narrative [e-journal], n. 18, 2007, s.p. Disponível em: $<\mathrm{http}: / / \mathrm{www}$. imageandnarrative.be/thinking_pictures/hudek.htm $>$. Consulta: 01/05/2013.

INOCENCIO, N. A redenção do olhar: uma abordagem semiótica. In: Nguzu. Revista do Núcleo de Estudos Afro-Asiáticos da UEL, ano 1, nº 1, mar-jul 2011

JAUREGUÍZAR, A. El viaje a Marte de Modesto Brocos. In: ARBOR Ciencia, Pensamiento y Cultura, 740, nov-dez 2009, pp. 1313-1332

JAUREGUÍZAR, A. El viaje a Marte de Modesto Brocos. In: ARBOR Ciencia, Pensamiento y Cultura, CLXXXV 740, noviembre-diciembre (2009)

JUNGHANS, M. O príncipe e o filho do jardineiro: Maximilian Zu Wied-Neuwied e Friedrich Sellow e a viagem ao Espirito Santo e Bahia (1815-1817). Comunicação apresentada ao PPGHCS/COC/Fiocruz, 2011.

JÚNIOR, T. Q. Preconceito de cor e a mulata na Literatura Brasileira. São Paulo: Ática, 1975.

KALMAR, I. The Houkah in the Harem: On Smoking and Orientalist Art. In:GILMAN, S.; ZHOU, X. (ed.). Smoke. London: Reaktion Press, 2004.

KNIGHT, J. S. Feminist Mysticism and Images of God: A Practical Theology. Chalice Press, 2011 
KUHN, F. As redes da distinção familiares da Inquisição na América Portuguesa do século XVIII. Varia História, vol. 26, nº 43 Belo Horizonte, Jun. 2010.

KURY, L. No calor da pátria. IN: Revista USP, São Paulo, nº 72, dez-fev. 2006/2007.

\section{LACERDA, J. B. O Congresso das Raças reunido em Londres. 1912}

LACERDA, J. B. Sobre os mestiços no Brasil. Tradução de "Sur le métis au Brésil" (Premier Congrès Universel des Races: 26-29 juillet 1911, Paris, Devouge, 1911). In: SCHWARCZ, L. K. M. Previsões são sempre traiçoeiras. João Baptista de Lacerda e seu Brasil branco. In: História, Ciências, Saúde Manguinhos. RJ, v.18, n.1, jan.-mar. 2011, p. 228.

LACOUTURE, A. B. Jules Breton: painter of peasant life. Yale University Press, 2002.

LAMAS, M. C. "Isidoro Brocos". In: Isidoro Brocos (1841-1914). Catálogo de Exposição, Museu de Bellas Artes de A Coruña, de 24 de nov. a 22 de dez., 1989

LARA, S. G. Customs and Costumes: Carlos Julião and the Image of Black Slaves in Late Eighteenth-Century Brazil. In: Slavery \& Abolition: A Journal of Slave and Post-Slave Studies, vol. 23, Issue 2, 2002.

LAURETIS T. D. Technologies of Gender: Essays on Theory, Film, and Fiction. Bloomington: Indiana University Press, 1987

LAURETIS, T. D. Figures of Resistance: Essays in Feminist Theory. Urbana and Chicago: University of Illinois Press, 2007.

LEITE, J.R.T. Dicionário crítico da pintura no Brasil. RJ: Artlivre, 1988.

LEMAIRE, G.-G. L’Univers des Orientalistes. Paris: Éditions Place des Victoires, 2000.

LETHBRIDGE, R. Zola and contemporary painting. In: NELSON, B. (ed.). The Cambridge Companion to Zola. Cambridge: Cambridge University Press, 2007

LÉVI-STRAUSS, C. A estrutura dos mitos. In: Antropologia Estrutural. RJ: Tempo Brasileiro, 1973.

LÉVI-STRAUSS, C. Olhar, escutar, ler. SP: Companhia das Letras, 2010.

LIMA, H. P. A presença negra nas telas: visita às exposições do circuito da Academia Imperial de Belas Artes na década de 1880. 19\&20, Rio de Janeiro, v. III, n. 1 jan. 2008. Disponível em: http://www.dezenovevinte.net/obras/obras_negros.htm.

LOURENÇO, M. C. F. Debates e posturas - Tempo humano. In: Almeida Júnior: um criador de imaginários. Catálogo da exposição na Pinacoteca do Estado. São Paulo, 25 jan.-15 abr. de 2007, p. 95.

MARTINS, H. Luís Gama e a consciência negra na literatura brasileira. Afro-Ásia, 17, 1996.

MASSÉ, M. C. Modesto Brocos. Artistas Galegos, Ed. Nova Galícia, 2000/1.

MATTOS, C. V. Independência ou morte!: O quadro, a Academia e o projeto nacionalista do Império. In: O brado do Ipiranga. SP: Edusp, 1999.

McCLINTOCK, Anne. Couro Imperial: raça, gênero e sexualidade no embate colonial. Campinas: Editora Unicamp, 2010. 
MEAGHER, J. "Orientalism in Nineteenth-Century Art". In: Heilbrunn Timeline of Art History. New York: The Metropolitan Museum of Art, 2004. Disponível em: <http://www.metmuseum.org/toah/hd/euor/hd_euor.htm>. Última consulta: 26/07/2013. NOCHLIN, L. The imaginary Orient. In: The politics of vision: essays on Nineteenth century art and society. New York: Harper \& How Publisher, 1983;

MELLO, S. J. de C., Marquês de Pombal. Diretório dos Índios, 1757.

MENEZES, P. R. A. O nascimento do cinema documental e o processo não civilizador. In: MARTINS, J. S.; ECKERT, C.; NOVAES, S. C. (orgs.). O imaginário e o poético nas ciências sociais. Bauru, EDUSC, 2005, p. 73

MILLER, P. B. "Des couleurs primitives": Miscegenation and French Painting of Algeria. In: Visual Resources, 24:3, 2008

MISKOLCI, R. O desejo da nação: masculinidade e branquitude no Brasil de fins do XIX. São Paulo: Annablume, 2012.

MOLLET, J. The painters of Barbizon: Corot, Daubigny, Dupré (1890). London: Kessinger Publishing, 2010.

MORAIS, F. O Brasil na visão do artista. São Paulo: Prêmio Editorial, 2002.

MORGAN, K. Slavery and the British Empire, from Africa to America. Oxford: Oxford University Press, 2007.

MOURA, C. E. M. A travessia da Calunga Grande. Três séculos de imagens sobre o negro no Brasil. São Paulo: Edusp, 2012.

MULVEY, Laura. "Visual pleasure and narrative cinema". In: Visual and other pleasures. Indianápolis: Indiana University Press, 1989.

MURRAY, C. Key Writers on Art: From Antiquity to the Nineteenth Century. Routledge, London \& New York, 2003.

MURRAY, C. J., Encyclopedia of the Romantic Era, 1760-1850. Routledge, 2012.

NAVES, R. A forma difícil: ensaios sobre arte brasileira. São Paulo: Editora Ática, 2007.

NAVES, Rodrigo. Almeida Júnior: o sol no meio do caminho. In: Seminários CEBRAP, 2003.

NOCHLIN, L. The imaginary Orient. In: The politics of vision: essays on Nineteenth century art and society. New York: Harper \& How Publisher, 1983;

NORDMANN, J. T. Taine et la critique scientifique. Paris: Presses Universitaires de France, 1992.

NUNES, J. L. S. Modesto Brocos e a "Retórica dos Pintores". Tese de Doutorado (em andamento), Programa de Pós-Graduação em Artes Visuais da Escola de Belas Artes, Universidade Federal do Rio de Janeiro.

NUNES, José Luiz da Silva. Modesto Brocos: A Retórica dos Pintores. 19\&20, Rio de Janeiro, vol. V, n. 1, jan. 2010. Disponível em: http://www.dezenovevinte.net/criticas/mb retorica.htm

OLIVAL, F. Rigor e interesses: os estatutos da limpeza de sangue em Portugal.

Cadernos de Estudos Sefarditas, no 4, 2004, pp. 151-182. NEPOMUCENO, R.; SANT’ANNA, A. O Jardim de D. João: a 
aventura da aclimatação das plantas asiáticas à beira da lagoa e o desenvolvimento do Jardim Botânico do Rio de Janeiro, que vence dois séculos de umidade, enchentes, transformações da cidade, novos padrões científicos e mantém-se exuberante, com seus cientistas e suas árvores. Casa da Palavra, 2007.

PANOFSKY, E. "Iconografia e Iconologia: Uma introdução ao estudo da arte da Renascença". In: Significado nas Artes Visuais. São Paulo: Perspectiva, 1986

PANOFSKY, E. The Life and Art of Albrecht Dürer. New York: Princeton University Press, 2005.

PEARL, S. About faces: physiognomy in nineteenth-century Britain. Cambridge: Harvard University Press, 2010.

PELLEGRINI, T. Realismo: Postura e método. In: Letras de Hoje. Porto Alegre, v. 42, n. 4, dezembro 2007, pp. 137-155.

PENA, C. Presentación. In: PENA, C. (org.) Centro y Periferia en la Modernización de la Pintura Española. Catálogo de Exposição. Madrid, Palácio de Velázquez, Bilbao, Museo de Bellas Artes, 19931994.

PERUTTI, D. C. Considerações sobre a representação do negro na obra de Almeida Júnior. In: Perspectivas - Revista de Ciências Sociais, vol. 37 (2010).

PERUTTI, D. C. Considerações sobre a representação do negro na obra de Almeida Júnior. Paper para o GT Pensamento Social Brasileiro, no XIV Congresso Brasileiro de Sociologia. RJ, 2009.

PICASSO JOVEM. A Coruña: Fundación Pedro Barrié de la Maza, Conde de Fenosa, 2002.

PIMENTEL, M. R. O enigma da cor: dissertação sobre a variedade das cores da espécie humana. In: Ellipsis, 8, 2010, pp. 49-74.

PLATO, J. D. Multiple Wives, Multiple Pleasures: Representing the Harem, 18001875. Madison: Fairleigh Dickinson University Press, 2002;

POLLOCK, G. "A Tale of Three Women: Seeing in the Dark, Seeing Double, at least, with Manet". In: Differencing the Canon. Feminist Desire and the Writing of Art's Histories. London and New York: Routledge, 1999

POLLOCK, G. Differencing the Canon. Feminist Desire and the Writing of Art's Histories. London and New York: Routledge, 1999;

PREVSNER, N. Academias de arte: passado e presente. São Paulo: Companhia das Letras, 2005.

PROENÇA FILHO, D. A trajetória do negro na literatura brasileira. Estudos Avançados, São Paulo, v. 18, n. 50, Abr. 2004. Disponível em: $<$ http://www.scielo.br/scielo.php?script=sci_arttext\&pid=S010340142004 000100017\&lng=en\&nrm=iso $>$. Consulta: 10/05/2013. 
QUINLAN, S. M. The Great Nation in Decline: Sex, Modernity and Health Crises in Revolutionary France C.1750-1850. Hampshire, Ashgate Publishing, 2007

RIBALTA, A. Galicia en la Actual Exposición de Bellas Artes. In: Revista Regional, n. 8 , ago. 1887

RIBEYROLLES, C. de. Brasil Pitoresco. Belo Horizonte E São Paulo, Ed. Itatiaia/EDUSP, 1975, 1861, vol. 1, p. 203.

RICHARDSON, J., McCULLY, M. A life of Picasso (1881-1906), vol. 1. Knopf, 2007.

RODRIGUES, N. As raças humanas e a responsabilidade penal no Brasil. Companhia Editora Nacional, 1938, p. 128. Disponível em $<$ http://www.brasiliana.com.br/obras/as-racas-humanas-e-aresponsabilidade-penal-no-brasil/pagina/128/texto $>$. Consulta: $10 / 05 / 2013$.

RODRIGUES, R. N. As coletividades anormais. Brasília: Ed. do Senado Federal, vol. 76, 2006

RODRIGUES, R. N. As raças humanas e a responsabilidade penal no Brasil. Rio de Janeiro, Guanabara, 1957.

RODRIGUES, R. N. Os Africanos no Brasil. RJ: Biblioteca Virtual de Ciências Humanas do Centro Edelstein de Pesquisas Sociais, 2010

ROGER, J. Buffon. Cornell University Press, 1997.

ROSEMBLUM, R.; JANSON, H. W. EI arte del siglo XIX. AKAL/Arte y Estética, 1984.

RUGENDAS, J. M. Viagem pitoresca através do Brasil. SP: Círculo do Livro, s/d, p. 248.

SAID, E. W. Orientalismo: o oriente como invenção do ocidente. São Paulo, Companhia das Letras, 2003.

SAMAIN, E. (org.). Como pensam as imagens? Campinas: Editora Unicamp, 2012.

SAMPAIO, G. R. Juca Rosa e as relações entre crença e cura no Rio de Janeiro Imperial. In: CHALHOUB, S.; MARQUES, V. R. B.; SAMPAIO, G. R.; SOBRINHO, C. R. G. (orgs.). Artes e ofícios de curar no Brasil. Campinas, Editora Unicamp, 2003.

SANTOS, R. V.; MAIO, R. V. (orgs.) Raça, Ciência e Sociedade. RJ, Editora Fiocruz/CCBB, 1996.

SCHAEFFER, J.-M. Le corps est image. In: Image [\&] Narrative, 15, Battles around Images: Iconoclasm and Beyond, nov. 2006, s.p. Disponível em: http://www.imageandnarrative.be/inarchive/iconoclasm/schaeffer.htm. Consulta a 10/05/2013.

SCHORSCH, J. Jews and Blacks in the Early Modern World. Cambridge University Press, 2004

SCHWARCZ, L. K. M. Nem preto, nem branco, muito pelo contrário. Cor e raça na intimidade. In: História da vida privada no Brasil, vol. 4. SP: Companhia das Letras, 2004, pp. 173-244.

SCHWARCZ, L. K. M. O espetáculo das raças. Cientistas, instituições e a questão racial no Brasil - 1870-1930. São Paulo, Companhia das Letras, 2004.

SCHWARCZ, L. K. M. O sol do Brasil. São Paulo: Companhia das Letras, 2008. 
SCHWARCZ, L. K. M. Questões de fronteira. In: Novos Estudos. São Paulo, Cebrap, $\mathrm{n}^{\mathrm{0}}$ 72, jul. 2005.

SCHWARCZ, L. K. M.. Retrato em negro e branco. Jornais, escravos e cidadãos em São Paulo no final do século XIX. SP: Companhia das Letras, 1987, p. 25.

SEYFERTH, G. A antropologia e a tese do branqueamento da raça no Brasil: a tese de João Baptista Lacerda. In: Revista do Museu Paulista, 30, 1985; SKIDMORE, T. E. Preto no branco. RJ: Paz e Terra, 1989.

SEYFERTH, G. João Baptista Lacerda. In: Revista do Museu Paulista, n.s., 30, 1985.

SEYFERTH, G. O futuro era branco. In: Revista de História, ed. nº 69, jun. 2011.

SILVA, H. A. Mandioca, a rainha do Brasil? Ascensão e queda da Manihot esculenta em São Paulo. Dissertação (Mestrado em História Social) Programa de Pós Graduação em História Social, Universidade de São Paulo, São Paulo, 2008.

SILVA, M. A. C. Imagens de permanência: considerações acerca do álbum Brasil Pitoresco de Charles Ribeyrolles e Victor Frond. In: Revista de História da Arte e Arqueologia, n. 10, jul.-dez. 2009.

SIMONIS, Y. 1980. Claude Lévi-Strauss: Ou, La Passion de L'inceste. Introduction Au Structuralisme. Paris Flammarion, 1980

SKIDMORE, T. E. Preto no branco. RJ: Paz e Terra, 1989

SLENES, R. W. As provocações de um Abraão africano: a nascente nação brasileira na Viagem Alegórica de Johann Moritz Rugendas. Revista de História da Arte e Arqueologia, n. 2, 1995/96, pp. 273-274.

SMALLS, J. Slavery is a Woman: "Race," Gender, and Visuality in Marie Benoist's Portrait d'une negrèsse (1800). In: Nineteenth-Century Art Worldwide, vol. 3, issue 1, Spring 2004.

SMALLS, J. Slavery is a Woman: "Race," Gender, and Visuality in Marie Benoist's Portrait d'une negrèsse (1800). In: Nineteenth-Century Art Worldwide, vol. 3, issue 1, Spring 2004.

SOARES, M. C. Engenho sim, de açúcar não. O engenho de farinha de Frans Post. In: Vária história, Belo Horizonte, vol. 25, $\mathrm{n}^{\circ}$ 41: p 61-83, jan-jun 2009

SOLLORS, W. Neither black, nor white, yet both. Thematic explorations of interracial literature. Cambridge: Harvard University Press, 1999. pp. 8182.

SOUZA, G. M. Pintura Brasileira Contemporânea: os Precursores. In: Discurso, n. 5, São Paulo, 1974

SOUZA, J. B. A. de. Mãe negra de um povo mestiço: devoção a Nossa Senhora Aparecida e identidade nacional. Estudos Afro-Asiáticos (29), março de 1996.

SOUZA, L. M. Os desclassificados do ouro. A pobreza mineira no século XVIII. Rio de Janeiro, Graal, 1990.

SOUZA, P. M. Visualidade da Escravidão: representações e práticas de vestuário no cotidiano dos escravos na cidade do Rio de Janeiro oitocentista. Tese (Doutorado em História da Cultura), Departamento de História da PUCRio, Rio de Janeiro, 2011.

STAROBINSKI, J. Os emblemas da razão. São Paulo: Companhia das Letras, 1988. STEPAN, N. L. Picturing tropical nature. London, Reaktion Books, 2006 
STOCKING, G. W. Jr. Victorian anthropology. New York: Free Press, 1987;

STOLCKE, V. "Los mestizos no nacen sino que se hacen". In: STOLCKE, V.; COELLO, A. (Ed.) Identidades Ambivalentes en América Latina (Siglos XVI-XXI). Barcelona: Bellaterra, 2007.

STRIETER, T. W. Nineteenth-century European Art: A Topical Dictionary. Greenwood Publishing Group, 1999

STRIETER, T. W. Nineteenth-century European Art: A Topical Dictionary. Greenwood Publishing Group, 1999.

STROTHER, Z.S. Display of the Body Hottentot. In Lindfors, B., (ed.), Africans on Stage: Studies in Ethnological Show Business. Bloomington, Indiana, Indiana University Press, 1999.

THUILLIER, Jacques. Peut-on parler d'une peinture « pompier » ?. Paris: Presses Universitaires de France, février 1984.

TORAL, A. No limbo Acadêmico. Comentários sobre a exposição "Almeida Júnior um criador de imaginários". ARS, vol. 5, n. 10, São Paulo.

TURNER, J. (ed.). From Renaissance to Impressionism: Styles and movements in Western Art, 1400-1900. The Grove Dictionary of Art. London: Macmillan Reference Ltd., 2000.

VÁSQUEZ, F. Los pintores orensanos de la "Escuela de Roma": aproposito de dos nuevos cuadros de Silvio Fernández. Porta da Aira: Revista de Historia del Arte Orensano, $n^{\circ} .4,1991$.

VEGA, R. B. de la. Artistas y críticos españoles - siluetas de pintores, esculptores y críticos. Barcelona, 1891.

VERONA, E. M. O romance, a mulher e o histerismo no século XIX brasileiro. In: Histórica - Revista Eletrônica do Arquivo Público do Estado de São Paulo, n. 32, 2008. Disponível em $<\mathrm{http}$ //www.historica.arquivoestado.sp.gov.br/materias/anteriores/edicao 32/materia06/texto06.pdf $>$. Consultta: 10/05/2013.

VERSINS, P. Encyclopédie de l'utopie, des voyages extraordinaires et de la science fiction. L'Age d'Homme, 2000.

VIANA, L. O idioma da mestiçagem. Campinas: Editora Unicamp, 2007.

VIEIRA, Padre Antônio. Sermão XX - Maria Rosa Mística, do Padre Antônio Vieira. In: Sermões, Padre Antônio Vieira, Erechim: Edelbra, 1998, (s/p).

WEINER, J. Aesthetics is a cross-cultural category. In: INGOLD, T. Key Debates in Anthropology. London, Routledge, 1996.

WEINER, J. Aesthetics. In: BARNARD, A. \& SPENCER, J. (ed.). Encyclopedia of social and cultural anthropology. London \& New York: Routledge, 2002.

WILLIAMS, L. Introduction. In: Catálogo de exposição de Joaquin Sorlla Y Bastida. Exhibited by The Hispanic Society of America, February 8 to March 8, 1909.

WISEMAN, B. (org.). The Cambridge Companion to Lévi-Strauss. Cambridge University Press, 2010, p. 296-314.

WISEMAN, B. 2007. Ideas in Context. Lévi-Strauss, Anthropology, and Aesthetics. Cambridge University Press

WÖLFFLIN, H. Conceitos fundamentais da história da arte. São Paulo, Martins Fontes, 2001. 
YEE, J. The black maid and her mistress in Manet e Zola. In: DAMLÉ, A.;

L'HOSTIS, A. (eds.) The Beautiful and the Monstrous: Essays in

French Literature, Thought and Culture. Bern: Peter Lang, 2010.

ZÍLIO, C. A modernidade efêmera: anos 80 na Academia. In: 180 anos de Escola de

Belas Artes. Anais do seminário EBA 180, 20-11 de nov., 1996, Rio de Janeiro.

Fontes:

“A REDEMPÇÃO DE CHAM”. Gazeta de Noticias, 5/9/1895. Fantasio na

Exposição II, p. 1.

“MODESTO BROCOS”. O Paiz, 27/07/1892. "Artes e artistas", p. 2.

“MODESTO BROCOS". O Paiz, 27/07/1892. Artes e artistas, p. 2

"PALESTRA". O Paiz, 02/09/1895, p. 1., ass. A.A.

ALVES, G. Notas do "Salon" - Modesto Brocos e Aurelio Figueiredo. A Noite, Rio de Janeiro, 18 set. 1912, p. 1.

AZEVEDO, A. O mulato. São Paulo: Montecristo Editora, 2013, (s/p).

BANCROFT, Hubert Howe. "Chapter the Twenty-First: Fine Arts". In: The Book of

The Fair. Chicago, San Francisco: The Bancroft Company, 1893.

Disponível em: http://columbus.gl.iit.edu/bookfair/ch25.html. Consulta:

$01 / 03 / 2013$

BILAC, O. [pseudônimo ass. Fantasio]. “A redempção de Cham”. Gazeta de Noticias, 05/09/1895. Fantasio na Exposição II, p. 1.

BROCOS, M. A questão do ensino de Bellas Artes, seguido de critica sobre a direção de Bernardelli e justificação do autor. Rio de Janeiro, 1915.

BROCOS, M. Retórica dos Pintores. Rio de Janeiro: Typ. D’A Industria do Livro, 1933.

BROCOS, M. Viaje a Marte. Valencia, Editorial Letras y Artes, 1930.

BUFFON, J.-L. L. C. de. A natural history of the globe and of men, p. 181.

London, Thomas Tagg, 1831.

COSME DE MORAES. Folhetim: o salão de 1896 II. Liberdade, 20 set. 1896, p. 1.

DEBRET, J.-B. Rio de Janeiro, cidade mestiça: ilustrações e comentários de Jean-

Baptiste Debret. Organização de Patrick Straumann. São Paulo:

Companhia das Letras, 2001, p. 24.

DEBRET, J.-B. Viagem pitoresca e histórica ao Brasil. Belo Horizonte/São Paulo: Itatiaia/EDUSP, 1978, vol. 1.

EXPOSIÇÃO GERAL DE BELAS ARTES. MODESTO BROCOS. Gazeta de Noticias, Rio de Janeiro, 12 out. 1894, p.2.

EXPOSIÇÃO MODESTO BROCOS (RETROSPECTIVA).Ministério da Educação e Saúde, Museu Nacional de Belas Artes. Rio de Janeiro, Fev. 1952., s.p.

GAYOSO, Raymundo José de Souza. Compendio Histórico-Político dos Principios da Lavoura no Maranhão: suas producções, e progressos, que tem tido até ao prezente, entraves que a vão deteriorando; e meios que tem 
lembrado para desvanece-los, em augmento da mesma lavoura, e sem prejuizo do real patrimônio. P. N. Rougeron, 1818.

GAZETA DE NOTÍCIAS no dia 29/07/1893, p. 1

GAZETA DE NOTÍCIAS, Rio de Janeiro, 1 nov. 1894, p.1.

GONZAGA DUQUE. "Exposição Brocos”. In: Contemporâneos (Pintores e Escultores). Rio de Janeiro, Typografia Benedicto de Souza, 1929, pp. 88-89. Crítica originalmente publicada no Diario do Commercio, em 1892.

GUIMARÃES, B. A escrava Isaura. São Paulo: Klick Editora, s/d, p. 14.

LACERDA, J. B. Fastos do Museu Nacional. Rio de Janeiro, Imprensa Nacional, 1905. Disponível em:

$<$ http://www.obrasraras.museunacional.ufrj.br/o/0054/0054.pdf $>$ Consulta: 14/07/2013.

MURGUÍA, M. Nuestro pensamiento. La Illustración Gallega y Asturiana, no 1, Madrid, 20 de marzo de 1879.

NETTO, C. [ass. C. N. ]. “A redempção de Cham - Fantasia Symbolista (a proposito do quadro de Modesto Brocos)”. Gazeta de Noticias, 19/9/1895, pp. 1-2.

NOTAS SOBRE ARTE. Jornal do Commercio, Rio de Janeiro, 1 set. 1895, p.2.

NOTAS SOBRE ARTE. Jornal do Commercio, Rio de Janeiro, 10 set. 1901, p.3.

NOTAS SOBRE ARTE. Jornal do Commercio, Rio de Janeiro, 7 set. 1895, p. 2

PARLAGRECO, C. Revista Brazileira, 1895, anno I, tomo I.

SILVA, M. da. BELAS ARTES. Impressões sobre o salão deste ano. A PINTURA. O Jornal, Rio de Janeiro, 20 ago. 1921, p. 3.

THE RIO NEWS, Rio de Janeiro, 17 de setembro de 1895, s.p.

WALTON, W. Art and Architecture. v. II. Brazil and Mexico. Art and Architecture. Philadelphia: G. Barrie, 1893, p. 93-96. Disponível em: http://columbus.gl.iit.edu/artarch/00254007.html. Consulta: 01/05/2013 
